\title{
Revista
}

\section{PERcursos Linguísticos}

\author{
Volume 11
}

Edição N. 29

Ano 2021

O texto na pesquisa e no ensino: conhecimentos, práticas e desafios na contemporaneidade

Organizadores: Vanda Maria Elias e Rivaldo Capistrano Júnior 


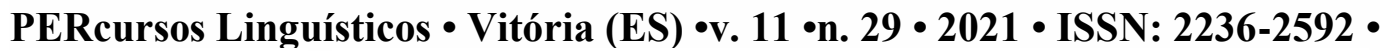

Dossiê temático $\bullet O$ texto na pesquisa e no ensino: conhecimentos, práticas e desafios na contemporaneidade •

\title{
PPGEL- UFES
}

\section{PERcursos Linguísticos}

\author{
VITÓRIA \\ $2021 / 02$
}

UNIVERSIDADE FEDERAL DO ESPÍRITO SANTO

\section{Dossiê temático}

O texto na pesquisa e no ensino: conhecimentos, práticas e desafios na contemporaneidade

Organizadores: Vanda Maria Elias e Rivaldo Capistrano Júnior 
PERcursos Linguísticos • Vitória (ES) •v. 11 •n. 29 • 2021 • ISSN: 2236-2592 •

Dossiê temático $\bullet O$ texto na pesquisa e no ensino: conhecimentos, práticas e desafios na contemporaneidade •

Dados Internacionais de Catalogação na publicação (CIP)

PERcursos linguísticos [recurso eletrônico] / Universidade Federal do Espírito Santo, Programa de PósGraduação em Linguística. - v. 11, n. 29 (2021)- . - Dados eletrônicos. - Vitória: UFES, 2011-

Quadrimestral.

ISSN: 2236-2592

Sistema requerido: Adobe Acrobat Reader.

Modo de acesso: World Wide Web: <http://periodicos.ufes.br/percursos $>$

1. Linguística - Periódicos. 2. Linguística - Estudo e ensino. I. Programa de Pós-graduação em Linguística. II. Universidade Federal do Espírito Santo.

CDU: $81(05)$

Ficha catalográfica elaborada por:

Saulo de Jesus Peres

CRB6 - Reg. 676/ES

CCHN/ PPGEL - Programa de Pós-Graduação em Linguística

Universidade Federal do Espírito Santo

Av. Fernando Ferrari, no 514

Campus Universitário - Goiabeiras

CEP 29075-910

Vitória - ES

Tel: 027 4009-280 
PERcursos Linguísticos • Vitória (ES) •v. 11 •n. 29 • 2021 • ISSN: 2236-2592 •

Dossiê temático $\bullet O$ texto na pesquisa e no ensino: conhecimentos, práticas e desafios na contemporaneidade •

\section{PERcursos Linguísticos}

Esta revista é um periódico quadrimestral.

\section{Reitoria}

Reitor: Paulo Sérgio de Paula Vargas

Vice-Reitor: Roney Pignaton da Silva

Pró-Reitoria de Pesquisa e Pós-Graduação

Pró-Reitor: Valdemar Lacerda Jr.

Centro de Ciências Humanas e Naturais

Diretor: Renato Rodrigues Neto

Vice-Diretor: Ricardo Correa de Araújo

Departamento de Línguas e Letras

Chefe: Mário Cláudio Simões

Sub-chefe: Junia Claudia Santana de Mattos Zaidan.

Programa de Pós-Graduação em Linguística Mestrado em Estudos Linguísticos Coordenadora: Gesieny Laurett Neves Damasceno

Coordenador Adjunto: Lillian Yacovenco

\section{EQUIPE EDITORIAL}

Patrick Rezende (Editor-gerente)

Guilherme Brambila

Elaine Cristina Borges Souza

Mônica Lopes Smiderle de Oliveira

Micheline Mattedi Tomazi

Maria da Penha Pereira Lins

\section{CONSELHO EDITORIAL}

Ana Cristina Carmelino (UNIFESP)

Anna Olga Prudente (PUC-RIO)

Adriana Baptista (UFRJ)

Alexandre Timbane (ACIPOL)

Alexsandro Rodrigues Meireles (UFES)

Bernardo Limberger (PUC- RS)

Bruno Deusdará (UERJ) 
PERcursos Linguísticos • Vitória (ES) •v. 11 •n. 29 • 2021 • ISSN: 2236-2592 •

Dossiê temático $\bullet O$ texto na pesquisa e no ensino: conhecimentos, práticas e desafios na contemporaneidade •

Daniel Ferraz (USP)

Davi Borges Albuquerque (UNB)

Daniervelin Renata Marques Pereira (UFTM)

Edenize Ponzo Peres (UFES)

Edna Maria Fernandes dos Santos Nascimento (UNESP)

Elena Godoy (UFPR)

Fernanda Mussalim (UFU)

Gustavo Ximenes Cunha (UFMG)

Guilherme Brambila Manso (Sedu-ES)

Isadora Machado (UFBA)

Janice Helena Chaves Marinho (UFMG)

José Olímpio de Magalhães (FALE/UFMG)

Júlia Maria da Costa de Almeida (UFES)

Júlio Araújo (UFC)

Junia Mattos Zaidan (UFES)

Juscelino Pernambuco, (UNESP/UNIFRAN)

Karylleila Santos Andrade (UFT)

Kyria Finardi (UFES)

Lilian Coutinho Yacovenco (UFES)

Lillian V. F. DePaula (UFES)

Lúcia Helena Peyroton da Rocha (UFES)

Luciano Vidon (UFES)

Luís Fernando Bulhões Figueira (UFES)

Luiz Antonio Ferreira (PUC/SP)

Maria Cristina Giorgi (CEFET- RJ)

Maria da Penha Pereira Lins (UFES)

Maria Flavia de Figueiredo (UNIFRAN)

Maria Luiza Braga (UFRJ)

Maria Silvia Cintra Martins (UFSCAR)

Marina Célia Mendonça (UNESP)

Marta Scherre (UNB/UFES)

Mayara Oliveira Nogueira (PUC-RIO) 
PERcursos Linguísticos • Vitória (ES) •v. 11 •n. 29 • 2021 • ISSN: 2236-2592 •

Dossiê temático $\bullet O$ texto na pesquisa e no ensino: conhecimentos, práticas e desafios na contemporaneidade •

Mayelli Caldas de Castro (IFES)

Michele Freire Schiffler (UFES)

Micheline Mattedi Tomazi (UFES)

Pedro Henrique Lima Praxedes Filho (UECE)

Patrick de Rezende Ribeiro (PUC-RIO)

Roberto Perobellli Oliveira (UFES)

Renata Martins Amaral (PUC-RIO)

Rita Maria Ribeiro Bessa (UFBA/UEFS)

Rivaldo Capistrano Souza Júnior (UFES)

Sandra Mara Moraes Lima (UNIFESP)

Tatiany Pertel Sabaini Dalben (UESC)

Vanda Elias (PUC-SP)

A revista está indexada em:

LATINDEX,

Diadorim,

JOURNALSEEKER, SEER, SUMÁRIOS.ORG, Journals4free, SHERPA/RoMEO, Google Scholar, $\quad$ LIVRE,WorldCat.org,EZB-Elektronische Zeitschriftenbibliothek, WZB, ERIHplus, CIRC, CCG / IBT - UNAM, Vérsila-Biblioteca Digital, REDIB , SEER , ZDB ，JURN, DOAJ , Periódicos.Capes, The Linguist List, BASE, I2OR, Europub , MLA - Modern Language Association 
PERcursos Linguísticos • Vitória (ES) •v. 11 •n. 29 • 2021 • ISSN: 2236-2592 •

Dossiê temático $\bullet O$ texto na pesquisa e no ensino: conhecimentos, práticas e desafios na contemporaneidade •

\section{SUMÁRIO}

\begin{tabular}{|c|c|}
\hline $\begin{array}{l}\text { PALAVRA DOS EDITORES } \\
\text { GUILHERME BRAMBILA E PATRICK REZENDE }\end{array}$ & 10 \\
\hline APRESENTAÇÃO & $11-15$ \\
\hline $\begin{array}{l}\text { O TEXTO NA LINGUÍSTICA TEXTUAL: } \\
\text { ENTREVISTA À LEONOR LOPES FÁVERO } \\
\text { LEONOR LOPES FÁVERO } \\
\text { VANDA MARIA ELIAS } \\
\text { RIVALDO CAPISTRANO JÚNIOR }\end{array}$ & $16-23$ \\
\hline $\begin{array}{l}\text { O TEXTO NA LINGUÍSTICA } \\
\text { ENTREVISTA À VANDA MARIA ELIAS }\end{array}$ & 24- 31 \\
\hline $\begin{array}{l}\text { MULTIMODALIDADE E HIPERTEXTUALIDADE: } \\
\text { CAMINHOS PARA PESQUISA E ENSINO } \\
\text { CLARICE GUALBERTO; ZÁIRA SANTOS }\end{array}$ & $32-49$ \\
\hline $\begin{array}{l}\text { O DEBATE SOBRE O PEDIDO DE IMPEACHMENT } \\
\text { DE BOLSONARO: POLÊMICA, ARGUMENTAÇÃO } \\
\text { ESTRATÉGIAS DE TEXTUALIZAÇÃO }\end{array}$ & $50-65$ \\
\hline \begin{tabular}{lrrlr}
\multicolumn{2}{l}{ BHARBARA } & BONELLE & DE & SOUSA; GABRIELA \\
MALINI & DE & AGUIAR; & RIVALDO CAPISTRANO \\
JÚNIOR & & & & \\
\end{tabular} & \\
\hline $\begin{array}{l}\text { TEXTO, CONTEXTO E PARATEXTO NA SÉRIE DE } \\
\text { TIRAS “OS SANTOS” } \\
\text { ELISA RIBEIRO DA SILVA }\end{array}$ & $66-84$ \\
\hline $\begin{array}{l}\text { O FORMATO DAS TIRAS NO INSTAGRAM E A } \\
\text { CONSTRUÇÃO DE SENTIDO } \\
\text { KLEBER SOARES ARAÚJO }\end{array}$ & $85-105$ \\
\hline $\begin{array}{l}\text { PLATAFORMA } \boldsymbol{T E A M S} \text { : INTERAÇÃO E ENSINO } \\
\text { ALBA FERNANDES CALDAS }\end{array}$ & 106-124 \\
\hline $\begin{array}{l}\text { OS GÊNEROS DIGITAIS COMO FERRAMENTAS } \\
\text { PARA O ENSINO DA LEITURA NO ENSINO } \\
\text { FUNDAMENTAL }\end{array}$ & $125-135$ \\
\hline
\end{tabular}


PERcursos Linguísticos • Vitória (ES) •v. 11 •n. 29 • 2021 • ISSN: 2236-2592 •

Dossiê temático $\bullet O$ texto na pesquisa e no ensino: conhecimentos, práticas e desafios na contemporaneidade •

FERNANDA DE OLIVEIRA PEREIRA

MARILÚCIA DOS SANTOS DOMINGOS STRIQUER

ANÁLISE DA CONVERSAÇÃO: PANORAMA DOS

$136-146$

ESTUDOS NO BRASIL E REPERCUSSÃO NO

ENSINO

LEONOR LOPES FÁVERO

AXIOLOGIA E LINGUÍSTICA: UMA REFLEX̃̃O

$147-167$

SOBRE OS VALORES SOCIAIS E A MENTIRA NO

CURRÍCULO DE POLÍTICOS

ROSANI MARLOW; MARIA DA PENHA LINS

UMA ANÁLISE MULTIMODAL DE BRINQUEDOS

FIDGET TOYS NA PERSPECTIVA DA SEMIÓTICA

SOCIAL

CLÁUDIA REGINA PONCIANO FERNANDES; JOSÉ MARIA DE AGUIAR SARINHO JÚNIOR

ANÁLISE DAS MARCAS DE SUBJETIVIDADE NO

TEXTO DE GÊNERO NOTÍCIA SOB UM OLHAR

ENUNCIATIVO

CLAUDIA TOLDO; ESTELA METTLER PIVA.

CONTRIBUIÇÕES DA REFERENCIAÇÃO PARA O

ENSINO-APRENDIZAGEM DE LÍNGUAA

PORTUGUESA

VALDINAR CUSTÓDIO FILHO

RETEXTUALIZAÇÃO E PRINCÍPIOS DE

TEXTUALIDADE: ESTRATÉGIAS PARA O

APRIMORAMENTO DA ESCRITA ACADÊMICA

ANDRÉA PISAN SOARES AGUIAR; SUELI CRISTINA

MARQUESI

A INFORMATIVIDADE NO PROCESSO DE ESCRITA ARGUMENTATIVA ESCOLAR:

ELABORAÇÃO DE INSTRUMENTOS DIDÁTICOS A

PARTIR DE ARTICULAÇÕES TEÓRICO-

METODOLÓGICAS

ALINE ARNEMANN

TEXTO COMO DISCURSO: A FORMAÇÃO DO

LEITOR CONSCIENTE DO PROCESSO DE

ENUNCIAÇÃO

MARIA APARECIDA LINO

CLAUDIA ASSAD ALVARES 
PERcursos Linguísticos • Vitória (ES) •v. 11 •n. 29 • 2021 • ISSN: 2236-2592 •

Dossiê temático $\bullet O$ texto na pesquisa e no ensino: conhecimentos, práticas e desafios na contemporaneidade •

\begin{tabular}{|l|c|}
\hline MULTIMODALIDADE CONSTITUTIVA E & $279-296$ \\
ESTRATÉGIAS DISCURSIVAS EM PRÁTICAS DE & \\
LEITURA MEDIADA & \\
PATRÍCIA FERREIRA NEVES RIBEIRO & \\
\hline $\begin{array}{l}\text { DISCURSOS EM DISSENSO: UM OLHAR } \\
\text { SEMIOLINGUÍSTICO SOBRE A CONSTRUÇÃO } \\
\text { ARGUMENTATIVA E O ENSINO DE LÍNGUA }\end{array}$ & $297-317$ \\
$\begin{array}{l}\text { GLAYCI KELLI REIS DA SILVA XAVIER; ILANA DA } \\
\text { SILVA REBELLO;NADJA PATTRESI DE SOUZA E } \\
\text { SILVA }\end{array}$ & \\
\hline $\begin{array}{l}\text { ENSINO-APRENDIZAGEM DA ORALIDADE } \\
\text { FORMAL E O APREÇO Ã TOLERÂNCIA E Ã }\end{array}$ & $318-335$ \\
DIVERSIDADE DE PONTOS DE VISTA & \\
SIRLEY SIQUEIRA & \\
\hline POLÍTICA EDITORIAL & $336-341$ \\
\hline
\end{tabular}




\section{PERcursos Linguísticos • Vitória (ES) •v. 11 •n. 29 • 2021 • ISSN: 2236-2592 • Dossiê temático $\bullet O$ texto na pesquisa e no ensino: conhecimentos, práticas e desafios na contemporaneidade •}

\section{PALAVRAS DOS EDITORES}

Reafirmando o compromisso da Revista PERcursos Linguísticos com a produção acadêmica de alto nível na área dos Estudos da Linguagem, publicamos mais um volume temático da linha Estudos Sobre Texto e Discurso. Neste volume, temos a satisfação de apresentar uma coleção de importantes artigos organizados por Vanda Maria Elias e Rivaldo Capistrano Júnior. Dos diversos trabalhos submetidos, 17 artigos foram selecionados para compor o dossiê temático $O$ texto na pesquisa e no ensino: conhecimentos, práticas e desafios na contemporaneidade. Os trabalhos que fazem parte do volume partem da compreensão de texto enquanto objeto multifacetado, de modo que refletem e discorrem sobre práticas de pesquisa e de ensino que discutem processos de textualização e sentidos considerando a pluralidade de conhecimentos dos sujeitos e da situação comunicativa-interacional, incluídos nessa seara o conhecimento sobre a língua e recursos multimodais na configuração e compreensão do projeto de dizer.

Os artigos do presente dossiê são contribuições de pesquisadores vinculados a universidades e centros de ensino brasileiros, com enfoque em diferentes abordagens que alcançam não só o âmbito teórico, como também a prática com a linguagem em esferas diversas.

O volume também oferece ao leitor duas entrevistas com grandes nomes dos estudos linguísticos, Leonor Lopes Fávero e Vanda Maria Elias. As entrevistas abordam questões pertinentes e recalcitrantes sobre o texto a partir das perspectivas de duas grandes teóricas da Linguística Textual.

Esperamos, assim, que este dossiê seja uma referência para os interessados em questões relacionadas ao texto tanto no contexto acadêmico quanto do ensino. Aproveitamos e agradecemos aos autores e aos organizadores pela contribuição.

Desejamos uma excelente leitura a todos e um 2022 promissor nas pesquisas em Linguística!

Vitória, Espírito Santo, dezembro de 2021.

Patrick Rezende

Guilherme Brambila

Editores 


\section{PERcursos Linguísticos • Vitória (ES) •v. 11 •n. 29 • 2021 • ISSN: 2236-2592 • Dossiê temático $\bullet O$ texto na pesquisa e no ensino: conhecimentos, práticas e desafios na contemporaneidade •}

\section{APRESENTAÇÃO}

Este dossiê é composto por dezessete artigos que apresentam em comum o objeto texto, compreendido em sua complexidade constitutiva. Na sequenciação dos artigos, orientada tematicamente, observam-se três seções: o texto na Linguística Textual; o texto na pesquisa; e o texto no ensino.

A primeira seção $O$ texto na Linguística Textual é composta pelas entrevistas das Professoras Doutoras Leonor Lopes Fávero, a quem agradecemos pela generosidade na concessão da entrevista, e Vanda Maria Elias. Suas narrativas rememoram escolhas que as conduziram à LT; evidenciam seus posicionamentos acerca de questões conceituais e procedimentos teóricoanalíticos; apontam contribuições da LT para o ensino; e indicam perspectivas para estudos do texto nesses tempos marcados por práticas comunicativas e interacionais em contextos digitais.

A segunda seção $\mathbf{O}$ texto na pesquisa se subdivide em duas: "o texto em contexto digital" e "o texto na escrita, na oralidade e em ampla acepção". Nessa primeira subdivisão, como indicado a seguir, estão contidos seis artigos que trazem em sua constituição reflexões teóricas e aplicadas sobre textos e processos de construção de sentidos em contextos propiciados por tecnologias digitais da informação e comunicação (TDIC).

No artigo Multimodalidade e hipertextualidade: caminhos para pesquisa e ensino, Clarice Gualberto e Záira Santos discutem as noções de texto, hipertexto e multimodalidade, com base em estudos da Semiótica Social e da LT. A reflexão indica percursos metodológicos possíveis para o desenvolvimento de pesquisas e aspectos que precisam ser observados em análises multimodais, numa perspectiva que realça a imbricação e a interdependência daquelas noções na produção e interpretação de textos.

Uma discussão sobre como a polêmica se constitui em comentários (postagens reativas) da rede social Facebook é o objetivo do artigo $\mathbf{O}$ debate sobre o pedido de impeachment de Bolsonaro: polêmica, argumentação estratégias de textualização, produzido por Bharbara Bonelle de Sousa; Gabriela Malini de Aguiar; e Rivaldo Capistrano Júnior. As análises indicam que referentes (objetos de discurso) e relações intertextuais contribuem para a instauração, manutenção e atualização da interação polêmica, bem como constituem-se, no jogo polêmico, em relevantes estratégias de violência verbal. 


\section{PERcursos Linguísticos • Vitória (ES) •v. 11 •n. 29 • 2021 • ISSN: 2236-2592 • Dossiê temático $\bullet O$ texto na pesquisa e no ensino: conhecimentos, práticas e desafios na contemporaneidade •}

De que maneira as concepções de texto, contexto e paratexto podem ser articuladas na análise de tiras produzidas e veiculadas nas redes sociais Twitter e Instagram? Oferecer uma resposta a essa questão, sob a cobertura teórica de estudos do texto na abordagem sociocognitiva, é o objetivo do artigo de Elisa Ribeiro da Silva, intitulado Texto, contexto e paratexto na série de tiras "Os Santos".

Também respaldado teoricamente na abordagem sociocognitiva de texto, o artigo $\mathbf{O}$ formato das tiras no Instagram e a construção de sentido, de Kleber Soares Araújo, examina tiras adaptadas do jornal (suporte impresso) e outras veiculadas especificamente no Instagram (suporte digital), considerando a integração de vários modos de linguagem. Como resultado, indica-se que o leitor cria expectativas de leitura com base no formato apresentado e que alterações do formato podem mudar o processamento textual e potencializar, ou suprimir, aspectos que envolvem a leitura dos textos em quadrinhos.

O artigo Plataforma Teams: interação e ensino, de Alba Helena Fernandes Caldas, propõe uma discussão centrada em duas questões: como textos ambientados em plataforma digital hipertextos - são constituídos em termos de características, aspectos contextuais, multimodais, composicionais e interacionais? E quais são os tipos de interação que esses textos produzem em um ambiente de ensino? Na base do artigo, encontram-se estudos do texto, do hipertexto e da interação.

A proposta de uma sequência didática para o trabalho com a leitura do gênero anúncio publicitário veiculado pelo Facebook, norteada por pressupostos teórico-metodológicos constituídos pela vertente didática do Interacionismo Sociodiscursivo, é o foco do artigo Os gêneros digitais como ferramentas para o ensino da leitura no ensino fundamental, de Marilúcia dos Santos Domingos Striquer. A proposta visa à identificação e à compreensão das principais estratégias persuasivas que podem levar ao consumismo o gênero textual em questão. Por sua vez, na subseção "o texto nas modalidades oral e escrita e em ampla acepção", encontram-se quarto artigos descritos a seguir.

O artigo Análise da Conversação: panorama dos estudos no Brasil e repercussão no ensino, de Leonor Lopes Fávero, situa-se na intersecção entre pesquisa e ensino. O texto realiza uma relevante discussão historiográfica sobre a conversação no Brasil e volta-se para a questão do ensino da oralidade em sala de aula, com sugestões de atividades. 


\section{PERcursos Linguísticos • Vitória (ES) •v. 11 •n. 29 • 2021 • ISSN: 2236-2592 • Dossiê temático $\bullet O$ texto na pesquisa e no ensino: conhecimentos, práticas e desafios na contemporaneidade •}

Com uma proposta de reflexão sobre texto e valores na educação para uma sociedade democrática, o artigo Axiologia e linguística: uma reflexão sobre os valores sociais e a mentira no currículo de políticos, de Rosani Marlow e Maria da Penha Lins, analisa uma notícia política, realçando metodologicamente a interface entre Axiologia, Linguística Textual e Pragmática.

O artigo Uma análise multimodal de brinquedos fidget toys na perspectiva da Semiótica Social, de Cláudia Regina Ponciano Fernandes e José Maria de Aguiar Sarinho Júnior, propõe uma discussão sobre infância e brincadeiras representadas em brinquedos conhecidos como fidget toys, com a finalidade de identificar modos de comunicação e recursos semióticos que nos brinquedos estabelecem interação com o observador; e de verificar significados e discursos sobre infância e brincadeira comunicados nesses brinquedos.

Analisar enunciativamente o advérbio na construção do sentido da notícia, com a fundamentação da Teoria da Enunciação, é o que propõe o artigo Análise das marcas de subjetividade no texto de gênero notícia sob um olhar enunciativo, de Claudia Toldo e Estela Mettler Piva.

$\mathrm{Na}$ terceira e última seção $\mathbf{O}$ texto no ensino, formada por um conjunto de sete artigos, o foco se volta para propostas didáticas, visando ao ensino da leitura, da escrita e da oralidade.

No artigo Contribuições da referenciação para o ensino-aprendizagem de língua portuguesa, o autor Valdinar Custódio Filho enfatiza a natureza argumentativa da linguagem; elege o processo da referenciação como estratégia a ser explorada em práticas pedagógicas; e propõe uma análise de duas atividades em que a construção da coerência passa pela percepção da argumentatividade dos referentes. As relações entre Linguística Textual e ensino e aprendizagem de língua portuguesa estão no centro desta reflexão que traz novas possibilidades para o trabalho pedagógico com estratégias de textualização.

No artigo Retextualização e princípios de textualidade: estratégias para o aprimoramento da escrita acadêmica, as autoras Andréa Pisan Soares Aguiar e Sueli Cristina Marquesi verificam como a retextualização e os princípios de textualidade podem constituir estratégias para o aprimoramento da escrita de textos acadêmicos. Sob esse enfoque, as autoras demonstram que a atividade de escrita propicia um momento de reflexão sobre o próprio ato de escrever, que integra múltiplas etapas. 
PERcursos Linguísticos • Vitória (ES) •v. $11 \bullet$ n. 29 • 2021 • ISSN: 2236-2592 • Dossiê

temático $\bullet O$ texto na pesquisa e no ensino: conhecimentos, práticas e desafios na contemporaneidade •

Quais contribuições o uso da informatividade traz para a elaboração de instrumentos didáticos, a fim de ancorar o processo de escrita escolar? Essa é a questão central do artigo A informatividade no processo de escrita argumentativa escolar: elaboração de instrumentos didáticos a partir de articulações teórico-metodológicas, da autora Aline Arnemann. Tendo como base teórica estudos sobre a informatividade no quadro da Linguística Textual, a autora apresenta uma proposta didática, que pode promover ações discentes e docentes no processo de escrita argumentativa.

Uma análise de charges que tem como tema o racismo é o que se encontra em foco no artigo Texto como discurso: a formação do leitor consciente do processo de enunciação, de Maria Aparecida Lino. O trabalho discute como as novas e atuais perspectivas da Linguística do Texto e da Análise do Discurso podem contribuir para um ensino de língua mais consciente do processo enunciativo inerente à produção textual.

Considerando a hipótese de que as categorias texto, contexto e intertexto podem ser acionadas, em tarefas de leitura mediada, pela focalização de estratégias linguístico-discursivos em gêneros textuais escritos, o artigo Multimodalidade constitutiva e estratégias discursivas em práticas de leitura mediada, de Patrícia Ferreira Neves Ribeiro, apresenta uma proposta didática para o ensino da leitura de anúncio publicitário e poema, ressaltando a noção de multimodalidade.

Com a ancoragem teórica da Semiolinguística de Análise do Discurso, o artigo Discursos em dissenso: um olhar semiolinguístico sobre a construção argumentativa e o ensino de língua, de Glayci Kelli Reis da Silva Xavier; Ilana da Silva Rebello; e Nadja Pattresi de Souza e Silva, analisa a construção argumentativa e os imaginários sociodiscursivos em tiras do Armandinho e em um texto jornalístico sobre o tema da privatização, tendo em vista contribuir para a formação de leitores críticos.

No artigo Ensino-aprendizagem da oralidade formal e o apreço à tolerância e à diversidade de pontos de vista, de Sirley Siqueira, as razões pelas quais o gênero textual debate regrado pode ser uma opção para a aquisição de usos formais da fala em público, e também para a formação cidadã pautada no respeito ao outro estão na base da proposta pedagógica que é voltada para a aquisição da oralidade formal na Educação Básica. 
PERcursos Linguísticos • Vitória (ES) •v. $11 \bullet$ n. 29 • 2021 • ISSN: 2236-2592 • Dossiê

temático $\bullet O$ texto na pesquisa e no ensino: conhecimentos, práticas e desafios na contemporaneidade •

Sob diferentes olhares, os trabalhos aqui reunidos oferecem um conjunto de discussões conceituais, teórico-metodológicas e historiográficas, bem como de propostas didáticas, em que ganha relevo o texto em sua multiplicidade de formas, linguagens e contextos.

É nosso desejo que a leitura desses trabalhos lhes seja proveitosa, cara leitora e caro leitor, e que lhes despertem novas e desafiadoras investigações.

Vanda Maria Elias

Rivaldo Capistrano Júnior

Dezembro, 2021 


\title{
PERcursos Linguísticos • Vitória (ES) •v. 11 •n. 29 • 2021 • ISSN: 2236-2592 • Dossiê temático $\bullet O$ texto na pesquisa e no ensino: conhecimentos, práticas e desafios na contemporaneidade •
}

\section{O TEXTO NA LINGUÍSTICA TEXTUAL: ENTREVISTA À LEONOR LOPES FÁVERO}

\section{THE TEXT IN TEXTUAL LINGUISTICS: AN INTERVIEW WITH LEONOR LOPES FÁVERO}

\author{
Leonor Lopes Fávero ${ }^{1}$ \\ Vanda Maria da Silva Elias ${ }^{2}$ \\ Rivaldo Capistrano Júnior ${ }^{3}$
}

A Professora Doutora Leonor Lopes Fávero, uma pioneira dos estudos em Linguística Textual no Brasil e membro emérito do Grupo de Trabalho Linguística de Texto e Análise da Conversação (GT LTAC), da Associação Nacional de Pós-Graduação e Pesquisa em Letras e Linguística (ANPOLL), é Titular de Linguística da Faculdade de Filosofia, Letras e Ciências Humanas da Universidade de São Paulo (USP) e Titular de Língua Portuguesa da Pontifícia Universidade Católica de São Paulo (PUC-SP). Bolsista de Produtividade e Pesquisa (PQ, nível 1A) do Conselho Nacional de Pesquisa (CNPq). Possui graduação em Letras Neolatinas pela USP (1954), doutorado em Linguística Aplicada e Estudos de Linguagem pela PUC-SP (1974) e livre-docência em Semiótica e Linguística Geral pela USP (1993). Fez estágio de pósdoutoramento, com bolsa da FAPESP, na Université de Paris VII - Denis Diderot, sob a supervisão de Sylvain Auroux. Fez parte do Projeto de Gramática do Português Falado (PGPF), desde seu início em 1988, e do Projeto de Estudos da Norma Linguística Urbana Culta de São Paulo (Projeto NURC/SP), a partir de seu ingresso na USP. É líder do Grupo de Pesquisa História das Ideias Linguísticas (Brasil e Portugal) e Identidade Nacional. Desenvolve e orienta pesquisas em Linguística Textual, Análise da Conversação, História das Ideias Linguísticas e Ensino e Aprendizagem de Língua Materna.

É autora de vários livros, capítulos de livros e de artigos em periódicos nacionais e internacionais. No campo da Linguística Textual e da Análise da Conversação, damos destaque às seguintes publicações: Linguística Textual: introdução (1983) e Critérios de textualidade (1985a), em coautoria com Ingedore G. Villaça Koch; Intencionalidade e aceitabilidade como

\footnotetext{
${ }^{1}$ Professora titular de Linguística da USP (aposentada) e Titular de Língua Portuguesa da PUC-SP. Atua em: História das Ideias Linguísticas, Linguística Textual e Estudos da Oralidade. E-mail: 1plfavero@uol.com.br ${ }_{2}^{2}$ Professora do Departamento de Letras da Universidade Federal de São Paulo. E-mail: vanda.elias@gmail.com ${ }^{3}$ Professor do Programa de Pós-Graduação em Linguística da Universidade Federal do Espírito Santo (PPGEL/UFES), Vitória-ES, Brasil. E-mail: r.capistrano@uol.com.br
} 


\section{PERcursos Linguísticos • Vitória (ES) •v. 11 •n. 29 • 2021 • ISSN: 2236-2592 • Dossiê temático $\bullet O$ texto na pesquisa e no ensino: conhecimentos, práticas e desafios na contemporaneidade •}

critério de textualidade (1985b); A informatividade como elemento de textualidade (1985c); Contribuição a uma tipologia textual (1987), em coautoria com Ingedore G. Villaça Koch; Rediscutindo a coesão e a coerência (1989); Coesão e coerência textuais (1991); Frame como elemento de coerência nas perguntas e respostas (1993a); O tópico discursivo (1993b); Estratégias de construção do texto falado: a correção (1996), em coautoria com Maria Lúcia C. V. O. Andrade e Zilda G. O. Aquino; Oralidade e escrita: perspectivas para o ensino de língua materna (1999), em coautoria com Maria Lúcia C. V. O. Andrade e Zilda G. O. Aquino; O par dialógico pergunta-resposta (2006), em coautoria com Maria Lúcia C. V. O. Andrade e Zilda G. O. Aquino; Reflexões sobre oralidade e escrita no ensino de Língua Portuguesa (2011), em coautoria com Maria Lúcia C. V. O. Andrade e Zilda G. O. Aquino; Correção, em coautoria com Maria Lúcia C. V. O. Andrade e Zilda Aquino (2015); Linguística Textual na História das Ideias Linguísticas (2017), em coautoria com Márcia A. G. Molina; Linguística Textual história, delimitações e perspectivas (2019); Artigo de opinião e argumentação: estudo sobre a referenciação e objetos de discurso (2020), em coautoria com Maria Lúcia C. V. O. Andrade; Topicalidade em comentários on-line do Instagram (2021), em coautoria com Ana Rosa Ferreira Dias, Geralda de Oliveira Santos Lima, Maria Cristina de Moraes Taffarello, Maria Lúcia da Cunha Victório de Oliveira Andrade, Maria da Penha Pereira Lins, Marise Adriana Mamede Galvão e Rivaldo Capistrano Júnior; Análise da Conversação: panorama dos estudos no Brasil e repercussão no ensino (2021).

Sua dedicação ao ensino e à pesquisa tem início nos anos de 1960, na PUC-SP, onde permaneceu até o fim dos anos de 1980, quando ingressou na Universidade de São Paulo. Lá, permaneceu até sua aposentadoria em 2001. Em 2002, retorna à PUC-SP, atuando no Programa de Estudos Pós-Graduados em Língua Portuguesa até os dias de hoje.

Com esta entrevista, rendemos uma justa homenagem à Professora Doutora Leonor Lopes Fávero, que, nesse percurso de trabalho de mais de cinco décadas, dedica-se, com muita competência e capacidade crítica, à formação de professores e pesquisadores nos mais diferentes níveis de ensino, sempre compartilhando generosamente seu saber. 


\section{PERcursos Linguísticos • Vitória (ES) •v. $11 \bullet$ n. 29 • 2021 • ISSN: 2236-2592 • Dossiê temático $\bullet O$ texto na pesquisa e no ensino: conhecimentos, práticas e desafios na contemporaneidade •}

Agradecemos à Professora Doutora Maria Lúcia da Cunha Victório de Oliveira Andrade ${ }^{4}$ as sugestões apresentadas, que muito contribuíram para a elaboração desta apresentação.

\section{A Entrevista}

1. Vanda e Rivaldo: A que se deve, nos anos de 1980, seu interesse pela Linguística Textual? Quais foram os teóricos que a inspiraram?

Leonor: Sempre me incomodaram muito questões não abordadas ou abordadas de forma insatisfatória nas gramáticas, como a pronominalização, as relações entre sentenças não ligadas por conjunção, a escolha dos artigos (definido e indefinido), a consecutio temporum e muitas outras até que, no fim da década de 70 do século passado, um amigo que morava na Itália me enviou duas publicações que estavam sendo lá muito discutidas e que me foram de grande valia: a obra de W. Dressler, Einfübrung in die Textlinguistic, de 1970 em tradução italiana (Introduzione alla linguística del texto) e a de Maria Elisabeth Conte, La linguística testuale, de 1972

2. Vanda e Rivaldo - Em trabalhos acadêmicos encontramos uma flutuação terminológica entre "Linguística Textual" e "Linguística de Texto". A senhora considera essas expressões equivalentes?

Leonor: Perfeitamente. Eu mesma já usei ora um, ora outro. Trata-se de um adjunto adnominal.

3. Vanda e Rivaldo: Considerando o texto em toda a complexidade que lhe é constitutiva e em sua multiplicidade de formas e de linguagem, como a senhora o define?

Leonor: Se num primeiro momento Dressler dizia que texto é o signo linguístico primário, a unidade fundamental da língua e o homem fala ou escreve não por frases, mas por textos e se

\footnotetext{
${ }^{4}$ Foi orientanda de Mestrado, em Língua Portuguesa da PUC-SP, e de Doutorado, em Semiótica e Linguística Geral da USP, da Professora Doutora Leonor Lopes Fávero e com ela realizou inúmeras atividades acadêmicocientíficas e estabeleceu uma relação de amizade, que se estende para além da Universidade. Realizou estágio de pós-doutoramento na Universidad Pompeu Fabra (Barcelona, Espanha) sob a supervisão do Prof. Teun A. van Dijk, desenvolvendo pesquisa em Análise Crítica do Discurso. Atua no Programa de Pós-Graduação em Filologia e Língua Portuguesa da USP e também na Graduação em Letras. É líder do NEAC (Núcleo de Estudos em Análise Critica do Discurso - CNPq/USP) e integrante do NURC (CNPq/USP). É membro do Grupo de Trabalho Linguística de Texto e Análise da Conversação (GT LTAC) - ANPOLL.
} 


\section{PERcursos Linguísticos • Vitória (ES) •v. 11 •n. 29 • 2021 • ISSN: 2236-2592 • Dossiê temático $\bullet O$ texto na pesquisa e no ensino: conhecimentos, práticas e desafios na contemporaneidade •}

pensava em elaborar gramáticas textuais, em 1997 Beaugrande 5 afirmava que "texto é um evento comunicativo no qual convergem ações linguísticas, cognitivas e sociais". E prosseguia: "um texto não existe como texto a menos que alguém o processo como tal". Hoje esses estudos se alargaram muito ao receberem subsídios da Pragmática, da Inteligência Artificial, da Teoria dos Atos de Fala, da Psicologia Cognitiva, da Filosofia, da Antropologia, da Análise do Discurso e de outras mais. Acentuou-se, assim, seu caráter multi e transdisciplinar. Assim, creio que uma excelente conceituação de texto encontra-se em Capistrano Júnior et al (2019, p. 161) ${ }^{6}$ : "Realização humana que assume uma dada configuração espaço-temporal, organizada sobre determinado suporte, em interações situadas e ancoradas em processos cognitivos e aspectos socioculturais, constituindo-se num evento comunicativo singular.

4. Vanda e Rivaldo: A Linguística Textual não é a única disciplina que tem o texto como objeto de análise. O que caracteriza o fazer da Linguística Textual? Quais são seus objetivos e suas categorias de análise? Quais seriam suas delimitações?

Leonor: A Linguística Textual tem como uma de suas características não trabalhar com a ideologia e atualmente estuda temas voltados para a transdisciplinaridade e a multimodalidade, abordando inclusão social, racismo, feminismo, gênero das palavras. Suas categorias de análise são as já conhecidas, propostas inicialmente por Beaugrande e Dressler em 1981, às quais se têm feito acréscimos como os contextualizadores (propostos por Marcuschi), a relevância, os vários tipos de conhecimento prévio, os gêneros midiáticos. Seu objetivo é sempre o texto, visto não como produto acabado, mas como processo, de realização social e comunicativa.

5. Vanda e Rivaldo: Quais as possíveis contribuições da Linguística Textual para o ensino da leitura e da escrita?

\footnotetext{
${ }^{5}$ BEAUGRANDE, Robert de. New foundations for a science of text and discourse: cognition, communication, and freedom of access to knowledge and society. Norwood, New Jersey, Ablex, 1997.

${ }^{6}$ CAPISTRANO JÚNIOR, R. et al. Organização tópica na interação em rede: aspectos textuais, contextuais e de coerência. Revista (Con)Textos Linguísticos - Linguística Textual e Análise da Conversação: conceitos e critérios de análise, Vitória, v. 13, n. 25, 159-180, 2019. Disponível em: <https://periodicos.ufes.br/contextoslinguisticos/article/view/27886>. Acesso em 15 out. 2021.
} 


\section{PERcursos Linguísticos • Vitória (ES) •v. $11 ・$ •n. 29 • 2021 • ISSN: 2236-2592 • Dossiê temático $\bullet O$ texto na pesquisa e no ensino: conhecimentos, práticas e desafios na contemporaneidade •}

Leonor: A Linguística Textual muito tem contribuído e muito tem ainda a contribuir com o ensino da língua materna. Começo com uma citação de Marcuschi: "Desde os anos 80 do século XX, admite-se de forma quase unânime que o texto é o melhor ponto de partida e chegada para o tratamento da língua em sala de aula". Muitos estudos já foram realizados e propostas apresentadas. E o que dizem os Parâmetros Curriculares Nacionais (PCN's) e a Base Nacional Comum Curricular (BNCC): "o texto é o produto da atividade verbal oral ou escrita que forma um todo significativo qualquer que seja sua extensão [...] um texto só é um texto quando pode ser compreendido como unidade significativa global, quando possui textualidade." (BRASIL, 1997, p. 23) e a BNCC afirma que o objetivo "é possibilitar aos estudantes participar de práticas de linguagem diversificadas." (BRASIL, 2018, p. 63). Isto não significa que se deve fazer do texto um pretexto para as aulas de gramática ou trazer para a aula o que aprenderam na faculdade (como muitos professores ainda o fazem). Deve-se considerar, também, o trabalho com os gêneros orais e escritos, mas é preciso cuidado com essa atividade, pois, como diz Coscarelli (2007, p. 81) “estamos criando nova camisa de força. Sai a Gramática Textual e entra o gênero textual". Outro ponto que merece destaque é a questão da oralidade. Hoje não se pode mais pensar a língua falada e a língua escrita como modalidades invariantes. E, como já afirmou Bechara (1985 apud FÁVERO, ANDRADE, AQUINO, 1999, p. 12): “... não se trata de ensinar aos alunos a fala, mas de mostrar a grande variedade de usos da fala, dando-lhes consciência de que a língua não é homogênea, monolítica ...”. Nos PCNs, já há progressos, mas não há clareza como realizá-la, deixando de fora a questão do contexto. Devese ressaltar que o livro didático ainda apresenta lacunas nessa questão, fato já apontado por pesquisadores como Lopes da Silva $(2020)^{7}$. Vê-se que o intercâmbio entre a Linguística de Texto e a sala de aula é necessário, urgente e imprescindível.

6 - Vanda e Rivaldo: Quais os desafios teórico-metodológicos da Linguística Textual na contemporaneidade?

Leonor: Na contemporaneidade, os desafios teórico-metodológicos da Linguística Textual são vários, podemos dizer assim. Nos eixos de ensino de leitura, escrita e oralidade, a Linguística Textual pode orientar o trabalho didático do professor de Língua Portuguesa, direcionando as

\footnotetext{
${ }^{7}$ LOPES, Daiane Lopes da. Oralidade e ensino: um estudo sobre a oralidade em livros didáticos de Língua Portuguesa. 2020. 133 f. Dissertação (Mestrado em Língua Portuguesa) - Programa de Estudos Pós-Graduados em Língua Portuguesa, Pontifícia Universidade Católica de São Paulo, 2020.
} 


\section{PERcursos Linguísticos • Vitória (ES) •v. 11 •n. 29 • 2021 • ISSN: 2236-2592 • Dossiê temático $\bullet O$ texto na pesquisa e no ensino: conhecimentos, práticas e desafios na contemporaneidade •}

atividades em sala de aula, visando a um trabalho reflexivo relativo ao uso de unidades linguísticas no texto e não se preocupando com listas de nomenclatura. Ao ensinar a ler e a escrever de modo reflexivo, é preciso trabalhar com textos do domínio do argumentar (editorial, artigo de opinião, entre outros), apontando estratégias para enfatizar a persuasão, o envolvimento, visando ao senso crítico do estudante. Ensinar a ler e a escrever é desafiador e requer conhecimentos temáticos e estar consciente das transformações sociais, para embasar seus argumentos, e estratégias linguístico-textuais para se adequar a língua ao contexto situacional, proporcionando que o aluno se torne um autor e não apenas um repetidor de ideias dos outros. É preciso também tratar da multimodalidade e da grande utilização dos textos digitais que estão tão presentes em nossas vidas. A partir da utilização da linguagem multimodal, o professor pode tornar suas aulas mais motivadoras, dado que essa linguagem integra som, imagem, texto e animação. Desse modo, o professor pode levar o aluno a perceber como tais estratégias são utilizadas e como o uso de tais recursos auxilia na construção textual e no processo de interação. A importância das mídias digitais na vida das pessoas é inegável, através delas estão se modificando ambientes de educação, de trabalho, de entretenimento e a própria forma de se comunicar e pensar. Estão ocorrendo novas práticas discursivas, fazendo surgir novas formas de comunicação e, portanto, novos gêneros textuais. Esses gêneros chamados de virtuais ou digitais são produzidos nos ambientes eletrônicos (WhatsApp, Twitter, Facebook, Instagram etc) trazem novas perspectivas de análises e estudos para as práticas de leitura e escrita e, consequentemente, para as pesquisas em Linguística Textual.

\section{Sugestões de obras de autoria, edição e coedição de Leonor Fávero}

FÁVERO, L. L.; KOCH, I. G. V. Linguística Textual: introdução. São Paulo: Cortez, 1983.

FÁVERO, L. L.; KOCH, I. G. V. Critérios de textualidade. Revista Veredas. Revista da PUCSP, $n^{\circ}$ 104. São Paulo, PUCSP, 1985a, p.17-34.

FÁVERO, L. L. Intencionalidade e aceitabilidade como critério de textualidade. In: FÁVERO, L. L.; PASCHOAL, M. S. Z. (Orgs.) Linguística Textual: texto e leitura. Série Cadernos PUC, 22. São Paulo, EDUC - Editora da PUC-SP, 1985b, p. 31-37.

FÁVERO, L. L. A informatividade como elemento de textualidade. Letras de Hoje. v. 20, n. 2, 1985c, p. 13-20.

FÁVERO, L. L. Rediscutindo a coesão e a coerência. In: Seminários do Grupo de Estudos Linguísticos do Estado de São Paulo. Anais. Lorena, 1989. p. 320-328.

FÁVERO, L. L. Coesão e coerência textuais. São Paulo: Ática, 1991. 


\section{PERcursos Linguísticos • Vitória (ES) •v. 11 •n. 29 • 2021 • ISSN: 2236-2592 • Dossiê temático $\bullet O$ texto na pesquisa e no ensino: conhecimentos, práticas e desafios na contemporaneidade •}

FÁVERO, L. L. Frame como elemento de coerência nas perguntas e respostas In: Seminários do Grupo de Estudos Linguísticos do Estado de São Paulo. Anais. Ribeirão Preto, 1993a. p. 205-212.

FÁVERO, L. L. O tópico discursivo. In: PRETI, D. (Org.). Análise de textos orais. São Paulo: Humanitas, 1993b, p.33-53.

FÁVERO, L. L.; ANDRADE, M. L. C. V. O.; AQUINO, Z. G. O. Estratégias de construção do texto falado: a correção. In: KATO, M. (Org.) Gramática do português falado: convergências. 1. ed. Campinas/São Paulo: Editora da UNICAMP/FAPESP, 1996, vol. V, p. 355-366.

FÁVERO, L. L.; ANDRADE, M. L. C. V. O.; AQUINO, Z. G. O. Oralidade e escrita: perspectivas para o ensino de língua materna. São Paulo: Cortez, 1999.

FÁVERO, L. L.; ANDRADE, M. L. C. V. O.; AQUINO, Z. G. O. O par dialógico perguntaresposta. In: JUBRAN, C. C. A. S. e KOCH, I. G. V. (Orgs.) Gramática do português culto falado no Brasil: Construção do texto falado. Campinas: Editora da UNICAMP, 2006, vol. I, p. 133-166.

FÁVERO, L. L.; ANDRADE, M. L. C. V. O.; AQUINO, Z. G. O. Reflexões sobre oralidade e escrita no ensino da língua portuguesa. In: ELIAS, V. M. (Org.) Ensino de língua portuguesa: oralidade, escrita e leitura. São Paulo: Contexto, 2011, p.13-28.

FÁVERO, L. L.; ANDRADE, M. L. C. V. O.; AQUINO, Z. G. O. Correção. In: JUBRAN, C. S. (Org.). A construção do texto falado. São Paulo: FAPESP/Editora Contexto, 2015, vol.1 (Gramática do português culto falado no Brasil), p. 241-256.

FÁVERO, L. L.; MOLINA, M. A. G. Linguística Textual na História das Ideias Linguísticas. In: CAPISTRANO JÚNIOR, R.; LINS, M. P. P.; ELIAS, V. M. (Orgs.). Linguística Textual: diálogos interdisciplinares. Vitória, São Paulo: PPGEL-UFES / Labrador, 2017, p.79-95.

FÁVERO, L. L. Linguística Textual: história, delimitações e perspectivas. Revista (Con)Textos Linguísticos - Linguística Textual e Análise da Conversação: conceitos e critérios de análise. v. 13 n. 25, p. 12-24, 2019.

FÁVERO, L. L.; ANDRADE, M. L. C. V. O. Artigo de opinião e argumentação: um estudo sobre referenciação e objetos de discurso. In: OLIVEIRA, E. G. de; CORDEIRO. I. C.; MACHADO, R. P.B.; SILVA, S. (Orgs.). Discurso e Argumentação: tecendo os efeitos de sentido, Campinas: Pontes, 2020, p. 125-137.

FÁVERO, L. L.; DIAS, A. R. F.; LIMA, G. de O. S.; TAFARELLO, M. C. de M.; ANDRADE, M. L. C. V. O.; LINS, M. P. P.; GALVÃO, M. A. M; CAPISTRANO JÚNIOR, R. Topicalidade em comentários on-line do Instagram. Revista (Con)Textos Linguísticos - Linguística de Texto e Análise da Conversação: abordagens metodológicas. Vitória, v.15, n.31, p. 146-169, 2021. 
PERcursos Linguísticos • Vitória (ES) •v. 11 •n. 29 • 2021 • ISSN: 2236-2592 • Dossiê

temático $\bullet O$ texto na pesquisa e no ensino: conhecimentos, práticas e desafios na contemporaneidade •

FÁVERO, L. L. Análise da Conversação: panorama dos estudos no Brasil e repercussão no ensino. Revista PERcursos Linguísticos - O texto na pesquisa e no ensino: conhecimentos, práticas e desafios na contemporaneidade (neste dossiê).

KOCH, I. G. V.; FÁVERO, L. L. Contribuição a uma tipologia textual. Letras \& Letras, Uberlândia, v. 3, n. 1, p. 03-10, 1987. 
PERcursos Linguísticos • Vitória (ES) •v. 11 •n. 29 • 2021 • ISSN: 2236-2592 • Dossiê temático $\bullet O$ texto na pesquisa e no ensino: conhecimentos, práticas e desafios na contemporaneidade •

O TEXTO NA LINGUÍSTICA TEXTUAL: ENTREVISTA À VANDA MARIA ELIAS

THE TEXT IN TEXTUAL LINGUISTICS: AN INTERVIEW WITH VANDA MARIA ELIAS

\author{
Vanda Maria Elias ${ }^{1}$ \\ Rivaldo Capistrano Júnior ${ }^{2}$
}

Conheci a Professora Doutora Vanda Maria Elias em 2006, por ocasião do lançamento do livro "Ler e compreender: os sentidos do texto", obra escrita em coautoria com a notável Professora Ingedore Grünfeld Villaça Koch. A parceria acadêmica e amiga com a saudosa Inge resultou na publicação de mais dois livros: "Ler e escrever: estratégias de produção textual", em 2009, e "Escrever e argumentar", em 2016. Os três livros situam-se na intersecção pesquisa-ensino e, com o mesmo rigor inerente às produções acadêmicas, voltamse para um público mais amplo e muito têm contribuído para a formação inicial e continuada de professores(as) e de estudantes de cursos de graduação e pós-graduação.

Em 2008, por ingresso na PUC-SP, tive a satisfação e a honra de ser o primeiro orientando de Doutorado da Professora Vanda Elias. Lembro-me bem de suas aulas, marcadas não só pelo seu entusiasmo com a pesquisa em Linguística Textual (LT) e seus temas, mas também pela sua generosidade, dinamismo e alegria, o que muito nos cativava, alunos(as) e orientandos(as).

Sua trajetória acadêmica tem início na PUC-SP, onde cursou Mestrado e Doutorado, sob a orientação da Professora Doutora Sueli Cristina Marquesi. Em 2000, defendeu a Tese "Do hipertexto ao texto: uma metodologia para o ensino de Língua Portuguesa a distância". Realizou estágios de pós-doutoramento na UNICAMP, sob a supervisão da Professora Doutora Ingedore Koch, e na UFC, sob a supervisão da Professora Doutora Mônica Magalhães Cavalcante.

\footnotetext{
${ }^{1}$ Professora do Departamento de Letras da Universidade Federal de São Paulo. E-mail: vanda.elias@gmail.com ${ }^{2}$ Professor do Programa de Pós-Graduação em Linguística da Universidade Federal do Espírito Santo (PPGEL/UFES), Vitória-ES, Brasil. E-mail: r.capistrano@uol.com.br
} 


\section{PERcursos Linguísticos • Vitória (ES) •v. 11 •n. 29 • 2021 • ISSN: 2236-2592 • Dossiê temático $\bullet O$ texto na pesquisa e no ensino: conhecimentos, práticas e desafios na contemporaneidade •}

Pessoa e professora fascinantes, pesquisadora competente, perspicaz, inquieta e inquietadora, a Professora Vanda vem se dedicando à pesquisa do texto em contextos diversificados e contribuindo para formar professores(as), mestres(as), doutores(as) e pesquisadores(as). Hoje, é professora do Departamento de Letras e do Programa de Pós-Graduação em Letras, da Universidade Federal de São Paulo.

Além dos livros já citados, é autora de artigos em periódicos científicos e de capítulos de livros, organizadora da obra "Ensino de língua portuguesa: oralidade, escrita e leitura", coorganizadora das obras "Linguística Textual e ensino", "Linguística Textual: diálogos interdisciplinares" e coordenadora da coleção "Linguagem \& Ensino".

$\mathrm{Na}$ entrevista que segue, a Professora Vanda Elias expõe sua vivência na LT, tece considerações sobre seu quadro teórico-analítico, problematiza conceitos, indica contribuições para o ensino e suscita novas questões de investigação. Trata-se de relevante contribuição para o entendimento do fazer da LT.

Em nome do Programa de Pós-Graduação em Linguística (PPGEL-UFES) e da Revista PERcursos Linguísticos, agradeço à Professora Vanda Elias a disponibilidade e generosidade na concessão desta entrevista.

\section{A Entrevista}

Rivaldo Capistrano Júnior: Do seu desenvolvimento na segunda metade dos anos de 1960, na Europa Central, especialmente na Alemanha, à sua implementação no Brasil, no início dos anos de 1980, a Linguística Textual (LT) já experimentou mudanças importantes em sua relativa curta história.

Aqui no Brasil, a Professora Ingedore Koch, uma pioneira nesse campo de estudos, desempenhou fundamental papel na consolidação da LT. Qual o legado de Koch para a LT brasileira?

Vanda Maria Elias: As contribuições de Ingedore Koch para o campo dos estudos do texto têm como marco a obra "Linguística Textual: introdução", produzida em conjunto com a Professora Leonor Lopes Fávero, e publicada em 1983. Na obra, as autoras tratam da origem 


\section{PERcursos Linguísticos • Vitória (ES) •v. 11 •n. 29 • 2021 • ISSN: 2236-2592 • Dossiê temático $\bullet O$ texto na pesquisa e no ensino: conhecimentos, práticas e desafios na contemporaneidade •}

e causas da constituição da LT no continente europeu e da concepção de seu objeto de investigação: o texto. Dessa obra em diante, são muitas as publicações (livros e artigos) de Ingedore Koch. No conjunto, as publicações são reveladoras de um denso percurso que muito contribuiu para a constituição, a consolidação e o reconhecimento de uma LT brasileira. Nesse sentido, as obras "Desvendando os segredos do texto" (2002) e "Introdução à Linguística Textual: trajetória e grandes temas" (2004), cada uma à sua maneira, oferecem um quadro de desafios investigativos aos linguistas de texto. Além disso, destaca-se na produção de Koch um outro conjunto de obras que, articulando teoria e ensino, são especialmente endereçadas a professores e professoras da Educação Básica. Obras publicadas nas décadas de 80 e 90, como "Texto e coerência" (1989) e "A coerência textual (1990), ambas em autoria com Luiz Carlos Travaglia; “A coesão textual” (1989); “A inter-ação pela linguagem” (1992); “O texto e a construção dos sentidos", entre outras, continuam na atualidade sendo grandes referências para professores e professoras em formação inicial ou continuada. A esse conjunto de produção especialmente concebida na articulação pesquisa/ensino, reúnem-se as obras "Ler e compreender"; "Ler e escrever" e "Escrever e argumentar", das quais tive o privilégio de participar como coautora. Ainda, na produção de Koch, destaca-se a organização, em conjunto com Clélia Jubran, da obra "Gramática do português culto falado no Brasil” (2006). Trata-se de uma publicação que focaliza a "construção do texto falado" e se concretiza no âmbito do projeto coletivo "Gramática do Português Falado", coordenado pelo Professor Ataliba de Castilho. O projeto envolveu pesquisadores/as de várias universidades brasileiras com a finalidade de documentar, descrever e refletir sobre a língua falada. Koch também foi pioneira ao introduzir na agenda da LT estudos sobre o hipertexto, um modo de produção textual conceptualmente diferente de nossas práticas textuais modeladas pela cultura impressa. Como pensar o texto no contexto da rede mundial de computadores? E o que dizer da coerência nesse tipo de produção? Quais as interfaces demandadas para a descrição e a explicação de fenômenos textuais no ambiente da rede? São algumas questões apontadas por Koch que vêm despertando cada mais vez o interesse de analistas de textos, levando em conta que, no mundo da "cultura da conexão" (JENKINS; GREEN; FORD, 2014), as práticas interacionais são compreendidas na perspectiva do continuum impresso/digital ou online/offline, o que significa atentar para esses contextos e suas características, sem deixar de observar como estão interrelacionados e são complementares. Resumidamente, todas as produções de Koch tiveram e têm significativa repercussão e impacto em nossa formação de pesquisador/a e isso se faz repercutir também na formação de novos professores/as e 


\section{PERcursos Linguísticos • Vitória (ES) •v. 11 •n. 29 • 2021 • ISSN: 2236-2592 • Dossiê temático $\bullet O$ texto na pesquisa e no ensino: conhecimentos, práticas e desafios na contemporaneidade •}

pesquisadores/as. Ingedore Koch é uma das pioneiras e um dos grandes nomes da LT brasileira, a quem muito agradecemos por toda a sua obra e fonte constante de motivação à pesquisa e ao ensino.

Rivaldo Capistrano Júnior: Considerando os rumos da LT na atualidade, você poderia nos apresentar um breve panorama de suas pesquisas, indicando novas questões de investigação para o texto?

Vanda Maria Elias: Tenho investigado e orientado pesquisas que focalizam o texto e $(\mathrm{m})$ seus contextos. Nesse sentido, nos processos de produção textual e construção da coerência, alguns temas têm sido privilegiados como a referenciação, a intertextualidade, a argumentação, a multimodalidade e a retextualização. Em relação à referenciação, por exemplo, investigações recobriram constituição e funções de objetos referenciais discursivos em artigos de opinião, redações escolares, provas de concursos, livros didáticos, comentários em mídias sociais digitais, newsletter etc. Também o fenômeno referencial vem sendo analisado na integração entre componentes verbais e visuais, como o que aconteceu em relação à pesquisa de doutorado de Rivaldo Capistrano Jr., que analisou referenciação e humor em tiras cômicas, deixando uma relevante contribuição para a compreensão do texto numa perspectiva plurissemiótica. Consideradas na relação constitutiva entre aspectos verbais e visuais, produções como memes, videoaulas, newsletters, webstories, publiposts, entre outras, vêm chamando a minha atenção e solicitando a ampliação de um olhar cada mais alargado sobre o objeto texto. Novos procedimentos metodológicos também vêm sendo requeridos quando, por exemplo, considerada a hipertextualidade e a constitutiva conexão entre textos no universo da rede. Demanda-se, portanto, o olhar estendido para uma pluralidade de textos ou "arranjos textuais" (ELIAS; CAVALCANTE, 2017). Concebido e compreendido sob o pressuposto da interação, o texto é analisado em relação ao que apresenta em sua materialidade e o que essa materialidade pressupõe de conhecimentos compartilhados, daí inferíveis. Assim, analisa-se a materialidade textual (verbal e não verbal) e o que essa materialidade sugere em termos de conectividade no interior do texto, em se tratando de palavras, parágrafos, imagens, desenhos, quadros, tabelas, cores etc., mas também em termos de conectividade com conhecimentos de outros textos, suas configurações e funções; da sociedade e de contextos de atuação humana. Nesses movimentos promovidos pela conectividade, partindo-se do texto, mas a ele não se limitando, venho privilegiando alguns 


\section{PERcursos Linguísticos • Vitória (ES) •v. 11 •n. 29 • 2021 • ISSN: 2236-2592 • Dossiê temático $\bullet O$ texto na pesquisa e no ensino: conhecimentos, práticas e desafios na contemporaneidade •}

temas: a intertextualidade e a produção de fake news, a "topicalização distribuída" em produções hipertextuais, a referenciação, a inferenciação, a argumentatividade, o balanceamento entre dado e novo, a hibridização oralidade - escrita, a multimodalidade, a hipertextualização, estratégias cognitivas textuais e socio interacionais, o contexto e a coerência.

Rivaldo Capistrano Júnior: Considerando o texto em toda a complexidade que lhe é constitutiva e em sua multiplicidade de formas e de linguagens, como você o define em suas pesquisas?

Vanda Maria Elias: Definir texto é um desafio para estudiosos da linguagem, como nos aponta, por exemplo, o estudo de Sandig (2009). Texto é texto quando assim o vemos e compreendemos, quando assim a ele nos referimos, diz-nos Beaugrande (1997). Essa declaração do autor é um convite para reflexão sobre texto, sobre a nossa competência textual, sobre modelos mentais que construímos de textos e de seus contextos. No interior da LT, vimos o quanto a concepção de texto foi sendo remodelada e as relações da LT com outras disciplinas foram se intensificando e se diversificando. Numa perspectiva sociocognitiva, como a que nos orienta na atualidade, texto é a concretização de um projeto de dizer, ou seja, uma realização que envolve sujeitos, intencionalidade, conhecimentos e estratégias em um movimento interacional centrado na busca pela coerência e sentidos.

Rivaldo Capistrano Júnior: Desde o seu Doutorado, você vem se dedicando, entre outros temas, à pesquisa do texto em contexto digital. Considerando o surgimento da Web social e, consequentemente, o estabelecimento de novas formas de interação e de novos modos de (re)produção, circulação e recepção de conteúdos nesse meio, como você conceitua hipertexto em seus trabalhos? Que desafios analíticos esse conceito impõe ao pesquisador?

Vanda Maria Elias: O hipertexto é um modo de produção marcado por links, elementos estes definidos pela função da conectividade. Os links funcionam como uma espécie de senha ou porta de entrada para acesso a textos, os mais diversos e numa quantidade que foge à mente humana alcançar. Esses elementos propiciam a conectividade entre textos: de temas diversos (politematização); de gêneros textuais diversos (poligenericidade); de autores diversos (poliautoria); e de linguagens diversas (polissemioticidade). No universo da rede e 


\section{PERcursos Linguísticos • Vitória (ES) •v. 11 •n. 29 • 2021 • ISSN: 2236-2592 • Dossiê temático $\bullet O$ texto na pesquisa e no ensino: conhecimentos, práticas e desafios na contemporaneidade •}

das produções hipertextuais, a delimitação de um texto já se impõe como um desafio ao analista pelos múltiplos links e pela ativação de alguns desses links, que podem nos levar a resultados imprevisíveis. Isso porque, na base da produção hipertextual, está uma quantidade incalculável de textos que são encapsulados em links, oferecidos de modo reticularizado e provenientes de fontes as mais variadas. No começo de minhas pesquisas sobre o texto em rede, no final dos anos 90, a novidade do hipertexto era o desafio que se impunha. Era preciso lidar com muitos textos conectados, proceder a um recorte e a uma análise do material selecionado, considerando a complexidade do ambiente de rede. De lá para cá, o desafio vem aumentando, principalmente após a Web 2.0, que propicia um modo de produção acentuadamente caracterizado pela polissemioticidade e pela poliautoria, esta última, em especial, levando-se em conta o sistema de comentários. No avançar das minhas investigações, passei a considerar fenômenos textuais como a referenciação em arranjos textuais compostos pela poligeneridade e poliautoria em portais de notícias. Mais recentemente, tenho investigado webstories e o processo de retextualização, quando produzidas por derivação, mas também aquelas que encontram na publicidade o seu propósito de constituição. Nessa agenda de estudos investigativos, o alcance das categorias analíticas propiciadas pela LT tem sido constantemente testado, e o diálogo com outros campos de conhecimento tem se intensificado, principalmente em razão das muitas linguagens que entram na composição das produções hipertextuais.

Rivaldo Capistrano Júnior: Ser um pesquisador implica não só ter o conhecimento de conceitos e procedimentos analíticos, mas também saber possibilidades do seu campo de investigação. Nesse sentido, quais as delimitações da LT?

Vanda Maria Elias: As delimitações da LT são definidas pelo que lhe constitui e caracteriza como um campo de investigação voltado a descrever e explicar procedimentos implicados na produção e compreensão de textos, e desenvolver modelos que deem conta desse objetivo, considerando o texto em sua complexidade constitutiva. Observando a trajetória da LT, vimos como seus limites foram redefinidos da fase transfrástica para a cognitiva, passando pela gramática de texto e virada pragmática, até chegarmos à fase sociocognitiva e interacional que, na atualidade, orienta as nossas investigações. Novos modos e contextos de produção textual, como os propiciados pelos avanços das tecnologias da informação e 


\section{PERcursos Linguísticos • Vitória (ES) •v. 11 •n. 29 • 2021 • ISSN: 2236-2592 • Dossiê temático $\bullet O$ texto na pesquisa e no ensino: conhecimentos, práticas e desafios na contemporaneidade •}

comunicação e, consequentemente, novos tipos de interação como a on-line (THOMPSON, 2018), têm motivado e realimentado a discussão sobre a concepção de texto, porque o que construímos como modelos textuais hoje, em ambiente de rede, é diferente daqueles baseados na cultura impressa. Pensar numa realidade como essa, por exemplo, é considerar que os limites da LT não se encontram apartados do texto e do seu contexto de produção/recepção; de seus suportes historicamente construídos; dos objetivos e interesses de seus/suas pesquisadores/as; das mudanças e transformações sociais e culturais; da nossa forma de ver e entender essas interconexões. Assim, penso que as delimitações devam ser compreendidas em termos transitórios ou temporários, ou situados. O texto e suas pistas contextualizadoras ou sinalizadoras da conectividade sujeito-língua-mundo oferecem um conjunto variado de desafios que testam os limites da LT e os nossos, analistas de texto, principalmente em se tratando das possibilidades e necessidade de diálogo com especialistas de outras áreas do saber. Ainda bem, porque foi isso que nos fez chegar até aqui e é isso que nos levará a muito mais longe.

\section{Referências}

BEAUGRANDE, R. New foundations for a science of text and discourse: cognition, communication, and the freedom of access to knowledge and society. Norwood, New Jersey, Ablex Publishing Corporation, 1997.

CAPISTRANO JÚNIOR, R. Referenciação, multimodalidade e humor em tiras cômicas do Gatão de meia-idade, de Miguel Paiva. Campinas, SP: Pontes, 2017.

CAPISTRANO JÚNIOR, R.; LINS, M. P. P.; ELIAS, V. M. (Org.). Linguística Textual: diálogos interdisciplinares. Vitória; São Paulo: PPGEL-UFES; Labrador, 2017.

ELIAS, V. M. (Org.). Ensino de língua portuguesa: oralidade, escrita, leitura. São Paulo: Contexto, 2011.

ELIAS, V. M.; CAVALCANTE, M. M. Linguística Textual e estudos do hipertexto: focalizando o contexto e a coerência. In: CAPISTRANO JÚNIOR, R.; LINS, M. P. P.; ELIAS, V. M. (Orgs.). Linguística Textual: diálogos interdisciplinares. São Paulo: Labrador, 2017, p. 317-338.

FAVERO, L. L.; KOCH, I. G. V. Linguística Textual: uma introdução. São Paulo: Cortez, 1983. 
PERcursos Linguísticos • Vitória (ES) •v. $11 ・$ •n. 29 • 2021 • ISSN: 2236-2592 • Dossiê temático $\bullet O$ texto na pesquisa e no ensino: conhecimentos, práticas e desafios na contemporaneidade •

JUBRAN, C. C. A. S.; KOCH, I. G. V. (Orgs.). Gramática do português culto falado no Brasil: Volume 1 - Construção do texto falado. Campinas: Editora da UNICAMP, 2006.

JENKINS, H.; GREEN, J.; FORD, S. Cultura da Conexão. Trad. Patrícia Arnaud. São Paulo: Aleph, 2014.

KOCH, I. G.V. Desvendando os segredos do texto. São Paulo: Cortez, 2002.

KOCH, I. G.V. Introdução à Linguística Textual. São Paulo: Martins Fontes, 2004.

KOCH, I.G.V. O texto e a construção dos sentidos. São Paulo: Contexto, 1997.

KOCH, I. G.V. A inter-ação pela linguagem. São Paulo: Contexto, 1992.

KOCH, I. G.V. A coesão textual. São Paulo: Contexto, 1989.

KOCH, I. G.V; TRAVAGLIA, L.C. A coerência textual. São Paulo: Contexto, 1990.

KOCH, I. G.V; TRAVAGLIA, L.C.A. Texto e coerência. São Paulo: Cortez, 1989.

KOCH, I. V.; ELIAS, V. M. Ler e compreender: os sentidos do texto. São Paulo: Contexto, 2006.

KOCH, I. V.; ELIAS, V. M.. Ler e escrever: estratégias de produção textual. São Paulo: Contexto, 2009.

KOCH, I. V.; ELIAS, V. M. Escrever e argumentar. São Paulo: Contexto, 2016.

MARQUESI, S. C.; PAULIUKONIS, A. L.; ELIAS, V. M. (Orgs.). Linguística Textual e ensino. São Paulo: Contexto, 2017.

SANDIG, Barbara. O texto como conceito prototípico. In: WIESER, Hans Peter; KOCH, Ingedore G. Villaça (Orgs.). Linguística textual: perspectivas alemãs. Rio de Janeiro: Nova Fronteira, 2009, p. 47-72.

THOMPSON, J. B. A interação mediada na era digital. v.12 - no 3 set./dez. São Paulo Brasil, 2018. p. 17-44 


\title{
MULTIMODALIDADE E HIPERTEXTUALIDADE: CAMINHOS PARA PESQUISA E ENSINO
}

\section{MULTIMODALITY AND HYPERTEXTUALITY: PATHS FOR RESEARCH AND TEACHING}

\author{
Clarice Gualberto ${ }^{1}$ \\ Záira Santos ${ }^{2}$
}

\begin{abstract}
RESUMO: Neste trabalho, com base no entendimento de que todo texto é multimodal e também um hipertexto, tecemos algumas reflexões em torno das contribuições da Semiótica Social Multimodal (KRESS, 2010, 2011, 2015) e da Linguística Textual (KOCH, 2005; XAVIER, 2002) para se pensar texto e a hipertextualidade. Para tanto, abordamos (a) as dimensões conceituais entre texto, hipertexto e multimodalidade; (b) percursos metodológicos que podem ser trilhados para o desenvolvimento de pesquisa e (c) aspectos que precisam ser observados e considerados em análises multimodais. A partir dessa discussão, buscamos demarcar como essas noções se imbricam e são interdependentes no processo de produção e recepção dos textos.
\end{abstract}

PALAVRAS-CHAVE: Multimodalidade. Hipertextualidade. Pesquisa. Ensino.

ABSTRACT: Based on the understanding that every text is multimodal and a hypertext, we reflect on contributions of Multimodal Social Semiotics (KRESS, 2010, 2011, 2015) and Textual Linguistics (KOCH, 2005; XAVIER, 2002) to discuss text and hypertextuality. To do so, we focus on (a) conceptual dimensions of text, hypertext and multimodality; (b) methodological paths that can be adopted for the development of research and (c) aspects that need to be observed and considered in multimodal analysis. By doing this, we aim to demarcate how these notions are intertwined and interdependent in the process of production and reception of texts.

KEYWORDS: Multimodality. Hipertextuality. Research. Teaching.

\footnotetext{
${ }^{1}$ Pós-doutorado em Semiótica pelo programa de Pós-Graduação em Estudos Linguísticos da Universidade Federal de Minas Gerais (PosLin - UFMG). Integrante do grupo GEMULTE/UFES/CEUNES - (Multi)letramentos, Leitura e Textos. E-mail: clagualberto@gmail.com.

${ }^{2}$ Professora adjunta da Universidade Federal do Espírito Santo - CEUNES/UFES no Departamento de Educação e Ciências Humanas - DECH e professora Permanente no Programa de Pós-graduação em Ensino na Educação Básica - PPGEEB CEUNES/UFES. Líder do grupo GEMULTE/UFES/CEUNES - (Multi)letramentos, Leitura e Textos e integrante do grupo de Pesquisa SAL - Sistêmica, Ambientes e Linguagens. E-mail: zbomfante@gmail.com.
} 


\section{PERcursos Linguísticos • Vitória (ES) •v. 11 •n. 29 • 2021 • ISSN: 2236-2592 • Dossiê temático $\bullet O$ texto na pesquisa e no ensino: conhecimentos, práticas e desafios na contemporaneidade •}

\section{Considerações iniciais}

[...] Todos os textos são multimodais (Kress e van Leeuwen, 1998, p.186)

[...] Todo texto é um hipertexto. (Koch, 2005, p. 61)

As epígrafes apontam para uma característica inerente a todo texto, justamente por ele carregar em si diversas camadas modais (palavra, imagem, diagramação, som, hiperlinks, design de cores e tipografias etc). O texto é tecido por diversos fios semióticos, que ocorrem de forma múltipla e plurilinear. Assim, todo texto não é de um único sentido, mas uma proposta de sentidos múltiplos. Adicionalmente, graças aos avanços tecnológicos, a partir da web 2.0, vemos imbricações nos textos verbais (escrito e oral) e visuais (imagem estática e em movimento), que mudaram a paisagem comunicacional e as formas de produção escrita e de leitura.

Essa perspectiva vai ao encontro da visão bakhtiniana quando situa que viver significa participar de um diálogo por meio do qual o homem se insere com toda a sua vida: com olhos, com os lábios, as mãos, a alma, o espírito, o corpo e todos os seus efeitos, investindo o seu ser no discurso, o qual penetra no tecido dialógico da vida humana. Logo, o mundo pronunciado pelos homens revela a sua existência; assim, o seu lugar ganha materialidade e concretude no que definimos por texto $(s)$.

O termo texto guarda uma diversidade de concepções muito próximas a modelos teóricos e pesquisas, os quais contribuíram para a formação do seu conceito, o que não deixa de ser algo natural, demonstrando evidências da renovação teórica num processo ininterrupto de criação nos estudos linguísticos. A noção de texto vem assumindo proeminência como um conceito muito abrangente para todos os tipos de trabalho como romances, livros, pinturas, anúncios, mídia eletrônica, filmes, obras e espetáculos teatrais (COLLOW, 2005). Os benefícios dessa abordagem mais textual, segundo Kress (2002), são muitos; mas, ao mesmo tempo, qualquer abordagem de um determinado campo privilegiará, por necessidade, uma visão em detrimento de outras possibilidades.

Adicionalmente, é muito comum nos deparamos com a noção de hipertexto, um termo que tem sido intensamente discutido, pesquisado e utilizado. Essa noção nos provoca a pensar nas camadas do texto, no armazenamento, na concatenação e na associação de informações. Menezes e Nascimento (2009) situam historicamente o percurso do conceito e asseveram que 


\section{PERcursos Linguísticos • Vitória (ES) •v. 11 •n. 29 • 2021 • ISSN: 2236-2592 • Dossiê temático $\bullet O$ texto na pesquisa e no ensino: conhecimentos, práticas e desafios na contemporaneidade •}

sua gênese é atribuída a Vannevar Bush desde 1945, a partir de suas preocupações com formas de armazenamento de informações, disponíveis na sua época. Vinte anos depois, em 1965, o termo é cunhado por Ted Nelson, ao se inspirar num artigo de Wedeless, afirmando que "não pensamos em sequências lineares, mas em espirais e em notas de rodapé". Logo, o conceito de hipertexto foi introduzido como uma forma "mais flexível, mais generalizada, e não-linear de apresentação de material sobre um assunto específico" (p. 521)

Nesses moldes, muito se tem debatido em torno dessa noção e os seus desdobramentos para o processo de produção escrita, leitura, autoria entre outros. No Brasil, diversos pesquisadores têm desenvolvido investigações sobre texto, hipertexto, multimodalidade e direcionado muitas pesquisas para o ensino. $\mathrm{O}$ trabalho com o hipertexto tem despertado o interesse de estudiosos como Coscarelli (2002), Xavier (2002), Koch (2005), Paiva e Nascimento (2006, 2009), Marcuschi (2005), Ribeiro (2008) bem como trabalhos sobre multimodalidade como Pimenta (2006), Heberle e Abreu (2011), Santos (2013), Gualberto (2016), Barbosa (2017), Gualberto e Santos (2019) etc. Além da Rede Latino Americana de Estudos em Multimodalidade (REDLEM), que busca promover e integrar investigações sobre multimodalidade na América Latina e Caribe. A partir dessa perspectiva, nosso objetivo neste trabalho consiste em discutir as noções de texto, hipertexto, multimodalidade e os seus desdobramentos na paisagem comunicacional, aventando alguns caminhos para pensar o desenvolvimento de pesquisas em torno do ensino.

É comum termos como multimodalidade, hipertexto, design, modo visual, modo verbal, recursos etc. irem se acomodando em nosso vocabulário, sem necessariamente estarmos situados numa esfera comunicativa na área de linguagem, comunicação, educação ou numa comunidade de pesquisa que envolvam essas áreas. Agasalhamos esses termos e, frequentemente, não temos a dimensão da interdependência ou imbricação que eles possuem. Com base em tais ponderações, o presente trabalho propõe uma reflexão sobre a contribuição dos estudos da Semiótica Social Multimodal para se pensar a (hiper)textualidade. Além destas considerações iniciais, o trabalho é constituído de três partes principais, cujos objetivos são: $(i)$ apresentar uma discussão conceitual das premissas que norteiam a Semiótica Social multimodal situando dimensões conceituais; (ii) articular essas premissas a percursos metodológicos que podem ser trilhados para o desenvolvimento de pesquisas e por último; (iii) enfatizar aspectos relevantes para se pensar análises multimodais. 


\section{PERcursos Linguísticos • Vitória (ES) •v. 11 •n. 29 • 2021 • ISSN: 2236-2592 • Dossiê temático $\bullet O$ texto na pesquisa e no ensino: conhecimentos, práticas e desafios na contemporaneidade •}

\section{Semiótica Social Multimodal - Uma outra Semiótica?}

A Semiótica Social Multimodal inaugura uma fase de estudos pós-estruturalistas, cujo foco recai no processo de significação e sua recepção, situando-os como parte da construção social. Segundo resumem Kress e van Leeuwen (2006), a Semiótica Social é a terceira escola semiótica que sucederam a primeira escola, denominada escola de Praga a partir da linguística estudada pelos Formalistas Russos; a segunda escola, denominada escola de Paris, marcada pela extensão das ideias de Saussure para os estudos em moda e fotografia (Barthes), cinema (Metz), música (Nattiez), entre outros. A Semiótica Social marca o início dos estudos aplicados a textos ao considerar todos os modos semióticos orquestrados em sua constituição.

Em 1988, Hodge e Kress lançam livro Social Semiotics, marcando uma nova fase para os estudos semióticos, muito influenciado pelas contribuições de Michael Alexander Kirkwood Halliday. Halliday (1978) traz, para os estudos da linguagem, a expressão Semiótica Social em sua obra Language as social semiotic: the social interpretation of language and meaning. Dez anos mais tarde, ao lançar a obra Social Semiotics, Hodge e Kress (1988) ressaltam que

\footnotetext{
Muitas pessoas contribuíram com ideias, críticas e materiais em vários estágios da lenta gestação deste livro, cuja ajuda agradecemos. De muitos escritores que nos influenciaram e que são mencionados em referências, gostaríamos de destacar M. A. K. Halliday, não apenas por seus textos teóricos, como Linguagem como Semiótica Social, mas por seus exemplos inspiradores como pesquisador, professor e explorador das funções sociais da linguagem (p. 9).
}

Ao demarcar a influência do pensamento hallidayano em seus trabalhos, Hodge e Kress trazem, para o centro da discussão, os desdobramentos da Linguística SistêmicoFuncional, cujo foco está centrado (i) nas funções sociais da linguagem, (ii) na noção de escolha do sistema de linguagem e (iii) as configurações de significado a partir do contexto. Hodge e Kress (1988) ampliam a compreensão de Halliday (1978) ao centrar nas práticas sociais de criação de significados de todos os tipos, sejam eles visuais, verbais ou aurais, ratificando as ideias hallidayanas de que existem muitos outros modos de significação em qualquer cultura que estão fora do reino da língua.

Adicionalmente, em relação à abordagem Semiótica Social Multimodal, Kress (2011) situa que 


\title{
PERcursos Linguísticos • Vitória (ES) •v. 11 •n. 29 • 2021 • ISSN: 2236-2592 • Dossiê temático $\bullet O$ texto na pesquisa e no ensino: conhecimentos, práticas e desafios na contemporaneidade •
}

\begin{abstract}
Uma abordagem Semiótica Social Multimodal fornece uma perspectiva mais rica sobre os muitos meios envolvidos na construção de significado e aprendizagem; em formas e formatos de conhecimento; nas muitas formas de avaliação; nas relações sociais [...]; na (auto-)construção da identidade; nos meios que são centrais no reconhecimento da agência e dos muitos tipos de trabalho semiótico (KRESS, 2011, p. $\left.208^{3}\right)$
\end{abstract}

Para o autor, a Semiótica multimodal comporta alguns aspectos:

$\checkmark$ Semiótica Social - Fornece um quadro teórico para enfocar todos os aspectos de construção de sentido: sobre os agentes que fazem signos complexos como textos; nos processos de construção de significado e nas entidades teóricas que estão envolvidas nisso - signo, texto, gênero, discurso, interesse, como exemplos;

$\checkmark$ Multimodalidade - centra-se nos meios materiais de representação, nos recursos para fazer textos: isto é, nos modos.

Essas duas características estão inteiramente interconectadas em todos os momentos, contudo, possuem suas respectivas distinções. Na visão de Kress (2011), as consequências educacionais de uma abordagem semiótica social multimodal derivam de ambos os aspectos e com os seus distintos focos. O termo multimodalidade ressalta a diversidade de recursos materiais além da fala e da escrita que as sociedades moldaram e que as culturas fornecem como meios para produção de significados. Nas palavras de van Leeuwen (2017), multimodalidade é “[...] o estudo de como significados podem ser construídos, e de fato são construídos em contextos específicos, com diferentes meios de expressão ou 'modos semióticos'” (p. $5^{4}$ ). Assim, ela foca nas características distintas dos diferentes modos. Não é uma teoria, embora sua compreensão traga um desafio para o lugar da linguagem e profundas implicações para pensar os significados, a representação e comunicação.

A Semiótica Social é uma teoria sobre a construção de significados em processos de interação na comunicação. Na visão de Kress (2011), é uma teoria sobre a criação de signos em todos os modos disponíveis em uma cultura. Logo, o signo é visto como um trabalho semiótico

\footnotetext{
${ }^{3}$ No original: "A multimodal social semiotic approach provides a richer perspective on the many means involved in making meaning and learning; on forms and shapes of knowledge; on the many forms of evaluation and assessment; on the social relations evident in pedagogy; on the (self-)making of identity and, in that, on the means that are central in the recognition of the agency and of the many kinds of semiotic work of learners in learning." (KRESS, 2011, p. 208).

${ }^{4}$ No original: "Multimodality is therefore the study of how meanings can be made, and actually are made in specific contexts, with different means of expression or 'semiotic modes' [...]" (VAN LEEUWEN, 2017, p. 5).
} 


\section{PERcursos Linguísticos • Vitória (ES) •v. 11 •n. 29 • 2021 • ISSN: 2236-2592 • Dossiê temático $\bullet O$ texto na pesquisa e no ensino: conhecimentos, práticas e desafios na contemporaneidade •}

dos agentes sociais. Portanto, a Semiótica Social lida com a avaliação do produtor do signo em relação ao ambiente de comunicação. Noutras palavras, lida com a avaliação retórica dos participantes, ocasião, objetos envolvidos ligados a práticas moldadas por relações de poder. A teoria inclui atenção aos meios de disseminação/circulação, ou seja, as mídias envolvidas. A ênfase recai, portanto, na produção de signo ao invés do uso do signo, visto que, para a perspectiva socialmente orientada, os signos são produzidos a cada interação e não usados. O ponto central da teoria está na visão de signo motivado, ou sejam a junção de forma e significado, que é produto da agência e do interesse do produtor. Esses aspectos ressaltam as perspectivas que norteiam a Semiótica Social Multimodal para o processo de produção de signos e, consequentemente, as implicações para se pensar o (hiper) texto, a sua produção e recepção.

\section{Multimodalidade, Texto e Hipertexto: Coisas distintas ou tudo a mesma coisa?}

A pergunta que intitula esta seção faz uma provocação para delimitarmos nossas lentes e dimensionar o olhar para os textos que se deflagram nas diversas práticas sociais de linguagem. Não estamos problematizando conceitos no intuito de criar dicotomias, mas buscamos compreender as interrelações que são estabelecidas e como podemos potencializar essas relações. Sabemos que vivemos em uma sociedade textualizada, leitura e escrita estão em toda parte e dialogamos com inúmeras interfaces semióticas. Nesse sentido, Cope e Kalantzis (2006) situam que "toda construção de significado é considerada multimodal, não podendo existir em uma única modalidade, mas tendo uma dela sempre predominante" (p. 9).

A partir dessas considerações, vemos que o termo multimodalidade ou multimodal parece ser recorrente para designar algo muito comum e característico da comunicação. Segundo Kress e van Leeuwen (2001), o termo virou até um modismo, estando em toda parte. Ele aparece na década de 90 em diferentes países com abordagens distintas, sendo impulsionado com publicações como a de Charles Goodwin (1998) sobre etnometodologia e análise da conversação para Journal of Pragmatics, em 1996, com as contribuições de Kress e van Leeuwen na obra Reading Images: The grammar of visual Design e em 2001 com a obra Multimodal Discourse.

Dada a recorrência do termo, Kress (2015) afirma que ele é oscilante ou ambíguo e até mesmo uma noção vaga para se referir ao que está externo, fora do mundo sociossemiótico. $\mathrm{Na}$ visão do autor, o uso do termo na área de Ciências Humanas e Sociais abrange um amplo espectro do que pode caracterizar "posições de senso comum" e "posições baseados na teoria" 


\section{PERcursos Linguísticos • Vitória (ES) •v. 11 •n. 29 • 2021 • ISSN: 2236-2592 • Dossiê temático $\bullet O$ texto na pesquisa e no ensino: conhecimentos, práticas e desafios na contemporaneidade •}

(p. 53). Ao usar a expressão "posições de senso comum", o autor cita trabalhos em que pesquisadores fazem ajustes para dar conta de alguns aspectos, deixando em proeminência as perspectivas teóricas existentes e suposições em vigor. Já "posições baseadas na teoria" integram a multimodalidade no quadro teórico que utilizam. Kress (2015) deixa claro seu posicionamento "baseado em teoria" para falar e pesquisar sobre agência, criação de significados, interesse, signos dentre outros. Logo, a teoria em que se baseia é a Semiótica Social, a qual trata da "criação de significado como criação de signos com todos os modos que estão disponíveis em uma cultura, onde a criação de signos é vista como o trabalho semiótico dos agentes sociais" (KRESS, 2011, p. 2095).

Ao delimitar um conjunto de reflexões epistemológicas e metodológicas no quadro da Semiótica Social, deparamo-nos com sua preocupação em discutir o processo de produção de signo (sign-making), significado (meaning making) e sua recepção, situando-os como parte da construção social. A Fig. 1, a seguir, mostra alguns aspectos importantes dentro da Semiótica Social.

Figura 1: Aspectos relacionados ao sentido no escopo da Semiótica Social

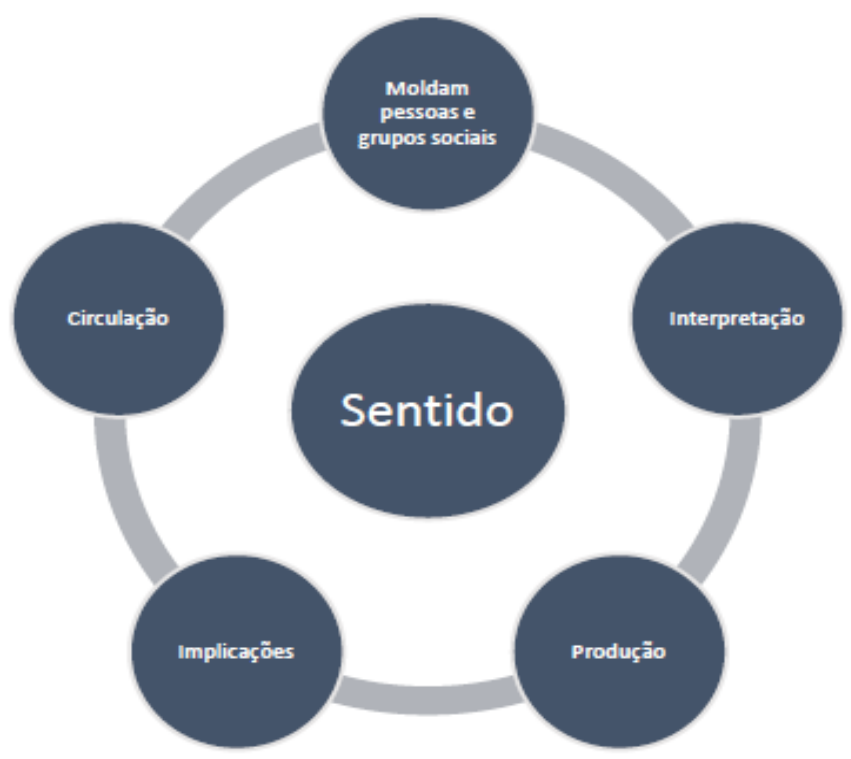

Fonte: elaboração das autoras

\footnotetext{
${ }^{5}$ No original: "it is a theory about meaning-making as sign-making with all the modes that are available in a culture, where sign-making is seen as the semiotic work of social agents." (KRESS, 2011, p. 209).
} 


\section{PERcursos Linguísticos • Vitória (ES) •v. 11 •n. 29 • 2021 • ISSN: 2236-2592 • Dossiê temático $\bullet O$ texto na pesquisa e no ensino: conhecimentos, práticas e desafios na contemporaneidade •}

Nessa perspectiva, observamos que usar o termo multimodalidade não se resume a adicionar outros modos dentro de uma mistura, é muito mais do que colocar a atenção em outros modos de produzir significados, pois as escolhas de um modo em detrimento de outro trazem implicações do que é e pode ser comunicado e aprendido. É elementar, no processo de produção de sentido, levar em consideração a circulação, a interpretação, as implicações dentro desse processo e como os significados moldam as pessoas e os grupos sociais.

Logo, é importante destacar conceitos-chaves que são delimitados no escopo da teoria que nos auxiliam olhar para o texto e sua composição multimodal, bem como refletir sobre processo de produção, circulação e interpretação de sentidos no contexto cultural. Ressaltamos que o intuito deste trabalho não consiste em compilar ou desenvolver tais conceitos problematizados no interior da teoria, dada a sua complexidade. Contudo, buscamos trazê-los para demarcar como direcionam para uma concepção de língua, sujeito, modos e recursos no processo de produção de sentido, mostrando a interdependência entre eles.

Figura 2: Conceitos-chave da Semiótica Social

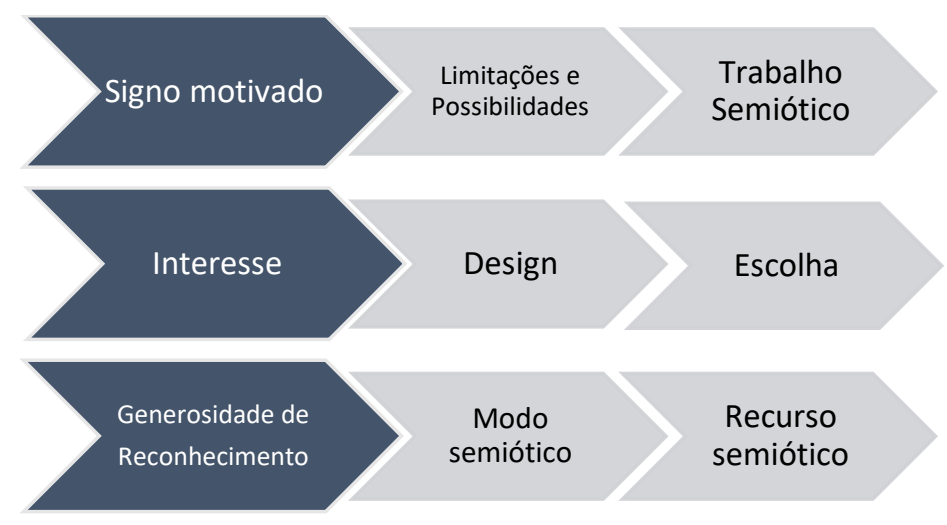

Fonte: elaboração das autoras

Dentre os conceitos elencados da Figura 2, Kress (1997) ao tratar do caráter não arbitrário do signo dentro do escopo da Semiótica Social Multimodal, enfatiza a noção de interesse e escolha de quem produz um signo por meio de uma relação motivada entre significante e significado, e, portanto, signos motivados”. Esse caráter motivado do signo demonstra sua gênese social, já que "o interesse dos produtores da representação/signo os leva a escolher um aspecto daquilo que querem representar, sendo este o critério naquele momento 


\section{PERcursos Linguísticos • Vitória (ES) •v. 11 •n. 29 • 2021 • ISSN: 2236-2592 • Dossiê temático $\bullet O$ texto na pesquisa e no ensino: conhecimentos, práticas e desafios na contemporaneidade •}

para a representação de um objeto; eles, então, escolhem a forma mais plausível que está disponível para sua representação" (KRESS, 1997, p. 14) ${ }^{6}$.

Em relação à generosidade de reconhecimento, ela está ligada aos aspectos que devemos reconhecer e aos quais devemos dar atenção no processo de produção de signo. Na percepção de Bezemer e Kress (2016), comunicação e aprendizagem estão intrinsicamente ligadas, constituem-se mutuamente e estão num domínio integrado de construção de significado. Assim, se os signos de aprendizagem não forem reconhecidos, eles não podem ser nem avaliados e nem, portanto, valorizados. Na visão dos autores, todos os signos "precisam ser levados a sério, independente de quem o produziu ou que modo foi utilizado" (p.5). Contudo, é necessária uma avaliação do ambiente em que o signo foi produzido ao invés de rotular a produção como "erro" ou produtor do signo como "incompetente". É importante investigar e estabelecer princípios semióticos aplicados pelos produtores do signo.

A rigor, todos esses conceitos vão delineando uma visão de texto dentro do escopo da teoria. Dentro do quadro teórico da Semiótica Social Multimodal, o texto é compreendido como objetos materiais, os quais são

\footnotetext{
[...] em parte, constitutivos das instituições sociais; proporcionam meios de "leitura" dos interesses e propósitos dos envolvidos na produção de textos em uma instituição; eles revelam os significados e os processos envolvidos em sua feitura. Os textos são resultados de processos iniciados e realizados por agentes sociais por razões sociais; e fornecem um meio de obter informações sobre esses processos e as finalidades dos agentes sociais (KRESS, 2011, p. $205^{7}$ )
}

As noções demarcadas colocam o texto como um artefato que se produz dentro de uma cultura, a partir dos modos e recursos que ela disponibiliza e do trabalho semiótico dos agentes sociais numa interação social que se materializa num conjunto multimodal. Nessa via, todos os significados que produzimos são complexos; essa projeção complexa de diferentes modos é vista como texto.

Ainda nessa direção conceitual, vários outros pesquisadores trazem uma visão que busca em grande medida, dialogar, complementar, ressaltar outros aspectos em relação à visão de texto. Ancorando-se nos estudos da Linguística Textual, Koch e Elias (2009) situam o texto como uma entidade multifacetada, fruto de um processo extremamente complexo de interação

\footnotetext{
${ }^{6}$ Tradução de: "The interest of makers of the representation/sign leads them to choose one aspect of the thing they want to represent as being criterial at that moment for the representation of an object; they then choose the most plausible form which is available to them for its representation." (KRESS, 1997, p. 14)

${ }^{7}$ No original: "Texts - as material objects - are in part constitutive of social institutions; they provide means of 'reading' the interests and purposes of those involved in the making of texts in an institution; they reveal the meanings and the processes involved in their making". (KRESS, 2011, p. 205).
} 


\title{
PERcursos Linguísticos • Vitória (ES) •v. 11 •n. 29 • 2021 • ISSN: 2236-2592 • Dossiê temático $\bullet O$ texto na pesquisa e no ensino: conhecimentos, práticas e desafios na contemporaneidade •
}

social de conhecimento da linguagem. A partir das contribuições e reflexões dos estudos da Semiótica Social e da Linguística Textual, Gualberto, Santos e Meira (2020) sintetizam a visão de texto:

\begin{abstract}
[...] a nossa compreensão de texto vai se constituindo, por meio do diálogo com as vozes de Beaugrande (1997), Cope e Kalantzis (2006) e Kress e van Leeuwen (2001), ao vislumbrá-lo como um evento comunicativo em que convergem ações linguísticas, culturais, sociais e cognitivas que vai se tecendo por uma malha de fios semióticos motivados, possibilitando novos designs, formas de interação e representação em um contexto comunicativo. Em outros termos, os sentidos vão se construindo em formas cada vez mais multimodais - nas quais modos representacionais interagem com padrões espaciais, táteis, gestuais, auditivos e orais de significação (p. 896)
\end{abstract}

Considerando a diversidade de conceitos sobre texto que vão se entrelaçando, podemos problematizar alguns questionamentos, baseados em Kress (2011 e 2015), para pensar a produção de sentido global do texto, tais como:

$\checkmark$ Como compreender o papel e a parcialidade de cada modo no trabalho semiótico?

$\checkmark$ Em nível macro, é possível olhar para o todo e ver as partes?

$\checkmark$ Em nível micro, é possível olhar a parcialidade de cada modo e perceber o todo?

$\checkmark$ Qual modo desempenha um papel mais "importante" em relação a outros?

$\checkmark$ Como cada modo contribui para o significado que está sendo construído?

$\checkmark$ Como os recursos semióticos estão disponíveis para os produtores de signos, e por quem?

Por meio desses questionamentos, podemos perceber a complexidade que reside no processo de composição e interpretação do texto, atribuindo sentido aos diferentes modos semióticos em eventos comunicativos, realizando, assim, uma integração. Para além dessas perguntas, é importante destacar as discussões que a noção de hipertexto traz dentro das concepções de texto que elencamos e o processo de produção e interpretação de sentido. Tal como a epígrafe de Koch (2005, p. 61) que abre esse trabalho "todo texto é um hipertexto", a autora acentua o caráter plurilinear do texto, considerando sua composição e a proposta de sentidos múltiplos.

Algumas características que marcam os textos trazem esse caráter hipertextual, seja impresso ou digital, evidentemente muito demarcado com as propiciações tecnológicas. Para Koch (2005), o hipertexto constitui-se de um suporte linguístico-semiótico hoje intensamente para estabelecer relações virtuais desterritorializadas, marcado por uma escritura nãosequencial e não linear e possibilita ao leitor virtual um acesso ilimitado de outros textos. Noutros termos, Marcuschi (1999) afirma que hipertexto, "trata-se de um processo de leitura e 


\section{PERcursos Linguísticos • Vitória (ES) •v. 11 •n. 29 • 2021 • ISSN: 2236-2592 • Dossiê temático $\bullet O$ texto na pesquisa e no ensino: conhecimentos, práticas e desafios na contemporaneidade •}

escrita multilinearizado, multissequencial e não determinado, realizado em um novo espaço o ciberespaço" (p.1). Para o autor, a novidade propriamente dita está na tecnologia, o que permite integrar de modo eficaz elementos que no texto impresso s estão sob a forma de notas, citações bibliográficas, referências, imagens, diagramas, fotos, "linearizando o deslinearizado e deslinearizando o linerarizado" (p.11).

Em suma, Koch (2005) delineia algumas das principais características para o hipertexto:

Figura 3: Características do hipertexto
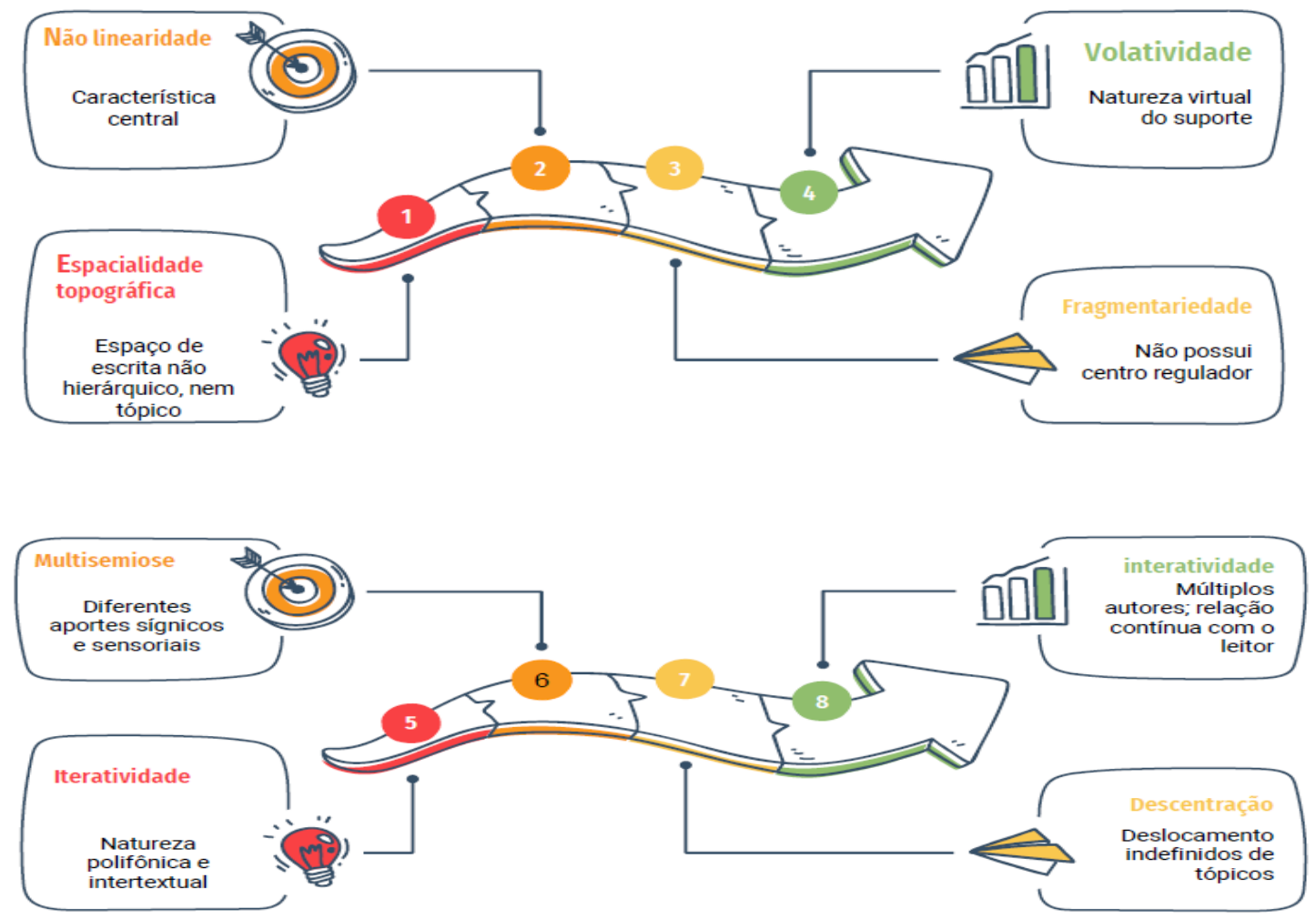

Fonte: baseado em Koch (2005, p. 64)

Dentro desse escopo, Menezes e Nascimento (2009), ao recuperar o histórico do conceito, retomam a visão Ted Nelson (2007), demarcando sua visão sobre design, estruturas e conexões de documentos, situando que as ideias humanas se manifestam como texto, conexões, diagramas e a forma como armazená-los e apresentá-los é um assunto crucial para a civilização. Esse histórico, na visão dos autores, já resolve a polêmica entre os que defendem o caráter hipertextual do pensamento (COSCARELLI, 2002; MARCUSCHI, 2005) e os que não veem uma diferença acentuada entre hipertexto eletrônico e impresso (KOCH, 2005; COSCARELLI, 2002). 


\title{
PERcursos Linguísticos • Vitória (ES) •v. 11 •n. 29 • 2021 • ISSN: 2236-2592 • Dossiê temático $\bullet O$ texto na pesquisa e no ensino: conhecimentos, práticas e desafios na contemporaneidade •
}

A forma de armazenamento e conexão entre as informações no hipertexto se dá por meio de links que são os "elos" ou os "nós" que remetem às informações relacionadas. De acordo com Lévy (1993)

\begin{abstract}
Tecnicamente, um hipertexto é um conjunto de nós ligados por conexões. Os nós podem ser palavras, páginas, imagens, gráficos ou partes de gráficos, sequências sonoras, documentos complexos que podem eles mesmos ser hipertextos. Os itens de informação não são ligados linearmente, como em uma corda com nós, mas cada um deles, ou a maioria, estende suas conexões em estrela, de modo reticular. Navegar em um hipertexto significa, portanto, desenhar um percurso em uma rede que pode ser tão complicada quanto possível. Porque cada nó pode, por sua vez, conter uma rede inteira (p.33).
\end{abstract}

As palavras de Lévy (1993) demarcam a estética de composição dos hipertextos e dimensionam como os caminhos de leitura podem ser trilhados. Esses caminhos serão delineados em decorrência do interesse do leitor, do impacto da multimodalidade como os recursos e modos disponíveis, considerando os princípios e entidades composicionais, os valores de informação (zonas de imagem) como saliência, molduras etc. Desse modo, vemos como a multimodalidade impacta no design dos hiper(textos), o que requer do leitor cuidado e análise para delinear os caminhos de leitura, para que a orquestração dos modos semióticos seja coerente e compatível com a perspectiva do todo do hipertexto, o que pode resultar, segundo Xavier (2002), um deslocamento ou desvio no sentido da incongruência e da insustentabilidade dos posicionamentos assumidos em um texto eletrônico.

Agasalhando as palavras de Marcuschi (1999), a leitura do hipertexto é como uma viagem por trilhas. Ela nos obriga a ligar esses nós para formar redes de sentido. A ligação desses nós consiste em olhar para as partes e construir o sentido do todo, ou seja, atentar-se para parcialidade de cada modo, o papel que cada um desempenha em relação a outros modos e como os recursos semióticos vão sendo articulados no trabalho semiótico de produção sentido (meaning making) do texto. Desse modo, um dos desafios para os estudos da linguagem é ver como os leitores operam com textos múltiplos bem como dimensionar os desdobramentos da visão plurilinear do texto na sua construção e, consequentemente, na leitura. Logo, é elementar uma lente multimodal para a leitura e análise dos textos.

\section{Análise Multimodal: alguns percursos metodológicos}

Considerando a importância de uma lente multimodal para olhar para os (hiper)textos, questionamo-nos: O que seria uma análise multimodal? Como fazer análise Multimodal? Para 


\section{PERcursos Linguísticos • Vitória (ES) •v. 11 •n. 29 • 2021 • ISSN: 2236-2592 • Dossiê temático $\bullet O$ texto na pesquisa e no ensino: conhecimentos, práticas e desafios na contemporaneidade •}

que fazer uma análise multimodal? Menos preocupados em ter respostas objetivas e mais engajados em compreender o trabalho semiótico, as escolhas realizadas dentro do (hiper)texto e os desdobramentos para a produção de sentidos na leitura e na escrita é elementar olhar para o (hiper)texto e compreender o papel de cada modo e como pode contribuir para construção de significados e a materialidade discursiva. Ressaltamos que esse trabalho transcende uma visão descritiva que se apoia em observar a articulação dos modos e o que eles podem dizer em termos de significados funcionais (representacionais, interacionais ou composicionais), conforme explicitam Kress e van Leeuwen (2006) na Gramática do Design Visual. Uma análise multimodal de texto implica:

$\checkmark$ Reconhecer a diferença entre os modos semióticos, a sua disponibilidade em cada comunidade comunicativa e a motivação de suas escolhas dentro do contexto cultural;

$\checkmark$ Reconhecer as diferenças e especificidades em cada situação contextual em que os modos e recursos são combinados para produzir sentidos;

$\checkmark$ Atentar para todos os modos, com o mesmo nível de detalhe.

Buscando ancorar a teoria em exemplos de práticas sociais de linguagem que se deflagram cotidianamente, Kress (2010) situa que [...] "o banal, o cotidiano e o normal é sempre o melhor local [...]" (p. 67 $7^{8}$ ). Logo, o nosso olhar precisa partir daquilo que nos rodeia, que desperta nossa curiosidade, das nossas práticas cotidianas. Por meio dessa perspectiva, desse banal, que nossas indagações ganham espaço e permitem-nos pensar sobre os dados, como coletá-los, como analisá-los etc. É importante compreender as preferências modais de determinadas culturas e os propósitos comunicacionais ensejados em cada situação comunicativa. Além desse horizonte, podemos investigar qual referencial teórico/teorias pode nos oferecer sustentação para compreender esses dados. A abordagem multimodal oferece um inventário analítico para investigar os meios materiais de representação, os modos, contudo, ela em si não dá envergadura para o mapeamento dos sentidos que são mediados por meio de sistemas e recursos semióticos, tendo em conta as dinâmicas culturais e ideológicas nas quais eles estão imersos. Por isso, já que a multimodalidade não é uma teoria, toda análise multimodal precisa elucidar a teoria que fundamenta esta forma de olhar para os modos semióticos de um

\footnotetext{
${ }^{8}$ Tradução de: "The banal, the everyday and unremarkable is always the best site to anchor theory". (KRESS, 2010, p. 67).
} 


\section{PERcursos Linguísticos • Vitória (ES) •v. 11 •n. 29 • 2021 • ISSN: 2236-2592 • Dossiê temático $\bullet O$ texto na pesquisa e no ensino: conhecimentos, práticas e desafios na contemporaneidade •}

texto. No contexto deste artigo, trabalhamos com a multimodalidade a partir da Semiótica Social. Esse percurso metodológico é esboçado na Fig. 4.

Figura 4: Percursos Metodológicos

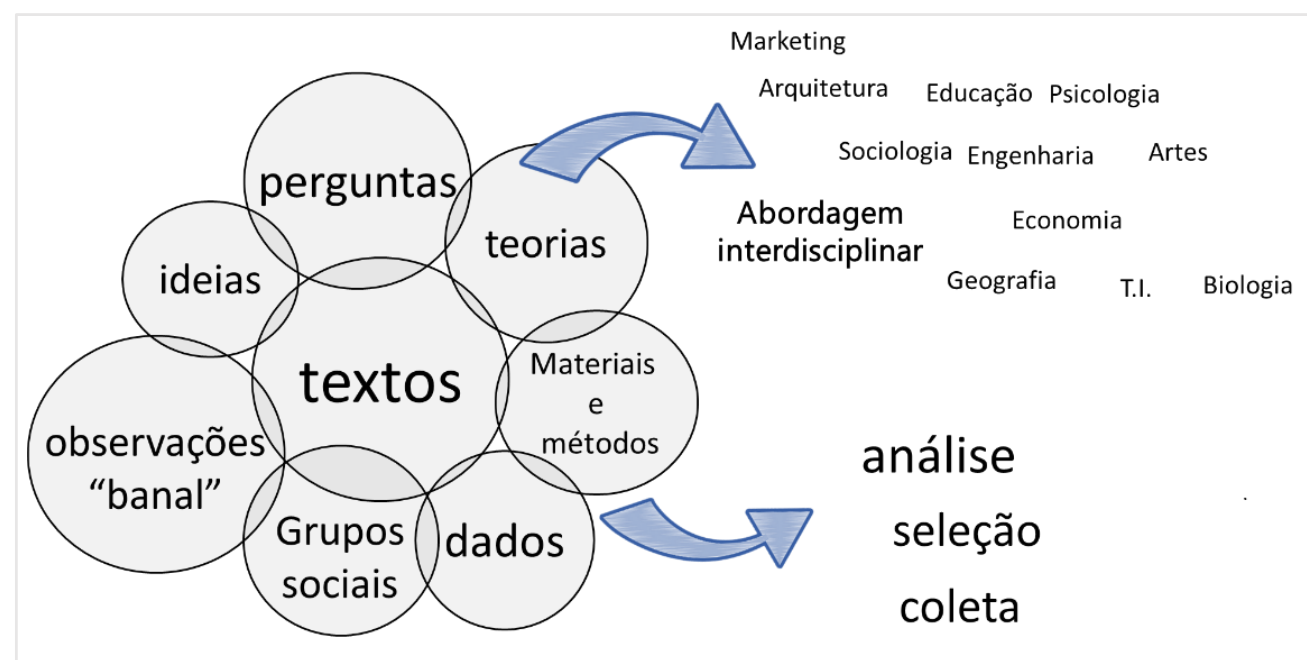

Fonte: elaboração das autoras

A Fig. 4 traz o texto como ponto em comum em todo o processo de análise. A partir dos textos com os quais interagimos em nosso cotidiano, refletimos e construímos ideias, que nos movem a elaborar perguntas. Para responder a esses questionamentos, precisamos buscar teorias relacionas às áreas envolvidas. Por exemplo, se o texto analisado é um filme, é necessário pesquisar autores das áreas de cinema, música, entre outras. Se é um jogo eletrônico, outros campos de conhecimento estão envolvidos. Cabe ao pesquisador selecionar essas teorias e estabelecer relações com seu objeto de estudo e com as questões sociais envolvidas (poder, identidade etc).

Assim, numa análise multimodal sob a ótica da Semiótica Social, nossas indagações partem da teia social em que estamos imersos. Investigamos, com uma visão holística, fenômenos por meio da seleção, coleta e análise de dados que possam contribuir com o entendimento do tecido social. Nas palavras de Kress (2010), “o social é motor da mudança comunicacional/semiótica, para a constante reprodução de recursos culturais/semióticos; e para 


\section{PERcursos Linguísticos • Vitória (ES) •v. 11 •n. 29 • 2021 • ISSN: 2236-2592 • Dossiê temático $\bullet O$ texto na pesquisa e no ensino: conhecimentos, práticas e desafios na contemporaneidade •}

a produção do novo" (p. $35^{9}$ ). Nesses moldes, a análise é mais que uma descrição de modos que compõem um determinado (hiper)texto. É preciso pensar em como se articulam, como se dá a sua composição; uma análise multimodal precisa contribuir com a dinâmica dos sentidos e com as dinâmicas culturais, em compreender as necessidades/objetivos de comunicação bem como suas mudanças. Logo, é necessário refletir sobre as escolhas motivadas, os signos criados, o design dos textos, os modos e recursos que vão tecendo esses textos, quais necessidades comunicativas precisam ser alcançadas dentro de um contexto cultural etc. A partir dessas compreensões e investigações, podemos sair de uma postura descritiva da multimodalidade e chegar a uma análise mais profunda das camadas dos textos.

\section{(In)conclusões}

As considerações tecidas até aqui buscam fomentar algumas reflexões sobre multimodalidade e (hiper)textos, pensando a leitura e escrita em tempos de mudanças constantes na paisagem semiótica, para desenvolver caminhos em nossas pesquisas. Sem a pretensão de ter respostas exatas ou objetivas, nosso intuito residiu em ressaltar os desafios para a linguística de como os leitores operam com textos múltiplos bem como os desdobramentos de uma visão plurilinear do texto e sua construção.

Elencamos um conjunto de conceitos da teoria da Semiótica Social Multimodal e como eles nos direcionam para olhar para a produção de signo (sign-making) e sentidos (making meaning), compreendendo a dinâmica da distribuição de poder e agências de controle - cruciais para a compreensão dos ambientes de comunicação. Mais do que reafirmar a multimodalidade presente nos hipertextos, nos questionamos sobre os movimentos de leituras e as trilhas que seguimos para criar conexões, ligar os "nós" e formar redes de sentido. Observamos que, num cenário em que o (hiper)texto pode ser produzido em ambientes digitais marcados pela não linearidade, fragmentalidade, interatividade, dentre outros aspectos, vale questionar, segundo Kress (2010), a noção de autoria, que vai além de uma visão anacrônica de plágio, carecendo de teorização. Na perspectiva do autor, é necessário observar os movimentos colaborativos de escrita bem como observar os rearranjos no poder que podem ser conceituados como uma mudança de estruturas de poder vertical para horizontal, de relações hierárquicas (pelo menos aparentemente) mais abertas, relações mais participativas, capturadas em muitos aspectos da comunicação contemporânea.

\footnotetext{
9 Tradução de: "the social is the motor for communicational/ semiotic change; for the constant remaking of cultural/semiotic resources; and for the production of the new" (KRESS, 2010, p. 35).
} 


\section{PERcursos Linguísticos • Vitória (ES) •v. 11 •n. 29 • 2021 • ISSN: 2236-2592 • Dossiê temático $\bullet O$ texto na pesquisa e no ensino: conhecimentos, práticas e desafios na contemporaneidade •}

Distante de chegar a uma conclusão, temos um caminho longo a percorrer para ir compreendendo a dinâmica das mudanças na comunicação e os desdobramentos para a produção escrita e de leitura dos (hiper)textos. Logo, se atentarmos para as mudanças sociais, e para os textos como efeitos dessas mudanças, temos um ponto de partida para as investigações e compreensão da relação dialética entre comunicação e sociedade.

\section{Referências}

BAKHTIN. M. O problema do texto na linguística, na filosofia e em outras ciências humanas. In: Estética da criação verbal. Trad. Paulo Bezerra.4 ed. São Paulo: Martins Fontes, 2006b, pp.307-335[1959-1961].

BARBOSA. V. S. Multimodalidade e Letramento Visual: uma proposta de intervenção pedagógica para integrar as habilidades de ler e ver no processo de ensino e aprendizagem de inglês como língua estrangeira. Tese (doutorado) - Universidade Estadual do Ceará, Centro de Humanidades, Programa de Pós-Graduação em Linguística Aplicada, Fortaleza, 2017.

BEZEMER, J.; KRESS, G. Multimodality, Learning and Communication. London: Routledge, 2016.

COLLOW, J. Literacy and the visual: broadning our vision. English Teaching: Practice and Critique, vol. 4, n.1, May, 2005, pp 6-19.

COSCARELLI, C. V. Entre textos e hipertextos. In: COSCARELLI, C. V. (Org.). Novas tecnologias, novos textos, novas formas de pensar. Belo Horizonte: Autêntica, 2002.

GOODWIN, C. Action and embodiment within situated human interaction. Journal of Pragmatics 32 (2000) p. 1489-1522. Disponível em: 〈http: www.elsiever.nl/locate/pragma〉

GUALBERTO. C. Multimodalidade em livros didáticos de língua portuguesa: uma análise a partir da semiótica social e da gramática do design visual. Tese (doutorado) - Universidade Federal de Minas Gerais, Faculdade de Letras, 2016.

GUALBERTO. C.; SANTOS, Z. Multimodalidade no contexto brasileiro: um estado de arte. Revista D.E.L.T.A., 35-2, 2019 (1-30).

GUALBERTO, C.; SANTOS, Z.; MEIRA, A. C. Multimodal metaphors: from language as a condition to text to the notion of texture as a meaning-making semiotic resource. Revista de Estudos da Linguagem, n. 28, v. 2, 2020.

HALLIDAY, M. A. K.; HASAN, R. Cohesion in English. London: Longman, 1976.

HALLIDAY, M. A. K. Language as social semiotic. London: Edward Arnold, 1978. 


\section{PERcursos Linguísticos • Vitória (ES) •v. 11 •n. 29 • 2021 • ISSN: 2236-2592 • Dossiê temático $\bullet O$ texto na pesquisa e no ensino: conhecimentos, práticas e desafios na contemporaneidade •}

HEBERLE, V. M.; ABREU, B. B. Investigating Multimodality: An analysis of students' diary journals. Revista do Programa de Pós-Graduação em Linguística Aplicada da UECE Linguagem em Foco - volume 3. N. 5, ano 2011.

HODGE, R.; KRESS, G. Social Semiotics. New York: Cornell University Press, 1988.

KOCH, I. G. V. A construção de sentidos no hipertexto: demandas linguísticas e cognitivas. In: ENCONTRO NACIONAL SOBRE HIPERTEXTO, 1, 2005, Recife. Anais. Disponível em: <www.ufpe.br/hipertexto2005/TRABALHOS/ Ingedore.htm>. Acesso em: 26 set. 2007.

KOCH, I. G. V. Desvendando os segredos do texto. 4 ed. São Paulo: Cortez, 2005.

KOCH, I. G. V.; ELIAS, V. M. Ler e escrever: estratégias de produção textual. São Paulo: Contexto, 2009.

KRESS, G. Before Writing. London: Routledge, 1997.

KRESS, G. Multimodality: A Social Semiotic Approach to Contemporary Communication. London: Routledge, 2010.

KRESS, G. Discourse Analysis and Education: A Multimodal Social Semiotic Approach. In: ROGER, Rebecca (Org). An Introduction to Critical Discourse Analysis in Education. London:

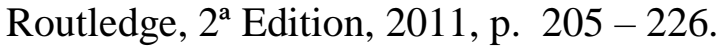

KRESS, G. Semiotic work: Applied Linguistics and a social semiotic account of Multimodality. AILA Review 28 (2015), 49-71.

KRESS, G.; BEZEMER, J. Writing in a multimodal world of Representation. In BEARD, R.; MYHILL, D.; NYSTRAND, M.; RILEY, J. (Eds.). SAGE Handbook of Writing Development (pp. 167-181). London: Sage, 2009.

KRESS, G.; VAN LEEUWEN, T. Multimodal Discourse: The modes and media of contemporary communication. London: Arnold, 2001.

KRESS, G.; VAN LEEUWEN, Theo. Front Pages: (The critical) analysis of newspaper layout. In BELL, Allan; GARRET, Peter. (Eds.) Approaches to media discourse. Blackwell Publishing, 1998. p. 186-219.

LÉVY, Pierre. As tecnologias da inteligência: o futuro do pensamento na era da informática. Rio de Janeiro: Editora 34, 1993.

MARCUSCHI, L. A. Heráclito e o hipertexto: o logos do hipertexto e a harmonia do oculto. In: ENCONTRO NACIONAL SOBRE HIPERTEXTO, 1, 2005, Recife. Anais. Disponível em: <www.ufpe.br/hipertexto2005/TRABALHOS/Marcuschi\%20(Confer\%EAncia.htm>. Acesso em: 27 out. 2008.

MARCUSCHI, L. A. Linearização, cognição e referência: o desafio do intertexto. Comunicação apresentada no IV Colóquio da Associação Latinoamericana de Analistas do Discurso. Santiago, Chile, Abril, 1999. 


\section{PERcursos Linguísticos • Vitória (ES) •v. 11 •n. 29 • 2021 • ISSN: 2236-2592 • Dossiê \\ temático $\bullet O$ texto na pesquisa e no ensino: conhecimentos, práticas e desafios na contemporaneidade •}

MENEZES, V.; NASCIMENTO, M. (Org.) Sistemas adaptativos complexos: lingua(gem) e aprendizagem. Belo Horizonte: Faculdade de Letras/FAPEMIG, 2009.

NELSON, T. H. Transliterature. 2007. Disponível em: <http://transliterature.org/>. Acesso em: 2 set. 2019.

PAIVA, V. L .M. O; NASCIMENTO, M. Texto, hipertexto e a (re)configuração de (com)textos. In: LARA, G. M. P. (Org.). Lingua(gem), texto, discurso: entre a reflexão e a prática. v. 1. Rio de Janeiro: Lucerna; Belo Horizonte: FALE/UFMG, 2006. p. 155-179.

PAIVA, V. L. M. O; NASCIMENTO, M. Hipertexto e Complexidade. Linguagem em (Dis)curso, Palhoça, SC, v.9, n.3, p. 519-547, set/dez. 2009.

PIMENTA, S. M. O. P. O signo da receptividade: uma visão sócio-construcionista da interação. Belo Horizonte: Faculdade de Letras da UFMG, 2006.

SANTOS, Z. B. A representação e a interação verbal e visual: uma análise de capas e reportagens de revistas na perspectiva da Gramática Sistêmico-Funcional e da Gramática do Design Visual. Tese (doutorado) - Universidade Federal de Minas Gerais, Faculdade de Letras, 2013.

VAN LEEUWEN, T. Multimodal Literacy. Viden Om Literacy, n. 21, 2017.

XAVIER, A. C. O hipertexto na sociedade de informação: a constituição do modo de enunciação digital. Tese (Doutorado em Linguística) - IEL, UNICAMP, 2002. 


\title{
O DEBATE SOBRE O PEDIDO DE IMPEACHMENT DE BOLSONARO: POLÊMICA, ARGUMENTAÇÃO E ESTRATÉGIAS DE TEXTUALIZAÇÃO
}

\section{THE DEBATE ABOUT BOLSONARO'S IMPEACHING REQUEST: POLEMIC, ARGUMENTATION AND TEXTUALIZATION STRATEGIES}

\author{
Bharbara Bonelle de Sousa ${ }^{1}$ \\ Gabriela Malini de Aguiar ${ }^{2}$ \\ Rivaldo Capistrano Júnior ${ }^{3}$
}

\begin{abstract}
RESUMO: Propomos neste artigo uma discussão sobre como a polêmica em sua vertente argumentativa (AMOSSY, 2017) se materializa e se atualiza em comentários (postagens reativas) da rede social Facebook. Para tanto, selecionamos, na página UOL do Facebook, no dia 17 de março de 2021, a Webnotícia "OPOSIÇÃO ENTREGA PEDIDO IMPEACHMENT DE BOLSONARO À CÂMARA DE DEPUTADOS e constituímos como objeto de análise dezesseis (16) comentários a essa postagem motivadora. Desse modo, considerando a relevância de fenômenos textuais para a investigação da polêmica em sua vertente argumentativa (CAVALCANTE et al., 2020, 2021), elegemos como categorias analíticas a referenciação e a intertextualidade. Com base nas análises empreendidas, podemos concluir que referentes (objetos de discurso) e as relações intertextuais i) contribuem para a instauração, manutenção e atualização da interação polêmica e ii) constituem-se, no jogo polêmico, em relevantes estratégias de violência verbal, reforçando o caráter dicotômico da polêmica.
\end{abstract}

PALAVRAS-CHAVE: Argumentação polêmica. Referenciação. Intertextualidade. Comentários do Facebook.

ABSTRACT: We propose in this article a discussion on how the polemic in its argumentative aspect (AMOSSY, 2017) materializes and is actualized in comments (reactive posts) of the social network Facebook. To do so, we selected, on the UOL page, on March 17, 2021, the Webnotice "OPPOSITION SENDS REQUEST FOR IMPEACHMENT OF BOLSONARO TO THE CHAMBER OF DEPUTES, and constituted as object of analysis sixteen (16) comments to this motivating post. Thus, considering the relevance of textual phenomena for the investigation of controversy in its argumentative aspect (CAVALCANTE et al., 2020, 2021), we chose referencing and intertextuality as analytical categories. Based on the analysis undertaken, we can conclude that referents (objects of discourse) and intertextual relations i) contribute to the establishment, maintenance and updating of the polemical interaction and ii) constitute, in the

\footnotetext{
${ }^{1}$ Doutoranda do Programa de Pós-Graduação em Linguística da Universidade Federal do Espírito Santo, Centro de Ciências Humanas e Naturais, Vitória, Espírito Santo, Brasil. E-mail: bharbara bonelles@hotmail.com

${ }^{2}$ Graduanda em Letras Português-Espanhol na Universidade Federal do Espírito Santo, Centro de Ciências Humanas e Naturais, Vitória, Espírito Santo, Brasil. E-mail: gabrielamalinideaguiar@hotmail.com

${ }^{3}$ Docente do Departamento de Línguas e Letras e do Programa de Pós-Graduação em Linguística (UFES), Vitória, ES, Brasil. E-mail: r.capistrano@uol.com.br.
} 


\section{PERcursos Linguísticos • Vitória (ES) •v. $11 \bullet$ •n. 29 • 2021 • ISSN: 2236-2592 • Dossiê temático $\bullet O$ texto na pesquisa e no ensino: conhecimentos, práticas e desafios na contemporaneidade •}

polemical game, relevant strategies of verbal violence, reinforcing the dichotomous nature of the polemic.

KEYWORDS: Polemic argumentation. Referencing. Intertextuality. Facebook comments.

\section{Introdução}

De acordo com Amossy (2017), as redes sociais digitais constituem-se num espaço de discussões de temas de interesse da sociedade, o que muito favorece o surgimento de controvérsias e, consequentemente, de interações conflituosas. Desse modo, buscamos analisar interações polêmicas em comentários da rede social digital Facebook. Para isso, elegemos como tema da postagem motivadora a Webnotícia "Oposição entrega pedido de impeachment de Bolsonaro à Câmara de Deputados", vinculada na página do UOL Notícias, e, como corpus de análise, comentários (postagens reativas) feitos a essa postagem.

O tema da postagem motivadora mostra-se controverso e relevante para a análise da modalidade argumentativa polêmica (AMOSSY, 2017), uma vez que coloca no centro das interações a polarização entre opositores e bolsonaristas (simpatizantes de Bolsonaro).

Como base teórico-metodológica, elegemos estudos sobre a argumentação, mais especificamente, da modalidade polêmica (AMOSSY, 2017; CAVALCANTE et al 2020), sobre a violência verbal (CABRAL, 2019 , 2018) e sobre a referenciação (KOCH e ELIAS, 2016; CAVALCANTE et al., 2017) e a intertextualidade (CAVALCANTE et al., 2021).

$\mathrm{Na}$ interface estabelecida, assumimos que fenômenos textuais, tais como a referenciação e a intertextualidade, são motivados por uma tentativa de explicar como o sujeito age sobre o seu dizer, reelaborando-o a todo instante, negociando-o com os prováveis interlocutores, para buscar atender a seus propósitos e que os diferentes modos como os textos se repetem uns nos outros atuam como vetor para que se construa pontos de vistas e sua relação com crenças, valores e posicionamentos. (CAVALCANTE et al., 2020).

Organizamos o trabalho em quatro seções. Na primeira seção, discutimos a função estratégica da argumentação na modalidade polêmica. Na segunda, tratamos da referenciação e da intertextualidade, com base nos pressupostos da Linguística Textual (LT), e destacamos suas funções argumentativas. Finalmente, na terceira, analisamos comentários do Facebook e buscamos evidenciar a função da atividade referencial e da intertextualidade no gerenciamento verbal de conflitos polêmicos. 


\section{PERcursos Linguísticos • Vitória (ES) •v. $11 \bullet$ n. 29 • 2021 • ISSN: 2236-2592 • Dossiê temático $\bullet O$ texto na pesquisa e no ensino: conhecimentos, práticas e desafios na contemporaneidade •}

\section{Polêmica como modalidade argumentativa}

Todo discurso é um ato de linguagem (CHARAUDEAU, 2015), baseado no princípio de alteridade (ato de linguagem se realiza numa troca com outro, não há "eu" sem "tu"), de influência (busca-se atingir o interlocutante) e de regulação (os parceiros procedem à regulação do jogo de influências). Dessa forma, existe uma espécie de polemicidade que é constitutiva do discurso, bem como uma argumentatividade que lhe é intrínseca, pois todo discurso carrega determinados valores axiológicos e certos posicionamentos a ele associados.

Nessa perspectiva, Amossy (2011), ao estudar a argumentação nos discursos, abandona a noção estritamente retórica, na qual a figura do locutor tinha um papel determinante na adesão do auditório a uma tese, e passa uma "concepção mais larga de argumentação, entendida como a tentativa de modificar, de reorientar, ou mais simplesmente, de reforçar, pelos recursos da linguagem, a visão das coisas da parte do alocutário.” (AMOSSY, 2011, p. 130)

A autora sugere que as práticas discursivas sejam analisadas em um continuum de argumentatividade em que os discursos, integrados em práticas sociais, apresentam uma dimensão argumentativa a eles associada e que poucos discursos têm realmente uma visada argumentativa, uma vez que empregam o modo persuasivo de argumentar.

Nesse sentido, a argumentatividade é inerente ao discurso. Frequentemente, tenta-se persuadir um auditório a aderir a uma tese, modificando a orientação do modo particular de ver as coisas. Assim, diz-se que há uma visada argumentativa quando o objetivo é convencer o locutor e uma dimensão argumentativa quando se tem a intenção de orientá-lo.

Diferentemente da concepção retórica de argumentação que visava influenciar os modos de pensar e de ver pela utilização do discurso, com vistas ao acordo, conforme PERELMAN E OLBRECHTS-TYTECA ([1970], 2020), AMOSSY $(2008,2017)$ defende que todo discurso busca, ao menos, orientar os modos de ver e de pensar do auditório e, assim, influenciá-lo.

Diz-se, então, que a concepção de argumentação de Amossy (2008) é modular e varia num continuum, podendo os textos apresentar diferentes possibilidades de modalidade argumentativa. Por modalidades argumentativas, entende-se como sendo os "tipos de troca argumentativa que, atravessando os gêneros do discurso, modelam a forma como a argumentação funciona num quadro tanto dialogal quanto dialógico" (AMOSSY, 2008, p. 232). Em vista disso, há diferentes formas de estrategicamente tentar influenciar o outro. 


\section{PERcursos Linguísticos • Vitória (ES) •v. 11 •n. 29 • 2021 • ISSN: 2236-2592 • Dossiê temático $\bullet O$ texto na pesquisa e no ensino: conhecimentos, práticas e desafios na contemporaneidade •}

Essas diferentes maneiras de argumentar são caracterizadas com base nos seguintes parâmetros: i) os papéis desempenhados pelos participantes no dispositivo enunciativo (parceiros, adversários); ii) a maneira pela qual ocorre a tentativa de persuasão (apaixonada, racional, colaborativa, instrutiva); e iii) o modo como o interlocutor é concebido (ser de razão e/ ou de sentimento, aluno ou discípulo, cúmplice ou rival etc.). Amossy (2008.p. 233-234) apresenta algumas possíveis modalidades, apontando gêneros do discurso que as privilegiam, conforme elencamos a seguir:

a) Modalidade demonstrativa: é aquela em que o locutor busca a adesão do(s) interlocutor(es) apresentando uma tese/ uma opinião, em um discurso monogerido ou dialogal, com base em raciocínio apoiado em provas. São exemplos de gêneros nos quais essa modalidade é recorrente: o editorial, o artigo de opinião, o debate eleitoral, etc.;

b) Modalidade patêmica: é a modalidade caracterizada fundamentalmente pelo apelo explícito aos sentimentos do auditório para angariar sua adesão à tese ou ao ponto de vista apresentado. Estes gêneros privilegiam a modalidade patêmica: o apelo à ajuda humanitária, o poema lírico, a declaração de amor, entre outros;

c) Modalidade pedagógica: é a da transmissão de um saber por um locutor autorizado a fazê-lo a um auditório que se encontra na condição de aprendiz. O modo de manifestação dessa troca também pode ser, como nas modalidades anteriores, monogerido ou poligerido. Gêneros como o manual escolar, a aula, a palestra, a história de literatura infantil, entre outros, são exemplos prototípicos de ocorrência dessa modalidade;

d) Modalidade de coconstrução: é aquela em que os participantes levantam conjuntamente uma questão e, da mesma forma, buscam resolvê-la, por meio de uma interação dialogal. A reunião profissional, a reunião de colegiado, a conversação familiar são exemplos de gêneros que privilegiam essa modalidade;

e) Modalidade negociada: é o tipo de troca em que os participantes debatem sobre um problema que os divide, mas para o qual estão dispostos a buscar e a estabelecer um acordo, por meio de uma negociação das divergências. As negociações comerciais, as trocas diplomáticas, as audiências de conciliação, entre outros, são gêneros que privilegiam a modalidade negociada;

f) Modalidade polêmica: caracteriza-se pela confrontação de teses antagônicas, em que se tenta desacreditar o opositor, mas também se tenta atingir o terceiro, que acompanha a interação à distância. Gênero como os comentários on-line, os debates são característicos da modalidade polêmica. 


\section{PERcursos Linguísticos • Vitória (ES) •v. $11 \bullet$ n. 29 • 2021 • ISSN: 2236-2592 • Dossiê temático $\bullet O$ texto na pesquisa e no ensino: conhecimentos, práticas e desafios na contemporaneidade •}

A modalidade polêmica foi a única das seis a receber de Amossy (2017) um tratamento metodológico especifico. Tratamos dela na próxima seção.

\section{A polêmica no espaço público}

A polêmica é um debate em torno de uma questão da atualidade, de interesse público, que comporta os anseios da sociedade mais ou menos importantes numa dada cultura (AMOSSY, 2017, p.49). A primeira marca da polêmica como debate da atualidade está na oposição de discurso. Esse antagonismo de opiniões é a condição essencial para a instauração da polêmica.

Essa condição supõe um debate que permite a cada um expor e defender seu ponto de vista, refutando e desqualificando o ponto de vista do outro. Essa condição se enquadra na retórica argumentativa. Assim, argumentamos quando temos um desacordo de opiniões, fazendo com que cada um justifique seu posicionamento.

Nesse contexto, de acordo com Amossy (2017), a polêmica intensifica o confronto que dá origem à atividade argumentativa. Em outras palavras, a polêmica é caracterizada como uma modalidade argumentativa construída pela retórica do dissenso, emergindo de eventos concretos, únicos e irrepetíveis.

Nessa modalidade argumentativa, caracterizada como uma interação fortemente antagonista que atravessa os gêneros e discursos atuam um Proponente e um Opositor, cujos propósitos não são convencer-se mutuamente, mas atrair a adesão de um Terceiro, que é levado a aderir ao ponto de vista, e não o adversário; assim a polêmica tem também por função atrair a adesão do Terceiro (AMOSSY, 2017).

Portanto, os traços que colocam a polêmica numa ancoragem conflitual se traduzem pela dicotomização, pela polarização e pela desqualificação do outro, e de forma secundária, pela violência verbal, e pelo pathos (emoção).

Nesse contexto, a primeira característica da polêmica é o choque de opiniões dicotômicas. Se há opiniões contraditórias é porque há uma dicotomização de posições. Enquanto no debate tenta-se chega a uma possível solução, a dicotomização torna o debate difícil, às vezes impossível de se resolver. Assim, a busca pelo acordo nem sempre é possível. Isso quer dizer que, em sociedades democráticas pluralistas, a polêmica preenche funções sociais importantes, 


\section{PERcursos Linguísticos • Vitória (ES) •v. $11 \bullet$ •n. 29 • 2021 • ISSN: 2236-2592 • Dossiê temático $\bullet O$ texto na pesquisa e no ensino: conhecimentos, práticas e desafios na contemporaneidade •}

precisamente em razão do que é geralmente criticado nela: uma gestão verbal do conflito realizada sob o modo de dissensão. (AMOSSY, 2017, p. 12)

Na polêmica há também uma distinção entre os actantes e os atores, havendo uma operação de polarização. A polarização, segunda característica da polêmica, se difere da dicotomização, pois, enquanto uma exacerba as oposições até torná-las inconciliáveis, a polarização realiza agrupamentos em campos adversos entre participantes, ela é de ordem social.

A polarização provoca um movimento de reagrupamento por identificação, e para se consolidar apresenta de forma pejorativa os outros. Ela supõe um inimigo em comum e tem como estratégia a subversão, fazer o outro levar o descrédito, definindo-o como um defensor de um ponto de vista caracterizado por sua má-fé e más intenções. Essa desqualificação da tese outro se configura como a terceira característica definidora da modalidade polêmica.

O discurso polêmico é um discurso desqualificador que gera o descrédito do adversário e o discurso que ele presumidamente sustenta. A desqualificação do outro pode ser compreendida sob duas formas: uma centrada no logos e outra, no ethos. Na primeira há uma tentativa em desmerecer o discurso do adversário pela inadmissibilidade de sua tese. Contudo, há uma necessidade de reconhecimento pelo auditório do discurso atacado pelo Proponente. Já a segunda maneira, centrada no ethos do Oponente, consiste em o Proponente depreciar o adversário atacando a sua imagem. (MACEDO e CAVALCANTE, 2019)

Assim, uma confrontação dicotomizada de teses antagônicas e a polarização que ela desencadeia supõem sujeitos profundamente implicados no debate. Isso quer dizer que o locutor coloca marcas de subjetividade no seu discurso e ele toma veemente uma posição afirmando, negando, interrogando, exclamando. A emoção no discurso é um resultado da implicação do locutor. O engajamento emocional se faz acompanhar de uma tentativa de tocar o coração dos leitores/espectadores.

O papel da emoção na polêmica deve ser revisto, assim como a questão da violência verbal. Amossy (2017) assegura que a violência verbal não uma condição suficiente, nem mesmo necessária para a instauração da polêmica, configurando-se mais como um acessório do que um traço definitório. À vista disso, a violência vernal se dá não como uma modalidade argumentativa, mas como um registro discurso. E assim, como o pathos manifesta e intensifica a dicotomização, a polarização e o descrétido que fundamentam os embates públicos.

Assim, nem toda violência verbal se configura como polêmica, pois não é uma condição essencial da polêmica, mas um traço opcional. Os procedimentos discursivos que criam uma impressão de violência verbal só se tornam polêmica quando são utilizados no contexto de 


\section{PERcursos Linguísticos • Vitória (ES) •v. $11 \bullet$ •n. 29 • 2021 • ISSN: 2236-2592 • Dossiê temático $\bullet O$ texto na pesquisa e no ensino: conhecimentos, práticas e desafios na contemporaneidade •}

uma confrontação de opiniões contraditórias. Assim, expressões avaliativas de desvalorização, como os insultos e ofensas se apresentam com meio de reforçar a visão negativa do outro, congelando-o no lado oposto, revelando traços de polarização do debate. (CABRAL, 2018)

Nessa perspectiva, as redes sociais digitais possuem um alto nível de trocas comunicativas por meio de comentários, favorecem a instaurações de interações polêmicas e possuem grande potencial para abordar as chamadas "discussões inflamadas". Esses espaços têm sido "palco para discussões violentas, de fortes controvérsias nas quais imperam discursos agressivos, cujos movimentos são marcados pela desqualificação do outro" (CABRAL, 2019, p.423).

Assim, alguns aspectos que configuram a interação ganham destaque nas estratégias de desqualificação do outro, que induzem, muitas vezes, à violência verbal em textos de ambientes digitais on-line, e, por conseguinte, nas interações polêmicas.

Convém ressaltar que a busca pelo acordo nem sempre é possível, pois, em sociedades democráticas pluralistas, essa busca ameaça a harmonia social, tendo em vista que "é, indubitavelmente, o conflito de opiniões que predomina no espaço democrático contemporâneo, o qual respeita a diversidade e a liberdade de pensamento e de expressão" (AMOSSY, 2017. p. $13)$.

Nesse sentido, o fato de ser uma "gestão verbal do conflito realizada sob o modo da dissensão" (AMOSSY, 2017. p. 12) faz com que a polêmica permita aos cidadãos viverem juntos sem apelar à violência física, gerindo o desacordo pela interação verbal.

De um modo geral, assumimos que a polêmica só pode ser examinada na interação, no acontecimento dos textos e também na forma como alguns deles evocam o saberes de outros. Portanto, é na interação e nas intertextualidades pressupostas que todos os atores da polêmica se colocam nos papéis sociais de Proponente, Oponente e Terceiro.

\section{Referenciação, intertextualidade e argumentação}

A argumentação é uma atividade presente em toda interação humana. Desse modo, os sujeitos das interações são tidos como entes discursivos que produzem textos a partir de posições determinadas institucionalmente, o que evidencia ser o uso da linguagem revelador das "relações que desejamos estabelecer, efeitos que pretendemos causar [...]", conforme defendem Koch e Elias (2016, p. 13).

No que diz respeito à inter-relação entre argumentação e referenciação, entendemos que, considerando os estudos de Koch e Elias (2016) e Cavalcante et al. (2020), a apresentação 


\section{PERcursos Linguísticos • Vitória (ES) •v. $11 \bullet$ •n. 29 • 2021 • ISSN: 2236-2592 • Dossiê temático $\bullet O$ texto na pesquisa e no ensino: conhecimentos, práticas e desafios na contemporaneidade •}

e a retomada de objetos de discurso (ou referentes) são realizadas negociadamente pelos sujeitos sociais em interações situadas, o que evidencia pontos de vista e assinala orientações argumentativas. Assim sendo, a referenciação é uma atividade argumentativa, e o referente (aquilo de que se vai tratar) é construído na argumentatividade, a partir do momento em que são introduzidos e retomados no texto (KOCH e ELIAS, 2016; CAVALCANTE et al., 2017).

Desse modo, a introdução referencial cumpre a função de apresentar o referente no texto, e as anáforas, por sua vez, retomam direta ou indiretamente o referente introduzido, mantendo-o e recategorizando-o (CAVALCANTE et al., 2017). Por sua vez, a dêixis, outro processo referencial, de acordo com Cavalcante (2012), aponta para a localização e a identificação de diversos aspectos (pessoas, objetos, eventos, processos).

Esses processos referenciais, como já dissemos, são decisivos para a orientação argumentativa (argumentatividade) que o sujeito intenciona imprimir ao texto, uma vez que os sujeitos operam diversas escolhas em relação ao que lhes parece ser a mais adequada ao seu projeto de dizer. Em outras palavras, os sujeitos marcam seus posicionamentos e orientam argumentativamente o locutor por meio de expressões nominais referenciais.

No que se refere à intertextualidade, assumimos o pressuposto sociocognitivo, como bem destaca Cavalcante (2021), de que há diversificados diálogos entre textos específicos, entre gêneros e marcas estilísticas autorais. Dessa maneira, tanto na produção quanto na recepção de um texto, os sujeitos recorrem ao conhecimento prévio de outros textos.

Nessa perspectiva, as diferentes formas com que os textos se repetem uns nos outros agem na construção de pontos de vistas e em sua relação com crenças, valores e posicionamentos. Assim, um texto de um determinado gênero pode fazer uma remissão a um fato já divulgado em textos anteriores, e, consequentemente pode trazer à tona uma dicotomização de teses ao abordar uma questão da atualidade, de interesse público. (CAVALCANTE et al., 2021).

Portanto, consoante Cavalcante et al (2020), assumimos que a modalidade polêmica nasce a partir das relações intertextuais, e só se efetiva na consideração do diálogo entre textos.

Dito isso, na próxima seção, passamos a analise de vinte comentários, extraídos da página do UOL do Facebook.

A interação polêmica em comentários do Facebook: uma proposta de análise 


\section{PERcursos Linguísticos • Vitória (ES) •v. $11 \bullet$ •n. 29 • 2021 • ISSN: 2236-2592 • Dossiê temático $\bullet O$ texto na pesquisa e no ensino: conhecimentos, práticas e desafios na contemporaneidade •}

Nosso corpus $^{4}$ foi veiculado na página UOL do Facebook. Trata-se da Webnotícia, intitulada "OPOSIÇÃO ENTREGA PEDIDO IMPEACHMENT DE BOLSONARO À CÂMARA DE DEPUTADOS".

Como os comentários eram muito numerosos, utilizamos dois critérios de seleção. $\mathrm{O}$ primeiro foi a seleção dos 20 (vinte) comentários mais recentes, na ocasião da coleta. Posteriormente, o segundo critério foi a seleção de comentários nos quais era evidente o uso de referentes (objetos de discurso) na confrontação de teses antagônicas e na desqualificação do opositor.

Dessa forma, chegamos a dezesseis (16) comentários, assim organizados textualmente: um $(01)$ comentário (C 1) com mais dois (02) comentários a comentário (CC 1.1 e CC 1.2$)$ e um (01) comentário (C 2) com mais doze (12) comentários a comentário (CC 2.1, CC 2.2, CC 2.3, CC 2.4, CC 2.5, CC 2.6, CC 2.7, CC 2.8, CC 2.9, CC 2.10, CC 2.11 e CC 2.12).

Figura 01: postagem motivadora

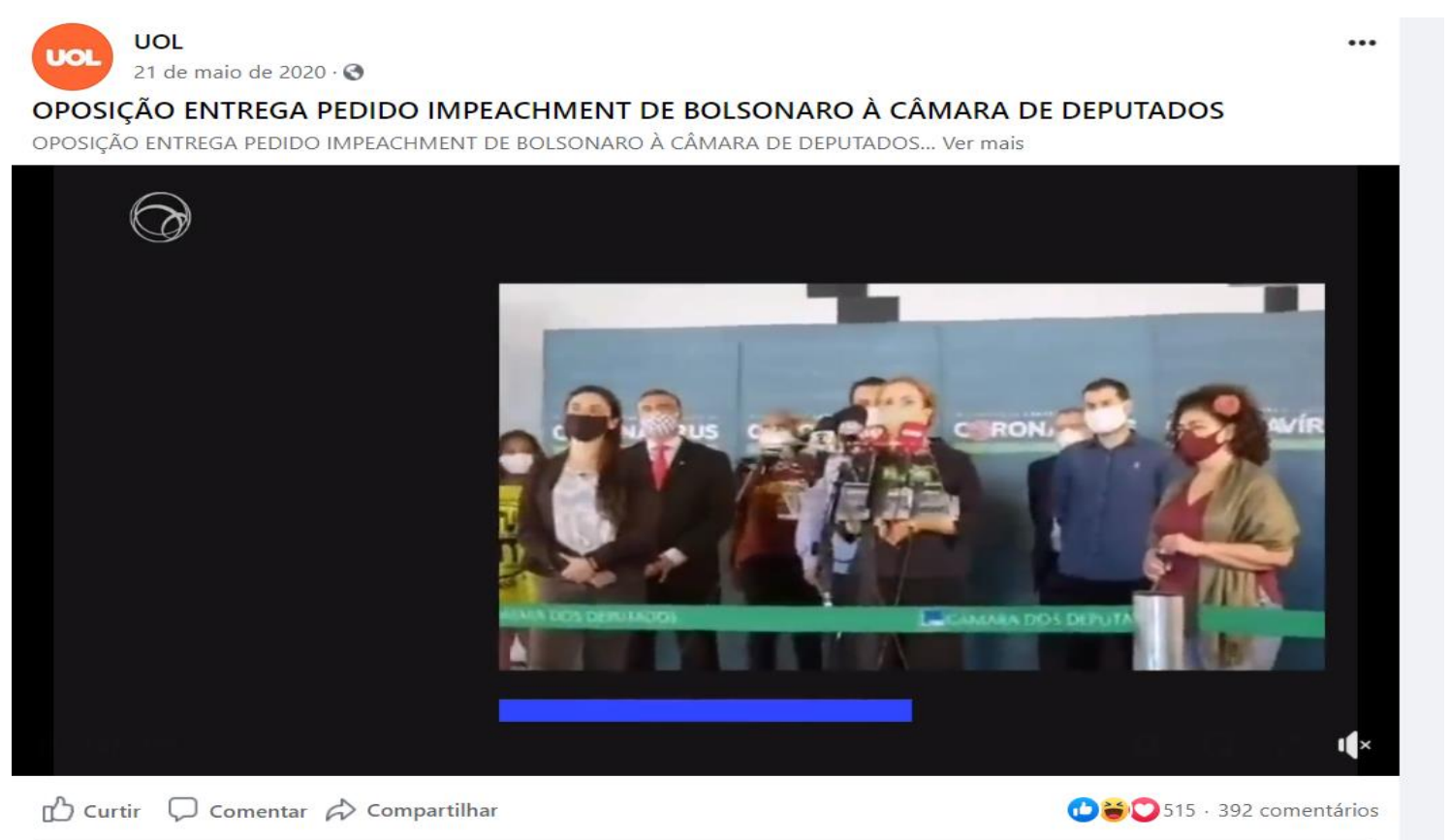

Fonte: https://www.facebook.com/21539158238/videos/2630608990540699/

Na figura 01, temos a Webnotícia, constituída por um título verbal escrito, “Oposição entre pedido de impeachment de Bolsonaro à Câmara de Deputados", e por um trecho de vídeo, com a duração de 2 minutos e 50 segundos, no qual Gleisi Hoffmann, Deputada e Presidente Nacional do Partido dos Trabalhadores (PT), questiona a competência do Presidente Jair

\footnotetext{
${ }^{4} \mathrm{O}$ corpus aqui analisado foi extraído da Pesquisa de Iniciação Científica, realizada por Gabriela Malini de Aguiar, bolsista PIBIC, em 2020/2021, sob a orientação do Prof. Dr. Rivaldo Capistrano Júnior.
} 


\section{PERcursos Linguísticos • Vitória (ES) •v. $11 \bullet$ •n. 29 • 2021 • ISSN: 2236-2592 • Dossiê temático $\bullet O$ texto na pesquisa e no ensino: conhecimentos, práticas e desafios na contemporaneidade •}

Messias Bolsonaro para governar o Brasil. No trecho do vídeo, o pré-candidato à prefeitura da cidade de São Paulo Guilherme Boulos defende que o dever de um Presidente, na área da saúde, é salvar vidas.

Como vimos anteriormente, a modalidade polêmica nasce a partir das relações intertextuais, e só se efetiva na interação entre sujeitos e no diálogo entre textos. Nesse sentido, a postagem motivadora teve origem a partir de uma notícia a respeito da entrega do pedido impeachment de Bolsonaro à Câmara de Deputados, por parte da oposição.

Ainda em relação à postagem motivadora, podemos observar que a página do UOL faz uso da intertextualidade por copresença (CAVALCANTE et al, 2020 e CAVALCANTE et al., 2021), como a citação do trecho em vídeo que demonstra partidos, entidades e movimentos sociais, entregando o pedido de impeachment do presidente do Brasil à Câmara. É a partir da utilização desse recurso que a polêmica se atualiza nessa postagem.

Em um segundo caso, a polêmica se atualiza a partir do pronunciamento televisivo na qual, políticos, entidades e movimentos sociais pedem a cassação do mandato de Jair Bolsonaro. Nesse contexto, os apelos intertextuais são de natureza muito mais ampla, porque correspondem a alusões, como referências vagas a diversos textos/situações inespecíficos que abordam a incapacidade administrativa e humana de governar o país.

E, por fim, a polêmica se atualiza na interação realizada por meio dos comentários da postagem reatiava, instaurando, assim, outra ocorrência intertextual por meio da metatextualidade, ou seja, o comentário de um texto por outro texto.

No que tange à análise da atualização da polêmica nos comentários, com respaldo em Amossy (2017), assumimos o posicionamento de que a Webnotícia, em si mesma, não instaura nenhuma dicotomização de uma interação polêmica. Isso ocorre nas trocas interacionais que acontecem em espaços de comentários, postagens reativas, nos quais os internautas assumem seus papéis sociais, ou seja, o de proponente, o de oponente e o de terceiro.

Feitas essas considerações, passamos à análise dos comentários.

Figura 02: Comentário 1 e comentários a comentários 


\section{PERcursos Linguísticos • Vitória (ES) •v. 11 •n. 29 • 2021 • ISSN: 2236-2592 • Dossiê temático $\bullet O$ texto na pesquisa e no ensino: conhecimentos, práticas e desafios na contemporaneidade •}

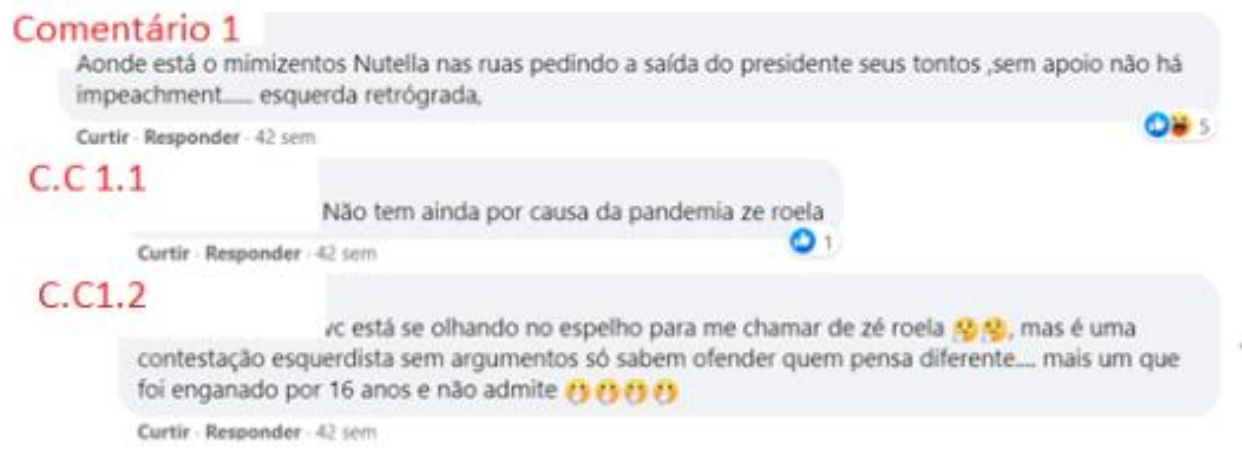

Fonte: https://www.facebook.com/21539158238/videos/2630608990540699/

A imagem 02 contém uma unidade de interação, na qual C1 faz um comentário, C.C. 1.1 (@C1) faz uma réplica e C.C.1.2 (@CC1.1), uma tréplica.

Podemos notar que a caraterística da dicotomização se evidencia nos comentários com a radicalização em polos opostos, na qual temos internautas que assumem diferentes posicionamentos. Um dos lados dessa polarização assume a extrema esquerda e o papel de Proponente e o outro, a extrema esquerda e o papel de Oponente.

Assim, C1 se lança como proponente da questão que norteia o embate: a falta de articulação da esquerda com líderes de outros partidos políticos, segundo C1. Podemos destacar, nas escolhas linguísticas de CI, uma orientação avaliativa de caráter negativo na qual por meio da introdução referencial "o mimizentos Nutella" - isto é, aquele que reclama muito, que vive resmungando, chorando - e do referente "esquerda retrógrada" o internauta busca desqualificar o oponente.

Por sua vez, C.C 1.1 responde ao comentário de C1 e assume o papel de oponente, argumentando que a pandemia inviabilizou uma possível aliança da oposição com dissidentes do bolsonarismo e por meio da anáfora "ze roela" busca desqualificar $\mathrm{C} 1$. A escolha lexical feita por C.C 1.1 evidencia o propósito de instigar a polêmica, tendo em vista o uso de palavras de cunho mais agressivo.

Já em C.C 1.2 há uma tréplica em que há uma desqualificação do adversário, no caso o adversário C.C 1.1, quando há a resposta: "vc está se olhando no espelho para me chamar de ze roela". O usuário enfatiza mais essa desqualificação quando chama o outro de "esquerdista", que é visto socialmente como um sentido ruim, por representar um extremo. Dando seguimento às ofensas, o usuário diz que o outro foi enganado por 16 anos, que, no caso, foi enganado pelo lado esquerdo. 


\section{PERcursos Linguísticos • Vitória (ES) •v. $11 \bullet$ •n. 29 • 2021 • ISSN: 2236-2592 • Dossiê temático $\bullet O$ texto na pesquisa e no ensino: conhecimentos, práticas e desafios na contemporaneidade •}

Figura 03: Comentário 02 e comentários a comentários

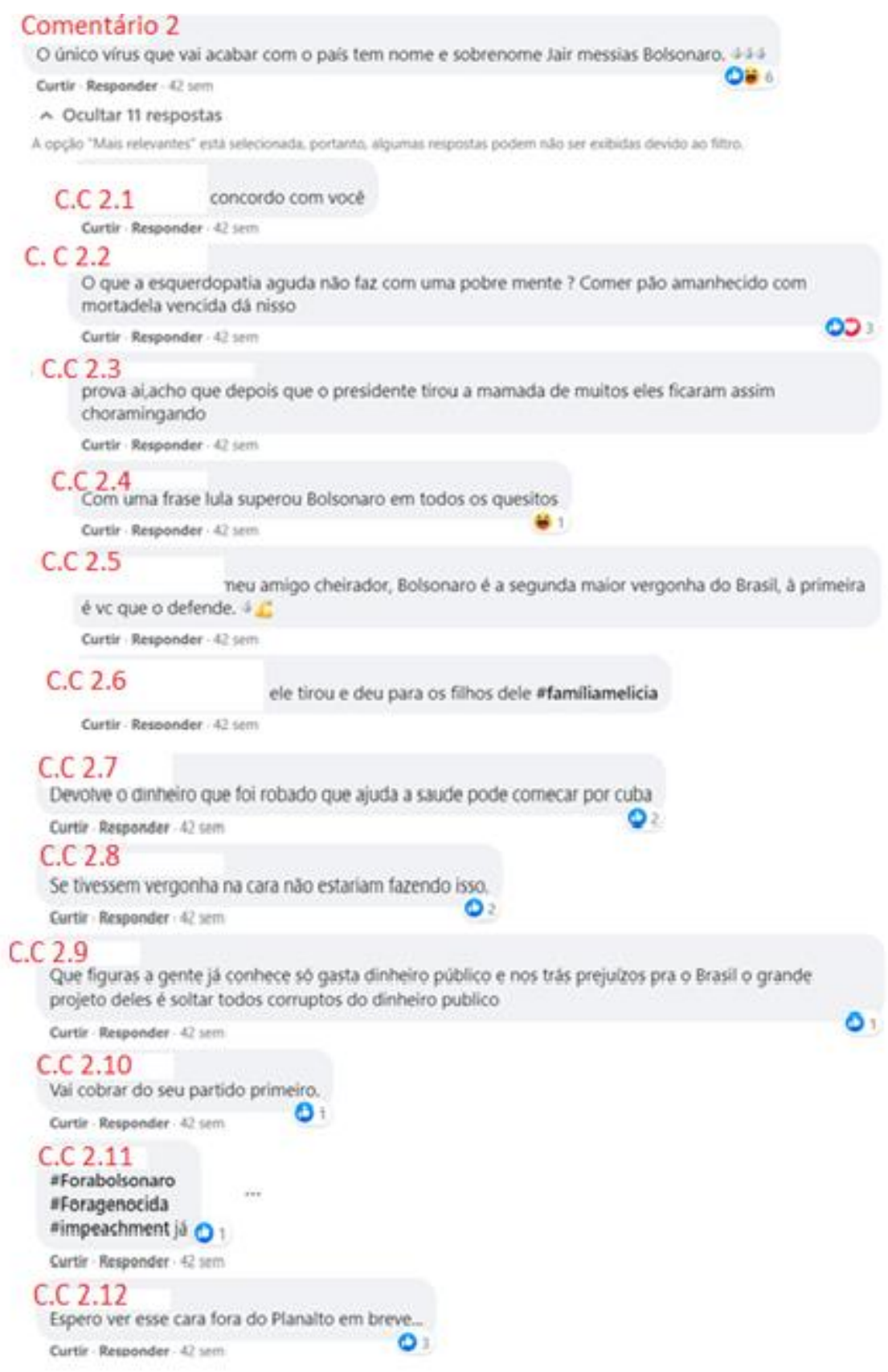

Fonte: https://www.facebook.com/21539158238/videos/2630608990540699/

No comentário 2, o internauta introduz o referente Jair Messias Bolsonaro, que, comparado a um vírus a ser eliminado, é considerado a raiz de todos os males que assolam o Brasil. Ao comparar o presidente a um vírus a ser eliminado, o internauta está fazendo intertextualmente alusão ao Coronavírus, agente causador da Covid-19. Isso contribui para a materialização do antagonismo nos comentários que se seguem. 


\section{PERcursos Linguísticos • Vitória (ES) •v. $11 \bullet$ n. 29 • 2021 • ISSN: 2236-2592 • Dossiê temático $\bullet O$ texto na pesquisa e no ensino: conhecimentos, práticas e desafios na contemporaneidade •}

Assim, esse comentário é desencadeador de uma interação polêmica em que atores sociais se polarizam em dois agrupamentos por identificação, os quais, por sua vez, atualizam visões dicotomizadas: um de opositores do presidente; outro de apoiadores.

No comentário a comentário 2.1, o internauta expressa concordância com o que foi dito no comentário 02 , mantendo a visão sobre o referente focalizado.

No comentário a comentário 2.2, os referentes "esquerdopatia aguda" e "pão amanhecido com mortadela vencida" buscam deslegitimar o grupo opositor, rebaixando-os e até buscando colocá-los fora da disputa. Para tanto, o internauta faz uso do recurso da intertextualidade para fazer alusão a uma expressão muito utilizada por simpatizantes da extrema direita para se referir aos petistas. $\mathrm{O}$ termo está ligado a um boato de que aos militantes petistas era dado sanduiches de pão com mortadela nos protestos e passeatas. Assim, nesse comentário, temos uma remissão operada pela parte verbal ao termo "mortadela".

Desse modo, por meio dessas expressões referenciais, o internauta, em C.C. 2.2, busca insultar o grupo adversário, invalidando o ponto de vista dos internautas, expresso no comentário 02 e em C.C 2.1. Trata-se do ataque ad hominem (AMOSSY, 2017), que busca desacreditar o grupo de opositores ao governo, no caso, apoiadores e eleitores do Partido dos Trabalhadores (PT).

O comentário a comentário 2.3 é uma réplica ao que disse o internata no Comentário 2 e faz, por meio da anáfora "o presidente", menção a Jair Bolsonaro. Por sua vez, o referente "mamada" estabelece uma relação intertextual por alusões amplas e desqualifica o grupo de opositores ao governo, referente inferencialmente instaurado por meio da anáfora indireta "eles".

A postagem reativa C.C. 2.4 introduz o referente Lula, qualificado como superior ao Bolsonaro, que, inferencialmente, é considerado inferior, o que constitui numa estratégia de desprestígio.

Nessa sequência, o comentário de C.C 2.5 promove a inflamação da interação polêmica, na qual o proponente estabelece uma desqualificação do adversário, sendo também uma violência ad hominem, visto que chama quem defendeu o presidente da república Jair Bolsonaro de cheirador, sendo contrário a um posicionamento favorável ao atual presidente.

Em C.C 2.6, há um posicionamento contrário à família de Bolsonaro, chamada de familiamilicia.

$\mathrm{Na}$ sequência, a análise dos próximos comentários também põe em evidência e atualizam o embate político entre duas frentes ideológicas: apoiadores do Presidente (C.C.2.7, 


\section{PERcursos Linguísticos • Vitória (ES) •v. 11 •n. 29 • 2021 • ISSN: 2236-2592 • Dossiê temático $\bullet O$ texto na pesquisa e no ensino: conhecimentos, práticas e desafios na contemporaneidade •}

\section{C.C. 2.8 , C.C. 2.9 e C.C. 2.10 ) e contrários a ele (C.C. 2.11, C.C. 2.12).}

Em C.C. 2.7, há uma crítica ao Partido dos Trabalhadores (PT) na medida em que esse concentrou verbas para Cuba na vez de seus mandatos. Portanto, esse proponente se coloca a favor do presidente Jair Bolsonaro.

Em C.C. 2.8, por meio do dêitico textual "isso", que, do ponto de vista textualdiscursivo, não só faz o apontamento ao vídeo, mas também encapsula seu conteúdo, há uma adesão ao dito em C.C. 2.7, uma vez que as pessoas que estão aspirando ao impeachment não têm vergonha na cara.

Em C.C. 2.9 e C.C. 2.10, novamente, há uma adesão ao dito em C.C. 2.7 e uma busca a desqualificação do interlocutor.

Já em C.C. 2.11, temos uma sequência de hashtags, referentes que fazem alusão a um posicionamento favorável ao que foi proposto no vídeo: \#forabolsonaro, \#foragenocida, \#impechment já. As hastags nos dão pistas para a formação da polarização no espaço público.

E, com o mesmo posicionamento do comentário a comentário 2.11, temos o comentário a comentário 2.12 que faz uma afirmação que condiz com um posicionamento favorável ao que se tem no vídeo, quando esse diz: "Espero ver esse cara fora do Planalto já".

\section{Considerações Finais}

Neste trabalho, buscamos evidenciar a interface possível entre a Linguística Textual e a Teoria da argumentação nos discursos (AMOSSY, 2017, 2018). Nesse sentido, critérios de análise da Linguística Textual, tais como a referenciação e a intertextualidade, podem ser convocados para a análise da modalidade polêmica.

Os resultados apontam que i) as interações polêmica se dão nos comentários, ou seja, nos textos que comentam o a postagem motivadora; ii) os referentes constituem-se em relevantes estratégias para deflagrar a violência verbal, evidenciando a dicotomia entre os pólos em discussão, iii) a modalidade polêmica tem origem a partir das relações intertextuais e só se concretiza com base no diálogo entre textos, uma vez que os comentários que atualizam teses dicotômicas citam, parafraseiam, aludem a outros textos.

Além disso, a violência verbal tem a função de reforçar e de aglutinar grupos antagônicos aos quais pertencem cada internauta; no caso, opositores e simpatizantes de Bolsonaro. Esse antagonismo engendrado a partir de pontos de vista dicotômicos tem origem em fatos ocorridos e em relações intertextuais. 


\section{PERcursos Linguísticos • Vitória (ES) •v. $11 \bullet$ n. 29 • 2021 • ISSN: 2236-2592 • Dossiê temático $\bullet O$ texto na pesquisa e no ensino: conhecimentos, práticas e desafios na contemporaneidade •}

\section{Referências}

AMOSSY, Ruth. A argumentação no discurso. São Paulo: Contexto, 2018.

AMOSSY, Ruth. Apologia da polêmica. São Paulo: Contexto, 2017.

AMOSSY, Ruth. Argumentação e análise do discurso: perspectivas teóricas e recortes disciplinares. Tradução Eduardo Lopes Piris e Moisés Olímpio Ferreira. EID\&A, Ilhéus, 1, Nov. 2011.

AMOSSY, Ruth. As modalidades argumentativas do discurso. In: LARA, Gláucia; MACHADO, Ida; EMEDIATO, Wander (Orgs.). Análises do discurso hoje, vol. 1. Rio de Janeiro: Nova Fronteira, 2008, p. 231-254.

CABRAL, Anal Lúcia Tinoco. Violência verbal e argumentação nas redes sociais: comentários no Facebook. Calidoscópio, v. 17, p. 416-432, 2019. Disponível em: $<$ http://revistas.unisinos.br/index.php/calidoscopio/article/view/cld.2019.173.01>. Acesso em: 28 set. 2021.

CABRAL, Anal Lúcia Tinoco; LIMA, Nelci Vieira de. Interações conflituosas e violência verbal nas redes sociais: polêmica em comentários no Facebook. (Con)Textos Linguísticos, v. 12, p. $\quad$ 39, 2018. Disponível em: $<$ https://periodicos.ufes.br/contextoslinguisticos/article/view/20626>. Acesso em: 28 set. 2021. CHARAUDEAU, Patrick. Discurso das mídias. São Paulo: Contexto, 2015.

CAVALCANTE, Mônica Magalhães. Revisitando os fatores de textualidade. II Ciclo de Conferência GEPEL-UFF. YouTube. Publicado pelo canal GEPEL-UFF, 2021. 1 vídeo (1h36min). Disponível em: $<$ https://www.youtube.com/watch?v=Ji_jw8Ld-jc $>$. Acesso em 29 set. 2021.

CAVALCANTE, Mônica Magalhães et al. O caráter interacional e intertextual da argumentação polêmica. Revista (Con)Textos Linguísticos, v. 15, n. 31, p. 48-65, 2021. Disponível em:

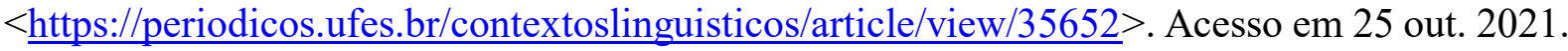
CAVALCANTE, Mônica Magalhães et al. Linguística Textual e Argumentação. Campinas, SP: Pontes Editores, 2020. 
PERcursos Linguísticos • Vitória (ES) •v. 11 •n. 29 • 2021 • ISSN: 2236-2592 • Dossiê

temático $\bullet O$ texto na pesquisa e no ensino: conhecimentos, práticas e desafios na contemporaneidade •

CAVALCANTE, Mônica Magalhães; MACEDO, Patrícia Sousa Almeida de. Estratégias de textualização na polêmica sobre culturas agrícolas no Brasil. Entre palavras, Fortaleza, v. 9, p. 303-320,

n.

1, jan-abr/2019.

Disponível

em:

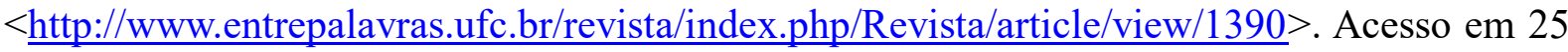
out. 2021.

CAVALCANTE, Mônica Magalhães et al. Coerência e referenciação. In: MARQUESI, S. C.; PAULIUKONIS, A. L.; ELIAS, V. M. (Orgs.). Linguística textual e ensino. São Paulo: Contexto, 2017. p. 91- 107.

KOCH, Ingedore Grünfeld Villaça. ELIAS, Vanda Maria. Escrever e argumentar. São Paulo: Contexto, 2016.

PERELMAN, Chaim \& OLBRECHTS-TYTECA, Lucie. Tratado da argumentação: a nova retórica. Trad. Maria Ermantina de Almeida Prado Galvão. 4.ed. São Paulo: Martins Fontes, 2020

UOL. Oposição entrega pedido impeachment de Bolsonaro à Câmara de deputados. Disponível em: https://www.facebook.com/21539158238/videos/2630608990540699/. Acesso em: 17/03/2021. 
TEXTO, CONTEXTO E PARATEXTO NA SÉRIE DE TIRAS “OS SANTOS"

\title{
TEXT, CONTEXT AND PARATEXT IN THE COMIC STRIP SERIES "OS SANTOS"
}

\author{
Elisa Ribeiro da Silva ${ }^{1}$
}

\begin{abstract}
Resumo: Nas últimas décadas, a evolução das tecnologias de informação e comunicação têm transformado de forma cada vez mais rápida o modo pelos quais os textos se relacionam, seus suportes e como a leitura e construção de sentido são sociocognitivamente estabelecidas. Com a internet consolidada como meio de publicar e consumir conteúdo, há uma proliferação de tiras em suportes digitais e diversas abordagens de análise desses textos são possíveis. Dessa forma, a proposta deste artigo é verificar de que maneira as concepções de texto, contexto e paratexto podem ser articuladas ao analisarmos tiras em ambientes digitais. Para isso, aplicaremos os conceitos em um exemplo de "Os Santos", tira brasileira produzida por Leandro Assis e Triscila Oliveira e veiculada nas redes sociais Twitter e Instagram. Como pressupostos teóricos, utilizamos a obra de Genette (2009) acerca dos elementos paratextuais, a definição de contexto de van Dijk (2012), poligenericidade pensado por Elias e Cavalcante (2017), focalização de Koch e Travaglia (2015) e os estudos sobre texto de Cavalcante e Custódio Filho (2010), Koch (2004) e Elias (2016).
\end{abstract}

Palavras-chave: Texto. Contexto. Paratexto. Quadrinhos. Tira.

\begin{abstract}
In recent decades, the evolution of information and communication technologies have transformed ever more rapidly the way texts relate to each other, their media, and how reading and the construction of meaning are sociocognitively established. With the internet consolidated as a means of publishing and consuming content, there is a proliferation of comic strips in digital media and several approaches to analyzing these texts are possible. In this way, the purpose of this paper is to verify how the concepts of text, context and paratext can be articulated when analyzing comic strips in digital environments. For this, we will apply the concepts in an example of "Os Santos", a Brazilian comic strip produced by Leandro Assis and Triscila Oliveira and published on the social networks Twitter and Instagram. As theoretical assumptions, we use the work of Genette (2009) about paratextual elements, van Dijk's definition of context (2012), polygenderness thought by Elias and Cavalcante (2017), focus by Koch and Travaglia (2015) and the studies on text by Cavalcante and Custódio Filho (2010), Koch (2004) and Elias (2016).
\end{abstract}

Keywords: Text. Context. Paratext. Comics. Comic Strip.

\section{Introdução}

A evolução das tecnologias de informação e comunicação transformou o modo como os textos são veiculados e relacionados com outros e abriu novas possibilidades para leitura e construção de sentidos. Esse rápido avanço, tão pautado no elemento visual, assegurou um

\footnotetext{
${ }^{1}$ Mestranda no Programa de Pós-Graduação em Letras da Universidade Federal de São Paulo. Contato: elisa_dribeiro@hotmail.com
} 


\section{PERcursos Linguísticos • Vitória (ES) •v. 11 •n. 29 • 2021 • ISSN: 2236-2592 • Dossiê temático $\bullet O$ texto na pesquisa e no ensino: conhecimentos, práticas e desafios na contemporaneidade •}

ambiente fértil para a circulação, armazenamento e leitura de tiras. Somado a isso, o desenvolvimento das tecnologias da informação e a convergência midiática, levaram autores e leitores a interagirem na produção de um conteúdo cada vez mais interativo e diversificado. Jenkins (2008) define essa nova era por intermédio do fluxo contínuo de conteúdo entre múltiplos suportes, da cooperação entre os mercados midiáticos e do comportamento migratório do público em busca de novas experiências e formas de interagir.

A internet tem permitido a existência de um novo espaço de criação e veiculação de conteúdo. Neste processo, há uma migração e readaptação dos textos nos novos meios de veiculação. Algumas das marcas constituintes do texto são mantidas e outras são alteradas devido aos novos aspectos de produção, circulação e recepção. Estes elementos colocam o sujeito em uma situação de interação, na qual age-se sobre o outro, mobilizando conhecimento de mundo, influenciando pensamentos e comportamentos por meio da escolha de elementos verbais e não verbais, dotados de intencionalidade (ELIAS, 2016). Sobre essa interação, Jenkins, Ford e Green (2014, p. 24) afirmam:

\footnotetext{
Essa mudança - de distribuição para circulação - sinaliza um movimento na direção de um modelo mais participativo de cultura, em que o público não é mais visto como simplesmente um grupo e consumidores de mensagens pré-construídas, mas como pessoas que estão moldando, compartilhando, reconfigurando e remixando conteúdos de mídia de maneira que não poderiam ter sido imaginadas antes. E estão fazendo isso não como indivíduos isolados, mas como integrantes de comunidades mais amplas e de redes que permitem propagar conteúdos muito além de sua vizinhança geográfica.
}

Essa propagação dos textos nos situa em nossos relacionamentos pessoais e profissionais, ajuda-nos a expressar quem somos, a construir comunidades e conscientizar as pessoas sobre os assuntos que nos preocupam na internet. Dada essa perspectiva de interatividade sob novas circunstâncias, interessa-nos entender como esses conteúdos estão presentes nas redes sociais e como algumas questões da textualidade podem ser analisadas.

O objetivo deste artigo, portanto, é analisar como os conceitos de texto, contexto e paratexto podem ser articulados nas tiras em ambientes digitais. Raça, classe, gênero e orientação sexual são alguns dos temas que circulam na internet. "Os Santos”, objeto de nossa análise, retrata justamente episódios de desigualdade na interseccionalidade destes temas. Trata-se de uma série em quadrinhos criada em 2019, veiculada nas redes sociais Twitter e Instagram e que tem como autores Leandro Assis e Triscila Oliveira.

A estrutura deste artigo está dividida em quatro seções, sendo as três iniciais de caráter teórico. A primeira irá detalhar a concepção de texto trabalhada pela Linguística Textual. A segunda abordará outro conceito, o de contexto, em uma perspectiva sociocognitivista 


\title{
PERcursos Linguísticos • Vitória (ES) •v. 11 •n. 29 • 2021 • ISSN: 2236-2592 • Dossiê temático $\bullet O$ texto na pesquisa e no ensino: conhecimentos, práticas e desafios na contemporaneidade •
}

relacionada à internet. A terceira retrata o conceito de paratextos trabalhado por Genette. Já a quarta e última seção irá ilustrar, a partir de um exemplo da série "Os Santos", como as tiras se apresentam em redes sociais e como podemos articular os conceitos de texto, contexto e paratexto.

\section{Um breve percurso sobre o conceito de texto}

Koch (2014, p. 59) afirma que "todo texto é, portanto, um objeto heterogêneo, que revela uma relação radical de seu interior com seu exterior. Dele fazem parte outros textos que lhe dão origem, que o predeterminam, com os quais dialoga, que ele retoma, a que alude ou aos quais se opõe". O texto une ações sociais e cognitivas, nas quais cultura e processamento mental estão interligados. Logo, a concepção contemporânea encara o texto como um processo, multifacetado, que percorre atividades linguísticas, sociocognitivas e discursivas. E o seu sentido é construído conjuntamente pelos sujeitos em interação. Elias (2016, p. 192) explicita que:

\begin{abstract}
Entender o texto como uma "entidade multifacetada" só é possível quando consideramos que a linguagem é uma forma de interação e, como tal, seu uso é regido pela intenção, apontando para relações que desejamos estabelecer, efeitos que pretendemos causar, comportamentos que queremos ver desencadeados, determinadas reações verbais ou não verbais que esperamos provocar no nosso interlocutor etc. Entendida não como realidade psicológica, mas, sim, num sentido puramente linguístico, a intenção é determinada pelo sentido do enunciado, isto é, ela se deixa representar de determinada forma no enunciado, sendo, pois, linguisticamente constituída.
\end{abstract}

Sendo assim, entendemos o texto como esse fenômeno multifacetado, que pode ter em sua constituição elementos de diferentes semioses, compondo uma produção multimodal. Nesse mesmo sentido, Cavalcante e Custódio Filho (2010, p. 64) trabalham o conceito de texto proposto por Koch e o ampliam, de modo a considerar também produções multimodais:

\footnotetext{
A produção de linguagem verbal e não verbal constitui atividade interativa altamente complexa de produção de sentidos que se realiza, evidentemente, com base nos elementos presentes na superfície textual e na sua forma de organização, mas que requer não apenas a mobilização de um vasto conjunto de saberes (enciclopédia), mas a sua reconstrução e a dos próprios sujeitos - no momento da interação verbal.
}

Ramos (2009, p. 20, grifo do autor) defende que "quadrinhos ou histórias em quadrinhos seriam um grande rótulo, um hipergênero, que agregaria diferentes outros gêneros, cada um com suas peculiaridades". Já a tira é "um formato utilizado para a veiculação de histórias em 


\section{PERcursos Linguísticos • Vitória (ES) •v. 11 •n. 29 • 2021 • ISSN: 2236-2592 • Dossiê temático $\bullet O$ texto na pesquisa e no ensino: conhecimentos, práticas e desafios na contemporaneidade •}

quadrinhos em suportes e mídias impressos e digitais" (RAMOS, 2017, p. 31). O autor explicita, ainda, que dentro deste formato circulam diferentes gêneros dos quadrinhos.

Dessa forma, valemo-nos da concepção de texto proposta por Cavalcante e Custódio Filho, uma vez que as tiras combinam diferentes signos. Compreendemos o texto como um processo e não apenas como mero produto ou registro verbal de um evento comunicativo. $\mathrm{O}$ texto, portanto, mantém relações com textos anteriores, que são responsáveis pela sua origem ou fizeram parte significativa do seu processo de criação. Modelos mentais e conhecimentos de mundo são acionados durante esse processo. Assim, o texto está profundamente inserido em uma relação sociocomunicativa, sempre mobilizando e construindo contexto. E é justamente sobre a concepção de contexto que discutiremos a seguir.

\section{Noções de contexto e redes sociais}

Ao abordar diferentes concepções de contexto, $\mathrm{KOCH}$ (2002, p. 21) recorre aos estudos de Malinowski, que criou os termos "contexto de situação" e "contexto de cultura" para apontar o contexto inicialmente como um mediador, pois as palavras e frases só fariam sentido se estivessem inseridas em uma situação de uso. Assim, o contexto era visto como um espalhamento verbal, que autora denomina co-texto.

Posteriormente, essa visão é ampliada para "a situação de interação imediata, a situação mediata (entorno sócio-político-cultural) e também o contexto sociocognitivo dos interlocutores" (KOCH, 2002, p. 04). De acordo com van Dijk (2012), Hanks (2008), Marcuschi (2002) e Koch (2002, 2004), a noção mais atual de contexto está ligada a "um estado de coisas que em parte está organizado a priori, e em parte está associado a uma significação que emerge de sua própria organização" (HANKS, 2008, p. 67).

Ao entrarmos em contato com um texto hierarquizamos as informações e realizamos conexões entre elas. As redes sociais, segundo Recuero (2005, p. 3), podem ser entendidas como um conjunto de dois elementos: atores (pessoas, instituições ou grupos) e suas conexões. Essas conexões são compreendidas como as relações e os laços sociais que ligam as pessoas por meio da interação social. Fluxos e trocas de informações que impactam as estruturas vigentes nas redes são provocados por essa interação entre os usuários das redes sociais. Quando um conteúdo é compartilhado, por exemplo, ele gera reações entre os seus leitores (idem, 2009, p. 31). 


\section{PERcursos Linguísticos • Vitória (ES) •v. 11 •n. 29 • 2021 • ISSN: 2236-2592 • Dossiê temático $\bullet O$ texto na pesquisa e no ensino: conhecimentos, práticas e desafios na contemporaneidade •}

As plataformas digitais disponibilizam as ferramentas para essa interação na internet, por meio de "curtidas", compartilhamentos dentro da própria plataforma ou em outras redes sociais, propagando o conteúdo de determinado tema a depender de seu interesse. Essas ações são dotadas de intencionalidade, seja produzir, consumir ou divulgar para fazer parte dessas narrativas. Sobre isso Jenkins, Ford e Green (2014, p. 54) afirmam que:

\footnotetext{
Quando o material é propagado, ele é refeito: seja literalmente, ao ser submetido aos vários procedimentos de remixagem e sampleamento, seja figurativamente, por meio de sua inserção em conversas em andamento e através de diversas plataformas. Esse contínuo processo de processo de transformação do propósito original e de recirculação está corroendo as divisórias percebidas entre produção e consumo.
}

Além disso, há também no ciberespaço a poligenericidade, que segundo Elias e Cavalcante (2017, p. 326), demandaria "considerar não apenas um texto e toda a complexidade dos aspectos que lhe são constitutivos, mas, sim, textos ou arranjos textuais envolvendo uma diversidade de gêneros textuais e de autores que atuam colaborativamente no espaço de redes sociais". À vista disso, o texto pensado a partir da interação demanda uma concepção de contexto na qual os sujeitos são vistos como "[...] atores sociais levando em conta o contexto sociocomunicativo, histórico e cultural para a construção dos sentidos e das referências dos textos" (CAVALCANTE, 2013, p. 19). Conforme explicam Koch e Elias (2006, p. 11) o texto, então, figura como próprio lugar de interação:

\footnotetext{
Na concepção interacional da língua o texto é considerado o próprio lugar da interação e da constituição dos interlocutores. Há lugar, no texto, para toda uma gama de implícitos, dos mais variados tipos, somente detectáveis quando se tem, como pano de fundo, o contexto sociocognitivo dos participantes da interação. [...] o sentido de um texto é construído na interação texto - sujeitos e não algo que preexista a essa interação.
}

Para van Dijk (2012), contexto é algo construído pelos atores sociais e não apenas algo extrínseco. Assim, a cada situação comunicativa, os participantes concebem uma representação mental por meio de modelos mentais, que definem e influenciam nossa compreensão e interação. Os modelos mentais, segundo o autor, expressam a maneira como os atores sociais interpretam a língua, com base em representações cognitivas de seus conhecimentos e experiências prévias, sendo interpretações pessoais.

Além disso, acionam nossa percepção a respeito das situações que já vivenciamos ou sobre as quais somente lemos ou ouvimos e são, portanto, uma forma de adquirir conhecimento de mundo. Dessa forma, existem percepções que não serão explicitadas pois supostamente são 


\section{PERcursos Linguísticos • Vitória (ES) •v. 11 •n. 29 • 2021 • ISSN: 2236-2592 • Dossiê temático $\bullet O$ texto na pesquisa e no ensino: conhecimentos, práticas e desafios na contemporaneidade •}

compartilhadas com o leitor e existem informações que serão explicitadas pois não estão nesse leque de informações compartilhadas.

Nesse processo, o autor pressupõe que alguns conhecimentos de mundo são compartilhados com o leitor. No que lhe concerne, o leitor ativa modelos mentais na situação de interação, para completar o modelo com o conhecimento que está pressuposto no texto. Dessa forma, cada sujeito vai construindo representações cognitivas individuais durante o processo de interação, que atuam de forma primordial no processo de construção de sentido.

Partindo dessa premissa, definir o contexto tendo em vista uma perspectiva sociocognitivista leva em consideração como os sujeitos constroem representações de si e dos outros sujeitos. Assim, é dinâmico, definido e redefinido durante o processo de interação. Fornecendo-nos, então, uma perspectiva que relaciona texto à sociedade, às relações existentes entre os sujeitos, como as de poder, por exemplo. Para entender sobre essa hierarquização de informações e construção de sentidos vamos falar sobre os paratextos a seguir.

\section{Relações paratextuais}

Genette (2009, p. 9, grifos do autor) explica que os textos não se apresentam isoladamente:

(...) esse texto raramente se apresenta em estado nu, sem o reforço e o acompanhamento de certo número de produções, verbais ou não, como um nome de autor, um título, um prefácio, ilustrações, que nunca sabemos se devemos ou não considerar parte dele, mas que em todo caso o cercam e o prolongam, exatamente para apresentá-lo, no sentido habitual do verbo, mas também em seu sentido mais forte: para torná-lo presente, para garantir sua presença no mundo, sua "recepção" e seu consumo, sob a forma, pelo menos hoje, de um livro.

Assim, os elementos paratextuais seriam estabelecidos em relação ao próprio texto: em torno dele ou sobre ele. E permitiriam que o conteúdo fosse melhor recebido, uma vez que figurariam como uma transação entre o conteúdo planejado pelo autor e editor e a interação do leitor. A proposta do crítico literário fala inicialmente de um corpus físico, o livro. Entretanto, posteriormente Genette (2009, p. 11) expande essa concepção e afirma que "não existe, e que jamais existiu, um texto sem paratexto".

Reconhecendo que os paratextos representam um reflexo do momento histórico e cultural em que foram produzidos, Genette (ibidem) elucida que "os caminhos e meios do paratexto não cessam de modificar-se conforme as épocas, as culturas, os gêneros, os autores, 


\title{
PERcursos Linguísticos • Vitória (ES) •v. 11 •n. 29 • 2021 • ISSN: 2236-2592 • Dossiê temático $\bullet O$ texto na pesquisa e no ensino: conhecimentos, práticas e desafios na contemporaneidade •
}

as obras, as edições de uma mesma obra, com diferenças de pressão às vezes consideráveis”. Consequentemente, os paratextos seriam adaptáveis de acordo com elementos extrínsecos.

No que concerne à Linguística Textual, o conceito paratexto foi trabalhado também sob o nome de fatores de contextualização, que são "elementos que contribuem para equacionar alternativas de compreensão" (MARCUSCHI, 1983, p. 16). Além disso, Brito (2018) e Brito e Ramos (2019) trabalharam as relações paratextuais analisando a ocorrência paratextos ficcionais. À vista disso, entendemos, conforme discutido por Ramos e Silva (2021), que a noção paratexto deve estar articulada ao do conceito de focalização, "a concentração dos usuários (produtor e receptor) em apenas uma parte do seu conhecimento, bem como a perspectiva da qual são vistos os componentes do mundo textual" (KOCH; TRAVAGLIA, 2002 [1990], p. 88).

Seguindo a metáfora apresentada pelos autores, seria como compartilhar o visor de uma câmera com o leitor, existe o que está de fato focalizado pela lente da câmera e há também elementos que estão no entorno dessa imagem. Ramos e Silva (2021, p. 215) explicam que:

\begin{abstract}
Expondo em outros termos: a valoração de um aspecto, resultante da focalização nele, torna um elemento textual e um gênero mais relevantes, estabelecendo em relação aos outros constituintes uma relação paratextual. Reitera-se: não se sugere com isso que os demais sejam menos importantes, apenas que ficaram de fora do visor da câmera proposta por Koch e Travaglia. Ou seja, numa posição de paratextos. Essa abordagem, como já dito, não ignora os princípios definidores do texto, do modo como é visto contemporaneamente. Ela, por outro lado, permite incorporar a perspectiva (real) de que uma mesma produção seja lida de maneiras distintas, assim com os constituintes dela. Do ponto de vista do pesquisador, chega a configurar uma espécie de método, que ajuda o analista a abordar aspectos diferentes de um mesmo texto, conforme seu interesse e a focalização que pretenda dar. A consequência é que passa a ser estabelecida uma de foco e fundo, em que este último exerce um papel paratextual. $\mathrm{O}$ que passa a ser o foco e o fundo irá depender do interesse que se tem e do olhar dado à produção $[\ldots]$
\end{abstract}

Esta relação de foco e fundo pode propiciar diferentes leituras que, por sua vez, podem colaborar para uma construção de sentidos que nem sempre é convergente $\mathrm{O}$ autor pode, por exemplo, dar mais visibilidade para um conteúdo do que outro. O que também é válido para o pesquisador, que pode decidir analisar a parte verbal de uma produção e não a imagética. Pode optar também por estudar as reações que os leitores manifestam por meio de curtidas e comentários ou os compartilhamentos de uma publicação. Essa abordagem focaliza um dos aspectos do texto em detrimento de outros, estabelecendo uma relação de foco e fundo, na qual o fundo atua como paratexto. Quais elementos irão desempenhar papel de foco e fundo serão definidos a partir do interesse que o autor ou o pesquisador têm e do que pretende, focalizar. 


\section{PERcursos Linguísticos • Vitória (ES) •v. 11 •n. 29 • 2021 • ISSN: 2236-2592 • Dossiê \\ temático $\bullet O$ texto na pesquisa e no ensino: conhecimentos, práticas e desafios na contemporaneidade •}

\section{Articulando texto, contexto e paratexto em "Os Santos"}

A série de tiras "Os Santos" é produzida em quadrinhos, no formato de tiras e retrata questões de gênero, raça, classe e orientação sexual ao narrar o cotidiano de duas famílias, ambas do Rio de Janeiro: uma negra, periférica, em que as mulheres trabalham na casa de uma segunda família, de classe média alta, composta por pessoas brancas.

As tiras surgiram em dezembro de 2019, passaram por um hiato em 2020 e 2021 pois os autores não queriam vincular os acontecimentos da série à pandemia de COVID-19 e voltou a ser publicada em 30 de agosto de 2021. Até 30 de setembro do mesmo ano 30 tiras publicadas foram publicadas no Twitter e no Instagram.

A história procura refletir a desigualdade racial e social existente no Brasil, país em que 6,3 milhões de pessoas exercem a atividade de trabalhadores domésticos, segundo a Pesquisa Nacional por Amostra de Domicílios Contínua (Pnad) (IBGE, 2019).

As tiras ganharam repercussão nas redes sociais após a página de Instagram Mídia Ninja (@midianinja), com quatro milhões de seguidores, registrados em setembro de 2021, compartilhar em seu perfil as publicações. De acordo com Assis, após esse compartilhamento, o número de pessoas seguindo sua página (@ leandro_assis_ilustra) aumentou de 3 mil para 450 mil em pouco mais de um mês. Em 23 de setembro de 2021, já havia aumentado para 800 mil.

Com a repercussão e reconhecimento do trabalho realizado por Assis e Oliveira, a partir de setembro do mesmo ano, a dupla ganhou um espaço semanal na área de charges do jornal "Folha de São Paulo". A primeira tira de "Os Santos" foi publicada no Instagram dia 5 de dezembro de 2019 e a trigésima em 8 de setembro de 2021. Já no Twitter, a data da primeira publicação foi 13 de dezembro de 2019 e a trigésima em 9 de setembro de 2021. É justamente a última tira publicada que reproduzimos a seguir: 
PERcursos Linguísticos • Vitória (ES) •v. 11 •n. 29 • 2021 • ISSN: 2236-2592 • Dossiê temático $\bullet O$ texto na pesquisa e no ensino: conhecimentos, práticas e desafios na contemporaneidade •
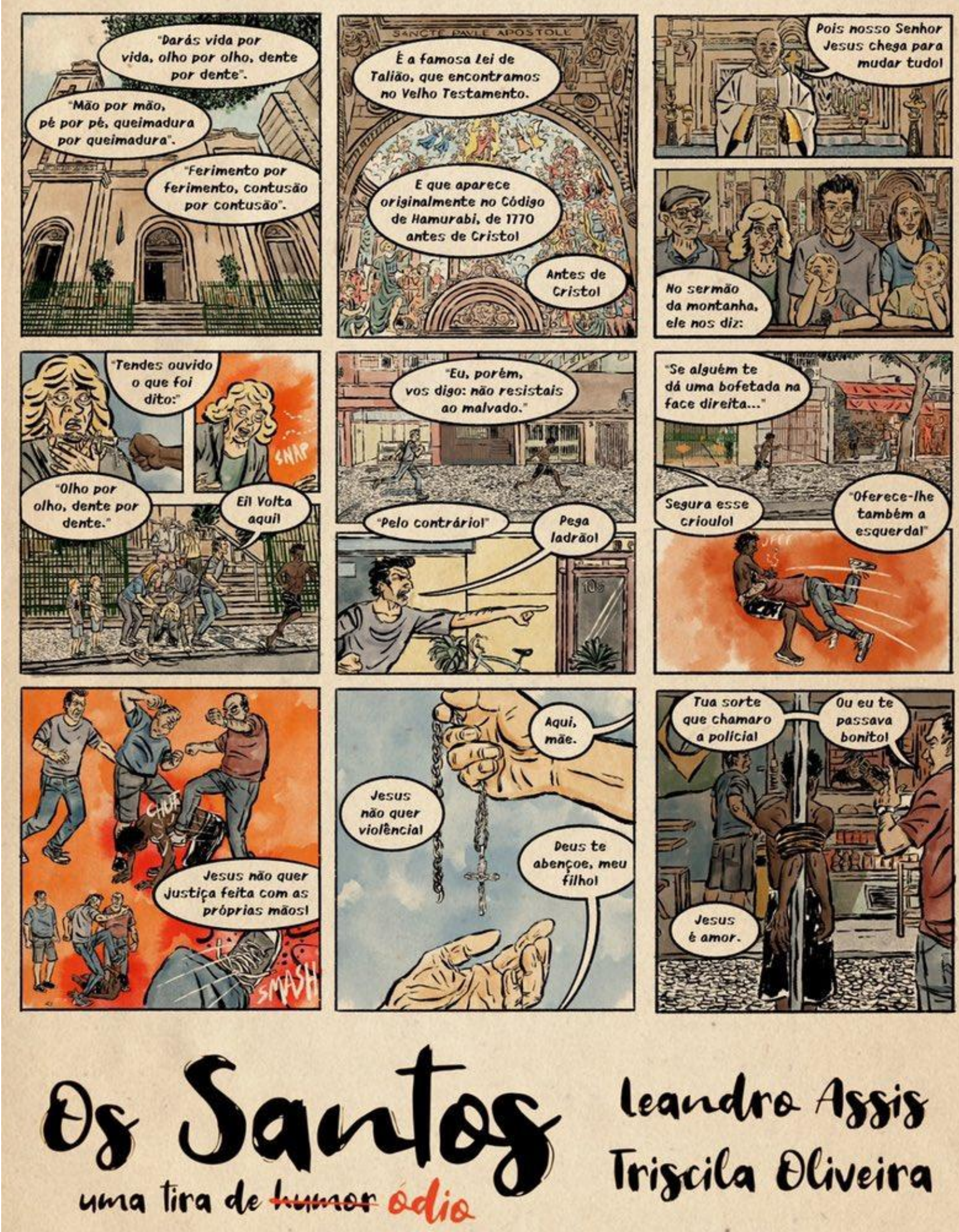

Fonte: ASSIS, Leandro; OLIVEIRA, Triscila. tira 30 "lei de Talião alma". Twitter: leandroassis73. Disponível em: < https://twitter.com/leandroassis73/status/1435940965114580993/photo/3>. Acesso em: 23 set. 2021. 


\section{PERcursos Linguísticos • Vitória (ES) •v. 11 •n. 29 • 2021 • ISSN: 2236-2592 • Dossiê temático $\bullet O$ texto na pesquisa e no ensino: conhecimentos, práticas e desafios na contemporaneidade •}

Na Figura 1 temos uma reprodução da tira, que é ampliada quando se clica na imagem publicada no Twitter. No primeiro quadro precisamos articular alguns conhecimentos para nos situarmos neste começo de história. Primeiro vemos a fachada de algum lugar, temos também três balões de fala e ao vermos o signo de aspas dentro dos balões, podemos entender que se trata de uma reprodução de algo escrito ou da fala de alguém.

Se tivermos o conhecimento religioso ou histórico saberemos que diz respeito a uma passagem da bíblia, sobre a lei de Talião. Aqui vemos que o contexto de leitura vai ser relevante, uma vez que o conhecimento enciclopédico pode ser acionado para construir sentidos.

Ainda há também a própria linguagem dos quadrinhos, temos um gênero que possui características próprias, como os balões de fala, que "para Acevedo (1990), possui dois elementos: o continente (corpo e rabicho/apêndice) e o conteúdo (linguagem escrita ou imagem) [...] podem indicar, por exemplo, voz alta, gritos, sons eletrônicos” (RAMOS, 2009, p. 36).

No segundo quadro podemos identificar vitrais e associando à imagem que vimos no primeiro quadro, entender que se trata de uma igreja católica. Nos balões de fala, alguém, ainda não revelado, mas que podemos supor ser um padre por tratar-se de uma igreja católica, explica que estava reproduzindo os dizeres da lei de Talião.

Mais uma vez, se tivermos conhecimento histórico ou religioso, podemos entender que esta acredita-se ser a lei mais antiga que existiu, na qual o autor de um delito devia sofrer castigo igual ao dano por ele causado e é frequentemente simbolizada pela expressão "olho por olho, dente por dente". O Código de Hamurabi, conjunto de leis criadas pelo sexto rei da Suméria Hamurábi, mais ou menos em 1700 a.C, traz um conceito similar ao texto bíblico:

\footnotetext{
$196^{\circ}$ - Se alguém arranca o olho a um outro, se lhe deverá arrancar o olho. $197^{\circ}$ - Se ele quebra o osso a um outro, se lhe deverá quebrar o osso.

$200^{\circ}$ - Se alguém parte os dentes de um outro, de igual condição, deverá ter partidos os seus dentes $202^{\circ}$ - Se alguém espancar outro mais elevado que ele, deverá ser espancado em público sessenta vezes, com o chicote de couro de boi. $206^{\circ}$ - Se alguém golpeia outro em uma rixa e lhe faz uma ferida, ele deverá jurar: "Eu não o golpeei de propósito", e pagar o médico. $209^{\circ}$ - Se alguém atinge uma mulher livre e a faz abortar, deverá pagar dez siclos pelo feto.

$210^{\circ}$ - Se essa mulher morre, se deverá matar o filho dele. (O Código de Hamurabi. Disponível em: http://www.dhnet.org.br/direitos/anthist/hamurabi.htm. Acesso em: 23 set. 2021).
}

O quadro seguinte apresenta o padre na parte superior do quadro, ele diz que Jesus veio para mudar tudo. Já na parte inferior, vemos quase a família dos "patrões" de "Os Santos": Liege, Camilo, Caíque, Renata e os gêmeos, filhos deles, que aparecem com expressões 


\section{PERcursos Linguísticos • Vitória (ES) •v. 11 •n. 29 • 2021 • ISSN: 2236-2592 • Dossiê temático $\bullet O$ texto na pesquisa e no ensino: conhecimentos, práticas e desafios na contemporaneidade •}

entediadas. Neste ponto e em toda a tira, é necessário articular o verbal e não verbal para construir sentidos.

O quarto quadro apresenta, ainda, as falas do padre e mostra uma cena na qual roubam um colar com um pingente de cruz que Liege está usando na saída da igreja. No quadro posterior, o padre segue recitando frases do Novo Testamento, mais uma vez, em termos de construção de sentidos, uma informação que requer conhecimento de mundo da parte do leitor. Na parte inferior do quadro Caíque persegue o ladrão.

O sexto quadro reproduz na parte de cima uma frase racista de Caíque "segura esse crioulo", enquanto o padre segue recitando "se alguém te dá uma bofetada na face direita... Oferece-lhe também a esquerda!”. Na parte de baixo do quadro, vemos um homem agarrando o ladrão. Aqui as linhas cinéticas _ “Acevedo (1990) as define como 'linhas que servem para indicar movimento. Segundo ele, é uma forma de reproduzir o momento de um gesto" (RAMOS, 2009, p. 116) - dão a ideia de o homem chegou correndo e agarrou o ladrão. E no quadro seguinte vemos três homens espancando o homem negro, enquanto o padre diz "Jesus não quer justiça feita com as próprias mãos!”.

O oitavo quadro mostra Caíque devolvendo o colar que fora roubado a Liege e ela diz "Deus te abençoe, meu filho". O próximo quadro mostra o ladrão amarrado em um poste e um dos homens dizendo que foi sorte terem chamado a polícia "ou eu te passava bonito". Precisamos articular a gíria "passava" com o significado de violência para entender a ameaça. O padre finaliza dizendo que "Jesus é amor". A crítica pode ficar ou não explícita de acordo com os conhecimentos com os quais o leitor constrói sentidos.

Os nove quadros da história em quadrinhos não são as únicas informações apresentadas ao leitor. Na parte debaixo da imagem, são apresentados também o título da série "Os Santos", seu subtítulo "Uma tira de humør ódio", uma recategorização que já antecipa aos leitores que não se trata de um conteúdo cômico. E logo depois temos os nomes dos autores. A imagem da tira está inserida em uma postagem, que apresenta outros conteúdos, como vemos a seguir: 


\section{PERcursos Linguísticos • Vitória (ES) •v. 11 •n. 29 • 2021 • ISSN: 2236-2592 • Dossiê temático $\bullet O$ texto na pesquisa e no ensino: conhecimentos, práticas e desafios na contemporaneidade •}

Figura 2 - Postagem no Twitter

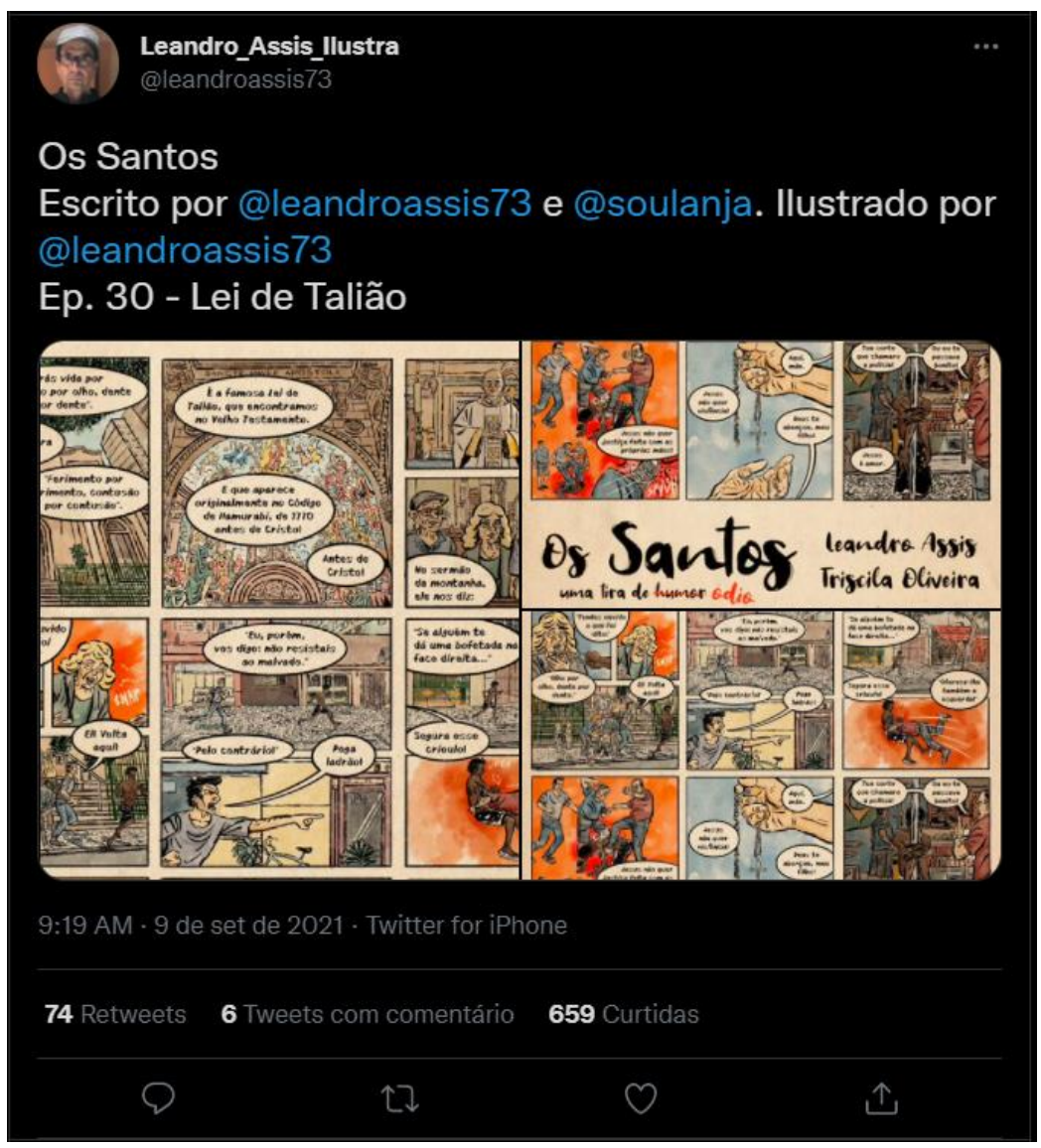

Fonte: ASSIS, Leandro; OLIVEIRA, Triscila. tira 30 “lei de Talião”. Twitter: @leandroassis73. Disponível em: https://twitter.com/leandroassis73/status/1226808566583111683. Acesso em: 20 set. 2021.

Na parte superior da figura 2 podemos identificar quem é o autor da publicação por meio do nome exibido: "Leandro_Assis_Ilustra", abaixo aparece seu endereço eletrônico no Twitter: “@leandroassis73” e ao lado esquerdo há uma foto em formato oval, modelo utilizado pela plataforma digital. Outras frases antecedem a história em quadrinhos, são elas "Os Santos", “Escrita por@leandroassis73 e @soulanja”, “Ilustrada por@ leandroassis73”.

Na sequência, o autor especifica informações da tira. Trata-se, neste caso, do "Ep. 30", intitulado "Lei de Talião". Se o leitor tem o conhecimento sobre o é a lei e lê o título antes da ver a tira, já pode construir alguns sentidos antes mesmo de lê-la. Na ideia inicial de Genette, o título era um paratexto que não seria tão relevante quanto a história em si. Aqui vemos que se trata de uma informação que pode antecipar ou até mesmo confundir a construção de sentidos. E que está integrado ao texto "principal".

Após essas informações, temos a tira em si, reproduzida na Figura 1. Abaixo da imagem, o Twitter registra automaticamente o horário em que o conteúdo foi publicado "09:19 AM", a data, "9 de setembro de 2021 " e o suporte utilizado para isso "Twitter for iPhone". Na linha 


\section{PERcursos Linguísticos • Vitória (ES) •v. 11 •n. 29 • 2021 • ISSN: 2236-2592 • Dossiê temático $\bullet O$ texto na pesquisa e no ensino: conhecimentos, práticas e desafios na contemporaneidade •}

seguinte aparecem algumas informações de interação, como é próprio dos hipertextos. Sabemos, então, que houve 74 "retweets", ou seja, 74 compartilhamentos dessa publicação no Twitter, 6 "tweets com comentário" e "659 curtidas".

Por fim, há quatro botões de ação que podem ser utilizados para interagir com a postagem: comentar, sinalizado por um balão de fala; compartilhar, sinalizado por um ícone com duas setas; curtir, sinalizado por um coração; e por fim um ícone de uma bandeja com uma seta que possibilita que você envie o conteúdo por mensagem direta, salve essa publicação ou copie o link dela. Há, ainda, um terceiro gênero nesse ambiente digital, os comentários, que podemos acessar rolando a tela da postagem para baixo:

Figura 3 - Comentários no Twitter

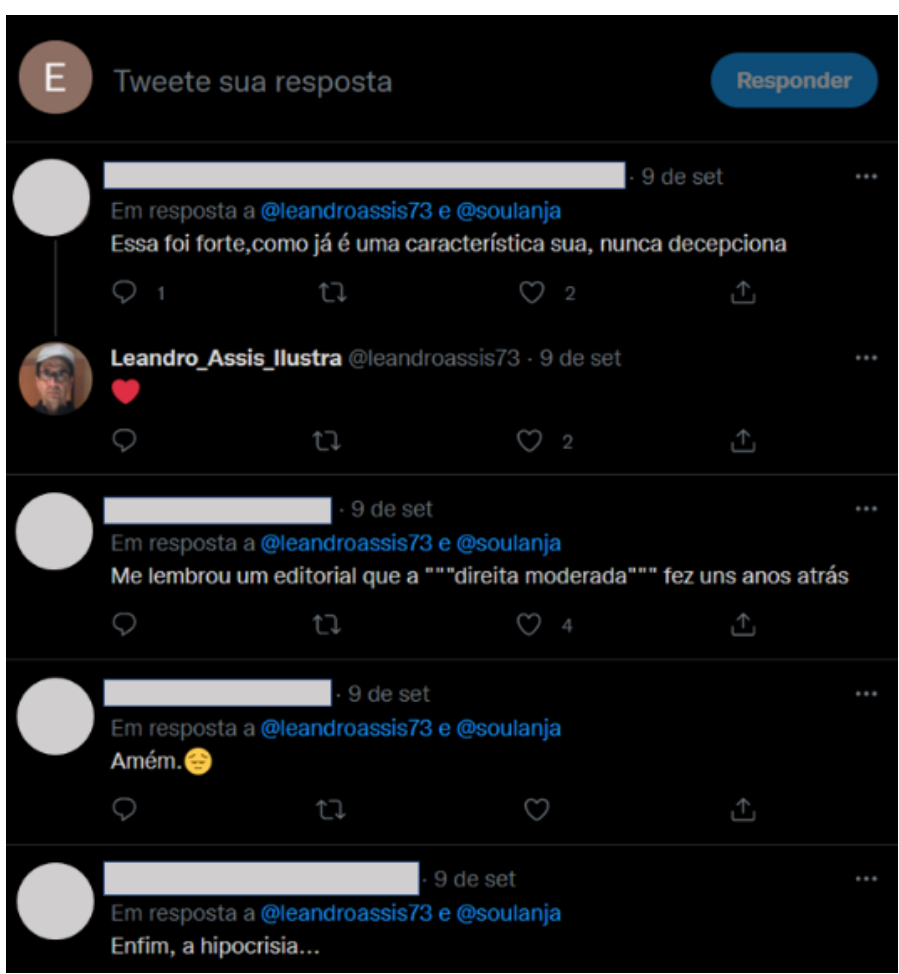

Fonte: ASSIS, Leandro; OLIVEIRA, Triscila. tira 30 "lei de Talião". Twitter: @leandroassis73. Disponível em: https://twitter.com/leandroassis73/status/1226808566583111683. Acesso em: 20 set. 2021.

Agora olhando para o Instagram, outra rede social na qual a obra é publicada, o leitor se depara ao abrir o aplicativo com a tira em destaque, como vemos a seguir: 


\section{PERcursos Linguísticos • Vitória (ES) •v. $11 ・ n .29 ・ 2021 ・$ ISSN: 2236-2592 • Dossiê temático $\bullet O$ texto na pesquisa e no ensino: conhecimentos, práticas e desafios na contemporaneidade •}

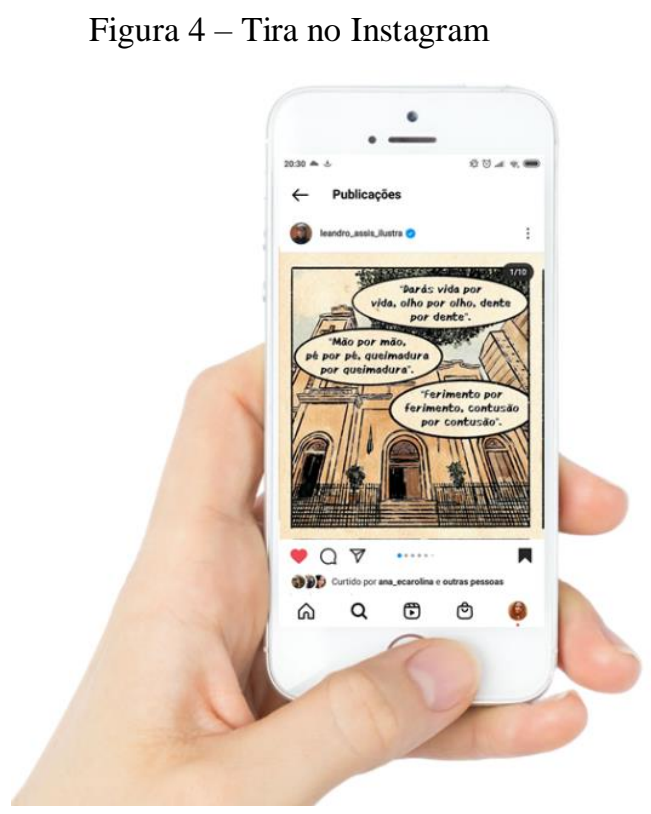

Fonte: ASSIS, Leandro; OLIVEIRA, Triscila. tira 30 “lei de Talião”. Instagram: @leandro_assis_ilustra. Disponível em: https://www.instagram.com/p/CTkllfwjNaN/. Acesso em: 20 set. 2021.

Os botões para ler todos os comentários e ver a postagem inteira estão mais abaixo, em alguns celulares, por exemplo, vai ser preciso rolar a tela para baixo para vê-los:

Figura 5 - Postagem e comentários no Instagram

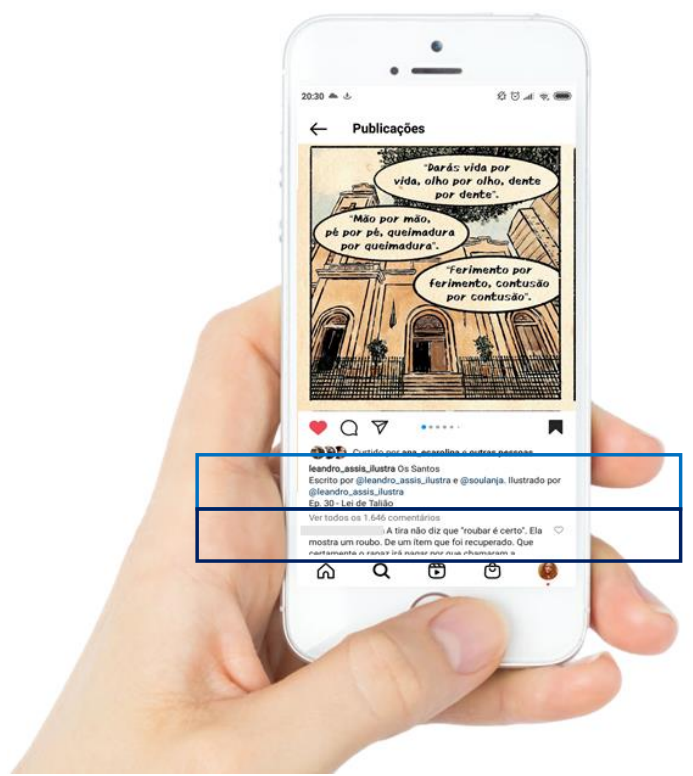

Fonte: ASSIS, Leandro; OLIVEIRA, Triscila. tira 30 “lei de Talião”. Instagram: @leandro_assis_ilustra. Disponível em: https://www.instagram.com/p/CTkllfwjNaN/. Acesso em: 20 set. 2021. 


\section{PERcursos Linguísticos • Vitória (ES) •v. 11 •n. 29 • 2021 • ISSN: 2236-2592 • Dossiê temático $\bullet O$ texto na pesquisa e no ensino: conhecimentos, práticas e desafios na contemporaneidade •}

A legenda aparece completa e se clicarmos em ver todos os comentários, chegamos então em uma tela na qual é possível ver os comentários completos e organizados pelo algoritmo da rede social:

Figura 6-comentários no Instagram

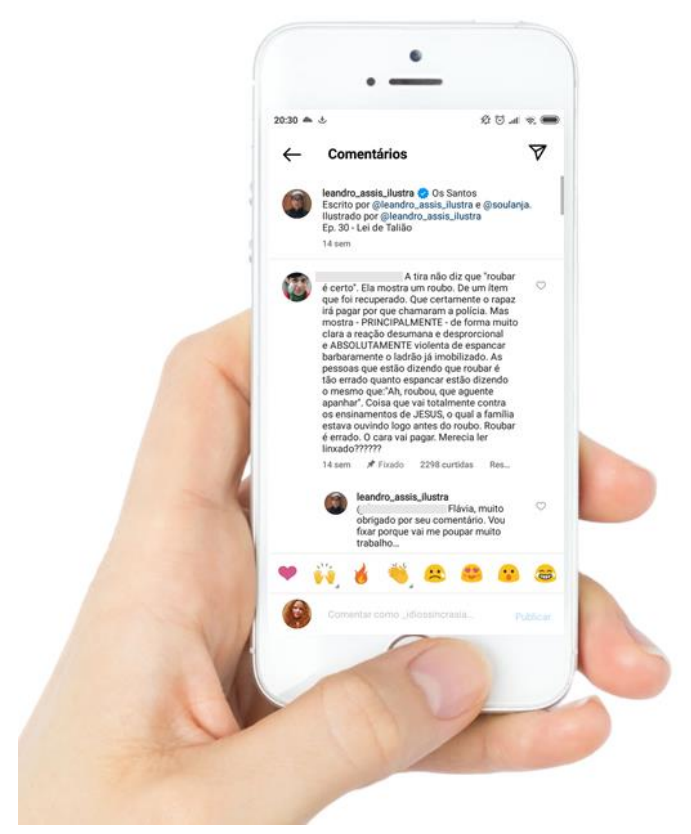

Fonte: ASSIS, Leandro; OLIVEIRA, Triscila. tira 30 “lei de Talião”. Instagram: @leandro_assis_ilustra. Disponível em: https://www.instagram.com/p/CTkllfwjNaN/. Acesso em: 20 set. 2021.

A coexistência de três gêneros, a tira, a postagem e os comentários é ainda mais explícita no Instagram, uma vez que estão lado a lado:

Figura 7 - Tira, postagem e comentários no Instagram 


\section{PERcursos Linguísticos • Vitória (ES) •v. 11 •n. 29 • 2021 • ISSN: 2236-2592 • Dossiê temático $\bullet O$ texto na pesquisa e no ensino: conhecimentos, práticas e desafios na contemporaneidade •}

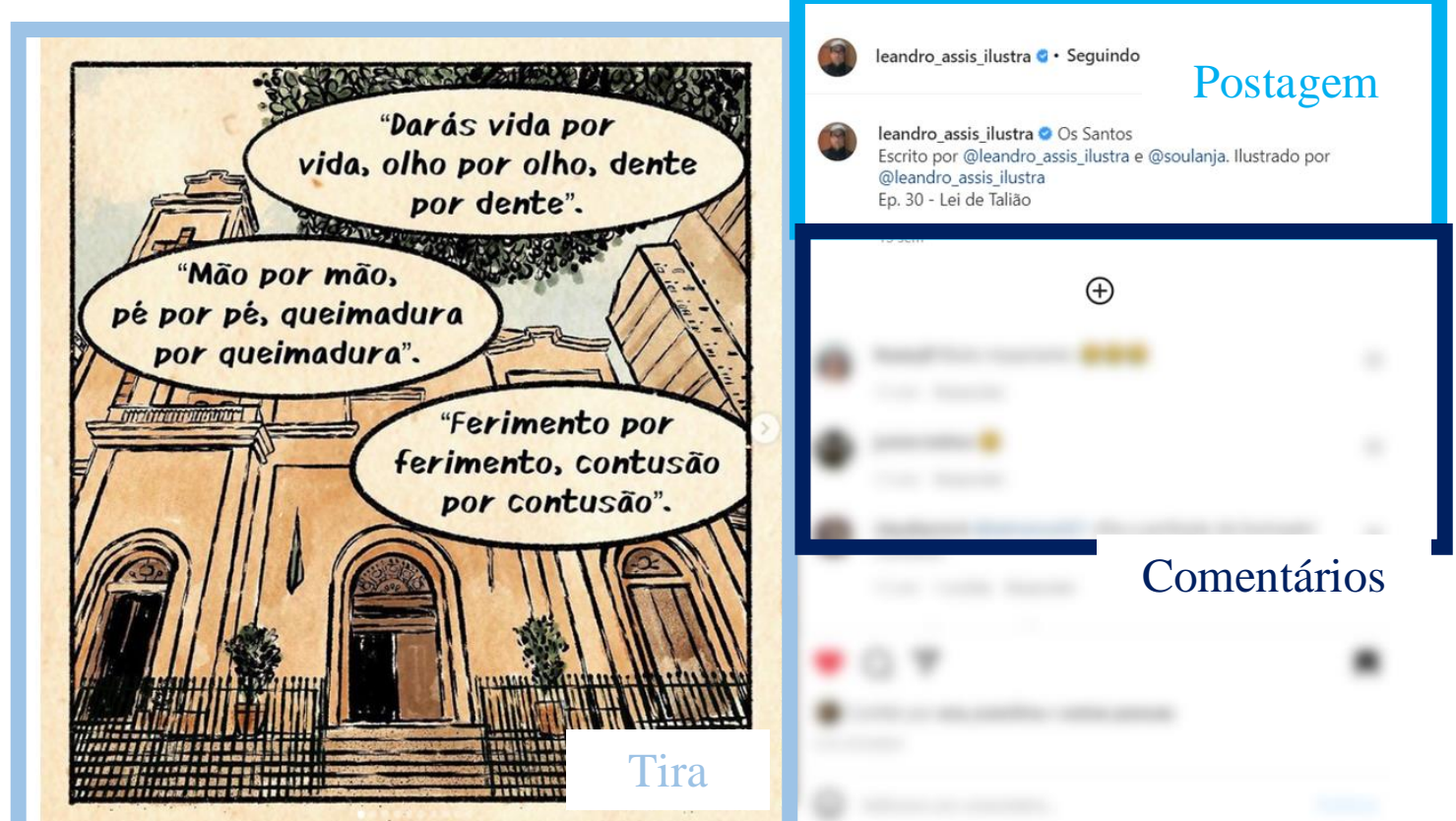

Fonte: ASSIS, Leandro; OLIVEIRA, Triscila. tira 30 "lei de Talião". Instagram: @leandro_assis_ilustra. Disponível em: https://www.instagram.com/p/CTkllfwjNaN/. Acesso em: 20 set. 2021.

Olhando para as figuras anteriores entendemos haver o que Elias (2014) e Elias e Cavalcante (2017) chamam de poligenericidade. Uma vez que nos exemplos ilustrados vemos pelo menos três gêneros: a própria postagem, a tira,e os comentários que demonstram as reações dos leitores, quais sentidos construíram, suas críticas, elogios ou até mesmo a fuga do tópico abordado na tira.

O que vemos aqui é a possibilidade de, a partir do texto focalizado, construir uma relação paratextual com os demais gêneros. Assim, se o foco da nossa discussão estiver na discussão sobre religião e violência e, por consequência, no conteúdo narrativo, a focalização estaria no conteúdo da tira, estabelecendo com os demais gêneros uma relação paratextual. Por outro lado, caso o foco esteja na avaliação de reação dos leitores e seus comentários, por exemplo, a tira é que passa a exercer um papel de paratexto.

\section{Considerações finais}

A produção textual em ambiente de rede traz consigo questões textuais e interacionais que demandam nossa atenção. Precisamos pensar em abordagens que abarquem a leitura e a construção de sentidos, considerando as diferentes semioses, a interação que as redes propiciam, o conhecimento de mundo e os modelos mentais dos leitores nos eventos comunicativos. Dessa forma, procuramos mostrar neste artigo como podem se estabelecer as relações de texto, contexto e paratexto aplicadas a tiras veiculadas em redes sociais. 


\section{PERcursos Linguísticos • Vitória (ES) •v. 11 •n. 29 • 2021 • ISSN: 2236-2592 • Dossiê temático $\bullet O$ texto na pesquisa e no ensino: conhecimentos, práticas e desafios na contemporaneidade •}

A concepção de texto como um processo e não apenas como mero produto ou registro verbal de um evento comunicativo é fundamental para a análise de tiras, uma vez que elas são compostas por diferentes signos e mantêm relações com textos anteriores. Na tira analisada foi possível identificar alguns desses textos e perceber como o conhecimento de mundo precisa ser acionado durante esse processo e como as redes sociais propiciam alguns caminhos de entrada para esse gênero.

O texto está profundamente inserido em uma relação sociocomunicativa, sempre mobilizando e construindo contexto. Logo, para construir sentidos e dependendo do interesse de pesquisa, podemos analisar apenas um dos gêneros presentes nesse ambiente digital. O texto veiculado em redes sociais possui marcas próprias devido ao suporte e aos gêneros, havendo muitas possibilidades de interação e construção de sentidos.

Pensando nisso, esta abordagem procura ressaltar a poligenericidade presente nas publicações, valendo-se do conceito de focalização para determinar o que terá papel paratextual e enxergando o contexto como essa coconstrução que é dinâmica e se reconfigura a partir do que os sujeitos pressupõem, quais são seus papéis sociais e conhecimento de mundo.

\section{Referências}

ASSIS, Leandro; OLIVEIRA; Triscila. Os Santos. Twitter: @leandroassis73. Disponível em: $<$ https://twitter.com/leandroassis73/>. Acesso em: 23 set. 2021.

BRITO, Karoline Caetano. Paratextos ficcionais em Watchmen. 190 f. Dissertação (Mestrado em Letras). Programa de Pós-Graduação em Letras, Universidade Federal de São Paulo. Guarulhos, SP: 2018

CAVALCANTE, Mônica Magalhães; CUSTÓDIO FILHO, Valdinar. Revisitando o estatuto do texto. Revista do Gelne, v. 12, n. 2, 2010, p. 56-71.

CAVALCANTE, Mônica Magalhães. Os sentidos do texto. São Paulo: Contexto, 2013.

ELIAS, Vanda Maria. Estudos do texto, multimodalidade e argumentação. Revista Virtual de Estudos da Linguagem, v. 14, 2016, p. 191-206.

ELIAS, Vanda Maria; CAVALCANTE, Mônica Magalhães. Linguística Textual e estudos do hipertexto: focalizando o contexto e a coerência. In: CAPISTRANO JÚNIOR, Rivaldo; LINS, Maria Penha Pereira; ELIAS, Vanda Maria. (Org.). Linguística Textual: diálogos interdisciplinares. São Paulo: Labrador, 2017. p. 317-338.

GENETTE, Gerard. Paratextos editoriais. Trad. Álvaro Faleiros. Cotia, SP: Ateliê Editorial, 2009. 


\section{PERcursos Linguísticos • Vitória (ES) •v. 11 •n. 29 • 2021 • ISSN: 2236-2592 • Dossiê temático $\bullet O$ texto na pesquisa e no ensino: conhecimentos, práticas e desafios na contemporaneidade •}

HANKS, William. O que é contexto. In: Bentes, Anna Christina; Rezende, Renato.; Machado, Marco Antônio (Orgs.) Língua como prática social: das relações entre língua, cultura e sociedade a partir de Bourdieu e Bakhtin, p. 169-203. São Paulo: Cortez, 2008.

JENKINS, Henry. Cultura da Convergência. Trad. Susana Alexandria. São Paulo: Aleph, 2008.

JENKINS, Henry; GREEN, Joshua; FORD, Sam. Cultura da Conexão. São Paulo: Aleph, 2014.

KENEDY, Eduardo. Gerativismo. In: MARTELOTTA, Mário Eduardo (Org.). Manual de Linguística. São Paulo: Contexto, 2009, p.127-140.

IBGE - Instituto Brasileiro de Geografia e Estatística. Pesquisa Nacional por Amostra de Domicílios (Pnad) Contínua. Rio de Janeiro, 2019. Disponível em: <https://biblioteca.ibge.gov.br/visualizacao/livros/liv101678.pdf>. Acesso em 23 set. 2021.

KOCH, Ingedore Grünfeld Villaça. Linguística Textual: Quo Vadis? In: Revista Delta, edição especial, 2001.

KOCH, Ingedore Grünfeld Villaça. Desvendando os segredos do texto. São Paulo: Cortez, 2002.

$\mathrm{KOCH}$, Ingedore Grünfeld Villaça. Introdução à Linguística Textual. São Paulo: Martins Fontes, 2004.

$\mathrm{KOCH}$, Ingedore Grünfeld Villaça. O texto e a construção dos sentidos. São Paulo: Contexto, 2014.

KOCH, Ingedore Grünfeld Villaça; ELIAS, Vanda Maria. Ler e compreender: os sentidos do texto. São Paulo: Contexto, 2006.

KOCH, Ingedore Grünfeld Villaça; TRAVAGLIA, Luiz Carlos. A coerência textual. 14. ed. rev. ampl. São Paulo: Contexto, 2002 [1990]).

MARCUSCHI, L. A. Linguística de Texto: o que é e como se faz. Recife: Mestrado em Letras e Linguística; Universidade Federal de Pernambuco, 1983.

MARCUSCHI, Luiz Antônio. Produção textual, análise de gêneros e compreensão. São Paulo: Parábola Editorial, 2008.

RAMOS, Paulo. A leitura dos quadrinhos. São Paulo: Contexto, 2009.

RAMOS, Paulo. Tiras no ensino. São Paulo: Parábola Editorial, 2017.

RAMOS, Paulo; BRITO, Karoline Caetano. Comicidade além da tira: paratextos como estratégia para produção do humor. Memorare, Tubarão, SC, v. 6, n. 2, p. 71-90, jul./dez./ 2019. Disponível

em: http://www.portaldeperiodicos.unisul.br/index.php/memorare_grupep/article/view/8542/4722. Acesso em 23 set. 2021. 
PERcursos Linguísticos • Vitória (ES) •v. $11 \bullet$ n. 29 • 2021 • ISSN: 2236-2592 • Dossiê

temático $\bullet O$ texto na pesquisa e no ensino: conhecimentos, práticas e desafios na contemporaneidade •

RAMOS, Paulo; SILVA, Elisa Ribeiro. Relações paratextuais em "Os Santos": focalização de um conceito. Cadernos de linguagem e sociedade, v. 22 n. 1 (2021), p. 204-224. Disponível em: https://periodicos.unb.br/index.php/les/article/view/35446. Acesso em 20 set. 2021.

RECUERO, Raquel. Um estudo do capital social gerado a partir das Redes Sociais no Orkut e nos Weblogs. Revista da Famecos. Porto Alegre: EDIPUCRS, nº 28, 2005.

RECUERO, Raquel. Redes Sociais na internet. Porto Alegre: Sulina, 2009.

VAN DIJK, Teun. Discurso e contexto: uma abordagem sociocognitiva. São Paulo: Contexto, 2012. 
O FORMATO DAS TIRAS NO INSTAGRAM E A CONSTRUÇÃO DE SENTIDO

\title{
THE COMIC STRIP FORMATS ON INSTAGRAM AND THE CONSTRUCTION OF MEANING
}

\author{
Kleber Soares Araújo ${ }^{1}$
}

\begin{abstract}
Resumo: O desenvolvimento da linguagem dos quadrinhos esteve relacionado aos seus suportes e, nesse sentido, as tiras foram impactadas pelas mudanças mercadológicas empreendidas pelo seu principal suporte, o jornal (GARCÍA, 2012). Devido à migração das tiras para outros suportes, questiona-se, todavia, se o formato apresentado por elas em suporte digital interfere na construção de sentido por parte do leitor. Considerando a hipótese de que o formato da tira, adequado ao suporte, interage com o processamento textual e interfere na compreensão do leitor, verificou-se como o formato composicional apresentado pelas tiras no Instagram interfere na construção de sentido. No âmbito da Linguística Textual, adotou-se uma concepção abrangente de texto, em uma perspectiva sociocognitiva interacional, que integra vários modos de linguagem, de acordo com Beaugrande (1997), Marcuschi (2008), Koch e Elias (2013), Koch (2015), Elias e Silva (2018) e Gualberto, Pimenta e Santos (2018). Foram analisados dois perfis autorais no Instagram, em que se examinou as tiras adaptadas do jornal (suporte impresso) e outras veiculadas especificamente no Instagram (suporte digital). Os resultados demonstraram que o leitor cria expectativas de leitura com base no formato apresentado e que as alterações podem mudar o processamento textual e potencializar, ou suprimir, aspectos que envolvem a leitura dos textos em quadrinhos.
\end{abstract}

Palavras-chave: Tiras. Texto. Leitura. Sentido. Rede social.

Abstract: The development of the comics was related to their medias and the comic strips were impacted by the market changes undertaken by newspapers (GARCÍA, 2012). With the circulation of the comic strips in the several medias, we questioned if the compositional format presented by them on the digital media interferes in the construction of meaning by the reader. Based on the Text Linguistics framework this research considers the hypothesis that the comic strips formats interacts with textual processing and interferes with reader's understanding and we adopted a concept of the multimodal text in a sociocognitive perspective according to Beaugrande (1997), Marcuschi (2008), Koch e Elias (2013), Koch (2015), Elias e Silva (2018) e Gualberto, Pimenta e Santos (2018). This paper examines two personal Instagram profiles with the aim of verifying how the compositional format of the comic strips interferes with the construction of meaning by the reader. We focus on comic strips adapted from the newspaper (printed media) and other published specifically on Instagram (digital media). The result showed that the reader creates reading expectations based on the format of the comic strips.

\footnotetext{
${ }^{1}$ Mestrando em Letras pela Universidade Federal de São Paulo (UNIFESP). E-mail: klrsoares@gmail.com
} 


\section{PERcursos Linguísticos • Vitória (ES) •v. 11 •n. 29 • 2021 • ISSN: 2236-2592 • Dossiê temático $\bullet O$ texto na pesquisa e no ensino: conhecimentos, práticas e desafios na contemporaneidade •}

The change of format interferes in textual processing and enhances, or suppresses, the aspects that involve the reading of comics.

Keywords: Comic strips. Text. Reading. Meaning. Social media.

\section{Introdução}

A relação entre gêneros e suportes, conforme conduzida por Marcuschi (2008), é evidenciada quando se analisa as tiras e os jornais. Além disso, ao tratar das tiras, posto como um gênero que compartilha da linguagem dos quadrinhos, aborda-se uma relação construída no decorrer dos anos que moldou a sua temática e o seu formato principalmente (GARCÍA, 2012). Ou seja, falar de tiras é também falar de seu formato. Mediante as mudanças impulsionadas pela internet, os estudos promovidos por Ramos $(2014,2015)$ têm indicado a transição das tiras cômicas, gênero textual estabelecido em suportes impressos, para suportes digitais. Apesar da mudança de ambiente, no qual as redes sociais se destacam, Ramos salienta que a identidade genérica das tiras não tem se alterado, mas que o seu formato composicional tem apresentado modificações devido às experimentações de linguagem promovidas no novo suporte. Nesse ensejo, o Instagram, uma rede social com foco no compartilhamento de fotos, foi criado em 2010 e adquirido pelo Facebook posteriormente. Em 2020, ele reunia diversas funções nativas de outras redes sociais e, atualmente, possui mais de 1 bilhão de usuários ativos por mês, tornando-se uma das redes sociais mais populares do mundo (INSTAGRAM..., 2020).

Diante do exposto, este estudo questiona se o formato apresentado pelas tiras no Instagram interfere na construção de sentido. Parte-se da hipótese de que o formato da tira, adequado ao suporte, repercute no modo de processamento textual, pois ele potencializa, ou suprime, aspectos presentes no gênero e, dessa forma, interfere na compreensão do leitor. Tendo isso em vista, objetiva-se verificar como o formato composicional, apresentados pelas tiras no Instagram, interfere na construção de sentido por parte do leitor. Além disso, pretende-se contribuir com as discussões a respeito do processo de construção de sentido em textos multimodais. Para tal, a primeira seção, "Do texto ao suporte", evidencia a necessidade de uma noção de texto mais abrangente em que a atividade textual não se realiza apenas por meio dos elementos linguísticos, mas considera-se também diversos conhecimentos de mundo e a integração de vários modos de linguagem. A segunda seção, “A tira e o seu formato", apresenta a relação próxima do suporte jornal com a tira e em como o suporte interferiu no formato das tiras e na sua linguagem. A terceira seção, "O formato e o sentido nas tiras do Instagram", 


\section{PERcursos Linguísticos • Vitória (ES) •v. 11 •n. 29 • 2021 • ISSN: 2236-2592 • Dossiê temático $\bullet O$ texto na pesquisa e no ensino: conhecimentos, práticas e desafios na contemporaneidade •}

analisa dois perfis autorais no Instagram e apresenta como os cartunistas veiculam as suas tiras e as construções de sentidos possíveis.

\section{Do texto ao suporte}

Em meio às águas, um bloco de gelo se desloca lentamente e a sua ponta evidente esconde sob a água uma massa ainda maior. A metáfora do iceberg é utilizada para relacionar o texto e o sentido que ele apresenta, considerando que, por um lado, a sua parte visível é identificada rapidamente e, por outro, há uma grande parte submersa que escapa aos olhos. Beaugrande (1997), que proporcionou essa metáfora, acreditava que a Ciência deveria avançar para compreender a forma como as pessoas se relacionam e torná-las capazes para o desempenho de suas funções sociais. Nesse contexto ecológico, a língua virtualmente determina as escolhas potenciais e o texto manifesta as escolhas reais. Os estudos realizados por ele proporcionaram uma noção ampliada de texto que pode ser pautada em três aspectos: o seu caráter sociocomunicativo, a interação e a conectividade. De acordo com Koch $(2015$, p. $17-$ 18), a concepção de texto se relaciona com o entendimento que temos de língua e de sujeito. A atual noção de texto apresenta uma "concepção interacional (dialógica)" de língua, o sujeito é visto como "ator/construtor social" e o texto passa a ser o "local de interação". Nessa concepção, a "compreensão" é tida como uma atividade interativa complexa, o sentido é construído e o texto é destacado como o local de interação.

Conforme mencionado, a noção de texto adotada remonta aos estudos de Beaugrande (1997) e compreende o texto como um evento que envolve os sujeitos em interação, em que estão presentes elementos linguísticos, fatores cognitivos e sociais. Essa definição, atualizada por Koch (2015, p. 22), apresenta o texto como "um evento dialógico (Bakhtin), de interação entre sujeitos sociais - contemporâneos ou não, copresentes ou não, do mesmo grupo social ou não, mas em diálogo constante.” Considerando essa interação, Marcuschi (2008, p. 89) realça que "o que faz um texto ser um texto é a discursividade, inteligibilidade e a articulação que ele põe em andamento.” Assim, como na metáfora do iceberg, o texto reserva ao leitor uma variada gama de implícitos que se concretizam quando consideramos o contexto sociocognitivo dos participantes (sujeitos ativos/construtores sociais). Nesse sentido, em consonância com Koch (2015, p. 26-27), o contexto permite que os sujeitos em interação interpretem determinado evento adequadamente e, para tal, ele abrange o "entorno verbal" (cotexto), a "situação de interação imediata, a situação mediada (entorno sócio-político-cultural) e também o contexto 


\section{PERcursos Linguísticos • Vitória (ES) •v. 11 •n. 29 • 2021 • ISSN: 2236-2592 • Dossiê temático $\bullet O$ texto na pesquisa e no ensino: conhecimentos, práticas e desafios na contemporaneidade •}

sociocognitivo" dos sujeitos. Além disso, Koch e Elias (2013) denotam que esses sujeitos, ao produzir ou ler um texto, fazem uso de estratégias sociocognitivas e ativam diversos tipos de conhecimentos armazenados, frutos de sua vivência, para auxiliar o entendimento do texto e a produção de sentido. A cada momento da interação, o contexto se altera e os sujeitos precisam se ajustar a ele e o contexto sociocognitivo permite que eles recorram aos diferentes conhecimentos compartilhados. Assim, as autoras evidenciam o caráter sociocomunicativo do texto e a importância da interação, pois os textos atuam em contextos comunicativos e o seu sentido só se completa com a participação dos sujeitos.

Cavalcante (2011) destaca a característica multimodal do texto ao enfatizar que ele engloba elementos linguísticos e não linguísticos (visuais, sonoros, cognitivos e outros). Dada essa característica, as pesquisas que envolvem o texto tendem a se preocupar também com os elementos visuais, os elementos composicionais (tipos, layout, diagramação) e como o sentido é construído pelo leitor. Essa noção expandida de texto, conforme salientado por Gualberto, Pimenta e Santos (2018, p. 18), indica que "todo texto é multimodal e não só aqueles que possuem imagens e palavras." Sendo assim, não é necessário diferenciar o "texto" do "texto multimodal", pois ambos compõem uma noção única. Sob esse aspecto, Elias e Silva (2018, p. 112) denotam que a multimodalidade, vista como "a coocorrência de vários modos de linguagem (semioses), que se integram na construção de significados em interações sociais, é inerente a toda manifestação linguística." Ao considerar o não linguístico, entende-se que o texto possui a integração de diferentes semioses e, como evento comunicativo, é constituído por diferentes elementos. Por essa razão, a construção de sentido é possibilitada pelo o uso de estratégias sociocognitivas, o acionamento de conhecimentos diversos e a criação de conexões entre eles.

A importância dessa conexão é explicitada por Koch e Elias (2016, p. 34) da seguinte maneira:

\footnotetext{
Se o texto é texto à medida que o vemos como tal, é porque nesse processo estabelecemos conexões entre texto, sujeitos e sociedade. O princípio de conectividade evidencia, portanto, que o texto não resulta apenas do conhecimento da língua, tampouco somente das intenções de quem o produz ou das interpretações de quem o lê (ouve), mas da complexidade dos aspectos envolvidos nas relações intersubjetivas constituídas de forma situada.
}

De acordo com as autoras, essa conexão é um ponto-chave, pois o texto pode estabelecer relações no próprio texto e com os contextos em que ocorrem, por essa razão, Beaugrande (1997) identificou os princípios de textualidade (coesão, coerência, intencionalidade, 


\section{PERcursos Linguísticos • Vitória (ES) •v. 11 •n. 29 • 2021 • ISSN: 2236-2592 • Dossiê temático $\bullet O$ texto na pesquisa e no ensino: conhecimentos, práticas e desafios na contemporaneidade •}

aceitabilidade, informatividade, situacionalidade e intertextualidade) como formas de conectividade. Nesse sentido, as formas de conectividade tornam-se condições para uma "ação linguística" e a textualidade um "modo de processamento" ou "empreendimento humano".

Compreendida a noção de texto e os elementos englobados (linguísticos, não linguísticos, cognitivos, sociais e contextuais), evidencia-se a importância da interação, pois os indivíduos realizam as suas funções sociais por meio de diversas possibilidades de interações e objetivos diferentes. Com base em suas competências sociocomunicativas, os indivíduos procuram identificar o que é mais adequado em cada prática social e, para tal, eles fazem uso de formas convencionalizadas, específicas e relativamente estáveis - os gêneros. ${ }^{2}$

Sobre essas formas relativamente estáveis, Bakhtin (2011, p. 261) escreve:

Todos os campos da atividade humana estão ligados ao uso da linguagem. Compreende-se perfeitamente que o caráter e as formas desse uso sejam tão multiformes quanto os campos da atividade humana [...]. Esses enunciados refletem as condições específicas e as finalidades de cada referido campo não só por seu conteúdo (temático) e pelo estilo da linguagem, ou seja, pela seleção dos recursos lexicais, fraseológicos e gramaticais da língua, mas, acima de tudo, por sua construção composicional.

Segundo Bakhtin (2011), a linguagem, em sua relação com a atividade humana, é caracterizada pelo uso "multiforme" e o emprego da língua se realiza por meio de "enunciados". O conteúdo, o estilo e a construção composicional fazem parte do enunciado e são determinados pela especificidade de cada campo. Mediante o exposto, Marcuschi (2008, p. 155) aponta os gêneros textuais como textos materializados "que apresentam padrões sociocomunicativos característicos por composições funcionais, objetivos enunciativos e estilos concretamente realizados na integração de forças históricas, sociais, institucionais e técnicas.” Assim, essas formas convencionalizadas são situadas "sócio-historicamente", pois estão relacionadas com diferentes situações sociais e, nesse contexto, toda interação ocorre por meio de um gênero que se realiza por um texto.

Cavalcante (2011, p. 44) salienta que "muitos gêneros estão intrinsicamente relacionados a algo que os apresenta. Essa entidade que veicula o gênero é designada, nos estudos do texto e do discurso, por suporte [...].” De acordo com a autora, essa relação próxima permite o reconhecimento do gênero e, em alguns casos, determina a sua escolha. Essa entidade

\footnotetext{
${ }^{2}$ Em tempo, entende-se que os gêneros são constituídos por duas dimensões (textual e discursiva) e que a escolha terminológica reflete a definição do objeto de estudo, conforme exposto por Bezerra (2017). Nesta pesquisa, utiliza-se o termo gênero textual, tendo gênero como forma sinônima, pois ele faz jus ao foco do estudo, o texto como um evento dialógico e local de interação, e à adoção do instrumental fornecido pela Linguística Textual.
} 


\section{PERcursos Linguísticos • Vitória (ES) •v. 11 •n. 29 • 2021 • ISSN: 2236-2592 • Dossiê temático $\bullet O$ texto na pesquisa e no ensino: conhecimentos, práticas e desafios na contemporaneidade •}

significativa no processo interacional é definida por Marcuschi $(2008$, p. 174) como um "locus físico ou virtual com formato específico que serve de base ou ambiente de fixação do gênero materializado como texto." Ainda segundo o autor, o suporte interfere no gênero e exerce um papel importante para que ele circule na sociedade. Além disso, ele pode ser convencional (elaborado para determinada finalidade) ou incidental (usos eventuais).

Com base nos autores, compreende-se que o suporte fixa, auxilia na apresentação, na delimitação e reconhecimento do gênero. Além disso, o fato de o suporte possuir um formato específico indica que ele é convencionalizado, elaborado para determinada finalidade, e pode contribuir com o gênero. No entanto, apesar do que possa parecer, o suporte não define o gênero, mas os gêneros aparentam possuir preferências por determinados suportes (MARCUSCHI, 2008).

Dessa forma, os gêneros são "formas-padrão" relativamente estáveis de enunciados utilizados para propósitos comunicativos específicos e, como vimos, são influenciados pela atividade humana, ou seja, são determinados pelo campo ou comunidade. Assim, dependendo do suporte no qual os gêneros estão fixados, infere-se a existência de particularidades que interferem na construção de sentido. Dessa forma, a noção de texto como um evento comunicativo - em que estão presentes os elementos linguísticos, não linguísticos e fatores cognitivos - que resulta do uso de estratégias sociocognitivas e de conhecimentos compartilhados entre os sujeitos envolvidos na interação, auxilia no entendimento dessa nova relação estabelecida em ambientes digitais, como o Instagram.

\section{A tira e o seu formato}

Considerando a noção de texto abordada na seção anterior, em que os elementos linguísticos são necessários, mas não suficientes para a construção de sentido, compreende-se que diferentes modos de linguagem atuam na construção de significados, conforme exposto por Elias e Silva (2018). Tendo em vista que a pesquisa propõe compreender como os formatos das tiras no Instagram interferem na construção de sentido, pontua-se brevemente o que são quadrinhos e tiras e como eles podem ser entendidos sob uma perspectiva dos estudos do texto e da linguagem.

Para Eisner (2010, p. 39), a função dos quadrinhos é 


\section{PERcursos Linguísticos • Vitória (ES) •v. 11 •n. 29 • 2021 • ISSN: 2236-2592 • Dossiê temático $\bullet O$ texto na pesquisa e no ensino: conhecimentos, práticas e desafios na contemporaneidade •}

encapsulamento desses eventos no fluxo da narrativa, eles devem ser decompostos em segmentos sequenciados.

Assim, observa-se que os quadrinhos conduzem a narrativa por meio de enquadramentos, tornando-a parte importante do processo criativo. Ademais, Barbieri (2017) compreende que os quadrinhos fazem parte da linguagem geral da narrativa, aproximando-a de outras linguagens, tais como cinema, ilustração, fotografia etc. Contudo, essa linguagem tem desenvolvido recursos próprios que garantem a sua autonomia ${ }^{3}$. Em seu estudo, Ramos (2017) aponta algumas características dos quadrinhos, entre elas: o uso da linguagem dos quadrinhos por diferentes gêneros; o predomínio de sequência ou tipo textual narrativo; a variedade de quadros; a percepção do gênero orientada pelo suporte e pelo formato e a tendência em se utilizar desenhos para compor as histórias.

Como visto, Ramos expressa a tendência em classificar os quadrinhos como gêneros. Para corroborar com essa afirmação, adota-se o conceito de hipergênero proposto por Maingueneau

[...] o hipergênero não é, propriamente falando, um gênero do discurso, um dispositivo de comunicação historicamente definido, mas um tipo de organização textual de coerções pobres, relativamente estável com o decorrer dos séculos, no interior do qual podem se desenvolver variadas encenações da palavra. (MAINGUENEAU, 2013, p. 123, supressão nossa)

Em consonância com esse raciocínio, Ramos (2018, p. 20) define os quadrinhos como "um grande rótulo, um hipergênero, que agregaria diferentes outros gêneros, cada um com suas peculiaridades." Desta forma, os quadrinhos, amparados por sua linguagem, são um hipergênero e as tiras, que compartilham dessa linguagem, podem ser vistas como um gênero (rótulo) dos quadrinhos.

O desenvolvimento da linguagem dos quadrinhos, sob uma perspectiva histórica, esteve relacionado com a evolução dos suportes na qual estavam atrelados e das mudanças impostas por ele, conforme apontamentos feitos por Eco (1993) e Garcia (2012). Essa relação se torna mais evidente ao se recuperar alguns marcos históricos dos quadrinhos modernos, como, por exemplo, a publicação das ilustrações protagonizadas pelos personagens Mickey Dugan (Yellow Kid), de Richard Outcault, New York Journal em 1896 (Figura 1).

Além do uso experimental de recursos formalizados e presentes nos quadrinhos modernos, como a sequencialidade e o balão de fala, a série criada por Outcault esteve no centro

\footnotetext{
${ }^{3}$ Para Barbieri (2017), o modo como os quadrinhos interagem com outras linguagens permitem pontos de vistas particulares. Entre elas, destacam-se: uso de cores, elementos caricatos, uso de perspectivas e profundidade, enquadramentos, ritmo gráfico, balões, legendas, onomatopeias e outros.
} 


\section{PERcursos Linguísticos • Vitória (ES) •v. 11 •n. 29 • 2021 • ISSN: 2236-2592 • Dossiê temático $\bullet O$ texto na pesquisa e no ensino: conhecimentos, práticas e desafios na contemporaneidade •}

de uma disputa entre Joseph Pulitzer, do New York World, e William Randolph Hearst, do New York Journal, pelo mercado da imprensa diária da cidade de Nova Iorque.

Figura 1 - The Yellow Kid e seu novo fonográfo, publicado em 25 de outubro de 1896

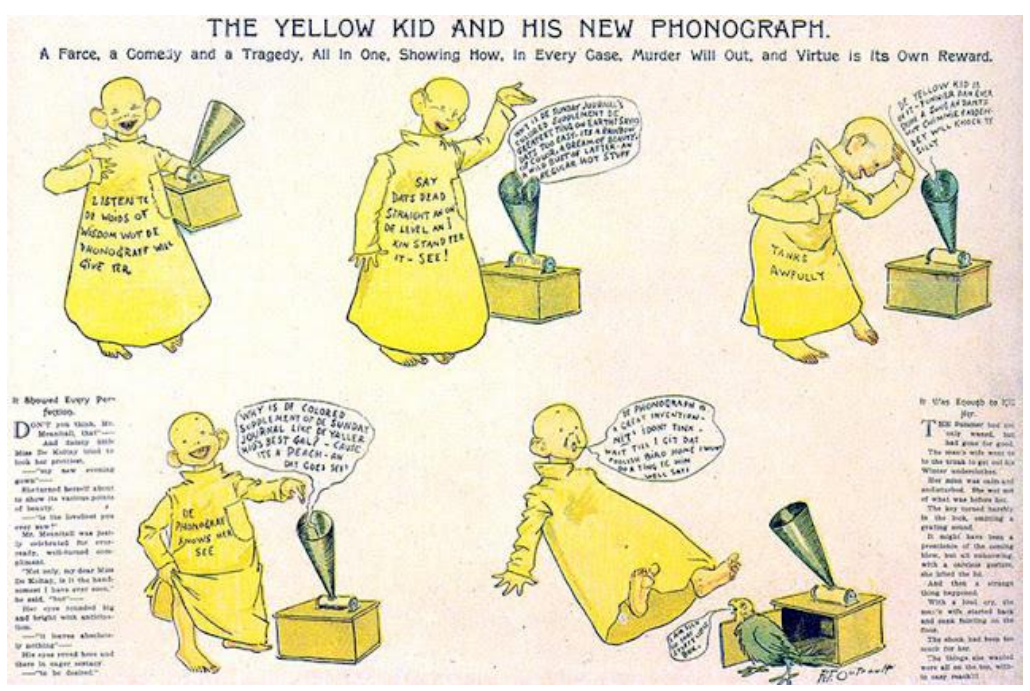

Fonte: García (2012, p.75)

De acordo com García (2012), esse período foi marcado pelo uso das histórias em quadrinhos para potencializar a vendagem dos periódicos e pela influência exercida pela imprensa como meio de comunicação. Essa disputa influenciou a relação entre os criadores das histórias e seus veículos (jornais) e, posteriormente, com as agências que intermediavam o negócio (syndicates). Cabe ressaltar que, com a popularização dos quadrinhos em grandes veículos de imprensa, surgiu a necessidade de padronizar o formato e viabilizar o seu acesso aos jornais que não possuíam os meios para produzir as suas próprias histórias. A atuação dos syndicates (agências), em distribuir seus conteúdos aos periódicos assinantes, possibilitou a padronização do formato e adequação das histórias a eles. De acordo com Ramos (2007), as histórias seriam alocadas entre as notícias dos jornais e, para facilitar a sua veiculação em diferentes periódicos, foi padronizado o modelo horizontal, mais comum, e o vertical, semelhantes a tiras. Dessa forma, o nome dado a esse tipo de histórias, tiras, procede da percepção de formato.

As tiras, como são conhecidas atualmente, são resultados dessa influência dos quadrinhos norte americanos e do plano de negócio desenvolvido na época. Apesar de existirem diferentes nomenclaturas (tirinhas é um exemplo) e diferentes "rótulos", que tendem a diferenciar tematicamente uma produção de outra, emprega-se, aqui, o termo tira de uma forma 


\section{PERcursos Linguísticos • Vitória (ES) •v. 11 •n. 29 • 2021 • ISSN: 2236-2592 • Dossiê temático $\bullet O$ texto na pesquisa e no ensino: conhecimentos, práticas e desafios na contemporaneidade •}

mais ampla em que se pode englobar tiras humorísticas, tiras de aventuras e outros. Com relação ao formato, as tiras apresentam-se, predominantemente, em formato de colunas (horizontais ou verticais), elas possuem, em geral, entre um e quatro quadros e os títulos aparecem na parte superior, conforme indicado por Ramos (2007) em seu estudo sobre tiras cômicas. Com o intuito de exemplificar, é apresentado um trecho da versão impressa do Caderno Ilustrada da Folha de S. Paulo (Figura 2) a seguir:

Figura 2 - Trecho da Ilustrada da Folha de S. Paulo, 21 de janeiro de 2021

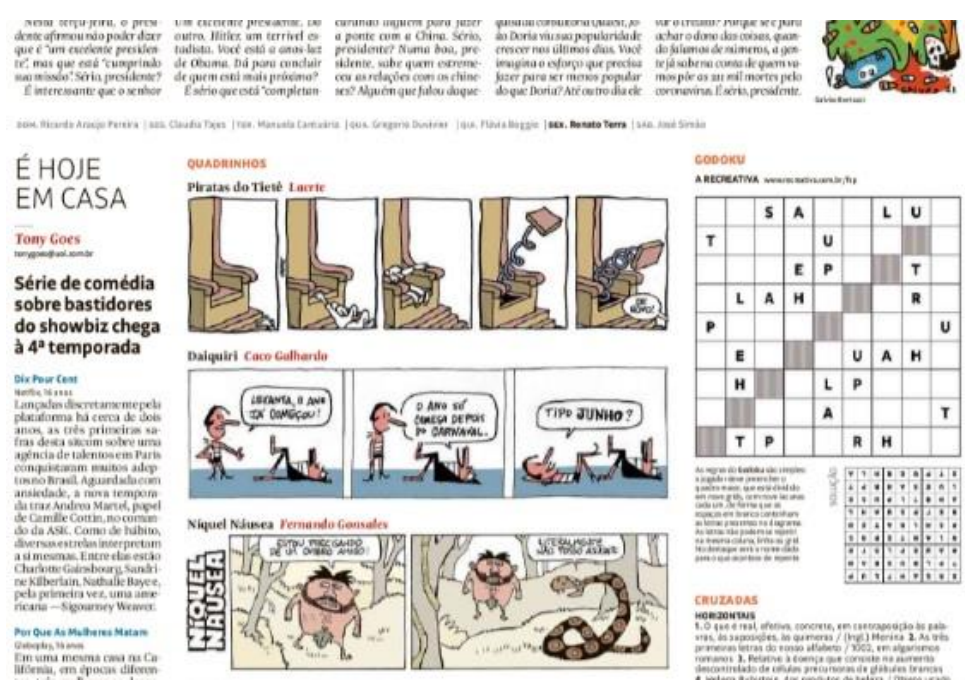

Fonte: Folha de S. Paulo (2021)

Na Figura 2, nota-se que as tiras seguem o padrão de publicação em colunas, própria do jornal, com os quadros (chamadas de vinhetas) na horizontal. O trecho apresenta três tiras com composições diferentes - variação no número de vinhetas e em seu tamanho. Apesar das mudanças ocorridas durante os anos, observa-se que as tiras são publicadas com características semelhantes aos seus precursores e isso se deve, em partes, pelo fato do seu suporte, o jornal, ter mantido determinadas características físicas. Sob esse aspecto, as tiras são criadas conforme o espaço disponível que variam de acordo com o suporte. As tiras da Ilustrada (Figura 2), compõem a página do jornal e competem pela atenção do leitor com as notícias, o horóscopo, passatempos etc. Assim, a exposição realizada se alinha à ideia de Marcuschi (2008, p. 174) de que o "suporte não é neutro e o gênero não fica indiferente a ele." A relação das tiras com os jornais demonstra como o suporte pode influenciar o gênero e, de certa forma, caracterizá-lo. Ao se deparar com o gênero tiras, o leitor criará expectativas, inclusive sobre a forma de leitura, com base no que ele conhece sobre o gênero e sobre o suporte. Com as mudanças 


\section{PERcursos Linguísticos • Vitória (ES) •v. 11 •n. 29 • 2021 • ISSN: 2236-2592 • Dossiê temático $\bullet O$ texto na pesquisa e no ensino: conhecimentos, práticas e desafios na contemporaneidade •}

proporcionadas pela internet, as tiras encontram novos lugares de circulação e, para tal, elas se adaptam aos recursos oferecidos pelo suporte.

\section{O formato e o sentido nas tiras do Instagram}

Devido a sua proposta visual e fluida, o Instagram tornou-se um lugar propício para a circulação das tiras e outras produções gráficas. No entanto, muitos perfis se dedicam a divulgar produções retiradas de outros suportes (jornais, livros, revistas, sites etc.). Mediante essa diferença de suporte, as tiras estão sujeitas às adaptações - reduções, reestruturação das vinhetas, mudança de sentido de leitura - que podem interferir no sentido construído pelo leitor.

Considerando o exposto, realizou-se uma pesquisa na plataforma com os termos "tiras", "tirinhas" e "cartum" no mês de setembro de 2020. Com base nos resultados, optou-se pela seleção de um perfil que também veiculasse as suas tiras em suporte impresso e outro que utilizasse o Instagram como fonte principal de divulgação. Desta forma, o corpus selecionado é composto por tiras autorais veiculadas em perfis próprios na rede social e que se destacam por utilizar o formato composicional na construção dos seus textos em quadrinhos. Ação promovida com o intuito de preservar os elementos textuais importantes, tal qual a intencionalidade (KOCH, 2020, p. 51) - vista como as diferentes formas como os sujeitos empregam seus textos para atingir suas intenções comunicativas - e a intertextualidade - que compreende as diferentes maneiras que "a produção/recepção" de um texto depende do conhecimento de outros textos. Após o levantamento dos perfis, definiu-se pelas tiras criadas por Caco Galhardo e Ademar Vieira, publicadas no período de julho a dezembro de 2020.

Caco Galhardo, cartunista e roteirista, com diversos livros publicados, é o criador das tiras "Os Pescoçudos" e personagens como "Chico Bacon” e "Lili”. Em 2019, publicou o livro "Cinco Mil Anos e quase todas as tiras" e, atualmente, colabora com a Folha de S. Paulo, caderno Ilustrada. As tiras selecionadas para a pesquisa foram publicadas na Folha de S. Paulo (suporte impresso) e republicadas em seu perfil do Instagram (suporte digital). No período analisado, Caco Galhardo publicou em seu perfil 83 vezes e, desse total, 45 publicações circularam na Folha de S. Paulo anteriormente. Com relação ao conteúdo, identificou-se o uso de charges, cartuns, tiras e outros tipos de publicações. Ressalta-se que a charge possui como principal característica a sua relação temática e, de certa forma, intertextual com algum evento ou notícia. Por essa razão, é comum localizarmos as charges em veículos jornalísticos. O cartum possui semelhanças com a charge - o uso da linguagem verbal e não verbal, o quadro único mas difere por não estar vinculado a um evento ou notícia. O cartum consegue apresentar "uma 


\section{PERcursos Linguísticos • Vitória (ES) •v. 11 •n. 29 • 2021 • ISSN: 2236-2592 • Dossiê temático $\bullet O$ texto na pesquisa e no ensino: conhecimentos, práticas e desafios na contemporaneidade •}

sequência entre um antes e um depois", conforme indicado por Ramos (2018, p. 21-23). No trecho retirado da Folha de S. Paulo (Figura 3), nota-se a informação da série, "Daiquiri”, e de autoria, "Caco Galhardo" registrada na parte superior.

Figura 3 - Tira publicada na Folha de S. Paulo - 23 de julho de 2020 Daiquiri Caco Galhardo

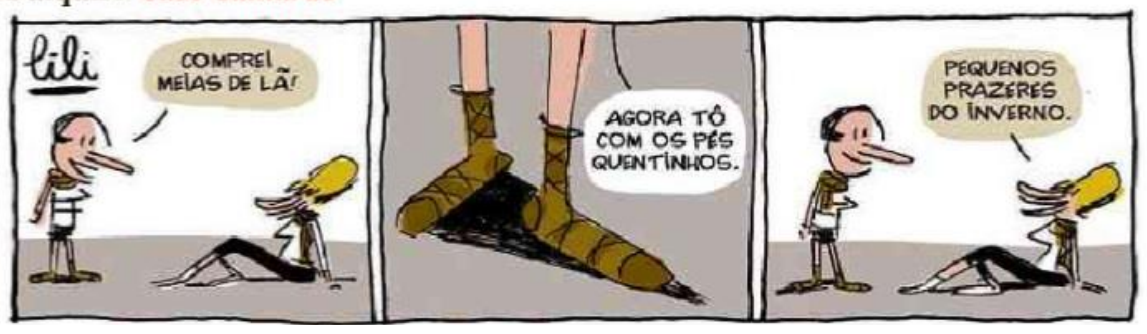

Fonte: Folha de S. Paulo (2020)

A tira difere da charge e do cartum por apresentar uma narrativa com desenvolvimento estabelecido ou inferido em que se predomina o uso de mais de uma vinheta. Aparentemente, a tira em destaque apresenta uma narrativa com início, meio e fim; contudo, ela pode estar ligada narrativamente, ou tematicamente, a uma tira anterior. Por essa razão, os leitores assíduos da série farão uso do seu conhecimento prévio para contextualizar a ação da personagem Lili e as suas características. Com relação à linguagem dos quadrinhos, contata-se o uso das vinhetas como contorno irregular encapsulando a narrativa, os balões de fala e os hiatos - espaços entre as vinhetas que demarcam as cenas narrativas e permitem ao leitor inferir sobre a dinâmica existente entre as vinhetas (RAMOS, 2018).

Considerando os aspectos relacionados ao suporte, infere-se que o autor elabora as suas histórias levando-se em conta o espaço disponível e o contexto de produção - público-leitor, linguagem, o seu lugar social e o momento de produção. No entanto, como visto, Caco Galhardo reedita algumas de suas tiras em seu perfil do Instagram e, em função disso, elementos diferentes do suporte jornal passam a ser considerados. Como comparativo, observa-se a publicação da tira Daiquiri (Figura 4):

Figura 4 - Daiquiri, de Caco Galhardo, publicada no dia 02 de agosto de 2020

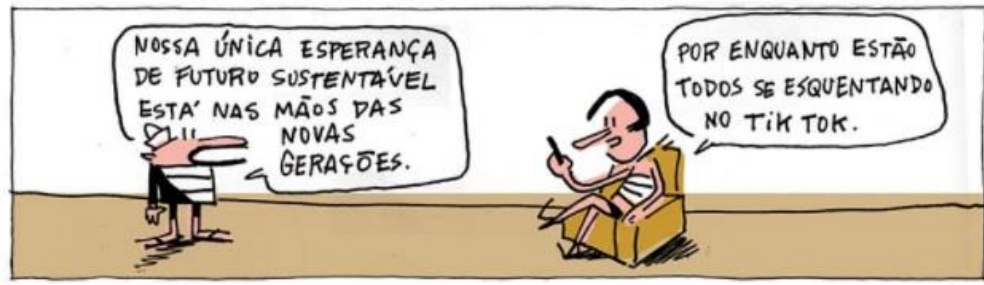

Fonte: Folha de S. Paulo (2020b) 


\section{PERcursos Linguísticos • Vitória (ES) •v. 11 •n. 29 • 2021 • ISSN: 2236-2592 • Dossiê temático $\bullet O$ texto na pesquisa e no ensino: conhecimentos, práticas e desafios na contemporaneidade •}

A tira publicada na Folha de S. Paulo (Figura 4) apresenta uma vinheta única e se aproxima de um cartum, contudo, com base nas publicações anteriores, infere-se que se trata de uma tira por seu conteúdo temático recorrente e ser inserida dentro de uma série já conhecida pelo público do jornal. A leitura da tira é realizada da esquerda para direita e, apesar da vinheta única, é possível definir dois momentos distintos ancorados pela fala dos personagens.

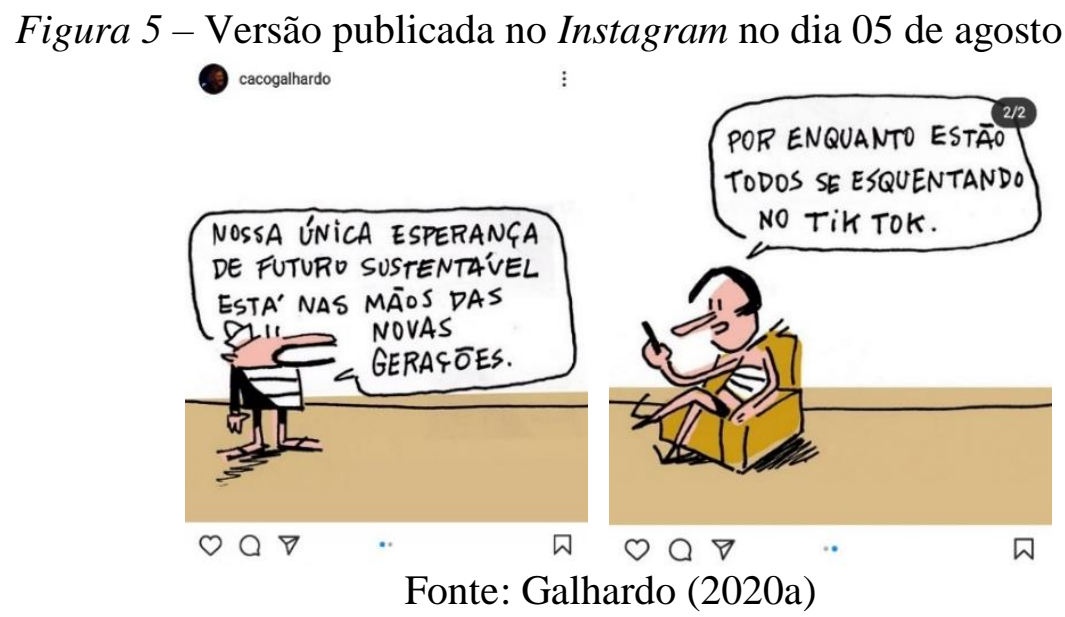

A tira publicada no Instagram (Figura 5), captura feita na versão mobile para o sistema Android, foi dividida em duas partes pelo autor. A imagem do personagem Chico (à esquerda) aparece na primeira tela e a personagem Lili (à direita) aparece na segunda tela, conforme indiciado pela marcação " $2 / 2$ ". A transição entre as imagens é fluida, pois o autor optou por manter a característica de vinheta única ao fazer uso do recurso do Instagram chamado de carrossel (ou sequencial), possibilidade de inserir até 10 imagens em uma única publicação. A diferença é evidenciada na forma como a transição entre as imagens ocorre, pois no Instagram não é possível identificar o corte da tira, ao contrário do que é apresentado propositalmente na Figura 5. Com o intuito de construir um sentido para a publicação, o leitor recorre aos seus conhecimentos sobre o gênero (formato, composição, sentido de leitura etc.), o suporte (forma de transição, legendas, comentários) e contextuais (personagens, temática e outros). O leitor que não conhece os personagens pode encontrar dificuldades para inferir sobre o interlocutor presente na tira e, devido ao uso de duas telas que simulam duas vinhetas, a inferência, que normalmente é ocasionada pelo hiato, possui efeito potencializado com relação à publicação do jornal, pois não é possível que o leitor visualize a tira em sua completude em um primeiro momento. Recurso que se alinha à necessidade de gerar uma expectativa inicial e proporcionar uma ruptura objetivando o humor. 


\section{PERcursos Linguísticos • Vitória (ES) •v. 11 •n. 29 • 2021 • ISSN: 2236-2592 • Dossiê temático $\bullet O$ texto na pesquisa e no ensino: conhecimentos, práticas e desafios na contemporaneidade •}

Nas publicações do Instagram, evidenciou-se o uso de diferentes formatos composicionais, conforme abaixo:

Figura 6 - Daiquiri, de Caco Galhardo, publicada no dia 29 de novembro de 2020

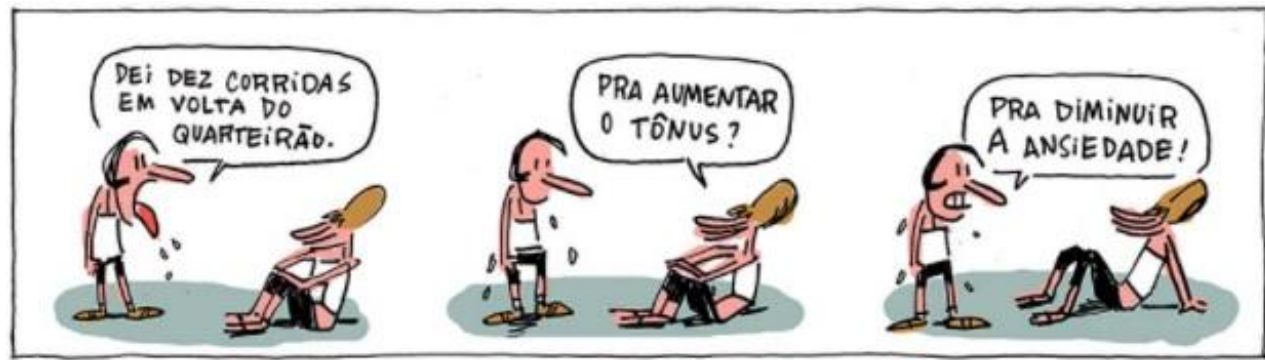

Fonte: Folha de S. Paulo (2020c)

Apesar de se assemelhar a uma vinheta única, entende-se que a tira (Figura 6) contém três vinhetas, mas apenas o contorno externo é visível. É possível identificar que os espaços dos personagens são delimitados e eles são retomados a cada cena em uma sequência narrativa.

Figura 7 - Versão publicada no Instagram no dia 30 de novembro de 2020

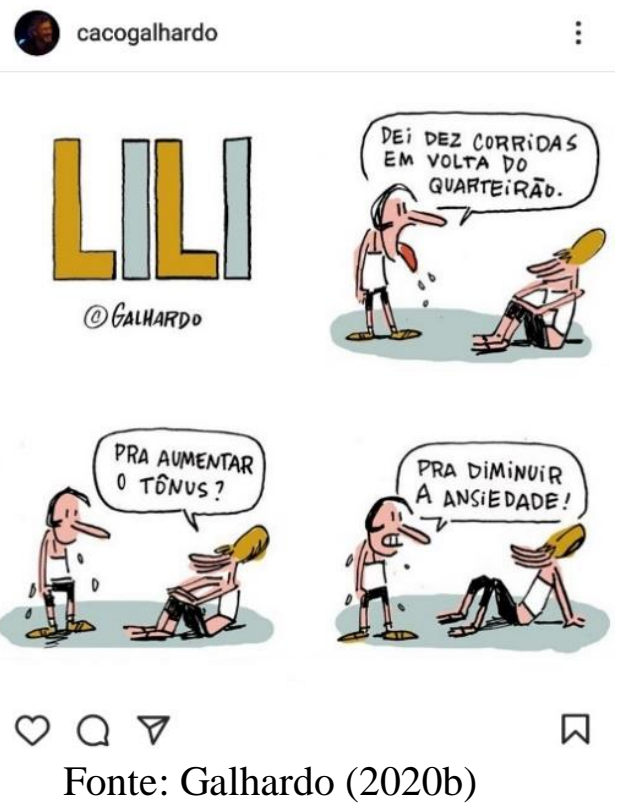

$\mathrm{Na}$ imagem seguinte (Figura 7), evidencia-se que o autor optou por alterar o formato da tira e a reformular a sua composição. Ele a divide em duas colunas com duas vinhetas e insere um título para ela (ausente na versão para o jornal). Aos leitores habituais, essa alteração pode não afetar a construção de sentido, contudo ele altera o sentido de leitura que passa a ser da 


\section{PERcursos Linguísticos • Vitória (ES) •v. 11 •n. 29 • 2021 • ISSN: 2236-2592 • Dossiê temático $\bullet O$ texto na pesquisa e no ensino: conhecimentos, práticas e desafios na contemporaneidade •}

esquerda para direita e da parte superior para a inferior. Nas tiras analisadas, não se notou dificuldades de leitura e na construção do sentido por parte dos leitores, pois os comentários indicam que o público que consome o conteúdo proposto no Instagram já possui conhecimento prévio do trabalho do cartunista e da temática presente em seus trabalhos. Até mesmo as publicações que envolvem um conhecimento contextual (acontecimentos e notícias) aparentam ser compreendidas.

Nas tiras analisadas, constata-se que o autor tem experimentado diferentes formatos de apresentação das suas tiras ao publicar no Instagram e, aparentemente, ele tem considerado os dois meios de circulação (jornal e rede social) ao produzir as suas tiras. Diferente do jornal, o cartunista pode ter um retorno (feedback e engajamento) sobre a sua publicação de imediato devido ao uso de botões de interação contidos na publicação por meio de símbolos - "coração" (curtida), "balão de fala" (comentário), "avião de papel” (compartilhar). Além disso, o autor pode explicitar a sua intenção e oferecer pistas contextuais por meio de uma legenda descritiva. Por sua vez, os comentários podem estabelecer uma relação hipertextual com a publicação, conforme observado no exame da próxima tira.

Ademar Vieira, jornalista, roteirista e quadrinista, é um artista amazonense formado em jornalismo pela Universidade Federal do Amazonas e atua com quadrinhos desde 1998. Publicou “Ajuricaba”, projeto premiado pela Prefeitura do Amazonas, em 2020 (ANDRADE, 2020). Em seu perfil do Instagram, analisou-se as publicações realizadas no período de julho a dezembro de 2020. Contatou-se a existência de 14 publicações nesse período e, desse montante, foram publicadas 11 tiras e 3 publicações relacionadas com a divulgação de seus livros. As histórias publicadas por Ademar, diferente do caso anterior, desenvolvem-se no espaço de 10 imagens reservadas pelo Instagram e, para fins de análise, apresenta-se uma sequência de três vinhetas da tira publicada no dia 10 de agosto de 2020 (Figura 8).

Figura 8 - Trecho, com três vinhetas, da tira publicada no dia 10 de agosto de 2020
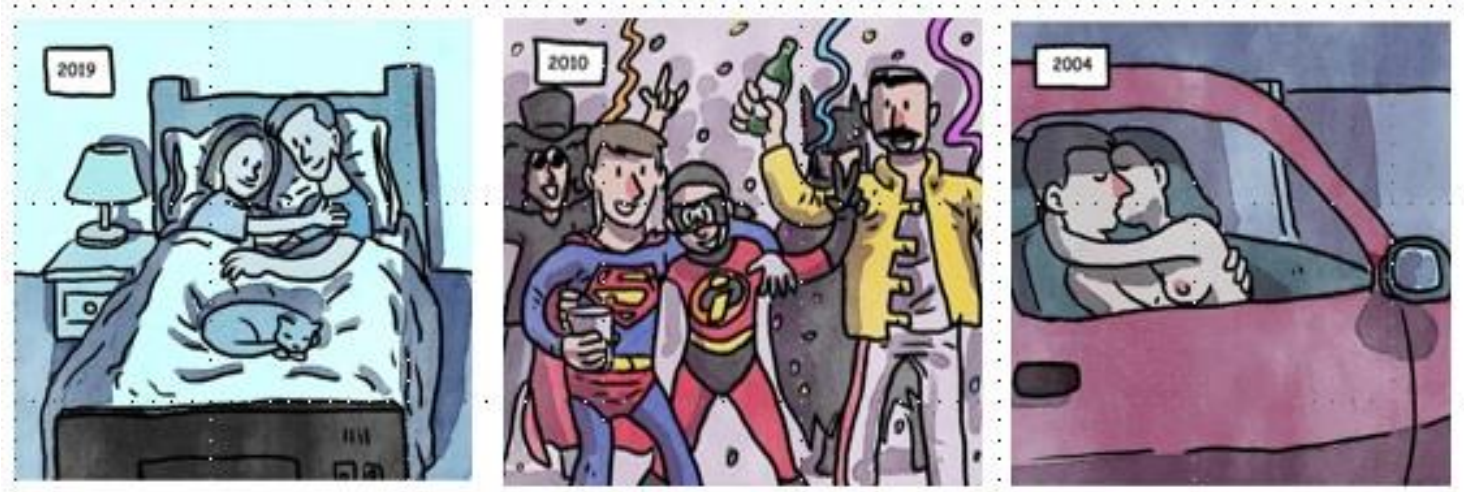


\section{PERcursos Linguísticos • Vitória (ES) •v. 11 •n. 29 • 2021 • ISSN: 2236-2592 • Dossiê temático $\bullet O$ texto na pesquisa e no ensino: conhecimentos, práticas e desafios na contemporaneidade •}

Fonte: Adaptado de Vieira (2020)

Na Figura 8, as vinhetas foram alocadas lado a lado para facilitar o entendimento. A tira, com o título “Yo Sólo Quiero Que Estés Bien" ("Eu só quero que vocêfique bem”, tradução livre), é composta essencialmente por elementos visuais e possui um balão de fala em sua última vinheta. Ela é composta por 10 telas do Instagram, em que cada uma delas corresponde a uma vinheta. O título da tira, informado na legenda pelo autor, funciona como uma pista contextual para que o leitor identifique, em conjunto com as informações visuais presentes no quadrinho, que se trata de um assunto de caráter íntimo e familiar. Conforme visto, os quadrinhos constroem a narrativa por meio de fragmentos de ações decompostas em diferentes segmentos (EISNER, 2010). As vinhetas costumam ser separadas por um espaço em branco, ou contorno do quadro, que delimitam essa ação e, com base na leitura da vinheta atual e a seguinte, o leitor procura inferir o que ocorreu nesse espaço de tempo. Esse processamento realizado pelo leitor é o que promove o desenvolvimento da narrativa. No entanto, essa forma de leitura sofre interferência, pois o leitor possui apenas a visão de uma vinheta por vez e isso o impede de visualizar a história no todo previamente para construir um sentido inicial ou estratégia.

Na primeira vinheta, identifica-se um casal, acompanhado por um animal de estimação, deitados em uma cama e a legenda, situada na parte superior à direita, apresenta uma função informativa e localiza a narrativa no espaço/tempo. Com base nisso, o leitor busca em suas representações mentais modelos que os auxiliem a entender como funciona o gênero, o modo de leitura no suporte e a prever o que acontecerá na próxima vinheta. A segunda vinheta, acionada pelo deslocamento da imagem anterior, quebra a expectativa gerada pelo leitor, pois apresenta os mesmos personagens em um outro cenário. A legenda da tira aponta para uma data anterior e, com base em novas informações, o leitor precisa reconstruir o que foi lido, criar outras relações e buscar um sentido para a narrativa. Para tal, ele fará uso do seu conhecimento prévio sobre o que está contido no texto para acrescentar as suas inferências (SCHNOTZ, 2009). Com base nisso, o leitor poderá intuir sobre a ocasião com base nas roupas, identificar os personagens pelos traços e que a narrativa regrediu para um período anterior ao da vinheta inicial. A terceira vinheta apresenta um novo cenário aparentemente desconexo dos anteriores. A legenda informa que o período regrediu novamente e que aquela cena se trata de uma data anterior as duas últimas vinhetas. As próximas vinhetas, não inseridas aqui, apresentam os personagens em diferentes situações e datas. O autor decidiu não colocar as vinhetas em ordem cronológica, mas manteve como fio condutor da narrativa os personagens principais (o casal) e 


\section{PERcursos Linguísticos • Vitória (ES) •v. 11 •n. 29 • 2021 • ISSN: 2236-2592 • Dossiê temático $\bullet O$ texto na pesquisa e no ensino: conhecimentos, práticas e desafios na contemporaneidade •}

uma legenda que situa o leitor no tempo. Na última vinheta, não incluída, há o desfecho que permite ao leitor, com base na sua leitura e nas informações paratextuais (legendas da publicação e comentários), construir um sentido para o texto criado pelo autor.

O campo "legenda" é o espaço que o autor utiliza para dar nome a sua publicação, indicar a intenção da publicação, criar o contexto ou referenciar. Esse espaço é muito utilizado para que os autores insiram etiquetas temáticas (hashtags) que vinculam a sua publicação a um assunto maior. As etiquetas são um elemento característico dos ambientes digitais e proporcionam uma ligação (hipertextual) com outras publicações. De acordo com Elias (2015, p. 60) o hipertexto "é uma construção que se realiza com base em elementos de conexão que remetem a múltiplos textos com linguagens e mídias variadas [...]”. Assim, o autor estabelece uma ligação entre a sua publicação e outras e cabe ao leitor identificar a profundidade dessa ligação e até que ponto ela é necessária para o seu entendimento. A área dos "comentários" é o espaço reservado para interação direta entre o autor e os leitores e entre os leitores. Dada a característica do suporte, cria-se uma relação hipertextual, pois os comentários estabelecem relações com os outros comentários (em tópicos por exemplo) ou estabelecem novas relações textuais criando outros referentes e sendo atualizados de forma dinâmica.

Com base no exposto, observa-se que o texto serve como estímulo para que o leitor ative diferentes conhecimentos para compor um sentido para a história. Nesses casos, o leitor tende a colocar as vinhetas em ordem cronológica para que elas façam algum sentido, mas isso só se tornou possível após a leitura da última vinheta. Além disso, devido ao seu formato, o autor potencializou o uso dos hiatos (elemento inferencial), uma característica das tiras e dos quadrinhos, ao suprimir a visão das tiras seguintes e a demandar que o leitor reconfigurasse o seu entendimento a cada tira.

Figura 9 - Trecho dos comentários da tira "Yo Sólo Quiero Que Estés Bien" 


\section{PERcursos Linguísticos • Vitória (ES) •v. 11 •n. 29 • 2021 • ISSN: 2236-2592 • Dossiê temático $\bullet O$ texto na pesquisa e no ensino: conhecimentos, práticas e desafios na contemporaneidade •}

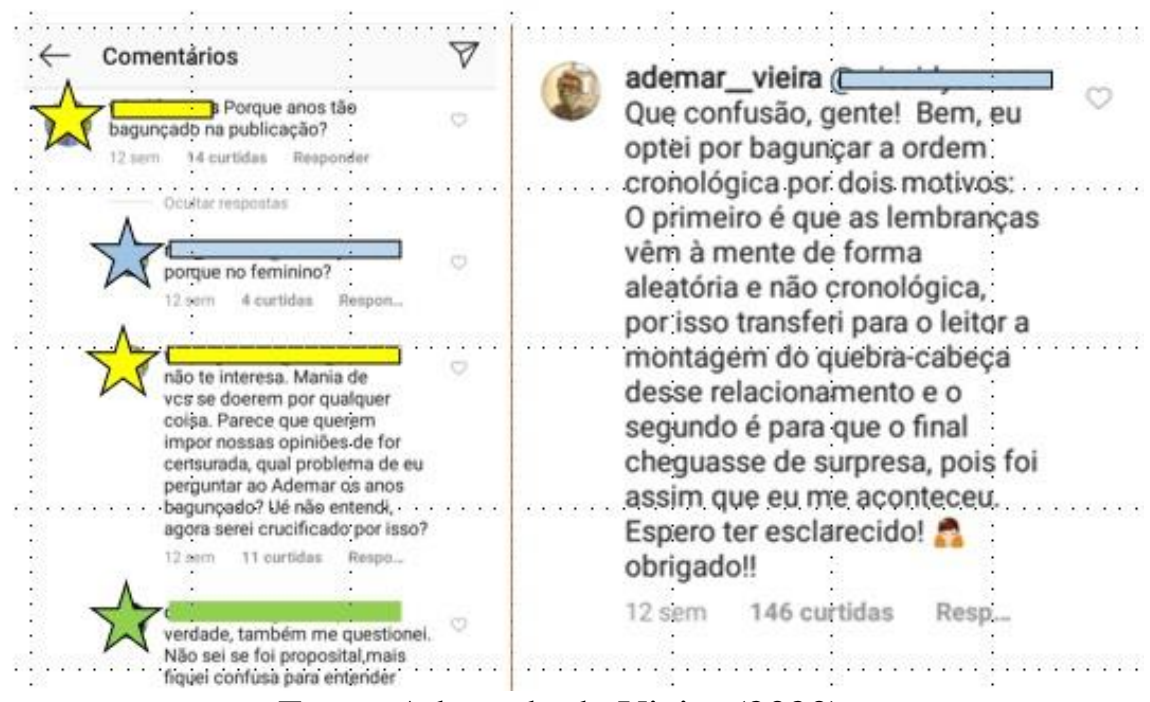

Fonte: Adaptado de Vieira (2020)

Na Figura 9, apresenta-se um trecho dos comentários que evidenciam a dificuldade imposta pelo formato composicional e, para tal, suprimimos as fotos e os nomes dos leitores. Nota-se que o leitor A, sinalizado em amarelo, comenta que "Porque os anos estão bagunçados na publicação".

É possível que o leitor tenha inferido que foi um erro na hora de publicar. Posteriormente, outros leitores acessam o comentário e respondem a ele. O leitor $B$, sinalizado em azul, questiona o leitor $A$ sobre algo que ele comentou anteriormente e o leitor $C$, em verde, retoma o tópico principal e diz que se questionou se o ato foi proposital, mas que teve dificuldades para entender. O tópico principal levantado pelo leitor $A$ diz respeito à organização das vinhetas na publicação, pois ele entende que a passagem do tempo demanda uma ordem cronológica. O leitor $B$ cria uma ruptura no tópico principal e a discussão passa a ser direcionada para outra temática de ordem social criando outros referentes e relações textuais que não se relacionam com a publicação. Isso denota a hipertextualidade existente nesse meio e a plasticidade no modelo de interação. A interação é finalizada quando o autor expõe o seu objetivo com a publicação (intencionalidade), mostrando que a publicação possui uma relação autobiográfica e que a ideia principal era reproduzir as lembranças de um relacionamento rompido.

\section{Considerações finais}




\section{PERcursos Linguísticos • Vitória (ES) •v. 11 •n. 29 • 2021 • ISSN: 2236-2592 • Dossiê temático $\bullet O$ texto na pesquisa e no ensino: conhecimentos, práticas e desafios na contemporaneidade •}

A migração de diferentes gêneros para suportes digitais propicia novas formas de interação, de produção e leitura em um ambiente sujeito à mudança. Nesse sentido, as tiras, que possuem uma identidade e formação genérica estável, têm encontrado um novo ambiente de divulgação e experimentação no Instagram. Diante disso, buscou-se compreender se o formato composicional, apresentado nas tiras do Instagram, interferiu na construção de sentido.

No que diz respeito ao suporte jornal, as tiras apresentaram, de forma preponderante, temáticas de cunho político, sociais e psicológicas devido ao contexto pandêmico presente no período. Essa temática reflete os interesses dos leitores e a relação ecológica existente entre o gênero e o suporte (veículo jornalístico). Com relação ao formato, o jornal reserva um espaço específico para as tiras e, por essa razão, o autor tem poucas possibilidades de experimentação de formato o que resulta na pouca variação de vinhetas.

As tiras no Instagram, por sua vez, quando adaptadas do jornal, exploraram as mudanças composicionais que privilegiavam o acesso e o compartilhamento em uma única tela. Tais mudanças alteraram o sentido de leitura em alguns casos, mas não foi constatado dificuldades por parte dos leitores em construir um sentido. A tira criada para o Instagram (Figura 8) apresentou composição diferente, pois o autor explorou o limite de 10 telas proposto pelo suporte digital e, em outras publicações, o número de vinhetas contidos em cada tela variava. Além disso, o autor fez uso dos recursos oferecidos pelo suporte para potencializar elementos presentes na linguagem dos quadrinhos (hiatos, sequência narrativa) e afetar a leitura. Constatou-se que alguns leitores tiveram dificuldades, pois a expectativa de leitura sofreu rupturas.

Mediante isso, em conformidade com Marcuschi (2008), demonstrou-se que as tiras possuem uma identidade vinculada aos jornais (suporte impresso) e que essa relação, embasada historicamente, propicia uma interferência do suporte no gênero (aspectos composicionais, tamanho, linguagem, público-alvo). O jornal, visto como suporte do gênero, apresenta um formato mais rígido que restringe as experimentações feitas pelo autor, por outro lado, o Instagram, assim como outros ambientes digitais, tem proporcionado experimentações no formato composicional das tiras e em outros aspectos que envolvem a linguagem dos quadrinhos. Schnotz (2009) denota que o texto serve como estímulos para que o leitor construa uma representação mental do conteúdo do texto. Da mesma forma, o suporte e o formato criam expectativas no leitor. O estudo revelou que a mudança de formato pode interferir na construção de sentido por parte do leitor, pois o autor pode fazer uso dos recursos do novo suporte para potencializar ou suprimir determinados aspectos da linguagem dos quadrinhos. Em alguns 


\section{PERcursos Linguísticos • Vitória (ES) •v. 11 •n. 29 • 2021 • ISSN: 2236-2592 • Dossiê temático $\bullet O$ texto na pesquisa e no ensino: conhecimentos, práticas e desafios na contemporaneidade •}

casos, a composição elaborada pelo autor quebra o conhecimento genérico prévio proporcionando novos estímulos. Ademais, ressalta-se que os apontamentos realizados com base no corpus fornecem indícios e possibilidades, mas dada as limitações da amostra, o desenvolvimento corrente dos recursos tecnológicos e as possibilidades criativas não é possível impor generalizações. Contudo, o mesmo cenário mostra-se um campo promissor para outros estudos.

\section{Referências}

ANDRADE, Luiz. Artista amazonense viraliza nas redes sociais com a publicação de tiras. Mapingua Nerd, Manaus, 3 jun. 2020. Disponível em: https://www.mapinguanerd.com.br/artista-amazonense-viraliza-nas-redes-sociais-com-apublicacao-de-tiras/. Acesso em: 27 set. 2021.

CAVALCANTE, Mônica Magalhães. Os sentidos do texto. São Paulo: Contexto, 2011.

BARBIERI, Daniele. A linguagem dos quadrinhos. São Paulo: Peirópolis, 2017.

BEAUGRANDE, Robert de. New foundations for a science of text and discourse: cognition, communication and freedom of access to knowledge and society. Norwood, New Jersey, Ablex Publishing Corporation, 1997.

BEZERRA, Benedito Gomes. Gêneros no contexto brasileiro: questões (meta)teóricas e conceituais. São Paulo: Parábola Editorial, 2017.

ECO, Humberto. Apocalípticos e integrados. 5. ed. São Paulo: Perspectiva, 1993.

EISNER, Will. Quadrinhos e arte sequencial: princípios e práticas do lendário cartunista. 4. ed. São Paulo: WMF Martins Fontes, 2010.

ELIAS, Vanda Maria. Hipertexto e leitura: como o leitor constrói a coerência? In: CABRAL, Ana Lucia Tinoco; MINEL, Jean-Luc; MARQUESI, Sueli Cristina. (orgs). Leitura, escrita e tecnologias da informação. São Paulo: Terracota Editora, 2015. (Coleção Linguagem e Tecnologia V.1). (p. 53-74)

ELIAS, Vanda Maria da; SILVA, Sandro Luis da. Multimodalidade na escrita de artigos científicos: aspectos teórico-analíticos e contribuições para o ensino. Linha D'Água (Online), São Paulo, v. 31, n.1, p.111-125, jan.-abril 2018. Disponível em: https://www.revistas.usp.br/linhadagua/article/view/140428. Acesso em: 21 set. 2021.

FOLHA DE S. PAULO. São Paulo: Grupo Folha, 23 jul. 2020. Ilustrada, B10. Disponível em: https://acervo.folha.com.br/leitor.do?numero $=49228 \&$ anchor $=6416240 \&$ origem $=$ busca\&origi nURL $=\& p d=a 0 d 7 d 9 d 8611 \mathrm{c} 53 \mathrm{e} 506 \mathrm{a} 17 \mathrm{be} 7 \mathrm{ca} 2 \mathrm{afe} 05$. Acesso em: 27 set. 2021. [2020a] 


\section{PERcursos Linguísticos • Vitória (ES) •v. 11 •n. 29 • 2021 • ISSN: 2236-2592 • Dossiê temático $\bullet O$ texto na pesquisa e no ensino: conhecimentos, práticas e desafios na contemporaneidade •}

FOLHA DE S. PAULO. São Paulo: Grupo Folha, 02 ago. 2020. Ilustrada, B10. Disponível em:https://acervo.folha.com.br/leitor.do?numero=49238\&anchor $=6416794 \&$ origem $=$ busca\&o riginURL $=\& p d=c b b 622 c 98 \mathrm{ae} 3 \mathrm{fac} 512754 \mathrm{a} 053 \mathrm{fe} 3778 \mathrm{f}$. Acesso em: 27 set. 2021. [2020b]

FOLHA DE S. PAULO. São Paulo: Grupo Folha, 29 nov. 2020. Ilustrada, C6. Disponível em: https://acervo.folha.com.br/leitor.do?numero $=49360 \&$ anchor $=6424320 \&$ origem $=$ busca\&origi nURL $=\& p d=873 a 5911 \mathrm{db} 3 \mathrm{bfc} 371374155441 \mathrm{~d} 76 f 24$. Acesso em: 27 set. 2021. [2020c]

FOLHA DE S. PAULO. São Paulo: Grupo Folha, 21 jan. 2021. Ilustrada, B10. Disponível em: https://acervo.folha.com.br/leitor.do?numero $=49413 \&$ anchor $=6427107 \&$ origem $=$ busca\&origi nURL $=\& p d=a 3 d 25 d 1 d a 202 e 1 e 795 d e e 5 e a e a 4 c e 915$. Acesso em: 27 set. 2021.

GALHARDO, Caco. \#cacogalhardo na @folhailustrada. [s.1.]. 05 ago. 2020. Instagram:@cacogalhardo. Disponível em: https://www.instagram.com/p/CDg78_KHTG0/. Acesso em: 27 set. 2021. [2020a]

GALHARDO, Caco. \#cacogalhardo na @folhailustrada. [s.l.]. 20 nov. 2020. Instagram:@ cacogalhardo. Disponível em: https://www.instagram.com/p/CIOLNh8n_C7/. Acesso em: 27 set. 2021. [2020b]

GARCÍA, Santíago. A novela gráfica. Martins Fontes, 2012.

GUALBERTO, Clarice Lage; PIMENTA, Sônia Maria de Oliveira; SANTOS, Záira Bomfante dos. Leitura e produção textual no contexto acadêmico: práticas e reflexões a partir da multimodalidade e da Semiótica Social. In: GUALBERTO, Clarice Lage; PIMENTA, Sônia Maria de Oliveira. SANTOS, Záira Bomfante dos. Multimodalidade e ensino: múltiplas perspectivas. São Paulo: Pimenta Cultural, 2018.

INSTAGRAM faz 10 anos como uma das maiores redes sociais do mundo e de olho no TIKTOK, para não envelhecer. Portal G1, [s.l.: s.n.], 06 ago. 2020. Economia, Tecnologia. Disponível em: https://g1.globo.com/economia/tecnologia/noticia/2020/10/06/instagram-faz10-anos-como-uma-das-maiores-redes-sociais-do-mundo-e-de-olho-no-tiktok-para-naoenvelhecer.ghtml. Acesso em: 27 set. 2021.

KOCH, Ingedore G. Villaça. Desvendando os segredos do texto. 8. ed. São Paulo: Cortez, 2015.

KOCH, Ingerdore G. Villaça. Introdução à Linguística Textual: trajetórias e grandes temas. 2. ed. São Paulo: Contexto, 2020.

KOCH, Ingedore G. Villaça; ELIAS, Vanda Maria. Ler e compreender os sentidos do texto. 3. ed. São Paulo: Contexto, 2013.

MARCUSCHI, Luiz Antonio. Produção textual, análise de gêneros e compreensão. São Paulo: Parábola, 2008.

MAINGUENEAU, Dominique. Análise de textos de comunicação. 6. ed. São Paulo: Cortez, 2013. 
PERcursos Linguísticos • Vitória (ES) •v. $11 \bullet$ n. 29 • 2021 • ISSN: 2236-2592 • Dossiê

temático $\bullet O$ texto na pesquisa e no ensino: conhecimentos, práticas e desafios na contemporaneidade •

RAMOS, Paulo. Tiras cômicas e piadas: duas leituras, um efeito de humor. São Paulo, 2007. 424 f. Tese (Doutorado em Filologia e Língua Portuguesa) - Faculdade de Filosofia, Letras e Ciências Humanas, Universidade de São Paulo.

RAMOS, Paulo. Pontos de fuga: registros de alargamento do formato das tiras. $9^{a}$ Arte, São Paulo, 3(1), 85-103. 2014. Disponível em:

https://www.revistas.usp.br/nonaarte/article/view/136898. Acesso em: 27 set. 2021.

RAMOS, Paulo. Tiras cômicas em suportes digitais. Estudos Linguísticos, São Paulo, 44 (2), p. 770-783, mai-ago. 2015. Disponível em: https://revistas.gel.org.br/estudoslinguisticos/article/view/1010. Acesso em: 27 set. 2021.

RAMOS, Paulo. A leitura dos quadrinhos. 2. ed. São Paulo: Contexto, 2018.

SCHNOTZ, Wolfgang. O que acontece na mente do leitor? Os processos de construções mentais durante a compreensão textual do ponto de vista da psicologia e da linguística cognitiva. In: WIESER, Hans Peter; KOCH, Ingedore (Orgs.). Linguística textual: perspectivas alemãs. Trad. Hans Peter Wieser. Rio de Janeiro: Nova Fronteira, 2009.

VIEIRA, Ademar. Esta tira cómica se llama "Yo Sólo Quiero Que Estés Bién. [s.1.]. 10 ago. 2020. Instagram: @ademar_vieira. Disponível em: https://www.instagram.com/p/CDtghivjn31. Acesso em: 27 set. 2021. 


\title{
PERcursos Linguísticos • Vitória (ES) •v. 11 •n. 29 • 2021 • ISSN: 2236-2592 • Dossiê temático $\bullet O$ texto na pesquisa e no ensino: conhecimentos, práticas e desafios na contemporaneidade •
}

\section{OS GÊNEROS DIGITAIS COMO FERRAMENTAS PARA O ENSINO DA LEITURA NO ENSINO FUNDAMENTAL}

\section{DIGITAL GENRES AS A TOOL FOR TEACHING READING IN ELEMENTARY SCHOOL}

\author{
Fernanda de Oliveira Pereira ${ }^{1}$ \\ Marilúcia dos Santos Domingos Striquer ${ }^{2}$
}

\begin{abstract}
RESUMO: Este artigo tem como objetivo apresentar quais capacidades de linguagem alunos do oitavo ano do Ensino Fundamental desenvolveram, a partir da implementação de uma sequência didática de gêneros que buscou trabalhar a leitura de um gênero digital: o anúncio publicitário veiculado pelo Facebook. Norteados pelos pressupostos teórico-metodológicos constituídos pela vertente didática do Interacionismo Sociodiscursivo, construímos uma proposta interventiva, implementamos em sala de aula e analisamos as capacidades de linguagem, para a leitura do gênero em questão, que os estudantes aprimoraram. $O$ foco principal do trabalho didático foi construir atividades que ajudassem os discentes a apreenderem e compreenderem os recursos persuasivos que constituem o anúncio publicitário do Facebook; além disso, por tratar-se de uma proposição norteada por uma problemática social, a intenção foi contribuir com ações que levassem os indivíduos ao uso consciente de produtos e serviços. Os resultados demonstraram que os estudantes-participantes identificaram e compreenderam as principais estratégias persuasivas que o referido gênero textual emprega, as quais podem levar ao consumismo.
\end{abstract}

PALAVRAS-CHAVE: Gêneros digitais. Anúncio Publicitário do Facebook. Sequência didática de gêneros.

ABSTRACT: This article aims to present which language skills that eighth-grade students have developed for reading a digital genre: the advertisement published by Facebook, at the end of the implementation of a didactic sequence of genres. Guided by the theoretical-methodological assumptions constituted by the didactic aspect of Sociodiscursive Interactionism, we built an interventionist proposal, implemented it in the classroom, and analyzed which language skills for reading the genre in question the students have improved. The focus of the didactic work was to build activities that would help students to understand the persuasive resources that constitute the Facebook advertisement; besides, as it is a proposition guided by a social issue, the intention was to contribute to actions that lead individuals to the conscious use of products

\footnotetext{
${ }^{1}$ Mestra em Letras pelo Programa de Mestrado Profissional em Letras em Rede - ProfLetras, da Universidade Estadual do Norte do Paraná (UENP). Cornélio Procópio, Paraná, Brasil. Professora da Secretaria do Estado de São Paulo. E-mail: nandaoliveira_8@ @otmail.com.

${ }^{2}$ Doutora em Estudos da Linguagem pela Universidade Estadual de Londrina (UEL). Londrina, Paraná, Brasil. Professora da Universidade Estadual do Norte do Paraná (UENP). E-mail: marilucia @uenp.edu.br.
} 


\section{PERcursos Linguísticos • Vitória (ES) •v. $11 \bullet$ •n. 29 • 2021 • ISSN: 2236-2592 • Dossiê temático $\bullet O$ texto na pesquisa e no ensino: conhecimentos, práticas e desafios na contemporaneidade •}

and services. The results demonstrate that the student-participants identified and understood which are the main persuasive strategies that this textual genre employs, which can lead to consumerism.

KEYWORDS: Digital media. Facebook Advertisement; Didactic sequence of genres.

\section{Introdução}

Em vistas de contribuir para a melhoria da qualidade da educação básica de nosso país, tendo como ponto de partida nossa prática docente e realidade escolar, interessamo-nos em elaborar e implementar uma proposta de intervenção didática destinada ao desenvolvimento da prática discursiva da leitura de gêneros, principalmente os digitais, que são, em essência, persuasivos. A premissa é a de que os anúncios publicitários, principalmente os veiculados pelas mídias digitais, estão cada vez mais presentes na vida das pessoas, influenciando-as ao consumo de forma, muitas vezes, inconsciente. Assim, é preciso que os alunos conheçam esse gênero textual, sobretudo, saibam participar da sociedade tendo-o como ferramenta mediadora, o que é possível, de acordo com os preceitos do Interacionismo Sociodiscursivo, quando o indivíduo conhece o gênero e suas operações complexas de uso social.

Nesse sentido, elegemos o gênero textual anúncio publicitário como eixo organizador de nossa proposta de intervenção ${ }^{3}$ destinada a alunos do $8^{\circ}$ ano do Ensino Fundamental. Contudo, em delimitação, o anúncio veiculado pela rede social Facebook, que torna o gênero diferente dos publicados em revistas e jornais, o que será melhor explanado no decorrer deste trabalho.

A construção da proposta interventiva e sua implementação teve como arcabouço teórico-metodológico os pressupostos da vertente didática do Interacionismo Sociodiscursivo (ISD) que sugere para o ensino escolar, a metodologia da sequência didática de gêneros (SDG) (DOLZ, NOVERRAZ E SCHNEUWLY, 2004), mas com as devidas adaptações, uma vez que a SDG foi originalmente construída para o trabalho com a produção de textos pelos alunos. Centrados em ações para o desenvolvimento da leitura discente, respaldamo-nos na afirmativa de Lopes-Rossi (2005, p. 81), para quem "Nem todos os gêneros se prestam bem à produção

\footnotetext{
${ }^{3}$ A proposta é parte integrante da dissertação de mestrado desenvolvida no Mestrado Profissional em Letras (ProfLetras), da Universidade Estadual do Norte do Paraná (UENP).
} 


\section{PERcursos Linguísticos • Vitória (ES) •v. 11 •n. 29 • 2021 • ISSN: 2236-2592 • Dossiê temático $\bullet O$ texto na pesquisa e no ensino: conhecimentos, práticas e desafios na contemporaneidade •}

escrita na escola, porque suas situações de produção e de circulação social dificilmente seriam reproduzidas em sala de aula".

Assim, neste artigo, nosso objetivo é apresentar os resultados alcançados após a implementação da SDG, demonstrando quais capacidades de linguagem os alunos desenvolveram para a leitura do anúncio publicitário do Facebook. Para tanto, este artigo organiza-se da seguinte forma: na primeira seção, apresentamos uma síntese das características que formam o anúncio publicitário no Facebook, conhecidas na construção de um modelo didático/teórico e transformadas em objeto de ensino e aprendizagem, bem como a apresentação de uma síntese da SDG produzida; na segunda seção, discorremos sobre a implementação da SDG junta à exposição de análises a respeito do desenvolvimento de capacidades de leitura alcançado pelos alunos participantes da pesquisa; depois, algumas considerações finais.

\section{As características regulares do gênero e a SDG construída para seu ensino}

Segundo Schneuwly e Dolz. (2004), um gênero é um instrumento social de interação e, para que ele possa ser transformado também em um objeto de ensino e aprendizagem escolar, os autores sugerem a realização de alguns procedimentos, os quais envolvem, de forma sintética, a elaboração de modelos didáticos e de sequências didáticas de gêneros. $\mathrm{O}$ objetivo da transposição é "levar o aluno ao domínio do gênero, exatamente como este funciona (realmente) nas práticas de linguagem de referência" (SCHNEUWLY; DOLZ, 2004, p. 68).

Para a construção de um modelo didático, que é "uma ferramenta para definir o objeto a ensinar e suas dimensões supostamente ensináveis" (DE PIETRO; SCHNEUWLY, 2014, p. 57), Barros (2012) sugere que, primeiro, a partir de procedimentos elaborados por Bronckart (2009), sejam aplicadas a um grupo de exemplares do gênero de interesse algumas análises, a fim de identificar os elementos característicos regulares do gênero, construindo assim o que a autora denomina de um modelo teórico. A partir de conhecidas as características, o professor pode eleger, diante de seu objetivo didático, do ano escolar de seus alunos, entre outros fatores, quais elementos serão tomados como conteúdos específicos nas atividades que formarão a SDG, a qual é definida por Dolz, Noverraz e Schneuwly (2004) como uma ordenação de atividades para que as capacidades de linguagem dos alunos sejam desenvolvidas. 


\section{PERcursos Linguísticos • Vitória (ES) •v. 11 •n. 29 • 2021 • ISSN: 2236-2592 • Dossiê temático $\bullet O$ texto na pesquisa e no ensino: conhecimentos, práticas e desafios na contemporaneidade •}

Conforme Schneuwly e Dolz (2004), uma SDG deve atuar para o desenvolvimento das três capacidades de linguagem: a de ação, a discursiva e a linguístico-discursiva. A capacidade de ação está ligada a promover que os alunos saibam considerar os fenômenos que formam o contexto de produção. A capacidade discursiva está na organização dos elementos que formam a estrutura do texto. A capacidade linguístico-discursiva envolve os mecanismos de textualização e os de mecanismos enunciativos. Em expansão, Cristovão e Stutz (2011) e Dolz (2015) apresentam mais duas capacidades de linguagem em seus estudos: a capacidade de significação, que corresponde à consideração dos aspectos amplos que formam um texto: os aspectos ideológicos, sociais, históricos, culturais etc.; e a capacidade multissemiótica, compreensão das multimodalidades ou multissemioses que constituem um texto.

Seguindo esses preceitos, para a construção de nossa proposta de intervenção didática, elaboramos um modelo teórico e depois um didático do anúncio publicitário do Facebook e a SDG. A seguir, no Quadro 1 apresentamos apenas os elementos característicos do gênero que foram delimitados no modelo didático. Assim, após analisarmos 17 exemplares recolhidos do feed de notícias das páginas pessoais do Facebook de 20 alunos de uma escola pública da região sul do estado do São Paulo, delimitamos do conjunto dos aspectos que são regulares do gênero, apenas aqueles que consideramos primordiais que os alunos apreendessem, visto serem, de acordo com a especificidade do gênero em questão, os mais significativos para a construção da persuasão pelos anunciantes. A saber:

Quadro 1 - Síntese das características do anúncio publicitário no Facebook tomadas como objeto de ensino da SDG

\begin{tabular}{|l|l|}
\hline $\begin{array}{l}\text { Os elementos do } \\
\text { contexto } \\
\text { produção }\end{array}$ & $\begin{array}{l}\text { Emissor: empresas fabricantes ou comercializadoras dos produtos ou serviços anunciados } \\
\text { - apresentados por meio do (1) logotipo e da exposição do nome do anunciante como (2) } \\
\text { link que remete o consumidor à página do Facebook do anunciante; }\end{array}$ \\
\hline $\begin{array}{l}\text { Os elementos } \\
\text { discursivos }\end{array}$ & $\begin{array}{l}\text { Tipo de discurso em predominância é o (3) discurso interativo (BRONCKART, 2009), } \\
\text { marcado com o emprego de pronomes possessivos e pessoais estabelecendo o contato } \\
\text { direto do anunciante com o leitor/usuário da rede social; Estrutura geral do texto: imagem; } \\
(4 \text { )texto de abertura; texto descritivo do produto; (5) slogan; logotipo da empresa; link de } \\
\text { acesso à página da empresa (esse formato é pré-determinado pelo Facebook); Sequência } \\
\text { predominante: (6) injuntiva; }\end{array}$ \\
\hline $\begin{array}{l}\text { Os elementos } \\
\text { linguístico } \\
\text { discursivos }\end{array}$ & $\begin{array}{l}\text { Variedade linguística informal: uso de termos coloquiais, gírias, hashtags e emojis (7); } \\
\text { Predomínio de adjetivos que enaltecem as qualidades dos produtos e serviços (8); As } \\
\text { vozes presentes são as dos anunciantes (9); }\end{array}$ \\
\hline $\begin{array}{l}\text { Os elementos } \\
\text { multissemióticos }\end{array}$ & $\begin{array}{l}\text { 1. Imagens (10): idealizam os produtos, trabalhando com o conceito de verossimilhança. } \\
\text { 2. Cores (11): reforçam a temática em abordagem; criam identidade visual ao anúncio. }\end{array}$ \\
\hline
\end{tabular}

Fonte: as pesquisadoras 


\section{PERcursos Linguísticos • Vitória (ES) •v. 11 •n. 29 • 2021 • ISSN: 2236-2592 • Dossiê temático $\bullet O$ texto na pesquisa e no ensino: conhecimentos, práticas e desafios na contemporaneidade •}

Esses 11 elementos foram, portanto, transformados em objeto de ensino e aprendizagem nas atividades que compõem a SDG e firmaram-se como categorias de análise para verificação do desenvolvimento das capacidades de linguagem dos alunos para a leitura do anúncio publicitário no Facebook, após a implementação da SDG, a qual é apresentada, em sinopse, pelo Quadro 2:

Quadro 2 - Sinopse da SDG do anúncio publicitário no Facebook

\begin{tabular}{|c|c|}
\hline OFICINAS & ATIVIDADES \\
\hline $\begin{array}{l}1.0 \text { problema social do } \\
\text { consumismo }\end{array}$ & $\begin{array}{l}\text { 1. Apresentação do filme "Delírios de consumo de Becky Bloom"; e leitura da } \\
\text { crônica "A cara vida moderna", de Walcyr Carrasco; } 2 \text {. Atividades para definição de } \\
\text { consumo e consumismo; } 3 \text {. Roda de conversa sobre a temática do filme e da crônica: } \\
\text { consumismo; 5. Confecção de mural com as opiniões sobre a temática em } \\
\text { abordagem. }\end{array}$ \\
\hline $\begin{array}{l}\text { 2.Reconhendo o gênero } \\
\text { textual }\end{array}$ & $\begin{array}{l}\text { 1. Roda de conversa e pesquisa sobre os anúncios em diferentes suportes; } 2 \text {. Leitura } \\
\text { de exemplares de propaganda e de anúncios publicitários e atividades; }\end{array}$ \\
\hline $\begin{array}{l}\text { 3.Diagnosticando } \\
\text { conhecimentos }\end{array}$ & 1. Diagnóstico sobre como os alunos interpretam os anúncios em suas leituras. \\
\hline $\begin{array}{l}\text { 4.O anúncio no } \\
\text { Facebook }\end{array}$ & $\begin{array}{l}\text { 1. Leitura de artigo "Quanto dinheiro o Facebook ganha com você (e como isso } \\
\text { acontece)" e questões de estudo do texto; } 2 \text {. Pesquisa sobre algoritmo no Facebook; } \\
\text { 3. Atividades sobre os elementos do contexto de produção do gênero; 4. Atividades } \\
\text { sobre o que é persuasão, tipos de persuasão e as necessidades humanas mobilizados } \\
\text { na publicidade. }\end{array}$ \\
\hline 5.Estrutura do gênero & $\begin{array}{l}\text { 1. Leitura de publicidade e localização de partes da estrutura geral; } 2 \text {. Atividades de } \\
\text { compreensão da estratégia persuasiva; } \\
\text { 3. Leitura de texto conceitual sobre a sequência tipológica injuntiva e exercícios; } 4 . \\
\text { Compreensão do emprego do modo imperativo e sua finalidade no gênero. }\end{array}$ \\
\hline $\begin{array}{l}\text { 6.Características } \\
\text { linguístico-discursivas }\end{array}$ & $\begin{array}{l}\text { 1. Atividades sobre linguagem formal e informal e seus contextos de uso; } 2 . \\
\text { Exercícios sobre discurso interativo; adjetivação objetiva e subjetiva; 3. Produção } \\
\text { textual de texto de abertura para um anúncio no Facebook. }\end{array}$ \\
\hline $\begin{array}{l}\text { 7.Ccaracterísticas } \\
\text { multissemióticas }\end{array}$ & $\begin{array}{l}\text { 1. Pesquisa sobre o papel da imagem e sua importância para o gênero; } 2 \text {. Leitura de } \\
\text { publicidades com foco no desenvolvimento da verossimilhança; } \\
\text { 3. Análise de cores em publicidades; } 4 \text {. Atividade para relacionar imagens e cores de } \\
\text { publicidades às necessidades humanas que elas motivam. }\end{array}$ \\
\hline $\begin{array}{l}\text { 8.Encerrando } \\
\text { trabalhos }\end{array}$ & $\begin{array}{l}\text { 1. Discussão para retomada das estratégias persuasivas do gênero; } 2 \text {. Busca no } \\
\text { Facebook por publicidades patrocinadas; } 3 \text {. Criação de documento no Word com } \\
\text { imagem das publicidades selecionadas durante a pesquisa; } 4 \text {. Elaboração de cartaz } \\
\text { com a imagem da publicidade e análise dos elementos, seguindo o modelo final; } 5 \text {. } \\
\text { Exposição do trabalho final. }\end{array}$ \\
\hline
\end{tabular}

Fonte: as pesquisadoras.

\section{A implementação da SDG e as capacidades de linguagem desenvolvidas}

$\mathrm{Na}$ apresentação do projeto aos alunos, seguimos a sugestão de Dolz, Noverraz e Schneuwly (2004) e inserimos os estudantes na problemática abordada pelo gênero textual. A Oficina 1 partiu de um problema social real: o consumismo, sobre o qual os alunos discutiram a partir de uma série de atividades. As respostas às atividades demonstram que a totalidade dos discentes reconheceu que o consumismo é uma prática da sociedade que foi se acentuando com 


\section{PERcursos Linguísticos • Vitória (ES) •v. $11 \bullet$ •n. 29 • 2021 • ISSN: 2236-2592 • Dossiê temático $\bullet O$ texto na pesquisa e no ensino: conhecimentos, práticas e desafios na contemporaneidade •}

a modernidade; identificou que ações de consumo exagerado estão presentes no cotidiano, se não na vida dos próprios alunos, na de algum familiar ou conhecido; e que o consumismo leva a um grande problema, o endividamento, que é uma das consequências de maior destaque nas respostas dos discentes.

A Oficina 2 buscou levar o aluno a compreender que o anúncio publicado no Facebook é um gênero específico, diferente dos veiculados por revistas e jornais. As atividades promoveram a realização de coleta de exemplares de anúncios publicados de jornal, revista e panfleto e trabalharam a especificidade da função social e estruturação, em decorrência da função do anúncio frente a outros gêneros. O que constatamos foi que, mesmo sem embasamento teórico, os alunos não têm dificuldades no reconhecimento do anúncio comparado a outros como reportagem, notícia e editorial.

Essa oficina contribuiu para que o aluno pudesse conhecer ainda mais a função social do anúncio publicitário. Conforme Schneuwly e Dolz (2004), este é um dos papéis da escola, fazer com que o aluno se instrumentalize, sabendo ler e escrever diferentes gêneros textuais para agir na sociedade. Assim, o principal resultado da Oficina 1 e 2 é que os alunos compreenderam a função do gênero textual anúncio publicitário e o valor dele na sociedade. Destacamos aqui a resposta para uma das perguntas: Você acredita que textos, como o anúncio publicitário, atraem o leitor a ponto de influenciá-lo a comprar algo, ou seja, ao ponto de persuadi-lo para que ele se torne consumidor? (Oficina 2; Atividade 1) - 18 alunos, dos 20 totais participantes, afirmaram que sim, demonstrando que compreenderam o caráter persuasivo que fundamenta o gênero.

A Oficina 3 teve como objetivo diagnosticar as capacidades de linguagem que os alunos tinham, no início da implementação da SDG, para a leitura do anúncio publicitário no Facebook. Primeiramente, para que fosse possível identificar a proximidade dos alunos com o referido gênero, elaboramos um questionário. A primeira pergunta nos levou à identificação de que 19, dos 20 alunos, tinham conta no Facebook; uma outra, que 17 deles afirmaram que recebiam em suas páginas pessoais anúncios de produtos; e as resposta a uma terceira questão demonstraram que 19 alunos já sentiram o desejo de comprar um ou mais produtos que receberam anunciados na rede social. No debate sobre as respostas, os discentes demonstraram entender como apenas a ação de receber o anúncio já é persuasiva; incluindo a discussão sobre 


\section{PERcursos Linguísticos • Vitória (ES) •v. $11 \bullet$ •n. 29 • 2021 • ISSN: 2236-2592 • Dossiê temático $\bullet O$ texto na pesquisa e no ensino: conhecimentos, práticas e desafios na contemporaneidade •}

a utilização do algoritmo, responsável por fazer um direcionamento preciso das publicidades a cada tipo de usuário.

Um outro exercício levou os alunos a identificarem as diferenças entre um anúncio publicado no Facebook e um publicado em revistas. Em síntese, as respostas dos alunos à atividade centraram-se em: 7 delas apontaram que a diferença é o lugar de publicação, mas não reconheceram o serviço à venda no anúncio do Facebook, fizeram-no apenas no anúncio da revista; outros 7 também afirmaram que a diferença é o lugar de publicação, mas que em revistas o anúncio apresentava mais explicações sobre o que estava sendo anunciado; 4 destacaram o uso de links no anúncio publicado em redes sociais, o que não existe em revistas; 2 apontaram os recursos disponíveis para um texto em redes sociais.

Voltando-nos aos elementos que delimitamos como primordiais para que os alunos apreendessem sobre o gênero, dos 11 elementos, os alunos demonstraram, nas atividades diagnósticas iniciais, identificar apenas 2: Link para o sítio da marca (2); Imagem (10). Esses resultados confirmaram a necessidade de desenvolver as capacidades de linguagem dos alunos para a leitura do referido gênero. Tais informações também foram importantes ferramentas para que pudéssemos avaliar, ao final da implementação de nossa SDG, se os alunos desenvolveram capacidades para a leitura do gênero ou não.

$\mathrm{Na}$ sequência, implementamos a Oficina 4, formada por atividades sobre o contexto de produção do gênero: o meio de circulação e o suporte; a questão do algoritmo no direcionamento pessoal dos anúncios; e o conceito e tipos de persuasão que constituem o gênero. As respostas às atividades demonstraram que a maioria, 18 estudantes, entendeu o processo realizado pelo algoritmo e como essa ferramenta tecnológica é um importante instrumento de persuasão para os anunciantes de produtos e serviços. Nossa ênfase é sobre o fato de que todos os 20 alunos responderam "sim" para uma das questões das atividades que tomaram a persuasão como objeto de ensino: $\mathrm{O}$ anúncio veiculado pelo Facebook pode ser considerado mais persuasivo do que os anúncios de revistas e jornais? As justificativas apresentadas nas respostas foram: 12 respostas basearam-se no fato de que as pessoas acessam mais o Facebook hoje do que leem revistas e jornais; 8 alunos responderam de maneira ainda mais precisa, exemplo: "Sim, porque no Facebook eles têm as informações do que você pode ter pesquisado, já o jornal e revista não, e no face as pessoas olham mais, jornal tem que ser mais padrão". 


\section{PERcursos Linguísticos • Vitória (ES) •v. $11 \bullet$ •n. 29 • 2021 • ISSN: 2236-2592 • Dossiê temático $\bullet O$ texto na pesquisa e no ensino: conhecimentos, práticas e desafios na contemporaneidade •}

Oficina 5 - o objetivo foi trabalhar os elementos que compõem o plano geral do texto. Apresentados aos alunos a definição e a função do logotipo, da logomarca e do slogan, atividades foram realizadas para apreensão de como esses recursos específicos do anúncio no Facebook agem na persuasão. Outros conteúdos específicos abordados na oficina foram a sequência tipológica injuntiva, mais particularmente, o emprego do modo imperativo e o emprego de pronomes como marcas da interação entre os interlocutores. Os resultados podem ser sintetizados por algumas das respostas à questão: Porque esse tipo de organização do texto - com o uso de pronomes - é importante para a publicidade? 4 alunos não foram específicos em suas respostas, já os outros 16 mostraram compreender que a intenção do anunciante é estabelecer proximidade com seu público consumidor, exemplos: "Porque vai ter um diálogo mais direto com o público, motivando a comprar; e Para convencer, pois tenta imitar uma conversa íntima”.

A Oficina 6 buscou trabalhar como a persuasão é estabelecida por meio da organização dos recursos linguísticos-discursivos, sendo um deles a variedade como recurso textual. Como atividade inicial, promovemos reflexões a respeito da escolha intencional das variantes formal ou informal da língua, de acordo com a imagem que o anunciante pretende passar da empresa a seu público e, sobretudo, diante de quem é o público-alvo do anúncio. Os alunos também

fizeram exercícios tendo como textos de apoio uma propaganda e uma publicidade direcionada a públicos diferentes e específicos, logo construídas com emprego de variantes distintas.

Para uma das atividades que solicitava que os alunos produzissem os textos de abertura e de apresentação do produto, todos os 20 alunos usaram a linguagem informal, em tom de conversa descontraída, como se o anunciante fosse um amigo do público-alvo. Destacamos algumas respostas: 6 incluíram traços de oralidade "Tá com calor? A Kibon resolve esse problema pra você!"; um discente acrescentou o neologismo "kidelícia”, brincando com o nome da marca Kibon; 2 acrescentaram hashtags, remetendo ao meio de circulação virtual do texto “\#nossanaturezaéumadelícia" e ao constante uso dos recursos digitais pelos jovens. Portanto, os alunos utilizaram, na produção de seus textos, elementos específicos do gênero que foram, durante as oficinas, objeto de ensino.

A adjetivação como um dos recursos persuasivos também foi conteúdo de ensino na Oficina 6. 


\section{PERcursos Linguísticos • Vitória (ES) •v. $11 \bullet$ •n. 29 • 2021 • ISSN: 2236-2592 • Dossiê temático $\bullet O$ texto na pesquisa e no ensino: conhecimentos, práticas e desafios na contemporaneidade •}

A Oficina 7 tratou dos aspectos multissemióticos do gênero em estudo (GONZALES, 2003; CRISTÓVÃO; STUTZ, 2011). A fim de iniciar a abordagem a respeito do uso da imagem na publicidade, levamos os alunos à sala de informática da escola, momento em que eles realizaram uma pesquisa sobre a importância da imagem em textos publicitários, e responderam questões como: Por que a imagem pode ser considerada um "convite ao público"? (Oficina 7; Atividade 1.c). Para essa pergunta, 13 respostas explicaram que a imagem atrai a atenção do público e desperta curiosidade sobre o produto ou serviço anunciado.

A fim de finalizar a SDG, e averiguar se ocorreu desenvolvimento, ou não, das capacidades de linguagem dos estudantes do $8^{\circ}$ ano, ao longo de todo o processo, iniciamos a Oficina 8. Nessa Oficina fomos capazes de perceber o que os discentes apreenderam, sobre a maneira como a persuasão é estabelecida no anúncio publicitário no Facebook por meio do processamento da leitura desse gênero textual.

Primeiramente fizemos um debate oral, após isso, solicitamos que os alunos registrassem suas respostas à questão: Depois de conhecer melhor o anúncio no Facebook, como você reage aos anúncios que visualiza na rede social? Dos 18 estudantes presentes na aula, 17 afirmaram que conseguem agora compreender melhor o gênero, algumas explicações dadas foram: "Depois de ver tudo isso eu comecei a parar de querer tudo que vejo na internet. Porque quando a gente depende dos pais para comprar as coisas é fácil querermos tudo, mas agora começo a pensar se realmente vale a pena para meu consumo"; "Olhamos com um olhar mais crítico e consciente, pois tipo pensamos duas vezes se vale a pena comprar ou não". Assim, o trabalho com a SDG promoveu a compreensão da função social do gênero e, para além disso, de seu poder persuasivo. As respostas demonstram que os alunos conseguiram, pelo menos teoricamente, levar para a prática discursiva cotidiana os conhecimentos estudados em sala de aula.

Divididos em 5 grupos, o segundo momento foi de pesquisa. Acompanhando a atividade, percebemos uma ação de curadoria, pois os estudantes estiveram empenhados em escolher bons exemplares do gênero para o trabalho. O objetivo de cada grupo era selecionar duas publicidades, disponíveis na rede social dos alunos, para que pudessem analisar as estratégias persuasivas utilizadas pelos textos instituídas nos elementos característicos do gênero. A partir dessa coleta, a turma elaborou um arquivo-documento, intitulado cartaz, com o uso do editor de texto Word, anexando os anúncios escolhidos e relatando as análises realizadas. 


\section{PERcursos Linguísticos • Vitória (ES) •v. 11 •n. 29 • 2021 • ISSN: 2236-2592 • Dossiê temático $\bullet O$ texto na pesquisa e no ensino: conhecimentos, práticas e desafios na contemporaneidade •}

O quadro a seguir organiza as categorias de análise priorizadas, pois, com elas, pudemos averiguar quais elementos característicos do gênero foram reconhecidos pelos grupos, durante o trabalho final, do processo de intervenção didática.

Quadro 3 - Elementos característicos do gênero identificados pelos alunos na atividade final

\begin{tabular}{|c|c|c|c|c|c|c|}
\hline $\begin{array}{l}\text { Capacidades de } \\
\text { linguagem }\end{array}$ & Elemento característico & Grupo 1 & Grupo 2 & Grupo 3 & Grupo 4 & Grupo 5 \\
\hline \multirow{2}{*}{$\begin{array}{l}\text { Capacidades de } \\
\text { ação }\end{array}$} & $\begin{array}{l}\text { 1. Logotipo/nome da } \\
\text { empresa }\end{array}$ & $\mathrm{X}$ & $\mathrm{X}$ & $\mathrm{X}$ & $\mathrm{X}$ & $\mathrm{X}$ \\
\hline & $\begin{array}{l}\text { 2. Link para o sítio da } \\
\text { marca }\end{array}$ & $\mathrm{X}$ & & & $\mathrm{X}$ & $\mathrm{X}$ \\
\hline \multirow{4}{*}{$\begin{array}{l}\text { Capacidades } \\
\text { discursivas }\end{array}$} & 3. Discurso Interativo & $\mathrm{X}$ & & $\mathrm{X}$ & $\mathrm{X}$ & $\mathrm{X}$ \\
\hline & 4. Texto de abertura & $\mathrm{X}$ & $\mathrm{X}$ & $\mathrm{X}$ & $\mathrm{X}$ & $\mathrm{X}$ \\
\hline & 5. Slogan & $\mathrm{X}$ & $\mathrm{X}$ & $\mathrm{X}$ & $\mathrm{X}$ & \\
\hline & 6. Sequência injuntiva & & & & $\mathrm{X}$ & $\mathrm{X}$ \\
\hline \multirow{3}{*}{$\begin{array}{l}\text { Capacidades } \\
\text { linguístico- } \\
\text { discursivas }\end{array}$} & 7. Variedade Informal & & $\mathrm{X}$ & $\mathrm{X}$ & $\mathrm{X}$ & \\
\hline & 8. Adjetivação & $\mathrm{X}$ & & $\mathrm{X}$ & $\mathrm{X}$ & \\
\hline & 9. Voz do anunciante & $\mathrm{X}$ & & $\mathrm{X}$ & & \\
\hline \multirow{2}{*}{$\begin{array}{l}\text { Capacidades } \\
\text { multissemióticas }\end{array}$} & 10. Imagem & $\mathrm{X}$ & $\mathrm{X}$ & $\mathrm{X}$ & $\mathrm{X}$ & $\mathrm{X}$ \\
\hline & 11. Cores & $\mathrm{X}$ & $\mathrm{X}$ & $\mathrm{X}$ & $X$ & $\mathrm{X}$ \\
\hline
\end{tabular}

Fonte: as pesquisadoras.

Acerca dos resultados, de 4 grupos de alunos formados para realização da atividade final, o Grupo 4 foi o que mais identificou os itens característicos do gênero: dos 11 itens parametrizados, 10 foram reconhecidos pelo grupo; o grupo 1, de 11 itens, identificou 9; o grupo 3 localizou 9; o grupo 5 identificou 7; e o grupo 2 identificou 6 itens. Portanto, a maioria dos elementos característicos do gênero foi apontada pelos discentes.

As dificuldades ficaram mais localizadas na não apreensão da função da sequência tipológica injuntiva, não marcada pelo grupo 1; na adjetivação, não identificada pelos grupos 2 e 5, e na voz do anunciante, não relacionada pelo grupo 5. Apesar disso, de forma geral, o que os alunos relacionaram demonstra que compreenderam a maioria dos elementos que forma as características específicas do gênero textual, as quais foram selecionadas no modelo didático. É importante expor ainda que, quando cada um dos grupos fez a apresentação dos cartazes para a sala de aula, pudemos constatar que a apreensão dos conteúdos trabalhados no projeto foi ainda maior. Por exemplo, ao expor o motivo da indicação do link como recurso persuasivo, 


\section{PERcursos Linguísticos • Vitória (ES) •v. 11 •n. 29 • 2021 • ISSN: 2236-2592 • Dossiê temático $\bullet O$ texto na pesquisa e no ensino: conhecimentos, práticas e desafios na contemporaneidade •}

um dos grupos argumentou sobre a rapidez na compra proporcionada por esse elemento. Exemplo: Grupo 4: "Se você clica no link, já vai para o site, aí pode comprar sem pensar muito se precisa ou não do produto".

\section{Considerações finais}

No processo de intervenção, tomamos o gênero não só como materialidade linguística, mas como instrumento de interação sociocomunicativa, pois contempla também os elementos de seu contexto de circulação e produção, assim como o concebem os estudiosos do ISD. Assim, ao final do processo de construção, implementação e análise de nossa proposta interventiva, os alunos demonstraram que ampliaram seus conhecimentos e desenvolvimento no processo de leitura do gênero.

\section{Referências}

BRONCKART, Jean-Paul. Atividade de linguagem, textos e discursos: por um interacionismo sociodiscursivo. Trad. De Anna Rachel Machado, Péricles Cunha. São Paulo: EDUC, 2009.

CRISTOVÃO, Vera Lúcia Lopes; STUTZ, L. Sequências Didáticas: semelhanças e especificidades no contexto francófono como L1 e no contexto brasileiro como LE. In: SZUNDY, Paula Tatianne Carréra Szundy et al (Org.). Linguística Aplicada e Sociedade: ensino e aprendizagem de línguas no contexto brasileiro. Campinas: Pontes Editores, 2011, p. $17-40$.

DOLZ, Joaquim; NOVERRAZ, Michèle; SCHNEUWLY, Bernard. Sequências didáticas para o oral e a escrita: Apresentação de um procedimento. In: ROJO, Roxane; SALES, Glaís (org.). Gêneros orais e escritos na escola. Campinas: Mercado de Letras, 2004.

LOPES-ROSSI, Maria Aparecida Garcia. Gênero discursivos no ensino de leitura e produção de textos. In: KARWOSKI, Acir Mário; GAYDECZKA, Beatriz; BRITO, Karim Siebeneicher (orgs.). Gêneros textuais: reflexões e ensino. Palmas e União da Vitória: Kaygangue, 2005, p. 79-93.

SCHNEUWLY, Bernard; DOLZ, Joaquim. Os gêneros escolares: das práticas de linguagem aos objetos de ensino. In: ROJO, Roxane; SALES, Glaís (org.). Gêneros orais e escritos na escola. Campinas: Mercado de Letras, 2004. 


\title{
ANÁLISE DA CONVERSAÇÃO: PANORAMA DOS ESTUDOS NO BRASIL E REPERCUSSÃO NO ENSINO ${ }^{1}$
}

\section{CONVERSATION ANALYSIS: OVERVIEW OF STUDIES IN BRAZIL AND IMPACT ON EDUCATION}

\begin{abstract}
Resumo: O trabalho apresenta uma síntese de como se instauraram os primeiros estudos sobre a conversação, a partir do trabalho do sociólogo Garfinkel - Studies in Etnomethodology - publicado em 1967. No Brasil, esses estudos se iniciam nos anos 1980, com o aparecimento dos primeiros estudos sobre a Linguística Textual e a Análise da Conversação que examinaram os elementos próprios da fala como os marcadores, o tópico, o turno. Em um segundo momento, quase concomitante, o interesse passa para a organização estrutural da conversação, numa abordagem mais especificamente linguística, procurando revelar as sistematicidades da língua. Surgem, então, as primeiras teses e dissertações e vários grupos se constituíram. O trabalho volta-se, também, para a questão do ensino da oralidade na sala de aula, com sugestão de atividades, ressaltando que os conhecimentos em torno do conceito de língua falada e língua escrita não são suficientes; é preciso que o professor disponha de subsídios em relação às especificidades dos textos que circulam em sociedade em domínios discursivos determinados.
\end{abstract}

Palavras-chave: Análise da Conversação. Oralidade e escrita. Ensino de língua portuguesa.

\begin{abstract}
The work presents a synthesis of how the first studies about conversation were established from the work of Garfinkel - Studies in Etnomethodology - published in 1967. In Brazil, these studies started in the 1980 with the first studies on Textual Linguistics and Conversation Analysis that examined elements of speech, with the markers, the topic, the shift. In a second moment, almost concomitantly, the interest shifts to the structural organization of the conversation, in a more specifically linguistic approach, seeking to reveal the systematics of the language. Then the first master's thesis and doctoral dissertations appear and several research groups are constitued.The work also focuses on the issue of teaching orality in the classroom, with suggetions of activities, emphasizing that knowledge about the concept of spoken and written language is not enough: it is necessary that the teacher has subsides in relation to the specificities of the texts that circulate in society, in determined discourse domains.
\end{abstract}

\footnotetext{
${ }^{1}$ Parte deste trabalho foi apresentada no I Encontro de Estudos do Texto em Contexto, na mesa-redonda Estudos do Texto na Atualidade, realizado na UNIFESP, em 2019, e na mesa-redonda, promovida pela Editora Parábola, intitulada A Oralidade e o Ensino de Língua, em 2020.

2 Titular de Linguística da USP (aposentada) e Titular de Língua Portuguesa da PUC-SP. Atua em: História das Ideias Linguísticas, Linguística Textual e Estudos da Oralidade, 1plfavero@uol.com.br
} 


\section{PERcursos Linguísticos • Vitória (ES) •v. 11 •n. 29 • 2021 • ISSN: 2236-2592 • Dossiê temático $\bullet O$ texto na pesquisa e no ensino: conhecimentos, práticas e desafios na contemporaneidade •}

Keywords: Conversation analysis. Orality and writing. Portuguese language teaching.

\section{Análise da Conversação}

Embora sociólogos, linguistas, antropólogos, educadores tenham se debruçado sobre o assunto e haja muitos trabalhos publicados, a concordância entre eles é pequena e ainda há muito o que fazer. A escrita tem sido vista como de estrutura complexa, formal, abstrata, enquanto a fala, de estrutura simples ou desestruturada, informal, dependente de contexto, porém os estudos sempre consideraram a fala como primária e a escrita como dela derivada. Entre nós, por exemplo, Mattoso Câmara, já em 1969, dizia: “a escrita decorre da fala e é secundária em relação a esta” (MATTOSO CÂMARA, 1969, p. 11). E Marcuschi, em 1993: "os gramáticos imaginam a fala como o lugar do erro, incorrendo no equívoco de confundir língua com a gramática codificada" (MARCUSCHI, 1993, p. 4).

\section{Como diz Biber (1988, p. 8):}

Certamente em termos de desenvolvimento urbano, a fala é o status primário. Culturalmente, os homens aprendem a falar, antes de escrever e, individualmente, as crianças aprendem a falar antes de ler e escrever. Todas as crianças aprendem a falar (excluindo-se as patologias), muitas crianças não aprendem a ler e escrever. Todas as culturas fazem uso da comunicação oral; muitas línguas são ágrafas. De uma perspectiva histórica e da teoria do desenvolvimento, a fala é claramente primária. (BIBER, 1988, p. 8).

Para os estudos sobre a língua falada, torna-se fundamental analisar como se instaura a conversação.

Há vários conceitos e posições sobre o que seja a Conversação. Há os que a conceituam, tomando-a num sentido amplo, como "o exercício prático das potencialidades cognitivas do ser humano em suas relações interpessoais." (MARCUSCHI, 1999, p. 16), englobando, assim, todo e qualquer tipo de interação, não só as conversações informais, espontâneas, sem planejamento prévio, como as formais, planejadas (debates, entrevistas, comunicações científicas etc.). Há, também, os que a consideram uma atividade, não planejada, na qual interagem dois ou mais interlocutores, que se alternam constantemente, discorrendo, constantemente, sobre temas do cotidiano. Seu desenvolvimento está ligado ao modo como a atividade interacional se organiza entre os participantes (FÁVERO, ANDRADE, AQUINO, 1999). Por conter elementos de ordem pragmática (pausas, hesitações, repetições, truncamentos, entre outros), foi considerada, até meados da década de 60 do século passado, como o lugar do caos, porém, com o surgimento dos estudos do texto, o 


\title{
PERcursos Linguísticos • Vitória (ES) •v. 11 •n. 29 • 2021 • ISSN: 2236-2592 • Dossiê temático $\bullet O$ texto na pesquisa e no ensino: conhecimentos, práticas e desafios na contemporaneidade •
}

enfoque deixa de fixar-se no produto e se desloca para o processo. Os estudos sobre ela Conversation Analysis - iniciam-se com a obra Studies in Ethnomethodology, do sóciólogo Garfinkel, publicada em 1967. O autor inicia sua obra com um capítulo intitulado $O$ que é etnometodologia? em que a conceituação de seu objeto de estudo se torna referência:

\begin{abstract}
The following studies seek to treat practical activities, practical circumstances, and practical sociological reasoning as topics of empirical study, and by paying to the most commonplace activities of daily life the attention usually accorded extraordinary events, seek to learn about them as phenomena in their own right. Their central recommendation is that the activities whereby members produce and manage settings of organized everyday affairs are identical with members the procedures for making settings "account-able". (GARFINKEL, H. 1967, p. 1)3.
\end{abstract}

A etnometodologia surgiu como uma dissidência da Sociologia, e a referida obra provocou mudanças, de "um paradigma normativo, para um paradigma interpretativo" (COULON, 1995). Sacks, Schegloff e Jefferson (1974) foram pioneiros nesses estudos, embora seu interesse não fosse linguístico, mas sociológico.

O termo designa "a metodologia usada pelos membros de uma sociedade na realização de suas atividades; é graças a essa metodologia que a realidade social e a ordem social são produzidas e que as pessoas concebem essa realidade como dada ou preestabelecida." (GULICH, 1991, p. 328-329).

Em síntese, consideram as seguintes características básicas da conversação:

- interação face a face entre pelo menos dois falantes; o número de participantes pode variar;

- ocorrência de pelo menos uma troca de falantes, e, na maioria dos casos, fala um de cada vez. O tamanho e a ordem dos turnos não são fixos;

- presença de uma sequência de ações coordenadas;

- execução num determinado tempo;

- planejamento simultâneo ou quase simultâneo à produção, sem possibilidade de apagamento.

\footnotetext{
${ }^{3}$ Os estudos a seguir buscam tratar atividades práticas, circunstâncias práticas e raciocínio sociológico prático como tópicos de estudo empírico e, ao dedicarem ás atividades mais comum do cotidiano a atenção usualmente dispensada a eventos extraordinários, procuram estudá-las como fenômenos em si. A recomendação desses estudos é a de que as atividades pelas quais os membros produzem e gerenciam situações de afazeres cotidianos organizados são idênticas aos procedimentos empregados pelos membros para tornar essas situações relatáveis. GARFINKEL, H. O que é etnometodologia? Tradução: Paulo Cortes Gago e Raul Francisco Magalhães. Revista Teoria e Cultura, Juiz de Fora, v. 4, n. 1 e 2, p. 113-134, jan./dez. 2009. Disponível em 〈https://periodicos.ufjf.br/index.php/TeoriaeCultura/article/view/12149>. Acesso em: 30 jul. 2021.
} 


\title{
PERcursos Linguísticos • Vitória (ES) •v. 11 •n. 29 • 2021 • ISSN: 2236-2592 • Dossiê temático $\bullet O$ texto na pesquisa e no ensino: conhecimentos, práticas e desafios na contemporaneidade •
}

Embora todos eles fossem sociólogos, logo atraíram a atenção dos linguistas por suas posições sobre o uso da linguagem em interação que não era caótica, no seu modo mais espontâneo e, sim, passível de análise; e isso no momento da explosão das propostas de Chomsky, que não se preocupava com os dados dos falantes em interação, mas afirmava que o falante é capaz de produzir e interpretar um número de frases bem formadas.

Porém, já em 1962, Hymes afirmava que o falante também é capaz de dominar as condições de uso adequado da língua, as possibilidades oferecidas por ela, isto é, além da competência linguística, é necessário considerar-se a competência comunicativa - conjunto de capacidades que permitem ao falante comunicar-se de modo eficaz em situações comunicativas específicas. Esses dois fatores (o fato de que, como afirmavam os sociólogos, a linguagem em interação não ser caótica, mas passível de análise e a consideração da competência comunicativa) foram responsáveis pela recepção da análise da conversação etnometodológica.

Mas, depois de algum tempo, como afirma o mesmo Coulon (ibid., p.26),

\begin{abstract}
A etnometodologia começa a cindir-se em dois grupos: o dos analistas da conversação que tentam descobrir, nas conversações, as reconstruções contextuais que lhes permitem dar um sentido e continuidade, e o dos sociólogos para os quais as fronteiras reconhecidas de sua disciplina se acham circunscritas aos objetos mais tradicionais que a sociologia estuda, como a educação, a justiça, as organizações, as administrações, a ciência. (COULON, 1995, p. 26).
\end{abstract}

No dizer de Heritage e Atkinson (1984), objetivo central das pesquisas em Análise da Conversação Etnometodológica é a descrição e explicação não da linguagem em si, mas dos métodos de ação humana, como atribuir responsabilidade, explicar-se, corrigir-se, isto é, das competências que os falantes comuns usam e de que se valem para participar de interações socialmente organizadas

Vejamos, agora, a recepção no Brasil.

\section{A Análise da Conversação no Brasil}

A década de 80 do século passado foi especialmente frutífera para a Linguística no Brasil, pois surgem os primeiros trabalhos sobre a Linguística Textual e a Análise da Conversação. O primeiro trabalho, sobre a Linguística Textual, de que se tem notícia é o do Professor Ignácio Antônio Neis da PUCRS, intitulado Por uma gramática textual, publicado na revista Letras de Hoje, revista do curso de Pós-Graduação em Linguística e Letras do Centro de Estudos Portugueses da PUCRS, em junho de 1981, no. 44. Seguem-se, em 1983, 


\section{PERcursos Linguísticos • Vitória (ES) •v. 11 •n. 29 • 2021 • ISSN: 2236-2592 • Dossiê temático $\bullet O$ texto na pesquisa e no ensino: conhecimentos, práticas e desafios na contemporaneidade •}

duas obras Linguística de texto - o que é e como se faz, de Luiz Antônio Marcuschi, publicado pela Revista do Mestrado em Letras da Universidade Federal de Pernambuco, série Debates e Lingüística textual - introdução, de Leonor Lopes Fávero e Ingedore V. Koch, publicado em São Paulo, pela Editora Cortez.

Surgem, então, as primeiras teses e dissertações que estudaram os elementos próprios da fala, como os marcadores conversacionais, dissertações de Maria Lúcia Oliveira Andrade em 1990, de Luiz Antônio da Silva e de Margareth M. Rosa, também em 1990, o tópico, dissertação de Zilda Aquino, em 1991, estudos sobre interrupções, hesitações, bem como aqueles voltados para os processos de construção do texto falado - repetição (Marcuschi), hesitação (Marcuschi), paráfrase (tese de José Gaston Hilgert, em 1989), correção (Fávero, Andrade e Aquino), perguntas e respostas (Fávero, Andrade e Aquino) e daí para o estudo dos gêneros orais (entrevistas, linguagem radiofônica, debates na televisão), semelhanças e diferenças e o meio social em que são produzidos, estabelecendo-se um diálogo com a Antropologia, Sociologia, Psicologia social e outras disciplinas focadas na interação do homem na sociedade. (Marcuschi, Paulo Galembeck, Kazuê M. de Barros, Dino Preti, Clélia Jubran, Mercedes Risso, Ingedore Koch, Gaston Hilgert, Hudinilson Urbano, Leonor L. Fávero e outros).

E a Análise da Conversação no Brasil foi caminhando por trilhas próprias, isto é, foi adquirindo sua identidade.

Quero ressaltar que, além dessas análises com objetivo de descrição linguística do "texto falado", houve e há ainda hoje, também, análises com a finalidade de discutir a passagem da oralidade para a escrita, "questão crucial para uma sociedade como a nossa, em que se precisa entender a passagem da oralidade para o letramento pleno a fim de acelerar o processo para as populações ainda alijadas até os dias de hoje da escrita e dos discursos que se organizam a partir dela" (GARCEZ, 2008, p. 21).

Essas linhas ainda se mantêm devendo-se ressaltar o diálogo com a Linguística Textual, inserindo a Análise da Conversação num quadro teórico mais amplo de estudo do texto. No decorrer desses anos, diversos grupos de estudos se constituíram. Cito alguns:

- NELFE, em 1991, na UFPE;

- Projeto da Gramática do Português Falado, coordenado pelo Professor Ataliba de Castilho, em 1988 - Grupo de Organização Textual Interativa, que, num primeiro momento discutiu a categoria de tópico discursivo, noção fundamentada na relação de interdependência entre turnos, promovida pelo movimento de entrosamento entre os interlocutores. O tópico é 


\section{PERcursos Linguísticos • Vitória (ES) •v. 11 •n. 29 • 2021 • ISSN: 2236-2592 • Dossiê temático $\bullet O$ texto na pesquisa e no ensino: conhecimentos, práticas e desafios na contemporaneidade •}

um processo essencial na organização textual-interativa da conversação (Maria Lúcia Andrade, Zilda Aquino e eu, elaboramos dois textos: correção e perguntas e respostas). Membros: Marcuschi, Clélia Jubran, Mercedes Risso, M. Cecília Souza e Silva, Mercedes Crescitelli, Ingedore Koch, Gaston Hilgert, Leonor L. Fávero com Maria Lúcia da Cunha V. Oliveira Andrade e Zilda Gaspar de O. Aquino;

- o projeto NURC, em Salvador, Recife, Rio, Porto Alegre e, principalmente em São Paulo, coordenado pelo Professor Dino Preti, que publicou regularmente as produções resultantes das pesquisas de seus membros que se utilizaram do corpus gravado na década de 70: elocuções formais, diálogo entre dois informantes e diálogo informante-entrevistador e que passaram, também, a abordar questões de oralidade em textos falados e escritos;

- na UFRJ - PEUL: Programa de estudo sobre o uso da língua;

- em Salvador;

- em Porto Alegre.

E hoje?

As questões aqui levantadas, relacionadas a uma microanálise, continuam sendo estudadas hoje, porém privilegiam-se questões relacionadas a uma macroanálise, como os gêneros orais (entrevistas, talk-shows, debates) interação em contextos policiais, interação na saúde (médico-paciente) e o grande tema: a cortesia. Congressos foram realizados sobre esse tema com êxito na Universidade Aberta de Lisboa e aqui no Brasil, havendo uma excelente bibliografia no exterior de autores como Briz, na U. de Valencia, Catherine KerbratOrecchioni da U. de Lyon, Diana Bravo, Penélope Brown e Stephen Levinson, Maria Victoria Escandell-Vidal e muitos outros.

\section{Novas perspectivas para o ensino}

Para tratar da oralidade em sala de aula, os conhecimentos em torno do conceito de língua falada e de língua escrita não são suficientes; é preciso que o professor disponha de subsídios em relação às especificidades dos textos que circulam na sociedade em domínios discursivos determinados, como o jornalístico, o acadêmico, o religioso, o jurídico etc., para que reconheça como se instaura seu processo de produção e de qual (ou quais) unidade(s) de análise se pode fazer uso para um estudo efetivo (FÁVERO; ANDRADE; AQUINO, 1999 e 2011).

Os PCN's de Língua Portuguesa (1998) abrem um espaço ainda pequeno para a inclusão de questões de oralidade em sala de aula; entretanto, poucos são os trabalhos que 


\section{PERcursos Linguísticos • Vitória (ES) •v. 11 •n. 29 • 2021 • ISSN: 2236-2592 • Dossiê temático $\bullet O$ texto na pesquisa e no ensino: conhecimentos, práticas e desafios na contemporaneidade •}

apresentam uma discussão quanto à aplicação ao ensino, como o fizeram Castilho (1998), Fávero (2005), Fávero, Andrade e Aquino (1999 e 2011), Marcuschi (2001), entre outros.

Apresento agora sugestões de atividades entre as quais se destacam: gravação de narrativa produzida por alunos (do ensino fundamental, médio e superior), transcrição e retextualização imediata para a modalidade escrita pelos mesmos alunos, mantendo o mesmo tópico, quando o aluno observará:

- eliminação de marcas estritamente interacionais, como marcadores, hesitações, truncamentos;

- inclusão da pontuação;

- substituição dos turnos por parágrafos;

- seleção lexical e estruturação sintática diferentes (por exemplo palavras mais longas no texto escrito).

Insisto em quão produtivo pode ser o processo. Inclusive em termos de utilização do texto pelo próprio aluno, nos diferentes níveis de escolaridade.

Nessa linha de trabalho, destaco, do discurso jornalístico, a análise, por exemplo, das manchetes e da linha fina (linha que surge logo abaixo da manchete e que contém a síntese da notícia).

Como já sugeriram Fávero, Andrade e Aquino (2011), o professor pode iniciar essa atividade lendo as manchetes das principais revistas de circulação nacional (como Veja, Isto é, Época etc.) ou de jornais ( $O$ Globo, Folha de S. Paulo, O Estado de S. Paulo etc.). Em seguida, pode mostrar como esses textos se estruturam, quais são suas especificidades, qual a variante linguística empregada, qual o efeito de sentido obtido com as escolhas lexicais feitas pelo enunciador:

- manchetes que relembram total ou parcialmente títulos de filmes ou de novelas:

- Merlís paulistanos: como o famoso personagem catalão da série Netflix, professores encantam alunos com metodologias e talentos... (Veja, 16/10/19).

- Os novos Merlís: professores criam métodos de ensino a distância originais para além dos aplicativos... (Veja, 15/07/20).

- O dono do pedaço : principal liderança de Paraisópolis quer transformar favela em polo de negócios (Veja, 18/09/19).

- Brasil, mostra tua cara (Correio Brasiliense, 17/04/06). 


\section{PERcursos Linguísticos • Vitória (ES) •v. 11 •n. 29 • 2021 • ISSN: 2236-2592 • Dossiê temático $\bullet O$ texto na pesquisa e no ensino: conhecimentos, práticas e desafios na contemporaneidade •}

- manchetes que retomam provérbios ou a Bíblia:

- Amar a si mesma (Claudia, outubro/18).

- A multiplicação dos santos: com o número recorde de canonizações, incluindo a da freira baiana irmã Dulce, a Igreja Católica tenta recuperar o rebanho perdido (Veja, 16/10/19).

- manchetes em que se empregam norma popular, gíria ou vocábulos em língua estrangeira:

- Bye-bye Curitiba (Veja,16/10/19)

- manchetes que retomam falas de autoridades:

- A boiada é aqui (Veja, 28/10/20).

É possível localizar na escrita textos com grande aproximação da oralidade, como ocorre na notícia a seguir (citada em Fávero, Andrade e Aquino, 2011) em que o enunciador parece dialogar com o leitor ao apresentar uma narrativa envolvente. Ao proceder à citação da voz de um dos envolvidos ("O avião não aterrissou, ele praticamente caiu no chão"), traz vivacidade ao texto, além de se responsabilizar o outro pela veracidade dos fatos. Observe-se, ainda, a diferença entre a seleção lexical empregada pelo enunciador (chocou-se contra o solo) e pela testemunha (caiu praticamente no chão) na narrativa do fato:

No momento do pouso, o aparelho chocou-se violentamente contra o solo, arremessando seus 36 passageiros ao solo .[...] "o avião não aterrissou, ele praticamente caiu no chão", contou a Veja um dos 36 passageiros a bordo (Veja, 6 jan.,1999 ,p.68. In: FÁVERO, ANDRADE e AQUINO, 2011).

Podem ser realizadas atividades escritas, utilizando-se os mesmos temas tratados durante as análises dessas notícias e manchetes, com o objetivo de estudar com o texto escrito se organiza.

Outra possibilidade, levantada também por Fávero, Andrade e Aquino (op.cit.), é tentar elaborar com os alunos um jornal falado, abordando temas (manchetes e notícias) de interesse da comunidade escolar. É produtivo observar como são adaptadas as notícias encontradas no jornal impresso para serem enunciadas em um jornal de rádio ou televisão.

Há, ainda, a questão do texto literário escrito, no caso, aqui, a crônica. 


\section{PERcursos Linguísticos • Vitória (ES) •v. 11 •n. 29 • 2021 • ISSN: 2236-2592 • Dossiê temático $\bullet O$ texto na pesquisa e no ensino: conhecimentos, práticas e desafios na contemporaneidade •}

É comum dizer-se que a crônica é um gênero híbrido que oscila entre a subjetividade da literatura e a objetividade do jornalismo, resultado da visão pessoal, subjetiva do cronista ante um fato qualquer, mas, diferentemente do repórter, o fato é para ele um meio e não um fim.

Não basta constatar a transposição da estrutura da conversação cotidiana, gênero primário (Cf. BAKHTIN, 1979), para o interior da crônica literária, gênero literário, para explicar a relação entre elas. Nela há a opção pelo coloquialismo que atrai o leitor, com a intenção de divertir, informar, ilustrar, utilizando-se de uma linguagem direcionada aos leitores apressados do jornal, veículo de informação diária, e cuja elaboração tem como característica primordial a urgência, pois “os acontecimentos são extremamente rápidos e o cronista precisa de um ritmo ágil para poder acompanhá-los Por isso sua sintaxe lembra alguma coisa desestruturada, solta, mais próxima da conversa entre dois amigos do que propriamente do texto escrito" (SÁ, 2002, p. 10-11).

Isso se observa tanto em crônicas do início do século passado, como nas de Lima Barreto e João do Rio, como nas atuais, recentes de Luís Fernando Veríssimo e de Humberto Werneck, nascidas hoje para saírem nos jornais ainda hoje, revelando seu vínculo com a história.

Na sala de aula, o trabalho com a crônica será extremamente produtivo, os índices de oralidade poderão ser explicitados, tanto os verbais como os não verbais que envolvem a conversação, por ela simulada e que vão constituindo sua textualidade. Poderão ser examinados, por exemplo, quanto à organização global, os tópicos e subtópicos, a organização dos diálogos (simétricos e assimétricos) e os pares adjacentes, elemento básico da interação.

Devem ser observadas também não só as marcas da oralidade, mas também as da modalidade escrita, fortemente presentes, como a estruturação dos parágrafos, a transição de um para outro etc., o que se deve ao óbvio - mesmo simulando a fala, a crônica não deixa de ser um gênero escrito.

\section{Conclusão}

Como se pode ver no decorrer do trabalho não se pode pensar a língua falada e a língua escrita como modalidades invariantes. Como já afirmava Berruto, em 1985, no interior dessas modalidades, há variações provocadas pelas condições de produção e pelo uso. 


\section{PERcursos Linguísticos • Vitória (ES) •v. 11 •n. 29 • 2021 • ISSN: 2236-2592 • Dossiê temático $\bullet O$ texto na pesquisa e no ensino: conhecimentos, práticas e desafios na contemporaneidade •}

Conforme já apontaram Fávero, Andrade e Aquino (2011), "há uma tendência hoje em dia para que a oralidade se apresente de modo constante no discurso escrito e esta é uma maneira eficiente de se construir um texto mais envolvente para o leitor como observamos no discurso jornalístico que traduz, no uso da marcas de oralidade na escrita, sua manifestação de criatividade e de modernidade, buscando influenciar o leitor e criar efeitos de sentido pretendidos" (FÁVERO, ANDRADE, AQUINO, 2011, p. 27).

\section{Referências}

BAKHTIN, M. (VOLOSHINOV). Marxismo e filosofia da linguagem. Trad. M. Lahud e Yara F. Vieira. São Paulo: Hucitec, 1979.

BERRUTO, G. Z. Per una caratterizzazione del parlato: l'italiano parlato ha un'altra grammatica? In: Holtus, G.; RADTKE, E. (Orgs). Gesprochenes Italienisch in Geschichte und Gegenwart. Tübingen: Narr, 1985, p. 120-153.

BIBER, D. Variation across speech and writing. Cambridge, UK: Cambridge University Press, 1988.

BRASIL. Parâmetros Curriculares Nacionais: Língua Portuguesa. Brasília: MEC/SEF, 1998.

CASTILHO, A. T. A língua falada no ensino de português. São Paulo: Contexto, 1998.

COULON, A. Etnometodologia. Petrópolis, Vozes, 1995.

FÁvero, L. L. Coesão e coerência no texto conversacional. In: Coesão e coerência textuais. 10. ed. revista e atualizada. São Paulo: Ática, 2005, p.84-99.

FÁVERO, L. L.; ANDRADE, M. L. C. V. O.; AQUINO, Z. G. O. Estratégias de construção do texto falado: a correção. In: KATO, M. A. (Org.) Gramática do português falado. v. 5. São Paulo: Humanitas/FFLCH/USP; Campinas: Editora da Unicamp, 1996, p. 355-366.

FÁVERO, L. L.; ANDRADE, M. L. C. V. O.; AQUINO, Z. G. O. O par dialógico perguntaresposta. In: JUBRAN, C. C. A. S; KOCH, I. G. V. Gramática do português culto falado no Brasil. v. 1, Construção do texto falado. Campinas: UNICAMP, 2006, p. 133-166.

FÁVERO, L. L; ANDRADE, M. L. C. V. O.; Aquino, Z. G. O. Oralidade e escrita: perspectivas para o ensino de ensino de língua materna. São Paulo: Cortez, 1999.

Reflexões sobre oralidade e escrita no ensino de Língua Portuguesa. In:

ELIAS, V. M. da S. (Org.). Ensino de língua portuguesa: oralidade, escrita e leitura. São Paulo, Contexto, 2011, p. 13-28.

GARCEZ, P. M. A perspectiva da Análise da Conversa Etnometodológica sobre o uso da linguagem em interação social. In: LODER, L.; JUNG, N. M. (Orgs.). Fala-em-interação social: uma introdução à Análise da Conversa Etnometodológica. Campinas, Mercado de Letras, 2008, p. 17-38. 


\section{PERcursos Linguísticos • Vitória (ES) •v. 11 •n. 29 • 2021 • ISSN: 2236-2592 • Dossiê temático $\bullet O$ texto na pesquisa e no ensino: conhecimentos, práticas e desafios na contemporaneidade •}

GARFINKEL, H. What is ethnomethodology? In: GARFINKEL, H. Studies in Ethnomethodology. Englewood Cliffs; New Jersey: Prentice-Hall, 1996 [1967], p. 1-34.

GULICH, E. Pour une ethnométhodologie linguistique: description des séquences conversationelles explicatives. In: DAUSENDSCHÖN-GAY, U. (Ed.). Linguistische Interaktionsanalysen. Tubigen: Niemeyer, 1991, p. 325-364.

HERITAGE, J.; ATKINSON, J. M. Introduction. In: ATKINSON, J. M.; HERITAGE, J. Structures of Social Action. Cambridge: Cambridge University Press, 1984, p. 1-15.

HYMES, D. The Ethnography of Speaking. In: GLADWIN, T.; STURTEVANT, W. (Eds.). Anthropology and Human Behavior. Washington: American Anthropology Association, 1962, p. 13-53.

MARCUSCHI, L. A. O tratamento da oralidade no ensino de língua. Universidade Federal de Pernambuco. Recife. Texto mimeografado, 1993.

Marcas de interatividade no processo de textualização da escrita. In: RODRIGUES, Â. C. S.; ALVES, I. M.; GOLDSTEIN, N. S. (Orgs.). I Seminário de Filologia e Língua Portuguesa. São Paulo: Humanitas, 1999, p.139-156.

. Da fala para a escrita: o tratamento da oralidade no ensino de língua. São Paulo: Cortez, 2001.

MATTOSO CÂMARA, J. Problemas de Lingüística descritiva. Petrópolis: Vozes, 1969.

SÁ, J. A crônica. 3. ed. São Paulo: Ática, 2002.

SACKS, H., SCHEGLOFF, E. \& JEFFERSON, G. A simplest systematics for the organization of turn-talking for conversation. Language, 50, 1974. 


\author{
AXIOLOGIA E LINGUÍSTICA: UMA REFLEXÃO SOBRE OS \\ VALORES SOCIAIS E A MENTIRA NO CURRÍCULO DE POLÍTICOS
}

\author{
AXIOLOGY AND LINGUISTICS: ONE REFLECTION ABOUT THE \\ SOCIAL VALUES AND THE LIE IN THE POLITICIAN'S \\ CURRICULUM
}

\author{
Maria da Penha Pereira Lins ${ }^{1}$ \\ Rosani Muniz Marlow ${ }^{2}$
}

\begin{abstract}
Resumo: Este artigo propõe uma reflexão sobre texto e valores na educação para uma sociedade democrática, considerando uma notícia política (EXAME, 2019), justificada pelo fato de a escola estar comprometida numa relação de forças de ação política que frequentemente a desqualifica. A metodologia faz a interface Axiologia (ARANHA, 1989; FREIRE, 1996), Linguística Textual (KOCH, 1999; 2011; [2004]2015; CAVALCANTE, 2016) e Pragmática (GRICE, 1982). Numa perspectiva linguística, a análise mostra uma organização textual estratégica da notícia, por parte da jornalista, para reprovação da mentira e exposição dos mentirosos e, por parte dos políticos, a negação da mentira e o esforço para atenuá-la ou recategorizá-la. Numa perspectiva sociopolítica, o processo de conscientização sobre valores deve fazer a conexão escola e vida. Assim, ao mesmo tempo em que a ética precisa fazer parte da formação política do aluno para (co)administrar a cidade para o bem-comum, espera-se que os governantes tenham essa formação e sejam exemplos de cidadania para os educandos, o que o fato noticiado contradiz. Por fim, numa perspectiva educacional, instituições e educadores comprometidos com o ideal crítico e democrático precisam desempenhar seu papel ético pelo necessário exercício da interação dialógica e da respeitosa convivência humana, para formar um cidadão crítico e uma sociedade democrática.
\end{abstract}

Palavras-chave: Axiologia. Organização Textual. Argumentação Pragmática. Desinformação.

Abstract: This article proposes a reflection about values in education for a democratic society, considering political news (EXAME, 2019), justified by the fact that the school is committed to a relationship of political action forces that often disqualifies it. The methodology makes the interface Axiology (ARANHA, 1989; FREIRE, 1996), Textual Linguistics (KOCH, 1999; 2011; [2004] 2015; CAVALCANTE, 2016) and Pragmatics (GRICE, 1982). From a linguistic perspective, the analysis perceived a strategic textual organization of the news, on the part of the journalist, for disapproval of the lie and exposure of liars, and, on the part of the politicians,

\footnotetext{
1 Lins é doutora em Linguística pela UFRJ e professora permanente da UFES/PPGEL. E-mail: mpenhalins@gmail.com. Dezembro/2021.

2 Marlow é doutora pela UFES/PPGEL e professora da FAMES. E-mail: rosanimarlow@gmail.com. Dezembro/2021.
} 


\section{PERcursos Linguísticos • Vitória (ES) •v. 11 •n. 29 • 2021 • ISSN: 2236-2592 • Dossiê temático $\bullet O$ texto na pesquisa e no ensino: conhecimentos, práticas e desafios na contemporaneidade •}

the denial of the lie and the effort to mitigate or recategorize it. From a sociopolitical perspective, the process of raising awareness about values must make the connection between school and life. Thus, at the same time that ethics need to be part of the student's political education to (co) manage the city for the common good, it is expected that government officials have this training and be examples of citizenship for students, which the reported fact contradicts. Finally, from an educational perspective, institutions and educators committed to the critical and democratic ideal need to play their ethical role through the necessary exercise of dialogic interaction and respectful human coexistence, to form a critical citizen and a democratic society.

Keywords: Axiology. Textual Organization. Pragmatic Argumentation. Desinformation.

\section{INTRODUÇÃO}

A proposta deste artigo é refletir sobre a importância dos valores na práxis educativa para uma sociedade democrática, através da análise do projeto de dizer de uma notícia política, publicada pela Revista Exame e compartilhada em redes sociais, em maio de 2019, com os respectivos título e subtítulo: Os ministros do governo Bolsonaro que mentiram no currículo: Mestrados e doutorados imaginários, omissões convenientes e autoplágio estão entre as inconsistências reveladas em membros da equipe. ${ }^{3}$

Justifica-se a pesquisa pelo fato de que não existe educação neutra e, sendo assim, a instituição escolar está inserida e comprometida numa relação de forças de ação política. Fazse necessário, então, promover meios de compreender e analisar os valores vigentes na política, que frequentemente perpassam o noticiário e que contribuem para a desqualificação da educação, da ciência e da escola pública.

Para isso, propõe-se uma interface teórica entre as seguintes áreas do saber: a Axiologia na Filosofia, para demonstrar a importância dos valores na educação para a sociedade, com vistas à formação ética e cidadã do educando; a Linguística Textual, para depreender o tópico, a referenciação e a intertextualidade no corpo noticioso e sua relação com a argumentação jornalística; e a Pragmática Linguística, com base na ruptura das máximas conversacionais da comunicação cooperativa, tendo em vista o emprego da mentira, entendido também como um desvio de conduta moral.

\footnotetext{
3 Disponível em: <https://exame.abril.com.br/brasil/os-ministros-do-governo-bolsonaro-que-mentiram-nocurriculo/?fbclid=IwAR3URevbacZZGuoMy6_sQF6zd4avIVvzjypdYjPGjCWIfqKxVciO5stjORI>. Acesso em 02 de jun. 2019.
} 


\section{PERcursos Linguísticos • Vitória (ES) •v. 11 •n. 29 • 2021 • ISSN: 2236-2592 • Dossiê temático $\bullet O$ texto na pesquisa e no ensino: conhecimentos, práticas e desafios na contemporaneidade •}

Dessa forma, consideramos principalmente os estudos dos seguintes autores: o filósofo da linguagem britânico Paul Grice, em Lógica e conversação (1982); o filósofo e educador Paulo Freire, em Pedagogia da Autonomia: Saberes necessários à prática educativa (1996); a filósofa e educadora Maria Lúcia de Arruda Aranha, em Filosofia da Educação (1989); a linguista e professora Ingedore Grünfeld Villaça Koch, em Desvendando os segredos do texto (2011), entre outras obras, e o jornalista e professor Francisco José Castilhos Karam, em Jornalismo, ética e liberdade (2014).

Muitas das posições freirianas discutem valores que precisam perpassar a práxis pedagógica, porque a educação é capaz de transformar as pessoas e, pela interação, mudar a sociedade. Assim, a Axiologia Filosófica reforça a importância do ensino dos valores pelo exemplo é abordado neste estudo como forma de reverberar os preceitos freirianos para a educação. Neste sentido, este artigo se organiza em três seções com a pretensão de apresentar (1) “A Axiologia Freiriana", (2) "A Linguística e a Pragmática" (3) "Para (não) dar conta da mentira".

\section{A Axiologia freiriana}

A Axiologia é uma disciplina da Filosofia que estuda os valores, teorias que surgem tardiamente, apenas no século XIX (ARANHA, 1989), o que contrasta com o ato de valorar, que sempre existiu e que "é uma tarefa humana e coletiva que nunca termina. Ele [o ato de valorar] fundamentará o projeto comum de dar um sentido ao nosso mundo"' (ARANHA, 1989, p. 119). Valor é, pois, estabelecer "juízos de valor". Avaliar uma realidade ou um conteúdo nos provoca atração ou repulsa.

Conforme entende Aranha (1989), é imprescindível a importância dos valores para a práxis educativa. No entanto,

[...] os valores transmitidos pela sociedade nem sempre são claramente tematizados, e até mesmo muitos educadores não baseiam sua prática em uma reflexão mais atenta a respeito. A educação se tornará mais coerente e eficaz se formos capazes de explicitar esses valores. (ARANHA, 1989, p. 119).

A filósofa faz uma reflexão de forma a estabelecer três esferas nas quais os valores contribuem na formação dos educandos e, assim, da própria sociedade: educação moral - para a formação de um sujeito autônomo; educação política - para a formação de um sujeito cidadão; 


\title{
PERcursos Linguísticos • Vitória (ES) •v. 11 •n. 29 • 2021 • ISSN: 2236-2592 • Dossiê temático $\bullet O$ texto na pesquisa e no ensino: conhecimentos, práticas e desafios na contemporaneidade •
}

e educação estética - para a formação de um sujeito livre, ao mesmo tempo racional e afetivo (ARANHA, 1989).

No primeiro aspecto, Aranha lembra que a moral do ser humano não é inata: ele aprende a ser moral, e assim, o papel desempenhado pela educação é de suma importância, não para “aulas de moral”, mas para a sua prática, "por meio do processo mesmo da educação, enquanto a consideramos uma interação entre seres sociais: aprende-se moral pelo convívio humano" (ARANHA, 1989, p. 119). A filósofa explica, então, que o indivíduo deve ser livre e consciente - autônomo - para escolher os seus valores:

\begin{abstract}
Tornar-se moral é assumir livremente regras que possibilitem o crescimento pessoal, entendendo-se pessoa como alguém que se integra em um grupo. Isso não é fácil, se pensarmos que a sociedade é plural e se constitui de valores conflitantes, diante dos quais devemos nos posicionar e escolher, ao mesmo tempo que aceitamos a divergência e o confronto de idéias [sic]. [...] Só então poderá rever maduramente os valores herdados e estabelecer propostas de mudança. (ARANHA, 1989, p. 120).
\end{abstract}

Na esfera política, Aranha entende que "a política diz respeito ao uso do poder que torna possível a administração da cidade, ou seja, o espaço da atuação do cidadão" (ARANHA, 1989, p. 120). Sendo assim, os valores de uma educação política favorecem a vida em comum, o espaço democrático. No entanto, forças hegemônicas estão em ação para despolitizar a educação. Nas palavras da autora,

[...] a educação das crianças e dos jovens tem atendido às expectativas dos grupos que detêm o poder em cada sociedade. Compreendemos, então, por que existe a escola dualista (uma para a elite e outra para os pobres, quando lhes é destinada alguma!). É a ideologia que nos impede de reconhecer que a exclusão de tantas pessoas das atividades escolares se deve menos à capacidade individual que às divisões propriamente políticas, que instauram o desequilíbrio do poder e, portanto, a dominação. (ARANHA, 1989, p. 120-121).

É, portanto, um desafio formar cidadãos e estimular o pluralismo numa sociedade que prega "segregação, preconceito, exclusão, quando as pessoas estão acostumadas a obedecer, porque a regra é o autoritarismo decorrente das relações fortemente hierárquicas" (ARANHA, 1989, p. 121). O desafio se percebe ainda na medida da desvalorização da arte: “A educação estética é instrumento de valorização integral do homem, isto é, de todo homem e de qualquer homem" (ARANHA, 1989, p. 121) e, sendo a estética a "faculdade de sentir", de "compreender pelos sentidos", a "arte tem um papel formador da personalidade" (ARANHA, 1989, p. 121). Por isso, muitos a tem como "subversiva", pois 


\section{PERcursos Linguísticos • Vitória (ES) •v. $11 \bullet$ n. 29 • 2021 • ISSN: 2236-2592 • Dossiê temático $\bullet O$ texto na pesquisa e no ensino: conhecimentos, práticas e desafios na contemporaneidade •}

Não é um exagero dizer que a postura estética ajuda a evitar as formas petrificadas, rígidas e intransigentes, do moralismo ou do fanatismo político. Talvez porque a arte esteja na dimensão do "sonho acordado", da utopia, que nada mais é do que a expressão da esperança. (ARANHA, 1989, p. 122).

Dessa forma, Aranha entende que os valores estão intrinsecamente alinhados a uma educação libertadora: "Educação e liberdade são inseparáveis porque a liberdade não é algo que nos é dado, mas uma conquista do homem ao longo de seu amadurecimento, de modo que ele aprende a ser livre" (ARANHA, 1989, p. 122). Assim, "a educação autêntica só pode ser a educação para a liberdade - e por meio dela -, a fim de que não se torne adestramento ou doutrinação." (ARANHA, 1989, p. 122).

Os valores e a liberdade na educação também são pautas dos estudos freirianos. Considerando especialmente a sua última obra, Pedagogia da Autonomia: saberes necessários à prática educativa (1996), Freire apregoa as exigências, as necessidades, os pré-requisitos, as bases, portanto, os valores que devem fazer parte da formação daqueles que se veem inseridos no processo de (auto)formação constante e na luta contra o modelo neoliberal opressor da educação brasileira. Para Freire, trata-se da questão "da formação docente ao lado da reflexão sobre a prática educativo-progressiva em favor da autonomia do ser dos educandos" (FREIRE, 1996, p. 9).

Sendo assim, Freire entende que, na relação docente e discente, deve haver a valorização da rigorosidade metódica, da pesquisa, do respeito aos saberes dos educandos, da criticidade, da estética e da ética, da corporificação das palavras pelo exemplo, da aceitação do novo e da rejeição da discriminação; da reflexão crítica sobre a prática e do reconhecimento e assunção das identidades culturais.

Continuando, sobre o ato de ensinar, ou seja, a relação educador e conhecimento, Freire aponta como valores necessários a consciência do processo educativo inacabado, o reconhecimento de ser condicionado, o respeito à autonomia do ser do educando, a curiosidade, o bom senso, a humildade, a tolerância, a luta pelos direitos dos educadores, a apreensão da realidade, a alegria, a esperança e a convicção de que a mudança é possível.

Por fim, considerando o ensino como especificidade humana, Freire aponta os seguintes valores como imprescindíveis ao professor: segurança do que ensina, competência profissional, generosidade, comprometimento, compreensão da educação como intervenção no mundo, liberdade, consciência da sua autoridade, bem-querer aos alunos, aptidão para a escuta e para o diálogo, e reconhecimento da condição ideológica da educação (FREIRE, 1996). 


\title{
PERcursos Linguísticos • Vitória (ES) •v. 11 •n. 29 • 2021 • ISSN: 2236-2592 • Dossiê temático $\bullet O$ texto na pesquisa e no ensino: conhecimentos, práticas e desafios na contemporaneidade •
}

Em Freire, temos sua insistência em afirmar que "formar é muito mais do que puramente treinar o educando no desempenho de destrezas" (FREIRE, 1996, p. 10) e que é necessária a "eticidade que conota expressivamente a natureza da prática educativa, enquanto prática formadora" (FREIRE, 1996, p. 10). Freire cita exemplos ainda muito atuais do que significa ética na prática:

\begin{abstract}
Falo [...] da ética universal do ser humano. Da ética que condena o cinismo do discurso [...], que condena a exploração da força de trabalho do ser humano, que condena acusar por ouvir dizer, afirmar que alguém falou A sabendo que foi dito B, falsear a verdade, iludir o incauto, golpear o fraco e indefeso, soterrar o sonho e a utopia, prometer sabendo que não cumprirá a promessa, testemunhar mentirosamente, falar mal dos outros pelo gosto de falar mal [...]. (FREIRE, 1996, p. 10).
\end{abstract}

Tais estudos sobre valores, como a ética, atestam que a educação, e assim, a escolha dos conteúdos e do método, está enraizada “- quer o professor saiba, quer não - em uma determinada concepção de homem e de sociedade, concepção essa que não é neutra, estando impregnada da visão política que a anima" (ARANHA, 1989, p. 151). Portanto, a formação do educador precisa levar em conta três aspectos, com ênfase, neste estudo, para a formação ética e política:

* quantificação: o professor deve adquirir conhecimentos científicos indispensáveis para o ensino de um conteúdo específico;

* formação pedagógica: a atividade de ensinar deve superar os níveis do senso comum, tornando-se uma atividade sistematizada;

* formação ética e política: o professor deve educar a partir de valores e tendo em vista um mundo melhor. (ARANHA, 1989, p. 152).

Especificamente com relação à ética na educação, Freire fala aos educadores:

É por esta ética inseparável da prática educativa, não importa se trabalhamos com crianças, jovens ou com adultos, que devemos lutar. E a melhor maneira de por ela lutar é vivê-la em nossa prática, é testemunhá-la, vivaz, aos educandos em nossas relações com eles. (FREIRE, 1996, p. 10).

Portanto, como educador, convém que o professor seja um cidadão que se posiciona e um profissional "comprometido com o mundo e disposto a participar, lutando contra o trabalho degradante, a submissão política, a alienação da consciência, as exclusões injustas e as diversas formas de preconceito" (ARANHA, 1989, p. 153).

\section{A Linguística Textual e a Pragmática}




\section{PERcursos Linguísticos • Vitória (ES) •v. 11 •n. 29 • 2021 • ISSN: 2236-2592 • Dossiê temático $\bullet O$ texto na pesquisa e no ensino: conhecimentos, práticas e desafios na contemporaneidade •}

O propósito deste artigo, de refletir sobre os valores na educação com vistas à cidadania plena, liga-se também a estudos linguísticos sobre o texto, objeto multifacetado que, nesta análise, coloca-se na interlocução jornalista e cidadãos leitores na forma do gênero notícia política em ambiente virtual.

A disciplina Linguística Textual (LT) surgiu na Europa, particularmente na Alemanha, por volta dos anos 60, numa perspectiva sintático-semântica para o estudo de frases e textos e, a partir de então, construiu uma trajetória que expandiu sua visão atual para uma análise sociocognitiva interacional do texto (KOCH, 1999; [2004] 2015). Sendo assim, neste trabalho, assumimos a definição de Marquesi e outros, que entendem o texto e seus sentidos como

[...] um processo que envolve aspectos linguísticos (e não linguísticos), conhecimentos armazenados na memória que são constantemente atualizados, e as vivências socioculturais definidoras das situações de comunicação e dos papéis que os sujeitos podem assumir. (MARQUESI; PAULIUKONIS; ELIAS, 2017, p. 7).

Ao se tomar um texto como objeto de análise, urge identificar o gênero textual que materializou a ação comunicativa entre os interlocutores, no caso jornalista e leitores de notícias de jornal. Conforme estudos de Bonini (2011), mudanças de posicionamentos teóricoconceituais para gênero e suporte podem ser observados desde as propostas de Bakhtin ([1953] 1975; 1992), passando pelo advento da internet como mídia de acesso público, no início dos anos 90, e, ainda hoje, com os desafios, por exemplo, para o entendimento do hipertexto e suas possibilidades (KOCH, 2011). Sobre essa temática, define Bonini:

a) gênero - unidade da interação linguageira que se caracteriza por uma organização composicional, um modo característico de recepção e um modo característico de produção. Pode ser de natureza verbal, imagética, gestual, etc. Como unidade, equivale ao enunciado bakhtiniano $;^{7}$

b) mídia - tecnologia de mediação da interação linguageira e, portanto, do gênero como unidade dessa interação. Cada mídia, como tecnologia de mediação, pode ser identificada pelo modo como caracteristicamente é organizada, produzida e recebida e pelos suportes que a constituem; e

c) suporte - elemento material (de registro, armazenamento e transmissão de informação) que intervém na concretização dos três aspectos caracterizadores de uma mídia (suas formas de organização, produção e recepção). (BONINI, 2011, p. 688).

Concordamos com Bonini que considerar que "o gênero realiza um propósito comunicativo" torna-se um problema de ordem epistemológica, visto que o gênero pode atender a mais de um propósito, além do significado subjetivo do próprio termo. Então, parece-nos mais 


\section{PERcursos Linguísticos • Vitória (ES) •v. 11 •n. 29 • 2021 • ISSN: 2236-2592 • Dossiê temático $\bullet O$ texto na pesquisa e no ensino: conhecimentos, práticas e desafios na contemporaneidade •}

adequado também afirmar que "o gênero realiza uma prática social” (BONINI, 2011, p. 689), especialmente se considerarmos as notícias.

Como exemplo do corpus proposto para esta análise, foi selecionada uma notícia veiculada no ambiente virtual, que não apresenta a estrutura clássica do gênero - a pirâmide invertida -, cujo primeiro parágrafo da notícia - o lide - cumpre a função de sumarizar o fato coberto, através da resposta para as questões: o quê?, quem?, como?, onde? e por quê? Entendemos que, neste caso, o propósito de fiscalizar e de expor ou de confrontar (in)verdades reorganiza as estruturas da notícia para melhor servir às argumentações da jornalista e/ou da linha editorial do jornal.

Contemporânea ao surgimento da LT, a Pragmática nasce por volta dos anos 60 , quando a Filosofia trazia importantes reflexões sobre a linguagem na perspectiva do seu uso. No entanto, diferente da LT que, à medida do avançar de seus estudos, visa e revisa o estatuto do texto, a Pragmática Linguística assume fenômenos da língua que estavam à margem dos estudos científicos porque não eram explicados pelo arsenal teórico linguístico disponível na época.

$\mathrm{Na}$ análise da notícia, além de refletirmos sobre valores sociais, as teorias da LT e da Pragmática dialogam para mostrar que a topicalização, a referenciação e a intertextualidade evidenciam a mentira e o esforço para recategorizá-la. Nos estudos sobre o texto, desenvolvidos pela LT, vários campos se abrem, sendo de interesse para esse trabalho considerar, de forma sucinta, as noções de tópico discursivo, argumentação, referenciação e intertextualidade, aliando-as ao princípio da cooperação e suas máximas, para uma tentativa de análise do fenômeno da mentira.

Para Cavalcante, a argumentação é constitutiva do discurso, mas é no texto que ela se expressa. A autora esclarece que, diante das diversas concepções teóricas sobre a argumentação", a LT "sempre, e por diferentes conduções metodológicas, incluiu a argumentação como um pressuposto inegável e como uma motivação para a análise de diversas estratégias de organização textual" (CAVALCANTE, 2016, p. 107). Além disso, que

[...] a LT pode contribuir para uma análise da argumentação nos discursos, pois os critérios analíticos da LT são como que motivados por uma tentativa de explicação para as escolhas textuais pelas quais o sujeito age sobre o seu dizer, reelaborando-o a todo instante, negociando-o com os prováveis interlocutores (em seus papéis sociais), para atender a seus propósitos. (CAVALCANTE, 2016, p. 116).

\footnotetext{
${ }^{4}$ Cavalcante (2016) apresenta um panorama das abordagens da argumentação em textos em quatro blocos: (1) trabalhos que são orientados pela Teoria dos Blocos Semânticos; (2) estudos que seguem a Análise Textual dos Discursos, proposta por Jean-Michel Adam; (3) estudos que adotam os critérios da Semiolinguística de Charaudeau e (4) estudos que lançam mão dos postulados da Retórica e da Nova Retórica.
} 


\section{PERcursos Linguísticos • Vitória (ES) •v. 11 •n. 29 • 2021 • ISSN: 2236-2592 • Dossiê temático $\bullet O$ texto na pesquisa e no ensino: conhecimentos, práticas e desafios na contemporaneidade •}

Citando, por exemplo, os estudos de Ruth Amossy na linguística do discurso, Cavalcante defende que é possível depreender, via LT, as estratégias textuais de mobilização do logos, do ethos e do pathos,

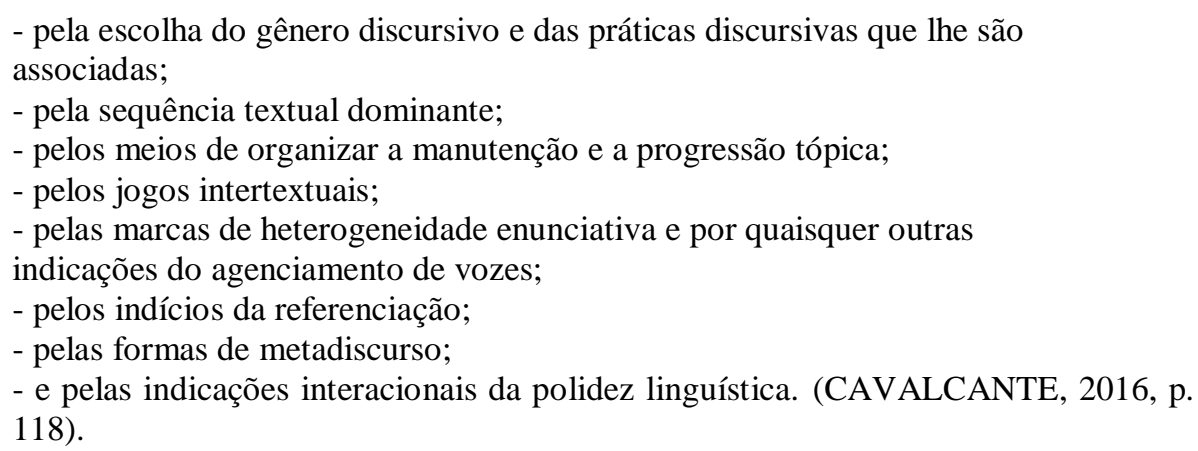

Quanto ao tópico discursivo, Cavalcante (2014, p. 80) define-o como tema central de um texto, não necessariamente identificável na superfície do texto, porque ele pode estar relacionado tanto aos aspectos cotextuais quanto ao contextuais. "Desse modo, a identificação dos tópicos ficará atrelada ao conjunto de todo o evento comunicativo" (CAVALCANTE, 2014, p. 81). A autora também entende a "topicalidade" como "princípio organizador de um texto" (CAVALCANTE, 2014, p. 89), fator deveras importante para a construção dos sentidos e para o desenvolvimento argumentativo do texto.

Concordamos com Jubram (2006), que entende o tópico como uma categoria abstrata e analítica que serve como fio-condutor da organização textual-interativa e que apresenta duas propriedades: de centração e de organicidade. A propriedade tópica da centração é manifestada quando os enunciados apresentam um conjunto de referentes que são concernentes entre si, relevantes e localizáveis no texto.

Já com relação à propriedade da organicidade, esta segue-se num plano hierárquico, com estabelecimento de ordenação e subordinação, e, num plano de linearidade, com a continuidade, descontinuidade ou transição entre tópicos. O quadro 1, a seguir, organiza os desdobramentos do tópico discursivo, com base em Jubram (2006):

Quadro 1 - Propriedades do tópico discursivo (JUBRAM, 2006)

\begin{tabular}{c|c|c|c|c|c|c}
\hline \multicolumn{3}{c|}{ Centração } & \multicolumn{4}{c}{ Organicidade } \\
\hline Concernência & Relevância & Pontualização & Plano Hierárquico & \multicolumn{3}{c}{ Plano Linear } \\
\cline { 4 - 6 } & & & Quadro tópico & Continuidade & Descontinuidade & Transição \\
\hline
\end{tabular}

\footnotetext{
${ }^{5}$ Logos [lógica], ethos [ética] e pathos [sentimentos, emoções] são, nos estudos retóricos, pilares da persuasão.
} 
PERcursos Linguísticos • Vitória (ES) •v. 11 •n. 29 • 2021 • ISSN: 2236-2592 • Dossiê

temático $\bullet O$ texto na pesquisa e no ensino: conhecimentos, práticas e desafios na contemporaneidade •

\begin{tabular}{c|c|c|c|c|c|c}
\hline & & $\begin{array}{c}\text { Supertópico } \\
\text { Subtópico }\end{array}$ & & $\begin{array}{c}\text { Ruptura } \\
\text { Cisão } \\
\text { Expansão }\end{array}$ & $\begin{array}{c}\text { Superposição } \\
\text { Movimento }\end{array}$ \\
\hline
\end{tabular}

Fonte: produção nossa

Sobre referenciação, os referentes, ou objetos de discurso, são entidades, representações, dadas e percebidas no texto a partir do uso de expressões referenciais, que podem ser termos repetidos, pronomes, elipses ou termos sinônimos. Sua principal função, por força do nome, é referir e, assim, elaborar uma dada realidade, construir uma versão de fatos, reelaborar práticas sociais pela linguagem.

Cavalcante (2014) afirma que o processo de construção de referentes implica assumir que a linguagem não expressa uma realidade pronta e acabada e que isso "não significa dizer que o papel da linguagem é ludibriar, é maquiar a realidade, é disfarçar a verdade" e "se isso é usado para fins mais ou menos lícitos, é algo que, pelo menos em princípio, escapa ao estudo da linguagem" na perspectiva da referenciação (CAVALCANTE, 2014, p. 105). Sendo assim, um dos fenômenos da referenciação é a recategorização dos objetos de discurso, que é "a possibilidade de um referente [introduzido] passar por mudanças [e ser recategorizado] ao longo do texto" (CAVALCANTE, 2014, p. 106) por questões diversas.

Cavalcante (2014) também aponta que o conceito de intertextualidade tem origem na crítica literária e no dialogismo bakhtiniano, mas "em princípio, os processos intertextuais podem apresentar-se em qualquer gênero, dentro de qualquer domínio discursivo" (CAVALCANTE, 2014, p. 146). A intertextualidade constitui-se na relação estabelecida entre textos e é percebida através de evidências tipográficas mais evidentes, configurando relações de copresença textual, ou de pistas inferenciais mais sutis, em relações de derivação textual.

O quadro 2, a seguir, reorganiza as relações intertextuais segundo Piègay-Gros (1996), citado por Cavalcante (2014, p. 146), com nossas inserções:

\begin{tabular}{c|c|c}
\hline \multicolumn{2}{c}{ Quadro 2 - Relações Intertextuais } \\
\hline Relações de Copresença & Relações de Derivação \\
\hline Citação [direta] & Implícita & Paródia \\
Referência & Plágio & Travestimento burlesco [satirização] \\
& Alusão & Pastiche [imitação] \\
[Citação indireta ou paráfrase]
\end{tabular}

Fonte: Cavalcante (2014, p. 146). Adaptação nossa.

A Pragmática, por seu turno, estuda os contextos da língua em uso, as escolhas linguísticas dos falantes, para dar conta de situações comunicativas e suas intenções na 


\section{PERcursos Linguísticos • Vitória (ES) •v. 11 •n. 29 • 2021 • ISSN: 2236-2592 • Dossiê temático $\bullet O$ texto na pesquisa e no ensino: conhecimentos, práticas e desafios na contemporaneidade •}

interação. O americano Paul Grice está entre vários filósofos que trouxeram importantes contribuições para a Linguística, entre as décadas de 60 e 70, porque partiam de um ponto de vista diferente dos estudos estruturalistas e gerativistas da época.

Para Grice, na interação comunicacional, os falantes agem, na prática, orientados por uma espécie de contrato conversacional implícito, cujo princípio geral é: "dê a sua contribuição conversacional tal como requerida, na altura em que ocorre, pelo propósito ou direção aceitos da troca verbal na qual você está envolvido" (GRICE, [1975] 1982, p. 126). Para o filósofo, as pessoas estão normalmente fornecendo uma quantidade apropriada de informação, estão dizendo a verdade, sendo relevantes, e tentando ser claras o quanto podem (GRICE, 1982).

Conforme Grice (1982), o princípio cooperativo organiza-se em máximas conversacionais de quantidade, qualidade, relação e modo, representadas sucintamente no quadro 3, a seguir.

\begin{tabular}{c|c|c|c}
\hline \multicolumn{2}{c}{ Quadro 3 - Máximas Conversacionais do Princípio da Cooperação (GRICE, 1982) } \\
\hline Quantidade & Qualidade & Relação & Modo \\
\hline Informar o necessário: nem & Ser verdadeiro: não & $\begin{array}{c}\text { Ser relevante; ser } \\
\text { mais nem menos do que } \\
\text { afirmar o que crê ser falso em relação ao } \\
\text { objetivo da conversa. }\end{array}$ & $\begin{array}{c}\text { Ser claro, ordenado } \\
\text { e breve. }\end{array}$ \\
$\begin{array}{c}\text { aquilo que é fundamental } \\
\text { para objetivos de uma } \\
\text { interação verbal. }\end{array}$ & $\begin{array}{c}\text { não afirmar aquilo que } \\
\text { não pode confirmar } \\
\text { veracidade. }\end{array}$ & & \\
\hline
\end{tabular}

Fonte: produção nossa

O princípio de cooperação dá credibilidade aos locutores porque, em tese, locutor e interlocutor estão cumprindo as máximas conversacionais. No entanto, a violação das máximas pode ser intencional: se o que é dito não é o suficiente para depreender sentido, pode ser que o locutor esteja aparentemente desobedecendo uma ou mais máximas e, assim, constituindo implicaturas para as quais acredita que o interlocutor consiga perceber e inferir o sentido pretendido (GRICE, 1982). Ainda segundo Grice (1982), falar a verdade - ser cooperativo - é fácil, enquanto que inventar e manter mentiras - não ser cooperativo - exige um considerável esforço, uma ruptura radical do contrato tácito entre os partícipes do ato comunicativo.

\section{Para (não) dar conta da mentira}

Os ministros do governo Bolsonaro que mentiram no currículo. Este é o título da notícia assinada pelo portal da revista Exame, da editora Abril, publicada no site da revista pela jornalista Clara Cerioni, em 22 de maio de 2019, às 18h34min, e a partir daí compartilhada em 


\section{PERcursos Linguísticos • Vitória (ES) •v. 11 •n. 29 • 2021 • ISSN: 2236-2592 • Dossiê temático $\bullet O$ texto na pesquisa e no ensino: conhecimentos, práticas e desafios na contemporaneidade •}

redes sociais, dentre estas o Facebook, de onde foi coletada para este estudo. O subtítulo da notícia, "olho" no jargão jornalístico, adianta que "Mestrados e doutorados imaginários, omissões convenientes e autoplágio estão entre as inconsistências reveladas em membros da equipe" do governo de Jair Bolsonaro. ${ }^{6}$

Dada a esfera midiática do texto em análise, convém considerar que Karam (2014) situa o jornalismo de mídia no atual cenário brasileiro de modo a revelar, de um lado, uma perda do "monopólio" da informação jornalística, e, de outro, a afirmar que o jornalismo ainda representa, no discurso, credibilidade e liberdade de imprensa. Segundo Karam,

[...] a informação jornalística não é mais - se é que algum dia foi - o principal produto oferecido aos veículos jornalísticos. No amplo espectro de interesses do campo da comunicação, o jornalismo é "mais um", embora ele sirva, como discurso, para falar em "credibilidade" como fator central de tais mídias e para defender a "plena liberdade de imprensa", tomando-se esta como liberdade de informações ou de negócios em quaisquer suportes tecnológicos. (KARAM, 2014, p. 201).

Dessa forma, Karam especifica qual é a base da credibilidade pública nas mídias: “As mídias públicas, as assessorias públicas e privadas, as mídias tradicionais que foram para a rede mundial de computadores, incluindo as redes sociais, estão na base na credibilidade contemporânea como referência pública comum”. (KARAM, 2014, p. 203).

Especificamente sobre a mentira no jornalismo, Lage (2005) afirma: "Tomada em sentido amplo, como supressão parcial da verdade, a mentira é rotineira e, em muitos casos, inevitável" (LAGE, 2005, p. 50). Na estrutura do texto informativo no jornalismo, Lage apresenta a mentira como uma estratégia, um ato deliberado:

\footnotetext{
A mentira é, no mundo moderno, uma estratégia como outra qualquer: não resulta de engano nem é questão de crença. É um ato deliberado, que geralmente se apóia em desejo atribuído ao receptor: querer algo é o primeiro passo para se acreditar que esse algo existe. (LAGE, 2005, p. 49).
}

Partindo para a análise, e inicialmente fazendo uso do arcabouço teórico da LT, quanto ao tópico discursivo, propomos, conforme quadro 4, um plano hierárquico em quatro níveis tópicos (A, B, C e D), em que o nível mais alto (A) apresenta o supertópico, o tópico mais abrangente: "Mentir no currículo".

\footnotetext{
${ }^{6}$ A configuração do portal da Revista Exame não permite comentários para a notícia, mas a interação dos leitores é observada a partir do compartilhamento da notícia nas redes sociais, blogs e outros suportes midiáticos. Um exemplo desse compartilhamento está disponível em: <https://www.facebook.com/323932337974376/posts/1254133784954222/ >. Acesso em 18 de dez. de 2021.
} 


\section{PERcursos Linguísticos • Vitória (ES) •v. 11 •n. 29 • 2021 • ISSN: 2236-2592 • Dossiê temático $\bullet O$ texto na pesquisa e no ensino: conhecimentos, práticas e desafios na contemporaneidade •}

Considerando o nível (B), percebemos dois quadros tópicos: No primeiro, “(1) Profissionais Mentirosos", ocorre uma ruptura tópica, tendo em vista que introduz que "No Brasil, mentir no currículo é algo praticado por cerca de 7 em cada 10 profissionais, de acordo com um levantamento da empresa DNA Outplacement" para, em seguida, tratar da mentira no currículo no campo político. Portanto, o tópico (1) é introduzido, mas não se desenvolve. Essa descontinuidade tópica denota uma estratégica da argumentação jornalística para conduzir o leitor ao tópico que será desenvolvido. Ou seja, ao considerar introdutoriamente que profissionais mentem no currículo, a jornalista, de certa forma, legitima a notícia que escancara profissionais com carreira política mentindo em seus currículos. Dessa forma, numa perspectiva linguística, a análise mostra uma organização textual estratégica da notícia, para reprovação da mentira e para a exposição dos mentirosos, evidenciando relações entre a forma de organização tópica e o gênero analisado.

Quadro 4 - Plano hierárquico de níveis tópicos

(A)

(B)

(1) Profissionais Mentirosos

Mentir no Currículo

(C)

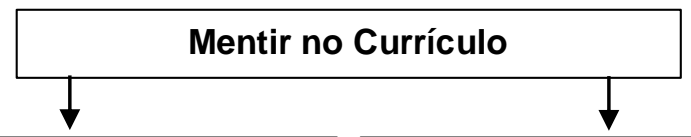

(2) Políticos e Figuras Públicas mentirosos

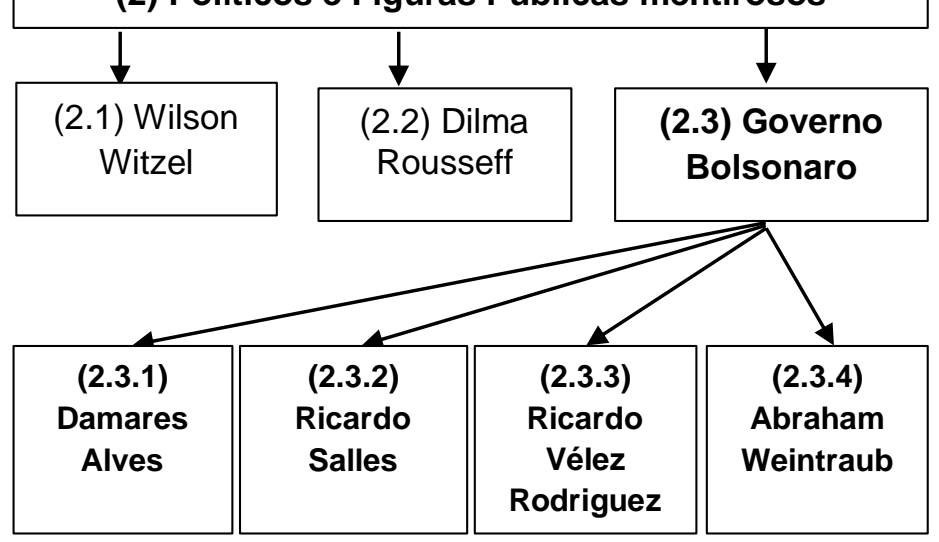

Já o segundo quadro tópico, “(2) Políticos e Figuras Públicas Mentirosos”, apresenta continuidade em três subtópicos, no nível (C): “(2.1) Wilson Witzel”, “(2.2) Dilma Rousseff” e "(2.3) Governo Bolsonaro", que cumprem a função argumentativa de comprovar que "Políticos e figuras públicas, que não deveriam se surpreender de ter suas vidas vasculhadas, também não hesitam em florear suas experiências pregressas". Os subtópicos (2.1) e (2.2) sustentam o argumento de que "A prática [de mentir no currículo] atravessa campos políticos", pois temos o Governador do Estado do Rio de Janeiro, eleito em 2018, pelo Partido Social Cristão (PSC) e a Presidente eleita em 2014, pelo Partido dos Trabalhadores (PT), como 


\section{PERcursos Linguísticos • Vitória (ES) •v. 11 •n. 29 • 2021 • ISSN: 2236-2592 • Dossiê temático $\bullet O$ texto na pesquisa e no ensino: conhecimentos, práticas e desafios na contemporaneidade •}

exemplos que diferem em termos de ideologias partidárias e tempo de gestão pública, mas que se aproximam como políticos que mentiram em seus currículos. Não há, no entanto, um desenvolvimento posterior desses subtópicos.

Considerando-se o subtópico “(2.3) Governo Bolsonaro”, temos a sua divisão em quatro segmentos tópicos, no nível (D), que organizam a argumentação de que: “É comum que em começos de governo, os novos membros sejam confrontados sobre a veracidade das informações dos seus currículos. Em 2019, foi a vez dos ministros de Bolsonaro”. Temos, então, os segmentos tópicos “(2.3.1) Damares Alves”; “(2.3.2) Ricardo Salles”; “(2.3.3) Ricardo Vélez Rodriguez"; e "(2.3.4) Abraham Weintraub”, ministros do Governo Bolsonaro, e a descrição de como procederam de forma inverídica em seus currículos.

Concluindo a questão da topicalização, é possível percebermos, pela organicidade tópica, que a argumentação parte de um sentido mais amplo - a mentira no currículo do profissional no Brasil -, focaliza a esfera política e dá ênfase à mentira no Governo Bolsonaro, tendo em vista a recorrência do fato no currículo de quatro ministros do atual governo, cujas imagens de perfil, inclusive, ilustram a notícia logo após o título e o olho, além da própria referência no título. Inclusive, a fotomontagem que encabeça o texto noticioso exibe a legenda "Ministros: é comum que em começos de governo, os novos membros sejam confrontados sobre a veracidade das informações (Agência Brasil/AFP/Agência Brasil/Reuters/EXAME)", sentença seguida do esclarecimento que verificar o currículo dos empossados de um novo governo é praxe do jornalismo com prerrogativa investigativa, ou seja, que não se trata de perseguição política, partidarismo, jornalismo tendencioso - acusações que maculam e servem de contra investida ao posicionamento de muitos jornais e jornalistas.

A intertextualidade é percebida em todo o texto noticioso porque a jornalista constrói seu projeto de dizer amparada em textos de outros jornais para dar conta de seu propósito comunicativo. Citamos como intertextualidade com relação de derivação os seguintes trechos, em que a jornalista apresenta parafraseados dados de outras instituições midiáticas que serviram de fontes para sua notícia: (1) quando, no primeiro parágrafo da notícia, os números estatísticos da empresa DNA Outplacement informam que 7 entre 10 profissionais brasileiros mentem no currículo; (2) quando a notícia do jornal O Globo é citada para reverberar a mentira do governador do Rio de Janeiro, Wilson Witzel; (3) quando o caso de Dilma Rousseff, que veio à tona no ano de 2009, pela revista Piauí, é evocado pela jornalista para então validar o argumento de que a mentira no currículo dos políticos transcende tempo e partido; (4) quando é afirmado que a mentira de Damares Alves tornou-se conhecida a partir da reportagem do 


\section{PERcursos Linguísticos • Vitória (ES) •v. 11 •n. 29 • 2021 • ISSN: 2236-2592 • Dossiê temático $\bullet O$ texto na pesquisa e no ensino: conhecimentos, práticas e desafios na contemporaneidade •}

jornal Folha de S.Paulo; (5) quando o site da Intercept Brasil apurou junto a universidade Yale a mentira no currículo de Ricardo Salles, em fevereiro de 2019; (6) quando o site Nexo noticiou que Ricardo Vélez Rodriguez, então Ministro da Educação, errou 22 vezes em seu currículo Lattes e (7) quando foram reveladas inconsistências no currículo do ministro Abraham Weintraub pelo jornal Folha de S.Paulo.

Apresenta-se ainda como exemplo de intertextualidade de copresença explícita que o ministro Ricardo Salles se pronuncia numa rede social, em 24 de fevereiro de 2019, e esse pronunciamento é acessado e recortado em forma de imagem, compondo a notícia, para comprovar a sua mentira e posteriores explicações quanto a esse pronunciamento. Já como exemplo de intertextualidade de copresença implícita, podemos citar (1) o "esquecimento" de Vélez de citar Carlos Henrique Cardim, o organizador da obra "Formação e Perspectivas da Social-democracia", título dado como de autoria de Vélez no currículo; e (2) os seguintes trechos de alusão às agências de notícias nacionais e internacionais, "Agência Brasil/AFP/Agência Brasil/Reuters/EXAME", na legenda da fotomontagem, como uma espécie de referenciação indireta para a qual a jornalista conta com a capacidade de inferência do seu interlocutor leitor para completar o sentido de que todas essas entidades agem da mesma forma, ou seja, conferem as informações levadas a público por políticos e outras personalidades.

Se considerarmos, agora, alguns aspectos de referenciação, dando vista ao processo de categorização e recategorização, é interessante perceber a mentira como objeto de discurso, e como seu conteúdo é recategorizado pelo mentiroso como "mera 'intenção", "ensino bíblico" e "equívoco da assessoria", conforme grifos nossos, no quadro 5 a seguir, quando os ministros ou seus respectivos assessores tentam explicar o fato, e como a mentira é classificada pela jornalista como "mestrados e doutorados imaginários", “omissões convenientes" e "autoplágio".

O quadro 5, portanto, destaca fragmentos da notícia que objetivam comparar a mentira, a tentativa da desconstrução da mentira, ou a "verdade" apurada dos fatos, para percepção da referenciação e recategorização dada tanto pelos ministros quanto pela jornalista.

\begin{tabular}{c|c|c}
\hline \multicolumn{3}{c}{ Quadro 5 - Recategorizações da mentira } \\
\hline Ministro & Mentira & "Verdade" \\
\hline Wilson Witzel & $\begin{array}{c}\text { "parte de seu curso de doutorado } \\
\text { na Universidade Federal } \\
\text { Fluminense (UFF) foi realizado na } \\
\text { universidade americana de } \\
\text { Harvard" }\end{array}$ & $\begin{array}{c}\text { "A assessoria informou que essa era uma } \\
\text { mera 'intenção' do hoje governador, que } \\
\text { nem chegou a se inscrever no processo do } \\
\text { chamado "doutorado sanduíche"” }\end{array}$ \\
\hline Recategorização & \multicolumn{2}{|c}{ "mestrados e doutorados imaginários" } \\
\hline
\end{tabular}


PERcursos Linguísticos • Vitória (ES) •v. 11 •n. 29 • 2021 • ISSN: 2236-2592 • Dossiê temático $\bullet O$ texto na pesquisa e no ensino: conhecimentos, práticas e desafios na contemporaneidade •

\begin{tabular}{|c|c|c|}
\hline Dilma Rousseff & $\begin{array}{l}\text { "títulos de mestre e doutora em } \\
\text { economia pela Unicamp" }\end{array}$ & $\begin{array}{l}\text { "Na verdade, ela havia concluído os } \\
\text { créditos mas não tinha nenhum dos } \\
\text { diplomas por não ter defendido tese. A } \\
\text { revelação veio à tona pela Revista Piauí, } \\
\text { em 2009." }\end{array}$ \\
\hline Recategorização & \multicolumn{2}{|c|}{ "mestrados e doutorados imaginários" } \\
\hline Damares Alves & $\begin{array}{c}\text { “'mestre em educação’ e ‘em } \\
\text { direito constitucional e direito da } \\
\text { família”" }\end{array}$ & $\begin{array}{l}\text { "seu título tem a ver com o ensino } \\
\text { bíblico. 'Diferentemente do mestre } \\
\text { secular, que precisa ir a uma universidade } \\
\text { para fazer mestrado, nas igrejas cristãs é } \\
\text { chamado mestre todo aquele que é } \\
\text { dedicado ao ensino bíblico"” }\end{array}$ \\
\hline Recategorização & \multicolumn{2}{|c|}{ "mestrados e doutorados imaginários" } \\
\hline
\end{tabular}

\begin{tabular}{|c|c|c|}
\hline \multicolumn{3}{|c|}{ Quadro 5 - Recategorizações da mentira (continuação) } \\
\hline Ministro & Mentira & "Verdade" \\
\hline Ricardo Salles & $\begin{array}{l}\text { "mestre em direito público pela } \\
\text { Universidade Yale" }\end{array}$ & $\begin{array}{l}\text { "Salles disse em seu Twitter que 'a } \\
\text { informação de } 2012 \text { foi veiculada } \\
\text { erroneamente por um equívoco da } \\
\text { assessoria"” }\end{array}$ \\
\hline Recategorização & \multicolumn{2}{|c|}{ "mestrados e doutorados imaginários" } \\
\hline $\begin{array}{l}\text { Ricardo Vélez } \\
\text { Rodriguez }\end{array}$ & $\begin{array}{c}\text { "ter citado como de sua autoria } \\
\text { única o livro 'Formação e } \\
\text { Perspectivas da Social- } \\
\text { democracia"” }\end{array}$ & $\begin{array}{l}\text { "O ministro decidiu na ocasião não se } \\
\text { pronunciar sobre as revelações" }\end{array}$ \\
\hline Recategorização & \multicolumn{2}{|c|}{ "omissões convenientes" } \\
\hline $\begin{array}{l}\text { Abraham } \\
\text { Weintraub }\end{array}$ & $\begin{array}{l}\text { "dois artigos idênticos publicados } \\
\text { em periódicos diferentes que } \\
\text { exigem ineditismo do material - } \\
\text { prática conhecida no meio } \\
\text { acadêmico como autoplágio" }\end{array}$ & ----- \\
\hline Recategorização & \multicolumn{2}{|c|}{ “autoplágio" } \\
\hline
\end{tabular}

Os instrumentos da LT deixam evidentes, no plano hierárquico dos tópicos dos políticos mentirosos e na recategorização da mentira apurada pela jornalista, conforme quadro 5, que, além de transgressão da ética, os governantes mentirosos atentam contra a ciência, a educação e a universidade pública ao inflarem seus currículos com títulos e obras mentirosas que, mediante contestadas, foram convenientemente recategorizadas. Portanto, essas autoridades não demonstraram nenhum compromisso com valores para o bem-comum, como a verdade, a humildade e o respeito.

Quantos às máximas conversacionais, estabelecemos que, deliberadamente, todas as figuras públicas mencionadas na notícia como mentirosas de fato descumpriram máximas conversacionais. Portanto, temos, no quadro 6 , o seguinte resultado para a violação das máximas do Princípio Cooperativo (GRICE, 1982). 


\section{PERcursos Linguísticos • Vitória (ES) •v. 11 •n. 29 • 2021 • ISSN: 2236-2592 • Dossiê temático $\bullet O$ texto na pesquisa e no ensino: conhecimentos, práticas e desafios na contemporaneidade •}

\begin{tabular}{|c|c|c|c|c|}
\hline \multicolumn{5}{|c|}{ Quadro 6 - Violação das máximas conversacionais do Princípio da Cooperação } \\
\hline Político & Quantidade & Qualidade & Relação & Modo \\
\hline $\begin{array}{l}\text { Wilson } \\
\text { Witzel }\end{array}$ & $\begin{array}{l}\text { Informou além do } \\
\text { que deveria estar no } \\
\text { currículo. }\end{array}$ & $\begin{array}{l}\text { Informou o que não } \\
\text { podia comprovar. }\end{array}$ & $\begin{array}{l}\text { Intenção de estudar não é } \\
\text { relevante para currículo. }\end{array}$ & Não foi claro. \\
\hline $\begin{array}{c}\text { Dilma } \\
\text { Rousseff }\end{array}$ & $\begin{array}{l}\text { Informou além do } \\
\text { que deveria estar no } \\
\text { currículo. }\end{array}$ & $\begin{array}{l}\text { Informou o que não } \\
\text { podia comprovar. }\end{array}$ & $\begin{array}{l}\text { Mestrado e Doutorado não } \\
\text { defendidos não são } \\
\text { relevantes para o Currículo }\end{array}$ & Não foi clara. \\
\hline $\begin{array}{l}\text { Damares } \\
\text { Alves }\end{array}$ & $\begin{array}{l}\text { Informou além do } \\
\text { que deveria estar no } \\
\text { currículo }\end{array}$ & $\begin{array}{l}\text { Informou o que não } \\
\text { podia comprovar. }\end{array}$ & $\begin{array}{l}\text { Ensino Bíblico não é } \\
\text { relevante para o Currículo. }\end{array}$ & Não foi clara. \\
\hline $\begin{array}{l}\text { Ricardo } \\
\text { Salles }\end{array}$ & $\begin{array}{l}\text { Informou além do } \\
\text { que deveria estar no } \\
\text { currículo. }\end{array}$ & $\begin{array}{l}\text { "A assessoria do } \\
\text { Ministro" informou o } \\
\text { que não poda } \\
\text { comprovar. }\end{array}$ & $\begin{array}{c}\text { Erros da assessoria não } \\
\text { deveriam constar no } \\
\text { Currículo. }\end{array}$ & $\begin{array}{l}\text { "A assessoria" } \\
\text { não foi clara. }\end{array}$ \\
\hline \multirow{2}{*}{\multicolumn{5}{|c|}{ Quadro 6 - Violação das máximas conversacionais do Princípio da Cooperação (continuação) }} \\
\hline & & & & \\
\hline $\begin{array}{c}\text { Ricardo } \\
\text { Vélez } \\
\text { Rodriguez } \\
\end{array}$ & $\begin{array}{c}\text { Informou menos do } \\
\text { que deveria estar no } \\
\text { Currículo } \\
\end{array}$ & $\begin{array}{l}\text { Informou o que não } \\
\text { podia comprovar. }\end{array}$ & $\begin{array}{c}\text { Coautores/organizadores } \\
\text { de obras deveriam constar } \\
\text { no Currículo. }\end{array}$ & Não foi claro. \\
\hline $\begin{array}{c}\text { Abraham } \\
\text { Weintraub }\end{array}$ & $\begin{array}{l}\text { Informou além do } \\
\text { que deveria estar no } \\
\text { currículo. }\end{array}$ & $\begin{array}{l}\text { Informou ineditismo } \\
\text { que não podia } \\
\text { comprovar }\end{array}$ & $\begin{array}{l}\text { Autoplágio não é relevante } \\
\text { para o Currículo. }\end{array}$ & Não foi claro. \\
\hline
\end{tabular}

Fonte: produção nossa

Especialmente em relação ao fenômeno da mentira, Grice (1982) entende que a mentira pode ser uma implicatura, assim sendo uma violação proposital de uma ou de mais máximas conversacionais, para a qual o locutor espera que o interlocutor faça a inferência mais apropriada para construção do sentido pretendido pelo locutor, só que de uma forma indireta. Mas Grice (1982) aponta também que a mentira pode ser uma ruptura total do princípio cooperativo e que manter essa mentira exigirá grande esforço da parte do locutor. Parece-nos, nos casos em análise, que a mentira se encaixa na segunda explicação dada por Grice, pois as tentativas de justificar a mentira são malsucedidas e tornam tais explicações ainda mais descabidas para a situação, razão, inclusive, para dar origem à notícia em análise.

Sendo assim, a mentira no jornalismo, tal qual as apresentadas na notícia, mostra-se, de fato, como uma estratégia discursiva rotineira, e até inevitável para o fim que se pretende: que o leitor ou espectador - o cidadão - acredite na mentira como verdade. Entendemos que esta prática está diretamente relacionada ao conceito de "pós-verdade", ou seja, "relativo a ou que denota circunstâncias nas quais fatos objetivos são menos influenciadores na formação da opinião pública do que apelos à emoção ou à crença pessoal" (G1, acesso em 29 de set. 2021). Aliado a isso, lembramos o crescente fenômeno de desinformação, do qual fazem parte as 


\section{PERcursos Linguísticos • Vitória (ES) •v. 11 •n. 29 • 2021 • ISSN: 2236-2592 • Dossiê temático $\bullet O$ texto na pesquisa e no ensino: conhecimentos, práticas e desafios na contemporaneidade •}

chamadas "fake news" e que, junto a outros fenômenos de compartilhamento de informação falsa, atestam a crise moral da sociedade atual, a começar pelas autoridades.

Aplicando tal análise na esfera da educação, esta que é difusa, para além da sua condição formal e institucional, entendemos que é possível pensar ética na política da mesma forma que Freire (1996) pensa ética na docência em relação à formação científica, à correção ética, ao respeito aos outros, à coerência:

\footnotetext{
Mulheres e homens, seres histórico-sociais, nos tornamos capazes de comparar, de valorar, de intervir, de escolher, de decidir, de romper, por tudo isso, nos fizemos seres éticos. Só somos porque estamos sendo. Estar sendo é a condição, entre nós, para ser. Não é possível pensar os seres humanos longe, sequer, da ética, quanto mais fora dela. Estar longe ou pior, fora da ética, entre nós, mulheres e homens é uma transgressão. (FREIRE, 1996, p. 16)
}

E assim, entendemos ser necessário que profissionais, seja do jornalismo, seja da educação, não desvinculem atividades laborais e vida social. No caso de professores de língua materna, para além de ensinar convenções gramaticais da escrita e gêneros textuais, suportes e esferas de interação que materializam a comunicação humana, estes cidadãos-professores devem se comprometer e se posicionar ética e criticamente sobre o que é dito e o que não é dito no texto, sobre os valores que se mostram nocivos para a vida em sociedade e sobre as ideologias hegemônicas que se disfarçam e, assim, impregnam-se em práticas de toda ordem, promovendo a corrosão dos valores mais caros para o bem-estar social.

\section{CONCLUSÃO}

Este artigo promoveu uma reflexão sobre a importância dos valores numa sociedade e para a educação que se pretende formadora de cidadãos plenos, com base na axiologia filosófica e freiriana. No entanto, para refletir sobre a crise moral que assola essa sociedade, a partir dos exemplos de seus governantes, o estudo debruçou-se sobre uma notícia jornalística que aponta várias personalidades políticas como mentirosas a partir da verificação de seus currículos por veículos midiáticos.

$\mathrm{Na}$ análise proposta, foram considerados autores da Filosofia da Educação, da LT, da Pragmática e também de alguns estudiosos da esfera jornalística, a fim de evidenciar a crise ética na política, com o emprego da mentira, sem a pretensão de esgotar o fenômeno apurado 


\section{PERcursos Linguísticos • Vitória (ES) •v. $11 \bullet$ n. 29 • 2021 • ISSN: 2236-2592 • Dossiê temático $\bullet O$ texto na pesquisa e no ensino: conhecimentos, práticas e desafios na contemporaneidade •}

nos noticiários e tão recorrente em muitas outras esferas da sociedade, mas evidenciando o mal exemplo dos políticos para a sociedade.

Como conclusão, numa perspectiva linguística, o tópico discursivo e a intertextualidade serviram de estratégias argumentativas para a proposição de sentido pelo jornalismo com vistas a certos resultados, no caso, enfatizar a mentira e os mentirosos. E mais, apesar das limitações desta análise, é possível perceber que a LT e a Pragmática podem contribuir com o Jornalismo para que, na interseção destas ciências, tenhamos profissionais melhor preparados para redigir, interpretar e analisar as notícias, a fim de, para além do objetivo de informar, possam comunicar, de forma imparcial e cooperativa, com o leitor e a sociedade em geral.

Numa perspectiva sociopolítica, o processo de conscientização de valores deve fazer a conexão escola e vida, para se viver segundo princípios na sociedade. Assim, ao mesmo tempo em que a ética precisa fazer parte da formação política do aluno para que, como cidadão, ele seja capaz de (co)administrar a cidade para o bem-comum, espera-se que os políticos e governantes tenham essa formação e sejam exemplos de cidadania para os educandos, o que o fato noticioso contradiz, ilustrando uma crise moral na política brasileira.

Por fim, numa perspectiva educacional, é preciso que instituições e educadores comprometidos com o ideal crítico e democrático, desempenhem, na prática pedagógica, o seu papel ético, não mediante aulas de moral, mas pelo necessário exercício da interação dialógica e da respeitosa convivência humana, com vistas à formação de um cidadão autônomo e de uma sociedade democrática.

É possível ampliar esse estudo linguístico sobre a mentira em ambientes de grande visibilidade social, como na mídia e na política, aprofundando o entendimento do contexto de “desordem da informação", percebidos, segundo a Unesco (2019), nos formatos de "informação incorreta", "desinformação" e "má-informação", e o impacto desse alcance dentro e fora da sala de aula. Outros autores da Linguística Textual, além dos utilizados, e de outras disciplinas, como a Pragmática e a Análise Crítica do Discurso, certamente podem contribuir com essa expansão. No entanto, esperamos que o apresentado até aqui instigue, para além de pesquisas, a prática valorativa na vida social e na esfera da educação.

No ano do primeiro centenário do nascimento de Paulo Freire (1921-2021) - patrono da educação brasileira -, este artigo confirma a importância de uma educação dialógica e de professores críticos para a formação de uma nação democrática. Concluímos, pois, com a necessária renovação da prática educativa conforme Freire (1986): ainda que a transgressão dos princípios éticos seja uma possibilidade, não podemos aceitar que seja virtude. 
PERcursos Linguísticos • Vitória (ES) •v. 11 •n. 29 • 2021 • ISSN: 2236-2592 • Dossiê

temático $\bullet O$ texto na pesquisa e no ensino: conhecimentos, práticas e desafios na contemporaneidade •

\section{Referências}

ARANHA, M. L. A. Filosofia da Educação. $2^{a}$ Ed. São Paulo: Moderna, 1989.

BONINI, A. Mídia / suporte e hipergênero: os gêneros textuais e suas relações. $R B L A$, Belo Horizonte, v. 11, n. 3, p. 679-704, 2011. Disponível em:

<http://www.scielo.br/pdf/rbla/v11n3/05.pdf>. Acesso em 13 de jun. 2019.

CAVALCANTE, M. M. Abordagens da argumentação nos estudos de Linguística Textual. ReVEL, edição especial vol. 14, n. 12, 2016. [www.revel.inf.br].

Os sentidos do texto. $1^{\mathrm{a}}$ ed. São Paulo: Contexto, 2014.

FREIRE, P. Pedagogia da Autonomia : Saberes necessários à prática educativa. $30^{\mathrm{a}}$ ed. São Paulo: Paz e Terra, 1996.

G1. 'Pós-verdade' é eleita a palavra do ano pelo Dicionário Oxford. Disponível em: $<$ https://g1.globo.com/educacao/noticia/pos-verdade-e-eleita-a-palavra-do-ano-pelodicionario-oxford.ghtml>. Acesso em 29 de set. 2021.

GRICE, P. Lógica e conversação. In.: DASCAL, M. (Org.) Fundamentos metodológicos da linguística. vol. IV, Campinas: s. ed., 1982.

JUBRAM, C. C. A. S. Tópico Discursivo. ; KOCH, I. G. V. (Org.). Gramática do Português Culto Falado no Brasil: Volume I - Construção do texto falado. Campinas: Editora da UNICAMP, 2006, p. 89-132.

KARAM, F. J. C. Jornalismo, ética e liberdade. São Paulo: Summus, 2014.

KOCH, I. G. V. O desenvolvimento da Lingüística Textual no Brasil. DELTA 15 Vol. 15, N. ${ }^{\circ}$ ESPECIAL, 1999, p. (165-180). Disponível em: <https://doi.org/10.1590/S010244501999000300007>. Acesso em 29 de set. 2021.

. Desvendando os segredos do texto. São Paulo: Cortez, 2011.

. Introdução à linguística textual: trajetória e grandes temas. São Paulo: Contexto, [2004] 2015. $173 \mathrm{p}$.

LAGE, N. Teoria e técnica do texto jornalístico. $7^{\mathrm{a}}$ ed. $2^{\mathrm{a}}$ reimp. Rio de Janeiro: Elsevier, 2005.

MARQUESI, S. C.; PAULIUKONIS, A. L.; ELIAS, V. M. (Org.). Linguística Textual e ensino. São Paulo: Contexto, 2017.

REVISTA EXAME. Os ministros do Governo Bolsonaro que mentiram no currículo. Disponível em: <https://exame.abril.com.br/brasil/os-ministros-do-governo-bolsonaro-que- 
PERcursos Linguísticos • Vitória (ES) •v. 11 •n. 29 • 2021 • ISSN: 2236-2592 • Dossiê temático $\bullet O$ texto na pesquisa e no ensino: conhecimentos, práticas e desafios na contemporaneidade •

mentiram-no-

curriculo/?fbclid=IwAR3URevbacZZGuoMy6_sQF6zd4avIVvzjypdYjPGjCWIfqKxVciO5stj ORI>. Acesso em 02 de jun. 2019.

UNESCO. Jornalismo, Fake News \& Desinformação: Manual para educação e treinamento em jornalismo. Série UNESCO sobre Educação em Jornalismo, 2019, 130 p. Disponível em: <https://unesdoc.unesco.org/ark:/48223/pf0000368647/PDF/368647por.pdf.multi>. Acesso em 18 de dez. 2021. 


\title{
PERcursos Linguísticos • Vitória (ES) •v. $11 \bullet$ •n. 29 • 2021 • ISSN: 2236-2592 • Dossiê \\ temático $\bullet O$ texto na pesquisa e no ensino: conhecimentos, práticas e desafios na contemporaneidade •
}

\section{PLATAFORMA TEAMS: INTERAÇÃO E ENSINO}

\section{TEAMS PLATFORM: INTERACTION AND TEACHING}

\author{
Alba Helena Fernandes Caldas ${ }^{1}$
}

\begin{abstract}
RESUMO: Frente ao isolamento social, muitas escolas ofereceram o ensino remoto aos estudantes, para manter as aulas, mesmo a distância. Assim, muitos alunos e professores passaram a utilizar as plataformas digitais como espaço de sala de aula. Nesse contexto, o ensino de leitura e escrita assume relevante função, uma vez que os textos produzidos e compartilhados por professores e alunos advêm dos recursos de multimídias, disponíveis no contexto digital. A partir desse cenário, temos como objetivo, neste artigo, propor uma discussão sobre como esses textos ambientados em plataforma digital - hipertextos - são constituídos em termos de características, aspectos contextuais, multimodais, composicionais, interacionais e quais são os tipos de interação que esses textos produzem em um ambiente de ensino. Com fundamentação teórica na Linguística Textual de perspectiva sociocognitiva e interacional, o trabalho foi desenvolvido por meio de pesquisa bibliográfica e análise de conteúdo, tendo sido selecionados como corpus hipertextos ambientados na plataforma Teams, na qual alunos e professores criam conteúdo e compartilham recursos de maneira integrada. Os resultados encontrados apontam que o uso da plataforma Teams como sala de aula pode ampliar as perspectivas teórico metodológicas para o ensino de leitura e escrita em ambiente digital, bem como as novas formas de interação, tornando o aluno autônomo, mais crítico, podendo alternar papeis de leitor e produtor de textos multimodais, de forma mais lúdica.
\end{abstract}

PALAVRAS-CHAVE: Hipertexto. Interação. Ensino.

\begin{abstract}
Faced with social isolation, many schools have offered remote learning to students, to keep classes going even at a distance. Thus, many students and teachers began to use digital platforms as classroom space. In this context, the teaching of reading and writing assumes a relevant role, since the texts produced and shared by teachers and students come from multimedia resources, available in the digital context. From this scenario, we aim, in this article, to propose a discussion about how these texts set on digital platforms - hypertexts - are constituted in terms of characteristics, contextual, multimodal, compositional, and interactional aspects, and what are the types of interaction that these texts produce in a teaching environment. With theoretical basis in Textual Linguistics of sociocognitive and interactional perspective, the work was developed through bibliographic research and content analysis, being selected as corpus hypertexts set in Teams platform, in which students and teachers create content and share resources in an integrated way. The results found point out that the use of the Teams platform as a classroom can expand the theoretical and methodological perspectives for teaching reading and writing in a digital environment, as well as new forms of interaction, making the student autonomous, more critical, being able to alternate roles of reader and producer of multimodal texts, in a more playful way.
\end{abstract}

KEYWORDS: Hypertext. Interaction. Teaching.

\footnotetext{
${ }^{1}$ Doutorado em Língua Portuguesa. Centro Universitário de Itajubá - Fepi. E-mail: albacaldas@yahoo.com.br
} 


\section{PERcursos Linguísticos • Vitória (ES) •v. 11 •n. 29 • 2021 • ISSN: 2236-2592 • Dossiê temático $\bullet O$ texto na pesquisa e no ensino: conhecimentos, práticas e desafios na contemporaneidade •}

\section{Introdução}

A prática de distanciamento social mudou as rotinas de pessoas e empresas, e não foi diferente para o setor da educação; afinal, as instituições de ensino tiveram de se adaptar a partir da definição de fechamento de escolas e universidades. Para a manutenção da prática pedagógica, muitas escolas tiveram que inovar, trazendo para o ambiente de sala de aula ferramentas digitais disponíveis na rede; dentre elas, destacamos a "Microsoft Teams", que funciona como um hub digital entre professores, alunos e coordenações de curso. A plataforma reúne conversas, conteúdo e aplicativos em um só lugar, simplificando o fluxo de trabalho dos coordenadores e diretores e, ao mesmo tempo, permitindo que os professores criem ambientes personalizados de aprendizado.

Conforme Boettcher (2005), não dá mais para separar educação on-line de educação presencial. Para o autor, passamos a utilizar a internet como amplo dispositivo para navegar, inventar, mobilizar os alunos a construir novos dispositivos para disparar, para autoconstruir. Nessa perspectiva, o professor pode despertar o interesse do aluno por meio de ambientes digitais com um trabalho lúdico e prazeroso, que o levará a uma maior socialização e um processo de relacionamento interpessoal, o qual propiciará o aprendizado coletivo. A partir daí, vislumbramos novos espaços de sala de aula, em que ferramentas on-line possuem um potencial de ensino inovador, além de facilitar o trabalho de professores e aprimorar o ensino e a aprendizagem dos alunos.

Dessa forma, cientes de que essas mudanças advindas da tecnologia convergem para mudanças sociais mais amplas - uma vez que "a vida contemporânea está mudando em muitos aspectos e isso impacta a linguagem e as práticas comunicativas" (BOETTCHER, 2005, p.12), bem como faz surgir novas formas de ação e interação mediada, que segundo Thompson (2018, p. 20) "envolve a extensão das relações sociais através do espaço e do tempo e certo estreitamento no leque de pistas simbólicas" - este estudo propõe uma discussão fundamentada nos estudos da Linguística Textual (doravante LT) de perspectiva sociocognitiva e interacional da linguagem, sobre os seguintes questionamentos:

i) como esses textos ambientados em plataforma digital são constituídos em termos de características e aspectos contextuais, multimodais, composicionais, interacionais?

ii) quais são os tipos de interação que esses textos produzem em um ambiente de ensino aprendizagem? 


\section{PERcursos Linguísticos • Vitória (ES) •v. 11 •n. 29 • 2021 • ISSN: 2236-2592 • Dossiê temático $\bullet O$ texto na pesquisa e no ensino: conhecimentos, práticas e desafios na contemporaneidade •}

Essas questões chamam-nos à atenção, uma vez que, por meio da plataforma digital, professores e alunos podem acessar, simultaneamente ou não, inúmeros recursos de multimídia, como imagens em movimento, vídeos, sons e animações, bem como selecionar e combinar diferentes aspectos semióticos (imagem, palavra, som etc.) na construção de sentidos pretendidos. Isso confirma que o uso de ferramentas digitais evidencia o aspecto multimodal do texto e que devemos ampliar a concepção de texto, abrangendo não só o aspecto verbal, como também as diversas linguagens presentes em sua constituição.

Além disso, considerando que a mídia digital plataforma Teams estrutura-se hipertextualmente, e apresenta certas peculiaridades, tais como não linearidade, não delimitação, multimodalidade (ou multissemiose), intertextualidade, conectividade, virtualidade, interatividade, buscaremos respaldo teórico nas pesquisas de Koch (2005), Marcuschi, (2007), Elias (2012, 2015), Elias e Cavalcante (2017), que se voltam para a análise de textos digitais, e têm impulsionado estudos e reflexões no sentido de (re)definir conceitos e critérios analíticos em LT.

De modo a alcançarmos os objetivos definidos, organizamos o artigo em três seções: a primeira apresenta considerações teóricas referentes aos estudos do texto e de hipertexto e suas caraterísticas, destacando a interação, alinhada aos estudos de Thompson (2018); a segunda se volta para uma breve descrição da plataforma digital Teams; a terceira seção apresenta como os hipertextos ambientados na da plataforma Teams são constituídos em termos de características e de aspectos contextuais, multimodais, composicionais, interacionais, mostrando quais são os tipos de interação que eles produzem em um ambiente de ensino aprendizagem. Para responder às perguntas que orientam essa discussão, selecionamos como corpus hipertextos ambientados na mídia digital plataforma Teams.

\section{Texto e hipertexto}

Caldas (2014) em sua tese de doutorado apresenta uma discussão teórica de vários estudiosos sobre texto e hipertexto e suas características, enfatizando os estudos de Lévy (2007, p. 44), para quem a definição de hipertexto é "uma coleção de informações multimodais disposta em rede para a navegação rápida e 'intuitiva'." O hipertexto permite ao leitor passar, quase momentaneamente, de um texto a outro e ter acesso, quase que ilimitado, a uma variedade de textos (verbais ou não verbais), selecionando-os por meio de links sucessivos em tempo real.

Lévy (1999), ainda, afirma que o hipertexto é 


\section{PERcursos Linguísticos • Vitória (ES) •v. 11 •n. 29 • 2021 • ISSN: 2236-2592 • Dossiê temático $\bullet O$ texto na pesquisa e no ensino: conhecimentos, práticas e desafios na contemporaneidade •}

um texto em formato digital, reconfigurável e fluido. Ele é composto por blocos elementares ligados por links que podem ser explorados em tempo real na tela. A noção de hiperdocumento generaliza, para todas as categorias de signos (imagens, animações, sons, etc.), o princípio da mensagem em rede móvel que caracteriza o hipertexto (LÉVY, 1999, p. 27).

Condizente com a definição de Lévy (1999), Leão (2005, p.15) conceitua o hipertexto como "um documento digital composto por diferentes blocos de informações interconectadas. Essas informações são amarradas por meio de elos associativos, os links". Para a autora, são os links que permitem ao leitor avançar na leitura de uma forma única e pessoal.

Podemos dizer que os links ocupam papel de destaque na definição do hipertexto. Gualberto (2012, p. 39) afirma, assim como Gomes (2011), que os links representam uma das características do hipertexto digital. "Eles funcionam como ligações entre nós, pois o hipertexto é constituído por nós (ou conceitos) e ligações ou links (relações)”. [...] Crystal (2005), por sua vez, também advoga ser o link de hipertexto a propriedade mais importante da internet, já que este possibilita a maior mobilidade do usuário, que pode ir de uma página ou de um site a outro na internet, dando vida à rede mundial de computadores.

Nesta pesquisa, adotamos a concepção de hipertexto de Lévy (1994, p. 33), que o define como "um conjunto de nós ligados por conexões. Os nós podem ser palavras, páginas, imagens, gráficos, sequências sonoras, documentos complexos que podem eles mesmos ser hipertexto". São os estudos do autor que se encontram na base de reflexões sobre o hipertexto feitas por estudiosos do texto.

Ressaltamos que ao assumirmos essa perspectiva de hipertexto fortalecemo-nos nos pressupostos da Linguística Textual, considerando que o texto, resultante do trabalho do leitorescritor, é construído por propósitos comunicativo-interacionais, já que esse leitor não constrói qualquer texto, nem o faz de qualquer modo, mas constrói um texto, dentre tantos possíveis, levando em conta a situação de comunicação, dos interlocutores e da sua relação com eles, bem como o objetivo que norteou a produção e interação.

Nesse percurso, tendo em vista os diferentes arranjos textuais que são possíveis na tela do computador, o leitor não só lê, como também pode ver ou ouvir itens apresentados não linearmente, em um processo de interação, no qual determina os caminhos de informação a serem traçados em um certo tempo.

Assim, dizemos que o leitor é também um coautor de uma escrita hipertextual, porque é possível, ao leitor, decidir o que quer construir e qual o caminho a percorrer para atualizar a sua construção, uma vez que se deparará com uma infinidade de tópicos e uma infinidade de 


\section{PERcursos Linguísticos • Vitória (ES) •v. 11 •n. 29 • 2021 • ISSN: 2236-2592 • Dossiê temático $\bullet O$ texto na pesquisa e no ensino: conhecimentos, práticas e desafios na contemporaneidade •}

caminhos, podendo associá-los e organizá-los em um todo coerente e não, simplesmente, em um pacote de informações (ELIAS, 2000, 2005, 2012).

Desse modo, o leitor do hipertexto é também um operador de multiplicidades e deve proceder de uma forma descontínua e multilinear. Muitas vezes, poderá retomar uma informação anterior para se situar, porque, no hipertexto, de cada ponto poderá chegar a novos hipertextos e de cada um desses a outros mais. É necessário conhecermos as principais características que determinam a natureza do hipertexto, visto que ler um texto hipertextual exige atenção do leitor a um novo formato textual.

Apresentamos a seguir as características do hipertexto, conforme estudos realizados por Koch (2005), Leão (2005), Xavier (2005), Marcuschi (2007), Coscarelli (2012) e Elias (2012).

A não linearidade na estrutura formal, geralmente, é considerada a característica central do hipertexto e diz respeito a uma leitura não sequenciada. O hipertexto, portanto, é uma espécie de texto no qual o leitor, ativamente, escolhe a sequência do material a ser lido. Nesse trabalho de escolha, o leitor não só lê, como também pode ver ou ouvir itens apresentados não linearmente, em um processo de interação, no qual determina os caminhos de informação a serem traçados em um certo tempo.

A espacialidade topográfica, pela própria natureza do suporte, é uma característica que faz do hipertexto algo essencialmente virtual. Nas palavras de Coscarelli (2012, p. 72), "Não é hierárquico nem tópico, não se definem bem seus limites”. O hipertexto consiste de tópicos e suas conexões. Os tópicos podem ser parágrafos, sentenças, palavras, gráficos etc. As conexões de um hipertexto são organizadas em caminhos/atalhos que fazem sentido operacional para o autor e o leitor. Cada tópico poderá participar de muitos caminhos e seu significado dependerá de atalhos feitos pelo leitor para atingir o objetivo pretendido.

Para Elias (2012, p. 89), a conectividade, concretizada na atualização de links, é que possibilita ao hipertexto a sua constituição em rede, a sua expansão reticular. "Nessa configuração, o leitor é sempre convidado a 'saltar' do ponto em que se encontra para outro ponto do hipertexto, bastando tão somente ativar os links sugeridos.”.

A escrita digital é uma descrição verbal e visual. Não é a descrição de um lugar, mas de uma escrita com lugares espacialmente realizados em tópicos (BOLTER, 1991). Embora o computador não seja necessário para a escrita topográfica, é somente no computador que o modelo se transforma em um natural e, por essa razão, convencional caminho para a escrita.

Nesse espaço, a escrita, em vez de possibilitar ao leitor, basicamente, o movimento de parágrafo para parágrafo, pode fazer com que este, por meio de cenas de vídeo em uma 


\section{PERcursos Linguísticos • Vitória (ES) •v. 11 •n. 29 • 2021 • ISSN: 2236-2592 • Dossiê temático $\bullet O$ texto na pesquisa e no ensino: conhecimentos, práticas e desafios na contemporaneidade •}

variedade de ordens, por exemplo, "caminhe" por uma cidade, tendo uma visão fotográfica de várias de suas construções.

Ainda, ao leitor, é permitido, na mesma tela do computador, disponibilizar um texto escrito abaixo ou ao lado da imagem de vídeo, em uma combinação que podemos chamar de multissemiose, característica que viabiliza a absorção simultânea das linguagens verbal e não verbal (sons, dança, desenhos, gestos, palavras, cores, ícones, efeitos sonoros, diagramas etc.) numa mesma superfície de leitura, de forma integrativa - algo impossível de ser realizado no suporte do texto impresso.

A fragmentariedade, de acordo com Marcuschi (2007, p. 151), é uma característica bastante central e "consiste na constante ligação de porções em geral breves com sempre possíveis retornos ou fugas [...]”. Os links ou nós criam um labirinto que se abre a vários caminhos e acessos aos milhões de hipertextos já indexados à internet. Essa característica está associada ao fato de o hipertexto não possuir um centro regulador imanente, já que o autor não tem mais controle do tópico e do leitor.

A acessibilidade ilimitada, conforme Marcuschi (2007) e Coscarelli (2012), é a característica que proporciona capacidade de acessar todos os tipos de fontes, sejam elas dicionários, enciclopédias, museus, músicas, vídeos, obras científicas, literárias, arquitetônicas etc.

A descentração ou multicentramento é apontada em virtude de um deslocamento indefinido de tópicos, isto é, da inexistência de um foco dominante. Todavia, Koch (2005) ressalta que não se trata de um simples agregado aleatório de fragmentos textuais.

A iteratividade, característica destacada em decorrência da natureza intrinsecamente polifônica e intertextual do hipertexto, é recursiva, pois a própria manipulação pelo leitor a altera.

A intertextualidade se destaca por ser a característica que funde e sobrepõe inúmeros textos que se tornam simultaneamente acessíveis a um simples click de mouse; o texto digital é um "texto múltiplo". Sendo assim, o hipertexto é, por sua própria natureza, intertextual.

A volatilidade é característica que diz respeito à própria natureza do suporte; isto é, o hipertexto não é estável, constituindo-se à medida que o leitor faz suas escolhas. Sendo essencialmente virtual, o hipertexto não apresenta a mesma estabilidade dos textos impressos, uma vez que as escolhas feitas pelos leitores são tão passageiras quanto as conexões estabelecidas por eles. 


\section{PERcursos Linguísticos • Vitória (ES) •v. 11 •n. 29 • 2021 • ISSN: 2236-2592 • Dossiê temático $\bullet O$ texto na pesquisa e no ensino: conhecimentos, práticas e desafios na contemporaneidade •}

A virtualidade é característica apontada por Leão (2005) como essencial, uma vez que o hipertexto constitui-se como uma matriz de textos potenciais. No dizer de Xavier (2005), intangível, mas realizável.

A interatividade refere-se à relação contínua do leitor com múltiplos autores, praticamente em superposição em tempo real; nas palavras de Marcuschi (2007, p. 151), "chegando a simular uma interação verbal face a face". Consoante a esse conceito, trazemos a essa discussão os apontamentos ponderados por Thompson (2018), que nos auxiliarão na ampliação do conceito de interação em contextos digitais.

\section{Novas formas de ação e interação}

Em seu artigo intitulado "A mídia e a modernidade" (1995), Thompson ressaltou que o desenvolvimento dos meios de comunicação tem papel fundamental na constituição das sociedades modernas, e isso tem sido reconhecido por muitos estudiosos. $\mathrm{O}$ autor defende que, se quisermos entender os meios de comunicação e seu impacto, devemos "analisá-los em relação aos tipos de ação e interação que eles tornam possíveis e criam" (THOMPSON, p.18). Assim, o autor apresenta as novas formas de ação e interação que foram criadas pela comunicação mediada por computadores ou outro dispositivo móvel em ambientes online e que estão cada vez mais presentes na vida cotidiana.

Thompson (1995) apresentou três tipos básicos de interação: i) interação face a face: ocorre em um contexto de copresença, espaço-temporal comum, dialógica e mobiliza múltiplos sinais simbólicos (gestos, palavras, cheiros, sons, etc.); ii) interação mediada: estendida no espaço e no tempo, dialógica, permite que as informações ou conteúdos simbólicos sejam transmitidos para indivíduos que estão distantes no espaço ou no tempo, ou em ambos; porém, é limitada nas possibilidades de sinalizações simbólicas, como ocorre em uma conversa telefônica; iii) quase-interação mediada: envolve a extensão das relações sociais no espaço e no tempo e apresenta restrição nas pistas simbólicas; de caráter monológico, a informação é em grande parte unidirecional; é orientada a potenciais destinatários, como, por exemplo, quando assistimos televisão, jornais, visto que estabelecemos interação social com pessoas que estão distantes no espaço e possivelmente no tempo.

De acordo com o seu estudo anterior, à luz da revolução digital e do crescimento da internet, Thompson amplia as suas ideias, acrescentando em seu estudo relacionado à teoria interacional dos meios de comunicação um quarto tipo de interação, a qual denomina de interação mediada on-line. Esta relação "envolve a extensão das relações sociais através do 


\section{PERcursos Linguísticos • Vitória (ES) •v. 11 •n. 29 • 2021 • ISSN: 2236-2592 • Dossiê temático $\bullet O$ texto na pesquisa e no ensino: conhecimentos, práticas e desafios na contemporaneidade •}

espaço e do tempo e certo estreitamento no leque de pistas simbólicas" (THOMPSON, 2018, p.20). É de caráter dialógico, orientada por uma multiplicidade de outros destinatários, ou seja, é de muitos para muitos.

Esse conceito advindo das ideias de Thompson é importante para o nosso estudo, haja vista que na plataforma Teams é possível que os participantes da reunião/aula criem ou mantenham relações sociais com pessoas distantes, podendo algumas serem conhecidas do contexto face a face, outras conhecidas por intermédio das redes sociais.

Vamos reproduzir aqui o Quadro 1 elaborado pelo autor, que de forma sintética traz as propriedades interacionais desses quatro tipos de interação e suas características.

Quadro 1: Quatro tipos de interação

\begin{tabular}{|c|c|c|c|c|}
\hline $\begin{array}{c}\text { Tipos de } \\
\text { interação }\end{array}$ & $\begin{array}{c}\text { Constituição } \\
\text { espaço-temporal }\end{array}$ & $\begin{array}{c}\text { Gama de } \\
\text { pistas } \\
\text { simbólicas }\end{array}$ & $\begin{array}{c}\text { Grau de } \\
\text { interatividade }\end{array}$ & Orientação de ação \\
\hline $\begin{array}{c}\text { Interação } \\
\text { face a face }\end{array}$ & $\begin{array}{c}\text { Contexto de } \\
\text { copresença }\end{array}$ & Completa & Dialógica & Outros em copresença \\
\hline $\begin{array}{c}\text { Interação } \\
\text { mediada }\end{array}$ & $\begin{array}{c}\text { Estendida no } \\
\text { espaço e no tempo }\end{array}$ & Limitada & Dialógica & Um para um \\
\hline $\begin{array}{c}\text { Quase- } \\
\text { interação } \\
\text { mediada }\end{array}$ & $\begin{array}{c}\text { Estendida no } \\
\text { espaço e no tempo }\end{array}$ & Limitada & Monológica & Um para muitos \\
\hline $\begin{array}{c}\text { Interação } \\
\text { mediada on- } \\
\text { line }\end{array}$ & $\begin{array}{c}\text { Estendida no } \\
\text { espaço e no tempo }\end{array}$ & Limitada & Dialógica & Muitos para muitos \\
\hline
\end{tabular}

Fonte: Thompson (2018, p.22)

Consideramos os quatros tipos de interação, assim como Thompson (2018, p.22), como efêmeras, pois não há linhas de demarcação clara entre os diferentes tipos de interação. "As tecnologias ou aplicativos específicos podem esmaecer os limites entre essas formas de interação, permitindo que os indivíduos interajam de modos que agrupam características de tipos diferentes".

Corroborando o que afirma Thompson (2018, p.22), podemos dizer, que em nossa prática social diária, os diferentes tipos de interação estão entrelaçados de "maneiras complexas e os indivíduos estão constantemente se movendo entre eles, ou mesmo interagindo de várias maneiras simultaneamente". Isso é perceptível no uso da plataforma Teams como ambiente de sala de aula; é o que tentaremos mostrar mais adiante, em nosso estudo. 


\section{PERcursos Linguísticos • Vitória (ES) •v. 11 •n. 29 • 2021 • ISSN: 2236-2592 • Dossiê temático $\bullet O$ texto na pesquisa e no ensino: conhecimentos, práticas e desafios na contemporaneidade •}

É importante ressaltar que apresentamos as características de hipertexto, no entanto, temos ciência de que muitas delas, como por exemplo conectividade e não linearidade, não são exclusivas do hipertexto, haja vista que são percebíveis, também, nos textos impressos. "É o que notamos quando lemos textos que compõem a bíblia, a enciclopédia, o dicionário, o jornal, etc.” (ELIAS, 2012, p.90). Dessa forma, Elias (2000, 2005) considera o hipertexto como um texto sem fronteiras delimitadas, que se expande pela atuação do leitor, na atividade de seguir ou atualizar links em uma dada sessão.

Assim, nessa ótica, podemos dizer que todo texto é um hipertexto, pelo menos do ponto de vista da interpretação. A diferença entre a leitura de um texto impresso e um hipertexto consiste no fato de que nesse último a sua apresentação é virtual, possibilitando por meio de links a articulação de recursos verbais, visuais e sonoros.

Nesse viés, denominaremos, desde aqui, como corpus deste estudo, os hipertextos ambientados na plataforma digital. Assim, na próxima seção, visamos realizar uma breve descrição da plataforma Teams, ferramenta que funciona com sala de aula remota e online por meio de inúmeros hipertextos.

\section{Plataforma Teams}

De acordo com as informações publicadas pela Microsoft, a mídia digital Teams é a plataforma da Microsoft para comunicação e colaboração em equipe. Lançado em 2016, o aplicativo faz parte do Office 360 e associa todas as suas plataformas (Word, Powerpoint, Excel, entre outras) em um só programa que visa simplificar e sistematizar a comunicação entre grupos (equipes). A plataforma possui um layout moderno e diversas ferramentas colaborativas que fornecem um ambiente para os grupos que não se resume ao momento das chamadas de vídeo. Cada "Team" é um grupo virtual no qual seus participantes podem interagir de diferentes formas, em um ambiente exclusivo que possibilita edição de documentos em conjunto, fácil compartilhamento de arquivos, controle de participantes por reunião e programa, bem como controle e realização de chamadas.

A plataforma Teams é um ambiente digital de ensino; nele o professor (administrador) pode compartilhar materiais, atividades, trabalhos, tarefas, sites, vídeos, livros, de forma antecipada. Dessa forma, os educadores têm tempo para preparar a equipe antes de admitir estudantes. 


\section{PERcursos Linguísticos • Vitória (ES) •v. 11 •n. 29 • 2021 • ISSN: 2236-2592 • Dossiê temático $\bullet O$ texto na pesquisa e no ensino: conhecimentos, práticas e desafios na contemporaneidade •}

Além disso, é possível organizar as turmas de acordo com o curso, ano, período, usar as ferramentas da Microsoft, criar e receber tarefas, corrigir e atribuir notas (a qual pode ser visualizada pelo aluno), trocar informações via e-mail ou mensagens instantâneas via chat. Quando uma atividade é proposta pelo professor, os estudantes recebem mensagem no e-mail. Ela fica disponível para os discentes com os prazos e alertas das atividades a serem cumpridas, podendo ser revistas pelo ícone de controle de fluxo. Na interface operacional da plataforma, as atividades finalizadas podem ser mantidas ou excluídas pelo professor (administrador).

Ao nosso ver, uma das limitações do uso da plataforma como ferramenta de ensino é o fato de ser pago; ainda assim, muitas instituições de ensino adquiriram este acesso pela necessidade de resolver a questão das aulas remotas.

A seguir, a imagem do layout da plataforma Teams referente a turmas criadas pela pesquisadora, que faz uso de tal plataforma com os seus alunos do Ensino Superior.

Figura 1: Plataforma Teams

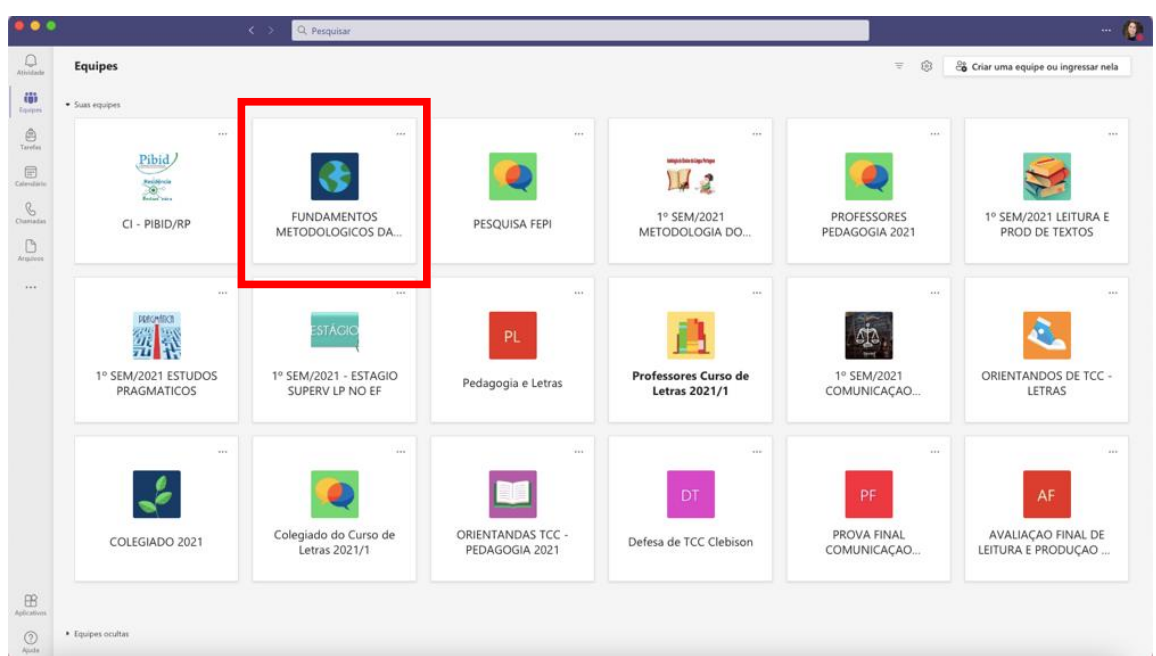

Fonte: <Aplicativo Microsoft Teams> acesso em 30 jun. 2021.

Cada uma dessas equipes configura-se como uma turma de alunos de uma determinada disciplina. A equipe é programada pelo professor que a organiza, conforme o dia da semana e o horário da aula, bem como insere os respectivos alunos na equipe a partir do número de matrícula institucional. É a criação de salas de aula virtuais que possibilita ao grupo interagir em forma de chat, videoconferência, compartilhamento e construção de arquivos. Em uma equipe, é possível a presença online de até 250 usuários.

Segundo, ainda, as informações publicadas pela Microsoft, a plataforma Teams apresenta alguns recursos, que podem auxiliar o professor em sua prática pedagógica, tais 


\section{PERcursos Linguísticos • Vitória (ES) •v. 11 •n. 29 • 2021 • ISSN: 2236-2592 • Dossiê temático $\bullet O$ texto na pesquisa e no ensino: conhecimentos, práticas e desafios na contemporaneidade •}

como: unificar a chamada, permitir o compartilhamento de arquivos, possibilitar a realização de chats em grupo e privado, a organização da agenda, e ainda o forms e o controle de presença. Temos, também, a possibilidade de montagem de equipes para trabalhos em grupos. Edição online e em conjunto de arquivos compartilhados, gravação das aulas com download em até 20 dias, controle de câmeras, microfones, interação e presença pelo organizador. $\mathrm{O}$ uso desses recursos digitais é fundamental para o êxito das aulas e motivação dos alunos. Cabe aos docentes se apropriarem criticamente dessas tecnologias, em prol de uma prática pedagógica significativa.

Embora a plataforma Teams apresente muitos recursos, maior flexibilidade para os professores com a criação e acesso imediatos à equipe, acreditamos que a falta de familiaridade com a plataforma dificulta, em um primeiro momento, a sua implementação e o êxito das atividades remotas de ensino por meio do Teams.

\section{Plataforma Teams: características e sentidos em um ambiente de aprendizagem virtual}

Considerando a definição de texto formulada por Beaugrande (1997), Koch (2005; 2012) e a de Koch e Elias (2017) de hipertexto (LÉVY,1994), podemos identificar a plataforma Teams como ambiente de muitos hipertextos, isso é perceptível na figura 2, a seguir, que configura o momento de uma aula magna para o curso de letras, cujo objetivo é a promoção da interação entre professores e alunos, alunos e alunos do curso, em prol da atualização do conhecimento. Há vários hipertextos na plataforma, cujos sentidos são construídos a partir da “interação entre sujeitos sociais, os quais, dialogicamente, nele se constituem e são construídos" (KOCH; ELIAS, 2017, p.7). 


\section{PERcursos Linguísticos • Vitória (ES) •v. 11 •n. 29 • 2021 • ISSN: 2236-2592 • Dossiê temático $\bullet O$ texto na pesquisa e no ensino: conhecimentos, práticas e desafios na contemporaneidade •}

Figura 2: Plataforma Teams

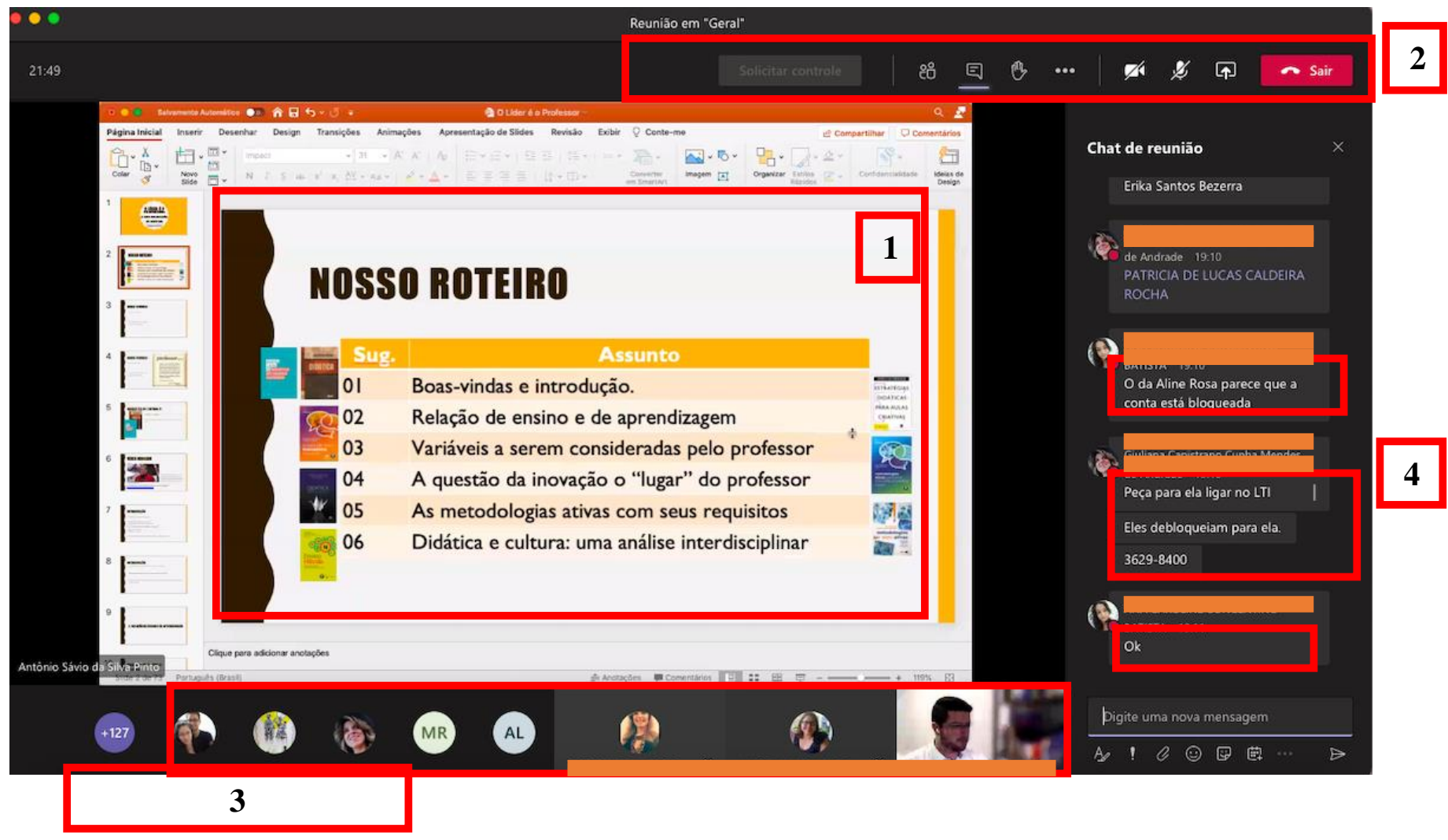

Fonte: Print da tela de uma aula magna em 08/02/21.

Nesse contexto, a plataforma Teams é constituída por inúmeros hipertextos, que se interlaçam por meio de múltiplas linguagens, ou seja, pela multimodalidade; vejamos: há um professor que apresenta um tema comum aos interlocutores, de forma oral e escrita, por meio do uso de diversas linguagens - o som, as imagens, as figuras, os tipos de letras, o vídeo.

Essa integração proporciona uma reflexão sobre como está organizado este hipertexto, a diagramação da página (layout), o formato, as cores das letras, os ícones, a formatação do parágrafo, os links etc.; além do verbal, complementam-se na composição e construção do sentido textual. Assim, a leitura do hipertexto é uma proposta de sentido e se acha aberta a várias alternativas de compreensão.

Considerando, ainda, a concepção dos autores de que texto é um evento comunicativo em que convergem ações linguísticas, culturais, sociais e cognitivas, bem como a de que o sentido não está no texto, mas é construído a partir dele pelo leitor, e estendendo-a para a concepção de hipertexto, podemos evidenciar, a partir da figura 2, alguns aspectos que retratam esses conceitos, objetos de pesquisa dos estudiosos do texto: 


\section{PERcursos Linguísticos • Vitória (ES) •v. 11 •n. 29 • 2021 • ISSN: 2236-2592 • Dossiê temático $\bullet O$ texto na pesquisa e no ensino: conhecimentos, práticas e desafios na contemporaneidade •}

as ações linguísticas evocadas pela imagem são referentes à leitura multimodal, tanto dos slides do professor, quanto dos comentários dos ouvintes no chat: as letras, a posição que ocupam são igualmente elementos que contribuem para a compreensão da construção do sentido. As ações sociais convergidas perpassam o conhecimento de mundo, do contexto em que se deu a imagem: primeiramente percebe-se que o slide é introdutório, devido à utilização da palavra roteiro, da enumeração de assuntos e da posição do slide na coluna à esquerda. E, as ações cognitivas dizem respeito à conexão das ações anteriores na construção do sentido da imagem como um todo: uma aula, nos momentos iniciais, em que o professor apresenta os tópicos pelos quais trabalhará no decorrer de sua explanação; paralelamente, busca-se a resolução de problemas alheios ao assunto da aula, conforme diálogo no chat. Isso retrata que a constituição do texto online e de seu sentido requer uma multiplicidade de operações cognitivas, que resultam de várias ações praticadas pelos sujeitos de forma negociada e situada.

No hipertexto, destacado em 1, na parte central da plataforma Teams, temos um slide Power point, elaborado, projetado e usado como ferramenta de ensino aprendizagem, pelo professor, para a exposição do conteúdo a ser trabalhado em sala de aula síncrona com os seus alunos. O professor atualiza as informações, ativando os links possibilitados pela conectividade, e convida os alunos a acompanhá-lo em seu raciocínio e exposição de ideias. E, é possível, também, que os alunos interrompam, perguntem, ou seja, interajam com o professor e com os próprios colegas em tempo real. As conexões de um hipertexto são organizadas em caminhos/atalhos que fazem sentido operacional para o professor e alunos. Assim, o hipertexto configura-se como um constructo "resultante da participação e do trabalho realizado colaborativamente por usuários em interação on-line" (ELIAS; CAVALCANTE, 2017, p. 321).

Dessa forma, a interatividade no hipertexto ocorre quando o leitor clica em palavras, expressões, ícones ou botões constitutivos de links. Os links, de modo geral, levam o leitor a um ponto pré-determinado pelo autor. Temos na figura 2 "Plataforma Teams", no destaque 2, vários ícones que, se ativados, levam-nos a objetivos distintos, tais como:

Quadro 2: Ícones

\begin{tabular}{|c|c|}
\hline \&? & Mostrar participantes \\
\hline 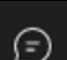 & Mostrar conversas \\
\hline
\end{tabular}




\section{PERcursos Linguísticos • Vitória (ES) •v. 11 •n. 29 • 2021 • ISSN: 2236-2592 • Dossiê temático $\bullet O$ texto na pesquisa e no ensino: conhecimentos, práticas e desafios na contemporaneidade •}

\begin{tabular}{|c|c|}
\hline$B_{3}$ & O usuário pode inserir GIFS \\
\hline & Salas para sessão de grupo \\
\hline & 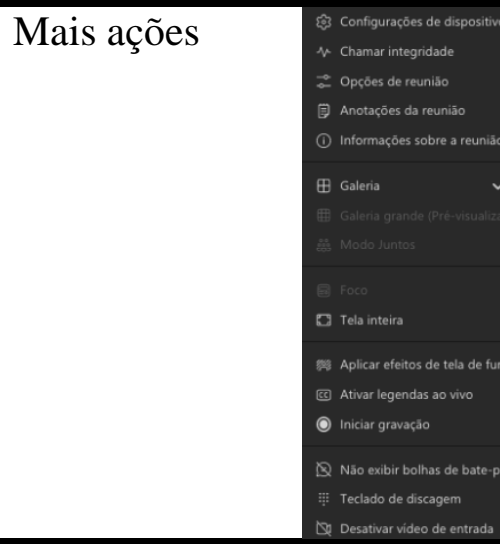 \\
\hline w & Visualização - Câmera \\
\hline Q & Áudio \\
\hline$\uparrow$ & Compartilhar \\
\hline$n$ sair $v$ & Sair \\
\hline
\end{tabular}

Fonte: elaborado pela pesquisadora.

No quadro 2, destacam-se os ícones, os quais chamamos de links semânticos, que estabelecem relações de sentido no hipertexto, e isso é muito importante para o percurso de leitura, tanto no sentido da profundidade da informação, quanto na amplitude de temas. Os links semânticos do hipertexto Plataforma Teams, acima demonstrados, ligam os textos à referência feita nele, produzindo relações de sentido ao promover associações entre as informações conhecidas se o link for atualizado pelo leitor. Assim, é possível ao participante da aula mudar a configuração de sua sala de aula ativando os links. Como, por exemplo, ao atualizar o ícone "mostrar participantes" é possível ver todos os nomes dos participantes da aula, estejam eles presentes ou ausentes naquele momento, bem como visualizar os seus respectivos áudio e vídeo. Atualizando "mostrar conversas", aparecem as informações, os diálogos, as perguntas, os vídeos, os links, inseridos no chat pelos alunos e professor. Os participantes da aula podem, também, interagir com o professor e colegas por meio de GIFS animados (tipo de arquivo que exibe movimentos com resolução baixa) que refletem o humor, a argumentação ou o sentimento dos participantes durante ou após a aula realizada. A ativação desses ícones é uma tentativa de 


\title{
PERcursos Linguísticos • Vitória (ES) •v. 11 •n. 29 • 2021 • ISSN: 2236-2592 • Dossiê temático $\bullet O$ texto na pesquisa e no ensino: conhecimentos, práticas e desafios na contemporaneidade •
}

transmitir sentido de forma mais rápida e econômica no contexto de interação, fazendo emergir sentidos acrescidos de outros significados, como, por exemplo, a emoção.

Ressaltamos que há outras possibilidades nos demais ícones presentes, que não entraram no escopo do presente artigo.

Ficam visíveis na plataforma Teams os espaços de discussão, de interação, de leitura, de escrita, por meio de textos multimodais, compartilhados e atualizados por diversas formas pelos participantes. No texto multimodal, o significado é criado por mais de um recurso semiótico. Assim, diante desse texto constituído pelos modos verbal e imagético, a imagem não se configura como uma simples ilustração do escrito, uma vez que esses modos semióticos interagem, estão integrados no texto e produzem sentido (KRESS; VAN LEEUWEN,1996). Para os autores, os recursos multimodais são elementos disponíveis na sociedade para criarmos a significação em determinados contextos interativos.

De tal modo, podemos dizer que os alunos em atividades remotas na plataforma Teams passam a construir novos sentidos por diferentes linguagens, presentes nos hipertextos. Esses elementos multimodais atuam na construção de sentidos, em que informações são expressas por diferentes semioses, sobretudo através de recursos visuais em conjunto com outras modalidades da língua. O ensino pautado na multimodalidade proporciona ao aluno o desenvolvimento de suas potencialidades, ampliando a possibilidade de acesso a diferentes práticas sociais, o que Soares (2002) nomeia de letramento digital. Para a autora,

\begin{abstract}
A tela, como novo espaço de escrita, traz significativas mudanças nas formas de interação entre escritor e leitor, entre escritor e texto, entre leitor e texto e, até mesmo, mais amplamente, entre o ser humano e o conhecimento. [...] A hipótese é de que essas mudanças tenham consequências sociais, cognitivas e discursivas, e estejam, assim, configurando um letramento digital, isto é, um certo estado ou condição que adquirem os que se apropriam da nova tecnologia digital e exercem práticas de leitura e de escrita na tela, diferente do estado ou condição - do letramento - dos que exercem práticas de leitura e de escrita no papel (SOARES, 2002, p. 146).
\end{abstract}

Nesse sentido, a plataforma Teams torna-se uma excelente ferramenta para o ensino de leitura e escrita na perspectiva de letramento digital, criando a possibilidade de desenvolver práticas pedagógicas mais dinâmicas e reflexivas

Logo mais, no destaque 3, na plataforma Teams, aparecem alguns dos participantes presentes demonstrados por fotos, por iniciais dos nomes, imagens e, ainda mais 127 participantes presentes na aula, embora não identificados individualmente com foto, por limitação do espaço do ambiente.

Retomamos os estudos de Thompson (2018, p.20) sobre o uso do computador ou outro dispositivo móvel, em que ambientes online trazem consigo novas formas de ação e interação, 


\section{PERcursos Linguísticos • Vitória (ES) •v. 11 •n. 29 • 2021 • ISSN: 2236-2592 • Dossiê temático $\bullet O$ texto na pesquisa e no ensino: conhecimentos, práticas e desafios na contemporaneidade •}

nomeadas por ele de interação mediada on-line, quando afirma que "envolve extensão das relações sociais através do espaço e do tempo e certo estreitamento no leque de pistas simbólicas [...] é orientada para uma multiplicidade de outros destinatários - é de muitos para muitos, e não de um para um”. É perceptível, na plataforma Teams, a multiplicidade de destinatários e o apresentador, o que confirma a posição de Thompson (2018). Ademais, podemos observar que as interações podem ocorrer de diferentes formas e por diversas ferramentas, como, por exemplo: professor e aluno (único), professor e alunos (classe), alunos e alunos, aluno e professor; tais interações podem ocorrer por via síncrona, via assíncrona, aula online, aula gravada, vídeo, chat, postagens, arquivos, tarefas, emotions, GIFS etc.

Nesse cenário, como já apontamos na figura 2, temos na plataforma Teams espaços de interação de forma ampliada que se configuram no mesmo plano espaço temporal, porém abarcam objetivos distintos. Vejamos no destaque 4 o diálogo de duas participantes no "chat de reunião", cujo objetivo é a resolução de um problema técnico ao acesso à plataforma; portanto, trata-se de algo distinto ao tema da aula ministrada, porém concomitante a esse diálogo. É notório que os participantes da aula utilizam diferentes tipos de interação de forma entrelaçada, são capazes de participar da aula e ao mesmo tempo lançar diálogo no chat, inserir vídeos, GIFS, dúvidas, bem como realizar outras diversas ações simultaneamente. Para Thompson (2018, p. 23), isso é fato e é percebido comumente nos contextos reais do dia a dia - as pessoas vivem em ambientes ricos em mídia, alternam continuamente entre os meios de comunicação disponíveis, "escolhendo qual meio usar, dependendo, em parte, do tipo de interação e relacionamento interpessoal que desejam iniciar e manter com outros indivíduos distantes".

Diante desses recursos multimodais e interacionais, presentes na plataforma Teams, o professor pode empreender uma discussão com seus alunos acerca dos significados múltiplos que, sensíveis ao contexto e às interpretações, resultam num sentido amplo.

Essa integração de linguagens multimodais com uma variedade de funções dentro de um mesmo espaço traz consigo ainda mais possibilidades ao ensino remoto de leitura e escrita realizado por meio da Plataforma Teams, tornando a ferramenta muito mais proveitosa e dinâmica como espaço de sala de aula.

\section{Conclusão}

Nosso principal objetivo neste artigo foi discutir e apresentar como os hipertextos são constituídos em termos de características, aspectos contextuais, multimodais, composicionais, 


\section{PERcursos Linguísticos • Vitória (ES) •v. 11 •n. 29 • 2021 • ISSN: 2236-2592 • Dossiê temático $\bullet O$ texto na pesquisa e no ensino: conhecimentos, práticas e desafios na contemporaneidade •}

interacionais e quais são os tipos de interação que esses textos produzem em um ambiente de ensino.

Como discutido, os hipertextos da plataforma Teams, utilizada como espaço de sala de aula, põe em evidência um ensino de leitura e escrita de forma participativa e interativa com características específicas: 1) interativo e colaborativo, professor e alunos atualizam os links possibilitados pela conectividade em busca de construção de sentidos já preestabelecidos no decorrer do processo de leitura. Conforme Thompson (2018), há uma multiplicidade de destinatários e, em face disso, envolve extensão das relações sociais através do espaço e do tempo, demarcado por pistas simbólicas; 2) multimodal, o significado é criado por diferentes funcionalidades de recursos semióticos, revelado pelas diversas interações dos participantes da aula.

A partir das considerações até aqui, acreditamos que aulas remotas via plataforma Teams podem auxiliar o processo de ensino de leitura e escrita na perspectiva de letramento digital, tornando o aluno autônomo, mais crítico, podendo alternar papeis de leitor e produtor de textos multimodais, de forma mais lúdica, seja registrando a sua opinião ou compartilhando as informações que ele tem sobre determinado tema ou assunto. Outrossim, tais aulas remotas tornam possíveis maiores trocas interativas e, consequentemente, o surgimento de novos sentidos.

Vale destacar que o estudo aqui apresentado é uma possibilidade de leitura, tendo em vista que outras possibilidades podem ser desveladas, conforme o conhecimento do professor e a experiência do ensino remoto por meio da plataforma. Assim, os exemplos apresentados tiveram a finalidade de ressaltar que os hipertextos ambientados em plataforma Teams requerem uma nova relação com o ensino de leitura e escrita, uma vez que são constituídos por características específicas, gerando novas formas de interação por meio de linguagem multimodal, que propicia aos leitores uma rede complexa de construção de sentido.

\section{Referências}

BEAUGRANDE, R. New Foudations for a Science of text and Discourse: Cognition, Comunication, and Freedon of acess to Knowledge and Society. Norwood: Ablex, 1997.

BOETTCHER, D. A internet como dispositivo potencializador didático. In:

SCHLÜNZEN, E. T. M.; JUNIOR, K. S.; PELLANDA, N.M. C. (Org.). Inclusão digital: tecendo redes afetivas/cognitivas. Rio de Janeiro: DP\&A, 2005.

BOLTER, J. D. Writing Space. The computer, hypertext, and the History of Writing. Hillsdale, N.J., Lawrence Erlbaum Associates, 1991. 


\section{PERcursos Linguísticos • Vitória (ES) •v. 11 •n. 29 • 2021 • ISSN: 2236-2592 • Dossiê temático $\bullet O$ texto na pesquisa e no ensino: conhecimentos, práticas e desafios na contemporaneidade •}

CALDAS, A. H. F. O hipertexto em sala de aula: uma proposta metodológica para o ensino de Língua Portuguesa. São Paulo, 2014. Tese (Doutorado em Língua Portuguesa) - Pontifícia Universidade Católica de São Paulo.

COSCARELLI, C. V. Hipertextos na teoria e prática. Belo Horizonte: Autêntica, 2012.

CRYSTAL, D. A Revolução da Linguagem. Trad. Ricardo Quintana. Rio de Janeiro: Jorge Zahar Ed., 2005.

CUNHA, J. C. (Org.) Práticas em sala de aula de línguas: Diálogos Necessários entre Teoria (s) e Ações Situadas. Campinas, São Paulo: Pontes, 2012.

ELIAS, V. M. da S. Do hipertexto ao texto: uma metodologia para o ensino de língua portuguesa a distância. São Paulo, 2000. Tese (Doutorado em Língua Portuguesa) - Pontifícia Universidade Católica de São Paulo.

ELIAS, V. M. Hipertexto, leitura e sentido. Calidoscópio. V.3, n.1, p. 13-19, jan/abr, 2005.

ELIAS, V. M.; CAVALCANTE, M. M. Linguística textual e estudos do hipertexto: focalizando o contexto e a coerência. In: CAPISTRANO JÚNIOR; R.; LINS, M. P. P; ELIAS, V, M. (Org.). Linguística textual: diálogos interdisciplinares. São Paulo: Labrador/PPGEL-UFES, 2017.

GOMES, L. F. Hipertexto no cotidiano escolar. São Paulo: Cortez, 2011.

GUALBERTO, I. M. T. Os hiperlinks e o desafio das conexões em hipertexto enciclopédico digital. In: COSCARELLI, C. V. Hipertextos na teoria e prática. Belo Horizonte: Autêntica, 2012.

KOCH, I. G. V. Desvendando os segredos do texto. 4. ed. São Paulo: Cortez, 2005.

KOCH, I. G. V. Flagrantes da construção interacional dos sentidos. In: BRAIT, Beth; SOUZAE-SILVA, M. C. (Org.). Texto ou discurso? São Paulo: Contexto, 2012.

KOCH, I.; ELIAS, V. Ler e compreender os sentidos do texto. São Paulo: Contexto, 2017.

KRESS, G.; VAN LEEUWEN, T. Reading images: the grammar of visual design. 5. ed. London; New York: Routledge, 1996.

LEÃO, L. O Labirinto da Hipermídia: arquitetura e navegação no ciberespaço. 3.ed. São Paulo: Iluminuras, 2005.

LEVY, P. A inteligência coletiva: por uma antropologia do ciberespaço. 5. ed. São Paulo: Loyola, 2007.

LEVY, P. Cibercultura. Rio de Janeiro: Editora 34, 1999.

LEVY, P. As tecnologias da inteligência. Rio de Janeiro: Editora 34, 1994. 
PERcursos Linguísticos • Vitória (ES) •v. $11 \bullet$ n. 29 • 2021 • ISSN: 2236-2592 • Dossiê

temático $\bullet O$ texto na pesquisa e no ensino: conhecimentos, práticas e desafios na contemporaneidade •

MARCUSCHI, L. A. Gêneros textuais: definição e funcionalidade. In: DIONISIO, Â. P.; MACHADO, A. R.; BEZERRA, M. A. (Org.). Gêneros Textuais \& Ensino. 5. ed. Rio de Janeiro: Lucerna, 2007.

MICROSOFT TEAMS. Disponível em < encurtador.com.br/efvwR>. Acesso 26 jul. 2021.

SOARES, M. Novas práticas de leitura e escrita: letramento digital. Educação e Sociedade, Campinas, v. 23, n. 81, p. 143-160, dez. 2002. Disponível em: http://www.scielo.br/pdf/es/v23n81/13935.pdf - Acesso em: 25 jul. 2021.

THOMPSON, J. B. The media and modernity: a social theory of the media. Cambridge: Polity, 1995.

THOMPSON, J. B. A interação mediada na era digital. v.12 - nº 3 set./dez. São Paulo - Brasil, 2018. p. $17-44$

XAVIER, A. C. Leitura, texto e hipertexto. In: MARCUSCHI, L.A. \& XAVIER, A. C. (Org.). Hipertexto e Gêneros Digitais: Novas formas de construção do sentido. 2. ed. Rio de Janeiro: Lucerna, 2005. 
PERcursos Linguísticos • Vitória (ES) •v. $11 \bullet$ n. 29 • 2021 • ISSN: 2236-2592 • Dossiê

temático $\bullet O$ texto na pesquisa e no ensino: conhecimentos, práticas e desafios na contemporaneidade •

\section{Uma análise multimodal de brinquedos fidget toys na perspectiva da Semiótica Social \\ A multimodal analysis of fidget toys from Social Semiotics perspective}

Cláudia Regina Ponciano Fernandes ${ }^{1}$

José Maria de Aguiar Sarinho Júnior ${ }^{2}$

Resumo: No contexto contemporâneo de possíveis impactos causados por uma realidade pandêmica da Covid 19, apresentamos uma discussão sobre infância e brincadeiras representadas em brinquedos conhecidos como fidget toys, seguindo estudos anteriores que defendem a questão de brinquedos como textos, representações semióticas (CALDASCOULTHARD; VAN LEEUWEN, 2004; ALMEIDA, 2006; 2018; SOARES; ALMEIDA, 2018). O presente estudo fundamenta-se na Semiótica Social (HODGE; KRESS, 1988), utilizando o sistema de modalidade da Gramática do Design Visual (KRESS; VAN LEEUWEN, 2006 [1996]), e o inovador esquema para a semiótica dos brinquedos (ALMEIDA, 2020; 2021). O propósito geral é discutir significados e discursos sobre infância e brincadeira em e por meio desses brinquedos. Especificamente, busca identificar e comparar quais e como os modos de comunicação e recursos semióticos recorrentes nos brinquedos dessa categoria estabelecem interação com o observador, bem como verificar quais e como os significados e discursos sobre infância e brincadeira são comunicados nesses brinquedos. Os resultados revelam um discurso promissor de alívio do estresse e ansiedade, materializados e reconfigurados em brinquedos existentes antes da pandemia, propagando e naturalizando brincadeiras repetitivas, prescritivas e de pouco movimento, além de incentivo ao consumo.

Palavras-chave: Brinquedos antiestresse. Semiótica Social. Multimodalidade.

Abstract: In contemporary context of possible impacts caused by the COVID-19 pandemic reality, we present a discussion on childhood and play represented in toys known as fidget toys, following previous studies that defend the issue of toys as texts, as semiotic representations(CALDAS-COULTHARD; VAN LEEUWEN, 2004; ALMEIDA, 2006; 2018; SOARES; ALMEIDA, 2018). The present study is based on Social Semiotics (HODGE; KRESS, 1988), using the modality system of Grammar of Visual Design Grammar (KRESS;VAN LEEUWEN, 2006 [1996]), and the innovative proposal framework to toy's semiotics as analytical categories (ALMEIDA, 2020; 2021). The overall purpose is to discuss meanings and discourses about childhood and play in and through these toys. Specifically, it aims to identify and compare which and how the modes of communication and recurrent semiotic resources in the toys of this category establish interaction with the observer, as well as to verify which and how meanings and discourses about childhood and play are communicated in these toys. The results reveal a promising discourse to relieve stress and anxiety, materialized and reconfigured in toys existing before the pandemic context, propagating and naturalizing repetitive, prescriptive and little-movement plays, and it also encourages consumption.

Keywords: Fidget toys. Social Semiotics. Multimodality.

\footnotetext{
1 Doutoranda em Linguística pelo Programa de Pós-Graduação em Linguística da Universidade Federal da Paraíba, João Pessoa, Paraíba, Brasil. E-mail: claudiaponcianoifpb@ hotmail.com

2 Doutorando em Linguística pelo Programa de Pós-Graduação em Linguística da Universidade Federal da Paraíba, João Pessoa, Paraíba, Brasil. E-mail: jaguiarsarinho@yahoo.com.br
} 


\section{PERcursos Linguísticos • Vitória (ES) •v. 11 •n. 29 • 2021 • ISSN: 2236-2592 • Dossiê temático $\bullet O$ texto na pesquisa e no ensino: conhecimentos, práticas e desafios na contemporaneidade •}

\section{Considerações iniciais}

O presente artigo apresenta um estudo dos significados e discursos sobre infância e brincadeira em e por meio de brinquedos contemporâneos conhecidos como fidget toys ${ }^{3}$, sendo, portanto, nosso objeto de estudo para esta discussão, a partir do pensamento de estudiosos que desenvolveram análise semiótica sobre brinquedos, como Caldas-Coulthard e van Leeuwen (2004), Almeida (2006; 2018), Soares e Almeida (2018). Tais autores defendem que os brinquedos tanto são objetos que podem ser usados pelas crianças para brincar quanto textos que podem ser lidos e analisados. Isso corrobora com a ideia da multiplicidade de textos que podem ser usados na pesquisa e no ensino, a partir de uma interligação entre conhecimentos e práticas contemporâneas.

Nesse panorama, a ideia para este estudo foi motivada por duas razões. Uma é o fato de pertencermos a um grupo de pesquisa que estuda temáticas referentes à multimodalidade, infância e brinquedos. A outra razão é a notoriedade recente de brinquedos identificados como pop-it, da categoria fidget toys, potencializada pela divulgação massiva da mídia neste ano de 2021, de forma análoga ao que ocorreu com brinquedos anteriores: piões, cubo mágico, mola maluca, bayblade, pokémons etc.

Segundo Lino (2021), em reportagem no veículo de comunicação Metrópoles, a comercialização desses brinquedos é investida desde 2019, mas sua busca aumentou durante a pandemia da Covid 19. Isso ocorreu devido à necessidade de entreter as crianças no contexto familiar, uma vez que elas ficaram sem aulas presenciais e sem contato físico com amigos. Essa mesma reportagem divulga que as buscas pelo termo "fidget toy" na ferramenta Google Trends, entre 2016 e 2020, se apresentaram inexpressivas, mas que houve um aumento superior a $1000 \%$ na procura do termo a partir de abril de 2021 , ocorrendo algo semelhante para a busca de "pop it" que passou de $2000 \%$ em maio de 2021. Já em reportagem do ES Brasil, Medeiros (2021) registra que os pop-it são a nova mania colorida para aliviar o estresse, informando que esses brinquedos estão disponíveis em capinhas de celular, mochilas, estojos, e em temas de festa.

Não é impressionante que um novo brinquedo do estilo pop-it, indicado para crianças maiores de três anos, conquiste o público infantil e até adulto, porém o que nos intriga é o apelo terapêutico voltado para o alívio de estresse e ansiedade, suas características visual, tátil e sonora (características comuns em brinquedos para crianças mais novas), cujas adaptações estão

\footnotetext{
${ }^{3}$ Uma categoria ampla de brinquedos divulgados como de propriedades terapêuticas e antiestresse que podem ser amassados, apertados, puxados e arremessados, fáceis de transportar por serem pequenos.
} 


\section{PERcursos Linguísticos • Vitória (ES) •v. 11 •n. 29 • 2021 • ISSN: 2236-2592 • Dossiê temático $\bullet O$ texto na pesquisa e no ensino: conhecimentos, práticas e desafios na contemporaneidade •}

voltadas a brinquedos anteriores da mesma categoria fidget toys, que julgam favorecer o bemestar das crianças.

Diante da perspectiva de que brinquedos se constituem textos - sejam eles brinquedos tradicionais ou mais recentes -, e, dessa forma, comunicam discursos implícitos sobre infância e brincadeira, entre outros, fizemos uma análise comparativa entre quatro brinquedos da categoria fidget toys em busca desses discursos. Os critérios de seleção se encontram na seção de metodologia. Este estudo fundamenta-se na perspectiva da Semiótica Social apresentada por Hodge e Kress (1988), considerando o texto como materialização de discursos a partir de uma variedade de modos e recursos semióticos orquestrados para comunicar significados resultantes do interesse dos produtores de signos. Como categorias analíticas, recorremos ao sistema de modalidade, inserido na metafunção interativa da Gramática do Design Visual (KRESS; VAN LEEUWEN, 2006 [1996] $)^{4}$, e ao esquema proposto para a semiótica dos brinquedos (ALMEIDA, 2020; 2021). Nesse sentido, surgem tais inquietações: 1) Quais modos de comunicação e recursos semióticos são recorrentes nos brinquedos analisados, e como são combinados para estabelecer interação com o observador? Quais aspectos sensoriais, afetivos e prescritivos são perpassados pela modalidade a partir das configurações visuais e materialidade desses brinquedos que comunicam significados e discursos sobre infância e brincadeira, e quais são eles?

O objetivo principal é discutir significados e discursos sobre infância e brincadeira em e por meio desses brinquedos contemporâneos da categoria fidget toys. Especificamente, buscamos: a) identificar e comparar quais e como os modos de comunicação e recursos semióticos recorrentes nesses brinquedos estabelecem interação com o observador; b) verificar e discutir quais e como os significados e discursos sobre infância e brincadeira são comunicados nesses brinquedos. A relevância do trabalho se justifica pela contribuição desse objeto de estudo para a área da Semiótica Social e Discurso Multimodal com ênfase na temática de multimodalidade e brinquedos como textos, pouco explorados no Brasil ${ }^{5}$, considerando que a noção de texto ainda é muito arraigada ao verbal, além de estudos inexistentes sobre brinquedos dessa categoria no campo do Discurso Multimodal no contexto brasileiro, por ser um brinquedo relativamente recente e por estudos anteriores sobre brinquedos se voltarem para bonecos/as, sobretudo.

\footnotetext{
${ }^{4}$ Os autores lançaram a $3^{\text {a }}$ edição da obra em 2020, mas utilizamos neste trabalho a versão de 2006.

${ }^{5}$ Os estudos sobre brinquedos referenciados neste trabalho se voltam para bonecos como atores sociais, réplicas de adultos em miniatura.
} 


\section{PERcursos Linguísticos • Vitória (ES) •v. 11 •n. 29 • 2021 • ISSN: 2236-2592 • Dossiê temático $\bullet O$ texto na pesquisa e no ensino: conhecimentos, práticas e desafios na contemporaneidade •}

Para organizar a discussão, este artigo se estrutura em quatro seções, além da introdução e considerações finais. A primeira contextualiza os brinquedos como objeto de estudo. A segunda seção resume os aspectos da Semiótica Social, da Gramática do Design Visual e do Letramento do Brinquedo, pertinentes para a análise. A terceira descreve os aspectos metodológicos do estudo. A última seção trata da análise e discussão dos resultados.

\section{Brinquedos como objeto de estudo}

Partindo da ideia substancial de que os brinquedos carregam consigo significados sociais, os quais são maximizados a partir de aspectos histórico-culturais, vale pontuar que esses artefatos, além de serem referenciados com base em suas características lúdicas, podem demonstrar como a sociedade em que as crianças estão inseridas tem se revelado.

Nesse contexto, os brinquedos, por suscitarem discussões não só sobre representações e perfis identitários, mas também acerca de papéis e práticas sociais, têm sido objeto de estudo de pesquisadores em multimodalidade, a partir dos construtos teóricos da Semiótica Social (HODGE; KRESS, 1988), tais como o estudo conduzido por Caldas-Coulthard e van Leeuwen (2004). O referido estudo revela como são transmitidos significados no tocante ao gênero, a partir da ideia de brinquedos como potenciais multimodais e de seus significados semióticos.

As pesquisas de Almeida (2006), por sua vez, remetem a uma investigação sobre o discurso presente nos anúncios de bonecas, cujas escolhas léxico-gramaticais e semânticodiscursivas apontam para a existência de particularidades da figura feminina nas estruturas sociais, brasileira e norte-americana, bem como buscam demonstrar que a correlação entre textos e imagens na composição dos textos midiáticos infantis não é aleatória. Almeida (2018), em seu estudo, maximiza a percepção imagético-verbal, uma vez que traz reflexões sobre os estímulos provocados por determinadas bonecas bebês, através dos aspectos visual, tátil e olfativo, voltados ao cuidado materno e às habilidades médicas, reiterando suas propriedades não apenas multimodais, mas também multissensoriais. Vale mencionar, ainda, que Soares e Almeida (2018) ampliam tais discussões, à medida que elegem a diferença e a inclusão das novas composições familiares da contemporaneidade, cujos impactos estão presentes na composição dos bonecos, o que pode provocar releituras de padrões hegemônicos historicamente compreendidos como normais pela sociedade.

\section{Sobre os fidget toys}




\section{PERcursos Linguísticos • Vitória (ES) •v. 11 •n. 29 • 2021 • ISSN: 2236-2592 • Dossiê temático $\bullet O$ texto na pesquisa e no ensino: conhecimentos, práticas e desafios na contemporaneidade •}

Como textos, os estudos anteriores já citados nos despertam um olhar crítico para esses brinquedos em termos do que eles comunicam, indo além de sua função de entretenimento, atentando para os significados semióticos imbuídos de valores culturais, ideologias e representações da realidade social conforme a época de inserção.

Neste estudo, compreendemos os brinquedos como representações semióticas produzidas e distribuídas globalmente por empresas, não só transmitindo mensagens para as crianças sobre o mundo social em que vivem, mas também refletindo como a sociedade se parece em termos de papéis, tecnologias, identidades e práticas sociais (CALDASCOULTHARD; VAN LEEUWEN, 2004). Conforme o pensamento desses autores sobre o significado dos brinquedos, esses artefatos são uma combinação entre os significados dados pelo produtor e o que as crianças fazem com eles ao brincar, sendo ao mesmo tempo, comunicações já produzidas e ferramentas com as quais são produzidos significados. Nesse sentido, temos visto que os brinquedos são constantemente ressignificados devido às exigências do contexto social, o que torna pertinente um olhar voltado para os significados e discursos sobre infância e brincadeira materializados nesses brinquedos em alta no Brasil em 2021.

Durante levantamento bibliográfico sobre brinquedos dessa categoria, não encontramos trabalhos voltados para o campo do Discurso Multimodal. Em contrapartida, encontramos dois estudos semelhantes dos mesmos autores, da área de Design, discutindo brinquedos como objetos da memória e referência da diversidade cultural (ENGLER et al., 2017; OLIVEIRA et al., 2021), nos quais aparece o fidget spinner ${ }^{6}$ como um tipo de pião moderno, caracterizado por seu movimento giratório, composto de rolamento no centro e pequenas hélices ao redor que giram por alguns minutos entre os dedos da criança. Os autores informam que a autoria e patente dessa peça giratória foram reivindicadas pela norte-americana Catherine Hettinger, em 1993, que criou essa nova proposta de brinquedo visando a tranquilizar as pessoas.

Os fidget toys têm sido divulgados pela mídia brasileira e redes sociais como brinquedos sensoriais que aliviam o estresse e ansiedade, incluindo propostas de vendas com kits compostos por diferentes tipos desses brinquedos. Já os pop it são um dos tipos de fidget toy, como informa o site hypiff.com/lab/7. No referido site, é possível encontrar a lista composta por 13 tipos de brinquedos para a categoria fidget toy e sua descrição: Pop It ou Push Bubble; Squeeze-A-Bean; Magnetic Rings; Hand Spinner; Spinner Magic Cube; Infinity Cube; Marble mesh fidget ou Mesh Tube; Noodle Stretch ou Strechy Strin; Pop Toobes;

${ }^{6}$ Brinquedo giratório de mão. Tradução própria.

${ }^{7}$ Disponível em: https://hypiff.com/lab/nomes-de-fidget-toys-lista-completa/. Acesso em: 16 set. 2021. 


\section{PERcursos Linguísticos • Vitória (ES) •v. 11 •n. 29 • 2021 • ISSN: 2236-2592 • Dossiê temático $\bullet O$ texto na pesquisa e no ensino: conhecimentos, práticas e desafios na contemporaneidade •}

\section{Squeezing toy; Fidget Twister ou Twisted Ring; Stress Relief Balls; Fidget Chains ${ }^{8}$ ou Flippy}

Chain. Encontramos, ainda, mais 12 tipos ao visitarmos três lojas virtuais ${ }^{9}$, modelos identificados como Bubble keychain; Fidget Pad; Links Chain ou Wacky Tracks; Squishy; Finger Rings; Spinner Simple Dimple; Simple Dimple; Push Bubble Fidget Spinner Toys (Octopus Spinner Pop it $)^{10}$; cubos pop it; polvo do humor, bonecos super-heróis de escalada ninja e splash balls ${ }^{11}$. Assim, no momento de coleta de dados para este artigo, listamos esses 25 tipos de brinquedos na categoria Fidget. Tais modelos podem ser visualizados em lojas virtuais ou em vídeos em redes sociais mostrando como as crianças brincam com eles.

No que diz respeito aos brinquedos da versão pop it, especificamente, vale mencionar que eles são objetos de silicone com bolhas para serem apertadas, apresentando-se em uma miríade de modelos (unicórnio, sorvete, coração, maçã, abacate, urso, besouro, borboleta, abelha, crocodilo, coruja, ovelha, cenoura, luvas etc.), formas (circular, losango, quadrado etc.), cores (colorido, verde, azul, amarelo, vermelho, laranja, lilás etc.), tamanhos (variando entre 10x10x3cm a $85 \mathrm{~cm}$ ), além de diversos objetos adaptados à função pop-it (capas para celular, bolsas, estojos, fones de ouvido, braceletes, numerais, jogos de tabuleiros etc.). Ademais, são vendidos por vários preços ${ }^{12}$ e indicados para crianças autistas, principalmente, pelo fato de esses brinquedos fornecerem informações sensoriais menos perturbadoras. Outro fato que merece ser destacado é que eles têm se tornado mania entre crianças de maneira geral (maiores de 3 anos), além de adultos associá-los ao plástico-bolha, que é utilizado para envolver produtos frágeis quando transportados. Os brinquedos da versão pop it aparecem em embalagens transparentes, em caixas ou envoltos em faixa de papelão, relacionados a vários fabricantes e marcas, como é possível visualizar em outras lojas virtuais ${ }^{13}$. Nessas embalagens de caixa ou papelão, os brinquedos aparecem com os nomes "Aperta Pop", "Pop fun" e "Poc Pop". Tal variedade nos instigou a buscar sua origem.

\footnotetext{
${ }^{8}$ Estoura Bolha ou Aperta Bolha/Aperta Pop; Espreme-vagem; Anéis Magnéticos; Brinquedo Giratório de Mãos; Cubo Mágico Girador; Cubo Infinito; Tubo de Rede Antiestresse; Cordão elástico; Tubos Pop; Brinquedos de Esmagar; Ciclone Antiestresse; Bolas de Alívio do Estresse; Correntes Antiestresse. Tradução própria.

${ }^{9}$ Disponíveis em: https://fidgettoys.com.br/; https://mundodosbrinquedos.com.br/collections/fidget-toys; https://www.topbrasilpresentes.com.br/; Acesso em 15 set. 2021.

${ }^{10}$ Chaveiro bolha; Mini controle de mão antiestresse; Trilhas Malucas/Dobráveis; Animais moles/esponjosos; Anéis de dedo; Covinha Simples Giratória; Covinha simples; Fusca de Bolha de Arremesso. Tradução própria.

${ }^{11}$ Bolas grudentas de respingo. Tradução própria.

${ }^{12}$ Em lojas virtuais, por exemplo, os preços variam entre R \$ 3,99 até R \$ 150,00. Há lojas virtuais próprias para esses brinquedos, a exemplo da Fidget Toys Brasil e da Trends Brinquedos, respectivamente disponíveis em: https://fidgettoys.com.br e https://www.trendsbrinquedos.com.br/search/?q=FIDGET\%20TOYS\&mpage=2. Acesso em: 13 set. 2021.

${ }^{13}$ Tais sites estão disponíveis em: https://ludopia.com.br/produto/aperta-pop-arco-iris-unicornio/; https://www.rihappy.com.br/pop-it-fidget-toys-brinquedo-anti-stress-sensorial-colorido-1002091208/p;

https://www.mpbrinquedos.com.br/poc-pop---trevo-arco-iris-0023286/p. Acesso em: 22 set. 2021.
} 


\section{PERcursos Linguísticos • Vitória (ES) •v. 11 •n. 29 • 2021 • ISSN: 2236-2592 • Dossiê temático $\bullet O$ texto na pesquisa e no ensino: conhecimentos, práticas e desafios na contemporaneidade •}

Encontramos informações sobre seus criadores no site Visão, em sua página Sociedade (POP IT..., 2021), e em um vídeo no canal CandyToyBox no YouTube (CANDYTOYBOX, 2021). Tais informações mostram que o pop it foi criado pelo casal Theo e Ora Coster, em 1975, fundadores da empresa israelita de jogos e brinquedos Theora Design, que também é responsável por mais de 190 jogos. A ideia do pop-it partiu de um sonho de Ora após a morte de sua irmã, que sofria de cancro da mama, pedindo para o marido imaginar um grande campo de seios de mulher cujos mamilos pudessem ser apertados de um lado para o outro. $\mathrm{Na}$ época, o brinquedo não fez sucesso, mas os filhos do casal recuperaram a ideia em 2013, fechando acordo com a empresa Foxmind. Assim, o brinquedo foi lançado em 2014 e comprado pela marca Target, em 2019, aparecendo com os nomes Last Mouse Lost, Go Bong, Last One Lost ${ }^{14}$ e Pop it.

Alguns aspectos apontam o auge de brinquedos da categoria Fidget no Brasil e sua velocidade de produção de novos modelos. Um exemplo disso é o site de loja virtual, de nome fidget toys, cuja especificidade é a venda apenas de brinquedos dessa categoria. Quando acessamos o site, na aba "loja", indo para opção "filtrar por categoria", observamos que além de a maior quantidade de itens está concentrada nos ícones "fidget toys" e na "Coleção Pop- it", a quantidade aumenta rapidamente em curto intervalo de tempo, considerando as consultas ao site por duas semanas seguidas durante início de produção deste artigo. Na primeira consulta, apareceram 269 opções para o primeiro ícone e 177 para o segundo; já em consulta realizada duas semanas após, visualizamos 275 opões para o primeiro ícone, permanecendo a mesma quantidade para o segundo, como mostram os prints da página no link https://bit.ly/3okhc66.

\section{Sobre Semiótica Social, Gramática do Design Visual e Letramento do Brinquedo}

Hodge e Kress (1988), ao discutirem acerca dos encaminhamentos teóricos referentes à linguagem em outros sistemas semióticos, ampliam a reflexão e a compreensão de textos considerando as diversas maneiras de materialização de discursos, indo além de signos verbais ou visuais. Essas diversas maneiras de expressar tais discursos correspondem aos modos de representação do pensamento (oral, escrito, visual, espacial, tátil, gestual e auditivo) combinados a partir de múltiplas escolhas semióticas decorrentes do contexto social, histórico e cultural, resultando no que designamos como multimodalidade. Desse modo, a Semiótica Social amplia a análise do signo verbal no processo de comunicação e reconhece os múltiplos

\footnotetext{
${ }^{14}$ Último rato perdido;Vai Bong; Último Perdido. Tradução própria.
} 


\section{PERcursos Linguísticos • Vitória (ES) •v. 11 •n. 29 • 2021 • ISSN: 2236-2592 • Dossiê temático $\bullet O$ texto na pesquisa e no ensino: conhecimentos, práticas e desafios na contemporaneidade •}

dispositivos semióticos selecionados para composição de um texto, levando-nos a refletir que tais escolhas não são aleatórias.

Para auxiliar na análise da multimodalidade em textos visuais, surge a Gramática do Design Visual (GDV), desenvolvida por Kress e van Leeuwen (2006 [1996]), atribuindo relevância às imagens inseridas em situações de comunicação. A GDV surge das metafunções de Halliday (1978) para categorizar o texto verbal, estabelecendo uma perspectiva multimodal que envolve os significados de imagens a partir dos seus significados representacionais, interativos e composicionais. Como a descrição dessas metafunções não é relevante para este estudo, haja vista que existem diversos trabalhos que as descrevem e ilustram, apresentamos somente uma síntese dessas metafunções para situar o leitor na categoria modalidade.

A metafunção representacional estabelece a representação do mundo por meio dos participantes representados, que podem ser classificados como pessoas, lugares ou objetos, constituindo, assim, duas estruturas: narrativa e conceitual. A primeira ocorre quando há a representação de ações realizadas, e a segunda, quando os participantes são expostos em uma classificação taxonômica, sem desempenhar ações.

A metafunção interativa corresponde à relação existente entre participante representado na imagem e o leitor/observador, que também é um participante - o participante interativo. Essa metafunção apresenta quatro recursos presentes no processo interativo: contato, distância social, perspectiva, e modalidade. É esta última que nos interessa neste trabalho, discorreremos sobre ela à parte.

A metafunção composicional diz respeito aos elementos visuais integrados na imagem, ou seja, aos elementos que correspondem à metafunção representacional e à interativa, podendo ser analisada pelas seguintes categorias: valor de informação, saliência e estruturação (ou enquadramento).

É válido informar que essas três metafunções ocorrem de maneira simultânea em qualquer texto, podendo uma ou outra ser enfatizada em uma análise. Assim, buscando analisar a multimodalidade desses brinquedos, recorremos especificamente ao sistema de modalidade, de Kress e van Leeuwen (2006 [1996]), cuja inserção se dá como uma das categorias da metafunção interativa, seguindo a abordagem multimodal para semiótica dos brinquedos (ALMEIDA, 2020), nomeada posteriormente pela autora como Letramento do Brinquedo (ALMEIDA, 2021). Sua proposta é voltada para a materialidade de brinquedos, baseada nesse sistema de modalidade dos autores supracitados. Tal sistema é eleito devido às características dos brinquedos que demandam brincadeiras sensoriais sugestionadas pelas 


\section{PERcursos Linguísticos • Vitória (ES) •v. 11 •n. 29 • 2021 • ISSN: 2236-2592 • Dossiê temático $\bullet O$ texto na pesquisa e no ensino: conhecimentos, práticas e desafios na contemporaneidade •}

formas, cores, material, sons e referências simbólicas a itens do mundo real de algumas crianças.

\section{Modalidade}

Em termos de imagens, Kress e van Leeuwen (2006 [1996]) apresentam a modalidade como referente ao valor de verdade que elas podem representar o mundo, de maneira real ou imaginária, baseando-se em orientações de codificação, ou seja, princípios abstratos que informam a forma como os textos são codificados por grupos sociais específicos, ou dentro de contextos institucionais específicos.

Os autores supracitados apontam quatro diferentes princípios de realidade, ou seja, critérios de valor para a representação de uma imagem: tecnológica, sensorial, abstrata e naturalista. A tecnológica refere-se à eficácia da representação visual de um projeto como principio dominante, e apresenta-se geralmente sem plano de fundo, colorido e iluminação, como nos métodos científicos. A sensorial refere-se ao contexto no qual o princípio do prazer é dominante, pois remete aos sentimentos subjetivos por meio dos sentidos (cheiro, sabor, temperatura etc.) como em certos tipos de arte, publicidade, moda, fotografia de alimentos, decoração de interiores, através dos quais a cor constitui uma fonte de prazer e de significados afetivos, transmitindo alta modalidade. A abstrata refere-se às orientações que são utilizadas pelas elites socioculturais, pela alta arte, em contextos acadêmicos e científicos, e assim por diante. A naturalista refere-se ao grau de equivalência entre o objeto imagético e o real, que se vê a olho nu, pois, quanto maior a correspondência entre eles, maior será a modalidade da imagem. É a de senso comum, que permanece dominante em nossa sociedade. A Figura 1 resume esses quatro princípios.

Figura 1 - Quatro princípios de realidade imagética

Tecnológica $\rightarrow$ Sem plano de fundo, colorido e iluminação,
como nos métodos científicos.
Abstrata $\rightarrow$ Orientaçoos utilizadas pelas elites socioculturais,
pela alta arte.

Fonte: Elaborado pelos autores, 2021. Baseado em Kress e van Leeuwen (2006 [1996]). 


\section{PERcursos Linguísticos • Vitória (ES) •v. 11 •n. 29 • 2021 • ISSN: 2236-2592 • Dossiê temático $\bullet O$ texto na pesquisa e no ensino: conhecimentos, práticas e desafios na contemporaneidade •}

Para Kress e van Leeuwen (2006 [1996]), a percepção da modalidade de uma imagem pode ser influenciada pelos marcadores referentes à saturação, modulação e diferenciação das cores, ao detalhamento, à contextualização, à profundidade, à iluminação e ao brilho. Embora os autores se detenham em imagens bidimensionais, eles também se referem à modalidade em objetos tridimensionais como os brinquedos, defendendo que eles podem incluir vários níveis de modalidade e serem representados com detalhes naturalistas ou de forma mais abstratas.

Nessa visão dos autores, a cor, por exemplo, na modalidade de representação visual tridimensional, se assemelha à dos visuais bidimensionais, pois em muitos brinquedos, especialmente para crianças pequenas, as cores são primárias, voltadas para o prazer, e não para representação naturalista. Eles destacam que este aspecto sensorial é ainda mais realçado pela forma apelativa destes brinquedos para os sentidos, como o tato e som. Exatamente o que observamos em alguns dos fidget toys, como os pop it.

Outro aspecto mostrado por Kress e van Leeuwen (2006 [1996]) é com relação aos materiais utilizados na representação tridimensional, que podem ser motivados de forma naturalista, a exemplo de carros de brinquedo feitos de metal, ou de animais fofos feitos de materiais macios e peludos, embora eles também possam ser menos realistas, quando desconsideram a variedade e especificidade da gama de materiais disponível, como no caso do plástico. Para os autores, os materiais também podem ter uma modalidade "mais que real", quando sua escolha é motivada por uma tentativa de criar prazer ou desprazer, relegando a tentativa de fazer o brinquedo parecer o que representa.

Os autores prosseguem afirmando que, em outros aspectos, a modalidade tridimensional difere da modalidade bidimensional, como nos aspectos de profundidade, iluminação e brilho. Considerando que os objetos tridimensionais já possuem profundidade, não há necessidade de representá-la, bem como não há necessidade de representar o jogo de luzes e sombras, pois elas ocorrem naturalmente.

\section{Estrutura do Letramento do Brinquedo}

Ainda sobre a modalidade, Almeida $(2020 ; 2021)$ defende que dois níveis de significação provaram ser particularmente eficazes na investigação das propriedades materiais dos brinquedos: o sensorial e o naturalista. Em seu estudo em prol de uma abordagem multimodal para a semiótica dos brinquedos, a autora propõe uma estrutura analítica que parte de brinquedos (humanizados ou não), focando na sua materialidade, com base nesses dois níveis de modalidade. Para propor essa estrutura, a autora relaciona cinco conceitos de autores 


\section{PERcursos Linguísticos • Vitória (ES) •v. 11 •n. 29 • 2021 • ISSN: 2236-2592 • Dossiê temático $\bullet O$ texto na pesquisa e no ensino: conhecimentos, práticas e desafios na contemporaneidade •}

diferentes à análise da materialidade dos brinquedos: modalidade sensorial e naturalista (KRESS; VAN LEEUWEN, 2006 [1996]), tecnocracia da sensualidade (VARNEY, 1999) ${ }^{15}$, representacionalidade densa e apego táctil (FLEMING, 1996) ${ }^{16}$. A autora associa o apego táctil e a tecnocracia da sensualidade ao conceito de modalidade sensorial, bem como relaciona a noção de representacionalidade densa ao conceito de modalidade naturalista. Para ela, enquanto os últimos são responsáveis pelo grau de realismo das representações dos brinquedos, os primeiros se referem aos significados interpessoais gerados por suas qualidades materiais. Já em Almeida (2021), podemos visualizar esquematicamente sua estrutura, conforme ilustramos na Figura 2.

Figura 2- Estrutura do Letramento do Brinquedo

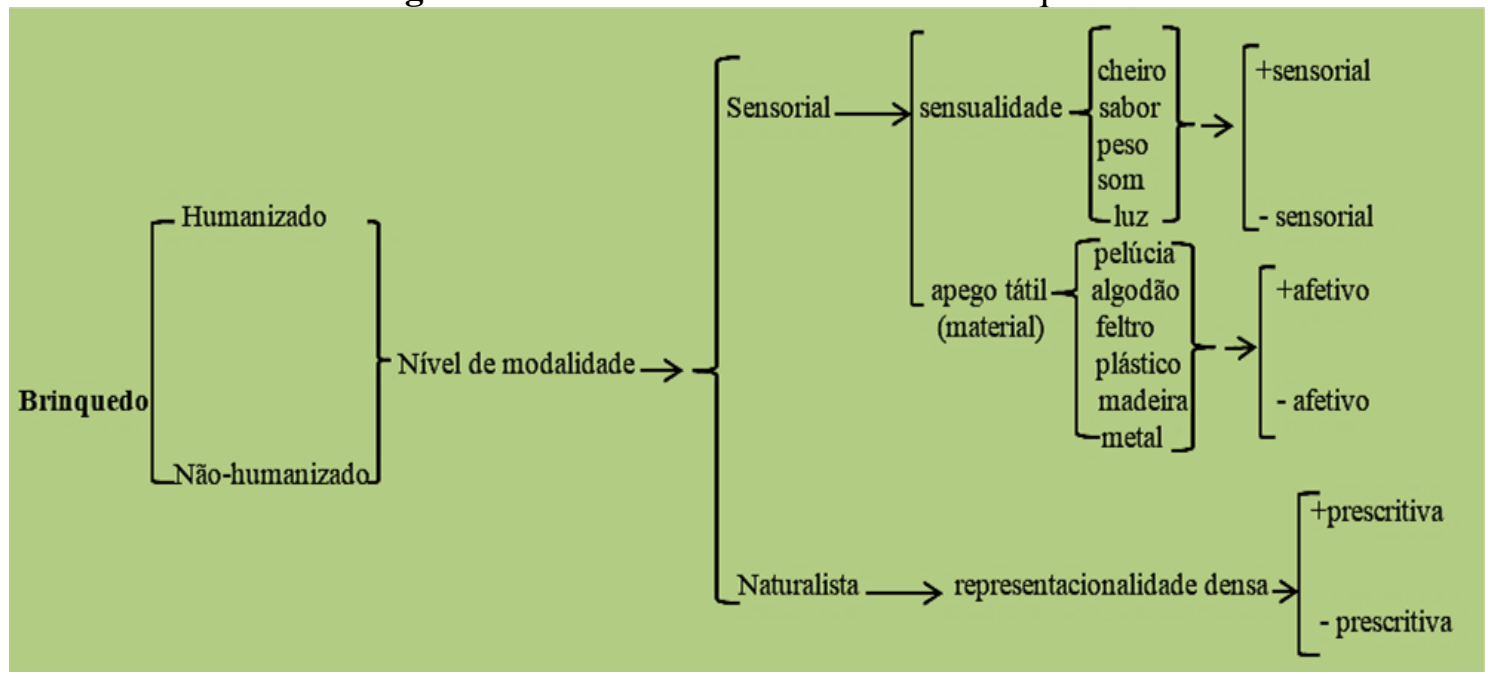

Fonte: Adaptado da Estrutura do Letramento do Brinquedo (ALMEIDA, 2021).

Diante do arcabouço teórico-metodológico exposto e considerando que as modalidades tecnológica e abstrata não correspondem aos brinquedos em discussão, prezamos por analisar os brinquedos seguindo o caminho desse quadro teórico da Figura 2, embora seja uma proposta relativamente recente, o que configura um desafio para o presente estudo. Dessa forma, os seguintes aspectos são observados na análise: se os brinquedos são humanizados ou não; seu nível de modalidade sensorial em termos de tipo de estímulo - se mais ou menos sensorial, e em termos de material - se mais ou menos afetivo -; seu nível de modalidade naturalista - de semelhança com a realidade -, e se são mais ou menos prescritivos.

\footnotetext{
${ }^{15}$ A autora o referencia assim: VARNEY, W. (1999). Toys, play and participation. In: Brian Martin (ed.), Technology and Public participation. Wollongong, Australia: Science and Technology Studies, University of Wollogong, pp. 15- 36.

${ }^{16} \mathrm{~A}$ autora o referencia da seguinte maneira: FLEMING, D. (1996) Powerplay: Toys as Popular Culture. Manchester: Manchester University Press.
} 


\section{PERcursos Linguísticos • Vitória (ES) •v. $11 \bullet$ n. 29 • 2021 • ISSN: 2236-2592 • Dossiê temático $\bullet O$ texto na pesquisa e no ensino: conhecimentos, práticas e desafios na contemporaneidade •}

\section{Caminhos metodológicos}

Para realização desta pesquisa, seguimos cinco etapas. A primeira foi uma consulta realizada no Google Acadêmico à procura de artigos acadêmicos em português no escopo teórico proposto, inserindo as palavras-chave fidget toys e brinquedos antiestresse, mas sem sucesso, exceto pelo trabalho citado que envolve o pião como objeto de memória e referência cultural. A segunda etapa foi outra consulta no contexto familiar e de amigos, durante um final de semana, via mensagens no aplicativo Whatsapp para saber se as crianças tinham algum fidget toy em casa e se poderiam registrá-lo, fotografando a frente e o verso do brinquedo. Nessa etapa, recebemos 43 imagens de fidget toys, porém, como 6 modelos se repetiram, contabilizamos somente 37 brinquedos diferentes, sendo 28 do tipo pop it e 9 fidget toys diversos. A terceira etapa envolveu tanto o agrupamento quanto a observação das imagens recebidas, dispondo-as lado a lado, visando observar e comparar os recursos semióticos nos brinquedos. No caso dos pop it, mostrando-os em frente e verso, cujas imagens podem ser visualizadas no link https://bit.ly/3okhc66. A quarta etapa foi referente à seleção de brinquedos para análise. E a última foi relacionada à análise e discussão de achados.

Tendo em vista a variedade de fidget toys e de seus diferentes modelos, necessitamos de um recorte de dados para análise. Assim, optamos por analisar quatro deles, pertencentes ao acervo pessoal inventariado, ou seja, fotos enviadas pelas crianças da família e por amigos: dois que remetem a brinquedos mais tradicionais (um do tipo squishy e um infinity cube) e dois mais recentes, do tipo pop-it (um modelo com formato de sorvete e outro modelo com formato de polvo). O corpus selecionado para análise, embora com quantidade reduzida de brinquedos, não compromete o objetivo proposto, e se justifica também pelo número limitado de páginas, característico de artigo.

A escolha do fidget toy do tipo squishy se justifica pela relativa semelhança em termos de apego tátil com os tradicionais brinquedos de amassar, puxar, esmagar, como a massa de modelar, enquanto o segundo, infinity cube, remete ao cubo mágico, além de serem brinquedos que não se repetiram nas imagens enviadas. Já a escolha dos dois brinquedos do tipo pop-it, que foi extremamente difícil de fazê-la diante da diversidade de opções enviadas, se explica por ser o tipo de fidget toy noticiado pela mídia como a tendência no momento (exemplos já citados) de escrita deste artigo, sendo um deles um brinquedo representativo da sua principal característica funcional distintiva (apertar e ouvir o barulho da bolha explodindo), que aparece em todos os 


\section{PERcursos Linguísticos • Vitória (ES) •v. 11 •n. 29 • 2021 • ISSN: 2236-2592 • Dossiê temático $\bullet O$ texto na pesquisa e no ensino: conhecimentos, práticas e desafios na contemporaneidade •}

modelos do tipo pop it, e o outro brinquedo por já ser visto como uma reconfiguração do pop it, agregado às características de outros fidget toys: spinner e expressão do humor.

Sobre esses dois brinquedos pop it, selecionamos o formato sorvete colorido (rainbow) e o octopus pop it, que já é uma variação do pop it. O pop it sorvete colorido corresponde ao modelo que compramos para observar e manusear, buscando melhor compreensão do mesmo. Já os demais brinquedos pertencem às crianças de nosso círculo familiar e de amizade.

A seguir, a análise desses quatro brinquedos.

\section{Fidget toys como textos: o que eles comunicam?}

De acordo com Almeida (2006; 2018), uma análise visual de brinquedos promove uma visão do brincar, considerando questões sociais relevantes. Partindo das ideias dessa autora, o mundo em miniatura representado nos brinquedos tende a refletir o que realmente existe na sociedade, e ao contrário dos estudos anteriores mencionados cujas análises se voltam para bonecos representativos de atores sociais específicos, como miniaturas de adultos, os brinquedos em questão focam no ato do brincar. Embora pareçam aparentemente inofensivos e interessantes, é relevante compreender o que eles nos comunicam, mesmo sem palavras.

Partimos, então, para o primeiro brinquedo analisado, mostrado na Figura 3.

Figura 3 - Fidget toy do tipo Squishy - Modelo bolo unicórnio

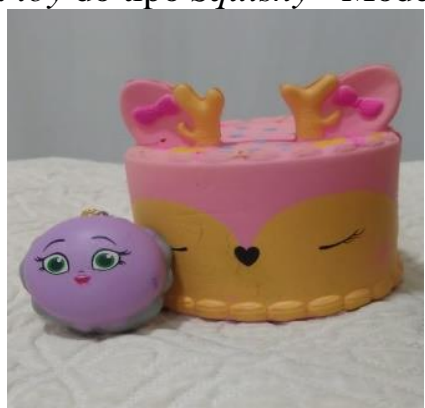

Fonte: Arquivo pessoal. Registrado por sobrinhas dos autores.

A Figura 3 mostra um fidget toy do tipo squishy (macio, mole, fofinho) em ângulo frontal, embora possamos visualizar dois brinquedos na referida imagem, nos detemos somente no modelo em formato de bolo unicórnio, que aparece nas cores amarela e rosa, em formato circular e com relativa altura. Os brinquedos desse tipo são feitos para serem esmagados e soltos para voltar a sua forma normal, indicado geralmente para crianças maiores de 6 anos. Além desse modelo, esses brinquedos aparecem geralmente em miniaturas para caber nas mãos, mas em uma variedade de opções, formas e cores (animais, sorvete, concha do mar, caixa de leite, marshmallow etc.). 


\section{PERcursos Linguísticos • Vitória (ES) •v. 11 •n. 29 • 2021 • ISSN: 2236-2592 • Dossiê temático $\bullet O$ texto na pesquisa e no ensino: conhecimentos, práticas e desafios na contemporaneidade •}

Olhando esse brinquedo pelas lentes da modalidade (KRESS; VAN LEEUWEN, 2006 [1996]) e seguindo o caminho da estrutura do Letramento do Brinquedo (ALMEIDA, 2021), o descrevemos como um brinquedo não humanizado, de modalidade sensorial alta, mais afetivo, relativamente naturalístico e altamente prescritivo.

A descrição do referido brinquedo como não humanizado decorre de sua configuração visual em formato circular e modelo de bolo unicórnio, sem traços antropomórficos, mesmo mostrando uma reação de olhos e nariz. Acreditamos que a modalidade sensorial alta decorra da proposta lúdica do brinquedo em si, que é voltada para o contexto do prazer visual, gustativo e tátil. O apelo visual se explica pelo aspecto em forma de bolo redondo e alto, pela personagem mitológica do unicórnio presente em outros domínios infantis, e pelas cores amarelo e rosa, que remetem a um bolo com calda de morango, o que pode despertar o prazer gustativo de saboreá-lo. O prazer tátil se explica pela maciez e certa liquidez interna do brinquedo (semelhante a um gel) sentida pelo toque com as mãos ao espremê-lo.

A questão de afetividade é subjetiva, haja vista que depende do contexto social de cada criança e de seu acervo de imagens e sensações armazenado na memória, sem quantidade de medição. Mas, conforme a estrutura de Almeida (2020; 2021), material macio e leve pode favorecer a uma maior afetividade, se comparado a um brinquedo mais duro. Acrescentamos que as referências a personagens infantis também podem aumentar a afetividade. É relativamente naturalístico devido a sua semelhança com um bolo temático real, embora seu peso seja irreal. É ainda muito prescritivo, pois sua identificação como um brinquedo squishy pressupõe visualmente e tactilmente como a criança deve brincar, mesmo que ela adote uma postura inversa.

Vejamos, agora, este brinquedo da Figura 4.

\section{Figura 4 - Fidget toy do tipo Infinite Cube}

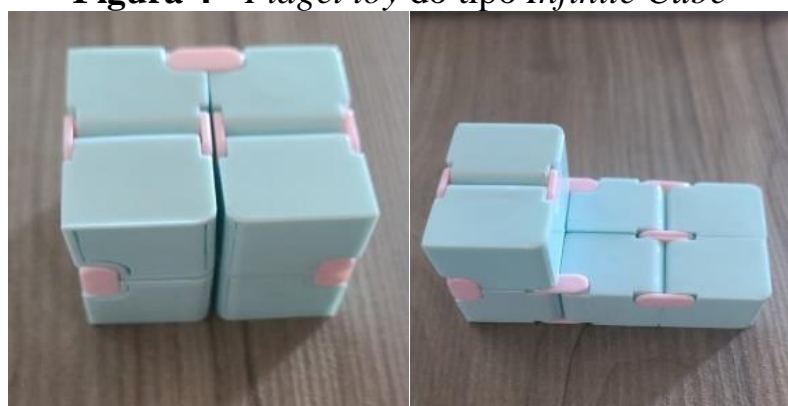

Fonte: Arquivo pessoal. Registrado por amigos dos autores.

A Figura 4 representa o fidget toy do modelo infinite cube (cubo infinito). Na referida imagem, o brinquedo aparece com ângulo de cima para baixo e com uma das possibilidades 


\section{PERcursos Linguísticos • Vitória (ES) •v. 11 •n. 29 • 2021 • ISSN: 2236-2592 • Dossiê temático $\bullet O$ texto na pesquisa e no ensino: conhecimentos, práticas e desafios na contemporaneidade •}

de desdobramento lateral, com formato de cubo, na cor azul claro predominante e com dobradiças na cor rosa. É um brinquedo que move nas mãos de acordo com as dobradiças, possibilitando uma sequência infinita de movimentos em qualquer direção. Seu formato remete ao tradicional cubo mágico do tipo quebra-cabeça, cujo objetivo é colocar todos os quadrinhos de uma única cor no mesmo lado, o que se torna difícil e instigante. Já neste tipo, a proposta é suscitar possibilidades de desdobramento sem finalidade prescrita.

Partindo para a análise multimodal desse brinquedo pela perspectiva teóricometodológica anunciada, o classificamos como um brinquedo não humanizado, de modalidade sensorial relativamente alta e afetiva, de modalidade naturalística alta, sendo pouco prescritivo.

Consideramos o brinquedo não humanizado devido ao seu formato evidente em cubo, sem semelhanças com a forma humana. A modalidade sensorial relativamente alta se justifica pela proposta do brinquedo em si, voltada para o contexto de prazer dominante relacionado aos aspectos principais: visual e tátil. O visual decorre do formato de cubos com dobradiças, nas cores azul e rosa, além do tamanho reduzido para caber na mão. O tátil advém do toque dos dedos em busca de possibilidades de movimentos dobráveis (e repetitivos), proporcionados pelas dobradiças, principais recursos semióticos identificadores do brinquedo e que provocam sons. A relativa afetividade decorre provavelmente dos recursos semióticos de cores claras, leveza do brinquedo e configuração em miniatura que facilitam o apego tátil, mesmo sendo um material plástico mais duro e liso se comparado ao brinquedo anterior. O nível naturalístico alto ocorre se adotarmos como referência de realidade o tradicional cubo mágico, devido ao seu formato semelhante com cubos que se movem. É pouco prescritivo porque seu nome "cubo infinito" e brincadeira sugerem vários desdobramentos.

Vejamos os dois brinquedos do tipo pop it, o primeiro na Figura 5.

Figura 5 - Fidget toy do tipo pop it - Modelo sorvete colorido
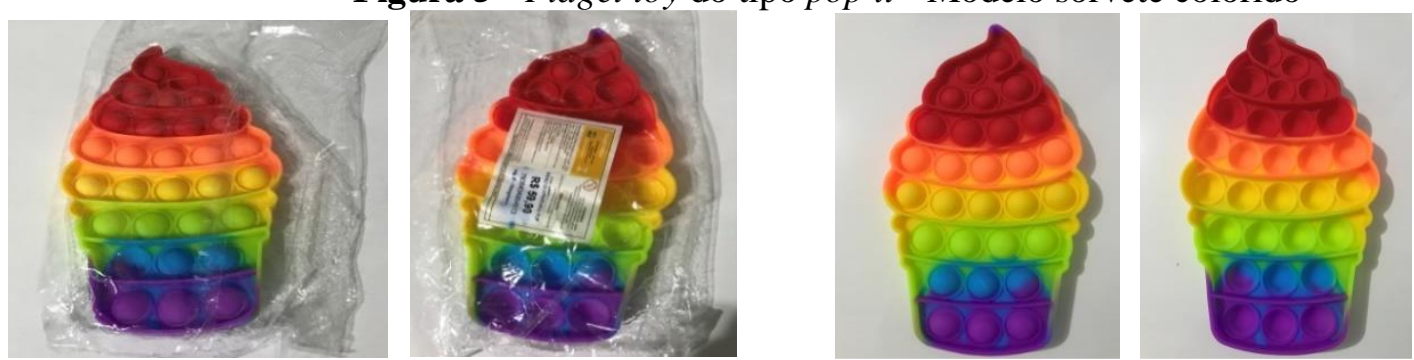

Fonte: Arquivo pessoal. Registrado pelos autores. 


\section{PERcursos Linguísticos • Vitória (ES) •v. 11 •n. 29 • 2021 • ISSN: 2236-2592 • Dossiê temático $\bullet O$ texto na pesquisa e no ensino: conhecimentos, práticas e desafios na contemporaneidade •}

A Figura 5 representa o modelo pop it, sendo o brinquedo comprado pelos autores no período de produção deste artigo. Na referida imagem, o brinquedo aparece em frente e verso, dentro e fora de uma embalagem transparente, apresentando o formato de sorvete, cores vibrantes (roxo, azul, verde-limão, amarelo, laranja e vermelho), além de 8 linhas com bolhas para apertar, somando 29 bolhas. Embora as informações verbais mostradas na embalagem sejam mínimas e não sejam objetos de análise neste estudo, é relevante registar que entre elas constam: selo com o símbolo do INNAC (Instituto Nacional de Avaliação da Conformidade em Produtos), dados sobre importador, fabricante, indicação de idade para crianças maiores de três anos e o preço.

Adentrando na análise multimodal desse brinquedo pop it, podemos considerá-lo um brinquedo não humanizado, de modalidade sensorial relativamente alta e afetiva, de nível naturalístico baixo, e altamente prescritivo.

Sua classificação como não humanizado se evidencia pela ausência de traços antropomórficos, apresentando-se em formato de sorvete. A modalidade sensorial relativamente alta advém do contexto de prazer dominante relacionado aos aspectos visual, tátil, sonoro e gustativo. O visual se explica pelas cores primárias (amarelo, azul, vermelho), que são vistas para o bem do prazer em vez de nível naturalista (KRESS; VAN LEEUWEN, 2006 [1996]), pela saliência das bolhas e pela forma de sorvete, sugerindo um brinquedo com apelo predominantemente visual. O tátil está atrelado ao material macio em silicone e repetição de bolhas sugestivas ao toque. O sonoro decorre do som ao estourar as bolhas quando pressionadas. O gustativo deriva da alusão ao sabor de sorvete decorrente do formato. A descrição como relativamente afetivo se dá pelo apego tátil potencializado pelo material em silicone, leve, dobrável, fácil de manusear e transportar nas mãos, como um sorvete. O nível naturalístico menor se explica pelos detalhes do formato de sorvete, que foge aos detalhes representacionais de um sorvete real que degustamos, sem bolhas salientes e sem coloridos, exceto quando acrescentamos guloseimas coloridas. É um brinquedo altamente prescritivo devido à função e nome atribuído a ele, "pop it".

Na sequência, apresentamos o brinquedo pop it, na Figura 6.

Figura 6 - Fidget toy do tipo pop it - Modelo polvo do humor reversível 


\section{PERcursos Linguísticos • Vitória (ES) •v. $11 \bullet$ n. 29 • 2021 • ISSN: 2236-2592 • Dossiê temático $\bullet O$ texto na pesquisa e no ensino: conhecimentos, práticas e desafios na contemporaneidade •}

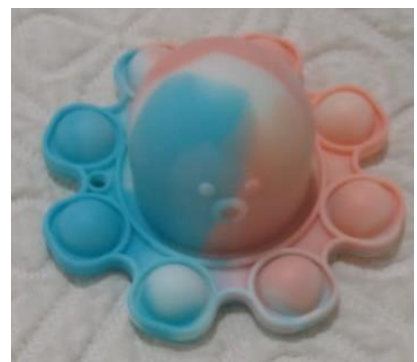

Fonte: Arquivo pessoal. Registrado por sobrinhas dos autores.

A Figura 6 representa o modelo pop it em formato de polvo. Este aparece nas cores azul, rosa e branco, com 8 bolhas para apertar nas bordas, uma bolha maior no centro (a cabeça do polvo), além de apresentar um furo na borda. É um modelo identificado como pop it polvo do humor (ou bipolar), cuja bipolaridade não está na expressão facial, mas na mudança de cor quando vira o brinquedo ao avesso, acessando a bolha maior, e funciona ainda como chaveiro. Na referida imagem, o brinquedo não aparece em frente e verso, mostrando a mudança de cor de dentro para fora, mesmo solicitando à criança que a enviou. De qualquer forma, o manuseio com um modelo semelhante pode ser visto em vídeos nas redes sociais.

Classificamos esse brinquedo como não humanizado (embora apareça uma reação humana pelos olhos e boca, comuns em brinquedos), de modalidade sensorial alta, sendo mais afetivo que o anterior, apresenta uma modalidade naturalista relativamente alta, e alta indicação prescritiva, embora menor que a anterior.

Sua caraterística não humanizada se evidencia pelo formato de polvo. A modalidade sensorial alta se explica pelo contexto de prazer dominante relacionado aos mesmos aspectos do pop it do modelo sorvete quanto à questão visual, tátil e sonora. $\mathrm{O}$ aspecto visual se evidencia pelo formato de polvo com corpo, braços e olhos; pelas cores rosa e azul predominantes de um lado e roxo de outro, relacionadas ao universo infantil de crianças menores, em vez de cores semelhantes ao polvo. O aspecto tátil decorre do material em silicone, maciez e saliência das bolhas. $\mathrm{O}$ sonoro se atribui ao som das bolhas estouradas. $\mathrm{O}$ brinquedo apresenta um nível naturalístico relativamente alto, maior que o modelo sorvete, devido ao formato de polvo, potencializado por seus detalhes representacionais de braços, olhos, corpo mole e mudança de cor ao virá-lo ao avesso. Isso o torna também mais afetivo, com apego tátil sugerido e expressão do humor revelada pela mudança de cor. É um brinquedo altamente prescritivo, porque sugere a pressão das bolhas, expressão de emoções pela cor e uso como chaveiro (já que vem com um furo). 


\section{PERcursos Linguísticos • Vitória (ES) •v. 11 •n. 29 • 2021 • ISSN: 2236-2592 • Dossiê temático $\bullet O$ texto na pesquisa e no ensino: conhecimentos, práticas e desafios na contemporaneidade •}

\section{Resultados e discussões}

Após análise desses brinquedos, em todos eles, percebemos: características não humanizadas; mais de um modo de comunicação (visual, tátil, sonoro, gustação); variedade de recursos semióticos (formas, cores, tamanho, maciez, leveza, sons, ícones de alimento, de personagens infantis) que, combinados, se comunicam com a criança de forma sensorial e naturalística para despertar sensações de toque, apego, audição, sabor. No caso dos brinquedos pop it, as formas circulares das bolhas alinhadas em sequência são os principais recursos semióticos identificadores desse tipo de brinquedo, demandando da criança seu toque para pressioná-las e ouvir o barulho, sugestionando movimento repetitivo com os dedos e do mesmo procedimento do lado oposto. O Quadro 1 sintetiza os achados.

Quadro 1 - Resultados

\begin{tabular}{|c|c|c|c|c|c|c|}
\hline \multirow{2}{*}{$\begin{array}{l}\text { Brinquedos } \\
\text { Não } \\
\text { humanizados }\end{array}$} & \multicolumn{4}{|c|}{ Modalidade sensorial } & \multicolumn{2}{|c|}{ Modalidade naturalista } \\
\hline & Estímulos & Material & Nível sensorial & $\begin{array}{l}\text { Nível } \\
\text { afetivo }\end{array}$ & $\begin{array}{c}\text { Nível de representação } \\
\text { do real }\end{array}$ & Nível de prescrição \\
\hline $\begin{array}{l}\text { Fidget squishy } \\
\text { bolo }\end{array}$ & $\begin{array}{l}\text { Visão - formato circular, altura } \\
\text { de bolo, cor amarelo e rosa, } \\
\text { ícone unicómio. } \\
\text { Tátil - maciez, liquidez, } \\
\text { leveza. } \\
\text { Gustação - ícone de bolo } \\
\text { temático com calda }\end{array}$ & $\begin{array}{c}\text { Silicone e } \\
\text { gel }\end{array}$ & + Sensorial & + Afetivo & Relativamente alto & $\begin{array}{l}\text { Altamente } \\
\text { prescritivo }\end{array}$ \\
\hline $\begin{array}{l}\text { Fidget infinite } \\
\text { cube }\end{array}$ & $\begin{array}{l}\text { Visão- formato quadrado, cor } \\
\text { clara (azul e rosa). } \\
\text { Tátil- dobradiça, flexibilidade, } \\
\text { leveza. }\end{array}$ & $\begin{array}{l}\text { Plástico } \\
\text { relativam } \\
\text { ente duro }\end{array}$ & $\begin{array}{l}\text { Relativamente } \\
\text { sensorial }\end{array}$ & $\begin{array}{l}\text { Relativamente } \\
\text { afetivo }\end{array}$ & Relativamente alto & Pouco prescritivo \\
\hline Pop it sorvete & $\begin{array}{l}\text { Visão - formato sorvete, cores } \\
\text { vibrantes arco-rís. } \\
\text { Tátil - bolhas, certa maciez } \\
\text { leveza. } \\
\text { Auditiva - som leve de estouro. }\end{array}$ & Silicone & $\begin{array}{c}\text { Relativamente } \\
\text { sensorial }\end{array}$ & $\begin{array}{l}\text { Relativamente } \\
\text { afetivo }\end{array}$ & Baixo & $\begin{array}{l}\text { Altamente } \\
\text { prescritivo }\end{array}$ \\
\hline $\begin{array}{l}\text { Pop it polvo } \\
\text { do humor }\end{array}$ & $\begin{array}{l}\text { Visão - formato de polvo, cor } \\
\text { clara azul e rosa, roxo (avesso) } \\
\text { Tátil - bolhas, certa maciez, } \\
\text { leveza. } \\
\text { Auditiva - som leve de estouro. }\end{array}$ & Silicone & + Sensorial & + Afetivo & Relativamente alto & $\begin{array}{l}\text { Altamente } \\
\text { prescritivo }\end{array}$ \\
\hline
\end{tabular}

Fonte: Elaborado pelos autores, 2021.

A multimodalidade voltada para características sensoriais e naturalísticas nesses brinquedos não representa somente uma estratégia de venda, até porque brinquedos produzidos para segurar, esmagar, desdobrar ou estourar não são novidades. A questão está no fato de como um discurso promissor de alívio do estresse e ansiedade em crianças, ao final de um período pandêmico, se materializa e se reconfigura nesses brinquedos a partir do próprio nome, "fidget toys" (brinquedos de inquietação, de antiestresse), brinquedos que já existiam 


\section{PERcursos Linguísticos • Vitória (ES) •v. 11 •n. 29 • 2021 • ISSN: 2236-2592 • Dossiê temático $\bullet O$ texto na pesquisa e no ensino: conhecimentos, práticas e desafios na contemporaneidade •}

no Brasil antes da pandemia da Covid 19, até mesmo na proposta pop it, propagando e naturalizando brincadeiras repetitivas, prescritivas e com pouco movimento, além de incentivo à cultura consumista de brinquedos industrializados, cujos nomes reforçam a presença da cultura americana. Nesse último caso, pode ser visto também como um brinquedo excludente, por privilegiar crianças de classe socioeconômica abastada devido ao preço elevado.

Partimos para a finalização da discussão apontando duas questões para reflexão. A primeira diz respeito à forma como estamos ensinando as crianças a aliviarem doenças emocionais, potencializadas pelo período pandêmico. A segunda é se a carência afetiva das crianças, da atenção que deve ser dada a elas, pode ser realmente suprida por brinquedos prontos, os quais se comunicam por configurações visuais e materiais, como se dissessem às crianças: "esmague-me", "aperte-me”, "desdobre-me”, "estoure-me”, em vez de brincadeiras inventadas com os pais ou responsáveis. Até quando brinquedos, como os pop it, serão as novas "chupetas eletrônicas" da vez?

\section{Considerações finais}

Neste artigo, analisamos quatro brinquedos fidget toys como textos multimodais, partindo da Semiótica Social (HODGE; KRESS, 1988) para o sistema de modalidade (KRESS; VAN LEEUWEN, 2006 [1996]) e o esquema do Letramento do Brinquedo (ALMEIDA, 2020; 2021), que neste caso nos possibilitou compreender as suas configurações multimodais. Vimos que mesmo sem palavras, os brinquedos comunicam significados implícitos sobre infância e brincadeira, favorecidos por necessidades de uma realidade social, indo além de um brinquedo usado pelas crianças em casa ou na escola.

Enquanto pesquisadores de multimodalidade, a análise de brinquedos como textos torna-se um desafio devido às possibilidades de interpretações, principalmente diante de brinquedos recentes no mercado que pressupõem um estado prévio de estresse e ansiedade, típico da vida adulta, como característico também da infância contemporânea. Isso reforça a questão de que não basta presentear a criança com mais um brinquedo, seja ele qual for. Fazse necessário o afeto da pessoa em vez do objeto, da naturalidade da brincadeira inventada em vez de brinquedos prescritivos. Os respectivos brinquedos podem até aliviar o estresse e a ansiedade por um tempo, mas podem causar ainda mais ansiedade para adquirir a coleção. É como um ciclo que se repete a cada novo brinquedo. 


\section{PERcursos Linguísticos • Vitória (ES) •v. 11 •n. 29 • 2021 • ISSN: 2236-2592 • Dossiê temático $\bullet O$ texto na pesquisa e no ensino: conhecimentos, práticas e desafios na contemporaneidade •}

\section{Agradecimentos}

Nossa profunda gratidão às crianças da família a aos colegas do grupo de pesquisa pelo registro e envio das imagens dos fidget toys.

\section{Referências}

ALMEIDA, Danielle Barbosa Lins de. Icons of Contemporary Childhood: A Visual and Lexicogrammatical Investigation of Toy Advertisements. Tese de doutorado. Programa de pós-graduação em Letras/Inglês e Literatura Correspondente (UFSC), 2006.

"It can cry, it can speak, it can pee": modality values and playing affordances in modality contemporary baby dolls's discourse. Ilha do Desterro, vol. 71, n.3, p. 143-160, 2018

Toys as texts: Towards a multimodal framework to toys' semiotics. Trabalhos em Linguística Aplicada, v.59, n.3, p. 2102-2122, 2020.

Cuarto Encuentro Conversaciones sobre Multimodalidad: Diálogos Sobre Materialidad Semiótica. Letramento do Brinquedo como ferramenta para uma investigação multimodal. RedLem - Red Latinoamericana de Estudios sobre Multimodalidad. Brasil e Chile, evento virtual, maio, 2021. Youtube. Disponível em: https://www.youtube.com/watch?v=azvOp0ElgaQ. Acesso em: 10 Set. 2021.

CALDAS-COULTHARD, Carmen Rosa; VAN LEEUWEN, Theo. Discurso crítico e gênero no mundo infantil: Brinquedos e a representação de atores sociais. Linguagem em (dis) curso, v. 4, n. esp., p.11-33, 2004.

CANDYTOYBOX. Who invented the pop it? History of Pop it. United States, setembro, 2021. Youtube. Disponível em: https://www.youtube.com/watch?v=Tt8-El8bDec. Último acesso em: 25 set. 2021.

ENGLER, Rita de Castro; et al. Objetos de memória como referência da diversidade cultural. RELACult - Revista Latino-Americana de Estudos em Cultura e Sociedade, v.3, n. esp., p.1$15,2017$.

HODGE, Robert; KRESS, Gunther. Social Semiotics. $1^{\text {st }}$. ed. Ithaca, NY: Cornel Universal Press. 1988.

KRESS, Gunther; VAN LEEUWEN, Theo. Reading images: the grammar of visual design. $2^{\text {nd }}$. ed. London/New York: Routledge. 2006 [1996].

LINO, Mariene. Pop It: brinquedo de silicone vira febre entre crianças. Metrópoles. 29 de agosto de 2021. Disponível em: https://www.metropoles.com/brasil/pop-it-brinquedo-desilicone-vira-febre-entre-criancas. Último acesso em: 30 set. 2021.

MEDEIROS, Dani. Fidget Toys: Nova mania colorida que alivia o estresse. ES Brasil. 7 de setembro de 2021. Disponível em: https://esbrasil.com.br/fidget-toys-nova-mania-coloridaque-alivia-o-estresse/. Último acesso em: 30 set. 2021. 
PERcursos Linguísticos • Vitória (ES) •v. $11 \bullet$ n. 29 • 2021 • ISSN: 2236-2592 • Dossiê

temático $\bullet O$ texto na pesquisa e no ensino: conhecimentos, práticas e desafios na contemporaneidade •

OLIVEIRA, Ana Cecília Carneiro; et al. Objetos De Memória: um estudo dos brinquedos como referência da diversidade cultural. Brazilian Journal of Development, v.7, n.1, p.38703884, 2021.

POP IT: A história por detrás do brinquedo da moda. Visão. 16 de setembro de 2021. Disponível em: https://visao.sapo.pt/atualidade/sociedade/2021-09-16-pop-it-a-historia-pordetras-do-brinquedo-da-moda/. Último acesso em: 30 set. 2021.

SOARES, José Leonardo dos Santos; ALMEIDA, Danielle Barbosa Lins de. Brinquedos como representação social e de gênero na infância: a ressignificação do conceito de família. Discursos Contemporâneos em Estudo, v.3, n. 2, p. 19-31, 2018. 


\title{
ANÁLISE DAS MARCAS DE SUBJETIVIDADE NO TEXTO DE GÊNERO NOTÍCIA SOB UM OLHAR ENUNCIATIVO
}

\section{ANALYSIS OF SUBJECTIVITY MARKS IN THE NEWS GENRE TEXT UNDER AN ENUNCIATIVE PERPECTIVE}

\author{
Claudia Toldo ${ }^{1}$
}

Estela Mettler Piva ${ }^{2}$

\begin{abstract}
RESUMO: Este trabalho se insere na linha de pesquisa da Teoria da Enunciação, idealizada na linguística enunciativa de Émile Benveniste. Trabalhamos, especialmente, com o texto $D a$ subjetividade na linguagem (1958), de Benveniste, que nos apresenta o conceito de subjetividade na linguagem e suas marcas no discurso. Observando esse conceito principal, o objetivo deste trabalho é analisar enunciativamente o advérbio na construção do sentido do texto do gênero notícia, mostrando que essas escolhas são marcas que desvelam uma subjetividade de sujeitos que se enunciam em textos. O corpus deste trabalho é um texto do gênero notícia selecionado de um jornal de circulação nacional, a fim de observar, analisar e descrever o emprego das formas - advérbios - em função da construção dos seus sentidos.
\end{abstract}

PALAVRAS-CHAVE: Linguística da Enunciação. Subjetividade. Notícia. Advérbios.

ABSTRACT: This work is in line with the Theory of Enunciation, idealized in Émile Benveniste's Linguistics of Enunciation. We work especially with the text Subjectivity in Language (1958), by Benveniste, which introduces us to the concept of subjectivity in language and its marks in discourse. Observing this main concept, the objective of this work is to enunciatively analyze the adverb in the meaning construction of the text of the news genre, showing that these choices are marks that unveil the subjectivity of subjects who enunciate themselves in texts. The corpus of this work is a text of the news genre selected from a newspaper with national circulation, in order to observe, analyze and describe the employ of the forms - adverbs - in the function of the construction of the meanings.

KEYWORDS: Linguistics of Enunciation. Subjectivity. News. Adverbs.

\footnotetext{
${ }^{1}$ Doutor em Letras. Professora de Língua Portuguesa e Linguística do curso de Letras da Universidade de Passo Fundo; Professora e Coordenadora do PPGL - Doutorado e Mestrado em Letras na mesma Universidade; realiza pesquisas em Teorias da Enunciação, principalmente, estuda as reflexões teóricas de Émile Benveniste; pesquisadora CNPq; claudiast @upf.br

${ }^{2}$ Graduada em Letras - Português/Inglês pela Universidade de Passo Fundo (UPF/RS). Foi bolsista PIBIC e atualmente é pesquisadora voluntária na linha de pesquisa "Constituição e interpretação do texto e do discurso", com orientação da professora Claudia Toldo; pivaestela@gmail.com
} 


\section{PERcursos Linguísticos • Vitória (ES) •v. 11 •n. 29 • 2021 • ISSN: 2236-2592 • Dossiê temático $\bullet O$ texto na pesquisa e no ensino: conhecimentos, práticas e desafios na contemporaneidade •}

\section{Considerações iniciais}

Ouvimos nas conversas do nosso dia a dia que "notícia boa deve ser imparcial", "um texto jornalístico é neutro, não pode demonstrar a opinião do jornalista que o escreveu" e assim por diante. Mas será que existe essa neutralidade nos textos que nós, locutores, independentemente da profissão, escrevemos? Essas e outras questões são o ponto de partida para a construção deste trabalho: quais são as marcas que o locutor deixa no texto que escreve? Como este locutor "se marca" no texto? Essas marcas são identificáveis mesmo em textos que, teoricamente, são objetivos?

Buscamos, nos estudos do linguista da Enunciação, Émile Benveniste, as respostas que queremos com esses questionamentos. Através do estudo do texto Da subjetividade na linguagem (1958), pretendemos entender melhor a neutralidade (ou não) nos textos e as marcas subjetivas deixadas pelo locutor.

Para exemplificar a teoria, escolhemos e analisamos um texto jornalístico de gênero notícia, colocando em foco o conceito de subjetividade. Nosso trabalho, portanto, é de cunho teórico-analítico: analisamos, a partir de uma reflexão teórica, a construção de sentido de determinadas formas linguísticas empregadas em um texto, enquanto corpus de análise. Nosso objetivo é observar o sentido construído pelos advérbios na notícia e mostrar que essas escolhas são marcas que desvelam uma subjetividade mesmo em textos que, teoricamente, são objetivos.

Passemos então, primeiramente, às considerações feitas por Émile Benveniste quanto à subjetividade na linguagem.

\section{A subjetividade da linguagem: uma marca explícita?}

Primamos pelo texto $D a$ subjetividade na linguagem, pois é nele que encontramos respostas para nossos questionamentos iniciais. É nesse texto de 1958, publicado no Journal de psychologie, que Benveniste nos explica seu olhar sob a subjetividade e o que, afinal, é ela. Também é nesse texto que reconhecemos quais são as marcas de subjetividade deixadas em um texto e como identificá-las, possibilitando-nos um deslocamento teórico-analítico. A palavra "subjetividade" nos faz pensar em vários significados e nos faz atribuir vários sentidos em diferentes situações; não seria diferente, portanto, o seu uso no texto de Émile Benveniste, que publica essa reflexão em um periódico da área de Psicologia, fato que prova a grandiosidade do 


\title{
PERcursos Linguísticos • Vitória (ES) •v. 11 •n. 29 • 2021 • ISSN: 2236-2592 • Dossiê temático $\bullet O$ texto na pesquisa e no ensino: conhecimentos, práticas e desafios na contemporaneidade •
}

tema e a intertextualidade da Linguística com outras áreas, especialmente, aqui, com a Psicologia.

Benveniste (2005, p. 284) inicia seu texto questionando: se "a linguagem é [...] um instrumento de comunicação, a que deve a ela essa propriedade?" Afirma que, por isso, sua função primeira é a de comunicar, de se fazer entender a outros indivíduos. Porém, logo em seguida, o linguista nos provoca a pensar sobre o uso da palavra "instrumento"; afinal, a linguagem é inerente ao ser humano e não foi criada ou inventada por ele. Nas palavras de Benveniste (2005, p. 285):

\begin{abstract}
Na realidade, a comparação da linguagem com um instrumento, e é preciso realmente que seja com um instrumento material para que a comparação seja pelo menos inteligível, deve encher-nos de desconfiança, como toda noção simplista a respeito da linguagem. Falar de instrumento, é pôr em oposição o homem e a natureza. A picareta, a flecha, a roda não estão na natureza. São fabricações. A linguagem está na natureza do homem, que não a fabricou.
\end{abstract}

Ou seja, nós só encontramos a linguagem no discurso dos falantes, uma vez que a língua só é língua quando enunciada. Por enunciação, trata-se da atividade de "colocar em funcionamento a língua por um ato individual de utilização" (BENVENISTE, 2006, p. 82). Em outras palavras, a enunciação é o ato de colocar a língua em ação, é a língua em sua função primeira: a de comunicar. Dessa forma, não podemos dizer que a linguagem é algo acessório ou que é um instrumento, pois ela faz parte da natureza dos seres humanos. Ao contrário dos instrumentos, que foram inventados, criados ou gerados pelos homens, a língua é inerente ao ser humano: nascemos com essa capacidade de nos comunicar e, por isso, somos seres sociáveis e distintos das outras espécies vivas justamente por termos essa faculdade da linguagem.

Se o homem se comunica com outros homens através da linguagem, é dessa forma e, somente dessa forma, que ele se constitui como sujeito. Somente depois de esclarecer essa relação entre homem e linguagem é que Benveniste nos diz que essa capacidade do locutor de se colocar como sujeito é o que chamamos de subjetividade. A subjetividade, por sua vez, é a maneira pela qual nós, falantes, nos expressamos. Benveniste (2005, p. 286) explica que: "eu não emprego $e u$ a não ser dirigindo-me a alguém, que será na minha alocução um $t u$ ”. Ou seja, nós falamos com outros falantes. Nós, enquanto locutores, propomo-nos como sujeito de nosso dizer à medida que instituímos o outro - enquanto "tu" - como nosso alocutário. É nesse exercício da língua e com a língua que encontramos o fundamento da subjetividade.

Percebemos que a subjetividade é um fator de extrema importância para que haja linguagem, para que a comunicação entre os homens seja possível. Toda vez que eu falo, 


\section{PERcursos Linguísticos • Vitória (ES) •v. 11 •n. 29 • 2021 • ISSN: 2236-2592 • Dossiê temático $\bullet O$ texto na pesquisa e no ensino: conhecimentos, práticas e desafios na contemporaneidade •}

coloco-me no lugar de $e u$ e esse lugar de $e u$ suscita, mesmo que inconscientemente, um $t u$, um interlocutor. É com esse contraste entre $e u$ e $t u$ que a linguagem acontece e que os sujeitos se comunicam.

De fato, a linguagem corresponde a isso em todas as suas partes. É tão profundamente marcada pela expressão da subjetividade que nós nos perguntamos se, construída de outro modo, poderia ainda funcionar e chamar-se linguagem. (BENVENISTE, 2005, p. 287).

Todas as línguas possuem os pronomes pessoais e são com eles que nos expressamos. Porém, “não há conceito de 'eu' englobando todos os $e u$ que se enunciam a todo instante na boca dos falantes" (BENVENISTE, 2005, p. 288), ou seja, não há e não teria como haver um conceito de eu para cada uso individual, e assim acontece com todos os signos da língua. Toda vez que nos apropriamos desse "tesouro virtual depositado no cérebro de cada falante" (CLG, 2012, p. 45), conforme Saussure, para colocar a língua em uso, temos uma nova enunciação. Então, toda vez que falamos "bom dia", falamos de um novo bom dia, de um novo ato enunciativo.

Se o $e u$ pode, então, se referir a um uso em particular e também é usado para se referir a todos os indivíduos em todos os seus usos de forma geral, o que é, afinal, o eu? Benveniste (2005, p. 288) nos responde: " $e u$ se refere ao ato de discurso individual no qual é pronunciado, e lhe designa o locutor." Estamos, portanto, diante de um termo que só é identificado e só faz sentido em seu uso atual, na língua em uso:

\footnotetext{
A realidade à qual ele remete é a realidade do discurso. É na instância de discurso na qual $e u$ designa o locutor que este se enuncia como "sujeito". É portanto verdade ao pé da letra que o fundamento da subjetividade está no exercício da língua. (BENVENISTE, 2005, p. 288).
}

Os pronomes pessoais, portanto, são alguns dos termos que sustentam a subjetividade da linguagem, que, por sua vez, está organizada de forma que "permite a cada locutor apropriarse da língua toda designando-se com eu." (BENVENISTE, 2005, p. 288). Dessa forma, o uso dos pronomes pessoais é uma (e talvez a primeira) marca que deixamos em nossos textos, juntamente com as flexões de verbos, adjetivos, advérbios, outros pronomes e outros termos que revelam a identidade de um texto ou mostram que determinado texto não é totalmente objetivo, como mostraremos, mais adiante, na análise.

Outra marca muito importante para desvelarmos a subjetividade de um texto se refere à sua temporalidade. Sabemos que as línguas, em geral, possuem tempos verbais passado, 


\title{
PERcursos Linguísticos • Vitória (ES) •v. 11 •n. 29 • 2021 • ISSN: 2236-2592 • Dossiê temático $\bullet O$ texto na pesquisa e no ensino: conhecimentos, práticas e desafios na contemporaneidade •
}

presente e futuro, porém sempre usamos como referência temporal o agora, o tempo presente, já que é nesse momento que o acontecimento de um fato e sua narração coincidem. Não poderia, então, ser diferente:

\begin{abstract}
Não há outro critério nem outra expressão para indicar o "tempo em que se estâ" senão tomá-lo como "o tempo que que se fala". Esse é o momento eternamente "presente", embora não se refira jamais aos mesmos acontecimentos de uma cronologia "objetiva" porque é determinado cada vez pelo locutor para cada uma das instâncias de discurso referidas. (BENVENISTE, 2005, p. 289, grifos do autor).
\end{abstract}

Assim dizendo, "a temporalidade humana com todo o seu aparato linguístico revela a subjetividade inerente ao próprio exercício da linguagem" (BENVENISTE, 2005, p. 289). A linguagem contém todas as formas linguísticas adequadas a cada momento e a cada tempo. Essas formas são apropriadas por cada falante na enunciação e, quando a linguagem é posta em discurso, há a possibilidade da subjetividade.

Cada vez que o falante se apropria da língua, ele se refere à sua pessoa, utilizando o eu e incitando um $t u$. Dessa forma e por esse motivo, o eu é uma nova enunciação toda vez em que é usado pelos falantes de uma língua. Assim é constituída a instância do discurso e a categoria de pessoa ("eu" e "tu"): a subjetividade instalada na linguagem. Destacamos que a "subjetividade" tratada neste trabalho diz respeito à capacidade de o locutor se propor como “sujeito". Como diz Benveniste (2005, p. 286): "É 'ego' que diz ego".

Assim, apoiamo-nos nas palavras de Flores (2013): “O homem é homem porque tem linguagem. Opor o homem à linguagem é opô-lo à sua própria natureza". Isso é evidenciado em Benveniste, uma vez que não podemos pensar o homem afastado de sua natureza subjetiva e intersubjetiva, porque é ele constituído pela linguagem. É dessa subjetividade que tratamos aqui.

Para analisarmos como o locutor se marca nos textos que escreve, escolhemos um gênero normalmente tido como objetivo e imparcial: a notícia; e uma marca que nos aponta a escolha do locutor: o advérbio. Passemos, agora, para um breve estudo desse tipo de texto.

\section{A notícia: um texto objetivo?}

Esta seção destina-se a uma reflexão acerca do gênero textual notícia, tomando-o como um texto "objetivo", considerando sua natureza informativa e questionando essa perspectiva do ponto de vista enunciativo.

Gênero textual jornalístico mais conhecido entre a população em geral, a notícia está presente em nosso dia a dia na televisão, no rádio, no jornal impresso, em revistas, nas redes 


\section{PERcursos Linguísticos • Vitória (ES) •v. 11 •n. 29 • 2021 • ISSN: 2236-2592 • Dossiê temático $\bullet O$ texto na pesquisa e no ensino: conhecimentos, práticas e desafios na contemporaneidade •}

sociais e em sites específicos. Trata-se de um gênero não literário de caráter informativo. Seu principal objetivo, portanto, é informar sobre algum acontecimento ocorrido na vida das pessoas que vivem em sociedade. Uma notícia é "normalmente reconhecida como algum dado ou evento socialmente relevante que merece publicação numa mídia" (BENASSI, 2013, p. 1793). As notícias apresentam textos descritivos e/ou narrativos, dando as principais informações sobre o tempo, o espaço e os "personagens” envolvidos.

Eis algumas características desse tipo de texto: os textos são, geralmente, curtos, pois são objetivos e pretendem resumir um fato; a linguagem utilizada é formal e clara, pois o objetivo é fazer com que o leitor entenda as informações rapidamente; os textos apresentam título e subtítulo; o autor, no caso, o jornalista, escreve sempre em terceira pessoa; por fim, o discurso é indireto, ou seja, é o locutor quem conta a história, quem "fala" no lugar dos personagens envolvidos.

A notícia conta fatos recentes e cotidianos, já que, como o próprio nome diz, noticia um fato. A estrutura desse texto é a seguinte: título principal; título auxiliar (subtítulo); lide, que é um parágrafo inicial onde as principais perguntas são respondidas (O quê? Como? Quem? Onde? Quando? Por quê?); corpo da notícia, onde as informações são mais detalhadas. A notícia também apresenta a data de publicação e edição, que é de extrema importância, segundo Benassi (2013, p. 1794), pois "não basta que uma notícia seja verdadeira; é necessário que ela pareça verdadeira. $\mathrm{O}$ relato de fatos numa notícia deve apresentar uma data precisa e a determinação do lugar onde ele ocorreu"; essa informação pode estar logo abaixo do subtítulo ou no final do corpo do texto.

Mas se o gênero notícia é assim tão imparcial e objetivo, será que o locutor se marca, de alguma forma no texto? Se sim, como isso acontece? Passemos agora à análise de uma notícia escolhida pelas autoras.

\section{Uma possibilidade de análise}

Neste momento, propomos uma breve e inconclusa análise de um texto, apontando algumas marcas que podem nos ajudar a olhar um texto tido como notícia e realizar algumas considerações sobre a subjetividade, deslocando a reflexão teórica para uma possível análise textual. O texto foi retirado do portal de notícias de Rede Globo de televisão, G1.com, e se 


\title{
PERcursos Linguísticos • Vitória (ES) •v. 11 •n. 29 • 2021 • ISSN: 2236-2592 • Dossiê temático $\bullet O$ texto na pesquisa e no ensino: conhecimentos, práticas e desafios na contemporaneidade •
}

intitula: "Dia do fogo completa um ano com apenas 5\% dos responsáveis punidos, aponta Greenpeace ${ }^{3 "}$ (Anexo A).

Esse texto consiste em uma notícia sobre o dia do fogo, um evento organizado por fazendeiros da região do Pará para queimar terras. Segundo o site da ONG GreenPeace (2020):

\begin{abstract}
Durante os dias 10 e 11 de agosto de 2019, aconteceu no Pará o que ficou conhecido como "Dia do Fogo", quando produtores rurais da região se mobilizaram para atear fogo na Amazônia. Apenas nesses dois dias, o Instituto Nacional de Pesquisas Espaciais (INPE) detectou 1.457 focos de calor no estado, um aumento de $1.923 \%$ no mesmo intervalo, quando comparado ao ano anterior. Enquanto no dia 9 de agosto foram detectados 101 focos na região, no dia 10 esse número pulou para 715 , um aumento de $707 \%$ de um dia para o outro.
\end{abstract}

Separamos seis trechos do texto que consideramos interessantes e, em seguida, analisamos esses excertos semanticamente para refletir sobre a objetividade ou subjetividade apresentada em cada um. Portanto, essa parte se organiza da seguinte forma: excerto do texto, análise, próximo excerto, análise; e assim sucessivamente.

Pretendemos mostrar algumas marcas da construção de sentido observadas no uso dos advérbios. É sábio que o advérbio acrescenta ou modifica o sentido de uma frase. Além disso, trata-se de um termo acessório, de acordo com a Gramática Tradicional. Assim diz Rocha Lima, em sua Gramática Normativa da Língua Portuguesa, referindo-se a frases com uso de advérbios: "A força emocional dessas frases pode ser tão poderosa, que se chegue a dispensar a presença de qualquer adjetivo" (LIMA, 2018, p. 227). Tendo isso em vista, a escolha de usar o advérbio ou não e de, se usar, qual advérbio escolher para aumentar, modificar ou acrescentar sentido à frase é do autor, é de quem está escrevendo o texto. Acreditamos que é nesse ponto que o locutor "se marca" no texto: nesta escolha pessoal e subjetiva de uso do advérbio, o locutor se propõe como sujeito do seu texto, construindo sentido(s) no texto. Vamos nos deter a essa classe gramatical, mesmo que, como já falamos, as marcas de subjetividade podem ser encontradas em diferentes classes gramaticais, apenas para exemplificar uma (entre as mais diversas) possibilidade de análise.

Iniciamos com o primeiro excerto, retirado do texto em anexo:

Um dia marcado pelo aumento elevado dos focos de incêndio na Amazônia, completa um ano nesta segunda-feira (10), com apenas 5\% dos responsáveis punidos, segundo a ONG Greenpeace.

\footnotetext{
3 Link da notícia: https://g1.globo.com/pa/para/noticia/2020/08/10/dia-do-fogo-completa-um-ano-com-apenas5percent-dos-responsaveis-punidos-aponta-greenpeace.ghtml. Acesso em: 2 ago. 2021.
} 


\section{PERcursos Linguísticos • Vitória (ES) •v. 11 •n. 29 • 2021 • ISSN: 2236-2592 • Dossiê temático $\bullet O$ texto na pesquisa e no ensino: conhecimentos, práticas e desafios na contemporaneidade •}

Destacamos a palavra apenas, que se caracteriza como um advérbio de exclusão. O sentido construído pelo uso desse termo enfatiza o dado que vem em seguida, os $5 \%$ dos responsáveis. Entende-se então que o uso do advérbio apenas significa que o número de responsáveis punidos é muito pequeno, diríamos insignificante, dada a importância do assunto. Seu uso nessa frase é acessório; se não tivéssemos esse termo, entenderíamos do mesmo jeito: “com 5\% dos responsáveis punidos". Portanto, mais uma vez, sua função principal é a de dar ênfase, ou seja, o locutor que o toma como possibilidade de marcar a ênfase acaba se colocando no texto à medida que aponta o olhar do interlocutor para essa informação.

Excerto 2:

"Mesmo com o Dia do Fogo sendo amplamente noticiado na imprensa do mundo inteiro, pouco foi feito para punir os culpados. Das 207 propriedades que registraram queima em floresta nesses dois dias, apenas 5,7\% foram autuadas", revela Rômulo Batista, porta-voz da campanha de Amazônia do Greenpeace Brasil.

Nesse parágrafo, queremos olhar para três termos: amplamente, pouco e apenas. Amplamente é um advérbio e indica que algo foi feito em grande quantidade, neste caso, seu sentido é de que a notícia foi bastante divulgada, ou seja, muitas pessoas ao redor do mundo a viram.

Em seguida, temos o uso advérbio de quantidade pouco, que serve como contraste do primeiro termo destacado, significa em pouca quantidade, em um número muito pequeno. Nesse caso, entendemos que muita coisa poderia e deveria ter sido feita contra esse crime ambiental, mas quase nada se concretizou, pouco foi feito. Portanto, o sentido construído e enfatizado por esses dois termos é dicotômico: mesmo com a grande divulgação do crime, quase nada foi feito para punição dos culpados.

Por fim, temos, novamente, o advérbio apenas, que constrói seu sentido, como no primeiro excerto, enfatizando o dado mostrado em seguida para dizer ao interlocutor que muitas outras propriedades poderiam e deveriam ter sido autuadas, mas somente em $5 \%$ delas aconteceu alguma ação, o que é um número muito pequeno. $\mathrm{O}$ uso desses advérbios, mobilizados pelo locutor do texto, apontam para o fato de direcionar a leitura do interlocutor para o que se comunica na notícia. O locutor propõe-se como sujeito quando mobiliza as formas da língua por sua conta. Instaura-se como "eu" à medida que se refere ao seu ato de discurso individual, em sua instância de discurso. Conforme Benveniste (2005, p. 288), "a realidade à qual ele remete é a realidade do discurso. É na instância de discurso na qual eu designa o locutor 


\section{PERcursos Linguísticos • Vitória (ES) •v. 11 •n. 29 • 2021 • ISSN: 2236-2592 • Dossiê temático $\bullet O$ texto na pesquisa e no ensino: conhecimentos, práticas e desafios na contemporaneidade •}

que este se enuncia como "sujeito"”. Eis aí uma possibilidade de identificarmos a subjetividade presente no texto em análise.

Excerto 3:

Pelo menos 66 deles já possuíam embargos por crimes ambientais anteriores ao Dia do Fogo, e reincidiram no delito.

Nesse trecho, gostaríamos de destacar a expressão pelo menos, que se classifica como uma locução adverbial. O termo possui um sentido de que do número total de proprietários (478), no mínimo, 66 já tinham praticado algum crime, o que é um número bem significativo. Essa informação também nos traz uma ideia de que uma pessoa que já cometeu alguma infração tem grandes chances de cometer de novo, pelo mesmo motivo, como é o caso desses 66 fazendeiros. Ao menos é o que podemos ler, a partir do sentido construído por essa locução empregada pelo locutor do texto.

\section{Excerto 4:}

No final do último mês de julho, uma equipe do Greenpeace sobrevoou a região afetada pelas queimadas do Dia do Fogo. As imagens feitas registram áreas já completamente desmatadas, outras ainda em fase de desmatamento e umas já convertidas em pasto, com atividade pecuária dentro.

Aqui, voltamos nosso olhar para o uso de dois termos: completamente e ainda. $\mathrm{O}$ primeiro é um advérbio usado para nos dizer o modo como as regiões ficaram depois do Dia do Fogo: completamente desmatadas. Ou seja, não foi uma parte da região, não foi $50 \%$, não foi quase toda destruída, ela foi desmatada completamente. $\mathrm{O}$ uso desse termo complementa o sentido e enfatiza a ação feita. Com esse advérbio, fica claro para o leitor que $100 \%$ do espaço foi desmatado.

A segunda forma linguística em negrito é o advérbio de tempo ainda, usado para dizer ao leitor que há outras áreas que não foram completamente desmatadas, como as primeiras, mas estas estão em fase de destruição, permanecem sendo desmatadas, ou seja, elas estão ainda em processo de desflorestação. Aqui temos uma marca que evidencia a temporalidade do dizer do locutor. Agora, "ainda" em fase de desmatamento. É a instância de discurso de quem fala. De quem usa a língua. De quem se propõe como sujeito do dizer. De quem se coloca no texto, ou seja, "a temporalidade humana com todo seu aparato linguístico revela a subjetividade inerente ao próprio exercício da linguagem". 


\title{
PERcursos Linguísticos • Vitória (ES) •v. 11 •n. 29 • 2021 • ISSN: 2236-2592 • Dossiê temático $\bullet O$ texto na pesquisa e no ensino: conhecimentos, práticas e desafios na contemporaneidade •
}

\section{Excerto 5:}

Somente os municípios de Novo Progresso, Itaituba, Altamira, São Félix do Xingu, Jacareacanga e Trairão foram responsáveis por $79 \%$ dos focos detectados no Pará em todo o mês de agosto. O recorde de queimadas foi sentido, inclusive, em São Paulo, quando o dia escureceu completamente às $15 \mathrm{hs}$, no dia 19 de agosto.

Sobre esse trecho, destacamos o uso de dois termos: somente e completamente. O primeiro se caracteriza como um advérbio de exclusão e funciona de maneira parecida com apenas. O sentido construído nesse uso é de que unicamente esses seis municípios citados foram os responsáveis por quase todos os focos em todo o estado. Sua função também é de enfatizar o dado mostrado em seguida, que já é, por si só, alarmante.

O segundo termo destacado, completamente, é um termo acessório para o entendimento da informação que o locutor quer passar, mas essencial para a construção do sentido da frase. Assim como seu uso no excerto 4, aqui também se destaca que o dia não ficou semi-iluminado ou com pouca luz, mas ficou totalmente escuro; um fato, com certeza, peculiar e raro de acontecer.

Percebemos que as marcas somente e completamente trazidas como exemplo são formas vazias, como defende Benveniste. Elas se preenchem de sentido nesse contexto e nessa instância de discurso, construída pelo locutor que se propõe como sujeito. Apoiamo-nos nas palavras de Benveniste (2005, p. 289):

\begin{abstract}
A linguagem é, pois, a possibilidade da subjetividade, pelo fato de conter sempre as formas linguísticas apropriadas à sua expressão; e o discurso provoca a emergência da subjetividade, pelo fato de consistir de instâncias discretas. A linguagem de algum modo propõe formas 'vazias' das quais cada locutor em exercício de discurso se apropria $[\ldots]$
\end{abstract}

\section{Excerto 6:}

Além disso, 580 focos de calor, o que representa 39,8\% do total, foram registrados em área de floresta e cerca de 32,8\% em áreas desmatadas.

Por fim, observamos o uso da expressão além disso, que é uma locução adverbial. Tratase de uma expressão usada para acrescentar algo ao que já foi dito. $\mathrm{O}$ texto evidencia diversas informações tristes e números preocupantes sobre o desmatamento, porém o locutor nos traz mais dados ainda. Este é o sentido da expressão: além de tudo o que já foi dito, ainda há mais dados e mais números assustadores. Essas informações são colocadas em cena pelo locutor que 


\section{PERcursos Linguísticos • Vitória (ES) •v. 11 •n. 29 • 2021 • ISSN: 2236-2592 • Dossiê temático $\bullet O$ texto na pesquisa e no ensino: conhecimentos, práticas e desafios na contemporaneidade •}

se propõe como sujeito de seu dizer, ou seja, a (sua) subjetividade é inerente ao próprio exercício da linguagem.

Todos os termos analisados servem para apoiar o sentido já trazido pelas outras informações das frases, mas sem esses termos, o leitor talvez não entenderia a gravidade da situação e não seria conduzido a chegar à conclusão, no final, de que o "Dia do fogo" trouxe desastres para o equilíbrio ambiental da região e causou fatos até irreversíveis. Isso construído e assumido pelo homem que fala, quando exercita a linguagem que lhe é própria, que é de sua natureza.

\section{Considerações finais}

Feito este estudo teórico com base nos pressupostos da teoria benvenistiana e analisando os advérbios de uma notícia, nossa conclusão parte de um pressuposto: não há texto neutro/imparcial e o sujeito que escreve sempre deixará suas marcas, de uma maneira ou de outra, através de pronomes, adjetivos, advérbios, ou seja, no arranjo que faz quando usa a língua.

Esperamos compartilhar este estudo com as demais áreas do conhecimento para que o mito do "texto neutro" seja desfeito e para que as pessoas entendam que não existe um texto totalmente e somente objetivo. Afinal, o modo como o falante usa a língua denuncia uma falta de objetividade, pois o locutor se apropria da língua para comunicar, e faz isso do seu jeito que é um jeito diferente do que qualquer outro sujeito faria. Nossa subjetividade está marcada nas nossas falas e escritas, pois nos apropriamos da língua e nos propomos como sujeitos quando a colocamos em uso.

Assim, destacamos que os sentidos são sempre únicos e irrepetíveis, a depender do modo como o sujeito imprime sua subjetividade quando toma a língua e a emprega de seu modo. Dessa forma, o sentido é dado pelo discurso, e não a priori. Os valores dos signos somente podem ser instituídos no instante em que o sujeito se apropria da língua em um ato enunciativo aqui e agora, sempre inéditos. Sublinhamos que os valores atribuídos aos advérbios selecionados para esta análise somente foram construídos nesta enunciação, pelo modo como eles se relacionam, por suas diferenças e por suas funções na constituição do próprio discurso. Isso evidencia que, para observar os sentidos de certas formas da língua, é preciso pensar no processo subjetivo inerente ao próprio uso da língua.

Sem dúvida, um maior número de análises, com maior aprofundamento teórico, possibilita chegar a evidências acerca da presença da subjetividade em textos que se querem 


\section{PERcursos Linguísticos • Vitória (ES) •v. 11 •n. 29 • 2021 • ISSN: 2236-2592 • Dossiê temático $\bullet O$ texto na pesquisa e no ensino: conhecimentos, práticas e desafios na contemporaneidade •}

objetivos. Fica aqui uma provisória tentativa de ver como o sentido se constrói no discurso, a partir da apropriação do sistema da língua por um locutor, ou melhor, por um homem que está na língua, a cada vez único e singular.

\section{Referências}

AZEVEDO, Gabriela. Dia do Fogo completa um ano com apenas 5\% dos responsáveis punidos, aponta Greenpeace. G1 Pará, Belém, 10 ago. 2020. Disponível em: https://g1.globo.com/pa/para/noticia/2020/08/10/dia-do-fogo-completa-um-ano-com-apenas5percent-dos-responsaveis-punidos-aponta-greenpeace.ghtml. Acesso em: 10 ago. 2021.

BENASSI, Maria Virginia Brevilheri. O gênero "notícia": uma proposta de análise e intervenção. In: CELLI - COLÓQUIO DE ESTUDOS LINGUÍSTICOS E LITERÁRIOS. 3, 2007, Maringá. Anais... Maringá, 2009, p. 1791-1799.

BENVENISTE, Émile. Problemas de linguística geral I. 5. ed. Campinas: Pontes, 2005.

BENVENISTE, Émile. Problemas de linguística geral II. 2. ed. Campinas: Pontes, 2006.

DIA DO FOGO COMPLETA UM ANO, COM LEGADO DE IMPUNIDADE. Greenpeace. Disponível em: https://www.greenpeace.org/brasil/florestas/dia-do-fogo-completa-um-anocom-legado-de-impunidade/. Acesso em: 2 ago. 2021.

FLORES, Valdir do Nascimento. Sujeito da enunciação: singularidade que advém da sintaxe da enunciação. D.E.L.T.A., v. 29, n. 1, p. 95-120. 2013. Disponível em: https://revistas.pucsp.br/index.php/delta/article/view/8623/14338. Acesso em: 2 ago. 2021.

GREENPEACE. Dia do fogo completa um ano, com legado de impunidade. 2020. Disponível em: https://www.greenpeace.org/brasil/florestas/dia-do-fogo-completa-um-ano-com-legadode-impunidade/. Acesso em: 2 ago. 2021.

LIMA, Rocha. Gramática normativa da língua portuguesa. 54. ed. Rio de Janeiro: José Olympio, 2018.

SAUSSURE, Ferdinand de. Curso de linguística geral. 28. ed. São Paulo: Cultrix, 2012. 


\section{PERcursos Linguísticos • Vitória (ES) •v. 11 •n. 29 • 2021 • ISSN: 2236-2592 • Dossiê \\ temático $\bullet O$ texto na pesquisa e no ensino: conhecimentos, práticas e desafios na contemporaneidade •}

\section{Anexo A}

\section{Dia do fogo completa um ano com apenas $5 \%$ dos responsáveis punidos, aponta Greenpeace}

ONG aponta que as ações do Dia do Fogo resultaram em 53 focos de calor dentro de Terras Indígenas e 534 em Unidades de Conservação

Por Gabriela Azevedo, G1 PA — Belém 10/08/2020 13h29 Atualizado há uma hora

Um dia marcado pelo aumento elevado dos focos de incêndio na Amazônia, completa um ano nesta segunda-feira (10), com apenas 5\% dos responsáveis punidos, segundo a ONG Greenpeace. O "Dia do Fogo" foi promovido por fazendeiros no Pará para gerar queimadas ilegais em diversos pontos da região, em agosto de 2019.

$\mathrm{Na}$ época, a mobilização foi denunciada por um jornalista de Novo Progresso, sudoeste do Estado. A Polícia Federal começou a investigar o caso após determinação do Ministério da Justiça e Segurança Pública. A investigação apontou que ação foi planejada em grupos de mensagens com fazendeiros, empresários e produtores rurais que teriam promovido as queimadas em áreas de unidades de conservação.

Em dois dias, o Instituto Nacional de Pesquisas Espaciais (INPE) detectou 1.457 focos de calor no estado, um aumento de $1.923 \%$ no mesmo período do ano anterior. O crescimento elevado também foi registrado de um dia para o outro. Enquanto no dia 9 de agosto, 101 focos foram detectados na região, no dia 10 o número pulou para 715, o que representa um aumento de $707 \%$ no número de queimadas.

"Mesmo com o Dia do Fogo sendo amplamente noticiado na imprensa do mundo inteiro, pouco foi feito para punir os culpados. Das 207 propriedades que registraram queima em floresta nesses dois dias, apenas 5,7\% foram autuadas", revela Rômulo Batista, porta-voz da campanha de Amazônia do Greenpeace Brasil.

De acordo com o Instituto Brasileiro do Meio Ambiente e dos Recursos Naturais Renováveis (Ibama), durante o último ano foram realizados 25 autos de infração devido a crimes ambientais na Amazônia. Esses autos foram traduzidos em R \$ 11 milhões em multas para os cofres da União.

\section{Propriedades identificadas}

O Greenpeace Brasil fez um levantamento com os Cadastros Ambientais Rurais (CAR) dos municípios de Novo Progresso, São Félix do Xingu Itaituba, Altamira, Jacareacanga e Trairão - atualizados pela última vez em fevereiro de 2020 - e identificou que quase metade dos focos de calor ocorridos no Dia do Fogo aconteceram dentro de propriedades rurais cadastradas no sistema fundiário do Pará. 


\section{PERcursos Linguísticos • Vitória (ES) •v. 11 •n. 29 • 2021 • ISSN: 2236-2592 • Dossiê \\ temático $\bullet O$ texto na pesquisa e no ensino: conhecimentos, práticas e desafios na contemporaneidade •}

A partir do cadastro, é possível identificar os proprietários dos 478 imóveis que tiveram focos de calor no dia da ação. As informações podem ser consultadas pelo sistema público da Secretaria de Estado de Meio Ambiente e Sustentabilidade do Pará (Semas/PA).

Pelo menos 66 deles já possuíam embargos por crimes ambientais anteriores ao Dia do Fogo, e reincidiram no delito. Destes imóveis, 99,37\% já apresentava traços de pastagem mapeados e classificados pelo MapBiomas em 2018.

\section{Áreas devastadas}

No final do último mês de julho, uma equipe do Greenpeace sobrevoou a região afetada pelas queimadas do Dia do Fogo. As imagens feitas registram áreas já completamente desmatadas, outras ainda em fase de desmatamento e umas já convertidas em pasto, com atividade pecuária dentro.

Em agosto de 2019 foi registrado o maior índice de focos de calor na Amazônia para o mês desde 2010. Somente os municípios de Novo Progresso, Itaituba, Altamira, São Félix do Xingu, Jacareacanga e Trairão foram responsáveis por $79 \%$ dos focos detectados no Pará em todo o mês de agosto. O recorde de queimadas foi sentido, inclusive, em São Paulo, quando o dia escureceu completamente às $15 \mathrm{hs}$, no dia 19 de agosto.

De acordo com o levantamento do Greenpeace, as ações do Dia do Fogo resultaram em 53 focos de calor dentro de Terras Indígenas e 534 em Unidades de Conservação. Além disso, 580 focos de calor, o que representa 39,8\% do total, foram registrados em área de floresta e cerca de $32,8 \%$ em áreas desmatadas. 


\title{
CONTRIBUIÇÕES DA REFERENCIAÇÃO PARA O ENSINO- APRENDIZAGEM DE LÍNGUA PORTUGUESA, COM ÊNFASE NA NATUREZA ARGUMENTATIVA DA LINGUAGEM
}

\author{
CONTRIBUTION OF REFERENTIALITY TO PORTUGUESE \\ TEACHING AND LEARNING, EMPHASIZING THE \\ ARGUMENTATIVE NATURE OF LANGUAGE
}

\author{
Valdinar Custódio Filho ${ }^{1}$
}

\begin{abstract}
Resumo: Este artigo tem como objetivo mais amplo propor uma reflexão sobre as relações entre linguística textual e ensino e aprendizagem de língua portuguesa. Parte-se do postulado assumido pela linguística textual praticada no Brasil na atualidade, que compreende a argumentação como um processo inerente à linguagem, já que em todos os textos há um direcionamento do locutor para mudar, em algum nível, o estado do interlocutor (CAVALCANTE et al., 2020). Com base nisso, elegemos o processo da referenciação como estratégia a ser explorada em práticas pedagógicas, propondo uma análise de duas atividades em que a construção da coerência passa pela percepção da argumentatividade dos referentes. Acreditamos que as atividades sugeridas se pautam pela promoção do aprendizado eficaz, no plano tanto da visada argumentativa quanto da dimensão argumentativa (AMOSSY, 2011). Além disso, ao levar em conta a ação do aprendiz sobre os textos, em vez de se ligar ao caráter meramente expositivo de mecanismos de coesão referencial, essas atividades permitem a renovação (a nosso ver, urgente) do trabalho pedagógico com estratégias de textualização.
\end{abstract}

Palavras-chave: Referenciação. Argumentação. Ensino de língua portuguesa.

\begin{abstract}
The broader purpose of this article is to suggest a reflection about the relation between text linguistics and Portuguese teaching and learning. It puts as a starting point the postulate assumed by text linguistics that takes place in Brazil nowadays, which comprehends argumentation as an inherent process of any language, once all texts have a direction, posed by locutors, to change, at some level, the interlocutor's state of being (CAVALCANTE at al., 2020). Based on this, we elect the process of referentiality as the strategy to be explored in pedagogical practices, proposing an analysis of two activities in which the building of coherence depends on the argumentative perception of the referents. We believe that these activities show the promotion of effective learning, in both the levels of argumentative aim and argumentative dimension (AMOSSY, 2011). Furthermore, these activities, taking account the apprentice action over texts, instead of putting attention only to the merely expositive view of mechanisms of referential cohesion, aloud the renovation (urgent, in our opinion) of the pedagogical work with textualization strategies.
\end{abstract}

Keywords: Referentiation. Argumentation. Portuguese Teaching.

\section{Introdução}

\footnotetext{
${ }^{1}$ Professor do Curso de Letras do Centro de Humanidades da Universidade Estadual do Ceará, Fortaleza-CE, Brasil. E-mail: valdinar.filho@uece.br.
} 


\section{PERcursos Linguísticos • Vitória (ES) •v. 11 •n. 29 • 2021 • ISSN: 2236-2592 • Dossiê temático $\bullet O$ texto na pesquisa e no ensino: conhecimentos, práticas e desafios na contemporaneidade •}

Nas discussões sobre ensino de língua portuguesa realizadas nas últimas quatro décadas no Brasil ${ }^{2}$, tem-se salientado a importância de as práticas de aprendizagem tomarem como elemento central o texto, entendido como instanciação das semioses e da interação na qual diversos aspectos - discursivos, interacionais, pragmáticos, cognitivos, gramaticais, semióticos - confluem para que haja a produção e compreensão de sentidos. Falar de texto, obviamente, pressupõe, em princípio, considerar um conjunto de perspectivas teóricas calcadas na enunciação, que tomam como ponto de partida a explicação dos fenômenos de linguagem com base no uso efetivo de enunciados, atrelados a sujeitos ancorados numa situação sócio-histórica. Dentre essas perspectivas, a linguística textual (doravante LT) desponta com proeminência, ao considerar um conjunto de parâmetros analíticos simultaneamente singulares e interdisciplinares ${ }^{3}$ como elementos responsáveis pela instauração da coerência.

Com a raiz fincada na LT (particularmente, a LT praticada no Brasil), este trabalho propõe uma reflexão sobre possíveis contribuições da perspectiva teórica da referenciação para o trabalho pedagógico com vistas a desenvolver as habilidades de argumentação de aprendizes na educação básica. Há, portanto, três eixos teóricos definidores do percurso que será trilhado aqui: argumentação, referenciação e ensino.

No que toca à argumentação, pautamo-nos pela proposta de Cavalcante et al. (2020), que estabelece uma interface entre a LT brasileira e a teoria da argumentação no discurso, de Amossy (2011, 2017), a fim de sustentar que o aspecto argumentativo da linguagem é a condição primeira para a ocorrência do processo interacional mediado por textos.

No que diz respeito à referenciação, consideramos a proeminência do fenômeno como estratégia textual-discursiva para a construção da coerência (CAVALCANTE, CUSTÓDIO FILHO e BRITO, 2014), a partir do que os objetos de discurso (ou referentes) construídos na interação revelam o trabalho de interlocutores que lidam com a materialidade semiótica e com as várias instâncias intervenientes nessa materialidade.

No que tange ao ensino ${ }^{4}$, propomos uma breve discussão sobre o modo como a referenciação costuma aparecer em livros didáticos de língua portuguesa, para sugerirmos que esse trabalho precisa passar por uma renovação que faça jus à produção de conhecimento na

\footnotetext{
${ }^{2}$ Alguns expoentes dessa discussão são Geraldi (1997), Antunes (2003, 2010), Koch e Elias (2006, 2009, 2018) e Suassuna (1995).

${ }^{3}$ Para considerações sobre o conceito de texto como objeto científico da LT e as relações interdisciplinares estabelecidas na área, sugerimos a leitura de Cavalcante e Custódio Filho (2010), Cavalcante et al. (2016) e Cavalcante et al. (2019).

${ }^{4}$ Caberia, ainda, propor uma reflexão sobre a relação entre a LT e prática docente, especialmente em cotejo com a Base nacional comum curricular (BRASIL, s/d). Em virtude da limitação de espaço, deixamos a discussão para outra ocasião.
} 


\section{PERcursos Linguísticos • Vitória (ES) •v. 11 •n. 29 • 2021 • ISSN: 2236-2592 • Dossiê temático $\bullet O$ texto na pesquisa e no ensino: conhecimentos, práticas e desafios na contemporaneidade •}

área, que avançou bastante em relação às primeiras considerações sobre coesão referencial (KOCH, 1999).

Cada um desses eixos responde por uma seção deste artigo, ao que posteriormente se acrescenta uma seção analítica na qual se discute a pertinência de duas atividades pedagógicas focadas em habilidades atinentes à construção de referentes, compreendida como processo argumentativo constitutivo das práticas de compreensão e produção.

\section{Linguística textual e argumentação - o panorama atual}

A linguística textual tem uma tradição de propor a análise de seus fenômenos com vistas a apontar características argumentativas. Apotheloz e Reichler-Béguelin (1995), por exemplo, em seu texto seminal sobre a recategorização referencial, falam em uma eventual função argumentativa das recategorizações lexicais explícitas. Do mesmo modo, Koch (2005, p. 3435) diz que "O sujeito, por ocasião da interação verbal, opera sobre o material linguístico que tem à sua disposição, realizando escolhas significativas para representar estados de coisas, com vistas à concretização de sua proposta de sentido" (grifo nosso).

Para além da referenciação, outros trabalhos em LT dos anos 2000 e dos anos 2010 dissertam sobre a natureza argumentativa das intertextualidades (KOCH, BENTES e CAVALCANTE, 2007, FORTE, 2013, CARVALHO, 2018), dos mecanismos de articulação (KOCH e ELIAS, 2018), bem como a possibilidade de construção de quadros tópicos de textos com sequência argumentativa predominante ${ }^{5}$ (SÁ, 2018).

Em muitos desses e em outros estudos, entende-se que as diversas estratégias de textualização apresentam uma função argumentativa, a qual revela determinado ponto de vista ${ }^{6}$, do locutor ou de alguma instância por ele acionada para compor o texto. Nesse viés, a argumentação ocupa um papel subordinado à estratégia. Por exemplo, quando, nessa perspectiva, afirma-se que uma expressão referencial pode assumir um papel argumentativo (como se vê em CAVALCANTE, CUSTÓDIO FILHO e BRITO, 2014), mostra-se que, em alguns casos, o caráter explicitamente avaliativo da expressão contribui para a construção argumentativa do texto.

Nos últimos cinco anos, a LT praticada no Brasil tem defendido uma conexão forte entre os parâmetros analíticos da disciplina e os pressupostos da teoria da argumentação no discurso

\footnotetext{
${ }^{5} \mathrm{O}$ estudo sobre as sequências textuais (inclusive a argumentativa) se encontra em Adam (2019).

${ }^{6}$ Para uma compreensão mais específica do conceito de ponto de vista, sugerimos a leitura de Cortez e Koch (2013).
} 


\section{PERcursos Linguísticos • Vitória (ES) •v. 11 •n. 29 • 2021 • ISSN: 2236-2592 • Dossiê temático $\bullet O$ texto na pesquisa e no ensino: conhecimentos, práticas e desafios na contemporaneidade •}

$(\mathrm{TAD})^{7}$. Essa postura provoca uma modificação na compreensão sobre o papel da argumentação nas investigações da área. A partir dessa configuração, Cavalcante et al. (2020, p. 30) afirmam que "todo discurso tende a orientar os modos de ver, de pensar e de sentir dos interlocutores"8. Isso implica que a razão de ser de todo texto se assenta na condição de que há um projeto de dizer constitutivamente argumentativo. O locutor que lança mão de um texto, portanto, pretende, em última instância, gerar um ou mais efeitos no interlocutor.

O que o novo paradigma aponta é que a argumentação é bem mais que uma função textual. Não se trata mais de investigar como os fenômenos que competem para a construção da coerência podem ter feição menos ou mais evidentemente argumentativa. Trata-se de compreender que a natureza constitutivamente argumentativa da linguagem define a construção da coerência, por meio da mobilização de estratégias acionadas para promover a interação, o que implica a participação de sujeitos que querem alguma(s) coisa(s) uns dos outros. Para nós, esse modo de encarar o texto, como objeto de pesquisa da LT, gera um conjunto de reflexões que, ao mesmo tempo em que perpetuam a tradição de ligar a LT à argumentação, garantem o avanço científico na medida em que há novas problematizações, novas perguntas teóricas e novos modos de buscar respostas.

Neste artigo, destacamos duas condições decorrentes desta perspectiva: a distinção entre visada argumentativa e dimensão argumentativa, e a agentividade dos sujeitos sociais. Aqui, apresentamos uma breve reflexão teórica sobre essas condições; posteriormente, na seção de análise, elas retornam, como elementos que podem/devem estar presentes na construção de atividades pedagógicas.

Sobre a visada e a dimensão argumentativa, Cavalcante et al. (2020, p. 30), partindo de Amossy, explicam que, "Na visada argumentativa, há estratégia programada de persuasão, pois o objetivo do locutor ao produzir um texto que comporte essa visada é levar o interlocutor a aderir à sua opinião ou tese sobre o tema debatido". Há textos de visada argumentativa entre os gêneros reconhecidos como predominantemente argumentativos. Por exemplo, os textos cujos títulos aparecem a seguir apresentam visada argumentativa.

(1)

Figura 1 - títulos e subtítulos de textos com visada argumentativa

\footnotetext{
${ }^{7}$ Essa interface tem sido difundida especialmente pelos membros do Grupo Protexto, da Universidade Estadual do Ceará (UFC).

${ }^{8}$ A mesma visão encontra-se em Cavalcante et al. (2019).
} 


\title{
PERcursos Linguísticos • Vitória (ES) •v. 11 •n. 29 • 2021 • ISSN: 2236-2592 • Dossiê temático $\bullet O$ texto na pesquisa e no ensino: conhecimentos, práticas e desafios na contemporaneidade •
}

\author{
RICARDO VOLPE E EUGÊNIO GREGGIANIN \\ O teto de gastos deve ser suspenso \\ temporariamente para reforçar as \\ medidas de combate à pandemia? \\ NÃO \\ Propósito é garantir a estabilidade, inclusive para as \\ futuras geraçöes \\ SIMONE DEOS E BRUNO CARAMELLI \\ 0 teto de gastos deve ser suspenso \\ temporariamente para reforçar as \\ medidas de combate à pandemia? SIM \\ Regra é disfuncional, e sabemos que os efeitos da \\ crise se estenderão
}

Fonte: Folha de São Paulo. Disponível em https://www1.folha.uol.com.br/opiniao/. Acesso em 12 abr. 2021.

Os textos correspondentes aos títulos fazem parte de uma seção do jornal Folha de São Paulo chamada "Tendências/Debates". Alguns dos textos dessa seção surgem de uma pergunta que o jornal lança e cuja resposta - sim ou não - equivale a uma tese. No caso ilustrado, um dos textos defenderá que "O texto de gastos deve ser suspenso temporariamente para reforçar os meios de combate à pandemia", e o outro defenderá a tese contrária. A coerência de cada um será construída por meio de uma organização a qual revele estratégias garantidoras do valor da tese defendida. A visada se encontra, justamente, nessa organização com vistas a construir a pertinência de uma tese.

Também há visada argumentativa no exemplo a seguir.

(2)

Figura 2 - exemplo de visada argumentativa em charge

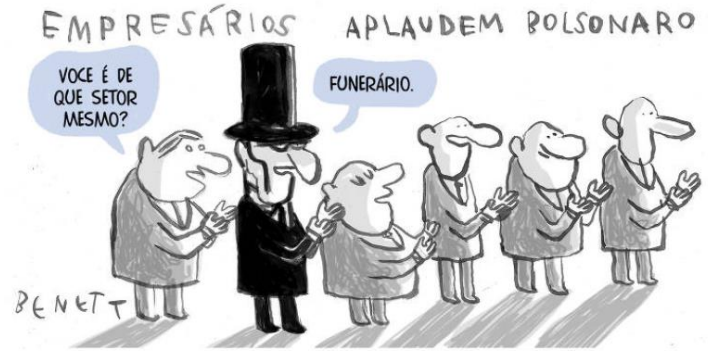

Fonte: Folha de São Paulo. Disponível em https://fotografia.folha.uol.com.br/galerias/1695890190757786-charges-abril-2021. Acesso em 12 abr. 2021.

A charge do exemplo (2) toma como mote a notícia de que alguns empresários aplaudiram o presidente Jair Bolsonaro durante um jantar em abril de 2021, época em que o Brasil passava por um momento crítico da pandemia pelo coronavírus, com números diários de 


\title{
PERcursos Linguísticos • Vitória (ES) •v. 11 •n. 29 • 2021 • ISSN: 2236-2592 • Dossiê temático $\bullet O$ texto na pesquisa e no ensino: conhecimentos, práticas e desafios na contemporaneidade •
}

mortes e infecções bastante elevados. A presença de um "empresário" do setor funerário gera o humor do texto e remete à ideia de que as ações do governo federal, associadas (obviamente) à figura do presidente, ocasionaram inúmeras mortes. Logo, há uma visada argumentativa, traduzida pela tese de que os empresários que aplaudem o presidente compactuam com esse quadro.

Já a dimensão argumentativa

\begin{abstract}
aparece na verbalização que produz um discurso ${ }^{9}$ cujo objetivo declarado é outro e não o argumentativo: um discurso de informação, uma descrição, uma narração cuja vocação é contar o registro de uma experiência vivida em um diário de viagem ou um diário, um testemunho que relata o que o sujeito viu, uma conversa familiar em que os parceiros jogam conversa fora sem a pretensão de fazer triunfar uma tese etc. Portanto, o que é importante é identificar e analisar a maneira como esses discursos destinados a, antes de tudo, informar, escrever, narrar, testemunhar, direcionam o olhar do alocutário para fazê-lo perceber as coisas de uma certa maneira. (AMOSSY, 2011, p. 132, grifo nosso)
\end{abstract}

Há dimensão argumentativa, por exemplo, no vídeo “Amiga falsa no Facebook!”. Nesse esquete, a personagem fala em voz alta enquanto acessa a sua conta de Facebook. A seguir, transcrevemos o trecho inicial dessa fala.

(3) Deixa eu ver aqui... Olha aí o Facebook da demônia! Essa minha amiga é ridícula mesmo, viu? Posta foto no Face como se tivesse (sic) a coisa mais linda do mundo. Se maqueia (sic) mal pra caramba, pelo amor de Deus, parece que levou duas chineladas na cara. O pessoal pensa que bochecha é boca e blush é batom. Hah, é o jeito que tem eu comentar, né? [digita no notebook] "Linda, linda. Coisa linda, ave maria, tá linda demais".

Disponível em https://www.youtube.com/watch?v=hwIqFY5u62c. Acesso em 25 set. 2021.

O exemplo (3), como parte de uma narrativa, não tem a "pretensão de fazer triunfar uma tese", mas mostra uma perspectiva do locutor que tem como objetivo gerar um efeito no interlocutor. Ao mostrar que a personagem faz um comentário (já que "é o jeito") falso na conta de Facebook de uma amiga, pretende-se, por meio do humor, criticar o comportamento recorrente de fazer comentários elogiosos em excesso, que decorrem mais de uma convenção social (comentar fotos de amigos) do que da expressão de uma admiração sincera. Essa crítica embutida na narrativa mostra que, no final das contas, a argumentação está por trás da construção de todo texto, e não apenas na construção de textos evidentemente persuasivos.

Uma vez que o ponto de partida dos textos é uma proposta argumentativa - seja como persuasão direta, seja como persuasão indireta - tem-se que os participantes da interação

\footnotetext{
${ }^{9}$ Em muitos casos (como nessa citação), o que Amossy chama de "discurso" equivale, para muitos teóricos da LT, a "texto".
} 


\section{PERcursos Linguísticos • Vitória (ES) •v. 11 •n. 29 • 2021 • ISSN: 2236-2592 • Dossiê temático $\bullet O$ texto na pesquisa e no ensino: conhecimentos, práticas e desafios na contemporaneidade •}

(locutor e seu(s) interlocutor(es)) assumem papéis que demandam, em algum nível, uma ação estratégica. É nesse sentido que a LT concebe, diferentemente de concepções que apontam para o assujeitamento, que "os sujeitos têm algum poder de mudar a realidade, por isso é possível observar os empreendimentos argumentativos na conjuntura do espaço social regrado por normas institucionais" (CAVALCANTE et al, 2020, p. 15, grifo nosso.).

Há agentividade, por exemplo, quando Ricardo Volpe, Eugênio Greggianin, Simone Deos e Bruno Caramelli (exemplo (1)), instados a defender uma tese sobre a relação entre o teto de gastos e o financiamento de medidas de combate à pandemia, selecionam os argumentos (e o modo de apresentá-los) que figurarão em seus textos, os quais "acontecem" num momento específico da realidade brasileira. Do mesmo modo, o chargista Bennet (exemplo (2)), ao criar uma cena fictícia para o jantar do presidente Bolsonaro com empresários, cria um texto único, com uma voz que reverbera um pensamento compartilhado, mas que tem uma realização singular. Também o criador do esquete sobre comentários no Facebook (exemplo (3)) aborda o assunto a partir de um modo de ver que ganha corpo com a materialidade estruturada por ele.

Nos casos aqui exemplificados, os sujeitos são agentes não porque trazem teses ou pontos de vista originais, mas porque, ao proporem interações (no plano da visada ou da dimensão argumentativa), atualizam temas já conhecidos por meio de um produto singular. Nesse movimento, há campo para se propor a mudança da realidade, seguindo-se o propósito primeiro de provocar algum tipo de reação no interlocutor.

A LT muito tem a contribuir com essa perspectiva de argumentação, na medida em que suas categorias de análise são motivadas "por uma tentativa de explicação para as escolhas textuais pelas quais o sujeito age sobre seu dizer, reelaborando-o a todo instante, negociando-o com os prováveis interlocutores (em seus papéis sociais), para buscar atender a seus propósitos" (CAVALCANTE et al., 2020, p. 15). As instâncias textual-discursivas e os fenômenos que competem para a construção de uma materialidade dotada de sentido são, portanto, elementos evidenciadores do trabalho argumentativo, e é a partir desse viés que devem estar presentes nas práticas de aprendizagem.

\section{Referenciação e argumentação}

A referenciação consiste numa abordagem teórica que investe na condição da referência textual como ação dos interlocutores. Partindo do pressuposto de que o papel primordial da linguagem é permitir que os interlocutores construam versões negociadas da realidade (MONDADA e DUBOIS, 2003), tem-se que os referentes são elaborações, instanciadas no 


\section{PERcursos Linguísticos • Vitória (ES) •v. 11 •n. 29 • 2021 • ISSN: 2236-2592 • Dossiê temático $\bullet O$ texto na pesquisa e no ensino: conhecimentos, práticas e desafios na contemporaneidade •}

texto, que possibilitam aos sujeitos da interação promoverem os sentidos das entidades sobre as quais querem/devem/podem falar. Essas entidades são mostradas de acordo com as possibilidades traçadas pela dinâmica sociodiscursiva em que se encontram.

Esse processo de reelaboração e negociação leva-nos a compreender que os referentes são objetos dinâmicos, passando por modificações dentro de um texto, as chamadas recategorizações ${ }^{10}$. Podemos ver como isso se efetiva a partir da análise do exemplo a seguir.

Trata-se de uma cena de O livro de Henrique, ficção histórica que tem como fio condutor o rompimento, no século XVI, da Inglaterra com o catolicismo europeu vigente e a consequente criação da religião anglicana. Na cena em questão, Henrique VIII, rei da Inglaterra, descobriu recentemente que sua segunda esposa, Ana Bolena, teria cometido adultério, com alguns membros da corte real. Henrique conversa sobre isso com Thomas Cromwell, seu braço direito.

(4)

- Cromwell, o que significa isso, quando uma mulher não consegue sossegar na cama? Oferecendo-se, de todas as maneiras? O que se passa em sua cabeça para fazer uma coisa dessas? [...] Uma única maneira é aquela apta para a procriação de filhos. A Santa Igreja sanciona essa maneira nos dias permitidos. Temo que qualquer homem ou mulher cristã que esteja escravo desses vícios [hábitos sexuais não sancionados pela Igreja] incorrerá em julgamento: o que você diria? Onde uma mulher que não foi criada em um prostíbulo poderia adquirir conhecimento de tais coisas?

- As mulheres conversam entre si - responde Cromwell. Como os homens.

- Mas uma matrona sóbria, religiosa, cujo único dever é ter um filho?

- Suponho que ela talvez queira alimentar o interesse de seu bom esposo, senhor. Para que ele não se aventure no Jardim de Paris ou algum outro lugar de má reputação. Se, digamos, estão casados há muito tempo.

- Mas três anos? Isso é muito?

- Não, senhor.

- Não faz nem três. - Por um momento, o rei esquece que não estamos falando dele, mas de um hipotético inglês temente a Deus, um homem dos bosques ou da lavoura. — Onde ela teria a ideia? — persiste ele. — Como saberia que o homem iria gostar?

Ele engole a resposta óbvia: talvez ela tenha conversado com a irmã, que esteve em sua [do rei] cama. Mas agora o rei já partiu de Whitehall [uma das residências do reil e voltou para o interior, para o camponês de dedos nodosos e sua esposa de avental e touca: o homem que se benze e pede licença ao papa antes de apagar a vela entre os dedos e se voltar solenemente à esposa [...].

Mas um dia, enquanto o camponês se dedica à labuta, o pequeno aprendiz de lenhador entra sorrateiramente e põe sua ferramenta para fora: agora, Joan, diz ele, agora, Jenny, dobre-se sobre a mesa e eu lhe ensinarei algo que sua mãe nunca lhe ensinou. [...] e, quando o honesto camponês volta à casa e a monta naquela noite, ela pensa em uma nova maneira de fazer as coisas, uma maneira mais doce, uma maneira mais suja, uma maneira que faz seus olhos se arregalarem de surpresa e o nome de outro homem irromper em sua boca. E, quando o marido recorda que seu nome na verdade é Henrique, isso não o faz coçar a careca?

MANTEL, Hillary. O livro de Henrique. Rio de Janeiro: Record, 2013, p. 261-262.

${ }^{10}$ Para maior aprofundamento do fenômeno da recategorização referencial, sugerimos a leitura dos trabalhos de Lima (2009), Cavalcante (2011), Custódio Filho (2011) e Cavalcante e Brito (2016). 


\section{PERcursos Linguísticos • Vitória (ES) •v. 11 •n. 29 • 2021 • ISSN: 2236-2592 • Dossiê temático $\bullet O$ texto na pesquisa e no ensino: conhecimentos, práticas e desafios na contemporaneidade •}

$\mathrm{Na}$ conversa entre os dois interlocutores, personagens do romance, os referentes salientes são compreendidos como tendo dupla identidade: ao mesmo tempo em que apresentam caráter genérico, são específicos. O rei inicia a interlocução falando de uma mulher genérica, "que não consegue sossegar na cama”, e, em suas perguntas, tece uma crítica ao comportamento desse tipo de mulher. Cromwell participa da interlocução, procurando justificar o que faria uma mulher casada ter um comportamento sexual mais liberado. Além disso, ao mesmo tempo em que tratam da mulher, os interlocutores também tratam de um marido genérico: "um hipotético inglês temente a Deus", que tem relações sexuais com a esposa dentro do que é permitido pela religião.

Esse caráter genérico das duas entidades está presente nos dois últimos parágrafos, quando o marido é construído como "o homem que se benze e pede licença ao papa", o "honesto camponês", e a mulher que o trai tanto pode ser "Joan" como "Jenny". No último parágrafo, também é apresentado um referente genérico: o amante, “o pequeno aprendiz de lenhador".

Ocorre que, na verdade, os referentes genéricos $<$ marido $>{ }^{11}$ e $<$ mulher $>$ são, ao mesmo tempo, os referentes <Henrique VIII > e <Ana Bolena>. Isso já está implícito no diálogo entre o rei e Cromwell, considerando-se que o tópico da conversa é o adultério da rainha. Contudo, há o reforço dessa dupla identidade quando o rei pergunta: "Mas três anos? Isso é muito?" (o que remete ao tempo em que ele e a rainha estão casados), e quando o narrador completa: "o rei esquece que não estamos falando dele, mas de um hipotético inglês temente a Deus", e depois afirma: "agora o rei já partiu de Whitehall e voltou para o interior, para o camponês de dedos nodosos e sua esposa de avental e touca".

Há, desse modo, um jogo duplo, que vai e volta no que diz respeito ao caráter menos ou mais individual dos referentes, o que é percebido pelos participantes da interação. Estes, sabedores de que o tema do adultério é espinhoso (ainda mais o adultério sofrido pelo rei), o abordam a partir de uma via indireta, tentando falar não dos indivíduos, mas de qualquer um que pudesse passar por isso. Trata-se de uma tentativa que permite a verbalização do tema sem ferir algum brio, mas que não esconde por completo o caso específico de que falam, o que é reforçado pelo narrador quando este sugere que o nome do camponês genérico pode ser "Henrique".

\footnotetext{
${ }^{11}$ Estamos usando os sinais < e > para marcar que o que está em tela não são as expressões em si, mas as entidades construídas, via textualização, para as quais essas expressões (e outras) podem ser usadas.
} 


\section{PERcursos Linguísticos • Vitória (ES) •v. 11 •n. 29 • 2021 • ISSN: 2236-2592 • Dossiê temático $\bullet O$ texto na pesquisa e no ensino: conhecimentos, práticas e desafios na contemporaneidade •}

Nesse jogo, ambos os interlocutores (e o leitor com eles e com o narrador) negociam para que o diálogo possa evoluir. Essa negociação revela as reelaborações e o dinamismo, construídos ao longo da interlocução, característicos da referenciação. Esse é o movimento constitutivo de todos os textos ${ }^{12}$.

Resta lembrar que, conforme assinalam Cavalcante (2011) e Custódio Filho (2011), a construção dos objetos de discurso não está atrelada apenas ao uso de expressões referenciais (sintagmas nominais). No exemplo analisado, essas expressões são importantíssimas para que se compreenda a negociação estabelecida entre os interlocutores, mas elas, por si, não são suficientes. É preciso reconhecer que o texto como um todo - o que comporta sua materialidade e as múltiplas relações que essa materialidade estabelece com instâncias diversas - fornece o campo para que os objetos sofram as recategorizações necessárias. Por exemplo, os enunciados sublinhados (os quais não têm natureza referencial, mas proposicional) também precisam ser levados em conta na construção da referência.

Registre-se, ainda, que tal construção só se efetiva mediante a articulação entre os diversos referentes, o que possibilita a geração de uma rede referencial (MATOS, 2018). O trabalho de fabricação dos sentidos que passa pela referenciação não pode se limitar ao mapeamento de um único referente, pois qualquer entidade construída em um texto se estabelece mediante a relação com outras entidades. Propor uma formulação do referente <marido/Henrique VII> no exemplo (4) não se sustenta se não se fizer, também, uma formulação para o referente <esposa/Ana Bolena> e para outros referentes salientes no excerto.

Finalmente, considerando o que se apontou na seção anterior sobre a relação entre textos e argumentação, é necessário firmar que a construção da referência está sempre atrelada a um projeto de dizer, o qual implica a busca por modificar o modo como o interlocutor pensa, age, sente. Isso vale tanto para a configuração de textos de visada argumentativa quanto para a concretização/percepção da dimensão argumentativa inerente a qualquer texto. A referenciação, como outras estratégias de textualização, está a serviço da argumentação, e, por isso, o papel dos sujeitos no trabalho de formular sentidos é essencial.

\section{Referenciação no ensino - a necessária renovação}

\footnotetext{
${ }^{12} \mathrm{O}$ movimento de negociação é, de fato, constitutivo, mas isso não implica que negociar, em todos os casos, leve à construção harmônica de referentes (ver, sobre isso, CUSTÓDIO FILHO, 2017). Nas interações polêmicas (AMOSSY, 2017), por exemplo, essa harmonia não ocorre.
} 


\section{PERcursos Linguísticos • Vitória (ES) •v. 11 •n. 29 • 2021 • ISSN: 2236-2592 • Dossiê temático $\bullet O$ texto na pesquisa e no ensino: conhecimentos, práticas e desafios na contemporaneidade •}

Reforçando o posicionamento destacado na introdução deste artigo sobre a importância do texto para as práticas de aprendizagem no ensino de língua materna, temos que os critérios analíticos da linguística textual, elementos fundamentais para a manifestação da coerência, devem fazer parte dos programas curriculares das escolas ${ }^{13}$. Além disso, se considerarmos a perspectiva aqui assumida sobre o papel constitutivo da argumentação na configuração dos sentidos mediados por textos, os critérios analíticos precisam ser tratados pedagogicamente como elementos reveladores do projeto de dizer dos sujeitos. O aprendizado necessário à produção e compreensão textual eficazes passa, pois, pela análise e uso de recursos argumentativos vários.

O reconhecimento do papel da referenciação no ensino propicia uma boa oportunidade para refletir sobre a presença das estratégias de textualização nas práticas pedagógicas. Considerando, por exemplo, as práticas mediadas pelos livros didáticos, percebe-se que, de modo geral, nos últimos vinte anos, há pouco espaço destinado a atividades que focalizam a referenciação ${ }^{14}$. Os livros optam por privilegiar as características (muitas vezes vistas de modo estanque) diretamente ligadas à estruturação dos gêneros textuais.

Além do pouco espaço, há outro problema no que diz respeito à necessária atualização teórica das atividades sobre referenciação. Os materiais costumam abordar principalmente a natureza coesiva do fenômeno, propondo atividades didáticas que reiteram as ideias presentes nas primeiras reflexões sobre coesão feitas no Brasil (como se vêm em KOCH, 1999). A título de ilustração ${ }^{15}$, vejamos os exemplos a seguir, que consistem de explicações as quais tocam no fenômeno da construção da referência.

(5)

Figura 3 - Exemplo de explicação em livro didático (1)

No texto, o substantivo Tasmânia é retomado pelos termos: ilha australiana, pequena ilha. Esses termos são utilizados como forma de evitar uma repetição do substantivo. O texto apresenta outro exemplo do mesmo procedimento coesivo. O nome próprio Austrália foi substituído por terra dos cangurus.

O uso de um termo com valor coesivo no lugar de outro(s) elemento(s) do texto, ou até mesmo de uma oração inteira, chama-se substituição.

\footnotetext{
${ }^{13} \mathrm{Na}$ BNCC (BRASIL, s/d), encontram-se, dentre as habilidades referentes à área de língua portuguesa, menções, ainda que às vezes de modo indireto, às estratégias de textualização.

${ }^{14} \mathrm{O}$ mesmo pode ser dito sobre articulação tópica, intertextualidade, metatextualidade, polifonia etc.

${ }^{15}$ Não se pretende, obviamente, que a apresentação de dois exemplos equivalha a um panorama sobre o tratamento da referenciação nos livros didáticos de língua portuguesa. Embora nossa experiência nos diga que uma análise mais substancial chegaria a conclusões parecidas com a que propomos, sabemos que essa afirmação só poderia ser feita de modo mais assertivo mediante uma análise mais substancial.
} 


\section{PERcursos Linguísticos • Vitória (ES) •v. 11 •n. 29 • 2021 • ISSN: 2236-2592 • Dossiê temático $\bullet O$ texto na pesquisa e no ensino: conhecimentos, práticas e desafios na contemporaneidade •}

Fonte: ABAURRE, M. L. M; ABAURRE, M. B. M.; PONTARA, M. Português: contexto, interlocução e sentido. Vol. 2 São Paulo: Moderna, 2008, p. 378.

(6)

Figura 4 - Exemplo de explicação em livro didático (2)

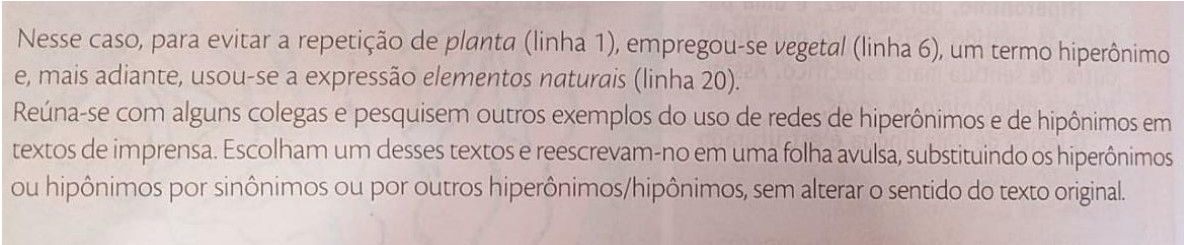

Fonte: FARACO, C. E.; MOURA, F. M.; MARUXO JÚNIOR, J. H. Língua portuguesa: linguagem e interação. Vol. 1 São Paulo: Ática, 2013, p. 208.

Nos dois exemplos, antes da explicação proposta, são apresentados os textos onde as expressões analisadas se encontram. O que chama atenção é a ênfase na natureza exclusivamente coesiva das expressões. Elas são compreendidas como elementos usados para a retomada classificada como substituição (especificando-se, em (6), a relação semântica hipônimo ou hiperônimo - entre os termos envolvidos na substituição).

Vale notar que, no período de publicação dos livros, a proposta da referenciação já gozava de certo prestígio na LT brasileira, de modo que os processos de reelaboração e negociação dos referentes, como condição fundamental da textualização, já poderiam fazer parte dos materiais didáticos. O que se vê é que essa atualização não ocorreu a contento nos anos 2010. Há, ainda, um caminho a ser percorrido. Esse caminho pressupõe assumir a referenciação como fenômeno textual-discursivo constitutivamente ligado à argumentação.

Na seção a seguir, apresentamos sugestões de práticas pedagógicas que julgamos mais condizentes com as perspectivas aqui assumidas.

\section{Referenciação calcada na argumentação - contribuições para a prática pedagógica}

A seguir, apresentamos duas propostas de atividades pedagógicas ${ }^{16}$ que julgamos representativas da ideia aqui assumida de que o ensino de estratégias de textualização, dentre as quais destacamos a referenciação, deve ser pautado por uma perspectiva que contemple a natureza argumentativa inerente aos textos, sendo as estratégias mecanismos reveladores dessa natureza. Na primeira atividade, focaliza-se a produção de um texto de visada argumentativa.

\footnotetext{
${ }^{16}$ Ambas as atividades estão presentes, com adaptações, em uma coleção didática a ser lançada, da qual este pesquisador é um dos autores. Elas são direcionadas ao $7^{\circ}$ ano do ensino fundamental e se incluem no campo da vida pública, mais especificamente, sobre as relações de consumo. Sobre os campos de atuação, ver o que recomenda a BNCC (BRASIL, s/d).
} 


\section{PERcursos Linguísticos • Vitória (ES) •v. 11 •n. 29 • 2021 • ISSN: 2236-2592 • Dossiê temático $\bullet O$ texto na pesquisa e no ensino: conhecimentos, práticas e desafios na contemporaneidade •}

Na segunda, mostra-se uma ação de compreensão textual para se perceber a dimensão argumentativa em um texto narrativo ${ }^{17}$.

Atividade 1 - referenciação na produção de texto de visada argumentativa

Você conhece os memes do tipo expectativa $\mathrm{X}$ realidade? Eles são construídos de modo a mostrar o contraste cômico entre a expectativa sobre uma situação desejada e a realidade percebida na situação concretizada.

Veja alguns exemplos de memes desse tipo. Nesses exemplos, as pessoas encomendaram um produto pela internet e tiveram uma "surpresinha" quando receberam a encomenda.

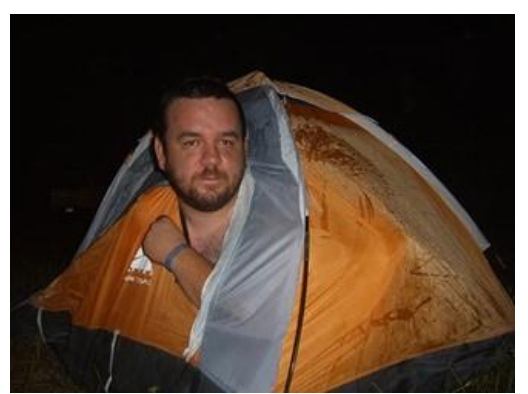

Expectativa: montar a barraca no sítio e dormir ao som do coaxar dos sapos e do canto dos grilos.

Realidade: você acaba descolando uma fantasia de Esfinge.
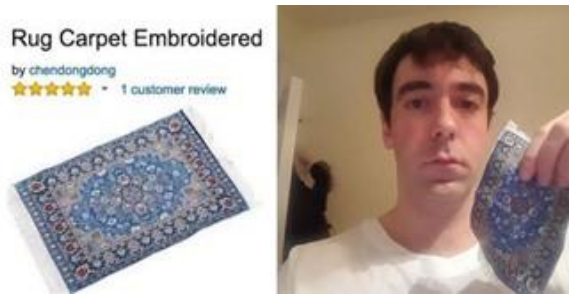

Expectativa: levantar da cama com o pé direito e pisar descalço em um tapete aveludado.

Realidade: você ganha um lenço com uma bela estampa.
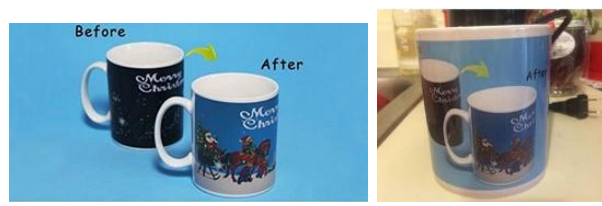

Expectativa: presentear a sua namorada com uma caneca natalina fotossensível. Realidade: ela ganha exatamente a caneca que foi anunciada.

Disponível em https://www.tecmundo.com.br/bizarro/106826-11-compras-feitasinternet-deram-errado.htm. Acesso em 7 abr. 2021.

Provavelmente, as pessoas envolvidas nesses memes devem ter ficado aborrecidas porque seu direito como consumidor não foi completamente atendido. Porém, ao mesmo tempo, parece que elas encararam a situação com uma dose de bom humor, pois revelaram suas histórias nas redes sociais.

${ }^{17}$ Não custa registrar que a escolha de uma prática de produção para tratar da visada argumentativa e de uma prática de compreensão para tratar da dimensão argumentativa não significa que haja os pares exclusivos "produção-visada" e "compreensão-dimensão". Óbvio é que atividades de produção que contemplem a dimensão argumentativa e atividades de compreensão sobre textos com visada argumentativa poderiam ser apresentadas. Caso o leitor tenha interesse em conhecer um exemplo de atividade que trata especificamente da distinção entre visada e dimensão argumentativas, sugerimos o trabalho de Abreu (2020). 


\section{PERcursos Linguísticos • Vitória (ES) •v. 11 •n. 29 • 2021 • ISSN: 2236-2592 • Dossiê temático $\bullet O$ texto na pesquisa e no ensino: conhecimentos, práticas e desafios na contemporaneidade •}

O humor pode ser uma forma eficaz de protesto. Por meio desse recurso, é possível estabelecer uma crítica sem parecer que se está chateado ou emocionalmente alterado. Isso contribui para que a crítica seja recebida de modo mais leve, o que talvez até possibilite que seja aceita mais facilmente.

A partir dessa ideia, sua tarefa será a de exercer seus direitos de consumidor usando o bom humor. Produza um texto de reclamação para uma empresa, a partir das instruções apresentadas a seguir.

- Sua reclamação pode partir de uma das situações mostradas nos memes, de uma situação que você ou alguém que conheça tenha vivido, ou de uma situação inventada por você. Caso precise de ideias para uma situação, uma busca pela internet pode ajudá-lo.

- Quando fizer o relato, tente ser original e engraçado. Pense em como você pode divertir as pessoas que lerão seu texto. Embora a audiência principal seja a empresa, outras pessoas também poderão ter acesso ao que você escrever.

- Defina qual será o estilo humorístico de seu texto. Duas estratégias comumente usadas são o pastelão e a ironia. O pastelão ocorre quando a situação é absurda ou exagerada, fora do comum. A ironia é utilizada para que haja um efeito implícito contrário ao que é dito; por exemplo, você pode apresentar expressões que aparentam revelar calma, quando, na verdade, está muito chateado.

- Procure se dirigir ao interlocutor (um suposto representante da suposta empresa) de modo gentil (irônico ou não).

- Se for necessário, escolha expressões que possam acentuar o humor do texto. Em um texto irônico, por exemplo, podem aparecer as expressões "encarecidamente", "humildemente", "prezado", "meus sinceros agradecimentos" etc.

- Lembre-se de apresentar informações detalhadas e organizadas.

- Lembre-se de fazer um pedido à empresa.

A atividade coloca o aluno para efetuar um projeto de dizer que passa pela proposição de uma tese: o produto/serviço recebido é defeituoso. O aluno, na posição de consumidor insatisfeito, deverá persuadir o interlocutor (a empresa vendedora do produto ou prestadora do serviço) a aderir a esta tese e, a partir disso, tomar uma decisão. Tem-se, portanto, uma prática pedagógica sobre um texto de visada argumentativa.

O aprendiz deverá lançar mão de estratégias que o permitam atingir o propósito elencado: fazer uma reclamação de consumo de modo bem-humorado. Para tanto, ao seguir às recomendações explicitadas nas instruções, e além delas, precisará dar atenção à construção de três referentes salientes na situação: o produto/serviço com problema, o consumidor (a imagem que criará de si mesmo, como sujeito insatisfeito que usa do humor para fazer sua queixa) e a empresa a quem se dirige.

Esses referentes, com as especificidades que terão, tomam corpo somente dentro desse texto, por isso a elaboração e negociação a ser efetivadas têm como limite de realização as possibilidades que a proposta de produção lhes garante (explícita ou implicitamente). Além disso, a criação do texto contará com uma organização textual particular do aluno, que tem espaço para imprimir suas marcas no texto. Dentre outros aspectos, ele deverá definir o tipo de 


\section{PERcursos Linguísticos • Vitória (ES) •v. 11 •n. 29 • 2021 • ISSN: 2236-2592 • Dossiê temático $\bullet O$ texto na pesquisa e no ensino: conhecimentos, práticas e desafios na contemporaneidade •}

produto que será foco da reclamação, o tipo de humor que usará e o modo como se dirigirá à empresa. Logo, estará assumindo o papel de sujeito agente.

Obviamente, os referentes acionados realizarão a coesão textual, mas, mais que isso, revelarão a orientação argumentativa do texto. Essa orientação será percebida, também, pela rede referencial que conecta o produto, o consumidor e a empresa, permitindo que essas três entidades se materializem de modo interdependente. Esse arcabouço pode servir de parâmetro para a avaliação do professor sobre o texto: o humor pretendido e a eficácia da argumentação dependem do modo como os referentes se estabelecem.

Vê-se, assim, que a prática sugerida se pauta por uma proposta em que o aluno se coloca como sujeito munido de estratégias para persuadir, dentre as quais se encontra a construção referencial. Acreditamos que as práticas pedagógicas com textos de visada argumentativa que se pautem pela integração das instâncias aqui elencadas, firmadas nos pressupostos da linguística textual, pode contribuir para o aprendizado eficaz das habilidades concernentes ao desenvolvimento da competência discursiva (BALTAR, 2004).

Atividade 2 - referenciação na compreensão da dimensão argumentativa de um texto A festa

Desatino do Sul parou para a festa que começou no dia em que Apolo Onze nasceu e depois não parou mais.

A casa de Apolo Dez e Madrugada vivia entupida de convidados que se espalhavam pelo salão, pelo jardim, pelo quintal, pelo pomar, ainda bem que o terreno era bem grande.

O pessoal das redondezas, e depois os de lugares mais distantes, todos vinham atraídos pelo evento. Passavam uns dias, se divertiam um pouco, e Desatino do Sul vivia disso.

Lá não se perdia tempo com outra coisa que não fosse festa.

Uma festa que não acabava nunca.

A festa do nascimento de Apolo Onze.

[...] Era tanto convidado que acabou se tornando obrigatória a presença de garçons para servir aquele pessoal todo. Olha aí. Não sei quantos novos empregos.

Todos os cantadores que existiam na cidade ainda eram poucos para tanta exigência de música.

Para os sapateiros, não faltava serviço, pois se tem coisa que acaba sapato é esse negócio de dançar em festa.

Os criadores de galinha ganhavam muito dinheiro: não sei quantos ovos para se fazer os doces, não sei quanto de miúdo, mais não sei quantos galetos.

A mulher do cachorro-quente vendia uma média de duzentos por dia, o que no final do mês dava uns seis mil e bastante.

$\mathrm{O}$ vendedor de amendoim quase não dava conta dos pedidos, quem não gosta de um amendoinzinho para acompanhar a besteira?

A cidade inteira vivia da festa.

O fornecedor de bebidas, o velhinho da confeitaria, a dona da butique, os floristas e, principalmente, os solteiros, as viúvas e os abandonados.

Dona Remédios da farmácia, por exemplo, passou a vender mais de quarenta sais de fruta por dia, além de uma quantidade enorme de xarope para o fígado, quadruplicando assim o seu faturamento. 


\section{PERcursos Linguísticos • Vitória (ES) •v. 11 •n. 29 • 2021 • ISSN: 2236-2592 • Dossiê temático $\bullet O$ texto na pesquisa e no ensino: conhecimentos, práticas e desafios na contemporaneidade •}

Como ninguém tinha motivo para chorar nunca, o fabricante de lenços resolveu lançar uma coleção especial de lenços com motivos festivos, que servissem para se usar nos cabelos, amarrar no pescoço ou enxugar o suor da dama, depois de uma música mais alegre.

[...] A única pessoa da cidade que não gostava da festa, pelo contrário, era o dono do pedaço que não pertencia aos Apolos.

Noctâmbulo (esse era o seu nome) tinha um pedação de terra e se achava muito importante por isso. [...]

Antes de Apolo Onze nascer e de começar a festa que tomou conta da cidade, Noctâmbulo contava com a população toda só para ele, não sei quantas mãos para servir de mão-de-obra.

Depois que a festa começou, o povo descobriu que podia trabalhar por conta própria e ainda se divertir, além de tudo.

Foi assim que ele perdeu, de uma só vez, todos os funcionários disponíveis no mercado.

[...] O que se sabe com certeza é que tudo que pode ser feito para acabar com uma festa, Noctâmbulo fez, pode apostar. Rogou praga, jogou pedra, acendeu vela, fez abaixo-assinado só com a sua assinatura, fez intriga, cara feia, desaforo, até que foi ao juiz reclamar do barulho e exigir uma solução.

O juiz foi averiguar, afinal era sua função, mas se divertiu tanto que terminou ficando lá. (Virou presidente do júri dos concursos de dança que aconteciam três vezes por dia e se sentia muito mais realizado profissionalmente do que antes). FALCÃO, Adriana. Luna Clara e Apolo Onze. São Paulo: Moderna, 2002, p. 20-24.

\section{Práticas de leitura ${ }^{18}$}

1. Participe da competição "Complete bem". Você deve preencher cada lacuna do comentário a seguir com uma palavra diferente. A pontuação para cada lacuna é a seguinte:

- se sua resposta não for coerente - 0 ponto;

- se sua resposta for coerente e dez ou mais pessoas escreverem a mesma palavra - 1 ponto;

- se sua resposta for coerente e cinco a nove pessoas escreverem a mesma palavra -2 pontos;

- se sua resposta for coerente e duas a quatro pessoas escreverem a mesma palavra -3 pontos;

- se sua resposta for coerente e somente você escrever a palavra - 5 pontos.

Antes de viverem sempre em festa, muitos dos moradores de Desatino do Sul eram empregados de Noctâmbulo e isso provavelmente os deixava

Com a vida girando em torno da festa, o sentimento dessas pessoas passou a ser de Além disso, particularmente para um grupo de cidadãos - o sapateiro, a mulher do cachorro-quente, o vendedor de amendoim, a dona da farmácia, entre outros -, a festa também trouxe

Entendemos que a atividade trabalha com a dimensão argumentativa inerente a todo texto. O que se coloca como tarefa é a interpretação de elementos de uma cena narrativa que implicam o reconhecimento de uma perspectiva colocada pelo narrador. A percepção sobre como a população de Desatino do Sul vivia antes e depois de a cidade girar em torno da festa revela determinado modo de encarar a vida, baseado na ideia de que as pessoas podem trabalhar

\footnotetext{
${ }^{18}$ A atividade contém outras questões de compreensão além da apresentada aqui.
} 


\section{PERcursos Linguísticos • Vitória (ES) •v. 11 •n. 29 • 2021 • ISSN: 2236-2592 • Dossiê temático $\bullet O$ texto na pesquisa e no ensino: conhecimentos, práticas e desafios na contemporaneidade •}

e se divertir ao mesmo tempo (e esse, na visão do narrador, parece ser o modo ideal de funcionamento de uma sociedade).

Para realizar essa compreensão de acordo com o molde que a questão coloca, o aluno que pretender ganhar mais pontos na competição deve preencher as lacunas com palavras menos usuais. Por exemplo, para a primeira lacuna, em vez de "tristes" ou "infelizes", pode-se usar "insatisfeitos" ou "desanimados"; para a segunda lacuna, em vez de "alegria" ou "felicidade", pode-se usar "euforia", "satisfação", "plenitude"; para a terceira lacuna, em vez de "dinheiro" ou "riqueza", pode-se usar "prosperidade", "lucro".

$\mathrm{Na}$ ação de completar, o aprendiz estará lidando com a construção dos referentes <habitantes de Desatino do Sul>, <profissões de Desatino do Sul ligadas à festa> e <Noctâmbulo>. De modo mais específico, está sendo abordada a recategorização dos moradores de Desatino do Sul. No texto, ao se confrontar o momento atual da cidade com o momento anterior, conclui-se que os habitantes, que hoje estão alegres, já estiveram infelizes um dia. O preenchimento das lacunas possibilita a reconstrução desse processo. Além disso, como na atividade anterior, esses referentes se ligam ao projeto de dizer do texto e devem ser compreendidos como partes de uma rede; é a relação entre eles no texto que permite a percepção de cada um como parte de um processo em que uma dada visão de mundo se apresenta.

A possibilidade de propor respostas diferentes para cada uma das lacunas indica que o processo de compreensão também se dá mediante a ação de sujeitos. Isso é verdade tanto nesse nível - em que se propõe uma interpretação e o aluno deve completá-la - quanto num nível mais elevado, mais próximo do que acontece práticas sociais efetivas de leitura - nas quais o leitor proficiente cria sua própria proposta de interpretação, a partir de elementos diversos, e fornece uma "resposta" ao texto.

A análise das duas atividades tem como objetivo mostrar que os pressupostos da linguística textual atual podem contribuir para a configuração de práticas pedagógicas eficazes. Para isso, é preciso concretizar as recomendações da BNCC (BRASIL, 2017), que coloca as práticas de leitura e produção, sempre inscritas numa dimensão discursiva, como ponto central das aulas de língua portuguesa. Dentre as diversas habilidades inerentes a essas práticas, a construção da referência, entendida como estratégia argumentativa, deve ocupar papel especial na condução das atividades.

\section{Considerações finais}




\section{PERcursos Linguísticos • Vitória (ES) •v. 11 •n. 29 • 2021 • ISSN: 2236-2592 • Dossiê temático $\bullet O$ texto na pesquisa e no ensino: conhecimentos, práticas e desafios na contemporaneidade •}

As ideias inscritas neste artigo partem de duas perspectivas que revelam novidades. De um lado, a proposta da linguística textual de descrever a configuração de qualquer texto a partir de uma base argumentativa. De outro, a necessidade de que as situações de ensino promovam o desenvolvimento de habilidades calcadas nos parâmetros que garantem a tessitura da coerência textual. Procuramos trabalhar com essas duas motivações a partir do fenômeno da referenciação, já que a construção de objetos de discurso é tributária do projeto de dizer de um locutor e resulta da negociação entre interlocutores, o que responde por parte significativa das relações geradoras de sentidos.

$\mathrm{Na}$ análise, ilustramos a aplicação pedagógica da referenciação em duas atividades, considerando seu papel na construção de textos de visada argumentativa, bem como na percepção da dimensão argumentativa de um texto narrativo. Salientamos que, em ambas as tarefas, os sentidos envolvidos na interação contam com a agentividade dos sujeitos. Acreditamos que a proposta exemplificada contém elementos que contribuem para a percepção de que o ensino de língua portuguesa pode se beneficiar do conhecimento teórico atualizado, quando este contribui para a confecção de momentos didáticos os quais propiciem ao aprendiz a ação sobre os textos.

Essa tônica vai ao encontro de uma concepção de professor o qual exerce seu papel de mediador altamente capacitado (GERALDI, 1997). Mais que fornecer explicações, esse profissional constrói situações em que a mobilização de recursos permitirá a sistematização de conhecimentos. Ao entender que a área de língua portuguesa ocupa um papel cada vez mais instrumental em vez de conteudístico, o professor propiciará as bases para que os estudantes possam desenvolver o que mais importa: os conhecimentos que os permitam interagir para argumentar e tentar modificar os modos de ver, pensar e sentir dos seus parceiros de comunicação.

\section{(7) Referências}

ABREU, Janieyre da Silva. Proposta para o ensino das relações discursivo-argumentativas em textos de alunos do ensino médio: um diálogo entre linguística textual e teoria da argumentação na língua. 2020. 188 f. Dissertação (Mestrado Profissional em Letras). Universidade Estadual do Ceará, Fortaleza, 2020.

ADAM, Jean-Michel. Textos: tipos e protótipos. São Paulo: Contexto, 2019.

AMOSSY, Ruth. Apologia da polêmica. São Paulo: Contexto, 2017. 


\section{PERcursos Linguísticos • Vitória (ES) •v. 11 •n. 29 • 2021 • ISSN: 2236-2592 • Dossiê temático $\bullet O$ texto na pesquisa e no ensino: conhecimentos, práticas e desafios na contemporaneidade •}

Argumentação e análise do discurso: perspectivas teóricas e recortes disciplinares. Tradução Eduardo Lopes Piris e Moisés Olímpio Ferreira. EID\&A, Ilhéus, n. 1, p. 129-144, nov. 2011.

ANTUNES, Irandé. Análise de textos: fundamentos e práticas. São Paulo: Parábola, 2010.

Aula de português: encontro e interação. São Paulo: Parábola, 2003.

APOTHÉLOZ, Denis; REICHLER-BÉGUELIN, Marie-José. Construction de la référence et strategies de designation. Tradução (inédita) Mônica Magalhães Cavalcante. In: BERRENDONNER, A.; REICHLER-BÉGUELIN, M.-J. (Org.). Du sintagme nominal aux objects-de-discours. Neuchâtsh: Université de Neuchâtsh, 1995, p. 227-271.

BALTAR, Marcos. A validade do conceito de competência discursiva para o ensino de língua materna. Linguagem em (Dis)curso - LemD, Tubarão, v. 5, n.1, p. 209-228, jul./dez. 2004.

BRASIL. Ministério da Educação. Base Nacional Comum Curricular. Brasília, DF: MEC, s/d.

CARVALHO, Ana Paula Lima de. Sobre intertextualidades estritas e amplas. 2018. 135f. Tese (Doutorado em Linguística). Universidade Federal do Ceará, Fortaleza, 2018.

CAVALCANTE, Mônica Magalhães. Referenciação: sobre coisas ditas e não ditas. Fortaleza: Edições UFC, 2011.

CAVALCANTE, Mônica Magalhães; BRITO, Mariza Angélica Paiva. O caráter naturalmente recategorizador das anáforas. In: AQUINO. Z. G. O.; GONÇALVES-SEGUNDO, P. R. (Org.). Estudos do discurso: caminhos e tendências. São Paulo: Paulistana, 2016, p. 119-133.

CAVALCANTE, Mônica Magalhães; CUSTÓDIO FILHO, Valdinar. Revisitando o estatuto do texto. Revista do Gelne. Teresina, v. 12, n. 2, p. 56-71, 2010.

CAVALCANTE, Mônica Magalhães; CUSTÓDIO FILHO, Valdinar; BRITO, Mariza Angélica Paiva. Coerência, referenciação e ensino. São Paulo: Cortez, 2014.

CAVALCANTE, Mônica Magalhães; et al. Linguística textual e argumentação. Campinas: Pontes, 2020.

CAVALCANTE, Mônica Magalhães; et al. O texto e suas propriedades: definindo perspectivas para análise. (Con)Textos Linguísticos, Vitória-ES, v. 13, n. 25, p. 25-39, 2019.

CAVALCANTE, Mônica Magalhães; et al. Desafios da Linguística Textual no Brasil. Intersecções, Jundiaí SP, v. 18, n. 1, p. 7-25, 2016. Disponível em http://www.portal.anchieta.br/revistas-e-livros/interseccoes/pdf/interseccoes-ano-9numero-1.pdf. Acesso em 16 set. 2021.

CORTEZ, Suzana Leite; KOCH, Ingedore. Villaça. A construção do ponto de vista por meio de formas referenciais. In: CAVALCANTE, M. M.; LIMA, S. M. C. (Org.). Referenciação: teoria e prática. São Paulo: Cortez, 2013, p. 9-29. 


\section{PERcursos Linguísticos • Vitória (ES) •v. 11 •n. 29 • 2021 • ISSN: 2236-2592 • Dossiê temático $\bullet O$ texto na pesquisa e no ensino: conhecimentos, práticas e desafios na contemporaneidade •}

CUSTÓDIO FILHO, Valdinar. Rediscutindo o princípio de construção negociada dos objetos de discurso. Revista de Letras, Fortaleza, v. 2, n. 36, p. 63-77, jul./dez. 2017.

Múltiplos fatores, distintas interações: esmiuçando o caráter heterogêneo da referenciação. 2011. 329f. Tese (Doutorado em Linguística). Universidade Federal do Ceará, Fortaleza, 2011.

FORTE, Jamille Saínne Malveira. Funções textual-discursivas de processos intertextuais. 2013. 129 f. Dissertação (Mestrado em Linguística). Universidade Federal do Ceará, Fortaleza, 2013.

GERALDI, João Wanderley. Portos de passagem. 4. ed. São Paulo: Martins Fontes, 1997.

KOCH, Ingedore Villaça. Referenciação e orientação argumentativa. In: KOCH, I. G. V.; MORATO, E. M.; BENTES, A. C. (Org.) Referenciação e discurso. São Paulo: Contexto, 2005, p. 33-52.

A coesão textual. 11. ed. São Paulo: Contexto, 1999.

KOCH, Ingedore Villaça; ELIAS, Vanda Maria. Escrever e argumentar. São Paulo: Contexto, 2018.

Ler e escrever: estratégias de produção textual. São Paulo: Contexto, 2009.

Ler e compreender: os sentidos do texto. 2. ed. São Paulo: Contexto, 2006.

KOCH, Ingedore Villaça.; BENTES, Anna Christina.; CAVALCANTE, Mônica Magalhães. Intertextualidade: diálogos possíveis. São Paulo: Cortez, 2007.

LIMA, Silvana Maria Calixto de. Entre os domínios da metáfora e da metonímia: um estudo de processos de recategorização. 2009. 204p. Tese (Doutorado em Linguística). Universidade Federal do Ceará, Fortaleza, 2009.

MATOS. Janaica Gomes. As redes referenciais na construção de notas jornalística. 259f. (Doutorado em Linguística). Universidade Federal do Ceará, 2018.

MONDADA, Lorenza; DUBOIS, Danièle. Construção dos objetos de discurso e categorização: uma abordagem dos processos de referenciação. Tradução Mônica Magalhães Cavalcante. In: CAVALCANTE, M. M.; BIASI-RODRIGUES, B.; CIULlA e SILVA, A. (Org.). Referenciação. São Paulo: Contexto, 2003, p. 17-52.

SÁ, Kleiane Bezerra de. Coerência e articulação tópica: uma análise a partir de redações do Enem. 2018. 260 f. Tese (Doutorado em Linguística). Universidade Federal do Ceará, Fortaleza, 2018.

SUASSUNA, Lívia. Ensino de língua portuguesa: uma abordagem pragmática. Campinas: Papirus, 1995. 


\title{
O ENSINO-APRENDIZAGEM DA ORALIDADE FORMAL E O APREÇO À TOLERÂNCIA E À DIVERSIDADE DE PONTOS DE VISTA
}

\author{
THE TEACHING-LEARNING OF FORMAL ORALITY AND THE \\ APPRECIATION OF TOLERANCE AND DIVERSITY OF POINTS OF \\ VIEW
}

\begin{abstract}
Sirley Siqueira ${ }^{1}$
RESUMO: Este artigo tem por objetivo reiterar a importância de se trabalhar gêneros textuais típicos da oralidade no contexto da Educação Básica. Assumindo uma concepção interacional da linguagem, pretende também apresentar algumas respostas para os seguintes questionamentos: "Qual é a relevância do trabalho com a oralidade em sala de aula?" e "Por que o gênero textual debate regrado pode ser uma opção para a aquisição de usos formais da fala em público e para a formação cidadã pautada no respeito ao outro?”. Apresenta ainda um exemplo de prática pedagógica voltada para a aquisição da oralidade formal, por meio do trabalho com o gênero debate regrado, desenvolvida com alunos do Ensino Médio. Tal atividade demonstrou ser um dos caminhos possíveis para o exercício da escuta atenta ao que o interlocutor tem a dizer, ao mesmo tempo em que promove o desenvolvimento da expressão oral formal requerida em diversas práticas sociais.
\end{abstract}

PALAVRAS-CHAVE: Oralidade. Ensino. Debate regrado.

ABSTRACT: This article aims to reiterate the importance of working with textual genres that are typical of orality in the environment of Basic Education. Assuming an interactional conception of language, it also intends to present some answers to the following questions: "What is the relevance of working with orality in the classroom?" and "Why the textual genre regulated debate can be an option for acquisition of formal uses of speech in public and for civic educational based on respect for the other?". It also presents an example of pedagogical practice aimed at the acquisition of formal orality, through work with the regulated debate genre, developed with high school students. This activity proved to be one of the possible paths for the exercise of attentive listening to what the interlocutor has to say, while promoting the development of the formal oral expression required in many social practices.

KEYWORDS: Orality. Teaching. Ruled debate

\section{Apresentação}

Nos últimos anos, o aprofundamento de posições ideológicas distintas tem reiterado a importância de se empreender um movimento contrário, no qual vozes discordantes possam ser

\footnotetext{
${ }^{1}$ Doutora em Estudos da Linguagem (UFF). Professora do Ensino Básico Técnico e Tecnológico do Colégio Pedro II. Coordenadora do Laboratório de Estudo de Práticas Educativas em Língua Portuguesa e Literatura (LEPELL CPII). E-mail: sirley.ribeirosiqueira@gmail.com
} 


\section{PERcursos Linguísticos • Vitória (ES) •v. 11 •n. 29 • 2021 • ISSN: 2236-2592 • Dossiê temático $\bullet O$ texto na pesquisa e no ensino: conhecimentos, práticas e desafios na contemporaneidade •}

ouvidas e estabelecido um diálogo saudável. Essa interlocução atenta e respeitosa ao que o outro tem a dizer, marco das sociedades civilizadas, precisa ser incentivada, assim como deve ser ampliada a capacidade de expor os próprios argumentos e defendê-los. Nesse sentido, precisa ser um compromisso de toda comunidade escolar a busca por relações mais harmoniosas, nas quais seja possível repelir discursos de ódio ou que atentem contra a democracia, a fim de contribuir para uma formação cidadã atenta ao bem-estar de toda coletividade.

A partir da década de 1980, período que coincide com a redemocratização brasileira, houve uma intensificação de trabalhos ligados ao ensino da língua materna como os de Marcuschi (1986), Koch (1996), Castilho \& Basílio (1996), Castilho (1998), Almeida (2006) e Geraldi (2006). Questões norteadoras desse período diziam respeito, principalmente, ao "Para que se ensina a Língua Portuguesa?". Essas inquietações ganharam relevo e culminaram na publicação dos Parâmetros Curriculares Nacionais (PCN) (BRASIL, 1997), documento que trouxe ainda maior visibilidade para a imprescindível mudança nas aulas de Português, as quais se pautavam, muitas vezes, quase exclusivamente no ensino de nomenclatura gramatical ou em práticas ligadas ao trabalho com o texto escrito. A partir desses referenciais nacionais, sobretudo, houve um crescente destaque para o ensino da linguagem e de gêneros orais (formais públicos) e a valorização dos contextos de uso e de circulação.

Em relação ao ensino da oralidade, por exemplo, encontramos a seguinte passagem no documento:

\footnotetext{
Ensinar língua oral deve significar para a escola possibilitar acesso a usos da linguagem mais formalizados e convencionais, que exijam controle mais consciente e voluntário da enunciação, tendo em vista a importância que o domínio da palavra pública tem no exercício da cidadania. Ensinar língua oral não significa trabalhar a capacidade de falar em geral. Significa desenvolver o domínio dos gêneros que apoiam a aprendizagem escolar de Língua Portuguesa e de outras áreas (exposição, relatório de experiência, entrevista, debate etc.) e, também, os gêneros da vida pública no sentido mais amplo do termo (debate, teatro, palestra, entrevista etc.). Já que os alunos têm menos acesso a esses gêneros nos usos espontâneos da linguagem oral, é fundamental desenvolver, na escola, uma série de atividades de escuta orientada, que possibilitem a eles construir, progressivamente, modelos apropriados ao uso do oral nas circunstâncias previstas. (BRASIL, 1997, p.67).
}

Mais recentemente, outro documento oficial, a Base Nacional Curricular Comum, doravante BNCC (BRASIL, 2018), estabelece as seguintes práticas de linguagem para o Ensino Fundamental e Médio: leitura, produção de textos, oralidade (escuta e produção oral) e análise linguística e semiótica (BRASIL, 2018, p.492). Trabalhar com todos esses eixos, de fato, é um 


\section{PERcursos Linguísticos • Vitória (ES) •v. 11 •n. 29 • 2021 • ISSN: 2236-2592 • Dossiê temático $\bullet O$ texto na pesquisa e no ensino: conhecimentos, práticas e desafios na contemporaneidade •}

desafio, especialmente em um contexto no qual se percebe uma drástica redução dos investimentos em educação - o que impacta não só a diminuição e precarização de recursos pedagógicos, mas, sobretudo, a formação inicial e continuada dos professores. Entretanto, mesmo em meio a tantos obstáculos, é imperioso que práticas sedimentadas no passado possam dar lugar a ações baseadas em referenciais teórico-metodológicos consistentes, os quais apoiem um trabalho no qual seja preconizado o uso linguístico.

Koch (2002, p. 17) afirma que, numa concepção interacional da língua, na qual os sujeitos são vistos como atores/ construtores sociais, "o texto passa a ser considerado o próprio lugar de interação e os interlocutores, como sujeitos ativos que dialogicamente - nele constroem e são construídos". Dolz e Schneuwly, também inspirados por uma concepção interacionista, afirmam que é preciso dar prioridade ao funcionamento comunicativo dos alunos. Isso deve ser feito com o intuito de:

- prepará-los para dominar a língua em situações variadas, fornecendo-lhes instrumentos eficazes:

- desenvolver nos alunos uma relação com o comportamento discursivo consciente e voluntária, favorecendo estratégias de autorregulação;

- ajudá-los a construir uma representação das atividades de escrita e de fala em situações complexas, como produto de um trabalho e de uma lenta elaboração. (DOLZ; SCHNEUWLY, p.42, 2004,).

Subsidiar nossas práticas diárias de sala de aula nessa concepção de texto e de sujeitos é um importante passo para refletirmos sobre o que consideramos mais relevante nas aulas de Língua Portuguesa, tendo em mente nosso compromisso como educadores, os quais desejam contribuir para a formação de cidadãos pensantes e que não se calam frente a injustiças. Portanto, de modo a reiterar a importância de tal temática, este artigo tem como objetivo contribuir para a expansão das discussões que envolvem o ensino da oralidade no âmbito escolar (RAMOS，2002; GOMES-SANTOS，2009; LEAL; GOIS，2012; NONATO， 2018), especialmente por meio da apresentação de uma prática pedagógica baseada no trabalho com o gênero debate regrado.

Ao longo deste texto, procuraremos responder a duas perguntas "Qual é a relevância do trabalho com a oralidade em sala de aula?" e "Por que o gênero textual debate regrado pode ser uma opção para a aquisição de usos formais da fala em público e para a formação cidadã pautada no respeito ao outro?". Além disso, também apresentaremos um exemplo de uma prática de ensino, desenvolvida com alunos do Ensino Médio do Colégio Pedro II, uma escola 


\section{PERcursos Linguísticos • Vitória (ES) •v. 11 •n. 29 • 2021 • ISSN: 2236-2592 • Dossiê temático $\bullet O$ texto na pesquisa e no ensino: conhecimentos, práticas e desafios na contemporaneidade •}

pública federal localizada no município do Rio de Janeiro, cujo principal eixo de ação foi a criação de uma Sociedade de Debates, sobre a qual discorreremos adiante.

\section{Qual é a relevância do trabalho com a oralidade em sala de aula?}

O meio acadêmico há muito tem defendido a necessidade de se fazer da oralidade um objeto de ensino (CASTILHO, 1998; SCHNEUWLY; DOLZ, 2004; FÁVERO et al, 2005; MAGALHÃES, 2006). Entretanto, ainda perdura, para muitos, o entendimento de que o ensino da língua escrita deve ser priorizado, uma vez que a fala seria uma habilidade adquirida espontaneamente, dado o fato de que as crianças já chegam à escola sabendo falar. Para desconstruir essa ideia equivocada, a de que as aulas de Língua Portuguesa devem ter como foco exclusivamente o texto escrito, é preciso rever as metas a que se propõe alcançar: se, de fato, almeja-se contribuir para a ampliação das competências de ouvir, falar, ler e escrever, o ensino da oralidade não pode ser visto como secundário ou mesmo dispensável.

De acordo com Schneuwly, é preciso assumir uma concepção mais rica e complexa do oral e uma relação mais dialética entre oral e escrita. Segundo o autor,

\footnotetext{
Não existe 'o oral', mas 'os orais' em múltiplas formas que, por outro lado, entram em relação com os escritos, de maneiras muito diversas: podem se aproximar da escrita e mesmo dela depender - como é o caso da exposição oral ou, ainda mais, do teatro e da leitura para os outros -, como também podem estar mais distanciados como nos debates ou, é claro, na conversação cotidiana. Não existe uma essência mítica do oral que permitiria fundir sua didática, mas práticas de linguagem muito diferenciadas, que se dão, prioritariamente, pelo uso da palavra (falada), mas também por meio da escrita, e são essas práticas que podem se tornar objetos de um trabalho escolar. (SCHNEUWLY, p.114, 2004).
}

Tal como há uma variedade de gêneros escritos, dos mais formais aos extremamente informais, há também uma gama de gêneros orais, os quais se distinguem pelo contexto situacional e pelas formas convencionais ligadas aos mesmos. Nesse sentido, é preciso perceber que, embora os alunos já dominem o oral cotidiano, é necessário empreender ações para que eles possam alcançar outras formas de produção, as quais exijam maior preparo, uma vez que estariam inseridas em contextos públicos mais formais.

Ferrarezi, acerca das expectativas de aprendizagem relacionadas ao ensino da oralidade, afirma que é preciso que a escola busque desenvolver nos alunos as habilidades de: 


\section{PERcursos Linguísticos • Vitória (ES) •v. 11 •n. 29 • 2021 • ISSN: 2236-2592 • Dossiê temático $\bullet O$ texto na pesquisa e no ensino: conhecimentos, práticas e desafios na contemporaneidade •}

- organizar o conteúdo a ser expresso;

- demonstrar princípios de cortesia e ${ }^{2}$ polidez ao falar;

- demonstrar desenvoltura e desinibição pessoal e, em certas situações específicas, boa dose de intrepidez;

- distinguir o tipo de público que ouve a fala produzida, proporcionando perfeita adequação entre o padrão produzido e as expectativas dos ouvintes;

- educar a voz, incluindo a impostação e a melodia expressiva;

- pronunciar adequada e claramente as palavras utilizadas;

- utilizar um vocabulário múltiplo, adequado às necessidades expressivas identificadas;

- construir sentenças adequadas àquilo que se quer expressar, no padrão que escolheu como mais adequado em cada situação real de vida;

- reconhecer a importância e as consequências da própria fala - desenvolver a fala responsável;

- integrar o falar com o ouvir, o ler e o escrever. (FERRAREZI, p. 73, 2014).

Todas essas demandas, de fato, reiteram a importância de se fazer da oralidade um objeto de ensino. Desse modo, a escola precisa assumir a tarefa de levar os alunos a irem além do domínio do oral distenso e buscar meios para que o ensino da oralidade formal tenha efetivamente seu espaço no ambiente escolar. É necessário, portanto, propor atividades que evidenciem aos alunos que há gêneros da oralidade que impõem controle consciente e voluntário do próprio comportamento e que exigem preparação. Essa mesma defesa é compartilhada por Costa-Maciel e Bilro, quando afirmam que:

Focar o ensino da oralidade no estudo desses gêneros [formais] possibilita aos indivíduos desenvolver competências que, em geral, não são apreendidas no cotidiano, por não fazerem parte das instâncias privadas de produção e por demandarem um maior grau de planejamento no uso da fala pública. (COSTAMACIEL \& BILRO, 2018, p.2).

Concordamos com Carvalho e Ferrarezi (2018, p.32) para quem “(...) as competências mais complexas da oralidade demandam ensino formal e sistemático: não são um 'dom' que qualquer um vai receber magicamente quando for mais velho". Assim, fica evidente a necessidade de planejamento e organização curricular a fim de que haja espaço para atividades voltadas para a ampliação da competência de falar em público, tendo em vista o contexto situacional, o assunto, o interlocutor e ainda a necessidade de se expressar de maneira respeitosa e atenta.

\footnotetext{
${ }^{2}$ Compartilhamos o mesmo entendimento de polidez, presente em Brown e Levinson (1987), o qual se apoia em duas noções: (a) a de que a comunicação é uma atividade racional que tem alguma finalidade, e (b) a noção de que cada um deseja proteger a sua face ou imagem pública. Essa imagem pública (face) diz respeito a dois tipos de desejo: (a) o desejo de autoafirmação, de não se submeter a condições, ter liberdade de ação: face negativa, e (b) o de ser aprovado, aceito, apreciado pelo(s) parceiro(s) da atividade comunicativa: face positiva.
} 


\section{PERcursos Linguísticos • Vitória (ES) •v. $11 \bullet$ •n. 29 • 2021 • ISSN: 2236-2592 • Dossiê temático $\bullet O$ texto na pesquisa e no ensino: conhecimentos, práticas e desafios na contemporaneidade •}

\section{Por que o gênero textual debate regrado pode ser uma opção para a aquisição de usos formais da fala em público e para a formação cidadã pautada no respeito ao outro?}

Há diversos gêneros típicos da oralidade que podem e devem também ser privilegiados em sala de aula, na Educação Básica, com o intuito de se trabalhar a oralidade formal. Alguns desses gêneros farão parte, inclusive, do cotidiano dos alunos que ascenderem a patamares mais elevados de ensino, como é o caso do seminário ou da exposição oral; ou ainda da entrevista, a qual fará parte da vida de muitos jovens e adultos, ao buscarem uma colocação no mercado de trabalho. Entretanto, há algumas potencialidades do debate regrado, as quais merecem ser mencionadas, uma vez que esse gênero:

a) fomenta o amadurecimento da escuta do outro, já que se trata de um gênero no qual há uma alternância imediata dos turnos de fala entre os interlocutores;

b) promove a construção coletiva de conhecimento e opiniões e, consequentemente, o respeito pelo outro;

c) desenvolve habilidades linguísticas como a capacidade de fazer referência ao discurso alheio e refutá-lo;

d) amplia o escopo do trabalho com o ensino de $\operatorname{argumentação~}^{3}$, muitas vezes, restrito ao texto escrito em contextos escolares.

É preciso reiterar, inclusive, a importância de se trabalhar com gêneros do argumentar em toda a Educação Básica e, sobretudo, no Ensino Médio. Isso porque é por meio deles que nos constituímos como sujeitos pensantes, capazes de entender os discursos alheios, as teses subjacentes e também podemos veicular nosso próprio posicionamento. É ainda através do trabalho com a argumentação que se exercita a escuta e o respeito ao nosso semelhante e que

\footnotetext{
${ }^{3}$ Adotamos a concepção de argumentação presente em Charaudeau, 2004, p.37, 44, segundo a qual ela se refere a uma prática social na qual o sujeito que quer argumentar se encontra restringido pelos dados da situação comunicativa e, ao mesmo tempo, livre para jogar com essas restrições, sendo possível realizar seu próprio projeto de fala e trabalhar estratégias. Com relação ao ambiente escolar, principalmente no Ensino Médio, a argumentação é objeto de estudo frequente, pois, para obter uma boa avaliação na redação do ENEM, é preciso dominar algumas técnicas argumentativas. Entendemos, entretanto, que esse não pode ser seu maior objetivo. Conforme aponta Ducrot (apud KOCH, 1998, p. 29), a argumentatividade está inscrita na própria língua e, mesmo quando narramos ou descrevemos, em maior ou menor grau, fazemos uso de estratégias argumentativas.
} 


\title{
PERcursos Linguísticos • Vitória (ES) •v. 11 •n. 29 • 2021 • ISSN: 2236-2592 • Dossiê temático $\bullet O$ texto na pesquisa e no ensino: conhecimentos, práticas e desafios na contemporaneidade •
}

se percebe a veiculação de discursos de ódio e discriminação, com o intuito de rediscuti-los e rejeitá-los.

Bentes (2018, p.47), reconhece as dificuldades de implementação de práticas educativas que levem as pessoas a serem mais solidárias, tolerantes, sem, no entanto, perderem a capacidade crítica e de indignação com relação às injustiças sociais. Para a autora, entretanto, “o engajamento em uma atitude mais sistematicamente reflexiva e crítica sobre sua própria linguagem e a linguagem do outro é fortemente influenciado pela imersão dos sujeitos em práticas de linguagem que sejam significativas para eles". Por conta disso, Bentes afirma que:

\begin{abstract}
A meu ver, só é possível desenvolver as necessárias disciplinas do silêncio, da escuta atenta de outrem e da reflexão sobre o que o outro fala, se os temas a serem tratados forem envolventes, instigantes, polêmicos, de interesse público. Também não vamos desenvolver as necessárias disciplina e polidez nas interações se não formos imersos no universo no qual se forjam polêmicas e disputas de sentido a serem necessariamente resolvidas de forma cordial e racional. (BENTES, 2018, p 48).
\end{abstract}

A BNCC, em diálogo com os PCN, também destaca a necessidade de se pautar o ensino no apreço à diversidade: “(...) é preciso intensificar o desenvolvimento de habilidades que possibilitem o trato com o diverso e o debate de ideias. Tal desenvolvimento deve ser pautado pelo respeito, pela ética e pela rejeição aos discursos de ódio" (BRASIL, 2018, p.490). Promover a convivência (e não apenas a tolerância) com a diversidade de pensamentos, variedades linguísticas, crenças, dentre tantos outros aspectos antropológicos, é, sem dúvida, um dos grandes objetivos a serem alcançados pelo sistema educacional brasileiro e cabe a cada um dos atores inseridos nesse cenário oferecer a sua contribuição.

\section{A voz e a vez dos alunos}

Negreiros e Vilas Boas (2017, p. 118) apontam que, em geral, há “um significativo distanciamento entre as atividades escolares com a prática oral". Essa indiferença em relação à oralidade, entretanto, precisa ser rompida. Concordamos com Dolz e Schneuwly (2004, p. 64), os quais partem da hipótese de que é por meio das representações do gênero e pelo seu caráter integrador que as práticas de linguagem se materializam nas atividades de produção oral e escrita, constituindo-se uma fundamental ferramenta didática. Desse modo, a fim de nos aliarmos a essa premissa, propusemos o Argumentação e Oralidade, sobre o qual apresentaremos mais detalhes adiante. Tal projeto, destinado a trabalhar a oralidade formal por meio do gênero debate regrado, busca também coadunar-se com o que está exposto em Dolz, Schneuwly e Pietro (2004) e, para que pudesse ocorrer dentro das nossas possibilidades, 


\section{PERcursos Linguísticos • Vitória (ES) •v. $11 \bullet$ •n. 29 • 2021 • ISSN: 2236-2592 • Dossiê temático $\bullet O$ texto na pesquisa e no ensino: conhecimentos, práticas e desafios na contemporaneidade •}

elaboramos, inicialmente, a seguinte sequência didática, a qual discorre acerca das oficinas oferecidas aos alunos antes do primeiro debate ser realizado:

Quadro 1: Oficinas preparatórias para a participação nos debates

\begin{tabular}{|c|c|c|c|c|}
\hline OFICINAS & OBJETIVOS & ATIVIDADES & MATERIAL & DURAÇÃO \\
\hline $\begin{array}{l}\text { Apresentação } \\
\text { de um debate }\end{array}$ & $\begin{array}{l}\text { 1. Despertar o interesse } \\
\text { pelo gênero debate } \\
\text { regrado. } \\
\text { 2. Levar os alunos a } \\
\text { ouvir com atenção os } \\
\text { argumentos expostos por } \\
\text { cada debatedor. } \\
\text { 3. Demonstrar como se } \\
\text { dá a contra-argumen- } \\
\text { tação na modalidade } \\
\text { oral. }\end{array}$ & $\begin{array}{l}\text { Apresentação de } \\
\text { um debate } \\
\text { promovido por } \\
\text { universitários } \\
\text { pertencentes a } \\
\text { outras Socie- } \\
\text { dades de Deba- } \\
\text { tes do Rio de } \\
\text { Janeiro. }\end{array}$ & $\begin{array}{l}\text { 1.Pilot } e \\
\text { quadro (para } \\
\text { anotaro tema). } \\
\text { 2.Mesas e ca- } \\
\text { deiras para os } \\
\text { espectadores. } \\
\text { 3.Sineta para } \\
\text { controlar o } \\
\text { tempo de cada } \\
\text { debatedor. }\end{array}$ & $1 h 20 \mathrm{~min}$. \\
\hline $\begin{array}{l}\text { Módulo } 1 \text { : } \\
\text { Regras de cor- } \\
\text { tesia e o gê- } \\
\text { nero debate } \\
\text { regrado (parte } \\
\text { 1) }\end{array}$ & $\begin{array}{l}\text { 1.Destacar a impor- } \\
\text { tância de se manter a } \\
\text { cortesia, com a adoção } \\
\text { de palavras e expressões } \\
\text { que indiquem respeito } \\
\text { aos demais debatedores. } \\
\text { 2.Apresentar } \\
\begin{array}{l}\text { detalhes os papéis dos } \\
\text { primeiros auatro } \\
\text { debatedores. }\end{array}\end{array}$ & $\begin{array}{l}\text { Exposição oral } \\
\text { do professor } \\
\text { acerca do gêne- } \\
\text { ro debate re- } \\
\text { grado, suas } \\
\text { regras de corte- } \\
\text { sia e os papéis } \\
\text { pré-definidos } \\
\text { para os quatro } \\
\text { primeiros de- } \\
\text { batedores. }\end{array}$ & $\begin{array}{l}\text { 1.Pilot e qua- } \\
\text { dro. } \\
\text { 2.Documento } \\
\text { em vídeo com- } \\
\text { tendo a primei- } \\
\text { ra parte de um } \\
\text { debate regrado }\end{array}$ & $45 \mathrm{~min}$. \\
\hline $\begin{array}{l}\text { Módulo } 2 \text { : } \\
\text { Regras de cor- } \\
\text { tesia e o gê- } \\
\text { nero debate } \\
\text { regrado (parte } \\
\text { 2) }\end{array}$ & $\begin{array}{l}\text { 1.Levá-los a com- } \\
\text { preender a importância } \\
\text { de se respeitar a opinião } \\
\text { alheia e de saber ouvi-la } \\
\text { com respeito e tole- } \\
\text { rância. } \\
\text { 2. Apresentar em } \\
\text { detalhes os papéis dos } \\
\text { quatro últimos deba- } \\
\text { tedores. }\end{array}$ & $\begin{array}{l}\text { Reiteração oral } \\
\text { do professor } \\
\text { acerca da im- } \\
\text { portância de se } \\
\text { criar um am- } \\
\text { biente de cordia- } \\
\text { lidade e empa- } \\
\text { tia; os papéis } \\
\text { dos quatro últi- } \\
\text { mos debatedo- } \\
\text { res. }\end{array}$ & $\begin{array}{l}\text { 1.Pilot e qua- } \\
\text { dro. } \\
\text { 2.Documento } \\
\text { em vídeo com- } \\
\text { tendo a segun- } \\
\text { da parte de um } \\
\text { debate regra- } \\
\text { do. }\end{array}$ & $45 \mathrm{~min}$. \\
\hline
\end{tabular}

\footnotetext{
${ }^{4}$ Como o colégio em que está sendo desenvolvido o projeto fica na capital do Rio de Janeiro, torna-se mais fácil entrar em contato com universitários para apresentação ao vivo do debate. Outros professores, entretanto, sem essa possibilidade, podem acessar o link http://ibdebates.org/site/videos no qual encontrarão muitos vídeos de debates de altíssima qualidade, promovidos por universitários de todo o Brasil.
} 
PERcursos Linguísticos • Vitória (ES) •v. $11 \bullet$ n. 29 • 2021 • ISSN: 2236-2592 • Dossiê temático $\bullet O$ texto na pesquisa e no ensino: conhecimentos, práticas e desafios na contemporaneidade •

\begin{tabular}{|c|c|c|c|c|}
\hline $\begin{array}{lr}\text { Módulo } & 3^{5}: A \\
\text { fala } & \text { em } \\
\text { público } & \end{array}$ & $\begin{array}{l}\text { 1. Fazer com que os que } \\
\text { têm receio de falar em } \\
\text { público possam vencer a } \\
\text { timidez expressar a sua } \\
\text { opinião sobre um tema } \\
\text { da atualidade. }\end{array}$ & $\begin{array}{l}\text { Cada aluno tem } \\
\text { a oportunidade } \\
\text { de falar por até } \\
\text { dois minutos. }\end{array}$ & $\begin{array}{lll}\text { Mesa e ca- } \\
\text { deiras em } & \text { cír- } \\
\text { culo } & & \\
\end{array}$ & $1 h$ \\
\hline $\begin{array}{l}\text { Módulo 4: a } \\
\text { preparação } \\
\text { parao debate }\end{array}$ & $\begin{array}{l}\text { 1.Deliberar com os } \\
\text { alunos o tema do debate. } \\
\text { 2.Esclarecer a impor- } \\
\text { tância do estudo e do } \\
\text { planejamento do dis- } \\
\text { curso a ser proferido no } \\
\text { debate. }\end{array}$ & $\begin{array}{l}\text { 1.Levantamento } \\
\text { de temas do } \\
\text { interesse dos } \\
\text { alunos e rele- } \\
\text { vantes para a } \\
\text { sociedade. De } \\
\text { preferência, es- } \\
\text { ses assuntos } \\
\text { devem estar li- } \\
\text { gados aos di- } \\
\text { versos campos } \\
\text { de saberes a que } \\
\text { os alunos têm } \\
\text { acesso na esco- } \\
\text { la. } \\
2 . \quad \text { Exposição } \\
\text { oral do pro- } \\
\text { fessor acerca da } \\
\text { relevância de se } \\
\text { preparar para o } \\
\text { debate, por meio } \\
\text { da pesquisa, } \\
\text { atentando-se } \\
\text { para o fato de } \\
\text { que é necessário } \\
\text { estudar argu- } \\
\text { mentos favo- } \\
\text { ráveis e contrá- } \\
\text { rios ao tema. }\end{array}$ & $\begin{array}{l}\text { Pilot e quadro } \\
\text { para anotar os } \\
\text { temas suge- } \\
\text { ridos e promo- } \\
\text { ver a escolha } \\
\text { dos mais ade- } \\
\text { quados. }\end{array}$ & $30 \mathrm{~min}$. \\
\hline
\end{tabular}

A elaboração da sequência didática acima foi importante para que pudéssemos ter mais clareza quanto ao passo a passo necessário, a fim de que os alunos conhecessem o gênero escolhido como instrumento para aquisição e/ou aperfeiçoamento da oralidade formal. Concordamos com Carvalho e Ferrarezi Jr. (2018, p.31) ao afirmarem que o trabalho com a oralidade deva ocorrer em sala de aula, como um conteúdo programático. Entretanto, a definição do currículo e da carga horária de cada disciplina ainda não é feita isoladamente por cada professor. Infelizmente, as escolas ainda possuem programas que privilegiam excessivamente o ensino de gramática, quando o tempo gasto nessa tarefa poderia estar sendo

\footnotetext{
${ }^{5}$ Consideramos bastante produtiva a atividade de fala em público antes da realização do debate regrado. É uma excelente oportunidade para os alunos perderem a inibição e se acostumarem à fala que requer maior planejamento.
} 


\section{PERcursos Linguísticos • Vitória (ES) •v. 11 •n. 29 • 2021 • ISSN: 2236-2592 • Dossiê temático $\bullet O$ texto na pesquisa e no ensino: conhecimentos, práticas e desafios na contemporaneidade •}

investido na ampliação das competências de ler, escrever, ouvir e falar, conforme está exposto nos PCN (BRASIL, 1997, p.23). Além disso, nem todos os professores compartilham do entendimento de que o ensino dessas competências é de responsabilidade de todos os docentes e não apenas do professor de Português, conforme prevê os PCN (BRASIL, 1997, p.50). Assim, dentro da realidade da nossa escola, para que fosse possível seguir a sequência didática que elaboramos, de maneira sistemática e contínua, elaboramos, em 2017, o projeto Argumentação e Oralidade, com o intuito de que o trabalho com a oralidade não se restringisse a dias isolados ao longo do ano.

Até $2019^{6}$, o projeto contava com quatro alunos bolsistas de iniciação científica e três alunos voluntários. Esses alunos, ao lado da professora responsável, criaram a Sociedade de Debates do Colégio Pedro II. O papel dos discentes participantes é atuar diretamente na escolha dos temas, na divulgação do calendário de debates para os demais alunos da escola e no convite a palestrantes externos (em geral, universitários experientes também envolvidos com o movimento de debates). É importante destacar o protagonismo que se deseja atribuir aos estudantes, especialmente em relação à seleção dos temas. Concordamos com a BNCC quando afirma que é preciso "discutir sobre temáticas vinculadas a questões que os preocupam ou instigam sua curiosidade, privilegiando as que tiverem maior repercussão entre os estudantes" (BRASIL, 2018, p.501).

A participação como debatedor ou como ouvinte é voluntária e aberta a qualquer aluno do Ensino Médio, interessado em aprimorar a sua fala em público, e não está vinculada à atribuição de nenhum grau ou nota. De modo a atender os dois turnos em que a escola funciona, sem prejudicar as aulas regulares de outras disciplinas, foi escolhido o horário de $12 \mathrm{~h}$ às $13 \mathrm{~h}$ para a realização semanal dos debates. O cartaz a seguir foi elaborado e exposto nos corredores da escola, com o intuito de motivar a participação dos alunos:

Imagem 1: cartaz de divulgação do projeto

\footnotetext{
${ }^{6}$ Com a interrupção das aulas devido à pandemia, os alunos interessados continuaram ativos e mantendo contato por meio de um grupo de WhatsApp. Dadas as limitações, os debates passaram a ser mensais, em ambientes virtuais.
} 


\section{PERcursos Linguísticos • Vitória (ES) •v. 11 •n. 29 • 2021 • ISSN: 2236-2592 • Dossiê temático $\bullet O$ texto na pesquisa e no ensino: conhecimentos, práticas e desafios na contemporaneidade •}

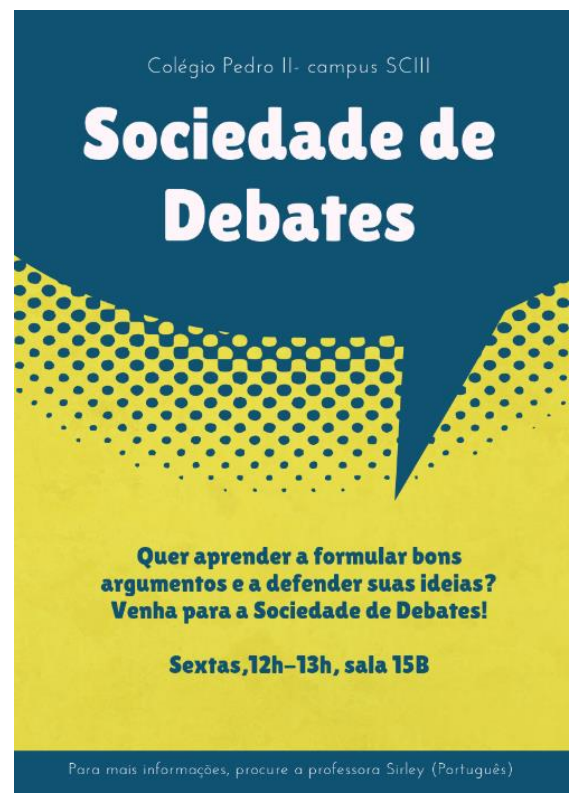

Fonte: arquivo pessoal da autora.

Uma Sociedade de Debates consiste em um grupo organizado de alunos debatedores e juízes e, geralmente, segue o padrão do Parlamento Britânico. Em tal modelo, há quatro duplas de debatedores que discutem a moção (recorte mais específico do tema escolhido) dada no dia do debate. Também no dia do evento, os debatedores descobrem se terão que argumentar favoravelmente à moção ou se deverão apresentar argumentos contrários a ela, de modo que duas duplas fiquem, portanto, a favor e duas duplas sejam contrárias, formando-se duas bancadas de duas duplas cada. $\mathrm{O}$ primeiro debatedor a proferir o seu discurso, pertence à bancada de defesa e o segundo, à bancada de oposição, de modo que as falas de defesa e oposição vão se alternando. Cada debatedor tem até sete minutos para apresentar seus argumentos.

A avaliação é feita por dois ou três avaliadores (em geral, a professora e dois alunos mais experientes) e julga a apresentação de argumentos acompanhados de referências, a oratória, a linha de raciocínio, a capacidade de responder as perguntas feitas e de refutar os argumentos da bancada oposta e, obviamente, de manter um comportamento no qual se revele respeito e cortesia pelos colegas debatedores. Ao final do debate, é declarado qual foi o melhor debatedor individual e qual foi a melhor dupla. Os avaliadores também precisam dar a todos os debatedores um "feedback" acerca do seu desempenho individual. Dada a facilidade de se gravar as falas por meio dos smartfones, a maioria dos debates foi gravada para composição de um corpus de pesquisa para a autora. Além disso, é encaminhado, por Whatsapp, o áudio do 


\section{PERcursos Linguísticos • Vitória (ES) •v. 11 •n. 29 • 2021 • ISSN: 2236-2592 • Dossiê temático $\bullet O$ texto na pesquisa e no ensino: conhecimentos, práticas e desafios na contemporaneidade •}

debate para que cada debatedor possa ouvir o seu próprio discurso e o dos colegas e, assim, melhorar cada vez mais as competências de ouvir e falar.

A BNCC reconhece a importância de se trabalhar com o gênero debate regrado. De acordo com o documento, é preciso: "Oportunizar a vivência de diferentes papéis em debates regrados (membro de uma equipe de debatedor, debatedor, apresentador/mediador, espectador - com ou sem direito a perguntas -, juiz/avaliador)" (BRASIL, 2018, p. 504). Além disso, nesse referencial, é destacada também a necessidade de se exercitar a escuta atenta, respeitando seu turno e tempo de fala, posicionando-se de forma fundamentada, respeitosa e ética diante da apresentação de propostas e defesas de opiniões, usando estratégias linguísticas típicas (como solicitar esclarecimento, detalhamento, fazer referência direta ou retomar a fala do outro, parafraseando-a para endossá-la, enfatizá-la ou enfraquecê-la), considerando propostas alternativas e reformulando seu posicionamento, quando for o caso, com vistas ao entendimento e ao bem comum.

Antes de passarmos às considerações finais, apresentaremos uma amostra ${ }^{7}$ da primeira metade de um debate cujo tema foi Eleições brasileiras e cuja moção foi Esta Casa repudia a existência de bancadas religiosas no Brasil. Conforme já dissemos, os alunos já sabiam qual seria o tema o debate, mas a moção (proposição a ser defendida ou contestada) souberam apenas com quinze minutos de antecedência. Também só no dia do debate, foi realizado um sorteio para saber quais debatedores se colocariam a favor da moção e quais seriam contrários a ela.

O objetivo de tais "regras", é o de levar os alunos a pesquisarem sobre o assunto, numa ação interdisciplinar. Nesse sentido, há o incentivo para sempre estarem dispostos a considerar a multiplicidade de posicionamentos que pode envolver uma questão e, assim, se colocarem no lugar do outro para compreender o seu ponto de vista. Afinal, nesse modelo de debate, podem, por meio de sorteio, acabar fazendo parte de uma bancada que defende algo bem diferente do que pensam.

A seguir, os estudantes, chamados de L1 e L3, advogam acerca da validade da moção, enquanto L2 e L4 discordam dela e tentam provar que é inadequada. Em outras palavras, a fim de convencer os juízes e a plateia, alternam-se discursos da defesa e de oposição. Para a transcrição das falas, preferimos não nos pautarmos pela língua escrita, justamente por ser outra

\footnotetext{
7 Informamos que todos os procedimentos foram realizados em conformidade com as normas institucionais e que foram atendidas as exigências da Resolução $n^{\circ}$ 510, de 7 de abril de 2016, referente a pesquisas envolvendo seres humanos.
} 


\section{PERcursos Linguísticos • Vitória (ES) •v. 11 •n. 29 • 2021 • ISSN: 2236-2592 • Dossiê temático $\bullet O$ texto na pesquisa e no ensino: conhecimentos, práticas e desafios na contemporaneidade •}

modalidade e ter características específicas, diferentes da modalidade oral. Optamos por seguir as normas que aparecem em Castilho \& Pretti (1986), as quais evidenciam os traços de planejamento on-line, típicos do discurso oral, como, por exemplo, hesitações, retomadas, falsas iniciações, etc.:

L1: boa tarde... eu sou a L. da 1303 e nós vamos repudiar a existência de bancadas religiosas em... em todos os campos políticos da nossa sociedade porque eles representam interesses ideológicos que vãofazer parte pra toda população eh ... sendo que eles deveriam representar a todos... tanto que eh... um exemplo que nós temos é a criminalização da homofobia que eh... por conta de ser a maior parte... eh... o congresso negligenciou... e ficou pro STF que não é algo para eles... e... mesmo que eles tenham sido eleitos pela maior parte... eles não representam todos... então eles não tinham que levar a ideologia deles... como uma forma de... como uma forma de...como uma forma de julgar ou tentar mandar no Brasil (...)

L2: boa tarde gente... eu sou o D. e... mais o quê?... só isso mesmo... a:: a gente acha necessário a questão de haver bancadas religiosas pro nosso governo por... por razões culturais muito evidentes... no nosso caso especificamente aqui no Brasil... uma coisa que é bastante interessante é a importância da diversidade... então como aqui a gente tá falando de bancadas... mais do que apenas a predominância uma religião associada ao ao estado... a gente precisa de uma representatividade diversificada porque::... a nossa composição ela também foi diversificada então a religião ela de certa forma atenderia desde... sei lá... cristãos eh... religiões mais africanas e até mesmo alguns cultos à divindades indígenas também (...)

Para além das características inerentes ao texto falado, evidentes nas amostras de L1 e L2, gostaríamos de destacar o fato de os alunos colocarem em prática as orientações acerca do que seria protocolar em uma fala nesse tipo de gênero: cumprimentam os ouvintes, se apresentam, demonstram respeito pelos colegas e empregam vocabulário adequado ao contexto.

Como a participação no projeto é voluntária e aberta a qualquer aluno interessado, constantemente, temos novos estudantes ingressando. Muitos desses alunos, inicialmente muito tímidos, querem apenas assistir aos debates. Com o tempo, ganham mais confiança e, incentivados pelos próprios colegas e pela professora, começam a debater também. L2, por exemplo, participava pela primeira vez do debate e, embora tenha demonstrado alguma insegurança logo na apresentação: “eu sou o D. e... mais o quê?... só isso mesmo...”, acaba se saindo muito bem, inclusive no argumento apresentado, já que destaca o apreço pela diversidade, a qual se estenderia a diferentes bancadas religiosas (cristã, de matriz africana ou 


\section{PERcursos Linguísticos • Vitória (ES) •v. 11 •n. 29 • 2021 • ISSN: 2236-2592 • Dossiê temático $\bullet O$ texto na pesquisa e no ensino: conhecimentos, práticas e desafios na contemporaneidade •}

indígena). De modo análogo, L1 também consegue deixar claro seu ponto de vista e argumenta que a existência de bancadas religiosas atrapalharia a promulgação de leis importantes para toda a sociedade, como a relacionada à homofobia.

As falas de L3 e L4, a seguir, são de alunos mais experientes. Ambos se apresentam de maneira mais completa, fazendo referência inclusive ao nome do Colégio, pois já estavam acostumados, inclusive, a debaterem em campeonatos com alunos universitários. Essa experiência acumulada é perceptível na retomada da fala da dupla, como faz L3: “completando o que a minha dupla trouxe", com o intuito de ampliar a argumentação feita anteriormente por L1.

L3: olá... boa tarde... eu me chamo L... eu faço parte da Sociedade de Debates do Colégio Pedro II... sou da turma 1203 e hoje eu vim aqui defender por que que nós repudiamos a existência de bancadas religiosas... em primeiro lugar eh:.... fazendo..... completando o que a minha dupla trouxe... eh: as bancadas religiosas elas defendem interesses ideológicos de religiões específicas... isso não é benéfico porque... porque elas não visam eh:: elas visam à criação das leis a aprovação das leis baseado no que seria benéfico para a população e sim para o que seria benéfico para o grupo específico que elas representam... um exemplo disso que ela trouxe a homofobia que foi negligenciada por muito tempo... eh:.: no Congresso... não criaram leis até criavam mas eles não aprovavam porque o Congresso composto por muitos deputados conservadores eh: de bancadas religiosas eles não aprovavam porque isso não representava a ideologia religiosa deles (...)

L4: boa tarde a todos... meu nome é G. P. e eu sou aluno do magnífico Colégio Pedro II... o lendário Colégio previsto na Constituição Federal de 1988...eh:: agradeço a presença da bancada de defesa... a sensatíssima bancada de oposição e também a mesa avaliadora... eh: senhoras e senhores eu começo trazendo o meu primeiro argumento que é justamente que a defesa dos interesses eh: da instituições religiosas... das bancadas religiosas... das pessoas eh:: que contém a sua religião dentro da política é extremamente importante e também extremamente eh:: lícito e previsto pela Constituição Federal... então senhoras e senhores esse é primeiro ponto que vim trazer pra mostrar pra vocês que repudiar a existência de repudiar a existência de bancadas religiosas é uma coisa ridícula... é uma coisa que não faz sentido nenhum quando é proposta pela bancada de defesa nesta manhã eh::: exatamente porque nós conhecemos uma expressão chamada lugar de fala que embora seja uma expressão que diversas 


\section{PERcursos Linguísticos • Vitória (ES) •v. 11 •n. 29 • 2021 • ISSN: 2236-2592 • Dossiê temático $\bullet O$ texto na pesquisa e no ensino: conhecimentos, práticas e desafios na contemporaneidade •}

vezes pode parecer contraditória tem o seu sentido sim... o que diz a ideia do lugar de fala? ela nos mostra por exemplo que quando uma pessoa ela vive aquilo que ela está dizendo... ela tem muito mais eh:.: ela tem muito mais autoridade sobre o que ela está falando (...)

A fala de L4 revela, como dissemos, mais intimidade com o gênero trabalhado. $\mathrm{O}$ estudante, além de se apresentar, também agradece à bancada de defesa e à bancada de oposição, caracterizada como "sensatíssima", da qual ele mesmo faz parte. A escolha do superlativo para qualificar a sua própria bancada, obviamente, não foi ao acaso, mas com uma clara intenção argumentativa. Também se percebe esse mesmo propósito quando se refere à moção como algo ridículo e que não faz sentido nenhum.

Nota-se ainda que, nesse primeiro minuto de fala, L4 apresenta dois argumentos que sustentam o seu posicionamento, que são: a) o fato de a Constituição garantir a existência de tais bancadas ("lícito e previsto pela Constituição Federal”) e b) a composição dessas bancadas ser justificável justamente por seus parlamentares serem pessoas ligadas à religião, o que conferiria a elas mais legitimidade em suas questões, pois estariam subsidiadas pelo que se chama de lugar de fala, expressão muito usada por ativistas ao se dar voz a pessoas que vivenciam determinada problemática.

Essa experiência acumulada por L3 e L4 nos prova o quanto é importante um trabalho recorrente com a oralidade formal e que, se é verdade que só se aprende a escrever, escrevendo, também é comprovado que só se aprende a fazer discursos orais, pondo isso em prática. A possibilidade de se ir além do falar cotidiano, restrito a indivíduos do núcleo familiar ou com os quais se tem intimidade, precisa ser uma meta a ser alcançada por toda comunidade escolar, portanto.

\section{Considerações finais}

Ao longo do texto, buscamos mostrar que as mudanças desejadas no ensino de Língua Portuguesa passam, sem desconsiderar outros fatores, pelo incremento do trabalho com gêneros orais, a fim de que aqueles que demandam maior formalidade tornem-se objeto de ensino.

A escolha do gênero debate regrado atendeu às nossas expectativas quanto ao desenvolvimento da fala em público e da elaboração de argumentos pertinentes, tão necessários em nossa sociedade. Entretanto, tão relevante quanto essas habilidades mencionadas é o 


\section{PERcursos Linguísticos • Vitória (ES) •v. 11 •n. 29 • 2021 • ISSN: 2236-2592 • Dossiê temático $\bullet O$ texto na pesquisa e no ensino: conhecimentos, práticas e desafios na contemporaneidade •}

respeito às regras de cortesia, a fim de que a discussão sempre fique restrita ao campo das ideias. Se almejamos uma sociedade melhor, isso passa pela assimilação do conceito de empatia e pela adoção de condutas condizentes com a civilidade.

Gostaríamos ainda de reafirmar nosso posicionamento de que é a partir da própria prática que são criadas e desenvolvidas as habilidades exigidas para a sustentação de ideias e, com o exercício constante, os educandos podem se tornar cada vez mais capazes de defenderem seus posicionamentos também na modalidade oral da língua. Desse modo, com esse entendimento de que se aprende a debater através da participação em debates e de que a modalidade oral da língua também deve ser um alvo da escola, é que reforçamos a importância de se oferecer cada vez mais oportunidades aos discentes de aprenderem através da experiência e, dessa maneira, paulatinamente, se tornarem mais confiantes e seguros ao assumirem a palavra em quaisquer contextos situacionais nos quais estiverem inseridos.

Nosso interesse é, portanto, pela formação de sujeitos cada vez mais autônomos, capazes de alçarem a sua voz em defesa de seus direitos a fim de que estes não sejam suprimidos ou concedidos em parte. Assim, as discussões aqui levantadas corroboram a necessidade de que as produções acadêmico-científicas cheguem aos professores da Educação Básica, de modo que haja uma constante interlocução entre os pesquisadores universitários das áreas de Educação e de Letras e aqueles responsáveis pela implementação das pesquisas.

\section{Referências}

ALMEIDA, Milton José de. Ensinar Português? In: GERALDI, João Wanderlei (org.). O texto na sala de aula. 4. ed. São Paulo: Ática, 2006.

BENTES, Anna Christina. Oralidade, política e direitos humanos. In: ELIAS, Vanda Maria (org.). Ensino de Língua Portuguesa: oralidade, escrita, leitura. 1.ed. São Paulo: Contexto, 2018.

BRASIL. MEC. Secretaria de Educação Fundamental. Parâmetros curriculares nacionais: Língua Portuguesa/ Secretaria de Educação Fundamental. Brasília. 1997.

BRASIL. Ministério da Educação. Base Nacional Comum Curricular. Brasília, 2018.

BROWN, Penelope; LEVINSON, Stephen. Politeness. Cambridge Univ.Press, 1987. 


\section{PERcursos Linguísticos • Vitória (ES) •v. 11 •n. 29 • 2021 • ISSN: 2236-2592 • Dossiê temático $\bullet O$ texto na pesquisa e no ensino: conhecimentos, práticas e desafios na contemporaneidade •}

CARVALHO, Robson Santos de; FERRAREZI Jr., Celso. Oralidade na Educação Básica: o que saber, como ensinar. 1.ed. São Paulo: Parábola, 2018.

CASTILHO, Ataliba Teixeira de; PRETI, Dino. (orgs.). A linguagem falada culta na cidade de São Paulo: materiais para seu estudo. 1.ed. São Paulo: T. A. Queiroz, 1986.

CASTILHO, Ataliba Teixeira de. A língua falada no ensino de Português. 1.ed. São Paulo: Contexto, 1998.

CASTILHO, Ataliba Teixeira de; BASILIO, Margarida. (org.) Gramática do Português falado. 1.ed. Campinas: Editora da UNICAMP/FAPESP, vol. IV, 1996.

CHARAUDEAU, Patrick. A argumentação talvez não seja o que parece ser. In.: GIERING, M. E.; TEIXEIRA, M. Investigando a linguagem em uso: estudos em linguística aplicada. São Leopoldo: Ed. Unisinos, 2004. p. 33-44.

COSTA-MACIEL, Débora Amorim Gomes da; BILRO, Fabrini Katrine da Silva. O que é ensinar a oralidade? Análise das proposições didáticas apresentadas em livros destinados aos anos iniciais da Educação Básica. Educação em revista, Belo Horizonte, v.34, p. 1-29, 2018.

DOLZ, Joaquim; SCHNEUWLY, Bernard. Gêneros e progressão em expressão oral e escrita elementos para reflexões sobre uma experiência suíça (francófona). In: SCHNEUWLY, Bernard e DOLZ, Joaquim. Gêneros orais e escritos na escola. Traduzido por Roxane Rojo e Glaís Sales Cordeiro. 1.ed. Campinas, SP: Mercado das Letras, 2004, p. 35-60.

DOLZ, Joaquim, NOVERRAZ, Michèle; SCHNEUWLY, Bernard. Sequências didáticas para o oral e a escrita: apresentação de um procedimento. In: SCHNEUWLY, Bernard e DOLZ, Joaquim. Gêneros orais e escritos na escola. Traduzido por Roxane Rojo e Glaís Sales Cordeiro. 1.ed. Campinas, SP: Mercado das Letras, 2004, p. 213-239.

FÁVERO, Leonor Lopes et al. Oralidade e escrita: perspectivas para o ensino de língua materna. 5. ed. São Paulo: Cortez, 2005. 


\section{PERcursos Linguísticos • Vitória (ES) •v. 11 •n. 29 • 2021 • ISSN: 2236-2592 • Dossiê \\ temático $\bullet O$ texto na pesquisa e no ensino: conhecimentos, práticas e desafios na contemporaneidade •}

FERRAREZI, Celso. Pedagogia do silenciamento: a escola brasileira e o ensino de língua materna. 1.ed. São Paulo: Parábola Editorial, 2014.

GOMES-SANTOS, S.N. Modos de apropriação; do gênero debate regrado na escola: uma abordagem aplicada. Delta, v.25, p. 39-66, 2009.

KOCH, Ingedore Villaça. (org.) Gramática do Português falado. 1.ed. Campinas: Editora da UNICAMP/FAPESP, vol. vi, 1996.

KOCH, Ingedore Villaça. A inter-ação pela linguagem. 4ª ed. São Paulo: Cortez, 1998.

KOCH, Ingedore Villaça. Desvendando os segredos do texto. São Paulo: Cortez, 2002.

$\mathrm{KOCH}$, Ingedore Villaça \& ELIAS, Vanda Maria. Fala e escrita. In: KOCH, Ingedore Villaça: Ler e escrever: estratégias de produção textual. 1.ed. São Paulo: Contexto, 2012.

LEAL, Telma Ferraz; GOIS, Sianne (Orgs.). A oralidade na escola: a investigação do trabalho docente como foco de reflexão. Belo Horizonte: Autêntica, 2012.

MAGALHÃES, Tânia Guedes. Oralidade na sala de aula: alguém "fala" sobre isso?. Instrumento. n.7, p. 65-81, 2006.

MARCUSCHI, Luiz Antônio. Análise da conversação. 1.ed. São Paulo: Ática, 1986.

MARCUSCHI, Luiz Antônio. Da fala para a escrita: atividades de retextualização. São Paulo: Cortez, 2001.

NEGREIROS, Gil; VILAS BOAS, Gislaine. A oralidade na escola: um (longo) percurso a ser trilhado. Letras, v.27, n.54, p. 115-126, jan./jun.2017.

NONATO, Sandoval. Processos de legitimação da linguagem oral no ensino de Língua Portuguesa: panorama histórico e desafios atuais. Cadernos Cedes. v. 38, n. 105, p. 222-239, maio-ago.2018.

SCHNEUWLY, Bernard. Palavra e ficcionalização: um caminho para o ensino da linguagem oral. In: SCHNEUWLY, Bernard e DOLZ, Joaquim. Gêneros orais e escritos na escola. Traduzido por Roxane Rojo e Glaís Sales Cordeiro. 1.ed. Campinas, SP: Mercado das Letras, 2004, p. 109-124.

SCHNEUWLY, Bernard; DOLZ, Joaquim. Gêneros orais e escritos na escola. Traduzido por Roxane Rojo e Glaís Sales Cordeiro. 1.ed. Campinas, SP: Mercado das Letras, 2004. 


\title{
A INFORMATIVIDADE NO PROCESSO DE ESCRITA ARGUMENTATIVA ESCOLAR: ELABORAÇÃO DE INSTRUMENTOS DIDÁTICOS A PARTIR DE ARTICULAÇÕES TEÓRICO- METODOLÓGICAS
}

\author{
INFORMATIVITY IN ARGUMENTATIVE WRITING PROCESS IN \\ SCHOOL: ELABORATION OF PEDAGOGICAL INSTRUMENTS \\ FROM THEORETICAL-METHODOLOGICAL ARTICULATIONS
}

Aline Rubiane Arnemann ${ }^{1}$

\begin{abstract}
RESUMO: Este artigo objetiva compartilhar discussões e reflexões acerca do critério de informatividade, com base em Arnemann (2020), elucidando contribuições do uso da informatividade na elaboração de instrumentos didáticos para ancorar o processo de escrita escolar. Para tal, abordamos noções elementares acerca da informatividade, a saber os graus baixo, médio e alto de informatividade e as definições que assumimos para os termos "dado" e "novo". Atreladas a essas noções, exploramos as recontextualizações realizadas do cenário científico para o escolar que culminaram na elaboração de quadros, quais sejam: Quadro para identificação de uso de estratégias argumentativas e Quadro autoavaliativo sobre o processo de produção textual, utilizados pelos participantes de pesquisa, Arnemann (2020), ao longo das produções textuais que desenvolveram e entre as etapas de escrita de cada produção; Levantamento de informações (novas e dadas) na produção textual e Quadro para sinalização da informatividade, decorrentes dos resultados de Arnemann (2020); e Mapeamento do interlocutor, reflexão posterior. Tais quadros advém de uma proposta teórico-metodológica e se configuram como instrumento e proposta didática, visto que tem o potencial de subsidiar ações discentes e docentes no processo de escrita argumentativa, diante dos desafios que quem estuda, ensina e/ou aprende enfrenta em relação ao texto.
\end{abstract}

PALAVRAS-CHAVE: Informatividade. Instrumento e proposta didática. Escrita argumentativa escolar.

ABSTRACT: This article aims to discuss and reflect on the criterion of informativity based on Arnemann (2020), elucidating contributions of the use of informativity in the development of teaching instruments to anchor the school students' writing process. Thus, we approach fundamental notions on informativity, namely the low, medium, and high degrees of informativity and the definitions we consider for the terms "given" and "new". Taking these notions into account, we explore the recontextualization from science to school context which culminated in the elaboration of the following frameworks: Framework for identifying the use of argumentative strategies and Self-evaluation framework on the textual production process,

\footnotetext{
${ }^{1}$ Doutora em Letras. arnemannaline@gmail.com
} 


\section{PERcursos Linguísticos • Vitória (ES) •v. 11 •n. 29 • 2021 • ISSN: 2236-2592 • Dossiê temático $\bullet O$ texto na pesquisa e no ensino: conhecimentos, práticas e desafios na contemporaneidade •}

which were used by the research participants, Arnemann (2020), throughout the writing productions they developed and between the writing stages of each production; Survey for information (new and given) in the writing production and Framework for signposting informativity, from the results of Arnemann (2020); and Interlocutor mapping, elaborated after the results. Such frameworks come from a theoretical-methodological proposal and are configured as instrument and pedagogical proposal, since they have the potential to support students and teachers' actions in the argumentative writing process, given the challenges in relation to the text faced by those who study, teach, and/or learn.

KEYWORDS: Informativity. Instrument and teaching proposal. Argumentative writing in school.

\section{Considerações iniciais}

Neste espaço, situamo-nos na posição de interlocutores diante do questionamento presente na chamada à qual este artigo se inscreve: “quais propostas teórico-metodológicas ou quais propostas didáticas configuram desafios para quem tem o texto como objeto de pesquisa e/ou de ensino na contemporaneidade?". Nesse sentido, a fim de contribuir com reflexões e com o desencadeamento de novas reflexões acerca da referida problemática, e considerando a natureza multifacetada e complexa do texto, discutimos, aqui, uma interface de pesquisa e ensino do texto. Dessa maneira, este artigo se inscreve como uma contribuição para o enfrentamento de um dos desafios atuais do trabalho com o texto em sala de aula no Brasil: as propostas teórico-metodológicas.

A definição desse ponto de vista de escrita se deve ao marco de origem desta discussão: a tese de doutorado Informatividade na sala de aula: o emprego de informações na construção de argumentos (ARNEMANN, 2020). Tal produção é resultado da preocupação com o ensino do texto em sala de aula e da percepção acerca da extrema necessidade de relação entre teoria e prática, pois somente essa articulação pode conferir efetividade na mediação entre conhecimentos científicos ou escolares e conhecimentos cotidianos, contribuindo para a aprendizagem do estudante.

Nesse sentido, com vistas a situar nosso interlocutor acerca da necessidade de resgate à referida tese neste texto, abordamos sumariamente seu contexto de desenvolvimento. Tal estudo é resultado de uma parceria ${ }^{2}$ entre Instituição de Ensino Superior - representada pelo Programa de Pós-Graduação em Letras (PPGL) da Universidade Federal de Santa Maria (UFSM) - e uma

\footnotetext{
${ }^{2}$ Autorizada pelo Comitê de Ética em Pesquisa e registrada sob o CAAE 78737817.0.0000.5346.
} 


\section{PERcursos Linguísticos • Vitória (ES) •v. 11 •n. 29 • 2021 • ISSN: 2236-2592 • Dossiê temático $\bullet O$ texto na pesquisa e no ensino: conhecimentos, práticas e desafios na contemporaneidade •}

Instituição de Ensino Básico - representada por uma escola pública situada no município de Santa Maria, RS.

Essa parceria propiciou a realização de uma Pesquisa-Ação - no viés de Thiollent (2011) e Burns (2010) - cujos envolvidos foram: a pesquisadora professora ${ }^{3}$, o professor titular ${ }^{4}$ da disciplina de Língua Portuguesa das turmas de terceiro ano de Ensino Médio da escola já mencionada e uma dessas turmas, identificada como $3^{\circ} \mathrm{C}$. Assim, no decorrer dos meses de junho a dezembro de 2018, a pesquisadora professora desenvolveu um processo de ensino de produção textual argumentativa com os terceiranistas em questão, com a colaboração do professor titular.

Para dinamizar o referido processo, foram realizadas duas grandes articulações: uma teórica e outra metodológica. A primeira envolveu a Linguística do Texto, com ênfase no critério de informatividade, os postulados da Teoria da Argumentação, de Perelman e Olbrechts-Tyteca (2014), a perspectiva sociointeracionista de ensino, de Lev S. Vygotsky, e as contribuições de Mikhail Bakhtin acerca da interação verbal e do dialogismo. A segunda teve a Pesquisa-Ação como eixo central, à qual foram acomodadas: a perspectiva genebrina de gêneros textuais, de Dolz e Schneuwly (2004), a sequência didática, de Dolz, Noverraz e Schneuwly (2004), o Desenvolvimento Profissional Corresponsável (DPC), de Richter (2008), Freitag e Richter (2015) e Bom Camilo (2017, 2020) e a pergunta problematizadora, de Freire e Faundez (1985).

Essas duas articulações, além de sustentarem o desenvolvimento do estudo em si e a elaboração de categorias de análise inerentes à cientificidade que a pesquisa requer, viabilizaram um constructo teórico-prático que não se restringe ao espaço de estudo acadêmico do texto. Indo além, contempla essa possibilidade e, sobretudo, propicia o uso efetivo de instrumentos didáticos para o ensino do texto em sala de aula, em especial na escola básica.

Convém pontuar que realizamos essas contextualizações com a finalidade de situar o leitor acerca do universo de pesquisa e do fulcro das discussões e reflexões que tecemos, nas seções subsequentes, acerca e a partir de um dos resultados da referida tese, o qual diz respeito à sinalização da informatividade, em especial ao uso de quadros - como instrumento didático - no trabalho com esse critério de textualidade no ensino de escrita argumentativa na escola. É por meio desse ponto que nos inscrevemos no espaço de discussão referente à proposta teórico-

\footnotetext{
${ }^{3}$ Autora deste estudo e da tese em comento, a qual, no momento de realização da geração de dados, representava a UFSM.

${ }^{4}$ Professor representante da Escola Estadual de Educação Básica Professora Margarida Lopes.
} 


\section{PERcursos Linguísticos • Vitória (ES) •v. 11 •n. 29 • 2021 • ISSN: 2236-2592 • Dossiê temático $\bullet O$ texto na pesquisa e no ensino: conhecimentos, práticas e desafios na contemporaneidade •}

metodológicas e/ou didáticas desafios que desafiam pesquisadores, professores e estudantes de textos hoje, no Brasil.

\section{O critério de informatividade: disposições teórico-metodológicas}

Iniciamos as discussões correspondentes ao tratamento teórico pelo critério de informatividade, proposto por Beaugrande e Dressler (1981), haja vista que tal tema tem posição essencial neste estudo. Nesse sentido, resgatamos uma comparação do texto com um tecido, muito oportuna aos estudiosos de texto, em especial, da Linguística do Texto. Esse paralelo se deve, pois o tecido somente assume tal natureza a partir da costura dos fios, os quais, isolados, são apenas fios. De semelhante maneira, o texto assume sua natureza a partir da articulação de seus elementos constitutivos, de modo que um elemento sozinho não confere textualidade ao texto. Esperamos que essa analogia, ao nosso interlocutor, inscreva-se com um grau baixo de informatividade, pois não traz novidades, mas informações dadas, ou seja, já de conhecimento.

Nessa continuidade, Beaugrande e Dressler (1981) defendem que, na constituição de um texto, entra em curso a operação de sete critérios de textualidade, quais sejam: coesão, coerência, intencionalidade, aceitabilidade, situacionalidade, intertextualidade e informatividade. Pontuamos que focalizar o estudo do texto a partir da informatividade não desconsidera a existência dos demais critérios (todos são fundamentais). Essa afirmação se vale para qualquer um dos critérios que seja tomado como foco (de investigação e/ou de ensino). Esperamos que essa seja, também, uma observação de grau baixo de informatividade ao nosso interlocutor.

Quando assumimos um foco, é possível aprofundar e aprimorar conhecimentos e saberes em relação ao que foi selecionado, além de estabelecer (novas) relações. Nesse caso, no que diz respeito ao critério de informatividade, recuperamos discussões que podem assumir um grau alto de informatividade para alguns interlocutores, diante de seu caráter de novidade e, por conseguinte, talvez demande maior processamento textual. Para outros, que já têm conhecimento acerca de determinadas noções, pode assumir um grau médio de informatividade, favorecendo, assim, um balanceamento entre informações novas e dadas que contribuiu com a construção de sentido. Esperamos não contemplar o grau baixo de informatividade para a grande maioria dos interlocutores deste texto.

Beaugrande e Dressler (1981) dispõem que a informatividade diz respeito à apresentação de informações novas em determinada extensão textual. Parece simples, 


\section{PERcursos Linguísticos • Vitória (ES) •v. 11 •n. 29 • 2021 • ISSN: 2236-2592 • Dossiê temático $\bullet O$ texto na pesquisa e no ensino: conhecimentos, práticas e desafios na contemporaneidade •}

entretanto essa definição assume complexidade, visto que a informatividade se trata de um fenômeno de linguagem no qual operam questões de ordem contextual e social. Explicamos: uma informação pode assumir um grau maior ou menor de novidade de acordo com cada indivíduo, que tem sua história, está inserido em determinado ambiente sociocultural e nele realiza determinadas interações com outros sujeitos, mediante distintos gêneros textuais.

Assim, uma mesma informação pode assumir uma enorme obviedade para uma pessoa, ao passo que, para outra, pode ser estapafúrdia. Em casos de obviedade, o interlocutor processa rapidamente a informação. Todavia, quando em excesso, as informações dadas podem causar desinteresse, pois a novidade é escassa. Por outro lado, a incompreensão requer um processamento maior da informação e, se não resolvida, pode ocasionar, também, desinteresse, uma vez que o interlocutor não consegue construir sentidos para o texto.

Essas elucidações mostram um excerto da complexidade da interação entre as informações e seus usuários. Isso faz muito sentido no contexto atual, com a ascensão digital global e com o fenômeno das Fake News, o qual tem acometido um número elevadíssimo de indivíduos. As pessoas têm revelado dificuldades e, em alguns casos, barreiras com o uso de informações. Por isso, nunca foi tão essencial o trabalho com informações e, aqui, a informatividade assume seu lócus de contribuição.

Desse modo, realizamos uma espécie de pingue-pongue entre as disposições dos teóricos proponentes do critério de informatividade, Beaugrande e Dressler (1981), e nossas contribuições, conforme as pistas textuais já indiciaram. Tomamos esse posicionamento a fim de conferir um tratamento teórico-prático acerca do critério de informatividade e alcançar, aqui, um dos postulados de Koch e Elias $(2014$, p.34) no que se refere às estratégias de escrita: o “ 'balanceamento' entre informações explícitas e implícitas; entre informações 'novas' e 'dadas', levando em conta o compartilhamento de informações com o leitor e o objetivo da escrita".

Conforme anunciamos, o critério de informatividade de um texto pode ser observado em uma escala de graus de informatividade: grau baixo - presença de informações previsíveis e dadas; grau médio - balanceamento entre informações novas e dadas; e grau alto predomínio de informações novas e imprevisíveis, de acordo com Beaugrande e Dressler (1981). Segundo os autores em comento, o grau médio de informatividade é o mais favorável para o estabelecimento da comunicação humana.

Desde a proposição do critério em questão até a atualidade, tivemos poucas iniciativas referentes ao uso da informatividade no contexto de ensino e aprendizagem de Língua Portuguesa, em especial de produção textual escrita nem alcançando, ainda, a produção textual 


\section{PERcursos Linguísticos • Vitória (ES) •v. 11 •n. 29 • 2021 • ISSN: 2236-2592 • Dossiê temático $\bullet O$ texto na pesquisa e no ensino: conhecimentos, práticas e desafios na contemporaneidade •}

oral e de textos multissemióticos - pauta para investigações vindouras. A enorme maioria das pesquisas que investigaram a informatividade se dedicaram a identificar o grau de informatividade de textos escritos escolares, na perspectiva do texto como um produto pronto e acabado. Isso se deve, também, em nosso ponto de vista à existência de uma lacuna teórica que viabilize o uso da informatividade no trabalho com o texto processo.

Nesse sentido, tal lacuna, atrelada a nossa preocupação com o ensino de escrita argumentativa em sala de aula, inscreveu-se como um espaço de oportunidade para investigar alternativas de trabalho com a informatividade. Assim, em Arnemann (2020), algumas perguntas impulsionaram nossas ações: como definir o que diz respeito a uma informação nova e o que se refere a uma informação dada? ${ }^{5}$ Como o produtor de um texto identifica quem é seu (possível) interlocutor, para, então, ponderar acerca das informações que pode utilizar no seu texto - quais pode deixar na implicitude e quais deve levar à explicitude? Como o professor pode auxiliar os estudantes a identificar o que é uma informação nova e o que é uma informação dada? Como o docente pode auxiliar os estudantes no processo de busca, seleção, apresentação e interpretação de informação?

Resgatamos as perguntas, a fim de acentuar que com elas inicia o conhecimento, pois, conforme expõem Freire e Faundez (1985, p. 24): "no ensino esqueceram-se das perguntas, tanto o professor como o aluno esqueceram-nas, e no meu entender todo conhecimento começa pela pergunta". Ademais, registramos que o pesquisador e o professor necessitam ser "perguntadores" e, na posição em que estão, ensinar os sujeitos sociais - especificamente, os estudantes - a perguntar. Nosso interlocutor pode estar questionando: qual a relação entre informatividade e as perguntas e por que tamanha ênfase dedicada às perguntas? Explicamos: a partir do momento em que o sujeito social se torna um "perguntador", ou um aprimorado "perguntador", há um processo anterior, que é o de tomada de consciência de seu lugar no e com o mundo e do potencial de sua atuação ativa nos meios em que interage. $\mathrm{O}$ sujeito "perguntador" tem, diante de si, a capacidade de questionar as informações e não somente no sentido de serem verdadeiras ou falsas, o que já é um avanço de grande valia, como também de questionar a finalidade do uso, a escolha das informações que foram para o plano explícito e aquelas que foram ocultadas, dentre inúmeras outras operações de pergunta em relação às informações.

\footnotetext{
${ }^{5}$ Beaugrande e Dressler (1981) dispõem que o interlocutor é responsável por definir o que é novo ou dado a ele, visto que assume a posição de receber a informação.
} 


\section{PERcursos Linguísticos • Vitória (ES) •v. 11 •n. 29 • 2021 • ISSN: 2236-2592 • Dossiê temático $\bullet O$ texto na pesquisa e no ensino: conhecimentos, práticas e desafios na contemporaneidade •}

Esse direcionamento à pergunta foi necessário no ensino da escrita argumentativa escolar a partir do viés da informatividade, pois os estudantes, participantes de pesquisa, demandaram tomar decisões em relação ao uso de informações em suas produções textuais. Com isso, pontuamos também que, para alcançar a possibilidade de trabalho com a informatividade no texto processo, com vistas a contribuir com um grupo social, foi e é fundamental aproximar teorias e métodos. A pergunta, portanto, inscreve-se como um método.

Retornando às perguntas que impulsionaram a referida pesquisa, exploramos as ações decorrentes, que se materializaram de diferentes maneiras, seja nas intervenções em sala de aula, nos textos e na elaboração de quadros que assumem uma funcionalidade de instrumento didático, ou seja, que possam ser utilizados em contextos de ensino. Iniciamos pela exposição de um deles - aqui elaborado a partir da reflexão acerca das ações realizadas - que se volta a auxiliar o produtor do texto a mapear seu (possível) interlocutor:

Quadro 1 - Mapeamento do interlocutor

\begin{tabular}{|c|c|c|c|}
\hline \multicolumn{2}{|c|}{$\begin{array}{l}\text { Possibilidades de perguntas } \\
\text { que o produtor pode realizar } \\
\text { a si em relação ao (possível) } \\
\text { interlocutor: }\end{array}$} & $\begin{array}{l}\text { Quais noções as respostas a essas perguntas } \\
\text { fornecem ao produtor de texto? }\end{array}$ & $\begin{array}{l}\text { Perfil de informações } \\
\text { de interesse do } \\
\text { (possível) } \\
\text { interlocutor: }\end{array}$ \\
\hline$\cdot \tilde{\pi}$ & 1. Onde mora? & $\begin{array}{l}\text { Localização geográfica: informações de } \\
\text { interesse para os habitantes locais. }\end{array}$ & \multirow{7}{*}{$\begin{array}{l}\text { As respostas - que } \\
\text { podem não ser exatas } \\
- \text { dessas perguntas } \\
\text { auxiliam o produtor a } \\
\text { mapear o interlocutor, } \\
\text { conferindo um perfil } \\
\text { de informações que } \\
\text { podem ser de } \\
\text { interesse dele. } \\
\text { Pontuamos que essas } \\
\text { respostas podem } \\
\text { auxiliar a mapear um } \\
\text { interlocutor, } \\
\text { particularmente, ou } \\
\text { um grupo de } \\
\text { interlocutores. }\end{array}$} \\
\hline$\underset{0}{0}$ & $\begin{array}{l}2 . \mathrm{Co} \\
\text { interc }\end{array}$ & $\begin{array}{l}\text { Contexto de interação: informações de } \\
\text { interesse para determinados grupos sociais. }\end{array}$ & \\
\hline 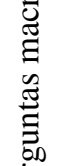 & $\begin{array}{l}3 . \mathrm{O} \text { que } \\
\text { dia a dia }\end{array}$ & $\begin{array}{l}\text { Contexto de trabalho, estudo e/ou lazer: } \\
\text { informações de interesse para atividades } \\
\text { obrigatórias ou eletivas de determinados } \\
\text { grupos sociais. }\end{array}$ & \\
\hline D̃ & $\begin{array}{l}4 . \mathrm{Oc} \\
\text { intere }\end{array}$ & $\begin{array}{l}\text { Assuntos: informações que podem atrair a } \\
\text { atenção do interlocutor. }\end{array}$ & \\
\hline \multirow{3}{*}{ 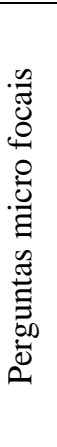 } & $\begin{array}{l}\text { 5.Quais informações } \\
\text { o interlocutor pode já } \\
\text { saber e que outras } \\
\text { podem ser novidade? }\end{array}$ & $\begin{array}{l}\text { No âmbito de cada um dos tópicos anteriores, o } \\
\text { que meu (possível) interlocutor já sabe e o que } \\
\text { pode ser novidade? }\end{array}$ & \\
\hline & $\begin{array}{l}6 . \mathrm{O} \text { que o interlocutor } \\
\text { espera que seja } \\
\text { resgatado? }\end{array}$ & $\begin{array}{l}\mathrm{Na} \text { esfera de informações compartilhadas, isto } \\
\text { é, de conhecimento de produtor e interlocutor, } \\
\text { o que o interlocutor espera que o produtor } \\
\text { resgate? }\end{array}$ & \\
\hline & $\begin{array}{l}7 . \mathrm{O} \text { que o interlocutor } \\
\text { espera encontrar no } \\
\text { âmbito da novidade? }\end{array}$ & $\begin{array}{l}\text { que o } \\
\text { e? }\end{array}$ & \\
\hline
\end{tabular}

Fonte: Elaborado pela autora deste artigo.

O quadro apresentado sistematiza perguntas e noções que podem ser utilizadas para auxiliar o produtor de qualquer texto - desde que claros os objetivos de ensino e de aprendizagem - a identificar informações de interesse do interlocutor que tem em vista, ou seja, pode ser empregado em diferentes situações. Por intermédio do uso dessa ferramenta, o 


\section{PERcursos Linguísticos • Vitória (ES) •v. 11 •n. 29 • 2021 • ISSN: 2236-2592 • Dossiê temático $\bullet O$ texto na pesquisa e no ensino: conhecimentos, práticas e desafios na contemporaneidade •}

produtor de um texto precisa mobilizar sua atenção voluntária - uma das funções psicológicas superiores, a qual é, consoante Luria (1981, p. 168), "manifestada como a capacidade que tem a pessoa de verificar o seu próprio comportamento" - quando se volta ao seu interlocutor, realizando o que caracterizamos como mapeamento do interlocutor.

Trabalhar com o mapeamento do interlocutor ampara o autor do texto, ao fornecer indícios de onde e quais informações pode buscar para utilizar em sua produção. Nesse sentido, entra em cena outro aspecto que também pode subsidiar o autor do texto: a natureza da informação, a qual o auxilia a identificar uma informação (com maior precisão) em outros textos e ponderar qual natureza se inscreve como mais adequada à realização da interpretação ou mais propensa a convencer o interlocutor. Vale destacar que, por vezes, é necessário que o pesquisador e/ou o professor, dependendo do grupo social com o qual esteja interagindo, auxilie no sentido de propor e realizar atividades que forneçam base para o desenvolvimento dessa atividade cognitiva.

Desse modo, categorizamos as informações - de acordo com sua natureza -, intentando que o produtor de texto, com auxílio da categorização, realize os processos referentes à identificação e ponderação de informações. As categorias de informação são as seguintes: 1 . Informação a partir de dado veiculado por fonte confiável; 2. Informação a partir de voz de especialista veiculada por fonte confiável; 3. Informação a partir de documento legal veiculado por fonte confiável; 4. Informação a partir de fato veiculado por fonte confiável; 5. Informação a partir de acontecimento; 6. Informação a partir de alusão histórica; 7. Informação a partir de ideal filosófico ou voz de especialista na área; e 8. Informação a partir de ideal sociológico ou voz de especialista na área. Para trabalhar com os participantes de pesquisa, em Arnemann (2020), essa categorização foi fundamental, a fim de auxiliá-los a identificar, na materialidade linguística dos textos, seus e dos outros, trechos que correspondem a informações.

Esclarecemos que essa categorização foi elaborada em um contexto científico. No entanto, como o objetivo se volta à utilização em outro contexto, a saber, a sala de aula escolar, conforme ocorreu em Arnemann (2020), realizamos o que Bernstein (1996) nomina como "recontextualização", ou seja, adaptamos de um contexto para outro, em nosso caso, a fim de conferir um caráter didático. Aqui, incorre-nos proceder uma explicação quanto ao processo de geração de dados junto aos participantes da pesquisa: durante os meses de junho a dezembro de 2018, o referido público produziu uma escrita diagnóstica, um artigo de opinião, duas redações do Exame Nacional do Ensino Médio e uma carta aberta, sendo essas produções realizadas, com exceção da diagnóstica (que teve somente uma versão), cada uma em três versões (escrita, 
PERcursos Linguísticos • Vitória (ES) •v. $11 \bullet$ n. 29 • 2021 • ISSN: 2236-2592 • Dossiê

temático $\bullet O$ texto na pesquisa e no ensino: conhecimentos, práticas e desafios na contemporaneidade •

reescrita e versão final). No intervalo entre as produções e entre as etapas de cada produção, desenvolvemos, junto aos discentes em questão, atividades de apoio, por meio das quais exploramos o trabalho com informações e subsidiamos o processo de escrita.

Dentre as atividades de apoio, uma das mais relevantes e que acompanhou todo o processo, com adaptações realizadas de acordo com a demanda, foi o Quadro de estratégias argumentativas, elaborado a partir das categorias de informação com a finalidade de auxiliar os estudantes a identificar informações e a percebê-las como um recurso essencial na construção da argumentação. Destarte, a seguir, resgatamos o referido instrumento didático:

Quadro 2 - Quadro para identificação de uso de estratégias argumentativas 
PERcursos Linguísticos • Vitória (ES) •v. 11 •n. 29 • 2021 • ISSN: 2236-2592 • Dossiê temático • O texto na pesquisa e no ensino: conhecimentos. práticas e desafios na contemporaneidade •

\begin{tabular}{|c|c|c|c|c|c|c|c|c|c|c|c|}
\hline \multirow{3}{*}{ 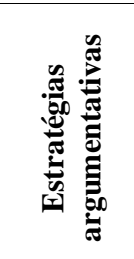 } & \multirow{2}{*}{\multicolumn{5}{|c|}{ Recursos }} & \multicolumn{6}{|c|}{ Estratégia argumentativa utilizada } \\
\hline & & & & & & \multicolumn{2}{|c|}{ Escrita } & \multicolumn{2}{|c|}{ Reescrita } & \multicolumn{2}{|c|}{ Versão final } \\
\hline & \multicolumn{5}{|c|}{ A ordem dos recursos pode variar } & $\begin{array}{l}\text { Marque com } \\
\text { um "x" a(s) } \\
\text { estratégia(s) } \\
\text { que você } \\
\text { usou }\end{array}$ & $\begin{array}{c}\text { Em qual(is) } \\
\text { linha(s) está? } \\
\text { Registre a } 1^{\mathrm{a} e} \text { a } \\
\text { última palavra } \\
\text { do trecho }\end{array}$ & $\begin{array}{l}\text { Marque com } \\
\text { um "x" a(s) } \\
\text { estratégia(s) } \\
\text { que você } \\
\text { usou }\end{array}$ & $\begin{array}{l}\text { Em qual(is) } \\
\text { linha(s) está? } \\
\text { Registre a } 1^{\mathrm{e} e} \text { a } \\
\text { última palavra } \\
\text { do trecho }\end{array}$ & \multirow{2}{*}{$\begin{array}{l}\text { Marque com } \\
\text { um "x" a(s) } \\
\text { estratégia(s) } \\
\text { que você } \\
\text { usou }\end{array}$} & $\begin{array}{c}\text { Em qual(is) } \\
\text { linha(s) está? } \\
\text { Registre a } 1^{a} \text { e } \\
\text { palavra última } \\
\text { do trecho }\end{array}$ \\
\hline $\begin{array}{c}\text { Estratégia } \\
1 \\
\end{array}$ & \multirow{5}{*}{$\begin{array}{l}\text { Informação a } \\
\text { partir de }\end{array}$} & + & $\begin{array}{l}\text { dados de pesquisas } \\
\text { com fonte confiável }\end{array}$ & + & \multirow{5}{*}{$\begin{array}{l}\text { desenvolvimento de } \\
\text { argumento }\end{array}$} & & & & & & \\
\hline $\begin{array}{l}\text { Estratégia } \\
\quad 2\end{array}$ & & + & $\begin{array}{l}\text { voz de especialista } \\
\text { veiculada por fonte } \\
\text { confiável }\end{array}$ & + & & & & & & & \\
\hline $\begin{array}{c}\text { Estratégia } \\
3\end{array}$ & & + & documento legal & + & & & & & & & \\
\hline $\begin{array}{c}\text { Estratégia } \\
4\end{array}$ & & + & $\begin{array}{c}\text { exemplo (fato } \\
\text { veiculado por fonte } \\
\text { confiável) }\end{array}$ & + & & & & & & & \\
\hline $\begin{array}{l}\text { Estratégia } \\
\quad 5\end{array}$ & & + & $\begin{array}{c}\text { exemplo } \\
\text { (acontecimento } \\
\text { corriqueiro) }\end{array}$ & + & & & & & & & \\
\hline $\begin{array}{l}\text { Estratégia } \\
\quad 6\end{array}$ & $\begin{array}{l}\text { Informação a } \\
\text { partir de } \\
\text { alusão } \\
\text { histórica } \\
\end{array}$ & + & $\begin{array}{l}\text { desenvolvimento de } \\
\text { argumento }\end{array}$ & + & $\begin{array}{l}\text { informações ou fatos } \\
\text { veiculados por fonte } \\
\text { confiável }\end{array}$ & & & & & & \\
\hline $\begin{array}{c}\text { Estratégia } \\
\quad 7\end{array}$ & $\begin{array}{l}\text { Informação a } \\
\text { partir de } \\
\text { ideal } \\
\text { filosófico/ } \\
\text { sociológico } \\
\text { ou voz de } \\
\text { especialista } \\
\end{array}$ & + & $\begin{array}{l}\text { desenvolvimento de } \\
\text { argumento }\end{array}$ & + & $\begin{array}{l}\text { informações veiculadas por } \\
\text { fonte confiável } \\
\text { ou } \\
\text { acontecimentos corriqueiros }\end{array}$ & & & & & & \\
\hline $\begin{array}{l}\text { Estratégia } \\
\quad 8\end{array}$ & \multirow[b]{3}{*}{$\begin{array}{l}\text { Apresentação } \\
\text { de contra- } \\
\text { argumento }\end{array}$} & & + & & \multirow{2}{*}{$\begin{array}{l}\text { desenvolvimento de } \\
\text { argumento }\end{array}$} & & & & & & \\
\hline $\begin{array}{l}\text { Estratégia } \\
\quad 9\end{array}$ & & + & $\begin{array}{l}\text { a partir de dados de } \\
\text { pesquisas por fonte } \\
\text { confiável }\end{array}$ & + & & & & & & & \\
\hline $\begin{array}{l}\text { Estratégia } \\
\quad 10\end{array}$ & & + & $\begin{array}{l}\text { exemplo (fato } \\
\text { abordado em fonte } \\
\text { confiável ou } \\
\text { acontecimento } \\
\text { corriqueiro) }\end{array}$ & + & $\begin{array}{c}\text { desenvolvimento de } \\
\text { argumento } \\
+ \\
\text { exemplo (fato abordado em } \\
\text { fonte confiável ou } \\
\text { acontecimento corriqueiro } \\
\text { para corroborar a voz do } \\
\text { autor da redação do ENEM) }\end{array}$ & & & & & & \\
\hline Outra est & D & & & & & & & & & & \\
\hline
\end{tabular}

Fonte: Arnemann (2020, p. 401). 


\section{PERcursos Linguísticos • Vitória (ES) •v. 11 •n. 29 • 2021 • ISSN: 2236-2592 • Dossiê temático $\bullet O$ texto na pesquisa e no ensino: conhecimentos, práticas e desafios na contemporaneidade •}

Tal quadro, empregado pelos participantes do estudo nos processos de produção do artigo de opinião, das redações do ENEM e da carta aberta, foi desenvolvido no contexto de pesquisa de Arnemann (2020) e revelou ser um instrumento didático que pode subsidiar tanto o docente quanto o discente no processo de escrita argumentativa. Diante dessa efetividade, asseveramos que tal quadro pode ser utilizado em sala de aula, com adaptações, se necessário, e de acordo com o contexto. Além do mais, defendemos que o processo de escrita não envolve somente o registro escrito; outros momentos - que têm ficado à margem, por inúmeras razões - podem exercer diferença crucial. No caso do instrumento didático em questão, verificamos que pode auxiliar o estudante a se familiarizar com as noções de informação, estratégia e argumentação - com vistas a internalizá-las - mediante o contato com o concreto, ou seja, por meio da identificação na materialidade linguística do (seu) texto, o que, por conseguinte, pode operar no exercício ativo do estudante, enquanto um sujeito que percebe como e de que se compõe seu texto.

Além do Quadro de estratégias argumentativas - que se inscreve como uma proposta didática efetiva -, outros elementos relativos à informatividade demandam atenção e, também, podem ser recontextualizados para a situação de ensino. Um deles se refere à definição do que é novo e do que é dado. Assim, ressaltamos que, antes de trabalharmos com conceitos mais elaborados, exploramos aqueles de natureza mais concreta e próxima à realidade dos discentes da turma $3^{\circ} \mathrm{C}$. Essa ação tem a função de realizar a mediação entre os conhecimentos cotidianos que os estudantes já têm e os conhecimentos escolarizados/científicos, com base em Vygotsky (1991, 2009). Em Arnemann (2020), isso se efetivou por meio do trabalho com o que o estudante já conhece, a noção de "dado", e o que ainda não conhece, a noção de "novo" no texto do outro. Para auxiliar os terceiranistas em cena no registro do que consideram dado ou novo, elaboramos o seguinte quadro:

Quadro 3 - Levantamento de informações (novas e dadas) na produção textual

\begin{tabular}{|c|c|c|c|c|c|}
\hline Texto & $\begin{array}{c}\text { Número de } \\
\text { informações } \\
\text { observadas }\end{array}$ & $\begin{array}{l}\text { As informações novas } \\
\text { tornam os textos mais } \\
\text { interessantes, pelo caráter } \\
\text { de novidade. Essas } \\
\text { informações apresentam } \\
\text { uma imprevisibilidade }\end{array}$ & $\begin{array}{l}\text { Em relação ao seu artigo de } \\
\text { opinião, você empregou } \\
\text { informações? Registre a } \\
\text { informação que você } \\
\text { empregou no espaço } \\
\text { referente ao texto e ao } \\
\text { caráter "novas" ou "dadas". }\end{array}$ & $\begin{array}{l}\text { Para que } \\
\text { você } \\
\text { empregou a } \\
\text { informação } \\
\text { em seu } \\
\text { texto? }\end{array}$ & $\begin{array}{l}\text { Você } \\
\text { entende } \\
\text { que } \\
\text { atingiu } \\
\text { seu } \\
\text { objetivo? } \\
\text { Por quê? }\end{array}$ \\
\hline Texto 1 & Novas & informações dadas. & & & \\
\hline
\end{tabular}




\section{PERcursos Linguísticos • Vitória (ES) •v. 11 •n. 29 • 2021 • ISSN: 2236-2592 • \\ Dossiê temático $\bullet O$ texto na pesquisa e no ensino: conhecimentos, práticas e desafios na contemporaneidade •}

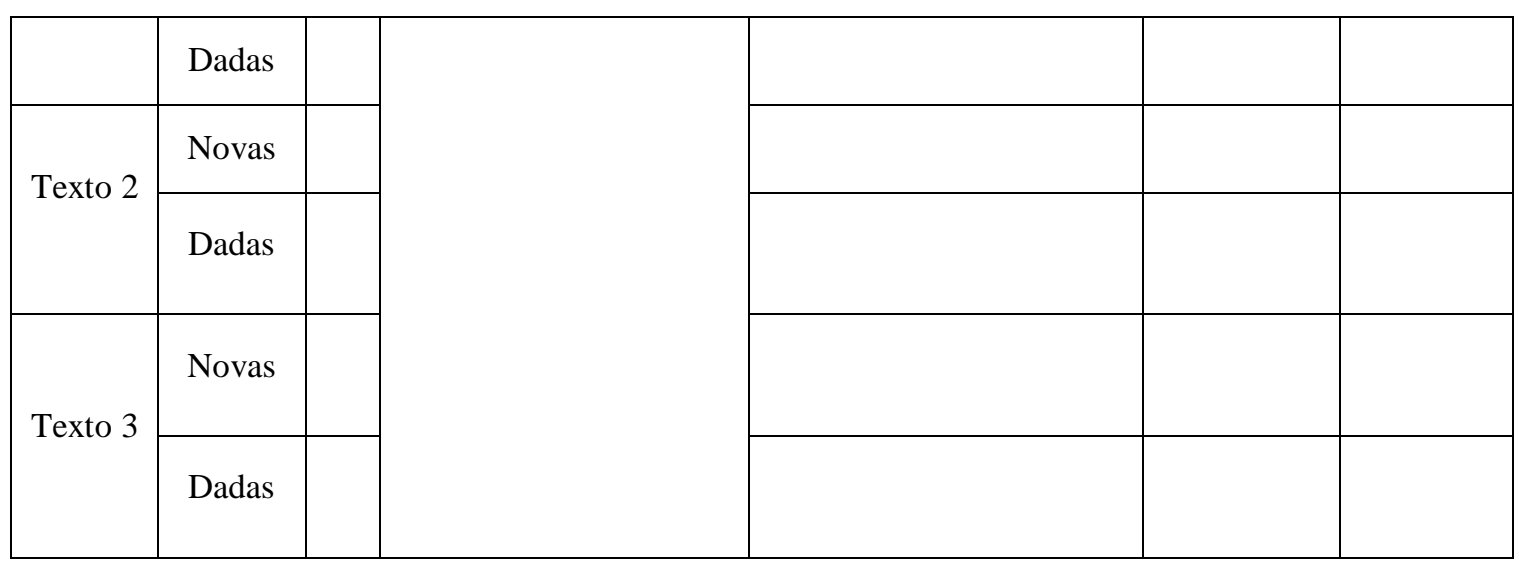

Fonte: Arnemann (2020, p. 376).

Esse quadro foi empregado como atividade de apoio na segunda produção textual realizada pelos participantes da pesquisa, na qual receberam uma proposta de redação do ENEM com quatro textos motivadores e foram convidados a identificar o que já conheciam e o que não conheciam nesses textos. $\mathrm{O}$ uso desse quadro, dentre outras funções, visa auxiliar o estudante a desmistificar o tabu que é construído em relação aos textos motivadores e/ou de apoio da redação do ENEM: são de difícil compreensão e de difícil processamento. Queremos defender, com tal asserção, que os textos não são, de todo, de difícil compreensão, o que está em falta são subsídios que o discente tem para auxiliar no processamento textual. É diante dessa ausência que inúmeros estudantes (e até alguns docentes) se agarram à ilusão de que, para ter um bom desempenho na redação do ENEM, precisam saber o tema antes. Esse quadro opera no contato do estudante com o texto e o exercício do registro o convida a desenvolver a atenção voluntária e a memória. Em relação a essa última, acentuamos seu papel, o qual nos termos de Vygotsky (1991, p.38), é "lembrar ativamente com a ajuda de signos".

A realização dessa atividade de apoio viabilizou a aproximação dos participantes da pesquisa com os textos motivadores, por meio da identificação do que consideraram novidade e o que já conheciam, favorecendo a autoidentificação (discente) sobre o que compõe seu texto. Realizado esse contato inicial com as noções de "dado", "novo" e informação, para as produções textuais seguintes, elaboramos outro quadro, o qual explora a informação de modo mais aprofundado e mais articulado ao processo de escrita argumentativa, convidando o estudante a avaliar como está trabalhando com a informação em sua própria produção. O quadro consta, a seguir, e expõe o tema da redação do ENEM que foi realizada na segunda produção textual com três momentos de escrita:

Quadro 4 - Quadro autoavaliativo sobre o processo de produção textual 
PERcursos Linguísticos • Vitória (ES) •v. 11 •n. 29 • 2021 • ISSN: 2236-2592 • Dossiê temático • O texto na pesquisa e no ensino: conhecimentos, práticas e desafios na contemporaneidade •

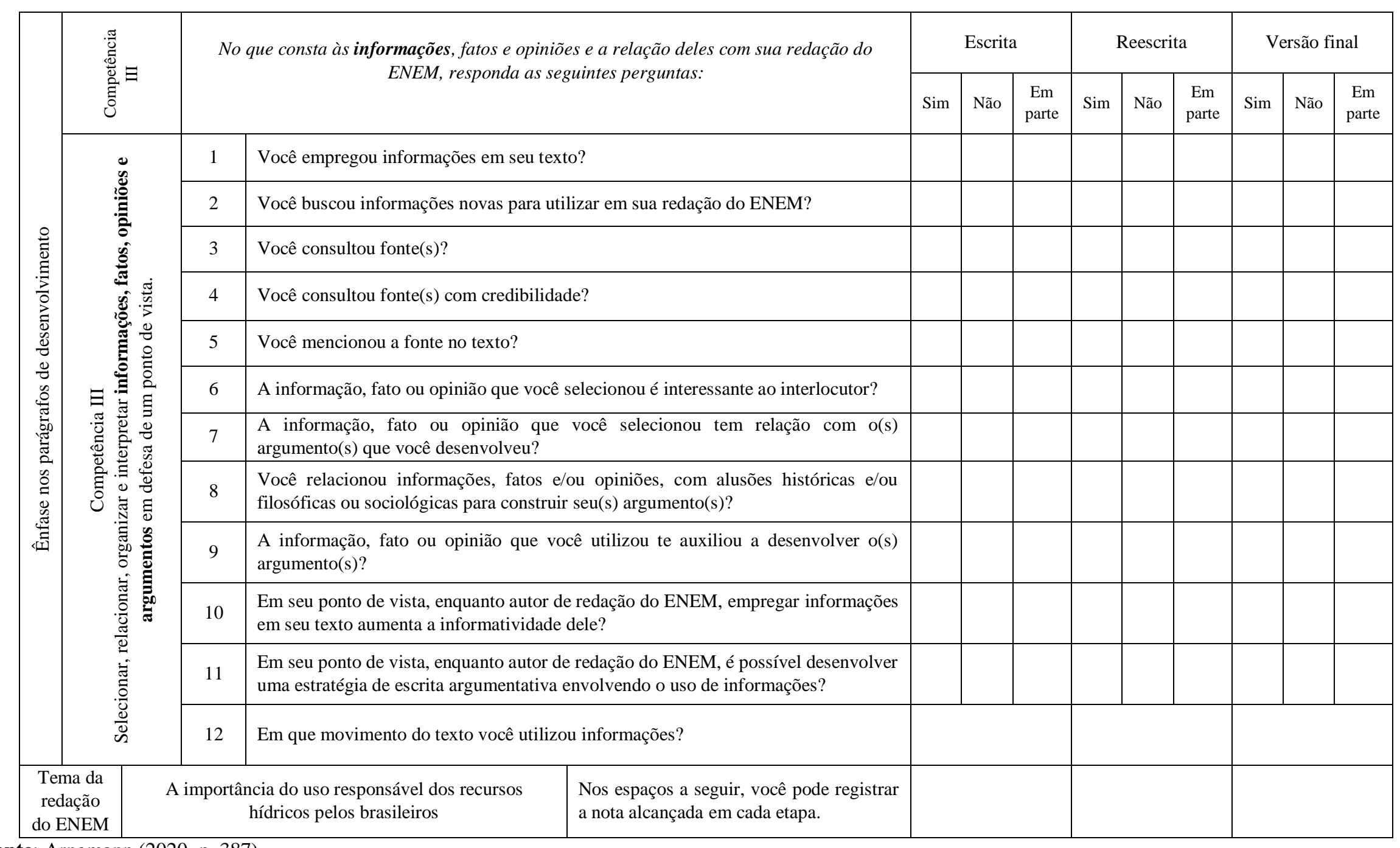

Fonte: Arnemann (2020, p. 387). 


\section{PERcursos Linguísticos • Vitória (ES) •v. 11 •n. 29 • 2021 • ISSN: 2236-2592 • Dossiê temático $\bullet O$ texto na pesquisa e no ensino: conhecimentos, práticas e desafios na contemporaneidade •}

Por intermédio dessa atividade de apoio, o estudante é convidado a se autoavaliar no que diz respeito a cada um dos momentos de escrita de sua produção, podendo, em cada um deles, realizar uma espécie de checklist (perguntas 1 a 5 , principalmente) sobre os elementos constitutivos da redação do ENEM, além de refletir (perguntas 6 a 12, especialmente) acerca do uso da informação em sua escrita argumentativa. É conferida ênfase à Competência III (item de avaliação da redação do ENEM), uma vez que se concentra no movimento referente ao desenvolvimento dos argumentos, portanto, estágio do texto que pode requerer maior uso de informações.

Após elucidarmos três atividades de apoio (Quadros 2, 3 e 4) que foram utilizadas pelos participantes de pesquisa, dedicamo-nos à exploração de quadros desenvolvidos no contexto de análise dos dados da pesquisa de Arnemann (2020) que podem ser recontextualizados para uso em sala de aula. Nesse momento, então, voltamo-nos à discussão das noções de "dado" e "novo", posto que as definições que assumimos foram fundamentais para a apreciação analítica e, por conseguinte, para os quadros que exploramos, a posteriori.

Convém pontuar que diferentemente de Beaugrande e Dressler (1981), que propuseram o critério de informatividade analisando um gênero textual da esfera expositiva, estudamos o uso da informatividade em sala de aula em gêneros textuais do campo argumentativo. Temos, aqui, uma distinção não apenas nos gêneros, como também nos (possíveis) interlocutores. Assim, ressaltamos que o produtor de texto argumentativo visa convencer o interlocutor a aderir a sua tese.

Beaugrande e Dressler (1981) dispõem que na oralidade, com recursos de entonação, comumente os falantes apresentam uma informação dada no início - estabelecendo um vínculo comunicativo com o ouvinte - e, ao final, apresentam a informação nova, ou seja, a novidade. $\mathrm{Na}$ esteira da argumentação escrita, isso pode ocorrer de modo similar, com as exceções de deslocamentos sintáticos aceitos em cada língua, as quais podem trazer uma informação nova para o início de uma oração e uma já conhecida ao final. Os teóricos em cena arguem que essa disposição entre o dado e o novo configura uma das cinco fontes de expectativa humana ${ }^{6}$ que propuseram, a qual diz respeito à sinalização da informatividade. Em nosso estudo, foi primordial definir o que corresponde à informação nova e o que corresponde à informação dada diante do contexto de escrita argumentativa escolar. Nesse sentido, focalizamos os termos "dado" e "novo" e, quanto àquele, dispomos que os

\footnotetext{
${ }^{6}$ Para conhecimento das outras quatro e da atualização teórica, consultar Arnemann (2020).
} 


\title{
PERcursos Linguísticos • Vitória (ES) •v. 11 •n. 29 • 2021 • ISSN: 2236-2592 • Dossiê temático $\bullet O$ texto na pesquisa e no ensino: conhecimentos, práticas e desafios na contemporaneidade •
}

elementos que o interlocutor já conhece são apresentados no início da oração, pois se referem ao conteúdo e/ou tema do texto em questão. Agora, o que é dito sobre esse conteúdo e/ou tema é apresentado ao fim da oração. Nesse viés, consideramos como "dado" o tema e/ou o conteúdo - apresentado no início da oração - pois são informações já de conhecimento ou mais previsíveis ao interlocutor, visto que é o que está em cena na interação verbal e, amiúde, é apresentado no texto ou enunciado que mobiliza a produção do texto em curso ou, ainda, na situação comunicativa em vigência (ARNEMANN, 2020, p. 60).

Ao passo que

\begin{abstract}
entendemos como "novo" o que é dito sobre o tema e/ou conteúdo, pois é aí que reside o caráter de novidade ao interlocutor: o que de novo, nessa situação comunicativa, pode ser dito sobre o tema, portanto está localizado ao fim da oração. O que é dito de novo em relação ao tema apresentado, diz respeito à informação que é selecionada e registrada na materialidade linguística. Ainda, consideramos como novo a interpretação que o interlocutor realiza acerca da informação que apresenta, pois se espera que em um texto do campo argumentativo não apenas tragam-se informações novas sobre o tema que é posto em questão, mas, e sobretudo, o que essas informações estão revelando ao interlocutor (ARNEMANN, 2020, p. 60).
\end{abstract}

Ao definirmos o que compreendemos como "novo", propomos que essa noção pode assumir duas classificações: a segunda, voltada à apresentação da informação nova, e a primeira, contemplando a apresentação e acrescentando a interpretação da informação. Essa classificação desempenha uma função muito relevante na identificação, tanto por parte de quem pesquisa, de quem ensina ou de quem aprende sobre a escrita argumentativa, visto que auxilia a demarcar, na materialidade linguística do texto, até que ponto o autor está apresentando uma informação e em que ponto passa a realizar a interpretação, ou seja, a registrar o que tal informação revela ou, ainda, auxilia a verificar que a interpretação não foi contemplada.

Concebemos esse ponto de vista para trabalhar com as informações novas no texto, pois, na imensa maioria dos casos, somente a apresentação da informação não é suficiente para conferir argumentatividade ao texto. Em consonância com Perelman e Olbrechts-Tyteca (2014), a informação é essencial para constituir a argumentação.

Nesse viés, para operar a identificação do que é dado e do que corresponde ao novo no interior de um parágrafo, buscamos apoio, também, em Charaudeau (2014), que dispõe acerca da organização do modo argumentativo e assevera que a argumentação se desenvolve mediante a seguinte organização: inicia com uma asserção de partida (A1), que é o ponto de partida, com vistas a chegar a uma asserção de chegada (A2), que é o fechamento da argumentação. Todavia, o autor explica que nem sempre é possível que se instaure uma argumentação efetiva com somente essas duas asserções. Por vezes, é necessário tecer uma asserção de passagem (Ap), a qual tem a função de estabelecer uma relação entre o ponto de partida e o ponto de chegada, de 


\section{PERcursos Linguísticos • Vitória (ES) •v. 11 •n. 29 • 2021 • ISSN: 2236-2592 • Dossiê temático $\bullet O$ texto na pesquisa e no ensino: conhecimentos, práticas e desafios na contemporaneidade •}

modo convincente. Em muitos casos, é na asserção de passagem que se inscrevem os exemplos e/ou ilustrações que o autor do texto busca para sustentar sua argumentação.

Assim, empregamos a classificação de Charaudeau (2014) para auxiliar na identificação do que corresponde ao dado e o que representa o novo, o que culminou na elaboração do quadro subsequente (P2 corresponde ao segundo parágrafo e P3 ao terceiro parágrafo):

Quadro 5 - Quadro para sinalização da informatividade

\begin{tabular}{|c|c|c|c|c|c|}
\hline \multicolumn{6}{|c|}{ Produção x } \\
\hline \multirow{2}{*}{ 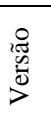 } & \multicolumn{2}{|c|}{ Ordem } & \multirow{2}{*}{$\begin{array}{c}\text { Início da oração - } \\
\text { apresentação do tema }\end{array}$} & \multirow{2}{*}{ Verbo } & \multirow{2}{*}{ Fim da oração - o que é dito sobre o tema } \\
\hline & $\mathrm{P}$ & A & & & \\
\hline & \multirow{3}{*}{$\mathrm{P} 2$} & A1 & & & \\
\hline & & Ap & & & \\
\hline & & $\mathrm{A} 2$ & & & \\
\hline & \multirow{3}{*}{ P3 } & A1 & & & \\
\hline & & Ap & & & \\
\hline & & $\mathrm{A} 2$ & & & \\
\hline
\end{tabular}

Fonte: Arnemann (2020, p. 156).

No contexto de investigação, esse quadro, além da identificação do que é dado e do que é novo, conferiu base para asseverarmos que:

os trechos que correspondem à informação dada apresentam o tema que será discutido, o qual advém da proposta de produção textual, podendo ser o tema em si ou uma especificação dele. Isso ocorre nas asserções de partida, especialmente no parágrafo 2, pois em alguns casos a apresentação do tema tem natureza anafórica, ou seja, recupera o que foi apresentado ao fim ou ao longo da asserção anterior ou, ainda, no decorrer do parágrafo, como é o caso de algumas asserções de chegada (ARNEMANN, 2020, p. 253).

Diante disso, entendemos que esse quadro pode ser utilizado em sala de aula, haja vista que configura um instrumento didático capaz de viabilizar a identificação, na materialidade linguística do texto, do dado e do novo e a observação da articulação entre os dois ao longo das asserções. Isso, por sua vez, propicia verificar se o texto está circular/redundante ou se está progredindo em termos de apresentação de novas informações, tanto no sentido de inserção de novos elementos quanto no desenvolvimento e delineamento dos já expostos.

Ainda, em se tratando somente do "novo", tal quadro pode subsidiar em sua classificação, ou seja, a identificar se a informação é somente apresentada ou se é apresentada e interpretada. Todavia, cabe expor que a classificação, metaforicamente, é apenas "a porta de 


\section{PERcursos Linguísticos • Vitória (ES) •v. 11 •n. 29 • 2021 • ISSN: 2236-2592 • Dossiê temático $\bullet O$ texto na pesquisa e no ensino: conhecimentos, práticas e desafios na contemporaneidade •}

entrada" para a realização de outras operações. Ao somente apresentar uma informação e identificar que apenas essa etapa foi realizada, o estudante (autor do texto) e o docente têm o diagnóstico de que a argumentação pode não ter sido contemplada com suficiência, pois a informação não foi explorada. Isso implica uma ausência de sinalização acerca do que o autor deseja explorar com aquela informação, ou seja, o que ela está revelando. Desse modo, a argumentação fica fragilizada, pois a exploração dos elementos necessários para o interlocutor aderir à tese proposta pelo autor do texto está incompleta.

Esse diagnóstico é fundamental para a corresponsável tomada de decisões em relação ao texto, ou seja, docente e discente necessitam encontrar estratégias para desenvolver a interpretação da informação. Tal processo não é simples, uma vez que o desenvolvimento da interpretação não depende apenas de habilidades e de prática de escrita. Além disso, necessita dos conhecimentos enciclopédicos, textuais, linguísticos e interacionais do sujeito em situação de aprendizagem.

Ainda, elaboramos outro quadro, com vistas a identificar quais categorias de informação constam nos textos dos sujeitos da pesquisa em pauta. Para tal, depreendemos como fundamental observar a origem das informações apresentadas. Desse modo, organizamos um quadro que permite registrar o trecho em que uma informação se apresenta no texto do estudante e o excerto correspondente no texto base empregado, o que viabiliza que se tenha, em um mesmo plano visual, ambos os registros. A seguir, resgatamos o quadro:

Quadro 6 - Quadro para identificação da fonte e categoria das informações

\begin{tabular}{|c|c|c|c|c||}
\hline \hline & $\begin{array}{c}\text { 1.Informação a partir de dado } \\
\text { veiculado por fonte confiável }\end{array}$ & $\begin{array}{c}\text { 2.Informação a partir de voz } \\
\text { de especialista veiculada por } \\
\text { fonte confiável }\end{array}$ & $\begin{array}{c}\text { 3.Informação a partir de } \\
\text { documento legal veiculado } \\
\text { por fonte confiável }\end{array}$ \\
$\begin{array}{c}\text { 4.Informação a partir de fato } \\
\text { veiculado por fonte confiável }\end{array}$ & $\begin{array}{c}\text { 5.Informação a partir de } \\
\text { acontecimento }\end{array}$ & $\begin{array}{c}\text { 6.Informação a partir de } \\
\text { alusão histórica }\end{array}$ \\
\hline $\begin{array}{c}\text { 7.Informação a partir de ideal filosófico } \\
\text { ou voz de especialista na área }\end{array}$ & $\begin{array}{c}\text { 8.Informação a partir de ideal sociológico ou voz } \\
\text { de especialista na área }\end{array}$ \\
\hline Parágrafo 2 na íntegra & Trechos dos textos base utilizados & Categoria \\
\hline Parágrafo 3 na íntegra & Trechos dos textos base utilizados & Categoria \\
\hline
\end{tabular}

Fonte: Arnemann (2020, p. 153).

Por meio desse quadro, pudemos realizar verificação entre o texto produzido pelos sujeitos de pesquisa e o texto base em que buscaram a informação. Esse procedimento auxiliou a identificar a categoria da informação, pois elementos externos à informação apresentada e/ou 


\section{PERcursos Linguísticos • Vitória (ES) •v. 11 •n. 29 • 2021 • ISSN: 2236-2592 • Dossiê temático $\bullet O$ texto na pesquisa e no ensino: conhecimentos, práticas e desafios na contemporaneidade •}

interpretada no texto do discente também requerem ser observados. Tal quadro nos forneceu base para subsidiar a observação de como as informações são recuperadas pelos sujeitos de pesquisa: por meio de paráfrase ou de alusão. Nos momentos em que verificamos a ocorrência de paráfrase, observamos um desenvolvimento mais restrito da interpretação da informação, o que indicia que o autor do texto está concentrado na fase de apresentação da informação. Já nas ocasiões em que observamos a ocorrência de alusão, percebemos que o autor do texto se dedicou (mais) a interpretar a informação que trouxe. Em termos espaciais, ao realizar uma alusão, que concerne a uma referência mais pontual e concisa acerca da informação, o produtor de texto dedica mais espaço à exposição de seu ponto de vista sobre a informação, o que, por conseguinte, favorece a manifestação da "voz autoral", muito importante em textos de natureza argumentativa.

Assim, tal quadro também pode ser utilizado em sala de aula como um instrumento didático, auxiliando inclusive no combate ao plágio, o qual não foi abordado na tese por não ter se manifestado nos textos dos participantes da pesquisa. Desse modo, tanto em relação ao Quadro 6 como ao Quadro 5, ajuizamos que o uso de ambos pode necessitar ou não de recontextualização, sendo esse ponto definido de acordo com os contextos de ensino e de aprendizagem. Estimamos que a adaptação pode contemplar uso tanto na Educação Básica como no Ensino Superior, em espaços cujo objetivo seja o ensino de produção textual argumentativa.

\section{Considerações finais}

Os desafios encontrados por pesquisadores, professores e estudantes em relação ao texto são inúmeros e de naturezas distintas, até porque o texto é um fenômeno resultante das interações humanas. Em meio a esse imenso "palheiro" (o universo do texto), encontramos uma "agulha", aqui representada pelos quadros - elaborados a partir do critério de informatividade -, que podem ser considerados como instrumentos e propostas didáticas para subsidiar o processo de escrita argumentativa.

Com base nessa analogia, percebemos que a construção de percursos linguísticos que aproximem teoria(s) e metodologia(s) pode exigir um trabalho cansativo, ardiloso e minucioso, principalmente por parte de pesquisadores professores, mas não é impossível. No momento em que a agulha é encontrada e pode servir como instrumento por aqueles que estão ávidos pelo saber - os estudantes -, os mais belos, fortes, criativos - dentre tantas outras atribuições tecidos podem ser construídos. Tecidos, nesse escopo, referem-se a textos. 


\section{PERcursos Linguísticos • Vitória (ES) •v. 11 •n. 29 • 2021 • ISSN: 2236-2592 • Dossiê temático $\bullet O$ texto na pesquisa e no ensino: conhecimentos, práticas e desafios na contemporaneidade •}

Aqui, é oportuno mencionar que a maioria dos participantes da pesquisa em pauta, hoje, encontra-se cursando uma graduação em uma universidade pública. Eles são sujeitos ativos que perceberam a realização de uma pesquisa de doutorado, na aula de Língua Portuguesa, em parceira com o professor titular, como uma oportunidade não somente de aprimorar a escrita argumentativa, mas, sobretudo, de promover mudanças de vida por meio do uso pertinente e adequado de informações em textos de natureza argumentativa.

Trazemos essa informação a fim de expor que os quadros discutidos neste estudo alguns já utilizados pelos estudantes e outros no aguardo por esse momento - são o resultado de articulações teórico-metodológicas e se configuram como instrumentos e propostas didáticas. Entretanto, a efetividade que defendemos que possuem se deve, também, ao trabalho corresponsável realizado entre os envolvidos: pesquisadora professora, professor titular e a turma $3^{\circ} \mathrm{C}$. Com isso, queremos lembrar que um dos desafios que pesquisadores, professores e estudantes de texto precisam superar diz respeito ao trabalho em parceira, pois é ela que permite que teoria e prática se encontrem e, por conseguinte, que aspectos teórico-metodológicos possam sustentar o desenvolvimento de propostas didáticas efetivas, tal como se configuram os quadros que discutimos neste artigo.

Por fim, registramos que o universo de pesquisa a nossa frente é bem amplo, muitas lacunas ainda se inscrevem no que diz respeito à informatividade, por exemplo. Aqui, esse critério de textualidade foi explorado como base para elaboração de instrumentos didáticos que podem subsidiar a escrita argumentativa. Pensando na esfera argumentativa, ainda é necessário investigar a informatividade nos gêneros textuais orais e multissemióticos, os quais carecem de propostas didáticas que viabilizem os processos de ensino e aprendizagem.

\section{Referências}

ARNEMANN, A. R. Informatividade da sala de aula: o emprego de informações na construção de argumentos. 2010, 438 p. (Doutorado em Estudos Linguísticos) - Universidade Federal de Santa Maria, RS, 2020.

BERNSTEIN, B. A estruturação do discurso pedagógico: classe, códigos e controle. Petrópolis: Vozes, 1996.

BEAUGRANDE, R. de.; DRESSLER, W. Introduction to Text Linguistics. New York: Longman, 1981.

BOM CAMILLO, L. A Teoria Holística da Atividade e a constituição do papel docente na formação inicial do educador linguístico. 2017, 169 p. (Doutorado em Estudos Linguísticos) - Universidade Federal de Santa Maria, RS, 2017. 


\section{PERcursos Linguísticos • Vitória (ES) •v. 11 •n. 29 • 2021 • ISSN: 2236-2592 • Dossiê temático $\bullet O$ texto na pesquisa e no ensino: conhecimentos, práticas e desafios na contemporaneidade •}

BOM CAMILLO, L. A constituição docente na formação inicial e a escuta supervisiva com base na Teoria Holística da Atividade. Revista Linguagens \& Cidadania. Santa Maria, n. 26, 2014. Disponível em: 〈https://periodicos.ufsm.br/LeC/article/view/v〉. Acesso em: 19 fev. 2020 .

BURNS, A. Doing Action Research in English Language Teaching: a gruide for practitioners. New York: Routledge, 2010.

CHARAUDEAU, P. Linguagem e discurso: modos de organização. Vários tradutores. 2 ed. 2 imp. São Paulo: Contexto, 2014.

DOLZ, J.; NOVERRAZ, M. SCHNEUWLY, B. Sequências didáticas para o oral e a escrita: apresentação de um procedimento. In: SCHNEUWLY, B.; DOLZ, J. Gêneros orais e escritos da escola. Tradução de Roxane Rojo e Glaís Sales Cordeiro. Campinas: Mercado de Letras, 2004, p. 81-108.

DOLZ, J. SCHNEUWLY, B. Os gêneros escolares - Das práticas de linguagem aos objetos de ensino. In: SCHNEUWLY, B.; DOLZ, J. Gêneros orais e escritos da escola. Tradução de Roxane Rojo e Glaís Sales Cordeiro. Campinas: Mercado de Letras, 2004, p. 61-80.

FREIRE, P.; FAUNDEZ, A. Por uma Pedagogia da Pergunta. 3. ed. Rio de Janeiro: Paz e Terra, 1985.

FREITAG, F.; RICHTER, M. G. Diálogos com Felipe Freitag: entrevista com o criador da Teoria Holística da Atividade, Marcos Gustavo Richter. IV Fórum de Estudos Interacionistas. UFSM, 2015. (Entrevista transcrita; material inédito).

KOCH, I. V.; ELIAS, V. M. Ler e escrever: estratégias de produção textual. 2. ed. 2 reimp. São Paulo: Contexto, 2014.

LURIA, A. R. Fundamentos de Neuropsicologia. Tradução de Juarez Aranha Ricardo. São Paulo: Editora da Universidade de São Paulo, 1981.

RICHTER, M. G. Aquisição, representação e atividade. Santa Maria: UFSM/PPGL-Editores, 2008.

PERELMAN, C.; OLBRECHTS-TYTECA, L. Tratado da Argumentação: A Nova Retórica. Tradução de Maria Ermantina de Almeida Prado Galvão. 3. ed. São Paulo: Martins Fontes, 2014.

THIOLLENT, M. Metodologia da Pesquisa-Ação. 18. ed. São Paulo: Cortez, 2011.

VYGOTSKY, L. S. A formação social da mente. 4. ed. bras. São Paulo: Martins Fontes, 1991.

VYGOTSKY, L. S. A construção do pensamento e da linguagem. 2. ed. Tradução de Paulo Bezerra. São Paulo: Martins Fontes, 2009. 


\title{
PERcursos Linguísticos • Vitória (ES) •v. $11 ・$ •n. 29 • 2021 • ISSN: 2236-2592 • Dossiê temático $\bullet O$ texto na pesquisa e no ensino: conhecimentos, práticas e desafios na contemporaneidade •
}

\section{TEXTO COMO DISCURSO: A FORMAÇÃO DO LEITOR CONSCIENTE DO PROCESSO DE ENUNCIAÇÃO}

\section{TEXT AS DISCOURSE: THE FORMATION OF A CONSCIENT LECTOR OF THE PROCESS OF ENUNCIATION}

\author{
Maria Aparecida Lino Pauliukonis ${ }^{1}$ \\ Claudia Assad Alvares ${ }^{2}$
}

\begin{abstract}
RESUMO: Considerando-se que um texto é resultante de uma interação em uma dada situação sociocomunicativa e que está fundamentado em "contratos" sociais que preveem um projeto de fala e de influência do emissor sobre o receptor, discute-se como as novas e atuais perspectivas da Linguística do Texto e da Análise do Discurso podem contribuir para um ensino de língua mais consciente do processo enunciativo pertinente à produção textual, com base numa proposta enunciativa de análise de textos chargísticos sobre o tema do racismo.
\end{abstract}

PALAVRAS-CHAVE: Texto. Discurso. Interação.

\begin{abstract}
Considering that a text is the result of the interation in a social communicative situation and that it is founded in social "contracts" which prevew the Project of speech and influence of the subject over the receptor, this paper discusses how the new and actual perspectives of Text Linguistic and the Analyse of Discours may contribute to the teaching of language that is more consciente of the enunciative process, presented in the textual production, with a proposal of the analysis of texts of charges with the theme of racism.
\end{abstract}

KEY WORDS: Text. Discourse. Interation

\section{Introdução}

As presentes considerações partem do princípio de que todo texto é uma unidade de sentido, construída, em níveis micro e macrotextuais, com o fim de se conseguir a atenção e a adesão do receptor às propostas apresentadas pelo emissor/enunciador. Tal finalidade precípua orienta para a importância do reconhecimento e análise de operações discursivas que visam à persuasão e à sedução do leitor/ouvinte. Considerando-se a constante crise no ensino da leitura e da interpretação de textos, intenta-se contribuir para uma reflexão sobre novas metodologias de ensino de texto, que visem à melhor formação do aluno, face a questões complexas referentes ao tratamento do texto como discurso.

\footnotetext{
${ }^{1}$ Professora Titular de Língua Portuguesa da Faculdade de Letras da UFRJ. E-mail: aparecidalino@gmail.com

${ }^{2}$ Professora Adjunta da Universidade de Pernambuco. E-mail: claudia.alvares@upe.br
} 


\section{PERcursos Linguísticos • Vitória (ES) •v. $11 \bullet$ •n. 29 • 2021 • ISSN: 2236-2592 • Dossiê temático $\bullet O$ texto na pesquisa e no ensino: conhecimentos, práticas e desafios na contemporaneidade •}

Primeiramente, serão apresentadas crenças que a Escola tradicional ainda mantém sobre Texto e Gramática; a seguir, um "novo" conceito de texto como unidade de sentido intencional que é fruto de uma operação estratégica; na sequência, serão discutidas questões propostas pelas teorias do Texto e do Discurso que podem contribuir para um ensino de leitura mais eficaz e producente, a partir de análises de textos do gênero chargístico.

É grande a perplexidade de educadores, pais e alunos diante do persistente fracasso de nossos estudantes em avaliações feitas em escalas mundiais (Pisa, Prova Brasil) em que alunos logram uma classificação medíocre, nos testes que medem a proficiência em leitura e produção de texto, em ciências e em matemática. Se o assunto crise do ensino é bastante antiga, muito se tem discutido sobre ela e uma vasta bibliografia ${ }^{3}$ tem dado mostras dessa preocupação da sociedade com alunos/cidadãos considerados alfabetizados, mas que são analfabetos funcionais em vários níveis.

Consciente de que a temática é extremamente complexa e escapa a uma solução simplista, neste espaço, serão apresentadas reflexões e alternativas para o problema, mediante o exame de duas questões: a forma como ainda se processa o ensino de gramática e uma nova visão de texto, fundamentada em teorias como a Linguística do Texto e a Análise do Discurso.

Toda pesquisa ou técnica didática deriva de um conjunto de regras, crenças e atitudes em relação a seu objeto de estudo. No caso do ensino de línguas maternas, a exigência do tradicional rigor normativo baseia-se na crença de que acima das variantes linguísticas usuais, há uma norma ideal, cuja dominação implica poder e distinção em uma sociedade que prestigia as diferenças sociais e o poder de uma elite dominante. O contrário, acredita-se, seria nenhuma exigência de padrão, um aceite incondicional das variantes que encontrariam respaldo nas diversas situações de uso da língua. Felizmente existe um meio-termo que pode nos ajudar a situar a questão e isso muito se deve aos novos conhecimentos acerca do objeto de estudo texto e Gramática - e a situação de interatividade que existe em todos os usos linguísticos. Tais noções trazem novos parâmetros para o entendimento do que seria considerar uma manifestação de texto como discurso.

Tradicionalmente o ensino de línguas tem se apoiado na normatividade e na prescrição de regras de realização da norma de prestígio; acredita-se que pela transmissão de modelos de "bom" uso e de uma metalinguagem, tradutora de um Sistema linguístico homogêneo, poder-

\footnotetext{
${ }^{3}$ Confira autores como Marcuschi (2009), Magda Soares (2016), Neves (2013), entre tantos outros.
} 


\section{PERcursos Linguísticos • Vitória (ES) •v. $11 \bullet$ •n. 29 • 2021 • ISSN: 2236-2592 • Dossiê temático $\bullet O$ texto na pesquisa e no ensino: conhecimentos, práticas e desafios na contemporaneidade •}

se-ia obter a contraparte de um desempenho eficiente na leitura e produção de seus textos.

A esse respeito, é oportuna a afirmação de Perini (2005, p. 25) sobre o ensino de gramática e sua eficácia para desempenho dos usuários na leitura e na produção de textos:

\footnotetext{
Concorda-se que o grande objetivo do ensino de língua portuguesa é levar os alunos a ler e escrever razoavelmente bem. Pergunto: será que o estudo da gramática pode ajudar na aquisição da leitura e da escrita? Acredito que a resposta é negativa. (...) Ninguém que eu saiba conseguiu até hoje levar um aluno fraco em leitura e redação a melhorar seu desempenho, apenas por meio da instrução gramatical.
}

Comprova a prática docente que o ensino, por meio da descrição e reconhecimento de uma modalidade linguística, por meio de metalinguagem apenas, não contribui para a eficiência dos usuários. Discute-se também a forma como os conteúdos são transmitidos em livros didáticos que privilegiam a descrição ou o reconhecimento de categorias, em detrimento da compreensão da funcionalidade dos fenômenos linguísticos e as implicações de sentido nas interações reais. Para citar alguns casos, no ensino de língua portuguesa, ainda imperam listas de prefixos e sufixos de origem grega e latina e de regras incoerentes para o emprego do hífen; a memorização simples de paradigmas de conjugações de verbos irregulares; a apresentação de coletivos de sentido e uso duvidosos e ainda as realizações de aumentativos, diminutivos e de plurais analógicos, sem respaldo no uso. Além disso, a prática usual do enfoque predominante de tópicos de morfologia e sintaxe, como classes de palavras e funções sintáticas como um fim em si mesmas.

Moura Neves (1990), ao falar do ensino de gramática na escola, cita que setenta por cento das aulas tradicionais de português, à época de sua pesquisa, eram dedicadas às classes de palavras e às funções sintáticas — esses itens eram fornecidos ao aluno por meio da transmissão de uma prática que enfatizava exceções ou simples reconhecimento e memorização, mas cuja justificativa era a cobrança em provas de concursos e/ou vestibulares que testavam o conhecimento pela memória e não pelo uso. Tudo isso dava ao aprendiz a sensação de que a língua portuguesa é muito difícil e só acessível a uns poucos privilegiados, não a ele, o próprio falante.

À medida que exames como o ENEM e outros concursos começaram a exigir respostas não padronizadas, interpretação de textos e redação argumentativa, em que se impõe uma competência linguística, em níveis textuais e pragmáticos, confirmou-se a fragilidade da prática pedagógica tradicional, refletida nos baixos desempenhos dos alunos na compreensão e na produção textual. Tal fato ainda é agravado pelo desinteresse atual dos jovens pela aquisição de uma base cultural mais sólida que tem sua fonte primordial na leitura de livros, jornais e revistas 


\section{PERcursos Linguísticos • Vitória (ES) •v. $11 \bullet$ •n. 29 • 2021 • ISSN: 2236-2592 • Dossiê temático $\bullet O$ texto na pesquisa e no ensino: conhecimentos, práticas e desafios na contemporaneidade •}

especializados, textos que estão em competição com outras mídias digitais, dentre elas a internet.

Caberia agora uma outra reflexão sobre como tem sido a posição da Escola diante dos avanços de novas pesquisas sobre teorias do discurso, publicações sobre aquisição da linguagem e cognição, levadas a efeito em centros universitários e discutidos em congressos especializados. Salvo raras exceções, a realidade atual não demonstra grandes mudanças: não se fez a transferência para o ensino das constatações a que chegaram as pesquisas em diversas áreas e, muitas vezes, em sala de aula, ensina-se o mesmo conteúdo com adoção apenas de uma nova metalinguagem; tais práticas, muitas vezes, substituem uma tradição que, bem direcionada, poderia resultar eficiente ensino. Assim, são transmitidas aos alunos noções dispersas sobre texto, discurso, comunicação, cognição etc., camufladas por novas nomenclaturas e tidas como salvadoras do ensino. Assim, a falta de sistematização, embasamento científico e visão crítica do problema contribuem para agravar a situação do ensino, conforme pontua Carneiro (2001).

Sabe-se que as novas concepções sobre o fenômeno da linguagem revelam-se fundamentais como embasamento para o professor que pode fornecer ao aluno uma visão mais profunda sobre as potencialidades do fato linguístico e sua adequação a cada situação comunicativa, pois os atos de linguagem possuem repertório próprio e regras de coerções e estratégias de realização necessárias para serem eficazes.

Deve ficar evidente que não se está questionando o ensino dos conteúdos ou a ênfase na modalidade culta da língua pela escola. Uma revisão crítica, todavia, sobre crenças e atitudes em relação à língua como um todo sistemático torna-se necessária, dadas as novas condições da clientela escolar. A ampliação da escolaridade a todas as classes sociais que se verificou, sobretudo a partir dos anos sessenta, permitiu o acesso à Escola de alunos de níveis sociais bem diversificados, dotados de repertório linguístico bastante heterogêneo. As salas de aula não são mais constituídas de alunos pertencentes a uma classe social que dominava um padrão mais ou menos homogêneo e compatível com o que a sociedade dela esperava. Justifica-se, assim, a ênfase nos estudos dos processos de variação linguística, para a compreensão mais profunda da heterogeneidade linguística vigente também na Escola.

Por outro lado, não se justifica adotar-se um falso liberalismo que prive esses alunos da obtenção de uma norma de prestígio ou da chamada língua de poder social; alijá-los, pois, da modalidade culta é não lhes permitir participar das decisões de uma sociedade letrada e de base 


\section{PERcursos Linguísticos • Vitória (ES) •v. $11 \bullet$ •n. 29 • 2021 • ISSN: 2236-2592 • Dossiê temático $\bullet O$ texto na pesquisa e no ensino: conhecimentos, práticas e desafios na contemporaneidade •}

cultural consolidada, mas dominadora e elitista que tem na linguagem uma forma a mais de repressão social e um símbolo da manutenção de status e poder.

Esse tema complexo da variedade e do preconceito linguístico tem sido analisado por vários linguistas e gramáticos, dos quais sobressaem obras como a de Marcos Bagno (1997). A propósito, nunca é demais repetir a máxima sobre a função do ensino de Gramática, proposta pelo linguista Evanildo Bechara (2004), para quem a grande missão do professor de português é transformar seu aluno em um "poliglota em sua própria língua", possibilitando-lhe meios de se posicionar e adotar a língua funcional adequada a cada situação de uso.

Pelo exposto, não se cogita aqui discutir o conteúdo do ensino de língua, ou a substituição de uma forma didática por outra ou teorias tradicionais por outras mais prestigiadas, mas trata-se de avaliar uma nova compreensão do que seja o fenômeno da linguagem como um todo, o que perpassa primeiramente pela discussão do que seja a realização do texto como discurso. Nesse caso, como consequência imediata, propõe-se que, em vez de focalizar-se $o$ quê deve ensinar a Escola, deve-se atentar para o como ensinar e o para quê ensinar; esses processos deixam de ser circunstanciais para se tornarem cruciais, na tentativa de resolução dos problemas de ensino - aprendizagem de língua, gramática e texto

\section{Uma visão discursiva de texto}

Como já se disse, uma certa corrente tradicional em educação tem concebido a aprendizagem linguística como o resultado da transmissão de uma modalidade de linguagem culta, escrita ou oral, reflexo de um código fechado e homogêneo, que o aluno deve dominar independentemente de qualquer saber linguístico anterior adquirido intuitivamente pelo uso. Da passagem dessa prática educacional que privilegia a transmissão de conteúdos de um Código de regras prescritivas, fechado e homogêneo, para uma outra alternativa que busca compreender a Língua como um instrumento de comunicação interativa e de construção da realidade, há muita diferença.

O Sistema linguístico deixa de ser considerado apenas como fonte de transmissão de informações sobre o mundo real, para operar como um mecanismo de recriação e transmissão desse real e uma forma de ação e de influência do sujeito emissor sobre o sujeito receptor e vice-versa. Diante disso, impõe-se um outro conceito de Gramática e de Texto e, por seu turno, adota-se uma nova postura pedagógica para o ensino de leitura, interpretação e produção textuais. 


\section{PERcursos Linguísticos • Vitória (ES) •v. $11 \bullet$ •n. 29 • 2021 • ISSN: 2236-2592 • Dossiê temático $\bullet O$ texto na pesquisa e no ensino: conhecimentos, práticas e desafios na contemporaneidade •}

Segundo desenvolvimento de concepções das teorias linguísticas e discursivas que abordam a Teoria da Enunciação, ou a Semântica Argumentativa do Discurso, propostas por Benveniste (1976) e por Ducrot (1987), respectivamente, a Língua só existe na interlocução, pois, através do uso, é possível deduzir o Sistema de regras que possibilita o jogo interativo. Dessa forma, as realizações de sentido do discurso não estão a priori, disponíveis no Sistema, mas são co-construídas e detectadas durante o processo de inter-comunicação. Este é realizado sempre por meio de textos de base argumentativa, em uma situação interacional bem definida e com regras próprias para sua realização.

Essa noção de texto como uma unidade de sentido - pertinente a um jogo de atuação comunicativa - constitui o objeto de estudo de teorias ligadas à Linguística do Texto e à Análise do discurso, que se caracteriza por possuir uma orientação temática concretizada em um texto, sempre a partir de uma função social. Estamos adotando aqui a noção de texto que o situa no nível do discurso, como sendo um conjunto de enunciados "em função", ou seja, a ocorrência da textualidade realiza-se sempre sob o ponto de vista socio-comunicativo-interacional. Portanto somente quando o emissor realiza intencionalmente (consciente ou não dessa operação) uma função textual, mas que é reconhecida pelo parceiro envolvido no processo de comunicação, o conjunto de enunciados linguísticos passa a se constituir como um texto coeso e coerente.

Considerada a relevância da noção de texto tido como unidade de comunicação, situada, intencional e interativa, (CHARAUDEAU, 2008) impõe-se refletir sobre uma proposta de ensino de texto fundada em uma nova metodologia de ensino que enfoca a interação linguística sempre como um ato de discurso. No lugar de um ensino centrado na descrição dos elementos do Sistema, isto é, na operação de reconhecimento e classificação dos termos envolvidos na constituição de frases e enunciados, propõe-se um trabalho produtivo de leitura/interpretação e produção de textos, que os vê como unidade superior da Língua, da qual todos os outros elementos são os seus constituintes; assim, morfemas, palavras e frases devem ser analisados a partir de sua função no texto produzido, o qual está limitado por restrições gramaticais do Sistema e por uma situação interativa de comunicação, regulada por um contrato social e enunciativo.

Esse enfoque pressupõe muitas mudanças na análise das partes constituintes dos textos. Nesse sentido, toda frase deve ser considerada como "enunciado", ou seja, pertencente a um texto realizável em uma dada situação; dentro dessa perspectiva, só é possível o reconhecimento 


\section{PERcursos Linguísticos • Vitória (ES) •v. $11 \bullet$ •n. 29 • 2021 • ISSN: 2236-2592 • Dossiê temático $\bullet O$ texto na pesquisa e no ensino: conhecimentos, práticas e desafios na contemporaneidade •}

de termos, por exemplo, concomitantemente à análise de sua inserção e funcionalidade no conjunto de enunciados de um texto. Poder-se-ia objetar que esse procedimento é antigo e diz respeito à análise do cotexto ou do contexto e que já se faz na tradição estruturalista, mas a proposta de análise que aqui se apresenta vai um pouco mais além da análise do cotexto e do contexto, tomados em seu sentido restrito, pois pressupõe a consideração "sine qua non" de análise da dinâmica interacional-discursiva, como se verá, a seguir.

De acordo com os conceitos de uma Análise Discursiva, não há textos “inocentes”, pois todos partilham de uma intencionalidade, cuja descodificação advém do reconhecimento de vários fatores determinantes: a situação ou contexto extralinguístico, o contrato comunicativo que impera entre os parceiros da comunicação, suas identidades sociais, as marcas linguísticas, "intencionais" ou não, deixadas no texto pelo Autor, além de noções importantes como as de gênero a que pertence o texto e os modos de organização de discurso que o constituem.

Essa visão do texto como o resultante/produto de um processo de coconstrução interativa e intencional entre um emissor e um real ou virtual receptor, por meio da tessitura de elementos linguísticos e não linguísticos, não é usual nos nossos manuais didáticos e tampouco nas aulas, durante práticas interpretativas, as quais ainda priorizam a análise classificatória dos elementos constitutivos da frase. O texto muitas vezes é apenas um pretexto para suporte dos elementos que são foco desse tipo de análise e, até mesmo, os exercícios de interpretação de textos literários, que poderiam propiciar treinamento na descodificação da estrutura textual e dos princípios da intertextualidade ou da discursividade, além do reconhecimento da criação poética, apenas abordam questões periféricas sobre o conteúdo do tema proposto, reconhecimento dos personagens ou a divisão formal em parágrafos, ou em versos etc. Paradoxalmente, cobram-se dos alunos práticas efetivas de interpretação e de produção textual; por isso não causa espanto a nenhum professor o medo provocado em muitos alunos por uma prova sobre interpretação, ou o mal-estar diante de uma página em branco com a exigência de redação de textos argumentativos coerentes de base autoral.

Se construir um texto é, de acordo com conceitos de teorias discursivas, operar argumentativamente, com tentativas de influência, pode-se acrescentar que interpretá-lo é reconhecer, desmontar essa operação e produzir uma outra, de cujo processo decorre sempre uma unidade textual diferente. Dessa forma descodificar um texto é captar sentidos possíveis, mas fundamentados nas estratégias discursivas usadas, e para os quais os operadores ou as marcas argumentativas orientam o raciocínio do leitor. 


\section{PERcursos Linguísticos • Vitória (ES) •v. $11 \bullet$ •n. 29 • 2021 • ISSN: 2236-2592 • Dossiê temático $\bullet O$ texto na pesquisa e no ensino: conhecimentos, práticas e desafios na contemporaneidade •}

Torna-se oportuno relembrar aqui a etimologia do verbo "ler", do latim "legere", que traz, entre os seus sentidos possíveis, o de "roubar, captar" sentidos. Assim o ato de ler definese como captar sentidos ou selecionar os "pertinentes", já que se determina um entre outros muitos possíveis. Trata-se a leitura, portanto, de uma operação de ordem subjetiva, mas também de uma complexa técnica e realização de um delicado "jogo" interativo que a Escola deve ensinar sistematicamente a seus alunos. O preparo para aquisição de uma leitura mais crítica e consciente depende do reconhecimento das várias operações e manobras ou estratégias que constroem o texto e possibilitam processos de leitura e interpretação. Dessa forma, em vez da tradicional pergunta o que o autor quis dizer? - outras indagações poderiam ser feitas: como o texto diz? Ou o que ele diz é realizado de que modo? E quais as consequências desse modo de dizer para o sentido ou ainda, há outros sentidos derivados de outras formas de dizer?

Acrescente-se a essas considerações a afirmativa do filósofo Bakhtin (1970), de que todo texto é um mosaico de citações, isto é, todo texto constrói-se por referência a outros tantos que são evocados de muitas formas, linguística e situacionalmente. Pelo reconhecimento dessa intertextualidade e da interdiscursividade, o leitor aprende a ouvir as vozes de outros textos/discursos que ecoam e podem ser captadas no espaço de "manobras" da construção textual - essas estratégias variam conforme o gênero textual e a tipologia; ou seja, formalmente, um texto narrativo difere de um texto argumentativo ou descritivo pelo modo de encadeamento ou de organização de elementos linguístico-discursivos.

Em que essa abordagem globalizante do ato comunicativo, a que têm se dedicado as várias fases da Linguística do Texto e da Análise do Discurso, difere de outras propostas de leitura que também se consideraram uma revolução no ensino?

Essas abordagens têm por objeto de estudo o texto como unidade de significação, fruto de várias competências comunicativas do emissor e do receptor, engajados em um processo de coconstrução de sentido. Elas pretendem ser uma antítese a algumas teorias anteriores, que trataram do texto como um produto, e passam a reconsiderá-lo como um processo dinâmico e fruto de interações. Representam, dessa forma, uma evolução pois se alinham a uma tendência geral das ciências modernas na busca de uma forma mais abrangente e integradora de aquisição do conhecimento humano.

Atualmente Física e Química juntam-se quando o interesse é o estudo da estrutura do átomo; a Biomatemática aplica a tecnologia dos computadores na busca de soluções para problemas ambientais e a Ecologia, cuja preocupação não se restringe apenas a fenômenos da 


\section{PERcursos Linguísticos • Vitória (ES) •v. $11 ・$ •n. 29 • 2021 • ISSN: 2236-2592 • Dossiê temático $\bullet O$ texto na pesquisa e no ensino: conhecimentos, práticas e desafios na contemporaneidade •}

natureza, estende sua atenção também a problemas socio-político-econômicos. Pode-se dizer, concordando com o linguista Bernardez (1982) que o campo da Ecologia hoje está para as Ciências experimentais, assim como a Linguística Textual e a Análise do Discurso estão para as Ciências humanas, ou resumindo a afirmativa com o enfoque de Bernardez (1982, p. 238): "A Linguística do Texto é de certo modo uma ecologia da Linguística" e, nesse sentido, podese acrescentar que ela é interdisciplinar e procura ver o fenômeno "texto" de forma mais abrangente e relacional, em uma perspectiva discursiva.

Deve-se ressaltar, portanto, o caráter integrador dessas análises: estuda-se o texto e suas relações com os vários fatores condicionantes: sociais, históricos, linguísticos, psicológicos e pragmáticos. Retoma aspectos já estudados pela Gramática tradicional, como o estudo do vocábulo, seus morfemas nominais e verbais, as noções de tempo, aspecto e modo, os conectivos e seus papéis coesivos e de operadores discursivos etc., mas analisa as categorias linguísticas segundo um prisma sociocomunicativo e interacional. Procura fugir ao reducionismo a que outras correntes de estudo estavam sujeitas, sem desvincular-se totalmente dos modelos teóricos anteriores, como os legados pelo estruturalismo e pelo gerativismo. Busca, por conseguinte, definir um rigor metodológico formal, sem o que cairia num trabalho impressionístico com o texto, ou com foco apenas no conteúdo, como o que foi praticado por um certo idealismo linguístico, que resistiu durante muito tempo no ensino de texto.

A Linguística do Texto e a Análise do discurso perseguem um objetivo comum: explicitar todos os fenômenos que ocorrem dentro do texto, integrando dados morfossintáticos, semânticos e pragmáticos ou extralinguísticos. Por serem tais enfoques interdisciplinares, enfrentam ainda questões relativas à definição, identidade e autonomia de seu objeto de estudo, como pontuam teóricos do texto e do discurso, como Koch \& Elias (2006), Charaudeau (2013) e Monnerat et alii (2021), entre outros.

Ressente-se, ainda hoje, no campo do ensino de texto, da falta de difusão de material didático, referente à análise da função dos componentes linguísticos ou de elementos significativos dentro do texto que levem o aluno a perceber todo o complexo processo de sua construção, responsável em grande parte por seu sentido. Pelas propostas tradicionais, como já foi dito antes, analisa-se prioritariamente o conteúdo, o quê o texto significa e não o modo ou o porquê de tal significado; o aluno acostumou-se a ver o texto como um produto pronto e acabado, um artefato, portador de um sentido hegemônico, no qual ele não tem mais interferência como um sujeito pensante e criativo e torna-se apenas decodificador e não coautor, 


\section{PERcursos Linguísticos • Vitória (ES) •v. $11 ・$ •n. 29 • 2021 • ISSN: 2236-2592 • Dossiê temático $\bullet O$ texto na pesquisa e no ensino: conhecimentos, práticas e desafios na contemporaneidade •}

como seria desejável.

Esta nova postura, em relação à análise de textos, apregoa que o aprendiz pode passar de leitor a ser também produtor do texto, na medida em que interpretar é também reconstruir, por meio de uma operação interativa com o autor, com a linguagem e o mundo.

Embora se tenha tornado um dos mais promissores campos de pesquisa na Europa, nos Estados Unidos, no Canadá e no Brasil, essa visão discursiva da gramática e do texto ocupa lugar de destaque em Universidades e em Congressos especializados, mas não se está transmitindo pedagogicamente, ainda, de forma bastante eficaz, para o aprendizado de línguas materna ou estrangeira; todavia as mudanças estão vindo devagar e se impondo de forma duradoura.

As disciplinas ligadas ao discurso configuram-se hoje como promissores campos de pesquisa, sobretudo por suas características interdisciplinares. Propõem uma nova dinâmica de investigação dos elementos constitutivos de um texto e sua funcionalidade. Urge, portanto, que um maior número de pesquisadores e professores dos diversos graus de ensino unam-se no sentido de se ampliar uma metodologia voltada para o ensino de texto como discurso; esses esforços poderão contribuir para mitigar os problemas atuais concernentes à proficiência em leitura, interpretação e produção textual.

\section{Proposta de análise de textos a partir de uma perspectiva discursiva}

A seguir, propõe-se uma aplicação dos conceitos discutidos na análise de textos chargísticos, cuja temática remete ao racismo no Brasil, retratado em diferentes épocas - desde o início do século XX até os dias atuais -, o que confirma sua longa persistência, embora seja negado como um problema estrutural da sociedade.

O tratamento da temática - texto como discurso, em função dos elementos linguísticos e discursivos que o constituem - levará em conta, primeiramente, o papel dos sujeitos enunciadores retratados nas charges; a imagem projetada do "Eu" em seu discurso, que é reveladora de sua identidade social e de seu discurso racista; a importância do cotexto para o sentido de língua mais explícito e do contexto social para a interpretação dos sentidos discursivos, mais implícitos; a análise também põe em relevo a competência semântica e pragmática do leitor necessária para o entendimento do léxico utilizado, bem como do peso social dos termos atribuídos ao objeto discursivo, que é responsável pela construção de tabus e preconceitos; o enfoque do mundo apresentado nas charges permitirá revelar crenças 


\section{PERcursos Linguísticos • Vitória (ES) •v. $11 \bullet$ •n. 29 • 2021 • ISSN: 2236-2592 • Dossiê temático $\bullet O$ texto na pesquisa e no ensino: conhecimentos, práticas e desafios na contemporaneidade •}

herdadas de vários imaginários sociais racistas arraigados na sociedade; e as avaliações subjetivas de termos negativos usados para definir raças e gêneros fundamentam a importância de se observar a função discursiva da seleção lexical utilizada nos textos; além disso, serão tratados também os processos de uso da modalização verbal em construções frasais para a confecção de argumentos tidos como válidos, a partir de crenças e valores compartilhados.

Seguem as análises dos textos, em função dos parâmetros linguístico-discursivos citados:

Já "nascemos" racistas:

Figura 1 - Racismo estrutural

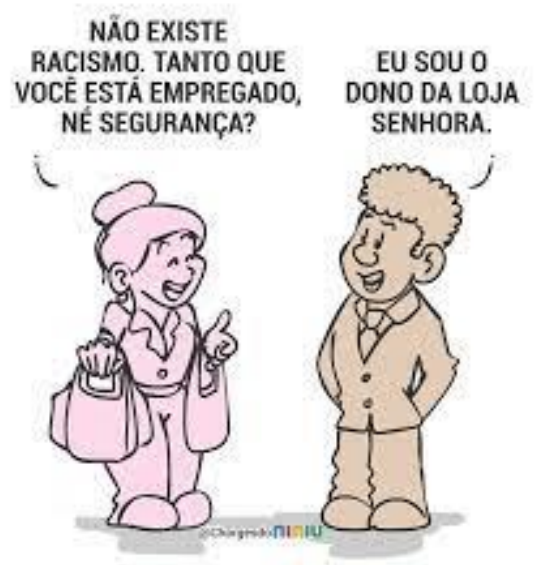

Disponível em:

https://p.facebook.com/chargesdoniniu/photos/a.444164088957199/4838232129550351/?type=3. Acesso em: ago. 2021.

Figura 2 - Negacionismo

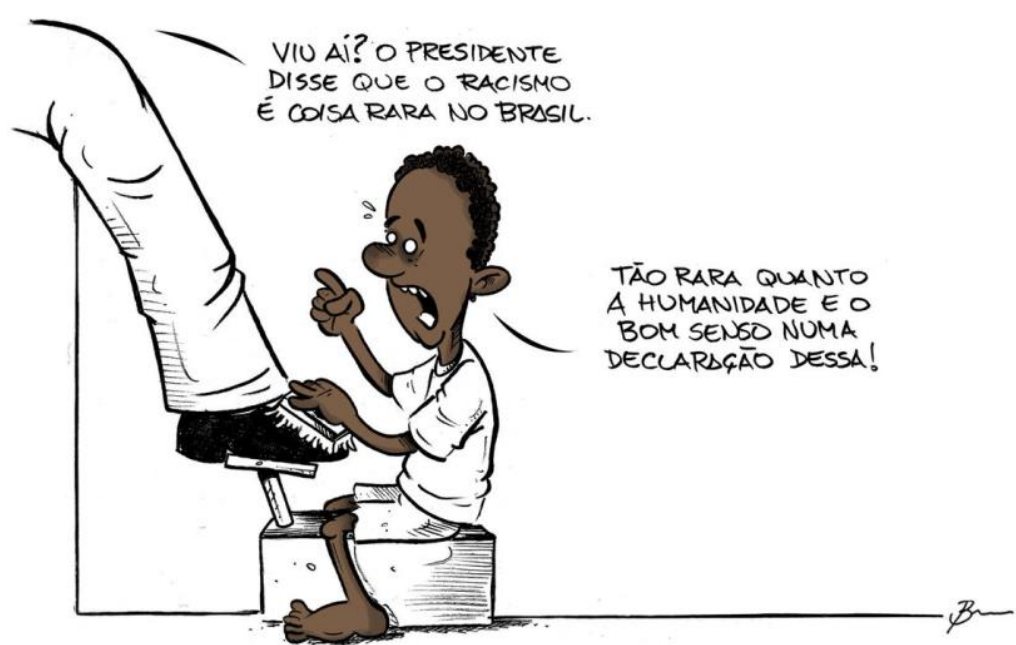

Disponível em: https://witter.com/brummmmm/status/1126449834200842240. Acesso em: ago. 2021.

Racismo e sociedade brasileira estão tão imbricados que não é possível identificar-lhes 


\section{PERcursos Linguísticos • Vitória (ES) •v. $11 ・$ •n. 29 • 2021 • ISSN: 2236-2592 • Dossiê temático $\bullet O$ texto na pesquisa e no ensino: conhecimentos, práticas e desafios na contemporaneidade •}

o ponto de partida; na verdade, "o racismo criou o Brasil”" (SOUZA, 2021). Se pensarmos em uma pirâmide de profissões, veremos que na base estão aquelas consideradas mais desprestigiadas, como faxineiras, babás, porteiros, seguranças, empregadas domésticas, engraxates, sapateiros, entre outras. Essas profissões, em geral, são ocupadas por negros, que, dificilmente, figuram no topo da pirâmide como médicos, engenheiros, arquitetos, advogados e outras profissões prestigiadas na sociedade em que vivemos.

E tais valores estão de tal forma entranhados em nós, que vemos com muita naturalidade uma criança negra trabalhar como engraxate e um adulto negro como segurança de loja; de um modo geral, não há quem se indigne contra esse estado de coisas justamente porque é tudo muito natural! Por outro lado, soa "estranho" um negro ser dono de loja, pois não é esse o "papel natural" que a sociedade lhe destina 4 .

Negar uma tal situação pode ser interpretado como uma forma cômoda de alienar-se e com isso aceitar que não se ampliem as políticas públicas a fim de reparar, ao menos um pouco, as injustiças seculares para com aqueles que, efetivamente, ajudaram a tornar grande o Brasil.

Finalmente, cabe observar o peso argumentativo do discurso do rapazinho sobre o argumento débil do adulto negacionista, visto que este apenas reitera a declaração do presidente ao passo que aquele, sob o aparente comparativo de igualdade, mostra a superioridade semântica de seu discurso, que é lúcido e realista.

Figura 3 - O verdadeiro não racista

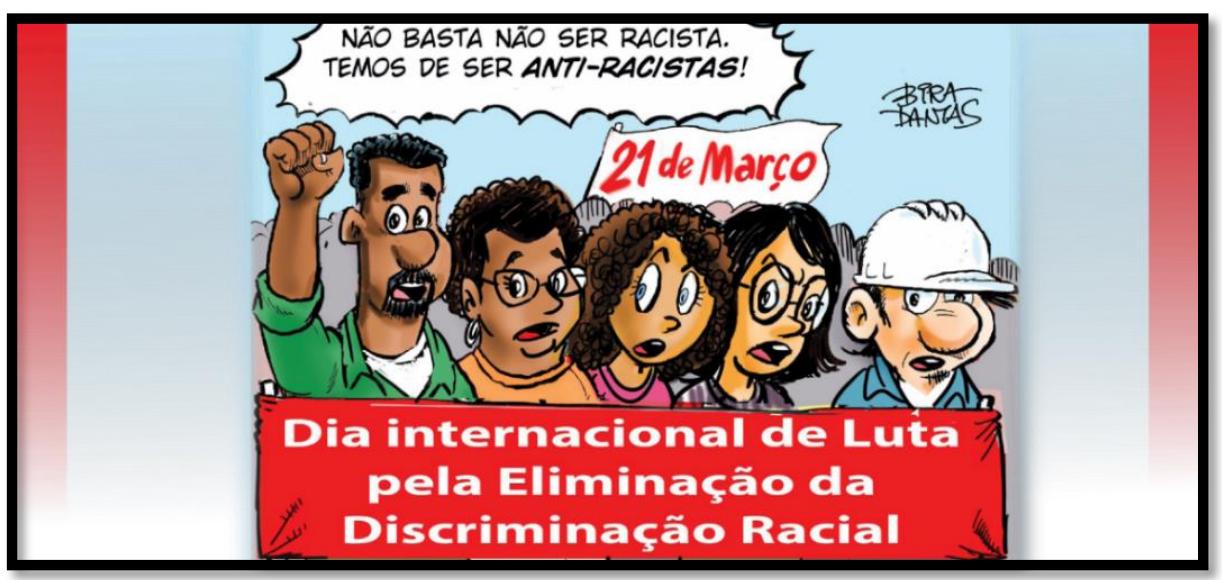

Disponível em: https://www.sinergiaspcut.com.br/2021/03/19/e-preciso-lutar-pela-construcao-de-uma-sociedadeigualitaria-segundo-coletivo-do-sinergia-cut/. Acesso em: ago. 2021.

\footnotetext{
${ }^{4}$ Não haveria problema algum em trabalhar como segurança de loja se tal papel fosse indiferentemente ocupado por pessoas, e não por suas cores primeiro. Quanto ao menino engraxate, não abordaremos aqui o trabalho infantil, mas tão somente a cor da pele relacionada à profissão que sobra, não à escolhida.
} 


\section{PERcursos Linguísticos • Vitória (ES) •v. $11 \bullet$ •n. 29 • 2021 • ISSN: 2236-2592 • Dossiê temático $\bullet O$ texto na pesquisa e no ensino: conhecimentos, práticas e desafios na contemporaneidade •}

Felizmente, as lutas antirraciais crescem a cada dia e ganham adeptos de várias cores; no entanto, é bom estar ciente de que aquele que se diz "não racista" é racista. O verdadeiro não racista é o antirracista, que tem plena consciência de que o atual estado de coisas não é natural; basta citar as novelas de televisão, por exemplo, que, mesmo com todo o avanço nas lutas, continuam com protagonistas brancos, ao passo que destinam os papéis menos visíveis aos negros.

Os elementos gramaticais presentes na oposição não racista $x$ antirracista deixam-nos entrever uma estrutura correlata de modalização deôntica, orientada para um caráter de obrigatoriedade, senão vejamos: não basta não ser $\mathrm{X}$, é preciso ser $\mathrm{Y}$; por outras palavras, não basta não ser racista (passivo), mas (implícito, o conector introduz o argumento mais forte) temos de ser antirracistas (ativos na luta contra o racismo). Note-se que o não apenas nega, ao passo que o anti-põe-se contra, de modo que seu peso semântico-argumentativo é bem superior. Seguramente, não são sinônimos.

Figura 4-O cheiro putrefato do preconceito

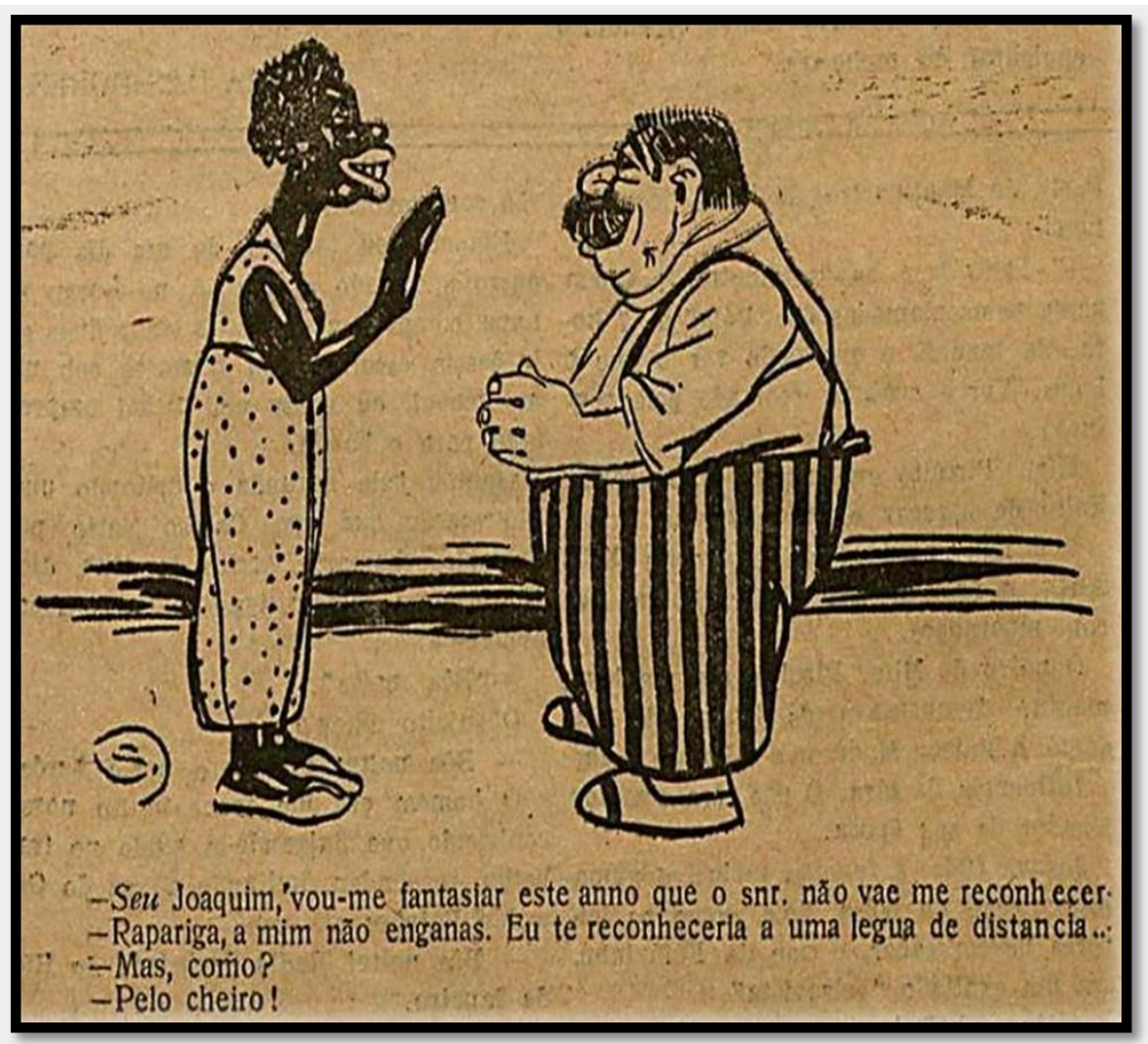

Charge publicada na revista D. Quixote em 1925, mostra diálogo entre mulher negra e senhor português — Foto: 


\section{PERcursos Linguísticos • Vitória (ES) •v. 11 •n. 29 • 2021 • ISSN: 2236-2592 • Dossiê temático $\bullet O$ texto na pesquisa e no ensino: conhecimentos, práticas e desafios na contemporaneidade •}

Biblioteca Nacional Digital/Reprodução

Disponível em: https://g1.globo.com/sp/sao-paulo/noticia/2020/11/20/estudo-da-usp-mostra-que-humoristasfortaleceram-branqueamento-da-sociedade-brasileira-com-piadas-racistas.ghtml. Acesso em: ago. 2021.

Nesta charge de 1925, o enunciador acrescenta à palavra cheiro um atributo pejorativo, a saber, "mau" ("mau cheiro"), e com ela estigmatiza os negros; na verdade, esse estereótipo de que a pele negra exala um cheiro característico - e desagradável - como se vê, é muito antigo e se mantém até hoje. E, note-se, o cheiro é tão forte que o $S e u$ Joaquim a reconheceria a uma légua de distância, ou seja, quase 5 quilômetros. A charge maldosa visa, como qualquer charge, à adesão dos interlocutores aos conteúdos defendidos por seus autores; é de se notar, no entanto, que, ao contrário das anteriores, cujo objetivo é conscientizar o público leitor da irracionalidade engendrada pelo racismo estrutural, esta apresenta um discurso que se acumplicia com uma sociedade recém-saída da escravidão e compactua com a natural inferiorização dos negros. Trata-se, pois, de um gênero "piada" que atrai o público leitor que pensa da mesma forma. Cabe destacar que qualquer pessoa que não tome banho, em geral, não cheira bem, independentemente da cor que tenha, mas o estereótipo parece bloquear a capacidade de pensar não só do consumidor desse tipo de discurso como também e, sobretudo, do produtor deste, o que comprova o preconceito.

Figura 5 - Racismo no Brasil mata

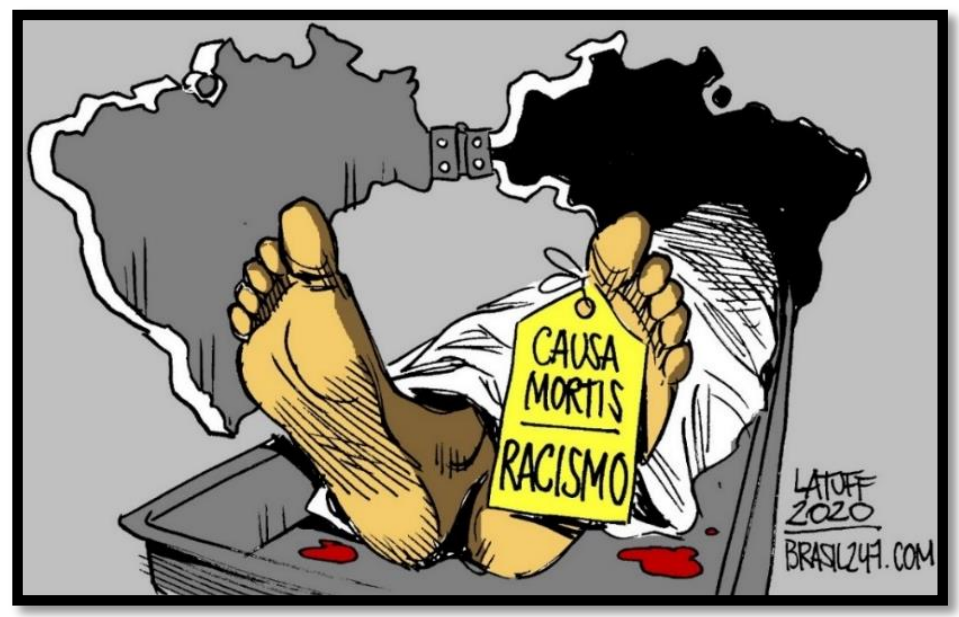

Disponível em: https://www.brasil247.com/charges/racismo-mata. Acesso em: ago. 2021.

Racismo no Brasil mata, conforme podemos observar a partir da figura 5. A causa mortis é o racismo, mas não é só: trata-se aqui de uma metáfora em que a "gaveta" onde ficará guardado o corpo até que seja reclamado por alguém é o mapa do Brasil, o que não deixa 


\section{PERcursos Linguísticos • Vitória (ES) •v. $11 \bullet$ •n. 29 • 2021 • ISSN: 2236-2592 • Dossiê temático $\bullet O$ texto na pesquisa e no ensino: conhecimentos, práticas e desafios na contemporaneidade •}

dúvidas quanto ao genocídio de negros, maioria da população, no Brasil. A metacharge a seguir o confirma:

Figura 6 - A banalização do genocídio negro

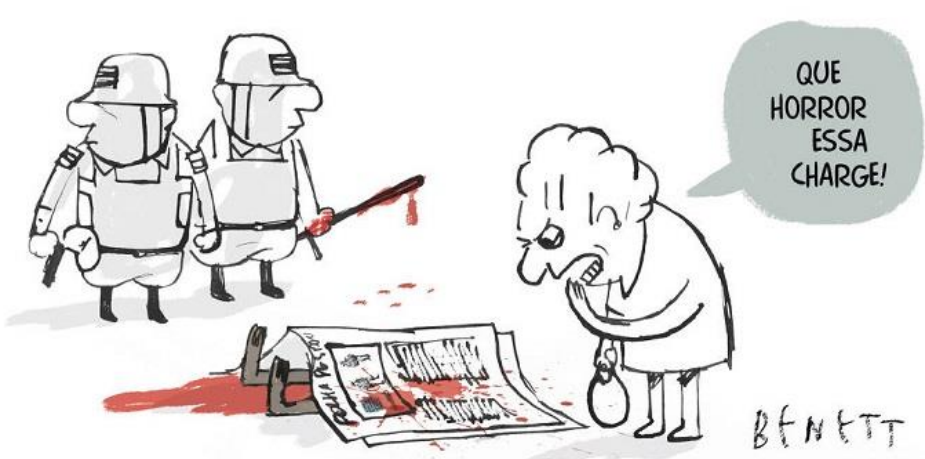

Disponível em: https://www.ocafezinho.com/2020/07/23/quando-explodira-o-antirracismo-brasileiro/. Acesso em: ago. 2021.

Note-se que a tal senhora fica "horrorizada" com a charge que estampa a página do jornal, mas não com a morte do negro que jaz sob aquelas páginas ensanguentadas pelo cassetete assassino de um policial. Quanto ao outro policial, parece estar ali para acobertar o colega. Por outras palavras, o genocídio da população negra banalizou-se a tal ponto, que passou a ser visto como "natural", quase ninguém mais se importa. Trata-se apenas de "mais um negro assassinado". E o que importa a idade? Eles estão marcados desde o nascimento, segundo se vê na análise da charge seguinte:

Figura 7 - Alvos fáceis

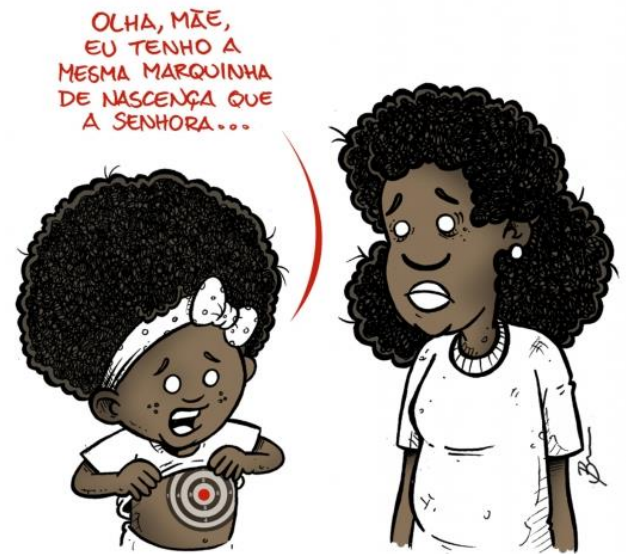

Disponível em: https://ceert.org.br/noticias/datas-eventos/43233/exposicao-20xarte-contra-o-racismo-e-acensura-no-brasil. Acesso em: ago. 2021.

A "marquinha de nascença" que a garotinha mostra à mãe na interação face a face 


\section{PERcursos Linguísticos • Vitória (ES) •v. $11 \bullet$ •n. 29 • 2021 • ISSN: 2236-2592 • Dossiê temático $\bullet O$ texto na pesquisa e no ensino: conhecimentos, práticas e desafios na contemporaneidade •}

intratexto também mostra ao leitor/enunciatário, na interlocução discursiva, que o verdadeiro alvo não é necessariamente aquela criança ou aquela mãe, mas qualquer um que tenha aquele tom de pele, aquele cabelo, ou seja: mais da metade da população do Brasil é um alvo potencial da sanha assassina da irracionalidade do preconceito, que, quando não mata fisicamente, o faz moralmente, uma vez que humilha o outro e o reduz a um lugar discursivo de inferioridade, retira-lhe a voz, ou melhor dizendo, sequer permite que ele tenha voz:

Figura 8 - Deboche e humilhação pública

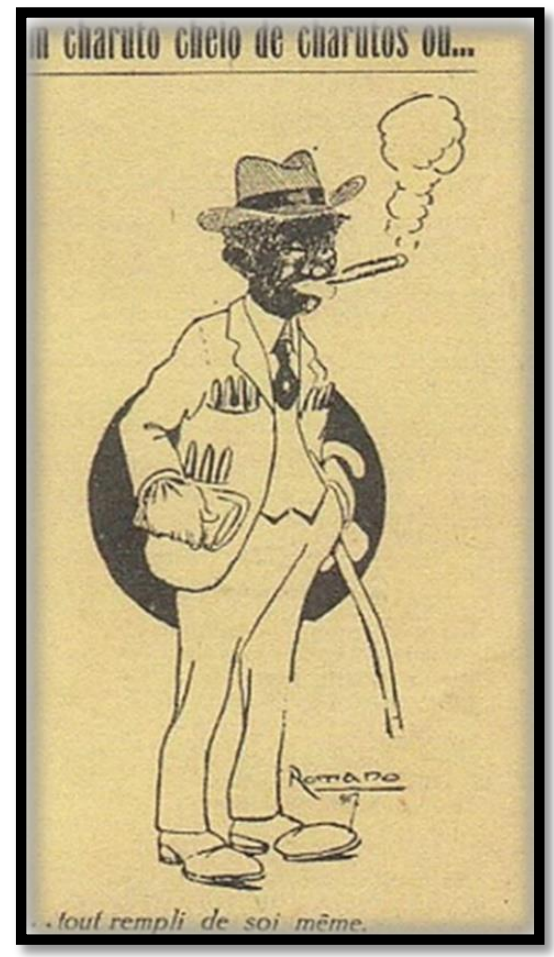

Charge da revista D. Quixote, na edição de agosto de 1917, debocha de homem negro elegante, 'todo cheio de si' - Foto: Biblioteca Digital do Senador Federal/Reprodução

Disponível em: https:/g1.globo.com/sp/sao-paulo/noticia/2020/11/20/estudo-da-usp-mostra-que-humoristasfortaleceram-branqueamento-da-sociedade-brasileira-com-piadas-racistas.ghtml. Acesso em: ago. 2021.

Figura 9 - Humilhação e crítica social 


\section{PERcursos Linguísticos • Vitória (ES) •v. $11 \bullet$ •n. 29 • 2021 • ISSN: 2236-2592 • Dossiê temático $\bullet O$ texto na pesquisa e no ensino: conhecimentos, práticas e desafios na contemporaneidade •}

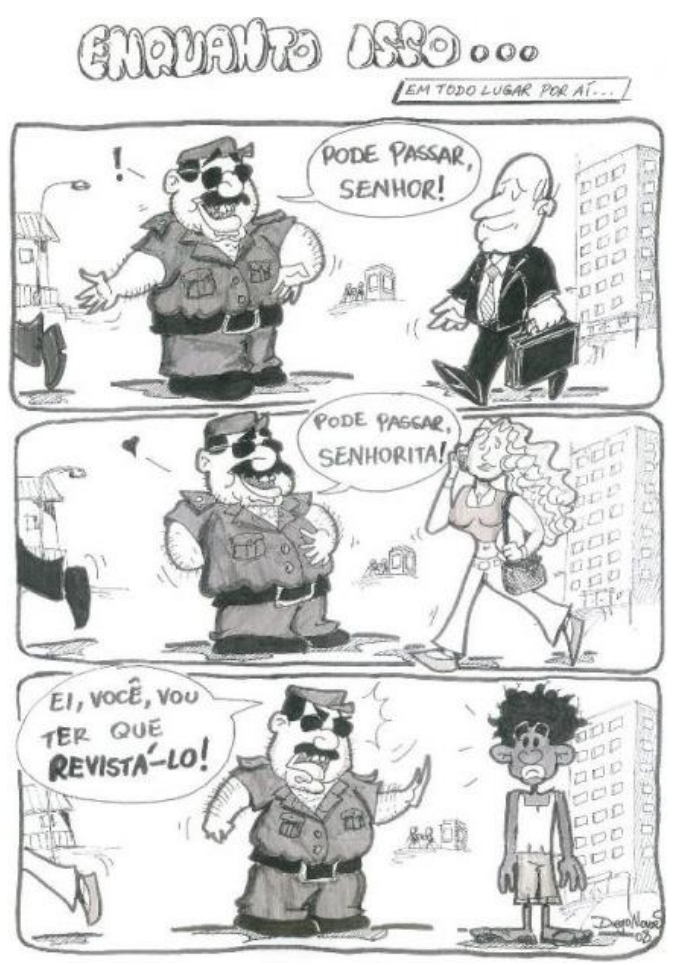

Disponível em: https://africaeafricanidades.online/imagens/policial.jpg. Acesso em: set. 2021.

Ao contrário da figura 9, cuja intenção é a denúncia social, a figura 8 é, literalmente, uma humilhação pública, visto que se trata de uma charge publicada em uma revista semanal que circulou em solo brasileiro durante dez anos, de 1917 a $1927^{5}$. Em 1917, ano de publicação da charge, não se pensava em antirracismo, ao menos não como se pensa hoje; naquele momento da história, o negro era motivo de deboche para os brancos, como demonstra a charge em questão. Enquanto isso... a figura 9 surge com um tom de denúncia em face do comportamento abusivo do guarda diante do rapazinho negro, que, "além de ser negro", está vestido modestamente em comparação aos demais que passaram por ele sem necessidade da revista. É de se notar que as formas utilizadas para se dirigir a cada interlocutor são bem diferentes; temos os respeitosos vocativos "senhor" e "senhorita" para os dois primeiros, mas a interjeição "ei" seguida do vocativo "você" para o terceiro; esses elementos linguísticos vêm acompanhados de toda uma mudança postural do guarda, além da expressão fisionômica fechada e do tom de voz ascendente, conforme nos mostra o negrito na última palavra, que é justamente "revistá-lo". É de se notar, na comparação das duas charges, separadas no tempo, por muitos anos, que o racismo é um fato histórico, permanente na sociedade e manifesta-se de

\footnotetext{
${ }^{5}$ Disponível em: https://pt.wikipedia.org/wiki/D._Quixote_(revista). Acesso em: set. 2021.
} 


\section{PERcursos Linguísticos • Vitória (ES) •v. $11 \bullet$ •n. 29 • 2021 • ISSN: 2236-2592 • Dossiê temático $\bullet O$ texto na pesquisa e no ensino: conhecimentos, práticas e desafios na contemporaneidade •}

várias formas: desvalorizando o outro por suas características, consideradas pejorativas, denegrindo seu comportamento e considerando natural que a situação se perpetue indefinidamente. Segue a figura 10, que mantém o tom racista:

Figura 10 - Alienação

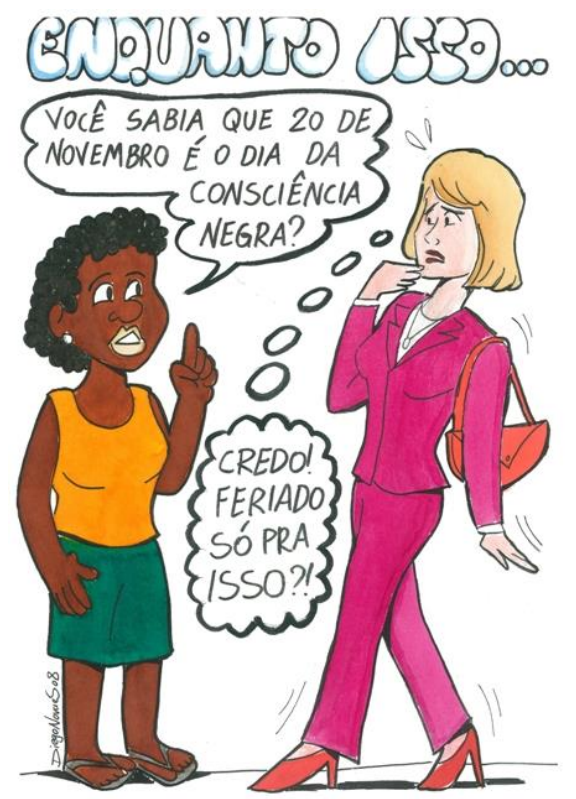

Disponível em: https://africaeafricanidades.online/imagens/Charge_3ed.jpg. Acesso em: set. 2021.

Temos aqui uma clássica representante da elite brasileira, branca, loira e muito bemvestida, e outra representante também clássica, mas de um grupo estigmatizado pelo racismo que grassa em nossa sociedade. Essa outra representante é negra e se veste com mais simplicidade, suas sandálias são bem mais modestas do que os sapatos de salto alto da representante da elite econômica. Ao procurar conscientizar a primeira sobre o dia da Consciência Negra, recebe de volta tão somente um olhar que parece ser de espanto, o que pode ser corroborado pelo pensamento da jovem senhora. Os significados pejorativos que impregnam o seu silêncio já vêm impressos no olhar que ela dirige à jovem negra que lhe dirige a palavra; vejamos: a primeira reação vem de surpresa com a interjeição "credo!", que pode significar aversão. A presença do advérbio "só" sugere a insignificância do fato, ao passo que o demonstrativo "neutro" funciona como reforço da pequenez do evento. O ponto de interrogação seguido da exclamação também é um reforço negativo não só da surpresa como também da determinação de um dia de feriado para um acontecimento tão, digamos, "banal", o que deixa bem claro para o leitor o nível de alienação sócio-política da jovem senhora para a qual, muito provavelmente, não deve existir sequer racismo no Brasil. Mas ele existe. Existe e 


\section{PERcursos Linguísticos • Vitória (ES) •v. $11 \bullet$ •n. 29 • 2021 • ISSN: 2236-2592 • Dossiê temático $\bullet O$ texto na pesquisa e no ensino: conhecimentos, práticas e desafios na contemporaneidade •}

é estrutural, tal como um iceberg, em que só vemos a ponta, como se pode observar na próxima figura, que é autoexplicativa:

Figura 11 - Racismo enraizado

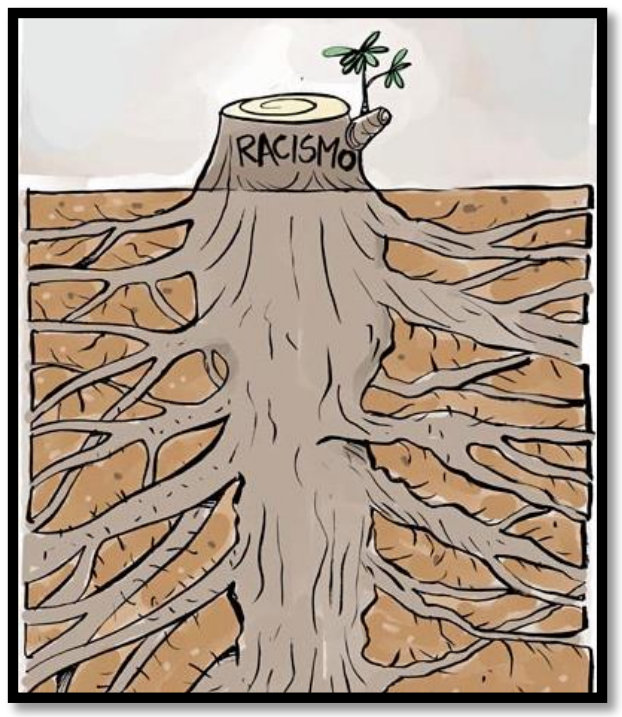

Disponível em: https://guiadoestudante.abril.com.br/blog/redacao-para-o-enem-e-vestibular/nova-proposta-deredacao-a-persistencia-do-racismo/. Acesso em: set. 2021.

Assim como a representante da elite, da charge anterior, o jovem alienado, que fizer a proposta de redação, não enxergará nem mesmo o que sobrou da pobre árvore depois que a motosserra se fez presente, muito menos o racismo que persiste camuflado na sociedade.

\section{Considerações finais}

O ponto de vista exposto aqui procurou abranger o que a análise discursiva do texto denomina de — problematização dos sentidos de um texto —, que consiste em compreender e analisar o "significado textual" primeiramente, em função da identidade dos produtores do ato comunicativo e de manobras para exercer uma ação de influência do emissor sobre o sujeito receptor, respeitando-se o conjunto de restrições linguísticas e discursivas. O significado, por sua vez, também deriva da situação de comunicação, de um contrato comunicativo que existe entre os interlocutores e de um projeto de fala e de influência do enunciador, os quais são reconhecidos e aceitos pelo receptor.

Procurou-se levar em consideração não somente as operações linguísticas fundamentais que constituem os sentidos da Língua, cujo reconhecimento serve de base para a compreensão, mas também processos discursivos que permitem reconstruir os contextos próprios de qualquer texto, cujas descodificações revelam implícitos que permitem uma interpretação mais rica e 


\section{PERcursos Linguísticos • Vitória (ES) •v. $11 ・$ •n. 29 • 2021 • ISSN: 2236-2592 • Dossiê temático $\bullet O$ texto na pesquisa e no ensino: conhecimentos, práticas e desafios na contemporaneidade •}

produtiva. Defende-se assim que, para uma leitura mais eficiente, é preciso identificar o quadro contratual e a situação discursiva da encenação, que vão determinar a identidade dos participantes e a finalidade desse ato, que se processa por diversos operações linguísticodiscursivas. Essas operações reconhecidas em sua função comunicativa constituem a base necessária para um processo mais consciente da enunciação e que contribuirá para a leitura, interpretação e produção de textos, orais ou escritos, em diferentes gêneros textual-discursivos.

\section{Referências}

ALMEIDA, Silvio. Racismo Estrutural. Coord. Djamila Ribeiro. São Paulo: Sueli Carneiro; Pólen, 2019. (Coleção Feminismos Plurais).

BAGNO, Marcos. Preconceito linguístico. São Paulo: Parábola, 1997.

BENVENISTE, Émile. Problemas de linguística Geral, v. 1. São Paulo: Companhia Editora Nacional, 1976.

BAKHTIN, Mikhail. La poétique de Dostoievski. Paris, Seuil, 1970.

BECHARA, Evanildo. Ensino de gramática: opressão ou liberdade? São Paulo: Ática, 2004.

BENEDICTO, Maria Margarete dos Santos. Quaquaraquaquá quem riu? Os negros que não foram... A representação humorística sobre os negros e a questão do branqueamento da belle époque aos anos 1920 no Rio de Janeiro (Versão Corrigida). 2018. Tese (Doutorado em História) - Universidade de São Paulo, São Paulo, 2018.

BERNARDEZ, Enrique. Introducción a la linguística del texto. Madrid: Espasa Calpe, 1982.

CARNEIRO, Agostinho Dias. Texto em construção. São Paulo: Moderna, 1996.

CARNEIRO, Agostinho Dias. Redação em construção. São Paulo: Moderna, 2. ed. 2001.

CHARAUDEAU, Patrick. Uma visão semiolinguística do texto e do discurso. In: PAULIUKONIS, Maria Aparecida Lino, GAVAZZI, Sigrid (Orgs.). Da língua ao discurso: reflexões para o ensino. Rio de Janeiro: Lucerna, 2. ed. 2007, 05-35.

PAULIUKONIS, Maria Aparecida Lino. Por uma interdisciplinaridade focalizada. In: MACHADO, Ida Lúcia et alii (Orgs.) A transdisciplinaridade, a interdisciplinaridade em estudos da linguagem. FALE/ UFMG, Belo Horizonte, 2013, 17-53.

DUCROT, Oswald. O dizer e o dito. Campinas: Pontes, 1987.

GERALDI, João Wanderley. Linguagem e ensino. Campinas: Mercado das Letras, 2002.

KOCH, Ingedore Villaça \& ELIAS Vanda. Ler e compreender: os sentidos do texto. São Paulo: 


\section{PERcursos Linguísticos • Vitória (ES) •v. $11 ・$ •n. 29 • 2021 • ISSN: 2236-2592 • Dossiê temático $\bullet O$ texto na pesquisa e no ensino: conhecimentos, práticas e desafios na contemporaneidade •}

Contexto, 2006.

MARCUSCHI, Luiz Antônio. Produção textual, análise de gêneros e compreensão. São Paulo: Parábola, 3. ed. 2008.

MONNERAT, Rosane et alii (Orgs.). Semiolinguística aplicada ao ensino. São Paulo, Contexto, 2021

NEVES, Maria Helena de Moura. Gramática na escola. São Paulo: Contexto, 8. ed, 1990.

NEVES, Maria Helena de Moura. Texto e gramática. São Paulo: Contexto, 2013

PAULIUKONIS, M. A. Lino; ASSAD Alvares, Claudia. Texto e construção de sentidos: propostas para leitura e interpretação. Linha d'Água: São Paulo, v. 34, n. 01, p. 116-136, jan.abr. 2021. DOI: http://dx.doi.org/10.11606/issn.2236-4242.v34i1p116-136. Disponível em: Vista do Texto e construção de sentidos: propostas para leitura e interpretação (usp.br). Acesso em: jun. 2021.

PAULIUKONIS, M. A. Lino; ASSAD Alvares, Claudia. Marcadores de oposição: análise e propostas didático-pedagógicas. SIMÕES, Darcilia; TEIXEIRA, Madalena (orgs.). Propostas Didático-pedagógicas para as Aulas de Português. Tomo I - Brasil. - (Coleção AILP Associação Internacional de Linguística do Português), v. 3. Tomo I, p. 144-168. - Rio de Janeiro: Dialogarts, 2019. ISBN 978-85-8199-131-3. Disponível em: http://www.dialogarts.uerj.br/arquivos/colecoes_ailp/propostas_didatico_pedagogicastomo1.pdf. Acesso em: mar. 2021.

PAULIUKONIS, Aparecida Lino \& MACHADO, Ida Lúcia (Orgs) Linguagem e discurso: modos de organização. Tradução e adaptação de obras de Patrick Charaudeau. São Paulo: Contexto, 2008.

PERINI, Mário. Gramática descritiva do português. São Paulo: Ática, 2005, p. 25.

REIS, Vivian. Estudo da USP mostra que humoristas fortaleceram 'branqueamento' da sociedade brasileira com piadas racistas. G1 SP, São Paulo, 20/11/2020. Disponível em: https:/g1.globo.com/sp/sao-paulo/noticia/2020/11/20/estudo-da-usp-mostra-que-humoristasfortaleceram-branqueamento-da-sociedade-brasileira-com-piadas-racistas.ghtml. Acesso em: ago. 2021.

RIBEIRO, Djamila. Pequeno manual antirracista. São Paulo: Companhia das Letras, 2019.

SOUZA, Jessé. Como o racismo criou o Brasil. Rio de Janeiro: Estação Brasil, 2021. 


\title{
CONSTITUVE MULTIMODALITY AND DISCURSIVE STRATEGIES IN MEDIATED READING PRACTICES
}

\author{
Patricia Ferreira Neves Ribeiro ${ }^{1}$
}

\begin{abstract}
Resumo: Este artigo centra-se sobre o ensino de interpretação e de compreensão e assume como objetivo primordial contribuir para o seu aprimoramento em cenário contemporâneo. Para isso, baseia-se, metodologicamente, em práticas de leitura mediadas (GERALDI, 2013), considerando de modo significativo a ativação de três tipos de memória, estreitamente ligadas a uma tripartida competência discursiva: linguística, situacional e semântico-pragmática (CHARAUDEAU, 2004). Em diálogo também com Cosson (2010), este trabalho propõe correlacionar as referidas memórias e as correspondentes competências, em uso em atividades de leitura orientada, à tripla taxonomia texto, contexto e intertexto (em sentido amplo). Partindo da suposição de que essas categorias podem ser acionadas em tarefas de leitura mediada, pela focalização de estratégias linguístico-discursivos dispostas em gêneros escritos organizados sob diferentes níveis de manifestação multimodal (DIONÍSIO, 2011), esta pesquisa apresenta uma proposta didática para o ensino da leitura na contemporaneidade com apoio em um anúncio publicitário - gênero multimodal por excelência - e em um poema - menos visualmente informativo. Considerando a multimodalidade intrínseca dos gêneros (ROJO; BARBOSA, 2015) e seu contínuo, este artigo apresenta, enfim, uma proposta teórico-metodológica que procura lidar com os desafios do ensino de leitura na atualidade e ultrapassá-los.
\end{abstract}

Palavras-chave: Leitura mediada. Estratégias linguageiras. Multimodalidade. Memórias. Competência discursiva. Abstract: This article focuses on interpretation and compreehension teaching and aims at
contributing to its improvement in a contemporary setting. To that end, the paper is based,
methodologically, on practices of mediated reading (GERALDI, 2013), considering the
activation of three types of memory, closely linked to a tripartite discursive competence:
linguistic, situational and semantic-pragmatic (CHARAUDEAU, 2004). In parallel with
Cosson (2010), this work proposes to match the mentioned memories with their corresponding
competences, in use in guided reading activities, to the triple taxinonomy that involves text,
context and intertext (in a broad sense). Assuming that these categories can be activated through
mediated reading tasks, by focusing on linguistic-discursive strategies arranged in organized
written genres under different levels of multimodal manifestation (DIONISIO, 2011), this
research presents a didactic proposal for the teaching of reading in contemporary times by the
${ }^{1}$ Professora Associada do Departamento de Letras Clássicas e Vernáculas e do Programa de Pós-Graduação em
Estudos de Linguagem da Universidade Federal Fluminense (UFF). E-mail: patricianeves@id.uff.br. 


\section{PERcursos Linguísticos • Vitória (ES) •v. 11 •n. 29 • 2021 • ISSN: 2236-2592 • Dossiê temático $\bullet O$ texto na pesquisa e no ensino: conhecimentos, práticas e desafios na contemporaneidade •}

use of an advertisement - a traditional multimodal genre - and of a poem - less visually appealing. Considering the intrinsic multimodality of genres (ROJO; BARBOSA, 2015) and its continuum, this article presents, finally, a theoretical-methodological proposal which deals with the challenges of teaching reading skills nowadays and that seeks to surpass them.

Keywords: Mediated reading. Language strategies. Multimodality. Memories. Discursive competence.

Para conhecer as coisas, há que dar-lhes a volta, dar-lhes a volta toda.

(José Saramago)

\section{Leitura e mediação}

Em Janela da Alma, documentário produzido por João Jardim e Walter Carvalho em 2001, José Saramago, em atenção ao olhar sobre aquilo que nos cerca, tece a lição enunciada pela epígrafe. Neste artigo, a fala de Saramago conduz nossa reflexão sobre a maneira de acolhermos - como professores mediadores da relação entre o estudante e o texto - o leitor em formação, em suas trilhas de indagação, diante das produções textuais com as quais se põe em diálogo.

Ao acolher, o professor - mediador - materializa a mediação entre textos e leitores. Isso significa dizer que, dentre outras ações, ele oferece orientações claras ao aluno a respeito não só de como pode se apropriar dos textos, mas também de que deve assumir um olhar de interpretação para lê-los como espaço de encontro de vozes. À luz da perspicaz lição proferida por Saramago, esse acolhimento deve possibilitar, assim, que esse leitor em formação - ao se apropriar dos textos - construa seu próprio lugar de leitura, sem se deixar comandar por um único ângulo de análise, por um único jeito de ler, aquele muitas vezes imposto pelo professor. Além disso, na atividade de mediação, deve-se encorajar o leitor a movimentar-se sobre o texto, indo da linearidade do dito à profundidade de sentido suscitado; indo da "compreensão responsiva"2 à "interpretação criativa" (GERALDI, 2013, p. 33). Ou, na perspectiva do pesquisador francês Patrick Charaudeau (2018), partindo das atividades de interpretação e chegando à compreensão textual, tomada esta como "um momento de apreensão global do sentido que resulta de diferentes atividades de interpretação". (p. 10).

\footnotetext{
${ }^{2}$ Parece válido ressaltar que a perspectiva de responsividade adotada por Geraldi (2013) ancora-se em sua leitura qualificada dos postulados advindos de Bakhtin e do Círculo (2002).
} 


\section{PERcursos Linguísticos • Vitória (ES) •v. 11 •n. 29 • 2021 • ISSN: 2236-2592 • Dossiê temático $\bullet O$ texto na pesquisa e no ensino: conhecimentos, práticas e desafios na contemporaneidade •}

$\mathrm{Na}$ verdade, para se respeitar esse lugar de leitura conquistado pelo olhar de interpretação do aluno e fazer do ato de ler, em consequência, uma experiência de fato para a vida e de vida, como ressalta Petit (2009, p. 48), isto é, a fim de que o leitor em formação possa se informar, se formar, se inconformar, se deleitar..., ele deve ser conduzido a apreciar o texto segundo uma espécie de chave de leitura. De posse dessa chave, ele poderá "percorrer as palavras revirando-as do avesso para descobrir o dizível ainda e sempre coberto pela superfície das coisas, das simples coisas" (GERALDI, 2013, p. 31); ele poderá, afinal, dar a "volta toda" (SARAMAGO, 2001) para interpretar e compreender, finalmente, o lido.

Essa introdução nos conduz a uma pergunta: em atividades de leitura produtiva em sala de aula, como o professor pode, na prática, mediar esse processo de descobertas que convida o leitor em formação a pôr-se, efetivamente, em movimento sobre o texto - objeto multifacetado -, considerando-se, inclusive, os desafios da contemporaneidade?

Neste artigo, pretendemos justamente considerar esse como fazer com base em um trabalho de mediação do professor, na prática de leitura em sala de aula, focalizando, sobretudo, a construção linguístico-discursiva do texto, podendo as construções textuais estarem inseridas em diferentes tipos de troca (verbais, icônicas, gestuais). Isso significa que nosso interesse recai sobre a análise de estratégias linguageiras acionadas a partir dos diferentes componentes da linguagem - como a sintaxe, a morfologia, a fonologia, a semântica, a pragmática - dentro, é claro, de uma situação discursiva determinada, com vistas à conscientização de que a produção de sentido não pode apartar-se da essencial costura entre gramática, texto e discurso.

Diante disso, parece fundamental ressaltar que esse agenciamento nem sempre se dá apenas sobre o texto escrito, sobre o texto verbal, podendo ocorrer sobre textos orais, visuais, verbo-visuais $^{3}$ (como as tirinhas), verbo-sonoros (como as canções), verbo-voco-visuais ${ }^{4}$ (como os filmes musicais) dentre outros. Além disso, como bem ressalta Feres (2021, p. 82), mesmo os textos exclusivamente verbais e escritos "recorrem a imagens mentais, fruto da imaginação, além de se nutrirem de outros códigos de linguagem diversos do código linguístico, como os dos gestos, dos comportamentos institucionalizados, das vestimentas, que também incluem sentidos na sua compreensão final”.

\footnotetext{
${ }^{3}$ A verbo-visualidade é assumida aqui na perspectiva de Brait (2013), segundo a qual textos verbo-visuais são aqueles cuja constituição se dá pela articulação entre a dimensão linguística - oral e escrita - e a imagem.

4 Os textos verbo-voco-visuais são tratados, neste artigo, à luz das pesquisas de Paula (2017), para quem a verbivocovisualidade refere-se ao trabalho integrado entre as dimensões sonora, visual e o(s) sentido(s) das palavras.
} 


\section{PERcursos Linguísticos • Vitória (ES) •v. 11 •n. 29 • 2021 • ISSN: 2236-2592 • Dossiê temático $\bullet O$ texto na pesquisa e no ensino: conhecimentos, práticas e desafios na contemporaneidade •}

Também Dionísio (2011) considera a multimodalidade como "traço constitutivo do texto falado e escrito". (p. 139). Assim, tratando, por exemplo, da multimodalidade discursiva da escrita, a autora destaca que todos os gêneros - mesmo os escritos - são sempre multimodais, tendo em vista "a própria disposição gráfica do texto, no papel ou na tela de computador" (DIONÍSIO, 2011, p. 141), o que é confirmado por Rojo e Barbosa (2015). As pesquisadoras ressaltam, em referência à diagramação de textos escritos sem ilustração, a ideia da inerente multimodalidade dos gêneros. Mas o fazem ressalvando o fato de que há gêneros mais modelares para o trato da multimodalidade, o que ecoa também da reflexão de Dionísio (2011), ao afirmar que "há diferentes níveis de manifestação da organização multimodal". (p. 142).

Desse modo, por um lado, estruturados sob a semiose palavra-imagem, textos que se oferecem, na contemporaneidade, como aqueles filiados, por exemplo, ao gênero anúncio publicitário - que será retomado adiante -, colocam ainda mais em destaque processos de textualização que se assentam sobre recursos multimodais. Por outro lado, um poema sobre o papel - como visualizaremos à frente - pode ser tomado como um gênero menos multimodal por sua configuração ser, predominantemente, verbal.

Adiante, veremos que as estratégias linguageiras mencionadas, passíveis de identificação em atividades de leitura sobre textos com maior ou menor grau de manifestação da organização multimodal, são decorrentes do acionamento de uma tripla competência, correspondente à ativação de três tipos de memória: de discurso, das situações de comunicação e das formas (CHARAUDEAU; MAINGUENEAU, 2004, p. 326). Sobre essas memórias e competências, discorreremos, posteriormente, com vistas a fundamentar nossa proposição didática para um ensino de leitura atento também à multimodalidade discursiva no âmbito do continuum da informatividade visual (DIONÍSIO, 2011, p. 139).

$\mathrm{Na}$ interação entre autor-texto-leitor, o sentido coconstruído resulta de se dizer a informação de um modo e não de outro. Como um efeito do "funcionamento da língua" (MARCUSCHI, 2008), dentro de um contexto sócio-histórico específico, os aspectos linguístico-discursivos, no trato com o texto em sala de aula, não podem ser desprezados diante do objetivo de formação de um leitor crítico, criativo e autônomo.

Evitamos, assim, fazer o leitor em formação acreditar que o ato de ler e a produção do sentido podem se dar de acordo com as meras impressões de cada um; afinal, o que se aponta

como dito no texto deve estar respaldado pelo que, de fato, consta lá, na sua superfície ou nas entrelinhas. Deve estar autorizado pela presença de uma palavra, de uma expressão, de um sinal qualquer. Do dito é que se parte para o não dito; ou para os diferentes tipos de dizer implícito. (ANTUNES, 2010, p. 79) 


\section{PERcursos Linguísticos • Vitória (ES) •v. 11 •n. 29 • 2021 • ISSN: 2236-2592 • Dossiê temático $\bullet O$ texto na pesquisa e no ensino: conhecimentos, práticas e desafios na contemporaneidade •}

O que ocorre, entretanto, é que, na escola, as atividades de leitura centram-se, muitas vezes, sobre o mero reconhecimento e classificação das estruturas da língua, privilegiando-se o trabalho com habilidades metalinguísticas preocupadas, exclusivamente, com as funções morfossintáticas dos itens gramaticais. A dita prática docente voltada a uma gramática contextualizada "oculta, muitas vezes, o fato de que essa contextualização se refere normalmente à retirada de frases e períodos de um texto, sem qualquer referência ao funcionamento do fenômeno gramatical em estudo na produção de sentido dos discursos" (MENDONÇA, 2006, p. 222), à necessidade de entendê-lo para a efetiva interpretação e compreensão global dos textos. Tomado como pretexto para o ensino da gramática descontextualizada e identificado segundo um recorte autossuficiente, o texto é, muitas vezes, ignorado em sua dimensão global e multimodal de sentido.

Em consequência, não se ensina ao aluno a passagem do significado, apreendido na superfície do texto, à significação, discursivamente produzida no diálogo entre as experiências do leitor e as capturadas no ato da leitura. O aluno não é encaminhado a experimentar a leitura apropriando-se integralmente do texto lido, no âmbito de um circuito tanto de formação - para a vida -, quanto de prazer - de vida (PETIT, 2009, p. 48).

Ainda que haja, na atualidade, constantes campanhas em todo o país a ecoar a recorrente ideia de leitura como um bem - conforme o que comprova, por exemplo, o $\operatorname{slog}^{5} n^{5}$ promovido pela Assembleia Legislativa do Estado do Amapá no ano de 2021 -, é possível verificar certo distanciamento entre a promoção à leitura e o efetivo aprimoramento da competência leitora dos alunos ${ }^{6}$.

A esse respeito, Luiz Percival Leme Britto (1999) salienta que os slogans de campanhas de leitura, apesar de exaltarem a leitura como um meio de acesso à informação, não evidenciam a ideia de que a informação é oriunda, necessariamente, de jogos de poder, configurando-se sob a forma de um produto sócio-histórico. Dito de outro modo, campanhas de promoção à leitura, por si mesmas, parecem não ser suficientes à formação de leitores e, muito menos, de leitores críticos. Sob certa perspectiva, tais campanhas parecem servir mais à promoção

\footnotetext{
${ }^{5}$ Em anúncio assinado pela Assembleia Legislativa do Estado do Amapá, no ano de 2021, lê-se o seguinte texto, sob a ilustração de um sorridente livro: "Doe imaginação, doe livros". Disponível em: http://www.al.ap.gov.br/pagina.php?pg=exibir_noticia\&idnoticia=20120. Acesso em: 28 set. 2021.

${ }^{6}$ Dados do ENEM de 2019, por exemplo, mostram que 143.736 candidatos tiraram zero, entre os 3.935 .237 milhões que se submeteram ao exame. Os zeros de 40.624 candidatos foram motivados por fuga ao tema, o que se relacionaria, segundo ideias de Feres (2016), diretamente a uma inaptidão para a leitura.
} 


\section{PERcursos Linguísticos • Vitória (ES) •v. 11 •n. 29 • 2021 • ISSN: 2236-2592 • Dossiê temático $\bullet O$ texto na pesquisa e no ensino: conhecimentos, práticas e desafios na contemporaneidade •}

pessoal/institucional daqueles que as assinam do que a ações que contribuam, efetivamente, para a formação leitora dos estudantes do país.

$\mathrm{Na}$ verdade, as ações, empreendidas no universo da leitura mediada, é que levarão os alunos a perceberem que a informação é sempre um acontecimento interpretado. A significação do acontecimento "depende do olhar que se estende sobre ele, olhar de um sujeito que o integra num sistema de pensamento e, assim fazendo, o torna inteligível”. (CHARAUDEAU, 2006, p. 95). E esse olhar de interpretação, na efetiva construção do acontecimento, mobiliza índices linguísticos e semiológicos, segundo restrições situacionais e projetos de dizer. São índices que devem ser desvendados pelo leitor em formação em um trabalho de mediação do ato de ler, a fim de se atestar que a linguagem não é neutra. Cada construção linguística mobiliza "sentidos, visões de mundo e valores constitutivos das relações sociais mais amplas". (BARBOSA, 2013, p. 238).

Nesse sentido, retomamos a importante ideia da mediação. Segundo essa proposta, o professor assume o papel de orientador dos múltiplos caminhos que o aluno pode seguir a fim de alcançar a posição de sujeito leitor. Em sentido oposto, podemos nos deparar, em contrapartida, com resultados reveladores de possíveis problemas quanto ao encaminhamento dado à formação da competência leitora. A esse respeito, a qualidade das respostas apresentadas nas provas discursivas de Língua Portuguesa e Literatura Brasileira em diferentes vestibulares CEDERJ, promovidos - no âmbito do estado do Rio de Janeiro - pela Fundação CECIERJ, convida a uma análise.

Para citar um exemplo, numa das questões discursivas da prova de Língua Portuguesa e Literatura Brasileira do vestibular CEDERJ 2012/2 - a partir de trecho retirado da obra "Leite derramado", de Chico Buarque -, pedia-se aos estudantes que explicassem a imagem do casarão de Botafogo construída pelos adjuntos adnominais do período a seguir: "Ali há quartos enormes, banheiros de mármore com bidês, vários salões com espelhos venezianos, estátuas, pé-direito monumental e telhas de ardósia importadas da França". Ao enunciado proposto, alguns responderam, estritamente, à luz da classificação gramatical. Para ilustrar, segue a resposta de um aluno: "quartos (substantivo), enormes (adjunto adverbial), banheiros (substantivo), de mármore (adjunto adnominal) e com bidê (adjunto adnominal)". Como é possível observar, a resposta que poderia apontar para "imagens de luxo, monumentalidade, riqueza, exagero" despreza a construção do sentido para se fixar na obsessão gramatical.

Diante do exemplo apresentado, temos de concordar, em parte, com Perini (1996, p. 28), quando ele "exclui a possibilidade de se utilizar a gramática como um dos caminhos para a 


\section{PERcursos Linguísticos • Vitória (ES) •v. 11 •n. 29 • 2021 • ISSN: 2236-2592 • Dossiê temático $\bullet O$ texto na pesquisa e no ensino: conhecimentos, práticas e desafios na contemporaneidade •}

leitura", entendendo que, nesse caso, os conteúdos gramaticais - como unidades de ensino são tratados de forma isolada, analisados apenas estruturalmente no alcance da identificação e da classificação dos itens linguísticos. Entretanto, é possível estabelecer uma forma de mediar a relação do estudante com o texto com base no uso dos componentes gramaticais como um meio para a leitura, considerando-os totalmente integrados às condições de produção dos textos e, nessa direção, determinantes para a produção de sentido. Eis o que contemplaremos a seguir.

\section{Memórias, competências e estratégias}

Apesar de não almejarmos eleger o modelo de análise ideal a ser empregado em atividades de leitura mediada, pensamos que certas ações podem ser ensinadas aos alunos nos diferentes níveis da educação básica.

Somos instigados a fazer isso em decorrência de certo vão deixado diante do tratamento dispensado ao texto em sala de aula. A esse respeito, Marcuschi (2008, p. 52) nos alerta que, introduzidas como motivação para o ensino, "as formas de acesso, as categorias de trabalho e as propostas analíticas" - relativas aos textos lidos em sala de aula - não sofreram, no entanto, alterações.

Com respaldo na Teoria Semiolinguística do Discurso, de Patrick Charaudeau (1983,1992, 2001, 2004, 2006), podemos mobilizar um aporte teórico que permite amparar o professor frente a "propostas analíticas", organizadoras de "formas de acesso" e de "categorias de trabalho", em atividades de leitura mediada. Assim, pretendemos estabelecer uma ligação efetiva entre o que a teoria linguística oferece e o modo de se ensinar leitura na escola, na passagem entre o que a universidade ministra em seus cursos de formação de professores - que deve ser atravessado por uma discussão pedagógica - e o que a escola necessita na sua prática real de ensino de leitura.

Da Semiolinguística, aprendemos a lição de que os sujeitos, no âmbito de seus projetos de escritura, adotam estratégias discursivas que operam, geralmente, uma espécie de gestão de impedimentos e de autorizações na busca por se alcançar o objetivo de sentido pretendido. Essa dita gestão estratégica sugere que a produção de textos, para Charaudeau (1983), é simultaneamente uma expedição e uma aventura.

Como uma expedição, pressupõe-se que o sujeito produza enunciados, dentro de um projeto comunicativo, almejando que o interlocutor real coincida com o idealizado no sentido de aderir ao objetivo proposto. Para tanto, o enunciador lança mão de estratégias discursivas que dão clareza ao contrato comunicativo vigente, o qual rege com segurança e previsibilidade 


\section{PERcursos Linguísticos • Vitória (ES) •v. 11 •n. 29 • 2021 • ISSN: 2236-2592 • Dossiê temático $\bullet O$ texto na pesquisa e no ensino: conhecimentos, práticas e desafios na contemporaneidade •}

a relação entre os sujeitos em interação. Ao ver enunciado, por exemplo, "Era uma vez...", em contos de fadas, parece claro que o leitor espere a narração - em uma dimensão que pode ser tanto verbal, quanto verbo-visual - de um acontecimento, disparado pela situação inicial.

A esse respeito, vale ressaltar, contudo, que os efeitos de sentido pretendidos dentro da mise-en-scène expedicionária, traçada pelo sujeito que comunica, podem ou não ser os partilhados pelo leitor real.

Por um lado, mesmo sendo efeitos de sentido partilhados pelo leitor, Geraldi nos lembra de que ele não deve neles permanecer, "sob a pena de a experiência estética da leitura se tornar alienante: depois da última palavra, é preciso retornar à vida própria, enriquecido pelo trabalho produtivo da leitura". (GERALDI, 2013, p. 31). Diante da mesma expressão "Era uma vez...", apreendida, mais comumente, em contos de fadas, o leitor pode ser encaminhado à leitura de outro gênero textual, como um anúncio publicitário, dado em semiose verbo-visual. Desse anúncio - texto multimodal por excelência -, extraímos o seguinte trecho verbal, ao lado da fotografia de uma mulher com olhar sedutor, que faz alusão à imagem da Branca de Neve (seja pela cor preta dos cabelos, seja pelos tons azul e vermelho da roupa e dos acessórios, seja pela maçã que lhe é oferecida): "Era uma vez uma garota branca como a neve/ Que causava muita inveja não por ter conhecido sete anões/ Mas vários morenos de 1,80m".?

O emprego da expressão "Era uma vez..." pode suscitar, no leitor em formação, o sentido bifurcado da narração que se inicia (modo de organização discursivo típico dos contos de fadas) e da argumentação que se promove (dimensão própria das publicidades), confirmada pelo slogan que acompanha o texto: "Você pode ser o que quiser" e pela imagem, sedutoramente transgressora, da "princesa", em uma clara experiência de leitura produtiva. Nos distintos gêneros - conto de fadas e anúncio publicitário -, o uso do recurso "Era uma vez..." atende a objetivos diferentes.

Mais especificamente, tomada como expressão empregada em um dos anúncios publicitários de uma conhecida empresa de cosméticos, em diálogo com a semiose visual, "Era uma vez..." deve ser lida com apoio em uma proposta teórico-metodológica que atente para os recursos multimodais - bastante expressivos - em jogo. Ou seja, o texto deve ser apreendido, sob essa perspectiva, como uma produção não apenas verbal, mas também visual, com base na qual se realizam inferências. Segundo Charaudeau (2018), a inferência é um "mecanismo cognitivo pelo qual o receptor de uma mensagem interpreta, a partir de um ato de linguagem

\footnotetext{
${ }^{7}$ Esta propaganda está disponível em: https://www.pinterest.pt/pin/606930487257390535/. Acesso em: 28 set. 2021.
} 


\section{PERcursos Linguísticos • Vitória (ES) •v. 11 •n. 29 • 2021 • ISSN: 2236-2592 • Dossiê temático $\bullet O$ texto na pesquisa e no ensino: conhecimentos, práticas e desafios na contemporaneidade •}

dado, um sentido que ele tira dos elementos que foram enunciados, seja combinando-os entre si, seja apelando para dados da vizinhança linguística e para saberes sobre os interlocutores". (p. 14).

Tais ações inferenciais sobre as parcelas verbal e imagética das produções textuais podem ser tanto centrípetas, voltadas para dentro do texto, quanto centrífugas, expandidas para fora do texto (CHARAUDEAU, 2018). Sob esse segundo movimento inferencial, a atividade leitora mediada dá condições ao aluno de flagrar o "Era uma vez...", em primeiro lugar, na direção de uma história cujo protagonismo é o da princesa idealizada dos ficcionais contos de fadas (guardada no repertório imagético do leitor), em consonância com um imaginário sociodiscursivo de feminilidade tradicional. Em segundo lugar, possibilita ao aluno atestar o "Era uma vez..." na direção de "história" protagonizada, na contemporaneidade, por uma "princesa" transgressora. Tal "princesa" está evidenciada imageticamente, no anúncio, pela fotografia de uma mulher "real", orientada, agora, por um imaginário sociodiscursivo de feminilidade menos conservadora.

Por outro lado, não sendo todos esses efeitos de sentido partilhados pelo leitor, com base em procedimento teórico-metodológico que acene para a dimensão verbo-visual do texto, compreende-se a encenação discursiva como uma potencial aventura, dotada de imprevisibilidade. Como uma aventura, o ato de linguagem empreendido filia-se a um contrato comunicativo cuja vigência o leitor poderá não aceitar, seja, dentre outros fatores, por desconhecimento do contexto sócio-histórico, seja por falta de domínio de algum conhecimento prévio, seja pela ausência de controle sobre determinado mecanismo linguístico-discursivo em âmbito verbal e/ou visual.

Esses pontos devem ser considerados se estamos tratando de estratégias discursivas como recursos para a reflexão, em atividades de leitura mediada, com vistas à formação de leitores competentes diante dos desafios da contemporaneidade.

Nesse momento, é necessário retomar a ideia de que é possível ensinar a interpretar textos com base em instruções de como descortinar essas estratégias de produção de sentido neles presentes. Esse ponto sugere haver, então, uma relação estreita entre estratégias discursivas e interpretação de textos.

A professora Maria Aparecida Lino Pauliukonis nos lembra de que, "na linguagem da interpretação do texto, examinar estratégias discursivas é analisar caminhos de que se valeu o autor para melhor se aproximar de seus leitores e conseguir adesão dos espíritos ao que ele propõe”. (PAULIUKONIS, 2007, p. 244). Estrategicamente, elementos linguísticos e 


\section{PERcursos Linguísticos • Vitória (ES) •v. 11 •n. 29 • 2021 • ISSN: 2236-2592 • Dossiê temático $\bullet O$ texto na pesquisa e no ensino: conhecimentos, práticas e desafios na contemporaneidade •}

extralinguísticos são empregados de modo coordenado com vistas a se alcançar certo objetivo, cabendo ao mediador, na atividade de leitura, ajudar os leitores em formação a descortinar os efeitos de sentido produzidos por tais mecanismos linguístico-discursivos alinhados. E isso se faz por processos de inferências, análise de pressupostos e implícitos situacionais e o estabelecimento de relações intertextuais. É decorrente, nesse sentido, do acionamento de uma tripla competência, sendo esta correspondente à ativação de uma memória linguística, situacional e semântico-pragmática, assim triplamente classificada por Charaudeau (2004, p. 19).

$\mathrm{Na}$ apreciação das estratégias discursivas selecionadas face a determinado contrato de comunicação vigente, o leitor desvenda, com base em sua memória linguística, as instruções relativas à organização discursiva e formal do texto; de posse de uma memória situacional, descortina os procedimentos correspondentes ao projeto de fala do enunciador e seus propósitos de influência; por fim, calcado em uma memória semântico-pragmática, traz à luz os diferentes conhecimentos e crenças que circulam para a produção do sentido.

A seguir, vamos nos ater aos meios linguísticos e discursivos empregados para a consolidação de estratégias discursivas que demandam a ativação da tripla memória. Intentamos, assim, articular o estudo das memórias evocadas e das estratégias empregadas ao ensino de uma metodologia de leitura. O leitor em formação precisa ser conscientizado de que a ativação dessas três memórias, concretizadas no emprego de diferentes estratégias linguageiras, é essencial à atividade de leitura. Exemplifiquemos a proposta didática, com base, agora, em um gênero de texto não prototicamente multimodal, apresentado, de forma original, em material impresso. Trata-se do poema "À moda da casa", publicado pelo poeta José Paulo Paes no livro Anatomias, de 1967.

\section{Feijoada \\ Marmelada \\ Goleada \\ Quartelada}

À moda da casa

No que diz respeito à memória dos discursos, o poema em tela faz apelo a representações sociodiscursivas partilhadas em torno de uma época - década de 60 do século XX -, pautadas em saberes de conhecimento sobre o período da Ditadura Militar no Brasil e em saberes de crença sobre as opiniões circulantes a respeito do que esse período representou para uma nação submetida a poder ditatorial. Atento ao percurso da leitura mediada, o aprendiz é orientado a 


\section{PERcursos Linguísticos • Vitória (ES) •v. 11 •n. 29 • 2021 • ISSN: 2236-2592 • Dossiê temático $\bullet O$ texto na pesquisa e no ensino: conhecimentos, práticas e desafios na contemporaneidade •}

colocar em cena o fato de o ano de 1967 inserir-se numa fase antidemocrática brasileira, após o Golpe Militar de 1964, e a julgá-la como momento de grande luta velada por liberdade de expressão. Nesse caso, a leitura depende do acionamento do que Charaudeau (2018) designa por inferências centrífugas (externas) interdiscursivas (vinculadas aos saberes de crença e de conhecimento).

Quanto à memória das situações de comunicação, apela-se ao reconhecimento do lugar situacional em que o texto sob leitura se insere. Esse lugar situacional, organizado de acordo com um dispositivo comunicacional que o normatiza, define que o leitor tenha uma expectativa de troca, a estabelecer um contrato de reconhecimento, que, segundo Charaudeau (2008), é condição recíproca e diferenciada do sentido. Tratado pela poesia, o discurso político sobre o cenário de um Brasil ditatorial é passível de interpretação diferente em comparação à depreendida de uma conversa amigável ou de um debate, por exemplo. Na produção poética de José Paulo Paes, entrevê-se uma síntese político-social do Brasil de 60, tingida por uma intenção crítica e costurada sob uma forma experimental. Também, nesse momento, a atividade interpretativa acaba por acionar inferências denominadas centrífugas (externas) situacionais (ligadas às circunstâncias da enunciação) (CHARAUDEAU, 2018).

Portador de uma memória das formas de signos, o leitor em desenvolvimento é encaminhado a ver o texto segundo maneiras de dizer, interessando em como o texto diz o que diz, com base no acionamento de inferências ditas centrípetas (internas) (CHARAUDEAU, 2018). O julgamento acionado pelo leitor sobre o texto "À moda da casa" é, nesse sentido, de ordem estética. A referida forma experimental é descortinada pela leitura das palavras isoladas e dos trocadilhos que constroem a coerência textual. O próprio título desencadeia no leitor que está em situação interacional - a memória das formas dos signos para que construa o sentido de que o poema, à maneira da expressão inserida em cardápios (em um movimento intertextual), insinua como tudo acontecia no Brasil naquele momento. E essa insinuação é feita com contorno crítico, pela mistura, sobretudo, dos campos semânticos: da gastronomia à política.

Nessa trajetória entre os campos semânticos em contínuo, flagra-se, principalmente, no escopo de uma enunciação restrita, isto é, visualizada em termos microestruturais, a projeção de um efeito de sentido bifurcado para o termo "marmelada". Sob a ótica da culinária brasileira, a palavra contribui para retratar culturalmente o Brasil no âmbito do modo de organização descritivo; do ponto de vista político, atesta as combinações inescrupulosas que estão na base da implantação do regime militar no país, como o "financiamento" do futebol ("goleada") para propagação de uma imagem positiva do governo militar (“quartelada"), pelo viés do modo 


\section{PERcursos Linguísticos • Vitória (ES) •v. 11 •n. 29 • 2021 • ISSN: 2236-2592 • Dossiê temático $\bullet O$ texto na pesquisa e no ensino: conhecimentos, práticas e desafios na contemporaneidade •}

argumentativo de organização do discurso. O cenário político brasileiro da época busca aliar sua imagem à da seleção brasileira, para angariar a aprovação da população. Como alienadores do povo, os "ingredientes" do governo militar, uniformizados em torno do sufixo -ada (indicador de "provido de"), são servidos "à moda da casa", tática ("feijoada", "marmelada" e "goleada") - comida e futebol como instrumentos de alienação - e veladamente ("marmelada" e "quartelada") - como meio de repressão aos inimigos do governo militar.

No que concerne à multimodalidade, ainda que o texto analisado seja, em contínuo, um exemplar de gênero menos visualmente informativo (DIONÍSIO, 2011), a disposição gráfica das palavras no poema em tela - todas polissílabas, finalizadas em -ada e listadas, verticalmente, como pratos/ingredientes - é semioticamente relevante no alcance dos efeitos de sentido acima pontuados, sobretudo na relação com o título do texto: À moda da casa. A tímida organização multimodal do poema de Paes (1967) evoca, como já mencionado, o arranjo imagético próprio de pratos listados em cardápios ou de ingredientes, em receitas culinárias. E essa imagem visual, em consonância com a parcela verbal, sugere a representação de Brasil que se almeja sustentar.

Em suma, o que toda essa análise procura evidenciar é que o texto, lido sob o enfoque de uma contribuição teórica da área do discurso, é vislumbrado tanto consoante sua configuração linguística - timidamente multimodal - quanto em conformidade com seu funcionamento enunciativo-discursivo, atravessado por questões sociopolíticas e culturais. Em interface com o eixo enunciativo, social, histórico, cultural, enfim, discursivo, cabe à esfera linguística - em semiose verbo-visual - materializá-lo. No caso do texto de José Paulo Paes (1967), as escolhas mórficas em -ada importam como indícios de uma visão de mundo que se deseja instaurar, em determinada situação comunicativa, deixando evidente a argumentatividade do texto. E esse potencial argumentativo da construção textual só é apreendido quando, de produto, o texto passa a ser concebido como uma produção, isto é, como um evento dinâmico a envolver, para a construção do sentido, não só o autor, mas, sobretudo, o leitor.

Assim, reafirmamos que, diante da análise proposta, que é uma possível dentre outras, os textos, para serem lidos globalmente (considerando, claro, a própria multimodalidade da escrita), não podem prescindir do leitor e de suas memórias. Exposto à trama textual e discursiva, o leitor deve ser orientado a acionar sua tripla memória para o processo de construção e negociação do sentido, uma vez que o sentido não é fixo, não está no texto, nem é previamente dado (KOCH; ELIAS, 2009). 


\section{PERcursos Linguísticos • Vitória (ES) •v. 11 •n. 29 • 2021 • ISSN: 2236-2592 • Dossiê temático $\bullet O$ texto na pesquisa e no ensino: conhecimentos, práticas e desafios na contemporaneidade •}

No escopo da própria Teoria Semiolinguística do Discurso, essas memórias correspondem a três distintas competências (CHARAUDEAU, 2001) às quais os leitores recorrem, na encenação comunicativa, para preencher as muitas lacunas dos textos.

À memória dos discursos corresponde uma competência semântica, que exige do sujeito que comunica uma aptidão para produzir sentido, circunscrito às coerções situacionais, aos saberes de conhecimento e de crença supostamente partilhados pelos coenunciadores. À memória das situações de comunicação corresponde uma competência situacional, que determina ao sujeito construir seu discurso em função da identidade dos parceiros da troca, da finalidade de cada situação, da temática em jogo e das próprias circunstâncias materiais. À memória das formas de signos corresponde uma competência semiolinguística, que exige do sujeito que comunica estar apto a lidar ("manipular-reconhecer") com as categorias da língua ("formas dos signos, suas regras de combinação e seu sentido") em função das formas de organização da encenação do ato de linguagem e de seus objetivos correspondentes (CHARAUDEAU; MAINGUENEAU, 2004, p. 102).

Essas várias competências constituem, na visão de Patrick Charaudeau (2008), o que designa por competência discursiva. A articulação estreita entre os três tipos de memória enseja uma associação entre as competências semântica, situacional e semiolinguística e as coloca em funcionamento para a produção de atos de linguagem portadores de sentido e de vínculo social.

Em diálogo com Cosson (2010), é possível também correlacionar as referidas memórias e as correspondentes competências, postas em uso na atividade de leitura orientada, à tripla taxonomia texto, contexto e intertexto (em sentido amplo). Aplicando-a aos textos dos diversos domínios discursivos, verifica-se que, na trajetória de uma interpretação mediada, o professor pode aplicar essa proposta tridimensional ao trabalho com a leitura em sala de aula. Para a leitura da obra em si mesma, isto é, do texto, aciona-se no aluno sua memória das formas de signos para apreensão de efeitos de sentido via competência semiolinguística; para a leitura do texto em contexto - considerando que as produções textuais são também sócio-historicamente determinadas -, mobiliza-se no aluno uma memória das situações de comunicação com vistas à produção de efeitos de sentido pela aplicação de conhecimentos de uma competência situacional; por fim, para a leitura das produções textuais como intertexto/interdiscurso, apelase à memória dos discursos, com base nos saberes de conhecimento e de crença, ou seja, na diversidade de conhecimentos trazidos pelo aluno, que o interpelam ao acionamento de uma competência semântica. 


\section{PERcursos Linguísticos • Vitória (ES) •v. 11 •n. 29 • 2021 • ISSN: 2236-2592 • Dossiê temático $\bullet O$ texto na pesquisa e no ensino: conhecimentos, práticas e desafios na contemporaneidade •}

$\mathrm{Na}$ continuidade desse raciocínio que relaciona memória-competênciatexto/contexto/intertexto (em sentido amplo), reavemos o conceito de texto como formado por uma série de atos de linguagem (macroatos de linguagem), dependentes da visada que lhes é conferida por seu criador, em uma situação de comunicação que lhes deu origem (MACHADO, 2008, p. 184). Esse "criador" se vê obrigado a transitar, estrategicamente, entre restrições e liberdades, experimentando, na imagem sugerida por Charaudeau (2004, p. 29), a obediência às regras de uma expedição e a transgressão de uma aventura. Nesse sentido mesmo, retomamos três pontos essenciais da teoria proposta por ele e do apresentado em Ribeiro (2016, p. 65), fundados, agora, na atualização das seguintes associações:

Quadro 1: Texto - forma, situação e discurso

\begin{tabular}{|l|l|}
\hline Produção textual & Abordagem \\
\hline Ato de linguagem & $\begin{array}{l}\text { Materialidade significante e construção linguística } \\
\text { (restrições formais) TEXTO }\end{array}$ \\
\hline Produzido em situação contratual & $\begin{array}{l}\text { Finalidade e visada enunciativa, identidade dos } \\
\text { parceiros, propósito temático e circunstâncias } \\
\text { materiais particulares (restrições situacionais) } \\
\text { CONTEXTO }\end{array}$ \\
\hline Originário em um sujeito & $\begin{array}{l}\text { Sobredeterminado em parte pelas propriedades da } \\
\text { situação comunicativa e em parte pelas propriedades } \\
\text { singulares de sua intervenção (restrições } \\
\text { discursivas) INTERTEXTO/INTERDISCURSO }\end{array}$ \\
\hline
\end{tabular}

Fonte: Adaptado de Charaudeau (2004)

O quadro demonstra que, sob relações contratuais, as produções de sentido, inevitavelmente, circunscrevem-se a restrições formais, situacionais e discursivas. Nas práticas sociais de comunicação, essas restrições devem ser consideradas e reconhecidas para que ocorra, de fato, a interação. Ao assumir a posição de mediador de leitura, o professor deve orientar o leitor em formação a - em seu caminho de compreensão responsiva e interpretação criativa -, mediado pela proposta tridimensional sugerida por Cosson (2010), acionar a sua tripla memória e recorrer às três competências essenciais à produção/interpretação/compreensão de "atos de linguagem, portadores de sentidos e de vínculo social”. (CHARAUDEAU, 2008, p. 8).

Por fim, resta dizer que, neste trabalho de mediação, é preciso também que o professormediador, para além de suscitar em seus alunos a emergência de uma tripla competência discursiva, esteja atento à emergência de uma que o "capacite a apreender o sentido-sensação emanado pelo texto". (FERES, 2010, p. 127). Em outros termos, na atividade de leitura, sobretudo a da leitura literária, faz-se necessário pôr em cena uma competência fruitiva, assim 


\section{PERcursos Linguísticos • Vitória (ES) •v. 11 •n. 29 • 2021 • ISSN: 2236-2592 • Dossiê temático $\bullet O$ texto na pesquisa e no ensino: conhecimentos, práticas e desafios na contemporaneidade •}

cunhada por Feres (2010). Para a autora, essa competência refere-se a habilidades sobre as quais o leitor deve ter domínio "não só para perceber as sensações provocadas pelas estratégias analógicas articuladas na tessitura textual, como também para criar um 'estado de aceitabilidade favorável' a fim de se deixar afetar interiormente pelo texto". (FERES, 2010, p. 127).

Sobretudo, para fruir, o leitor, além de acionar habilidades situacionais, discursivas e semiolinguísticas, tem de se colocar em identificação com aquele coenunciador projetado pelo texto, imaginado como um sujeito envolvido pelas experiências contadas e pelas construções originais, principalmente as poéticas.

Nesse sentido, ainda, é válido dizer que: (i) uma "seleção de textos que desconsidere os leitores em formação"; (ii) "a obrigatoriedade de leitura de textos estéticos que nada dizem a estes leitores"; (iii) a ausência, enfim, de um trabalho que acolha esses estudantes em atividades de leitura podem, segundo Geraldi (2013, p. 47), colocar em xeque o referido "estado de aceitabilidade favorável”. Podem, enfim, acabar por inibir a emergência da necessária competência leitora.

\section{Para arrematar}

Neste artigo, o objetivo primordial foi o de destacar o ponto central da mediação do professor na prática de leitura, focalizando, sobretudo, as estratégias linguístico-discursivas dos textos - no âmbito de um contínuo informativo visual de gêneros escritos - e as habilidades e memórias que, em correspondência, devem ser acionadas para uma leitura competente, sobretudo em cenário contemporâneo.

Sustentamos que o leitor em formação deve ser implicado no ato de ler por uma orientação que o conduza a pôr em cena, no escopo da multimodalidade constitutiva dos textos, uma memória multifacetada - discursiva, situacional, formal; uma orientação que o possibilite trafegar pelo texto em contexto e intertexto/interdiscurso; enfim, uma condução que o desperte também para uma competência fruitiva.

Acreditamos que, assim, ele consiga, de fato, "conhecer as coisas" - por compreendêlas, por senti-las - ao movimentar-se sobre o circuito textual sinuoso de uma "volta toda".

\section{Referências}

ANTUNES, Irandé. Análise de textos: fundamentos e práticas. 1. ed. São Paulo: Parábola, 2010. 


\section{PERcursos Linguísticos • Vitória (ES) •v. 11 •n. 29 • 2021 • ISSN: 2236-2592 • Dossiê temático $\bullet O$ texto na pesquisa e no ensino: conhecimentos, práticas e desafios na contemporaneidade •}

BAKHTIN, Mikhail. Estética da criação verbal. 4. ed. São Paulo: Martins Fontes, 2003.

BARBOSA, Marinalva Vieira. O lugar da teoria na prática de ensino de leitura e análise de textos. In: BARBOSA, Juliana Bertucci; BARBOSA, Marinalva Vieira (Org.). Leitura e mediação: reflexões sobre a formação do professor. 1. ed. São Paulo: Mercado de Letras, 2013. p. 231-262.

BRAIT, Beth. Olhar e ler: verbo-visualidade em perspectiva dialógica. Bakhtiniana, São Paulo, v.8, n.2, p. 43-66, jul./dez. 2013.

BRITTO, Luiz Percival Leme. Leitura e política. In: EVANGELISTA, Aracy Alves Martins; BRANDÃO, Heliana Maria Brina; MACHADO, Maria Zélia Versiani (Org.). A Escolarização da leitura literária: o jogo do livro infantil e juvenil. 1. ed. Belo Horizonte: Ceale/Autêntica, 1999.

CHARAUDEAU, Patrick. Langage et discourse: éléments de sémiolinguistique - théorie et pratique. 1. ed. Paris: Hachette, 1983.

CHARAUDEAU, Patrick. Grammaire du sens et de l'expressión. 1. ed. Paris: Hachette, 1992.

CHARAUDEAU, Patrick. De la competencia social de comunicación a las competencias discursivas. Revista interamericana de estúdios del discurso - ALED, v.1, n. 1, p. 7-22, 2001.

CHARAUDEAU, Patrick. Visadas discursivas, gêneros situacionais e construção textual. In: MACHADO, Ida Lúcia; MELLO, Renato de (Org.). Gêneros: reflexões em análise do discurso. 1. ed. Belo Horizonte: NADE/FALE-UFMG, 2004. p. 13-41.

CHARAUDEAU, Patrick. Discurso das mídias. Tradução Ângela M. S. Corrêa. 1. ed. São Paulo: Contexto, 2006.

CHARAUDEAU, Patrick. Linguagem e discurso: modos de organização. Coordenação da equipe de tradução Ângela M. S. Corrêa e Ida Lúcia Machado. 1. ed. São Paulo: Contexto, 2008.

CHARAUDEAU, Patrick. Compréhension et interpretation: interrogations autour de deux modes d'appréhension du sens dans les sciences du langage. In: ACHARD-BAYLE, G.; GUÉRIN, M.; KLEIBER, G.; KRYLYCHIN, M. (Orgs.). Les sciences du langage et la question de l'interprétation (aujourd'hui). Limoges: Les Éditions Lambert-Lucas, 2018. p. 2155. Disponível em português em: https://ciadrj.letras.ufrj.br/wp-content/uploads/ 2019/11/ARTIGO-CHARAUDEAU-2019-3.pdf. Acesso em: 11 mar. 2020.

CHARAUDEAU, Patrick; MAINGUENEAU, Dominique. Dicionário de Análise do Discurso. 1. ed. São Paulo: Contexto, 2004.

COSSON, Rildo. O espaço da literatura na sala de aula. In: PAIVA, Aparecida; MACIEL, Francisca; COSSON, Rildo (Coordenação). Literatura. Vol. 20. Brasília: MEC, 2010. p. 5568. 


\section{PERcursos Linguísticos • Vitória (ES) •v. 11 •n. 29 • 2021 • ISSN: 2236-2592 • Dossiê temático $\bullet O$ texto na pesquisa e no ensino: conhecimentos, práticas e desafios na contemporaneidade •}

DIONÍSIO, A. P. Gêneros multimodais e multiletramento. In: KARXOSKI, B. G. \& BRITO, K. S. (Org.). Gêneros textuais: reflexões e ensino. 3. ed. Rio de Janeiro: Nova Fronteira, 2011. p. $138-152$.

FERES, Beatriz dos Santos. Competência para ler com emoção. In: MENDES, Emília; MACHADO, Ida Lúcia (Org.). As emoções no discurso. Vol. 2. 1. ed. São Paulo: Mercado de Letras, 2010. p. 123-140.

FERES, Beatriz dos Santos. O ato de ler numa perspectiva interativa: os níveis de construção de sentido dos textos. In: DIAS, André; FERES, Beatriz dos Santos; ROSÁRIO, Ivo da Costa (Org.). Leitura e formação do leitor: cinco estudos e um relato de experiência. 1. ed. Rio de Janeiro: 7 Letras, 2016. p. 29-42.

FERES, Beatriz dos Santos. Da interpretação à compreensão de textos. In: XAVIER, Glayci; REBELLO, Ilana; MONNERAT, Rosane (Org.). Semiolinguística aplicada ao ensino. 1. ed. São Paulo: Contexto, 2021.

GERALDI, Jõao Wanderley. Leitura e mediação. In: BARBOSA, Juliana Bertucci; BARBOSA, Marinalva Vieira (Org.). Leitura e mediação: reflexões sobre a formação do professor. 1. ed. São Paulo: Mercado de Letras, 2013. p. 25-48.

KOCH, Ingedore; ELIAS, Vanda Maria. Ler e escrever: estratégias de produção textual. 1. ed. São Paulo: Contexto, 2009.

MACHADO, Ida Lúcia. As palavras de uma Análise do Discurso. In: LARA, Gláucia Muniz Proença; MACHADO, Ida Lúcia; EMEDIATO, Wander (Org.). Análises do Discurso Hoje. Vol. 2. 1. ed. Rio de Janeiro: Nova Fronteira, 2008. p. 177-198.

MARCUSCHI, Luiz Antônio. Produção textual, análise de gêneros e compreensão. 1. ed. São Paulo: Parábola, 2008.

MENDONÇA, Márcia. Análise linguística no ensino médio: um novo olhar, um outro objeto. In: BUNZEN, Clécio; MENDONÇA, Márcia (Org.). Português no ensino médio e formação do professor. 1. ed. São Paulo: Parábola, 2006. p. 199-226.

PAES, José Paulo. Anatomias. 1. ed. São Paulo: Cultrix, 1967.

PAULA, Luciane de; SERNI, Nicole Mioni. A vida na arte: a verbivocovisualidade do gênero filme musical. Raído. Dourados, MS, v. 11, n. 25, p.178-201, jan./jun. 2017.

PAULIUKONIS, Maria Aparecida Lino. Texto e contexto. In: VIEIRA, Silvia Rodrigues; BRANDÃO, Silvia Figueiredo (Org.). Ensino de gramática: descrição e uso. 1. ed. São Paulo: Contexto, 2007. p. 239-258.

PERINI, Mário. Gramática Descritiva do Português. 2. ed. São Paulo: Ática, 1996.

PETIT, Michèle. A arte de ler: ou como resistir à adversidade. 1. ed. São Paulo: 34, 2009. 
PERcursos Linguísticos • Vitória (ES) •v. $11 \bullet$ n. 29 • 2021 • ISSN: 2236-2592 • Dossiê

temático $\bullet O$ texto na pesquisa e no ensino: conhecimentos, práticas e desafios na contemporaneidade •

RIBEIRO, Ana E. Textos multimodais: leitura e produção. 1. ed. São Paulo: Parábola Editorial, 2016.

RIBEIRO, Patricia Ferreira Neves. Práticas de leitura mediada no ensino básico: entre situações, sentidos e formas. In: DIAS, André; FERES, Beatriz dos Santos; ROSÁRIO, Ivo da Costa (Org.). Leitura e formação do leitor: cinco estudos e um relato de experiência. 1. ed. Rio de Janeiro: 7 Letras, 2016. p. 55-72.

ROJO, Roxane; BARBOSA, Jaqueline P. Hipermodernidade, multiletramentos e gêneros discursivos. 1. ed. São Paulo: Parábola Editorial, 2015.

SARAMAGO, José. Depoimento no documentário Janela da Alma. In: JARDIM, João; CARVALHO, Walter. Janela da Alma. Europa Filmes, 2001. 


\title{
DISCURSOS EM DISSENSO: UM OLHAR SEMIOLINGUÍSTICO SOBRE A CONSTRUÇÃO ARGUMENTATIVA E O ENSINO DE LÍNGUA
}

\section{DISCOURSES IN DISAGREEMENT: A SEMIOLINGUISTIC VIEW ON ARGUMENTATIVE CONSTRUCTION AND LANGUAGE TEACHING}

\author{
Glayci Kelli Reis da Silva Xavier ${ }^{1}$ \\ Ilana da Silva Rebello ${ }^{2}$ \\ Nadja Pattresi de Souza e Silva ${ }^{3}$
}

\begin{abstract}
RESUMO: Muito se discute sobre a importância de o professor levar para a sala de aula temas atuais, a fim de possibilitar a formação de alunos mais críticos e participativos na sociedade. No entanto, como desenvolver um trabalho significativo com textos em sala de aula? Quais são os desafios para quem tem o texto como objeto de ensino na contemporaneidade? A partir dessas reflexões/inquietações, com apoio principalmente nos pressupostos teóricos da Semiolinguística de Análise do Discurso, de Charaudeau, o trabalho em tela tem por objetivo analisar a construção argumentativa e os imaginários sociodiscursivos em tiras do Armandinho e em um texto jornalístico sobre o tema da privatização. Por meio da análise da construção dos argumentos e contra-argumentos e dos imaginários sociodiscursivos que engendram os discursos favoráveis ou contrários à privatização, com este trabalho, espera-se contribuir para o ensino da compreensão da significação indireta (CHARAUDEAU, 2018) e, por consequência, para a formação de leitores críticos.
\end{abstract}

PALAVRAS-CHAVE: Argumentação. Semiolinguística. Imaginários sociodiscursivos. Privatização. Ensino de língua.

ABSTRACT: It is extensively discussed the importance of raising current issues in the classroom environment to mould critical students who can really participate in society. However, how can a meaninful text approach be developed nowadays? What are the challenges for those who take texts as their teaching object? Considering these questions, based on the theoretical principles of Charaudeau's Semiolinguistics Discourse Analysis perspective, the main purpose of the present study is to analyze the argumentative construction and the sociodiscursive imaginaries in comic strips featuring Armandinho and in a journalistic text about privatization. By analyzing the construction of arguments and counterarguments and the sociodiscursive imaginaries which produce favorable and unfavorable discourses about privatization, this text is intended to contribute to the teaching and learning of the indirect signification comprehension (CHARAUDEAU, 2018) and, as a consequence, to the formation of critical readers.

KEYWORDS: Argumentation. Semiolinguistics. Sociodiscursive imaginaries. Privatization. Language teaching.

\footnotetext{
${ }^{1}$ Doutora em Estudos de Linguagem e Professora Adjunta de Língua Portuguesa do Instituto de Letras da Universidade Federal Fluminense (UFF). E-mail: glaycikelli@id.uff.br.

${ }^{2}$ Doutora em Letras e Professora Associada de Língua Portuguesa do Instituto de Letras da Universidade Federal Fluminense (UFF). E-mail: ilanarebello@id.uff.br.

3 Doutora em Estudos de Linguagem e Professora Adjunta de Língua Portuguesa do Instituto de Letras da Universidade Federal Fluminense (UFF). E-mail: nadja_pattresi@id.uff.br.
} 


\title{
PERcursos Linguísticos • Vitória (ES) •v. 11 •n. 29 • 2021 • ISSN: 2236-2592 • Dossiê \\ temático $\bullet O$ texto na pesquisa e no ensino: conhecimentos, práticas e desafios na contemporaneidade •
}

\section{Introdução}

\begin{abstract}
Aprender a argumentar é a pedagogia mais profunda da vida do estudante, porque ele constitui-se, ao mesmo tempo, pesquisador e cidadão. [...] Não basta apenas expô-lo aos gêneros argumentativos, uma vez que, para que ele compreenda de que maneira se constrói a argumentação dentro de cada texto, faz-se necessário que o professor o oriente a levá-lo a identificar o tema abordado, as condições em que o discurso é produzido e o modo como o autor constrói a argumentação em relação ao gênero utilizado.
\end{abstract}

Pedro Demo (2009, p. 79).

No dia a dia, não é difícil encontrar professores que falam que os alunos apresentam muitas dificuldades quando o assunto é compreender o que leem. Por mais incoerente que possa parecer, viver a era da informatização e estar conectado não significa necessariamente ser leitor. Jovens e adolescentes estão, cada vez mais, buscando leituras fáceis, rápidas e resumidas. Como, então, desenvolver um trabalho frutífero com textos em sala de aula e efetivamente despertar o interesse dos alunos pela leitura? Quais são os desafios para quem tem o texto como objeto de ensino na contemporaneidade?

A BNCC, um dos documentos oficiais que norteia a Educação Básica no Brasil, advoga pela necessidade de o ensino de língua portuguesa ser centrado no texto - "Tal proposta assume a centralidade do texto como unidade de trabalho [...]" (BRASIL, 2017, p. 67), sem, no entanto, tomá-lo como pretexto para o ensino de gramática, mas

[...] Os conhecimentos sobre os gêneros, sobre os textos, sobre a língua, sobre a norma-padrão, sobre as diferentes linguagens (semioses) devem ser mobilizados em favor do desenvolvimento das capacidades de leitura, produção e tratamento das linguagens, que, por sua vez, devem estar a serviço da ampliação das possibilidades de participação em práticas de diferentes esferas/ campos de atividades humanas. (BRASIL, 2017, p. 67)

Defende-se, dessa maneira, que o trabalho com o texto seja uma espécie de passaporte, que, além de propiciar o letramento, permita ao aluno participar, de forma crítica, de diferentes áreas sociais. Além disso, retomando a epígrafe, cabe ressaltar que é importante expor o aluno a diferentes gêneros que expressam opinião para que possa desenvolver sua autonomia, ter seus próprios julgamentos e não ser facilmente conduzido pelos imaginários dominantes de determinado grupo social. Como afirma Charaudeau (2016, p. 34), "todo ponto de vista, todo julgamento, tem seu contrário" e, portanto, diante de um mesmo fato, "os indivíduos veem coisas diferentes, não sentem as mesmas emoções, não veem as mesmas causas e fazem julgamentos que lhes são próprios". Dessa maneira, o estudo da argumentação pode levar o indivíduo a se expressar melhor com relação a suas próprias visões e à visão do outro.

Nesse sentido, a partir dessas reflexões iniciais, este estudo, baseado principalmente na teoria Semiolinguística de Análise do Discurso, criada pelo professor emérito da Universidade 


\section{PERcursos Linguísticos • Vitória (ES) •v. 11 •n. 29 • 2021 • ISSN: 2236-2592 • Dossiê temático $\bullet O$ texto na pesquisa e no ensino: conhecimentos, práticas e desafios na contemporaneidade •}

Paris XIII Patrick Charaudeau, visa a contribuir com o ensino de leitura, por meio do cotejo de dois gêneros - tira de jornal e artigo de opinião - que versam sobre o mesmo tema - a privatização de instituições públicas - e trazem em si opiniões antagônicas, destacando o modo argumentativo de organização do discurso e os imaginários sociodiscursivos. Com o estudo proposto, pretende-se mostrar que é possível desenvolver um trabalho significativo com textos em sala de aula.

\section{Semiolinguística: contrato, estratégias e imaginários}

De acordo com o professor Charaudeau (2008, p. 68), texto representa "o resultado material do ato de comunicação e [que] resulta de escolhas conscientes (ou inconscientes) feitas pelo sujeito falante dentre as categorias de língua e os modos de organização do discurso, em função das restrições impostas pela situação" e comunicar "é proceder a uma encenação. [...] [O] texto, para produzir efeitos de sentido visando um público imaginado por ele, o locutor seja ao falar ou ao escrever - utiliza componentes do dispositivo da comunicação em função dos efeitos que pretende produzir em seu interlocutor."

Assim posto, para a Semiolinguística, todo ato de linguagem é uma encenação, chamada de mise en scène, da qual participam, no mínimo, quatro sujeitos - dois parceiros, externos ao texto, seres sociais: o eu-comunicante (EUc) e o tu-interpretante (TUi), e dois protagonistas, internos ao texto, seres discursivos: o eu-enunciador (EUe) e o tu-destinatário (TUd). Pensando no gênero textual artigo de opinião, o eu-comunicante é aquele que detém a iniciativa do ato de produzir o texto, o jornalista que assina a matéria. Ao planejar o texto, esse sujeito comunicante põe em cena um eu-enunciador - a identidade que assume no texto, e idealiza um interlocutor, o tu-destinatário, que pode coincidir ou não com o tu-interpretante, aquele que efetivamente lê o artigo. Por essa razão, Charaudeau (2008) diz que todo ato de linguagem é uma expedição e uma aventura:

[...] aventura é o que está inscrito no campo do imprevisível. Se, de um lado, o sujeito comunicante é senhor de sua encenação, do outro lado (o da recepção propriamente dita), ocorre o contrário: (i) o sujeito interpretante pode não dominar completamente os efeitos produzidos na instância de comunicação do sujeito comunicante; voltamos a lembrar que o EUc tem controle total apenas sobre o destinatário, ou seja TUd; (ii) mas, pode também ocorrer que o sujeito comunicante não seja capaz de dominar seu próprio inconsciente e deixe transparecer evidências que não estão contidas em seus atos de linguagem; em outras palavras, pode produzir, no sujeito-interpretante efeitos não previstos ou desejados; e, por fim, cabe lembrar (iii) que, muitas vezes, o sujeitointerpretante não está totalmente consciente do contexto sócio-histórico que deu origem ao ato de comunicação, o que pode alterar, consideravelmente, sua interpretação. (CHARAUDEAU, 2008, p. 57) 


\section{PERcursos Linguísticos • Vitória (ES) •v. 11 •n. 29 • 2021 • ISSN: 2236-2592 • Dossiê temático $\bullet O$ texto na pesquisa e no ensino: conhecimentos, práticas e desafios na contemporaneidade •}

Comunicar, portanto, é uma aposta, pois o sujeito que comunica, a despeito de respeitar o contrato do gênero e de utilizar estratégias, pode não ser compreendido como pensava e, consequentemente, o texto não produzirá o efeito desejado.

A noção de contrato, termo emprestado do discurso jurídico, prevê um acordo entre os sujeitos sobre as representações linguageiras das práticas sociais. Os sujeitos envolvidos na mise en scène do ato de linguagem precisam levar em consideração quem são os parceiros, se estão face a face, se são únicos ou múltiplos, o canal utilizado para a transmissão e os imaginários culturais e saberes compartilhados, por exemplo.

Dessa maneira, ao produzir o artigo de opinião, o jornalista, se quiser lograr êxito em sua comunicação, precisa atender ao que prevê o contrato do gênero - gênero textual veiculado, normalmente, em jornais, revistas e sites da internet, e, por ser argumentativo, inclui as opiniões e interpretações do jornalista, análises de dados e pesquisa, causas e consequências, dados estatísticos, dentre outras características, a respeito de temas da atualidade. Assim, ao colocar em cena um eu-enunciador, “[...] a instância midiática impõe ao cidadão uma visão de mundo previamente articulada, sendo que tal visão é apresentada como se fosse a visão natural do mundo. [...]" (CHARAUDEAU, 2006a, p. 151) e isso porque, ao lado das restrições impostas pelo contrato, todo ato de linguagem também prevê um espaço de liberdade, que possibilita àquele que comunica a utilização de estratégias, agrupadas, por Charaudeau (2009), sob três rótulos: legitimação, credibilidade e captação.

O jornal procura legitimar-se como um veículo de comunicação sério, comprometido com a instância cidadã e com a verdade dos fatos. O eu-comunicante, com o projeto de texto, deve demonstrar que tem aptidão para desempenhar uma determinada identidade social. Por exemplo, um jornalista, porta voz do jornal, deve construir uma imagem de veículo de comunicação imparcial e confiável. Não é à toa que a mídia utiliza o recurso linguístico citação, que funciona, estrategicamente, como uma fonte de verdade.

Ao lado da estratégia de legitimação, o eu-comunicante também pode adotar atitudes de neutralidade, de distanciamento e de engajamento, que resultarão em credibilidade. Normalmente, o leitor espera de um veículo de comunicação uma postura neutra, objetiva, no entanto, não é difícil que, em meio à concorrência, os jornais demonstrem, de forma explícita, um engajamento diante daquilo que enunciam.

Por último, ainda no espaço de liberdade, o sujeito que comunica pode ter por objetivo principal a captação e, para isso, pode se valer das atitudes de sedução - quando induz o interlocutor a sentir que ele será o beneficiário ao consumir o jornal, de polêmica - quando 


\section{PERcursos Linguísticos • Vitória (ES) •v. 11 •n. 29 • 2021 • ISSN: 2236-2592 • Dossiê temático $\bullet O$ texto na pesquisa e no ensino: conhecimentos, práticas e desafios na contemporaneidade •}

reporta opiniões diferentes sobre um mesmo assunto, e de dramatização - quando apela para o estado emocional do interlocutor.

O espaço de liberdade, assim, permite ao eu-comunicante encenar "suas intenções de forma a produzir determinados efeitos - de persuasão ou de sedução ${ }^{4}$ - sobre o sujeito interpretante (TUi), para levá-lo a se identificar - de modo consciente ou não - com o sujeito destinatário ideal (TUd) construído por EUc. [...]” (CHARAUDEAU, 2008, p. 56).

Dessa forma, diante do exposto, é possível identificar a intencionalidade, o que equivale a projeto de fala (CHARAUDEAU, 2008, p. 48), na base de qualquer ato de linguagem. Ler de forma rápida e superficial, sem levar em consideração todo o contexto de produção, nem sempre permite perceber a intencionalidade de quem produziu o ato de linguagem e as escolhas linguageiras que dão conta dos efeitos. Há de se enfatizar que:

as palavras nada significam em si. Isoladas, só apontam para o que dizem, não para o que significam. Pois há as palavras e o que está implícito nas palavras, e o que está implícito nas palavras depende de outras palavras, das condições em que foram enunciadas, de sua enunciação. É na situação de enunciação que as palavras revelam os pensamentos, as opiniões e as estratégias daquele que as emite. (CHARAUDEAU, 2016, p. 21).

Posto isso, frente ao desafio de perceber a intencionalidade propulsora de um texto e de se alcançar, por meio de inferências interpretativas, a compreensão da significação indireta ${ }^{5}$, é preciso identificar os imaginários que se tem do social, da cultura da qual os indivíduos não só fazem parte, mas que também constroem. Nesse sentido, em todo ato de linguagem, as interpretações da realidade são feitas a partir dos saberes de crença e de conhecimento produzidos e partilhados pelos membros de um mesmo grupo. Esses saberes configuram-se em diversos imaginários sociodiscursivos, que "dão testemunho das identidades coletivas, da percepção que os indivíduos e os grupos têm dos acontecimentos, dos julgamentos que fazem de suas atividades sociais". (CHARAUDEAU, 2006b, p. 207).

Partindo do conceito de imaginário social introduzido por Castoriadis entre os anos 60 e 70, Charaudeau (2006b) acrescenta o elemento discursivo, pois, segundo o semiolinguista,

[...] os grupos sociais produzem discursos de configuração diversa que dão sentido a essas materializações. Uns se fixam em textos escritos (ou na tradição oral) de maneira

\footnotetext{
4 Segundo Charaudeau (2009, s/p), persuadir é "fazer pensar recorrendo à razão" e seduzir é "fazer sentir recorrendo à emoção".

${ }^{5}$ De acordo com Charaudeau (2018), a compreensão é o resultado total da apreensão de um texto e pode concentrarse no conhecimento do idioma - compreensão do sentido literal, ou no conhecimento obtido a partir da relação estabelecida entre enunciados/circunstâncias de produção/recepção do ato de linguagem - compreensão da significação indireta. Para um maior aprofundamento, recomenda-se a leitura do capítulo "Da interpretação à compreensão de textos", de Beatriz Feres, parte da obra Semiolinguística aplicada ao ensino, publicada pela editora Contexto, em 2021.
} 


\title{
PERcursos Linguísticos • Vitória (ES) •v. 11 •n. 29 • 2021 • ISSN: 2236-2592 • Dossiê temático $\bullet O$ texto na pesquisa e no ensino: conhecimentos, práticas e desafios na contemporaneidade •
}

\begin{abstract}
mais ou menos imutável e assim podem ser transmitidos de geração em geração: as doutrinas religiosas, as teorias científicas, os manifestos políticos ou literários. Outros circulam nas comunidades sob configurações variáveis, às vezes mais estáveis, como os provérbios, as máximas e os ditados, às vezes menos, como os torneios de linguagem ou as frases circunstanciais, mas cuja variedade não altera seu sentido de base contido em uma espécie de núcleo semântico mais estável; [...] Esses textos, ditados, slogans, enunciados diversos, são apresentados de maneira simples, pois devem ser compreendidos pela maioria, e desempenham diversos papéis de apelo, de manifesto, de acusação, de potência, de reivindicação. Daí o qualificativo "discursivo" para caracterizar esses imaginários sociais. (CHARAUDEAU, 2006b, p. 206-207).
\end{abstract}

De forma mais específica, de acordo com Charaudeau (2006b, p. 197), os saberes de conhecimento "dizem respeito aos fatos do mundo e à explicação que se pode dar sobre o porquê ou o como desses fenômenos." São provenientes, assim, de uma razão científica que procura explicar a realidade a partir de dados objetivos. Esse tipo de saber é muito utilizado em textos jornalísticos para criar um efeito de credibilidade.

Ao contrário, os saberes de crença são aqueles que procedem de um juízo, de uma avaliação do sujeito que comunica a respeito dos fatos e "o sujeito que fala faz sua escolha segundo uma lógica do necessário e do verossímil, na qual pode intervir tanto a razão quanto a emoção. [...]" (CHARAUDEAU, 2006b, p. 198). Neste ponto, vale a pena lembrar que

[...] o contrato de informação midiática é, em seu fundamento, marcado pela contradição: finalidade de fazer saber, que deve buscar um grau zero de espetacularização da informação, para satisfazer o princípio de seriedade ao produzir efeitos de credibilidade; finalidade de fazer sentir, que deve fazer escolhas estratégica apropriadas à encenação da informação para satisfazer o princípio de emoção ao produzir efeitos de dramatização. (CHARAUDEAU, 2006a, p. 92).

Assim, concluindo essa primeira seção, pelo que foi apresentado até aqui, fica latente a importância da adequação dos atos de falar/escrever às restrições do gênero e da situação de comunicação como um todo, da escolha das estratégias que melhor dão conta do projeto de texto e dos imaginários sociodiscursivos que podem corroborar os sentidos pretendidos. Por outro lado, da parte da instância receptora, cabe identificar as estratégias utilizadas na transformação de categorias linguísticas em categorias discursivas, impregnadas de intencionalidades, para um começo de trabalho relevante com a escrita/fala e a compreensão de textos, pois

a leitura aprofundada de diferentes gêneros textuais deve ser um passaporte para a interação com o mundo, não apenas de leitura da palavra, de forma superficial, mas do mundo - como um meio ou, talvez, o meio de interação legítima do Tuinterpretante-aluno com o mundo. A falta de leitura pode levar o indivíduo a ter dificuldade para entender o mundo, a tomar a sua palavra e a agir realmente como sujeito. (REBELLO, 2021, p. 39). 


\section{PERcursos Linguísticos • Vitória (ES) •v. 11 •n. 29 • 2021 • ISSN: 2236-2592 • Dossiê temático $\bullet O$ texto na pesquisa e no ensino: conhecimentos, práticas e desafios na contemporaneidade •}

\section{O que significa argumentar na perspectiva semiolinguística?}

Como um fenômeno de linguagem de múltiplas dimensões, a argumentação é um processo que tem recebido destaque em diferentes perspectivas de estudo e áreas de atuação. Desde a retórica clássica, com base na tríade aristotélica ethos, logo e pathos, às investigações da nova retórica, a que se vinculam, por exemplo, Perelman e Olbrechts-Tyteca (2005), e às pesquisas de caráter textual-discursivo, como as divulgadas em Cavalcante et al. (2020), a construção argumentativa e seus mecanismos têm sido objeto de exame. A presente proposta filia-se a este último campo, mais especificamente ao viés desenvolvido pela Semiolinguística, teoria de Análise do Discurso cujas bases centrais já foram apresentadas.

Pela ótica de Charaudeau (2008, p. 68, grifo do autor), a argumentação constitui, junto ao descritivo e ao narrativo, um dos modos de organização do discurso, ou seja, um dos "princípios de organização da matéria linguageira", que "[...] dependem da finalidade comunicativa do sujeito falante". Sustentando essas três formas de organizar o ato de linguagem, considera-se, ainda, o modo enunciativo, uma exclusividade do aporte teóricometodológico da Semiolinguística. Nesse caso, analisam-se as formas como o enunciador se relaciona consigo mesmo, expressando explicitamente seu ponto de vista; com seu interlocutor, interpelando-o diretamente, e com o dito, apagando as marcas de pessoalidade ou recorrendo ao discurso relatado. Para isso, mobilizam-se, respectivamente, três estratégias que sinalizam essas funções enunciativas: a elocução, a alocução e a delocução.

No modo de organização argumentativo, além dessas possibilidades de construção enunciativa, produzem-se uma lógica e uma encenação do dizer para se expressar uma convicção e uma explicação ao interlocutor a fim de "persuadi-lo a modificar seu comportamento" (CHARAUDEAU, 2008, p. 205). Decorrem daí duas importantes constatações. A primeira corresponde ao fato de que a argumentação se sustenta em um tripé que prevê um sujeito argumentante, uma proposta sobre o mundo e um sujeito-alvo. A segunda envolve o reconhecimento de que argumentar abarca uma busca tanto de racionalidade, uma vez que o argumentante se pauta por um ideal de verdade para explicar algo sobre o mundo, quanto de influência, considerando que se mobiliza também um ideal de persuasão cujo fim é levar o destinatário a partilhar determinado universo de discurso, inclusive com recursos descritivos ou narrativos, por exemplo. 


\section{PERcursos Linguísticos • Vitória (ES) •v. 11 •n. 29 • 2021 • ISSN: 2236-2592 • Dossiê temático $\bullet O$ texto na pesquisa e no ensino: conhecimentos, práticas e desafios na contemporaneidade •}

Assim, segundo Charaudeau (2008), o argumentativo se organiza por uma razão demonstrativa e uma razão persuasiva. Aquela compreende a lógica argumentativa, mecanismo por meio do qual se instituem relações de causalidade, de modo geral, entre as asserções sobre o mundo, e esta abrange a encenação argumentativa em si, mecanismo que aciona provas com base em argumentos que sustentam tais proposições.

$\mathrm{Na}$ lógica argumentativa, verificam-se três elementos inter-relacionados de forma explícita ou implícita: uma asserção de partida (A1), que indica um dado ou premissa sobre o mundo; uma asserção de chegada (A2), que corresponde à conclusão que deve ser aceita em razão de A1, e uma asserção de passagem, que reúne um ou mais elementos (provas, argumentos, inferências) que possibilitam associar A1 e A2. Isso se dá com apoio em imaginários sociodiscursivos que devem ser partilhados entre os interlocutores a fim de se provar a validade da relação de causalidade entre a asserção de partida e a de chegada.

Em termos linguísticos, as articulações lógicas entre A1 e A2 podem se estabelecer por diferentes modos de encadeamento, tais como a disjunção $(O u$ se investe nos Correios ou sua precarização será maior); a restrição (Os Correios prestam um serviço essencial, mas não recebem os investimentos necessários), a finalidade (Defende-se a privatização dos Correios para que o serviço se torne mais eficiente) e a consequência (Os Correios não recebem os investimentos necessários à sua modernização, então perdem competitividade no mercado).

Como se disse, para que haja argumentação, essa lógica precisa se inscrever em uma encenação argumentativa. Para isso, mobiliza-se um dispositivo que associa uma (i) proposta ou tese sobre o mundo por meio de uma relação ampla de causalidade; (ii) uma proposição, por meio da qual o sujeito se mostra favorável ou contrário à proposta ou, ainda, assume uma atitude de ponderação e a (iii) persuasão, que explicita o quadro de raciocínio que alicerça a posição assumida pelo sujeito (a de justificativa, a de refutação ou a de ponderação da tese).

Nesse sentido, para fornecer ao destinatário meios de julgar a validade do que está em jogo na argumentação, o sujeito argumentante utiliza-se de diversas estratégias. De acordo com Menezes (2006, p. 96-97, grifo nosso), aciona-se:

[...] um conjunto de procedimentos, que são de ordem semântica (relativos aos valores e domínios de avaliação), discursiva (que consistem no uso de determinadas categorias da língua e no recurso a outros modos de organização, trazendo, por exemplo, a definição, a nomeação, a comparação, a citação, o questionamento, a narrativa etc. [...]) e composicional (que consistem em repartir, distribuir, hierarquizar os elementos do dispositivo argumentativo ao longo do texto, de forma a facilitar o reconhecimento de diferentes articulações do raciocínio ou a compreensão das conclusões da argumentação). 


\section{PERcursos Linguísticos • Vitória (ES) •v. 11 •n. 29 • 2021 • ISSN: 2236-2592 • Dossiê temático $\bullet O$ texto na pesquisa e no ensino: conhecimentos, práticas e desafios na contemporaneidade •}

Essa construção discursiva ancorada em relações de causalidade e na produção de um quadro de raciocínio com fins persuasivos é típica de gêneros argumentativos, como se verá adiante, com a análise de tiras de Armandinho e de um artigo sobre o tema da privatização. Pela circulação social desses gêneros e pela relevância de se desenvolver a capacidade de argumentar, inerente à natureza humana, no ensino básico, algumas possibilidades de abordagem desse processo serão exploradas a seguir.

Assim, pretendemos partilhar alternativas que preencham a lacuna a que Charaudeau (2008, p. 201, grifo do autor), de forma tão pertinente, se refere: "Se as instruções oficiais recomendam que se desenvolvam as capacidades de raciocínio dos alunos, nada é dito sobre o modo de se chegar a isso.”.

\section{Análise semiolinguística da construção de argumentos e contra-argumentos em textos sobre a privatização: a língua em uso}

Argumentar faz parte da vida do ser humano. A criança, desde cedo, sabe "negociar" suas ideias, alegando seu "bom comportamento", a tarefa feita ou mesmo apelando emocionalmente pelo choro. Algo tão natural na vida cotidiana, ao chegar à escola, a argumentação pode parecer distante do aluno, a depender da forma como a abordagem é conduzida. Torna-se necessário, então, planejar e repensar as práticas que envolvem a argumentação na escola. De acordo com a BNCC, uma das competências para a Educação Básica é:

Argumentar com base em fatos, dados e informações confiáveis, para formular, negociar e defender ideias, pontos de vista e decisões comuns que respeitem e promovam os direitos humanos, a consciência socioambiental e o consumo responsável em âmbito local, regional e global, com posicionamento ético em relação ao cuidado de si mesmo, dos outros e do planeta. (BRASIL, 2017, p. 9).

Para o sucesso dessa empreitada, é importante que o estudo da argumentação não fique limitado aos anos finais do Ensino Fundamental ( $8^{\circ}$ e $9^{\circ}$ anos), tampouco ao Ensino Médio. Assim, defende-se que este pode ser desenvolvido desde cedo, por meio de diferentes perspectivas. Como afirmam Dolz e Schneuwly (2004, p. 64), o trabalho com textos na escola deve ocorrer em espiral, ou seja, objetivos semelhantes devem ser "abordados em níveis de complexidade cada vez maiores ao longo da escolaridade". E tal ideia é corroborada pelos documentos oficiais, que apresentam em seu conteúdo, seja direta ou indiretamente, a indicação do trabalho com a argumentação nos diferentes níveis de ensino. 


\section{PERcursos Linguísticos • Vitória (ES) •v. 11 •n. 29 • 2021 • ISSN: 2236-2592 • Dossiê temático $\bullet O$ texto na pesquisa e no ensino: conhecimentos, práticas e desafios na contemporaneidade •}

Contudo, cabe ressaltar que, quando se sugere aqui trabalhar a argumentação desde a fase escolar inicial, não se quer dizer que se deva utilizar, por exemplo, um artigo de opinião ou carta do leitor no $1^{\mathrm{o}}$ ano do Ensino Fundamental. Para além dos gêneros canônicos, a argumentação está presente nos mais variados textos, em diferentes níveis. De acordo com Koch (1998, p. 29), a argumentatividade está inscrita na própria língua, pois, quando se interage por meio da linguagem, há sempre objetivos a serem atingidos: almeja-se estabelecer relações, causar certos efeitos, suscitar comportamentos, ou seja, pretende-se atuar sobre o outro de modo a desencadear determinadas reações. Por isso, para analisar a argumentação produzida na/pela linguagem, é preciso considerar a diversidade e o dinamismo provenientes das mais diversas situações de uso da língua.

Nessa perspectiva, com vistas ao desenvolvimento de um trabalho de leitura e interpretação de textos argumentativos na escola, será apresentada a análise de exemplares que trazem em si um debate de visões opostas, com a proposição de argumentos e contraargumentos sobre o tema "privatização". A análise empreendida aqui pode ser parte de um projeto ou sequência didática, que inclua posteriormente o exercício de construção de argumentos e produção de textos orais e/ou escritos. $\mathrm{O}$ corpus de análise incluirá tirinhas do personagem Armandinho, de Alexandre Beck, e trechos ${ }^{6}$ de um artigo publicado no site da Associação dos Profissionais dos Correios (ADCAP), em que se tenta promover um debate com a sociedade para discutir os argumentos usados pelo governo a favor da privatização da estatal.

A utilização de textos provenientes da esfera midiática também está em consonância com os documentos oficiais que regem o ensino em nosso país, já, que, segundo eles, é importante que os alunos:

[...] incorporem em suas vidas a prática de escuta, leitura e produção de textos pertencentes a gêneros da esfera jornalística em diferentes fontes, veículos e mídias, e desenvolvam autonomia e pensamento crítico para se situar em relação a interesses e posicionamentos diversos. Também estão em jogo a produção de textos noticiosos, opinativos e a participação em discussões e debates de forma ética e respeitosa. (BRASIL, 2017, p. 509)

Observe-se, então, uma sequência de quatro tiras do Armandinho, dispostas na ordem em que foram divulgadas. Os exemplares foram publicados na rede social Facebook, entre 23 e 24 de agosto de 2021, época em que que se intensificou a movimentação do Governo Federal

\footnotetext{
${ }^{6}$ Devido à extensão do presente trabalho, optou-se por utilizar somente trechos do artigo, cotejando o conteúdo com as tiras de Armandinho. O texto integral está disponível em: https://adcap.org.br/index.php/trabalhadoresdos-correios-afirmam-que-argumentos-usados-pelo-governo-a-favor-da-privatizacao-da-estatal-nao-temembasamento/. Último acesso em 27 ago. 2021.
} 
PERcursos Linguísticos • Vitória (ES) •v. 11 •n. 29 • 2021 • ISSN: 2236-2592 • Dossiê temático $\bullet O$ texto na pesquisa e no ensino: conhecimentos, práticas e desafios na contemporaneidade •

para privatizar diversas instituições públicas e mistas, dentre elas os Correios. As tiras estão interligadas entre si e são parte de uma narrativa maior, pois, juntas, contam a mesma história. Nelas, Armandinho e seu amigo Pudim conversam sobre a privatização da "pracinha" onde costumam brincar, apresentando visões opostas sobre o tema.

Nicolau e Magalhães (2013, p. 64) definem as tiras (ou tirinhas) como "uma sequência narrativa em quadrinhos humorística e satírica que utiliza a linguagem verbal e não verbal, transmitindo, em sua grande maioria, uma mensagem de caráter opinativo". Nesse caso, traz em si a visão do cartunista a respeito de determinado assunto, orientando o modo de ver do leitor. Por ser um texto multimodal, que tem seu projeto de dizer semiotizado em diferentes linguagens, a análise começará pela parte visual do texto.

Figura 1 - Tirinhas do Armandinho
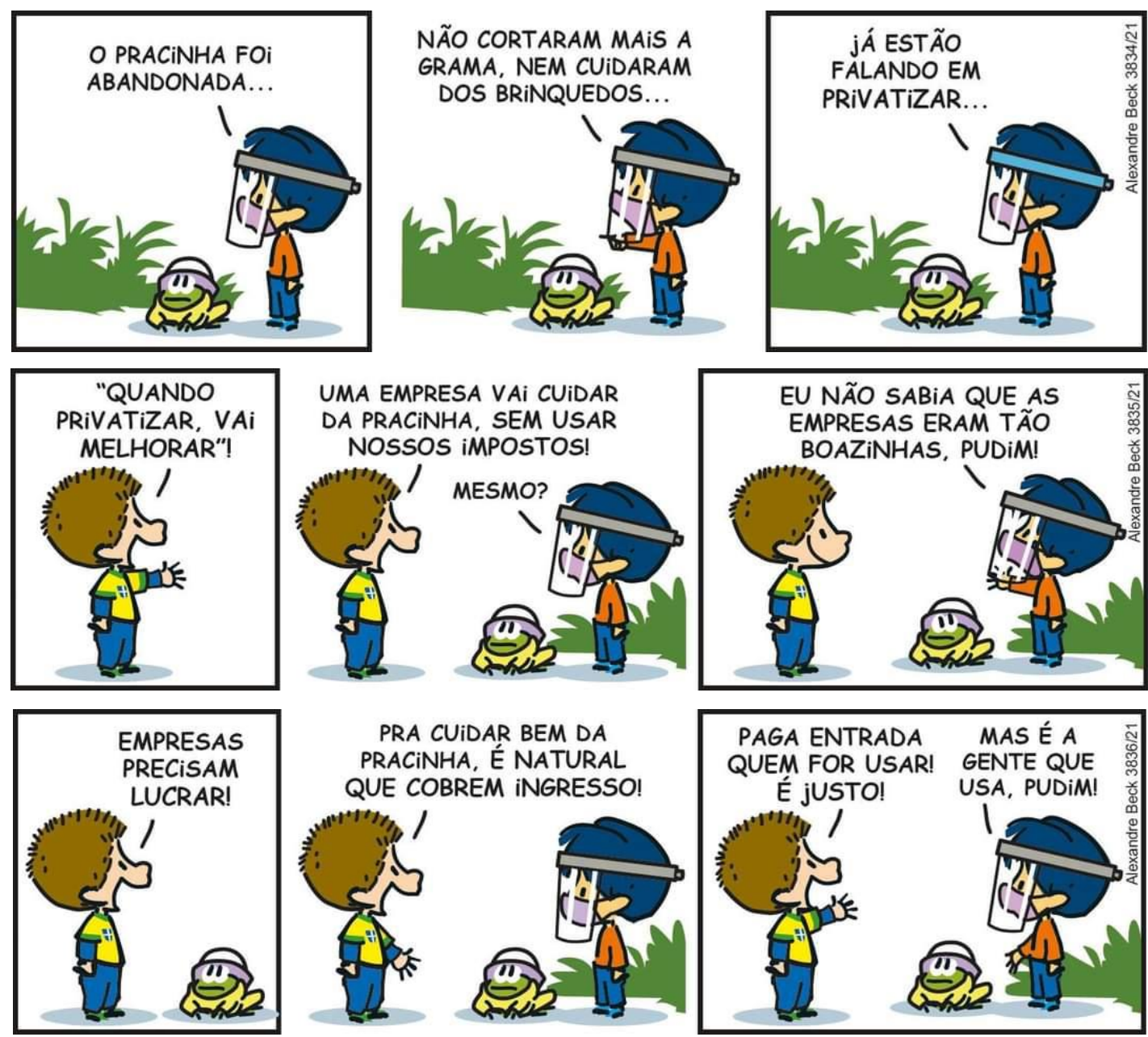


\section{PERcursos Linguísticos • Vitória (ES) •v. 11 •n. 29 • 2021 • ISSN: 2236-2592 • Dossiê temático $\bullet O$ texto na pesquisa e no ensino: conhecimentos, práticas e desafios na contemporaneidade •}
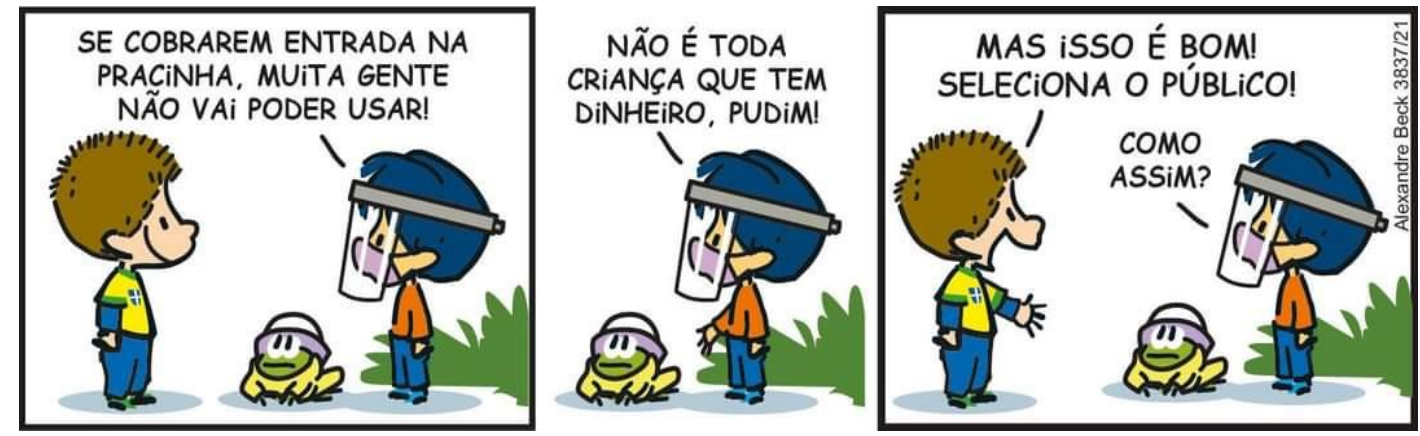

Fonte: BECK, Alexandre. Post em rede social. Florianópolis, SC, agosto, 2021. Facebook. Disponível em: https://www.facebook.com/tirasarmandinho/. Último acesso em: 24 ago. 2021.

Destaca-se, nas imagens, a figura dos personagens que, por suas vestes, já antecipam, de alguma maneira, o posicionamento que irão assumir, revelando a identidade coletiva a que se filiam. Segundo Charaudeau (2016, p. 29), a identidade coletiva tende a ser constantemente defendida, reforçada ou lembrada e, confrontado com a diferença do outro, o grupo tende a diferenciar-se para se afirmar, sentir-se forte (ou até mesmo não ser confundido).

Pudim usa roupas que remetem ao uniforme da seleção brasileira de futebol, adereço do qual os movimentos pró-governo apropriaram-se como símbolo. Além disso, em pleno período de pandemia (2021), o menino está sem máscara, clara alusão aos seguidores do presidente brasileiro, que não defende seu uso ${ }^{7}$. Pudim terá, portanto, um discurso a favor da privatização, já que a posição política do grupo com o qual se identifica é pelo liberalismo, a favor do estado mínimo ${ }^{8}$.

Armandinho, por outro lado, usa máscara e proteção facial (face shield), inclusive em seu sapinho de estimação e, numa visão oposta à do amigo, mostra que se preocupa com a propagação da doença. Apesar de suas roupas não trazerem nenhuma marca específica de grupo político, veremos que seu discurso será contra a privatização. Charaudeau $(2015$, p. 18) afirma que "o pertencimento a um grupo é, em primeiro lugar, o não pertencimento a outro grupo, e a busca do grupo, enquanto entidade coletiva, é igualmente a busca do não outro". No cenário, o

7 Consultar as notícias: "Bolsonaro contraria ciência e diz a apoiadores que eficácia de máscara é 'quase nenhuma", disponível em https://g1.globo.com/politica/noticia/2020/08/19/bolsonaro-contraria-ciencia-e-diz-aapoiadores-que-eficacia-de-mascara-e-quase-nenhuma.ghtml; "Bolsonaro diz que máscaras são 'ficção' e ataca medidas de proteção contra Covid", disponível em https://istoe.com.br/bolsonaro-diz-que-mascaras-sao-ficcao-eataca-medidas-de-protecao-contra-covid/ . Acesso em 23 set. 2021.

${ }^{8}$ Consultar notícia: "Governo anuncia plano para privatizar nove empresas estatais; veja lista", disponível em: https://g1.globo.com/economia/noticia/2019/08/21/governo-anuncia-plano-para-privatizar-nove-empresasestatais.ghtml. Acesso em 23 set. 2021. 


\section{PERcursos Linguísticos • Vitória (ES) •v. 11 •n. 29 • 2021 • ISSN: 2236-2592 • Dossiê temático $\bullet O$ texto na pesquisa e no ensino: conhecimentos, práticas e desafios na contemporaneidade •}

mato alto que cresce ao fundo representa a falta de cuidados com o local, o que reforça a ideia de "abandono".

Agora passemos à parte verbal, pois, afinal, como aponta Charaudeau (2016, p. 10), "é na situação de enunciação que as palavras revelam os pensamentos, as opiniões e as estratégias daquele que as emite". A narrativa se inicia com a contextualização do tema, falando sobre o estado físico da pracinha (qualificação) que, segundo Armandinho, "foi abandonada": "Não cortaram mais a grama, nem cuidaram dos brinquedos". O uso de palavras negativas como "não" e "nem" reforçam a ideia de "abandono". A partir dessa observação, o personagem introduz o tema da privatização: "já estão falando em privatizar...".

Nas tirinhas seguintes, surge Pudim, proferindo argumentos a favor da privatização da pracinha, enquanto Armandinho refuta tais afirmativas, num jogo de argumentação e contraargumentação. Koch e Elias (2017, p. 34) apontam que "toda argumentação é diálogo, porque envolve sujeitos, seus conhecimentos e formas de compreensão da realidade; porque pressupõe liberdade de pensar e expressar o pensamento". Por esse motivo, as autoras reforçam que, no jogo argumentativo, pode não ser suficiente apenas justificar uma tese, mas também “considerar a existência de teses contrárias que podem ser evocadas, citadas, refutadas ou em relação as quais podemos fazer alguma concessão" (KOCH; ELIAS, 2017, p. 34).

Segundo Charaudeau (2008, p. 222), conforme já foi mencionado, dentro do dispositivo argumentativo, por meio de uma proposição, em um quadro de questionamento, coloca-se em causa a proposta (tese), desenvolvendo a argumentação em tal ou qual direção: o sujeito mostrase de acordo (justifica) ou em desacordo com a proposta (refuta). Então, num ato de persuasão, recorre a diversos procedimentos (semânticos, discursivos e de composição) para estabelecer a prova da posição adotada na proposição.

$\mathrm{Na}$ construção da tirinha, o cartunista optou por apresentar as teses a favor da privatização na figura do Pudim e aquelas que as refutam na figura do Armandinho. Dentro do espaço interno ao texto, relativo à interação entre os personagens, tem-se:

- proposta sobre o mundo 1 (implícita): "é preciso privatizar a pracinha";

- sujeito argumentante: Pudim (EUe);

- sujeito-alvo: o Armandinho e os leitores da tirinha, todos idealizados (TUd).

- proposta sobre o mundo 2 (implícita): "Se cobrarem entrada na pracinha, muita gente não vai poder usar! Não é toda criança que tem dinheiro, Pudim!” ( $A$ privatização não é uma coisa boa para todos e prejudica principalmente a parcela pobre da população). 


\section{PERcursos Linguísticos • Vitória (ES) •v. 11 •n. 29 • 2021 • ISSN: 2236-2592 • Dossiê temático $\bullet O$ texto na pesquisa e no ensino: conhecimentos, práticas e desafios na contemporaneidade •}

- sujeito argumentante: Armandinho, dando voz ao cartunista (EUe);

- sujeito-alvo: o Pudim e os leitores da tirinha, todos idealizados (TUd).

Já no espaço externo ao texto, considerando-se sua produção-recepção, tem-se:

- proposta sobre o mundo (implícita): a privatização não é uma coisa boa para todos e prejudica principalmente a parcela pobre da população;

- $\quad$ sujeito argumentante: o cartunista (EUc);

- sujeito-alvo: leitores da tirinha, seres sociais (TUi).

Esquematicamente, em uma visão macrotextual, considerando a tirinha como um todo, pode-se, então, representar a organização dos argumentos por meio do seguinte quadro:

Quadro 1: Argumentos da tirinha

\begin{tabular}{|c|c|}
\hline $\begin{array}{l}\text { Argumentos favoráveis à privatização } \\
\text { (Pudim) }\end{array}$ & $\begin{array}{l}\text { Argumentos contrários à privatização } \\
\text { (Armandinho) }\end{array}$ \\
\hline $\mathrm{XXX}$ & $\begin{array}{l}\text { “A pracinha foi abandonada...” (Há uma } \\
\text { precarização da instituição pública com o intuito de } \\
\text { desqualificá-la e depois vendê-la). }\end{array}$ \\
\hline $\begin{array}{l}\text { “'Quando privatizar, vai melhorar'! Uma empresa vai } \\
\text { cuidar da pracinha, sem usar nossos impostos!” (A } \\
\text { pracinha não é bem cuidada pelo poder público, por } \\
\text { isso é preciso privatizar; impostos são cobrados, mas } \\
\text { não são bem administrados). }\end{array}$ & $\begin{array}{l}\text { “Mesmo? Eu não sabia que as empresas eram tão } \\
\text { boazinhas, pudim!” (As empresas privadas só visam } \\
\text { ao lucro, não fazem nada sem algo em troca). }\end{array}$ \\
\hline $\begin{array}{l}\text { "Empresas precisam lucrar! Pra cuidar da pracinha, é } \\
\text { natural que cobrem ingresso!" (No mundo capitalista, } \\
\text { é assim que funciona: empresas trazem beneficios, } \\
\text { mas precisam lucrar em troca, para valer a pena e } \\
\text { fazerem um bom trabalho). }\end{array}$ & XXX \\
\hline $\begin{array}{c}\text { "Paga entrada quem for usar! É justo!” (Nessa lógica, } \\
\text { só deve usar quem pagar por isso. Quem paga tem } \\
\text { direito aos benefícios). }\end{array}$ & $\begin{array}{c}\text { "Mas é a gente que usa, Pudim! Se cobrarem entrada } \\
\text { na pracinha, muita gente não vai poder usar! Não é } \\
\text { toda criança que tem dinheiro, Pudim!” (Isso vai } \\
\text { restringir o público e prejudicar principalmente os } \\
\text { mais pobres, que não têm condições para custear a } \\
\text { atividade.). }\end{array}$ \\
\hline $\begin{array}{l}\text { "Mas isso é bom! Seleciona o público!" (O fato de } \\
\text { cobrar afastará moradores de rua, assaltantes e } \\
\text { aqueles que depredam o local e que fazem mau uso } \\
\text { dele; somente pessoas "selecionadas" irão usá-lo). }\end{array}$ & $\begin{array}{c}\text { “Como assim?” (Isso aumentará a segregação social } \\
\text { e tirará o benefício dos mais necessitados, que } \\
\text { também têm direito ao lazer). }\end{array}$ \\
\hline
\end{tabular}

Fonte: Criação nossa.

Mesmo que a tirinha direcione a conclusão para a não privatização, o leitor julgará os argumentos que considera mais relevantes e que condizem com a sua ideologia político-social para adotar sua posição. Num movimento dialógico (pois todo texto é lugar de interação), irá concordar, discordar, refletir, reformular. Pensando agora para o nível microtextual, ou seja, para o sentido de língua, que leva ao sentido de discurso, destacam-se, ainda, alguns aspectos. 


\section{PERcursos Linguísticos • Vitória (ES) •v. 11 •n. 29 • 2021 • ISSN: 2236-2592 • Dossiê temático $\bullet O$ texto na pesquisa e no ensino: conhecimentos, práticas e desafios na contemporaneidade •}

A fala de Pudim, em sua primeira aparição, é escrita entre aspas e exemplifica um caso de delocução (discurso relatado). Isso significa que é uma voz coletiva, algo repetido como uma fórmula cristalizada pelo grupo a favor da privatização. Para Charaudeau (2015, p. 26), é por meio da língua que se dá a integração social e que se forja a simbólica identitária; portanto, a língua é necessária à constituição de uma identidade coletiva e garante a coesão de uma comunidade. Além disso, a referência de Armandinho às crianças, indivíduos mais frágeis socialmente, que precisam de proteção e não têm recursos financeiros, pode também ser considerada como simbólica, representando as classes menos abastadas e as minorias.

$\mathrm{Na}$ construção linguística, destacando-se as ideias centrais em debate, a lógica argumentativa se desenvolve nas seguintes relações de causalidade (modos de encadeamento):

1. Consequência: "A pracinha foi abandonada" (A1) $\rightarrow$ logo "estão falando em privatizar" (A2).

2. Causa: "Quando privatizar, vai melhorar" $(\mathrm{A} 1) \rightarrow$ porque "uma empresa vai cuidar da pracinha, sem usar nossos impostos" (A2).

3. Finalidade: "É natural que cobrem ingresso" $\rightarrow$ para "cuidar bem da pracinha".

4. Oposição: "Paga entrada quem for usar! É justo!" (A1 - Armandinho) $\rightarrow$ mas “não é toda criança que tem dinheiro" (A2 - Pudim).

5. Restrição: "Muita gente não vai poder usar" (A1 - Armandinho) $\rightarrow$ mas isso é bom que "seleciona o público" (A2 - Pudim).

Numa gradação de argumentos, considerando-se as relações de causalidade visíveis, pode-se afirmar que os argumentos contra a privatização têm mais peso. Tal ideia se confirma ao considerar que essa é a posição defendida pelo personagem principal da tira, conhecido por sua visão crítica e social, comparado por muitos, com a Mafalda de Quino. Contudo, cabe destacar que a relação de causalidade em seus diferentes modos de encadeamento nunca é puramente formal, visível na superfície textual (CHARAUDEAU, 2009, p. 211). A causalidade pode estar no implícito; depende tanto do conteúdo semântico e das relações de sentido que se estabelecem entre as asserções, quanto das condições lógicas que caracterizam tal relação.

Em seguida, em um movimento comparativo, serão apresentados fragmentos de um artigo sobre o mesmo tema. "Trabalhadores dos Correios afirmam que argumentos usados pelo governo a favor da privatização da estatal não têm embasamento"9 é um texto que versa especificamente sobre a privatização dos Correios, que pretende, como diz o subtítulo abaixo

\footnotetext{
${ }^{9} \mathrm{O}$ texto integral está disponível em: https://adcap.org.br/index.php/trabalhadores-dos-correios-afirmam-queargumentos-usados-pelo-governo-a-favor-da-privatizacao-da-estatal-nao-tem-embasamento/. Último acesso em 27 ago. 2021.
} 


\section{PERcursos Linguísticos • Vitória (ES) •v. 11 •n. 29 • 2021 • ISSN: 2236-2592 • Dossiê temático $\bullet O$ texto na pesquisa e no ensino: conhecimentos, práticas e desafios na contemporaneidade •}

do título, "promover um debate com a sociedade para discutir o tema". O texto é de grande extensão e tem várias estratégias argumentativas em si. Contudo, devido ao espaço determinado para este trabalho, destacam-se apenas os trechos que, de alguma maneira, têm afinidade com as tirinhas analisadas.

Sem um autor definido, o texto mostra-se como uma "voz coletiva" daqueles que têm "conhecimento de causa", pois foi publicado no site da Associação dos Profissionais dos Correios (ADCAP). Ou seja, o fato de representar os profissionais que trabalham na instituição já se interpõe como um "discurso de autoridade" (estratégia de legitimação). O artigo tem como objetivo principal, conforme diz o título, elencar alguns dos argumentos usados pelo governo a favor da privatização da estatal e refutá-los, apresentando contra-argumentos. Em seus parágrafos iniciais, além de contextualizar o tema (1), justifica a abordagem do assunto (2) e apresenta a tese principal (3) a ser defendida ao longo do texto:

(1) Num momento em que a privatização parece voltar ser uma das maiores bandeiras defendidas por esse novo governo e os Correios voltaram ao noticiário através de declarações sobre a intenção de privatizar a estatal, (2) um debate mais aprofundado sobre o tema se faz extremamente necessário para que sejam esclarecidos os argumentos utilizados para justificar tal feito. Em meio a tantas versões sobre as razões para a privatização dos Correios, é de essencial importância que se esclareçam as verdades sobre alguns argumentos sem embasamento concreto que vêm sido utilizados por quem se coloca a favor da privatização da estatal. [...] (3) os Correios possuem características e qualidades que justificam plenamente sua manutenção como organização pública, diferentemente de muitas outras.

Contudo, apesar de a tese principal defender a manutenção dos Correios enquanto estatal, em um recurso de modalização ${ }^{10}$, para "proteger sua face”, o texto não inclui as outras instituições públicas em seu discurso, quando diz que "os Correios possuem características e qualidades que justificam plenamente sua manutenção como organização pública, diferentemente de muitas outras".

Quanto à construção de argumentos, percebe-se semelhanças entre o que se diz em sentido favorável e contrário à privatização nos dois gêneros apresentados, revelando que algumas afirmações já estão arraigadas no discurso dos grupos a favor da privatização e fazem parte de seu imaginário. O principal argumento utilizado é o de que "Quando privatizar, vai melhorar" (lembrando que, na tirinha, a fala de Pudim está entre aspas, representando uma voz

\footnotetext{
${ }^{10}$ Segundo Charaudeau (1992, p. 571-3), a modalização é parte do fenômeno linguístico da enunciação, que indica a posição assumida pelo locutor e pelo interlocutor no ato de linguagem e revela uma intenção de comunicação, dependendo da situação. Longe de ser uma categoria puramente formal, a modalização é uma construção conceitual e, para o autor, pode encontrar-se no implícito do discurso.
} 


\title{
PERcursos Linguísticos • Vitória (ES) •v. 11 •n. 29 • 2021 • ISSN: 2236-2592 • Dossiê temático $\bullet O$ texto na pesquisa e no ensino: conhecimentos, práticas e desafios na contemporaneidade •
}

coletiva). No artigo da ADCAP, encontram-se as seguintes afirmações acerca da posição do governo:

\begin{abstract}
Tarifas foram congeladas sem necessidade, dividendos foram retirados em excesso, gerando, assim, um enorme desequilíbrio econômico que afetou a estatal. Deste modo, decisões de gestões anteriores no Governo Federal, aliadas à onda do neoliberalismo que acomete o atual governo, o que se apresenta agora como solução é a privatização dos Correios. (Parágrafos 2-3)

[...] [O] governo prega que as privatizações seriam mais uma das soluções para a economia do país. [...] "Autoridades do governo se utilizam de falácias para sustentar uma narrativa de uma empresa falida, ineficiente, corrupta, deficitária, quando a realidade é justamente outra, bem diferente do que está sendo propalado, demonstrando, no mínimo, total desconhecimento da empresa, de seu negócio, de sua capacidade, de seu faturamento. (Parágrafo 6)

A busca incessante em se desfazer de empresas estatais marginaliza a busca por dados de efetividade concretos e exclui do debate público novos modelos de gestão para a empresa prosperar. (Parágrafo 7)
\end{abstract}

Na tira, a fala de Pudim, portanto, ecoa as falas daqueles que fazem parte de seu grupo, com a mesma identidade coletiva. O trecho "[a]utoridades do governo se utilizam de falácias para sustentar uma narrativa de uma empresa falida, ineficiente, corrupta, deficitária" resume todos os argumentos utilizados pelos grupos liberais para justificar a privatização da estatal. Desse modo, o artigo procura, por meio de argumentos sólidos, desfazer o que eles chamam de "argumentos sem embasamento" e "falácias"11".

Os argumentos utilizados pela Associação assemelham-se àqueles utilizados por Armandinho, sendo que, no artigo, fala-se especificamente da estatal. No quadro 2, é possível comparar os contra-argumentos utilizados na tirinha e no artigo para refutar o discurso da privatização e perceber a semelhança de ideias: a instituição é precarizada pelo governo com o intuito de privatizá-la; as empresas privadas têm interesse na privatização visando somente ao lucro; a privatização restringe o público e privilegia os mais favorecidos; a privatização aumenta a segregação social e tira o benefício dos mais necessitados.

Quadro 2: Comparação de argumentos contrários à privatização

\begin{tabular}{|c|l|}
\hline Tirinha (Armandinho) & \multicolumn{1}{c|}{ Artigo (Correios/ADCAP) } \\
\hline $\begin{array}{c}\text { "A pracinha foi abandonada..." (Há } \\
\text { uma precarização da instituição } \\
\text { pública com o intuito de desqualificá- } \\
\text { la e depois vendê-la). }\end{array}$ & $\begin{array}{l}\text { Tarifas foram congeladas sem necessidade, dividendos foram } \\
\text { retirados em excesso, gerando, assim, um enorme desequilíbrio } \\
\text { econômico que afetou a estatal. (Parágrafo 2). } \\
\text { "O que sofremos hoje é por conta do contingenciamento, o que } \\
\text { prejudicou demais a imagem da empresa, já que perdemos pessoal } \\
\text { qualificado e investimentos deixaram de ser feitos" (Parágrafo 12). }\end{array}$ \\
\hline
\end{tabular}

\footnotetext{
${ }^{11}$ Plantin (2008, p. 120) define falácias como "um discurso viciado e vicioso, que se parece com um raciocínio válido: joga-se com o sentido das palavras, toma-se o efeito pela causa, responde-se bem a uma pergunta, mas não à pergunta feita, a conclusão só faz reformular as premissas etc.”.
} 


\section{PERcursos Linguísticos • Vitória (ES) •v. 11 •n. 29 • 2021 • ISSN: 2236-2592 • Dossiê temático $\bullet O$ texto na pesquisa e no ensino: conhecimentos, práticas e desafios na contemporaneidade •}

\begin{tabular}{|c|c|}
\hline $\begin{array}{c}\text { "Mesmo? Eu não sabia que as } \\
\text { empresas eram tão boazinhas, pudim!" } \\
\text { (As empresas privadas só visam ao } \\
\text { lucro, não fazem nada sem algo em } \\
\text { troca). }\end{array}$ & $\begin{array}{l}\text { O fato é que o interesse de grupos privados é apenas por agências } \\
\text { que abrangem capitais ou grandes municípios, que apresentam } \\
\text { serviços superavitários, deixando de lado as agências localizadas em } \\
\text { cidades onde a atividade não é lucrativa. Mais uma vez cabe lembrar } \\
\text { que essas localidades são atendidas exclusivamente pelos Correios e, } \\
\text { o mais importante, sem aporte de recursos da União. (Parágrafo 16) }\end{array}$ \\
\hline $\begin{array}{l}\text { "Mas é a gente que usa, Pudim! Se } \\
\text { cobrarem entrada na pracinha, muita } \\
\text { gente não vai poder usar! Não é toda } \\
\text { criança que tem dinheiro, Pudim!” } \\
\text { (Isso vai restringir o público e } \\
\text { prejudicar principalmente os mais } \\
\text { pobres, que não têm condições para } \\
\text { custear a atividade.). }\end{array}$ & $\begin{array}{l}\text { Caso a empresa venha mesmo a ser privatizada, a tendência é que o } \\
\text { custo do serviço postal aumente (Parágrafo12). Mais uma vez, cabe } \\
\text { lembrar que, para várias pessoas, os Correios são a única alternativa } \\
\text { para envio de documentos, encomendas e recebimento de contas. } \\
\text { Devido ao seu alcance, os Correios ajudam na prestação de serviços } \\
\text { financeiros e na inclusão bancária de milhões de brasileiros que } \\
\text { vivem em localidades carentes e que não precisam mais se deslocar } \\
\text { a cidades vizinhas para fazer operações bancárias. (Parágrafo 14) }\end{array}$ \\
\hline $\begin{array}{c}\text { "Como assim?" (Isso aumentará a } \\
\text { segregação social e tirará o benefício } \\
\text { dos mais necessitados, que também têm } \\
\text { direito ao lazer). }\end{array}$ & $\begin{array}{l}\text { No caso de privatização, Jaílson Pereira, presidente da AACB } \\
\text { (Associação dos Analistas de Correios do Brasil), acredita que de } \\
\text { imediato o país viveria um apagão postal. "O brasileiro no geral não } \\
\text { tem conhecimento de que os Correios são a única empresa que está } \\
\text { nos mais de } 5500 \text { municípios do país. Será que se privatizarem os } \\
\text { Correios vão manter o trabalho nas agências de pequeno porte, nas } \\
\text { cidades remotas, que não dão lucro?" (Parágrafo 17) }\end{array}$ \\
\hline
\end{tabular}

Fonte: Criação nossa.

Como conclusão, retomando a tese de que "os Correios possuem características e qualidades que justificam plenamente sua manutenção como organização pública”, o artigo reforça que:

Os Correios, com sua infraestrutura pronta e plenamente operacional, constituem uma plataforma de logística, de comunicações e de atendimento importante para a vida dos cidadãos, das empresas e dos governos. (Parágrafo 22)

Cuidar bem dessa infraestrutura, potencializando sua utilização em benefício dos brasileiros, é uma missão relevante para o Governo Federal, que deve enxergar os Correios como uma peça fundamental para o desenvolvimento de um país como o Brasil, à sua disposição, em todo o território nacional. (Parágrafo 23)

Esses são apenas alguns dos aspectos que podem ser observados em uma análise linguístico-discursiva, que considera o texto em seus diferentes gêneros, materializações e situações de uso. Enfim, as estratégias argumentativas discutidas até aqui podem ser facilmente abordadas em sala de aula, levando os alunos a refletirem sobre a construção textual e a perceberem que, conforme aponta Fiorin (2016, p. 9),

Se a sociedade é dividida em grupos sociais, com interesses divergentes, então os discursos sempre são o espaço privilegiado de luta entre vozes sociais, o que significa que são precipuamente o lugar da contradição, ou seja, da argumentação, pois a base de toda a dialética é a exposição de uma tese e sua refutação.

Ressalta-se, portanto, a importância de se desenvolver um trabalho com o texto que considere a diversidade de conhecimentos dos sujeitos e da situação comunicativo-interacional. 


\title{
PERcursos Linguísticos • Vitória (ES) •v. 11 •n. 29 • 2021 • ISSN: 2236-2592 • Dossiê temático $\bullet O$ texto na pesquisa e no ensino: conhecimentos, práticas e desafios na contemporaneidade •
}

\section{Aprender a argumentar, aprender a conviver: o texto na sala de aula para o exercício da cidadania (ou Considerações finais)}

\begin{abstract}
Os jovens têm se engajado cada vez mais como protagonistas da cultura digital, envolvendo-se diretamente em novas formas de interação multimidiática $e$ multimodal e de atuação social em rede, que se realizam de modo cada vez mais ágil. Por sua vez, essa cultura também apresenta forte apelo emocional e induz ao imediatismo de respostas e à efemeridade das informações, privilegiando análises superficiais e o uso de imagens e formas de expressão mais sintéticas, diferentes dos modos de dizer e argumentar característicos da vida escolar. Todo esse quadro impõe à escola desafios ao cumprimento do seu papel em relação à formação das novas gerações.
\end{abstract}

BNCC (BRASIL, 2017, p. 61)

Geraldi (1995, p.135), em seu clássico livro Portos de passagem, já apontava que o texto deveria ser o "ponto de partida (e ponto de chegada) de todo o processo ensino/aprendizagem da língua", já que é nele que a língua (objeto de estudos) se revela em sua totalidade. Além disso, é consenso entre professores e pesquisadores que o texto deve ser considerado preferencialmente em seu contexto real de produção, para que sejam percebidas todas as nuances da construção da significação. Retomando os pressupostos da Semiolinguística, na compreensão de um texto, é preciso ir além do sentido de língua (superfície linguística), observando-se o contrato de comunicação, as estratégias utilizadas e os imaginários envolvidos para que se alcance o sentido de discurso, por meio das inferências.

$\mathrm{Na}$ sociedade atual, principalmente no país polarizado no qual vivemos, em que as pessoas - alimentadas por uma avalanche de informações "fast-food" veiculadas pelas redes sociais - têm dificuldade de discernir o que é fato e opinião, ciência e senso comum, o jogo argumentativo ganha novos contornos. O debate público tem sido cada vez mais explorado, nem sempre de forma racional, em que as partes expressam seus argumentos de modo a defender sua tese. Na maior parte das vezes, principalmente em temas polêmicos, os lados, de forma irredutível, inflamam-se ao defender sua ideologia, buscando atingir um terceiro que venha a aderir a sua tese e somar-se ao grupo. Vivemos tempos difíceis, em que a argumentação por vezes se transforma em insultos e acusações, desqualificando o outro.

Se queremos um país mais democrático e um mundo melhor, temos de começar aprendendo a ouvir o outro e a respeitá-lo, mesmo que discordemos de seus argumentos. O debate pressupõe dois lados que apresentam suas ideias, em busca de um consenso e uma solução comum, e não uma via de mão única em que só um extremo tem razão. Por isso, o ensino de argumentação na escola torna-se cada vez mais urgente e necessário, não somente com o objetivo de preparar os alunos para provas de acesso ao nível superior, mas também de 


\section{PERcursos Linguísticos • Vitória (ES) •v. 11 •n. 29 • 2021 • ISSN: 2236-2592 • Dossiê temático $\bullet O$ texto na pesquisa e no ensino: conhecimentos, práticas e desafios na contemporaneidade •}

instrumentalizá-los para saber expressar suas opiniões respeitosamente e, além de tudo, não serem facilmente manipulados por informações de fonte duvidosa ou discursos passionais. Para isso, é preciso levar para a sala de aula uma diferente gama de gêneros argumentativos, para além dos canônicos, visando à formação de cidadãos críticos, conscientes de suas ações na vida em sociedade.

\section{Referências}

BRASIL. Ministério da Educação. Secretaria da Educação Básica. Base Nacional Comum Curricular. Brasília, DF: MEC, 2017.

DEMO, Pedro. O educador e a prática da pesquisa. Ribeirão Preto: Editora Alphabeto, 2009.

DOLZ, Joaquim; SCHNEUWLY, Bernard. Gêneros orais e escritos na escola. Campinas, SP: Mercado das Letras, 2004.

CAVALCANTE, Mônica et al. Linguística Textual e argumentação. São Paulo: Pontes, 2020.

CHARAUDEAU, Patrick. Grammaire du sens et de l'expression. Paris, Hachette, 1992.

CHARAUDEAU, Patrick. Discurso das mídias. Trad. Angela M. S. Corrêa. São Paulo: Contexto, 2006a.

CHARAUDEAU, Patrick. Discurso político. Trad. Angela M. S. Corrêa. São Paulo: Contexto, 2006b.

CHARAUDEAU, Patrick. Linguagem e discurso: modos de organização. São Paulo: contexto, 2008.

CHARAUDEAU, Patrick. Identidade social e identidade discursiva: o fundamento da competência comunicacional. In: PIETROLUONGO, Márcia (Org.). O trabalho da tradução. Rio de Janeiro: Contra Capa, 2009, p. 309-326.

CHARAUDEAU, Patrick. Identidade linguística, identidade cultural: uma relação paradoxal. In: LARA, Glaucia Proença.; LIMBERTI, Rita Pacheco. (Orgs.). Discurso e (Des)igualdade social. São Paulo: Contexto, 2015. p. 13-29.

CHARAUDEAU, Patrick. A conquista da opinião pública: como o discurso manipula as escolhas públicas. Trad. Angela M. S. Corrêa. São Paulo: Contexto, 2016.

CHARAUDEAU, Patrick. Compréhension et interpretation: interrogations autour de deux modes d'appréhension du sens dans les sciences du langage. In: ACHARD-BAYLE, Guy; GUÉRIN, Maximilen; KLEIBER; Georges; KRYLYCHIN, Marina. (Org.). Les sciences du langage et la question de l'interprétation (aujourd'hui). Limoges: Les Éditions Lambert-Lucas, 2018, p.21-55.

FIORIN, José Luiz. Argumentação. São Paulo: Contexto, 2016. 
PERcursos Linguísticos • Vitória (ES) •v. 11 •n. 29 • 2021 • ISSN: 2236-2592 • Dossiê

temático $\bullet O$ texto na pesquisa e no ensino: conhecimentos, práticas e desafios na contemporaneidade •

GERALDI, João Wanderley. Portos de passagem. São Paulo: Martins Fontes, 1995.

KOCH, Ingedore Villaça G. A inter-ação pela linguagem. 4. ed. São Paulo: Cortez, 1998.

KOCH, Ingedore Villaça G; ELIAS, Vanda Maria. Escrever e argumentar. São Paulo: Contexto, 2017.

MENEZES, William Augusto. Estratégias discursivas e argumentação. In: LARA, Glaucia Muniz Proença (Org.). Lingua(gem), texto e discurso: entre a reflexão e a prática. Rio de Janeiro: Lucerna; Belo Horizonte, MG: FALE/UFMG, 2006.

NICOLAU, Vitor; MAGALHÃES, Henrique. As tirinhas e a cultura da convergência: um estudo sobre a adaptação deste gênero dos quadrinhos às novas mídias. In: LUIZ, Lucio (Org.). Os quadrinhos na era digital: HQtrônicas, webcomics e cultura participativa. Nova Iguaçu, RJ: Marsupial, 2013.

PERELMAN, Chaïm; OLBRECHTS-TYTECA, Lucie. Tratado da argumentação: a nova retórica. 2. ed. São Paulo: Martins Fontes, 2005.

PLANTIN, Christian. A argumentação: história, teorias, perspectivas. Trad. Marcos Macionilo. São Paulo: Parábola, 2008.

REBELLO, Ilana da Silva. A Semiolinguística vai para a escola. In: XAVIER, Glayci; REBELLO, Ilana; MONNERAT, Rosane (Orgs.) Semiolinguística aplicada ao ensino. São Paulo: Contexto, 2021. 


\title{
RETEXTUALIZAÇÃO E PRINCÍPIOS DE TEXTUALIDADE: ESTRATÉGIAS PARA O APRIMORAMENTO DA ESCRITA ACADÊMICA
}

\section{RETEXTUALIZATION AND PRINCIPLES OF TEXTUALITY: STRATEGIES FOR ACADEMIC WRITING IMPROVEMENT}

\author{
Andréa Pisan Soares Aguiar ${ }^{1}$ \\ Sueli Cristina Marquesi ${ }^{2}$
}

\begin{abstract}
Resumo: Neste trabalho, nosso interesse é pensar a escrita acadêmica no âmbito da graduação. Mais especificamente, nosso objetivo é verificar como a retextualização e os princípios de textualidade podem constituir estratégias para o aprimoramento da escrita de textos acadêmicos. A título de exemplificação, recorremos a dois textos, versão A e versão B, produzidos pelo mesmo grupo de alunos de $2^{\circ}$ semestre de um curso de Direito. Observamos que a atividade de escrita, fundamentada no processo de retextualização e nos princípios de textualidade, propiciou um momento de reflexão sobre o próprio ato de escrever, que integra múltiplas etapas, sem as quais não se alcança o aprimoramento textual esperado.
\end{abstract}

Palavras-chave: Escrita acadêmica. Retextualização. Princípios de textualidade. Reescrita. Revisão.

Abstract: In this paper, our interest is to think about academic writing within the scope of graduation. More specifically, our objective is to verify how retextualization and principles of textuality can be strategies for the improvement of the writing of academic texts. We present two texts as exemples, the version $\mathrm{A}$ and the version $\mathrm{B}$, produced by the same group of students from the 2 nd semester of a Law course. We observed that the writing activity, based on the retextualization process and on the principles of textuality, provided a moment of reflection on the act of writing, which integrates multiple steps without which the expected textual improvement is not achieved.

Keywords: Academic writing. Retextualization. Principles of textuality. Re-writing. Revision.

\section{Introdução}

Ao ingressarem na universidade, os estudantes se veem diante da necessidade de elaborarem variados gêneros textuais, como resumos, fichamentos, resenhas e artigos.

\footnotetext{
${ }^{1}$ Pós-doutoranda na Pontifícia Universidade Católica de São Paulo - PUC-SP; bolsista PNPD/Capes. E-mail: andreapisan@uol.com.br.

2 Professora titular da Pontifícia Universidade Católica de São Paulo - PUC-SP. E-mail: suelimarquesi.sm@gmail.com.
} 


\section{PERcursos Linguísticos • Vitória (ES) •v. 11 •n. 29 • 2021 • ISSN: 2236-2592 • Dossiê temático $\bullet O$ texto na pesquisa e no ensino: conhecimentos, práticas e desafios na contemporaneidade •}

Contudo, nem sempre o conhecimento que trazem é suficiente para produzirem textos em que sejam observados, por exemplo, os propósitos comunicativos e a estrutura composicional de gêneros que circulam na esfera acadêmica, o que pode levá-los a enfrentar dificuldades.

Tendo em vista essa constatação, estabelecemos a seguinte pergunta de pesquisa: que estratégias podem ser utilizadas para que o estudante aprimore seus textos e seja bemsucedido na esfera comunicativa acadêmica? De modo a respondermos a essa questão, temos como objetivo, neste trabalho, verificar como a retextualização e os princípios de textualidade podem constituir estratégias para o aprimoramento da escrita de textos acadêmicos.

A fim de alcançarmos esse objetivo e respondermos à pergunta apresentada, dividimos este artigo em quatro seções, além desta Introdução, das Considerações Finais e das Referências. Na primeira seção, abordamos a escrita acadêmica como uma prática que requer continuidade para que possa ser aprimorada; na seção seguinte, tratamos da retextualização, com base nos estudos realizados por Travaglia (2003) e por Marcuschi (2007); na terceira seção, discorremos sobre os princípios de textualidade, fundamentados em Beaugrande e Dressler (1981) e em Beaugrande (1997), por fim, na última seção, procedemos à análise das versões A e B produzidas por alunos graduandos de $2^{\circ}$ semestre de Direito, como atividade inicial de elaboração de um projeto de iniciação científica.

\section{Escrita acadêmica}

A escrita é uma atividade que requer prática continuada e exige do indivíduo esforço e tempo para se dedicar a seu aprimoramento. Assim, não se trata de uma ação mecânica, como se pode supor, resumida ao ato de dispor as palavras umas após as outras. Nessa direção, Pinto $(2018$, p. 16) observa que dificilmente uma pessoa redige "logo à primeira tentativa [...] trabalhos académicos que sejam publicados imediatamente sem quaisquer recomendações. Para se alcançar esse estágio, todo um percurso tem de ser calcorreado e, quase sempre, com muita perseverança", perspectiva que reforça a ideia de que a escrita, em especial no âmbito acadêmico, requer exercício frequente.

Becker (2015), ao refletir sobre a percepção de seus alunos de que "bons escritores [...] já conseguiam redigir tudo certo na primeira vez" (p. 27), esclarece que para aqueles cuja escrita faz parte do cotidiano profissional, reescrever um texto várias vezes antes de 


\section{PERcursos Linguísticos • Vitória (ES) •v. 11 •n. 29 • 2021 • ISSN: 2236-2592 • Dossiê temático $\bullet O$ texto na pesquisa e no ensino: conhecimentos, práticas e desafios na contemporaneidade •}

considerá-lo terminado é algo habitual, o que surpreendeu seus alunos. Nem todos os estudantes de pós-graduação têm ideia de que é preciso revisar e reescrever qualquer texto produzido no âmbito acadêmico; para eles, o aluno "realmente inteligente faz o trabalho de uma vez, da melhor maneira que é possível" (BECKER, 2015, p. 72). Embora tais constatações observadas pelo autor tenham se originado no âmbito de pós-graduação, a ideia de que escrever é um ofício que não impõe dificuldade é compartilhada também por alunos da graduação, que o entendem, geralmente, como uma ação de etapa única, que dispensa revisões e reescritas para que se alcance o aprimoramento textual desejado.

No contexto acadêmico, em que circulam gêneros específicos, como artigos, dissertações, teses, resenhas, projetos de iniciação científica, entre outros, fica mais evidente que a escrita não se faz apenas por meio da colocação de palavras no espaço em branco do papel; é preciso que ela se mostre contextualizada, acurada, coerente e organizada, que não deixe margem para que o leitor faça interpretações equivocadas ou que lhe seja exigido esforço demasiado para que efetive a construção do sentido.

Desse modo, a escrita e, em especial, a escrita acadêmica, mostra-se uma atividade complexa que comporta uma ampla gama de tarefas, por exemplo, verificar o uso adequado de recursos sintáticos e lexicais, corrigir inadequações de vocabulário, de ortografia e de pontuação; verificar a inteligibilidade do texto, sua estrutura, a articulação lógica das ideias, a precisão dos enunciados e a adequação ao leitor; uniformizar o texto, aplicar regras e convenções em relação à formatação, todas ocorrem, como ressaltam Aguiar e Marquesi (2019), ao longo do continuum revisão e reescrita, as quais se dão durante todo o processo de escrita.

\section{Estudos sobre retextualização}

O termo retextualização foi proposto por Neusa Travaglia na década de 1990, na sua tese de doutorado sobre tradução. Para a autora, retextualização, ou re-enunciação, é o processo de tradução de uma língua para outra, pois o "tradutor recoloca em texto numa outra língua a reconstrução de um sentido que faz a partir de uma textualização anterior" (TRAVAGLIA, 2003, p. 63, grifo no original). Tal abordagem evidencia que, no processo tradutório, são acionados

todos os elementos que conferem textualidade a um texto e que foram acionados pelo produtor do texto original, com a diferença de que, manejando uma outra 


\section{PERcursos Linguísticos • Vitória (ES) •v. 11 •n. 29 • 2021 • ISSN: 2236-2592 • Dossiê temático $\bullet O$ texto na pesquisa e no ensino: conhecimentos, práticas e desafios na contemporaneidade •}

língua, o tradutor estaria de certa forma manejando outros elementos ou até os
mesmos elementos sob perspectivas diferentes (TRAVAGLIA, 2003, p. 63).

Essa concepção tem como base a noção de que cada tradução é um evento singular, tendo em vista que cada texto é único, ou seja, tem como foco um texto específico, o que resulta em um produto textual também de natureza individual e particularizada. Nesse sentido, a estudiosa propõe "uma abordagem da atividade tradutória mais diretamente pelo lado textual" (p. 61), em que a intenção comunicativa se concretiza verbalmente em uma forma linguística conforme aspectos relacionados a tempo, contexto, situação e objetivo, formando um todo dotado de sentido. Dessa forma, a intenção comunicativa é textualizada, colocada na forma de texto, motivada por algo que se quer comunicar (TRAVAGLIA, 2003, p. 63).

No entendimento de Travaglia, o processo de retextualização colocado no centro do ato tradutório confere mais abrangência a este último em relação a seus mecanismos do que se considerada a tradução apenas como recodificação, caso em que a língua é vista como código fixo e imutável, e não como um sistema de interação que comporta instabilidades, próprias da natureza da linguagem.

Apoiada em Dahlet (1991, p. 180 e ss.), Travaglia observa que a produção textual engloba três operações: o planejamento, a textualização, que se refere à produção textual propriamente dita, e a revisão, esta que comporta "operações de volta crítica ao texto e de adequação definitiva com a finalidade de reduzir falhas e apresentar a versão que o autor julga satisfatória" (p. 63), o que nos remete à atividade de revisão como parte de um processo contínuo de aprimoramento textual que engloba também a escrita e a reescrita (AGUIAR; MARQUESI, 2019; PINTO, 2017), como já pontuamos.

Marcuschi (2007) retoma o termo retextualização para aplicá-lo ao que também considera "tradução", mas de uma modalidade textual para outra: do texto falado para texto escrito, em uma mesma língua. $\mathrm{O}$ autor ressalta que retextualizar não se trata de uma ação mecânica, uma vez que envolve várias operações complexas "que interferem tanto no código como no sentido e evidenciam uma série de aspectos nem sempre bem-compreendidos da relação oralidade-escrita" (p. 46).

Outra observação importante da parte do autor é que a retextualização de uma modalidade a outra não diz respeito a transformar um texto "descontrolado e caótico", o texto oral, em um texto "controlado e bem-formado", o texto escrito. O processo de transformar um texto da modalidade escrita para a modalidade oral sempre acarreta interferências mais ou 


\section{PERcursos Linguísticos • Vitória (ES) •v. 11 •n. 29 • 2021 • ISSN: 2236-2592 • Dossiê temático $\bullet O$ texto na pesquisa e no ensino: conhecimentos, práticas e desafios na contemporaneidade •}

menos profundas no texto, conforme o que se pretende, mas não em razão de a fala ser desorganizada; o que ocorre é "a passagem de uma ordem para outra ordem" (MARCUSCHI, 2007, p. 47).

A ação de retextualizar é um evento linguístico rotineiro, presente no nosso cotidiano: sempre que repetimos ou relatamos o que o outro disse, ou mesmo quando fazemos uso do recurso da paráfrase, por exemplo, transformamos, reformulamos, recriamos e modificamos um enunciado, que resulta em um novo dizer. Marcuschi (2007) esclarece que as operações concernentes à retextualização seguem estratégias variadas, o que evidencia sua complexidade. Embora a preocupação central do estudioso seja a passagem da modalidade oral para a modalidade escrita, e vice-versa, ressalta que é possível a retextualização de textos escritos, em que também é observada a utilização de determinadas estratégias.

Em estudos que tratam da escrita e da reescrita de textos no ensino médio e na pósgraduação, respectivamente, Marquesi $(2011 ; 2010)$ aborda o princípio da retextualização para o texto escrito e, ao fazê-lo, afirma que escrita e reescrita requerem produtores textuais criativos em relação não só à exposição de ideias, mas também em relação à defesa do ponto de vista a elas relacionado. Para a autora, a existência desse produtor pressupõe um leitor que seja capaz de, com base nas leituras realizadas, incluindo as do próprio texto, construir sentidos e produzir um texto com originalidade e criticidade, o que, entendemos, aplica-se também a alunos da graduação, que enfocamos neste trabalho.

\section{Princípios de textualidade}

Os princípios de textualidade foram propostos por Beaugrande e Dressler, em 1981, na obra Introduction to text linguistics. Nela, denominaram tais princípios de critérios, ou padrões, a saber: coerência e coesão, intencionalidade, aceitabilidade, informatividade, situcionalidade e intertextualidade. Posteriormente, em 1997, em New foundations for a science of text and discourse, Beaugrande revisou os sete critérios propostos e, então, os denominou de princípios. Diferentemente de 1981, quando, juntamente com Dressler, definiu o texto como uma "ocorrência comunicativa" (BEAUGRANDE; DRESSLER, 1981, s.p.), Beaugrande considerou o texto segundo uma visão fundamentada não apenas no aspecto linguístico, mas também nos aspectos social e cognitivo. 


\section{PERcursos Linguísticos • Vitória (ES) •v. 11 •n. 29 • 2021 • ISSN: 2236-2592 • Dossiê temático $\bullet O$ texto na pesquisa e no ensino: conhecimentos, práticas e desafios na contemporaneidade •}

De acordo com essa concepção, o texto não é uma virtualidade, mas uma realidade, pois não se trata somente de um sistema formal, mas também de uma realização linguística em que os usuários da língua compartilham conhecimentos sobre o mundo e sobre a sociedade para, assim, construírem os sentidos necessários à compreensão do texto. Temos, assim, a articulação entre autor, leitor, texto e contexto.

A conjunção de aspectos linguísticos, sociais e cognitivos na produção de um texto envolve, segundo o autor, os sete princípios de textualidade, os quais representam "as mais importantes formas de conectividade" (BEAUGRANDE, 1997, s.p.) entre um texto e o conhecimento de mundo e da sociedade que o usuário da língua possui. Como lembra Marcuschi (2008), trata-se de princípios que convergem para a construção de sentidos mais do que princípios que orientam a boa formação textual.

Assim como defendeu em Beaugrande e Dressler (1981), Beaugrande (1997) destaca que a coesão e a coerência estão relacionadas ao texto; a intencionalidade e a aceitabilidade, aos indivíduos participantes do ato comunicativo. Contudo, adota um posicionamento diverso do observado na obra que concebeu juntamente com Dressler em relação aos princípios de informatividade, situcionalidade e intertextualidade: em vez de estarem vinculados ao usuário, estão vinculados à situação comunicativa.

Conforme postulam Beaugrande e Dressler (1981), a coerência é o resultado de como os elementos subjacentes à superfície textual configuram-se de modo a conferir sentido ao texto, por essa razão, é um fator de fundamental importância na constituição da textualidade, conceituação que, segundo Koch (2006), mostra-se redutora, porque

coerência não é apenas um critério de textualidade entre os demais (e centrado no texto!), mas constitui o resultado da confluência de todos os demais fatores, aliados a mecanismos e processos de ordem cognitiva, como o conhecimento enciclopédico, o conhecimento compartilhado, o conhecimento procedural, etc. $\mathrm{O}$ que se tem defendido é que a coerência resulta de uma construção dos usuários do texto, numa data situação comunicativa [...] (KOCH, 2006, p. 43).

De fato, a visão da autora amplia o entendimento acerca da coerência, bem como sua relevância na composição textual, no entanto, como ela mesma nota, assim como a coesão, a coerência sofreu alterações conceituais significativas ao longo do tempo, o que não invalida os estudos realizados anteriormente, como o de Beaugrande e Dressler que ora apresentamos. 


\section{PERcursos Linguísticos • Vitória (ES) •v. 11 •n. 29 • 2021 • ISSN: 2236-2592 • Dossiê temático $\bullet O$ texto na pesquisa e no ensino: conhecimentos, práticas e desafios na contemporaneidade •}

A coesão, outro importante princípio de textualidade, se dá no nível microtextual e diz respeito a como os vocábulos estão ligados entre si em uma sequência. A coerência manifestase no nível macroestrutural e se refere a como conceitos e relações subjacentes ao texto se conectam, formando uma unidade de sentido. Para os autores, trata-se de dois níveis de análise: a coerência é resultado de processos cognitivos, ao passo que a coesão é resultado de processos linguísticos e textuais presentes na materialidade linguística.

Se, por um lado, a coesão não é um critério fundamental nem suficiente para que um texto seja considerado como tal, por outro, o emprego de elementos coesivos confere ao texto maior legibilidade, tendo em vista que explicita, como observamos, as relações entre os elementos linguísticos nele presentes. Nessa direção, a coesão evidencia os encadeamentos que ocorrem em relação às ligações conceituais, ou seja, um texto é coeso porque os termos ligam-se em sequência justamente por se relacionarem conceitualmente.

Segundo Beaugrande e Dressler (1981), uma manifestação linguística constitui um texto se seu produtor tiver a intenção de mostrá-la e se o interlocutor aceitá-la como tal. Assim, a intencionalidade refere-se ao esforço do produtor para elaborar uma mensagem que seja coerente e coesa, e que produza os efeitos de sentido pretendidos. Por parte do produtor sempre há a intenção de construir significados; por parte do interlocutor há o empenho para reconhecer o que foi produzido como algo que adquire significado em uma dada situação comunicativa. Assim, a intencionalidade está relacionada com a aceitabilidade, que se refere à disposição do interlocutor em considerar um texto coerente, coeso e relevante. Em outras palavras, mesmo que um texto tenha incoerências, o interlocutor fará o possível para dar-lhe um sentido, cooperando para que o produtor alcance seus objetivos.

A informatividade, outro princípio que influencia na coerência de um texto, diz respeito ao grau de previsibilidade da informação veiculada, ou seja, quanto mais esperada for uma informação, mais previsível será o texto. Um alto grau de previsibilidade é indício de que o texto tem pouca informação relevante para o interlocutor, já um baixo grau de previsibilidade indica que o texto tem mais informações relevantes. Se a maioria das informações em um texto for inesperada, seu grau de informatividade será alto, exigindo que o leitor se esforce mais para sua compreensão.

Quanto à distribuição da informação, espera-se que haja equilíbrio entre informação dada e informação nova, assim como entre movimentos de retomada de informação já apresentada (retroação) e de introdução de nova informação (progressão). A ausência desse 


\section{PERcursos Linguísticos • Vitória (ES) •v. 11 •n. 29 • 2021 • ISSN: 2236-2592 • Dossiê temático $\bullet O$ texto na pesquisa e no ensino: conhecimentos, práticas e desafios na contemporaneidade •}

equilíbrio, conforme observa Koch (2006), pode tornar o texto circular porque traz apenas informações conhecidas, ou pode impossibilitar o processamento textual por causa da grande quantidade de informações novas que não têm ancoragem suficiente para que o interlocutor as assimile.

A situcionalidade, por sua vez, diz respeito a aspectos que tornam um texto relevante em determinada situação comunicativa. A relevância não resulta somente da ligação do texto com o mundo real, mas também da credibilidade de um dado texto em relação às perspectivas dos participantes de tal evento. Isso significa que certos elementos que se fazem presentes em uma situação comunicativa, como ideias e fatos, tornam-se relevantes quando o produtor os utiliza tendo como propósito alcançar determinados objetivos e quando o interlocutor é capaz de compreendê-los e, consequentemente, aceitá-los.

Por fim, a intertextualidade engloba em que medida a produção e a recepção de determinado texto requer o conhecimento de outros textos para que a compreensão se efetive. Ela também está relacionada a aspectos que dizem respeito a conteúdo, fatores formais e de tipologia textual, como explicam Koch e Travaglia (2011), e também ocorre em relação a textos traduzidos, conforme observa Travaglia (2003).

Os princípios de textualidade têm um importante papel na composição textual e, no âmbito da produção textual de graduandos, constituem elementos norteadores para o aprimoramento textual nas etapas que compõem o continuum escrita e reescrita (AGUIAR; MARQUESI, 2019), em uma perspectiva que vai além do aspecto prescritivo e estrutural.

\section{Análise}

Na sequência, apresentamos um exemplar de atividade de escrita do gênero projeto de iniciação científica, realizada no âmbito de uma disciplina optativa de escrita acadêmica de um curso de graduação em Direito de uma universidade particular de São Paulo. ${ }^{3,4}$

A atividade ocorreu em duas etapas: na primeira etapa, a docente da disciplina solicitou que os alunos, reunidos em grupos, com base nas discussões realizadas em sala de aula e na apresentação de exemplares do gênero, elaborassem em casa a versão A do texto, que deveria trazer os seguintes elementos: tema, sua contextualização, pergunta a ser respondida, objetivo(s), justificativa, delimitação, base teórica (incluindo dispositivo(s)

\footnotetext{
${ }^{3}$ Nossa participação nessa disciplina deu-se como parte das atividades de pós-doutorado.

${ }^{4}$ Em virtude da pandemia de Covid-19, as aulas foram realizadas remotamente na plataforma Teams.
} 


\section{PERcursos Linguísticos • Vitória (ES) •v. 11 •n. 29 • 2021 • ISSN: 2236-2592 • Dossiê temático $\bullet O$ texto na pesquisa e no ensino: conhecimentos, práticas e desafios na contemporaneidade •}

legal(ais)), procedimentos adotados, tópicos ou seções. Em sala de aula, as versões produzidas foram comentadas de forma detalhada em diálogo com os estudantes, de modo a se pontuar cada elemento solicitado na proposta da atividade, visando à sua compreensão para a elaboração da versão B do texto. Para fins desta pesquisa, a título de exemplificação, selecionamos aleatoriamente a versão A e a versão B produzidas por um dos grupos.

De modo a procedermos ao exame dos textos, selecionamos como categoria de análise a abordagem de conteúdo, especificamente no tocante à delimitação do estudo, uma vez que delimitar a abrangência da pesquisa, quer em relação ao tema, quer em relação aos objetivos, mostrou ser a dificuldade mais recorrente enfrentada pelos sete grupos que apresentaram seus trabalhos.

Em relação aos princípios de textualidade, elegemos a intencionalidade e a aceitabilidade, uma vez que o contexto acadêmico representa uma situação comunicativa muito específica, cujas expectativas, do ponto de vista da estrutura composicional de determinados gêneros, se mostram mais rígidas, ou seja, a não observância das partes que os compõem pode influenciar na aceitabilidade do interlocutor.

A seguir, passamos à análise.

Versão A

\section{Considerações iniciais}

"Não é da morte que temos medo, mas de pensar nela". Essa frase, de autoria de Lucius Annaeus Seneca, uma das figuras intelectuais mais significativas do Império Romano, expressa o ponto de partida deste Trabalho: levantar discussões a respeito das concepções contemporâneas do morrer, tema o qual carrega diversos estigmas, que, por sua vez, repelem universalmente a discussão social a respeito da morte.

À vista disso, serão, à priori exibidas as concepções já firmadas na realidade atual, tanto nos campos culturais, sociais, econômicos e religiosos, como no universo jurídico. À posteriori, será, então, delimitado o caminho para uma nova perspectiva sobre a morte. Isso será feito a partir de uma argumentação paralela, que colocará as concepções anteriormente tratadas em face de uma nova perspectiva, a qual permitirá a expansão cultural, racional e social, do leitor no tocante aos infortúnios causados pelos estigmas supracitados.

A partir de uma rica fundamentação teórica, a qual será sustentada em autores como: Elizabeth Kübler-Ross; Ana Claúdia Quintana Arantes; Eckhart Tolle; Friedrich Nietzsche; entre 


\section{PERcursos Linguísticos • Vitória (ES) •v. 11 •n. 29 • 2021 • ISSN: 2236-2592 • Dossiê temático $\bullet O$ texto na pesquisa e no ensino: conhecimentos, práticas e desafios na contemporaneidade •}

outros, as intolerâncias no que tange ao morrer serão desmanteladas. Quiçá, uma morte de fato se concretize: a morte de um obsoleto pensar. Afinal, como atestou Nietzche: "A imortalidade tem seu custo: morrer muitas vezes, enquanto se vive!"

\section{Versão B}

\section{DA JUSTIFICATIVA}

A abordagem que vigora hoje a respeito da morte na jurisdição é ultrapassada e carregada de estigmas. $O$ ânimo da escolha temática é proveniente justamente da observância dessa realidade estagnante, e do sentimento de necessidade de mudança. As noções jurídicas atuais acerca de fatos que envolvem a morte, causam no corpo social fervorosos debates, que por um lado, questionam as concepções preconcebidas e por outro, reafirmam-nas.

O Direito brasileiro é extremamente preservativo quanto ao direito à vida, o que de certa forma revela uma evolução legislativa, mas, de outro modo, repreende o direito à liberdade pelo próprio corpo em vários âmbitos. Tal situação torna-se mais clara em duas principais questões compreendidas pelo direito brasileiro: o aborto e a eutanásia.

O aborto é proibido no Brasil em um contexto subjetivo, em que sua realização só depende da escolha da mulher, ainda, a questão que envolve a proibição da eutanásia também indica a arbitrariedade do Estado brasileiro acerca do direito à liberdade. [...]

\section{DO TEMA}

O projeto propõe a abordagem da concepção jurídica vigente a respeito da morte no Direito Brasileiro, tanto na legislação, como na doutrina, por meio de estratégias de ressignificação, que possibilitem a compreensão dos problemas da concepção atual, abrindo espaço para a criticidade, a fim de construir um panorama para as possibilidades jurídicas do futuro dos direitos do abordo, e da eutanásia.

O tema, assim definido, alinha-se ao que dispõe o art $5^{\circ}$ da Constituição Federal, especialmente ao que tange à asseguração do direito de liberdade, que consequentemente, implica a liberdade sobre o próprio corpo.

\section{DOS OBJETIVOS}

\subsection{Gerais:}

- Contribuir para os estudos no campo jurídico, com o enfoque no plano da eutanásia e do abordo

- Adquirir conhecimentos jurídico-sociais necessários para o desenvolvimento de uma nova visão doutrinária e da pesquisa acadêmico-científica.

Específicos:

- Refletir sobre aspectos teóricos da bibliografia lida e resenhada. 


\section{PERcursos Linguísticos • Vitória (ES) •v. 11 •n. 29 • 2021 • ISSN: 2236-2592 • Dossiê temático $\bullet O$ texto na pesquisa e no ensino: conhecimentos, práticas e desafios na contemporaneidade •}

- Analisar e discutir textos normativos e concepções doutrinárias no tocante à morte.

- Expor possibilidades de mudança no que tange à legislação correspondente ao aborto e a eutanásia no Brasil.

\section{PERGUNTA A SER RESPONDIDA}

De que forma a perspectiva jurídica atual do Brasil, no que diz respeito aos direitos em torno da morte, afeta negativamente o direito de liberdade dos cidadãos e quais são as possibilidades futuras?

\section{BIBLIOGRAFIA}

ARANTES, A.C.Q. "A morte é um Dia Que Vale a Pena Viver: E um excelente motivo para se buscar um novo olhar para a vida". $3^{a}$ ed. Sextante, 2019.

TOLLE, ECKHART. "O poder do agora: um guia para iluminação espiritual". Rio de Janeiro: Sextante, 2002.

KÜBLER, E.R. "Sobre a morte e o morrer: O que os doentes terminais têm para ensinar a médicos, enfermeiras, religiosos e aos seus próprios parentes”. WWF Martins Fontes, 2017.

Notamos que na versão A, a delimitação do tema e do objetivo não foi observada. No trecho “"Não é da morte que temos medo, mas de pensar nela'. Essa frase, de autoria de Lucius Annaeus Seneca, uma das figuras intelectuais mais significativas do Império Romano, expressa o ponto de partida deste Trabalho: levantar discussões a respeito das concepções contemporâneas do morrer, tema o qual carrega diversos estigmas, que, por sua vez, repelem universalmente a discussão social a respeito da morte", em que há indicação do tema, temos, na verdade, o que seria o objetivo, que se mostra muito amplo: "levantar discussões a respeito das concepções contemporâneas do morrer". Da mesma forma, não há esclarecimento sobre quais seriam os diversos estigmas que repelem a discussão social sobre a morte, que se repete no trecho "Isso será feito a partir de uma argumentação paralela, que colocará as concepções anteriormente tratadas em face de uma nova perspectiva [...] no tocante aos infortúnios causados pelos estigmas supracitados", o que reforça a necessidade de delimitar o foco do estudo.

$\mathrm{Na}$ versão $\mathrm{B}$, o tema, qual seja, “[...] a abordagem da concepção jurídica vigente a respeito da morte no Direito Brasileiro, tanto na legislação, como na doutrina, por meio de estratégias de ressignificação, que possibilitem a compreensão dos problemas da concepção atual, abrindo espaço para a criticidade, a fim de construir um panorama para as possibilidades jurídicas do futuro dos direitos do abordo, e da eutanásia”, apresenta-se mais 


\section{PERcursos Linguísticos • Vitória (ES) •v. 11 •n. 29 • 2021 • ISSN: 2236-2592 • Dossiê temático $\bullet O$ texto na pesquisa e no ensino: conhecimentos, práticas e desafios na contemporaneidade •}

delimitado em comparação à versão A, embora ainda possa, no processo de revisão e reescrita de versões posteriores, ser mais refinado.

Na mesma direção, nessa versão, os objetivos são explicitados de modo a informar ao leitor o que de fato será realizado na pesquisa: a síntese do que se pretende alcançar em sentido amplo, que se refere aos objetivos gerais "Contribuir para os estudos no campo jurídico, com o enfoque no plano da eutanásia e do abordo; Adquirir conhecimentos jurídicosociais necessários para o desenvolvimento de uma nova visão doutrinária e da pesquisa acadêmico-científica", e as etapas necessárias para que isso ocorra, que se referem aos objetivos específicos "Refletir sobre aspectos teóricos da bibliografia lida e resenhada; Analisar e discutir textos normativos e concepções doutrinárias no tocante à morte; Expor possibilidades de mudança no que tange à legislação correspondente ao aborto e a eutanásia no Brasil". Esses elementos não foram considerados na versão $\mathrm{A}$, assim, não houve a delimitação necessária ao estudo.

Por fim, a ausência da pergunta de pesquisa na versão A prejudica não apenas a compreensão do leitor acerca do que se pretende realizar por meio do estudo, mas também, e principalmente, daqueles que estão propondo o estudo, uma vez que não têm um elemento para guiá-los/orientá-los “em suas reflexões teóricas, na definição dos procedimentos teóricoanalíticos e na análise e interpretação de dados" (MARQUESI, 2021 [no prelo], p. 120). Na versão B, a pergunta de pesquisa "De que forma a perspectiva jurídica atual do Brasil, no que diz respeito aos direitos em torno da morte, afeta negativamente o direito de liberdade dos cidadãos e quais são as possibilidades futuras?" tem a função tanto de guiar e orientar os estudantes na pesquisa como de delimitar o objeto de estudo.

No tocante à estrutura, notamos que na versão retextualizada, B, foram inseridos os itens justificativa, tema, objetivos - gerais e específicos - e bibliografia, que habitualmente compõem um projeto de iniciação científica e que foram solicitados no enunciado da atividade. A adição desses elementos de forma pontual auxilia na compreensão das partes que devem compor o gênero e de como elas devem se inter-relacionar para construir os sentidos necessários à situação comunicativa pertinente ao contexto acadêmico.

Quanto aos fatores de textualidade, lembramos que, para Koch e Travaglia (2011), a intencionalidade está relacionada à intenção do produtor de manifestar-se, linguisticamente, de forma coesiva e coerente, ainda que ela não se realize de modo integral. No entanto, a 


\section{PERcursos Linguísticos • Vitória (ES) •v. 11 •n. 29 • 2021 • ISSN: 2236-2592 • Dossiê temático $\bullet O$ texto na pesquisa e no ensino: conhecimentos, práticas e desafios na contemporaneidade •}

intenção só terá êxito se o texto for reconhecido e aceito como válido e pertinente pelo interlocutor.

Mais especificamente, o fato de o tema "levantar discussões a respeito das concepções contemporâneas do morrer, tema que carrega diversos estigmas [...]”, expressar, linguisticamente, o objetivo, como já pontuamos, revela uma inconsistência que pode acarretar a não aceitabilidade por parte do interlocutor. Nessa direção, a ausência de informações precisas acerca do tema e da base teórica, por exemplo, assim como a inexistência da pergunta a ser respondida, que auxilia na delimitação do escopo do estudo, também podem prejudicar o referido princípio de textualidade, essencial para que um texto seja considerado como tal, particularmente no ambiente universitário.

\section{Considerações finais}

A atividade de escrita na graduação, fundamentada no processo de retextualização e nos princípios de textualidade, propicia ao estudante um momento de reflexão sobre o próprio ato de escrever, entendido não como uma única ação, realizada de forma mecânica, mas como uma ação que integra múltiplas etapas que envolvem a escrita propriamente dita, a revisão e a reescrita, sem as quais não se alcança o aprimoramento textual desejado.

Notamos que os alunos, ao tomarem conhecimento da estrutura composicional do gênero projeto de iniciação científica, por meio da leitura de exemplares de projetos e da exposição da professora, compreenderam mais claramente como proceder à organização de suas partes canônicas e em que medida tal organização contribui para que o propósito comunicativo do gênero seja alcançado, o que demonstraram na versão B.

Além disso, a correção comentada da versão A, item a item, com aporte teórico da Linguística Textual, notadamente da retextualização e dos princípios de textualidade, possibilitou aos alunos produzirem a versão B do texto, com base na noção de escrita como processo.

Entendemos, assim, que este trabalho abre perspectivas para se pensar em estratégias que propiciem aos estudantes de graduação atividades reflexivas de produção escrita, de maneira a levá-los a explorar a criatividade e a autonomia, necessárias também no ambiente acadêmico. 


\section{PERcursos Linguísticos • Vitória (ES) •v. 11 •n. 29 • 2021 • ISSN: 2236-2592 • Dossiê temático $\bullet O$ texto na pesquisa e no ensino: conhecimentos, práticas e desafios na contemporaneidade •}

\section{Referências}

AGUIAR, Andréa Pisan Soares; MARQUESI, Sueli Cristina. Escrita, revisão e reescrita de textos acadêmicos: o encadeamento entre parágrafos. Revista Verbum - Cadernos de Pósgraduação, v. 8 , n. 2, p. 90-109, set. 2019. Disponível em: https://revistas.pucsp.br/verbum/article/view/44920. Acesso em: 24 set. 2021.

BEAUGRANDE, Robert-Alain de. Getting started. In: BEAUGRANDE, Robert-Alain de. New foundations for a science of text and discourse: cognition, communication, and the freedom of access to knowledge and society. New Jersey: Ablex Publishing Corporation, 1997. Disponível em: http://beaugrande.com/introduction_to_text_linguistics.htm. Acesso em: 22 set. 2021.

BEAUGRANDE, Robert-Alain de; DRESSLER, Wolfgang Ulrich W. Introduction to text linguistics. Tubingen: Max Niemeyer, 1981. Disponível em: http://beaugrande.com/introduction_to_text_linguistics.htm. Acesso em: 22 set. 2021.

BECKER, Howard S. Truques da escrita - para começar e terminar teses, livros e artigos. Trad. Denise Bottmann. Rio de Janeiro: Zahar, 2015.

$\mathrm{KOCH}$, Ingedore G. Villaça. Introdução à linguística textual. São Paulo: Martins Fontes, 2006.

KOCH, Ingedore G. Villaça; TRAVAGLIA, Luiz Carlos. Texto e coerência. 13. ed. São Paulo: Cortez, 2011.

MARCUSCHI, Luiz Antônio. Produção textual, análise de gêneros e compreensão. São Paulo: Parábola, 2008.

MARCUSCHI, Luiz Antônio. Da fala para a escrita - atividades de retextualização. 8. ed. São Paulo: Cortez, 2007.

MARQUESI, Sueli Cristina. Originalidade na escrita acadêmica: a pergunta de pesquisa em foco. Linguarum Arena, v. 12, p. 113-127, 2021. No prelo.

MARQUESI, Sueli Cristina. Escrita e reescrita de textos no ensino médio. In: ELIAS, Vanda Maria (org.). Ensino de Língua Portuguesa: oralidade, escrita, leitura. São Paulo: Contexto, 2011.

MARQUESI, Sueli Cristina. Escrita e reescrita de textos acadêmicos na pós-graduação: a textualização em foco. Páginas de Guarda, v. 9, p. 49-60, 2010.

PINTO, Maria da Graça Lisboa Castro. Os meandros da escrita académica. Alguns recados aos estudantes universitários. Revista Linha d'Água, v. 31, n. 1, p. 9-27, jan.-abr. 2018. Disponível em: <https://www.revistas.usp.br/linhadagua/article/view/133916/138975>. Acesso em: 26 set. 2021. 
PERcursos Linguísticos • Vitória (ES) •v. $11 \bullet$ n. 29 • 2021 • ISSN: 2236-2592 • Dossiê

temático $\bullet O$ texto na pesquisa e no ensino: conhecimentos, práticas e desafios na contemporaneidade •

PINTO, Maria da Graça Lisboa Castro. Da revisão da escrita: uma gestão exigente requerida pela relação leitor, autor e texto escrito. Revista Observatório, v. 3, n. 4, p. 488-517, jul.-set. 2017. Disponível em: https://sistemas.uft.edu.br/periodicos/index.php/obser vatorio/article/view/3400. Acesso em: 24 set. 2021.

TRAVAGLIA, Neusa Gonçalves. Tradução - Retextualização: a tradução numa perspectiva textual. Uberlândia: Edufu, 2003. 


\section{PERcursos Linguísticos • Vitória (ES) •v. 11 •n. 29 • 2021 • ISSN: 2236-2592 • Dossiê temático $\bullet O$ texto na pesquisa e no ensino: conhecimentos, práticas e desafios na contemporaneidade}

\section{POLÍTICA EDITORIAL}

A Revista PERcursos Linguísticos publica minimamente 3 (três) números anualmente e tem como objetivo a publicação de textos científicos nas diversas áreas da Linguística e Linguística Aplicada. Com esse propósito, abre um espaço para a um diálogo acadêmico, que possibilita o debate em torno de diferentes orientações teóricas, transitando desde os paradigmas relacionados com a descrição e a análise linguística até às instigantes perspectivas do discurso e da análise textual, e às questões típicas da ampla área de linguística aplicada.

Por definição da política editorial da Revista, são aceitas contribuições de artigos redigidos em português de pesquisadores doutores, mestres e estudantes de pós-graduação do Brasil e do exterior, bem como estudantes de graduação, em conjunto com seus respectivos orientadores.

Os textos submetidos para publicação na revista são avaliados anonimamente por dois pareceristas do Conselho Editorial. Caso o artigo não seja da área de avaliação desses pareceristas, consultores ad hoc emitirão o parecer também no sistema de avaliação duplo cego. No caso de discrepâncias na avaliação do artigo, ele será avaliado por um terceiro parecerista. Depois da análise, cópias dos pareceres serão encaminhadas aos autores, juntamente com instruções para modificações, quando for o caso. Os trabalhos que não responderem no devido tempo hábil para resposta, não serão publicados na edição a qual foi inserido. Dados e conceitos emitidos nos trabalhos, bem como a exatidão das referências bibliográficas, são de inteira responsabilidade dos autores. Só será admitido um artigo por chamada por autor(es).

Os artigos podem ser escritos em português, inglês ou espanhol.

Os dados e conceitos contidos nos artigos, bem como a exatidão das referências, serão de inteira responsabilidade do(s) autor(es).

Os originais apresentados não devem ter sido submetidos a outro periódico simultaneamente.

Não serão aceitos artigos de autoria de mais de três autores sem a devida justificativa que deverá ser aceita pelo conselho editorial da PERcursos.

Os direitos autorais referentes aos artigos aprovados serão concedidos, sem ônus, automaticamente à revista PERcursos Linguísticos, a qual poderá então publicá-los com base nos incisos VI e I do artigo $5^{\circ}$ da Lei 9610/98. 


\section{PERcursos Linguísticos • Vitória (ES) •v. 11 •n. 29 • 2021 • ISSN: 2236-2592 • Dossiê temático $\bullet O$ texto na pesquisa e no ensino: conhecimentos, práticas e desafios na contemporaneidade}

Os autores devem providenciar autorização para uso das imagens. Caso contrário, será necessário retirá-las e apenas descrevê-las.

Os direitos autorais referentes aos trabalhos aprovados serão concedidos, sem ônus, automaticamente à revista PERcursos Linguísticos, a qual poderá então publicá-los com base nos incisos VI e I do artigo $5^{\circ}$ da Lei 9610/98. O trabalho publicado poderá ser acessado pela rede mundial de computadores, sendo permitidas, gratuitamente, a consulta e a reprodução de exemplar do trabalho para uso próprio de quem o consulta. Essa autorização de publicação não tem limitação de tempo, ficando o site da revista responsável pela manutenção da identificação do autor do artigo. Casos de plágio ou quaisquer ilegalidades nos textos apresentados são de inteira responsabilidade de seus autores.

\section{DIRETRIZES PARA PROPOSIÇÃO DE DOSSIÊ TEMÁTICO (MEMBROS EXTERNOS À REVISTA)}

Os proponentes deverão contatar a Revista PERcursos com o título e proposta (resumo de até 400 palavras) do dossiê, para que seja analisada sua convergência com o escopo da revista.

Havendo aceite à proposta, os organizadores deverão encaminhar uma lista de, no mínimo, 10 (dez) especialistas na área do dossiê, para colaboração na avaliação dos artigos.

A edição de texto é de responsabilidade dos organizadores do dossiê, que deverão seguir as diretrizes editoriais da revista. É necessário informar à comissão da PERcursos aquele (s) que ficará (ão) responsável (is) por essa tarefa.

\section{NORMAS PARA PUBLICAÇÃO}

O trabalho deve ser digitado em Word for Windows, versão 6.0 ou superior, em papel A4 (21 $\mathrm{cm}$ X 29,7 cm), com margens superior e esquerda de $3 \mathrm{~cm}$ e direita e inferior de $2 \mathrm{~cm}$, sem numeração de páginas. A fonte deverá ser Times New Roman, tamanho 12, em espaçamento 1,5 entre linhas e parágrafos, com alinhamento justificado. Os trabalhos devem ter extensão mínima de 10 e máxima de 20 páginas, incluindo todos os dados, como tabelas, ilustrações e referências.

O trabalho deve obedecer à seguinte estrutura e ordem 


\section{PERcursos Linguísticos • Vitória (ES) •v. 11 •n. 29 • 2021 • ISSN: 2236-2592 • Dossiê temático $\bullet O$ texto na pesquisa e no ensino: conhecimentos, práticas e desafios na contemporaneidade}

- Título: centralizado, em maiúsculas com negrito, na fonte 14 , no alto da primeira página.

- Título na língua estrangeira escolhida (inglês ou espanhol, quando estas não forem a língua do texto do artigo): centralizado, em maiúsculas com negrito, na fonte 14 , no alto da primeira página.

- Nome do(s) autor(es): por extenso, com letras maiúsculas somente para as iniciais, em fonte 12 , duas linhas abaixo do título, alinhado à direita, com um número que remeterá à nota de rodapé para identificação da titulação e instituição a que pertence $(\mathrm{m}) \mathrm{o}(\mathrm{s})$ autor(es) e e-mail de contato. A identificação não deve exceder duas linhas da nota para cada autor.

- Resumo: em português para os textos escritos em português; na língua do artigo e em português para artigos escritos em língua estrangeira. Precedido desse subtítulo e de dois-pontos, em parágrafo único, de no máximo 200 palavras, justificado, sem adentramento, em espaçamento simples, duas linhas abaixo do nome do autor.

- Palavras-chave: no mínimo três e no máximo cinco; precedidas desse subtítulo e de dois-pontos, com iniciais maiúsculas, separadas por ponto, fonte normal, em alinhamento justificado, espaçamento simples, sem adentramento, com um espaço simples após o resumo.

- Resumo na língua estrangeira: precedido desse subtítulo e de dois-pontos, em parágrafo único, de no máximo 200 palavras, justificado, sem adentramento, em espaçamento simples, duas linhas abaixo do nome do autor.

- Palavras-chave em língua estrangeira: no mínimo três e no máximo cinco; precedidas desse subtítulo e de dois-pontos, com iniciais maiúsculas, separadas por ponto, fonte normal, em alinhamento justificado, espaçamento simples, sem adentramento, com um espaço simples após o resumo.

- Texto do artigo: iniciado duas linhas abaixo das palavras-chave em língua estrangeira, em espaçamento $1,5 \mathrm{~cm}$. Os parágrafos deverão ser justificados, com adentramento de $1,25 \mathrm{~cm}$ na primeira linha. Os subtítulos correspondentes às seções do trabalho deverão figurar à esquerda, em negrito, sem numeração e sem adentramento, com a inicial da primeira palavra em maiúscula. Deverá haver espaço duplo de uma linha entre o último parágrafo da seção anterior e o subtítulo. Todo destaque realizado no corpo do texto será feito em itálico.

Caso seja necessário apresentar uma sequência ou ordem dentro do próprio corpo de texto, a informação deverá ser numerada, sequencialmente, com algarismos arábicos entre parênteses. Se a informação for fora do parágrafo principal, essa deverá ser enumerada como algarismos arábicos, ser escrita com tamanho10, com recuo de $4 \mathrm{~cm}$ da margem esquerda, o espaçamento das entrelinhas da citação deve ser simples.

Para citações no corpo do texto, são seguidas as diretrizes abaixo:

- Texto com menos de três linhas completas: tamanho 12, com aspas e dentro do texto. Deve ser acompanhado da referência. Exemplo: (SILVA, 2005, p. 36-37). Quando o sobrenome vier fora dos parênteses, deve-se utilizar apenas a primeira letra em maiúscula. 


\section{PERcursos Linguísticos • Vitória (ES) •v. 11 •n. 29 • 2021 • ISSN: 2236-2592 • Dossiê temático $\bullet O$ texto na pesquisa e no ensino: conhecimentos, práticas e desafios na contemporaneidade}

- Textos com mais de três linhas completas: tamanho 10, com recuo de $4 \mathrm{~cm}$ da margem esquerda, o espaçamento das entrelinhas da citação deve ser simples. Deve ser acompanhado da referência. Exemplo: (SILVA, 2005, p. 36-37). Quando o sobrenome vier fora dos parênteses, deve-se utilizar apenas a primeira letra em maiúscula. Quando a referência estiver junto ao texto, deve-se aplicar ponto-final no trecho citado, inserir a referência e aplicar novamente o ponto-final.

- Referências: precedidas desse subtítulo, iniciadas à esquerda, justificadas, sem adentramento, em ordem alfabética de sobrenomes e, no caso de um mesmo autor, na sequência cronológica de publicação dos trabalhos citados, duas linhas após o texto. Para referências em geral (de livro, de autor-entidade, de dicionário, de capítulo de livro organizado, de artigo de revista, de tese/dissertação, de artigo/notícia em jornal, de trabalhos em eventos, de anais de evento, de verbete, de página pessoal). Só devem ser inseridos nas referências textos que foram utilizados ao longo do artigo.

Devem ser seguidos os exemplos abaixo:

Artigos científicos:

SOBRENOME, Nome por extenso. Título do artigo. Nome da revista, v. 1, n. 1, p. 1-10, Ano.

Livros autorais:

SOBRENOME, Nome por extenso. Título do livro. Número da edição. Cidade da editora: Editora. Ano.

SOBRENOME, Nome por extenso. Título do livro: subtítulo. Número da edição. Cidade da editora: Editora. Ano.

Livros organizados:

SOBRENOME, Nome do primeiro organizador por extenso; SOBRENOME, Nome do segundo organizador por extenso (Orgs.). Título do livro. Número da edição. Cidade da editora: Editora. Ano.

SOBRENOME, Nome do primeiro organizador por extenso; SOBRENOME, Nome do segundo organizador por extenso (Orgs.). Título do livro: subtítulo. Número da edição. Cidade da editora: Editora. Ano.

Livros com mais de 3 (três) organizadores poderão utilizar o recurso et al. 


\section{PERcursos Linguísticos • Vitória (ES) •v. 11 •n. 29 • 2021 • ISSN: 2236-2592 • Dossiê \\ temático $\bullet O$ texto na pesquisa e no ensino: conhecimentos, práticas e desafios na contemporaneidade}

Capítulos de livro:

SOBRENOME, Nome por extenso. Título do capítulo. In: SOBRENOME, Nome do organizador por extenso (Org.). Título do livro. Número da edição. Cidade da editora: Editora. Ano.

Teses e dissertações:

SOBRENOME, Nome por extenso. Título da tese: subtítulo. Tese de doutorado. Programa de pós-graduação (Sigla da Universidade), ANO.

Trabalho publicado em anais de congresso:

SOBRENOME, Nome por extenso. Título do trabalho. Nome do Congresso sem abreviações. Instituição responsável (quando houver). Cidade, ano, p. 1-10.

Páginas da internet:

Notícias:

SOBRENOME, Nome por extenso. Título da notícia. Nome do portal/jornal, data de publicação. Disponível em: (link da notícia). Último acesso em: (data do último acesso).

Redes sociais:

SOBRENOME, Nome por extenso. Post em rede social (inserir título quando houver). Cidade, mês, ano. Nome da rede social. Disponível em: (link da postagem). Último acesso em: (data do último acesso).

Os autores serão requeridos a ajustarem seus textos até que se adequem às normas da revista, sendo condição para publicação dos manuscritos.

No caso de haver transcrição fonética e uso de fontes do IPA, é necessário usar somente um tipo de fonte: silDoulosIPA, tamanho 12. A fonte pode ser obtida gratuitamente por meio do site: <http://scripts.sil.org/DoulosSIL_download>.

Anexos, caso existam, devem ser colocados após as referências, precedidos da palavra Anexo, em negrito, sem adentramento e sem numeração. 


\section{PERcursos Linguísticos • Vitória (ES) •v. 11 •n. 29 • 2021 • ISSN: 2236-2592 • Dossiê temático $\bullet O$ texto na pesquisa e no ensino: conhecimentos, práticas e desafios na contemporaneidade}

Os trabalhos que não se enquadrarem nas normas aqui expostas serão recusados.

Serão devolvidos aos autores trabalhos que não obedecerem tanto às normas aqui estipuladas quanto às normas de formatação.

\section{Declaração de Direito Autoral}

O autor de submissão à Revista PERcursos Linguísticos cede os direitos autorais à editora da revista (Programa de Pós-Graduação em Linguística - UFES), caso a submissão seja aceita para publicação. A responsabilidade do conteúdo dos artigos é exclusiva dos autores. É proibida a submissão integral ou parcial do texto já publicado na revista a qualquer outro periódico.

Os trabalhos aqui apresentados utilizam a licença Creative Commons CC BY: AttributionNonCommercial- NoDerivatives 4.0 International. Para mais informações, verificar:

\section{https://creativecommons.org/licenses/by-nc-nd/4.0/}

\section{PERcursos Linguísticos}

\section{Equipe editorial}

A/C Patrick Rezende (editor-gerente)

Guilherme Brambila

CCHN/ PPGEL - Programa de Pós-Graduação em Linguística

Universidade Federal do Espírito Santo

Av. Fernando Ferrari, ${ }^{\circ} 514$

Campus Universitário - Goiabeiras

CEP 29075-910 Vitória - ES

Tel: 0 XX 4009-2801

E-mail: percursoslinguisticos@ hotmail.com

patrickrezende@hotmail.com

guilhermebrambilamanso@ hotmail.com 